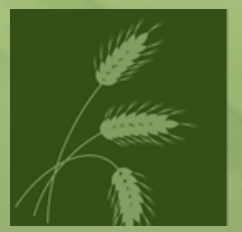

\title{
agronomy
}

Grafting as a

Sustainable Means

for Securing

Yield Stability

and Quality in

Vegetable Crops

Edited by

Marios Kyriacou, Giuseppe Colla and Youssef Rouphael Printed Edition of the Special Issue Published in Agronomy 
Grafting as a Sustainable Means for Securing Yield Stability and Quality in Vegetable Crops 



\section{Grafting as a Sustainable Means for Securing Yield Stability and Quality in Vegetable Crops}

Editors

Marios Kyriacou

Giuseppe Colla

Youssef Rouphael 
Editors

Marios Kyriacou

gricultural Research Institute

Cyprus
Giuseppe Colla

University of Tuscia

Italy
Youssef Rouphael

University of Naples Federico II

Italy

\section{Editorial Office}

MDPI

St. Alban-Anlage 66

4052 Basel, Switzerland

This is a reprint of articles from the Special Issue published online in the open access journal Agronomy (ISSN 2073-4395) (available at: https://www.mdpi.com/journal/agronomy/special_ issues/Grafting_Vegetable).

For citation purposes, cite each article independently as indicated on the article page online and as indicated below:

LastName, A.A.; LastName, B.B.; LastName, C.C. Article Title. Journal Name Year, Volume Number, Page Range.

ISBN 978-3-0365-0392-9 (Hbk)

ISBN 978-3-0365-0393-6 (PDF)

Cover image courtesy of Youssef Rouphael.

(C) 2021 by the authors. Articles in this book are Open Access and distributed under the Creative Commons Attribution (CC BY) license, which allows users to download, copy and build upon published articles, as long as the author and publisher are properly credited, which ensures maximum dissemination and a wider impact of our publications.

The book as a whole is distributed by MDPI under the terms and conditions of the Creative Commons license CC BY-NC-ND. 


\section{Contents}

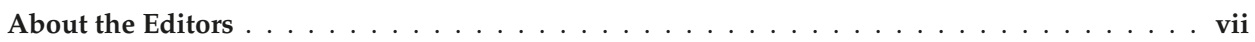

Marios C. Kyriacou, Giuseppe Colla and Youssef Rouphael

Grafting as a Sustainable Means for Securing Yield Stability and Quality in Vegetable Crops

Reprinted from: Agronomy 2020, 10, 1945, doi:10.3390/agronomy10121945 . . . . . . . . . . . 1

Tian Gong, Zachary T. Ray, Kylee E. Butcher, Zachary E. Black, Xin Zhao

and Jeffrey K. Brecht

A Novel Graft between Pac Choi (Brassica rapa var. chinensis) and Daikon Radish (Raphanus sativus var. longipinnatus)

Reprinted from: Agronomy 2020, 10, 1464, doi:10.3390/agronomy10101464 . . . . . . . . . . . .

Maryam Mozafarian, Nazatul Syaima Binti Ismail and Noémi Kappel

Rootstock Effects on Yield and Some Consumer Important Fruit Quality Parameters of Eggplant cv. 'Madonna' under Protected Cultivation

Reprinted from: Agronomy 2020, 10, 1442, doi:10.3390/agronomy10091442 . . . . . . . . . . 23

Branimir Urlić, Marko Runjić, Marija Mandušić, KatjaŽanić, Gabriela Vuletin Selak, Ana Matešković and Gvozden Dumičić

Partial Root-Zone Drying and Deficit Irrigation Effect on Growth, Yield, Water Use and Quality of Greenhouse Grown Grafted Tomato

Reprinted from: Agronomy 2020, 10, 1297, doi:10.3390/agronomy10091297 . . . . . . . . . . . 3

Marios C. Kyriacou, Georgios A. Soteriou and Youssef Rouphael

Modulatory Effects of Interspecific and Gourd Rootstocks on Crop Performance, Physicochemical Quality, Bioactive Components and Postharvest Performance of Diploid and Triploid Watermelon Scions

Reprinted from: Agronomy 2020, 10, 1396, doi:10.3390/agronomy10091396 . . . . . . . . . . . .

Mariateresa Cardarelli, Youssef Rouphael, Marios C. Kyriacou, Giuseppe Colla and Catello Pane

Augmenting the Sustainability of Vegetable Cropping Systems by Configuring Rootstock-Dependent Rhizomicrobiomes that Support Plant Protection

Reprinted from: Agronomy 2020, 10, 1185, doi:10.3390/agronomy10081185

Giuseppe Carlo Modarelli, Youssef Rouphael, Stefania De Pascale, Gölgen Bahar Öztekin, Yüksel Tüzel, Francesco Orsini and Giorgio Gianquinto

Appraisal of Salt Tolerance under Greenhouse Conditions of a Cucurbitaceae Genetic Repository of Potential Rootstocks and Scions

Reprinted from: Agronomy 2020, 10, 967, doi:10.3390/agronomy10070967 . . . . . . . . . . 75

Leo Sabatino, Giovanni Iapichino, Beppe Benedetto Consentino, Fabio D'Anna and Youssef Rouphael

Rootstock and Arbuscular Mycorrhiza Combinatorial Effects on Eggplant Crop Performance and Fruit Quality under Greenhouse Conditions

Reprinted from: Agronomy 2020, 10, 693, doi:10.3390/agronomy10050693 . . . . . . . . . . . .

Hira Singh, Pradeep Kumar, Ashwani Kumar, Marios C. Kyriacou, Giuseppe Colla and Youssef Rouphael

Grafting Tomato as a Tool to Improve Salt Tolerance

Reprinted from: Agronomy 2020, 10, 263, doi:10.3390/agronomy10020263 . . . . . . . . . . . . 107 
José-Luis Pardo-Alonso,Ángel Carreño-Ortega, Carolina-Clara Martínez-Gaitán, Iacopo Golasi and Marta Gómez Galán

Conventional Industrial Robotics Applied to the Process of Tomato Grafting Using the Splicing Technique

Reprinted from: Agronomy 2019, 9, 880, doi:10.3390/agronomy9120880 . . . . . . . . . . . . . 129

Enrica Allevato, Rosario Paolo Mauro, Silvia Rita Stazi, Rosita Marabottini,

Cherubino Leonardi, Anita Ierna and Francesco Giuffrida

Arsenic Accumulation in Grafted Melon Plants: Role of Rootstock in Modulating Root-To-Shoot

Translocation and Physiological Response

Reprinted from: Agronomy 2019,9, 828, doi:10.3390/agronomy9120828 . . . . . . . . . . . . . . 147

Hao Wei, Jin Zhao, Jiangtao Hu and Byoung Ryong Jeong

Effect of Supplementary Light Intensity on Quality of Grafted Tomato Seedlings and Expression of Two Photosynthetic Genes and Proteins

Reprinted from: Agronomy 2019, 9, 339, doi:10.3390/agronomy9060339 . . . . . . . . . . . . 163

Rana Shahzad Noor, Zhi Wang, Muhammad Umair, Muhammad Yaseen, Muhammad Ameen, Shoaib-Ur Rehman, Muzammil Usman Khan, Muhammad Imran, Waqar Ahmed and Yong Sun

Interactive Effects of Grafting Techniques and Scion-Rootstocks Combinations on Vegetative Growth, Yield and Quality of Cucumber (Cucumis sativus L.)

Reprinted from: Agronomy 2019, 9, 288, doi:10.3390/agronomy9060288 . . . . . . . . . . . . 179

Leo Sabatino, Giovanni Iapichino, Giuseppe Leonardo Rotino, Eristanna Palazzolo, Giuseppe Mennella and Fabio D'Anna

Solanum aethiopicum gr. gilo and Its Interspecific Hybrid with S. melongena as Alternative Rootstocks for Eggplant: Effects on Vigor, Yield, and Fruit Physicochemical Properties of Cultivar 'Scarlatti'

Reprinted from: Agronomy 2019, 9, 223, doi:10.3390/agronomy9050223 . . . . . . . . . . . . . 205

José-Luis Pardo-Alonso, Ángel Carreño-Ortega, Carolina-Clara Martínez-Gaitán and Ángel-Jesús Callejón-Ferre

Combined Influence of Cutting Angle and Diameter Differences between Seedlings on the Grafting Success of Tomato Using the Splicing Technique

Reprinted from: Agronomy 2019, 9, 5, doi:10.3390/agronomy9010005 


\section{About the Editors}

Marios Kyriacou is a Senior Research Officer and Head of the Department of Vegetable Crops at the Agricultural Research Institute, Nicosia, Cyprus. A member of the editorial boards of several leading journals in horticultural science, Dr. Kyriacou has an international reputation for his work on how pre and post-harvest factors could modulate the quality of fresh fruits and vegetables.

Giuseppe Colla is a Professor of Vegetable Production, Floriculture and Greenhouse Crop Management at the University of Tuscia, Italy. A member of the editorial boards of several leading journals in horticultural science, Professor Colla has an international reputation for his work on plant nutrition and plant biostimulants. He has coordinated many projects to improve horticultural production.

Youssef Rouphael is an Associate Professor at the University of Naples Federico II, Italy. He is Editor-in-Chief of MDPI's Agronomy journal and has been a guest editor on biostimulants in several international journals (Scientia Horticulturae; Frontiers in Plant Science; Agronomy-MDPI). He is a member of the scientific committee of Biostimulant.com. He is internationally known for his research in horticultural science. 



\title{
Editorial \\ Grafting as a Sustainable Means for Securing Yield Stability and Quality in Vegetable Crops
}

\author{
Marios C. Kyriacou ${ }^{1, *}$, Giuseppe Colla ${ }^{2}$ and Youssef Rouphael ${ }^{3, *}$ \\ 1 Agricultural Research Institute, P.O. Box 22016, 1516 Nicosia, Cyprus \\ 2 Department of Agriculture and Forest Sciences, University of Tuscia, 01100 Viterbo, Italy; giucolla@unitus.it \\ 3 Department of Agricultural Sciences, University of Naples Federico II, 80055 Portici, Italy \\ * Correspondence: m.kyriacou@ari.gov.cy (M.C.K.); youssef.rouphael@unina.it (Y.R.); \\ Tel.: +357-22-403-221 (M.C.K.); +39-081-2539-134 (Y.R.)
}

Received: 25 November 2020; Accepted: 30 November 2020; Published: 11 December 2020

Grafting is among the most ancient agricultural techniques, having been practiced since $2000 \mathrm{BC}$. Nowadays, this old technique holds a significant margin for improvement by adding contemporary advances in plant science and technology. Vegetable grafting is widely used in Cucurbitaceous (cucumber, melon and watermelon) and Solanaceous crops (eggplant, pepper and tomato) [1,2]. Grafting provides opportunities to exploit natural genetic variation for specific root traits to influence the phenotype of the shoot. By selecting a suitable rootstock, grafting can manipulate scion morphology and physiology and can manage biotic stresses including foliar and soil borne pathogens, arthropods, viral diseases, weeds and nematodes, as well as abiotic stresses such as thermal stress, drought, salinity, nutrient deficiency and imbalances in soil, adverse soil $\mathrm{pH}$ (alkalinity and acidity), heavy metals contamination and organic pollutants [3-5]. The current research topic "Grafting as a sustainable means for securing yield stability and quality in vegetable crops" compiles 12 research papers and 2 review articles that examine the implications of vegetable grafting for crop growth and productivity, resource use efficiency (water and fertilizer), nutritional and functional quality of the produce as well as tolerance to biotic and abiotic stress. The present research topic contains scientific articles of high standard coming from several prestigious research groups. As such, it is geared to increase knowledge among scientists, breeding companies and farming communities on the benefits of grafting vegetables towards securing productivity and stability of the agricultural sector, thus improving food security.

Grafting methods vary considerably depending on the kind of crop, the growers' experiences as well as the availability of grafting facilities (hand grafting, automatic or semi-automatic machines). In their review paper, Lee et al. [6], summarized the major grafting methods in cucurbits and solanaceous crops as follows: (i) cleft grafting, (ii) hole insertion, (iii) pin grafting, (iv) splice and (v) tongue approach grafting. In the same review, Lee et al. [6] affirmed that the differences in diameter between the scion and rootstock have a significant effect on the grafting success. However, the alignment of rootstocks and scions of variable diameters is an arduous task, liable to human error that may consequently impact the success of seedling grafting [6]. Pardo-Alonso et al. [7] carried out an experiment aiming to determine the combined effect of cutting angle and different rootstock/scion random diameters on the grafting success of tomato using the splice technique. In their research, the authors reported that an increased grafting angle is associated with a higher survival rate of grafted tomato plants irrespective of the variations in diameter between scion and rootstock. The authors concluded that using the splicing technique in tomato with a cutting angle ranging between $50^{\circ}$ and $70^{\circ}$ could definitely improve the grafting conditions and consequently simplify the demands for manual and automated (i.e., robotized) grafting systems. The same research group in a successive experiment investigated the influence of different robot working speeds (from 100 to $600 \mathrm{~mm} / \mathrm{s}$ ) on the tomato grafting success [8]. In their work, the authors showed that the use of low speeds (between 100 and $300 \mathrm{~mm} / \mathrm{s}$ ) allows a success rate around $90 \%$; at medium speeds (between 400 and $500 \mathrm{~mm} / \mathrm{s}$ ) the success rate remains above $80 \%$, while at a 
test speed of $600 \mathrm{~mm} / \mathrm{s}$ the success rate dropped significantly below $70 \%$. The authors concluded that professional nurseries dealing with automated tomato grafting should use a velocity close to $300 \mathrm{~mm} / \mathrm{s}$, which results in significantly higher speeds compared to manual grafting by expert workers while securing high success rates. Moreover, Wei et al. [9] carried out a glasshouse experiment to assess the physiological and molecular responses of supplementary light intensity $\left(50,100\right.$, or $150 \mu \mathrm{mol} \mathrm{m}^{-2} \mathrm{~s}^{-1}$ PPFD) for a period of 10 days on grafted tomato seedlings ('Super Sunload' and 'Super Dotaerang') grafted onto the commercial rootstock 'B-Blocking'. Light intensity of 100 or $150 \mu \mathrm{mol} \mathrm{m}{ }^{-2} \mathrm{~s}^{-1}$ boosted the seedling performance of tomato in terms of fresh and dry biomass, leaf area, SPAD index and root biomass compared to those supplied with $50 \mu \mathrm{mol} \mathrm{m}^{-2} \mathrm{~s}^{-1}$, with no significant differences observed between the 100 and $150 \mu \mathrm{mol} \mathrm{m} \mathrm{m}^{-2} \mathrm{~s}^{-1}$ LED treatments. A putative mechanism involved in the superior seedling performance at 100 and $150 \mu \mathrm{mol} \mathrm{m} \mathrm{m}^{-2} \mathrm{~s}^{-1}$ implicates the enhanced expression of photosynthesis-related genes PsaA and PsbA compared to their expression at $50 \mu \mathrm{mol} \mathrm{m}^{-2} \mathrm{~s}^{-1}$. The authors concluded that supplemental light at $100 \mu \mathrm{mol} \mathrm{m}^{-2} \mathrm{~s}^{-1}$ should be adopted by growers to achieve grafted tomato seedlings of high quality.

Noor et al. [10] conducted a two-year experiment on greenhouse cucumber, where four rootstocks (bitter gourd, bottle gourd, pumpkin and ridge gourd) and five grafting techniques (hole insertion, splice grafting, single cotyledon, tongue approach and self-rooted control) were tested. Grafting cucumber plants onto bottle gourd significantly increased plant survival rates and yield performance compared to the other rootstocks, most successfully by employing the splice grafting followed by tongue approach, single cotyledon and finally the hole insertion approach. The interactive effects of grafting technique and rootstock combination were less pronounced on fruit quality attributes, since besides the improvement of fruit mineral composition, the fruit dry matter and other quality traits were not significantly influenced by either of the tested factors. Concerning an important solanaceous species such as eggplant, Sabatino et al. [11] investigated the rootstock effect of two accessions of Solanum aethiopicum gr. gilo and the interspecific hybrid S. melongena $\times$ S. aehtiopicum gr. gilo on the vigor, productivity and fruit quality composition of eggplants compared to the most commonly used rootstock $S$. torvum. The results of their study clearly showed that $S$. melongena $\times S$. aehtiopicum gr. Gilo demonstrated high compatibility and improved the grafting success, vigor, earliness and marketable yield without detrimental effect on nutritional quality traits; thus, they indicated that this interspecific hybrid could be considered a potential rootstock for eggplant that may replace the most commonly used S. torvum. The synergistic effect of grafting and arbuscular mycorrhizal fungi (AMF) on crop performance and fruit quality was also demonstrated by Sabatino et al. [12] on greenhouse eggplant. Although, the beneficial effect of grafted (onto S. torvum, S. macrocarpon and S. paniculatum) and inoculated plants was only evident with respect to yield and yield-related components, compared to non-grafted and non-inoculated controls, synergistic action between grafting and AMF was only recorded on the nutritional and functional quality of eggplant fruit. Sabatino and co-workers [12] demonstrated that grafting eggplant onto S. torvum or S. paniculatum boosted significantly the synthesis and concentration of antioxidant molecules, such as ascorbic and chlorogenic acids, and reduced the accumulation of glycoalkaloids. Similar results were also observed in eggplant grafted onto two tomato (Emperador and Optifort) and four Solanum (S. torvum, S. integrifolium, S. grandiflorum $\times$ S. melongena and S. melongena $\times$ S. integrifolium) rootstocks, which resulted in higher consumer fruit quality parameters compared to non-grafted and self-grafted plants [13]. Particularly, greenhouse eggplant grafted onto tomato rootstocks exhibited the lowest pulp color difference and oxidation potential, while the sweetest taste during the sensory evaluation was recorded in eggplant fruits harvested from plants grafted onto S. torvum. Concerning watermelon, Kyriacou et al. [14] investigated how interspecific pumpkin and bottle gourd rootstocks interact with two diploid and two triploid mini-watermelon scions and one large-fruited diploid scion with respect to yield and physicochemical traits and bioactive compounds at harvest and following postharvest storage at $25^{\circ} \mathrm{C}$ for 10 days. Watermelon plants grafted onto the interspecific hybrid had improved yield, fruit lycopene content and firmness accompanied with minimal reduction in sugars compared to those grafted onto 
bottle gourd rootstock. The authors also demonstrated that ambient postharvest storage for 10 days boosted pulp lycopene levels.

Vegetable grafting is also developing around the globe as a means to overcome abiotic and biotic stresses which are responsible for $70 \%$ and $30 \%$ of the yield gap, respectively [15]. Among the major abiotic stresses, salinity and drought are the ones forecasted to rise due to global climate change [15]. In their review, Singh et al. [16] summarized the main physiological and biochemical mechanisms of grafting tomato to improve salt tolerance. The effectiveness of grafting in imparting tomato tolerance/resistance to soil and/or water salinity has been associated to several, biochemical, physiological and molecular mechanisms at scion and rootstock levels: (i) sodium and/or chloride exclusion; (ii) high photosynthetic, proline or antioxidant activities (APX, CAT); (iii) useful QTL's; (iv) increased content of abscisic acid, cytokinines and reduced content of ethylene precursor; as well as (v) increased root growth, length and root-to-shoot ratio [16]. Moreover, Modarelli et al. [17] evaluated the response to salinity ( $150 \mathrm{mM} \mathrm{NaCl}$ and a non-saline control) in different melon, watermelon, bottle gourd, luffa, Cucurbita maxima and interspecific C. maxima $\times$ C. moschata rootstocks in terms of plant growth parameters and photosynthetic pigments (chlorophyll and carotenoids). The authors demonstrated that luffa, melon, watermelon and bottle gourd rootstocks were salt sensitive, whereas interspecific hybrid (CMM-R2), melon genotypes (CM6, CM7, CM10, and CM16), along with watermelon (CV2 and CV6) and bottle gourd (LS4) were salt tolerant and proposed as candidate salt-resistant rootstocks to be introduced into breeding programs. Urlic et al. [18] showed that tomato plants grafted onto commercial rootstocks such as Emperador and Maxifort were able to increase yield under both optimal and sub-optimal (deficit irrigation [DI] or partial root-zone drying [PRDZ]) conditions. Interestingly, grafted tomato plants grown under DI exhibited minimal yield reduction compared to the full irrigation water regime, while water use efficiency was highly improved by the combination of grafting and DI or PRZD treatments. Furthermore, Allevato et al. [19] demonstrated in a hydroponic experiment that grafting melon cultivar Proteo onto two intraspecific (Dinero and Magnus) and three interspecific (RS841, Shintoza and Strong Tosa) hybrids was able to mitigate the detrimental effect of a heavy metal such as arsenic. Interspecific hybrid RS841 was the most efficient rootstock in securing crop productivity under heavy metal conditions and was also able to reduce the translocation of arsenic to the fruits.

Concerning the implications of grafting for improving tolerance/resistance to biotic stress, Cardarelli et al. [20] reviewed the potential benefits of grafting in boosting tolerance/resistance to soil borne diseases through modulation of indigenous suppressive microbial communities. In their review, the authors summarized the main disease-resistance/tolerance mechanisms identified in grafted vegetable plants grown in soil infested by pathogens as follows: (i) modulation of the root system architecture; (ii) antifungal rhizodeposits; (iii) microbial barrier; and (iv) sap flow modification. Notwithstanding, the enormous significance of grafting as a means for securing yield stability and quality in vegetables crops, commercial its practice has heavily centered on the production of high-value solanaceous and cucurbit crops. Among future perspectives is the extension of grafting practice to other seasonal crops including combinations where both rootstock and scion deliver harvestable products. In this respect, Gong et al. [21] explored the feasibility of a novel graft within the Brassicaceae family involving pac choi (Brassica rapa L. var. chinensis) and daikon radish (Raphanus sativus L. var. longipinnatus) to create a plant with harvestable leafy pac choi above ground and daikon radish taproot below ground. Grafted pac choi-daikon demonstrated no decrease in SPAD value, canopy size, leaf number, leaf area, or aboveground weight compared to self-grafted pac choi plants. Taproot formation (length, diameter, fresh and dry weight), however, was reduced by comparison to non- and self-grafted daikon radish plants. This innovative pilot study nevertheless demonstrated the potential of creating harvestable rootstock-scion combinations as a means of saving growth space and minimizing waste. Such unique grafting model systems may assist in elucidating scion-rootstock synergy and sink competition in horticultural crops. 
Author Contributions: Conceptualization, M.C.K., G.C. and Y.R.; writing-original draft preparation, M.C.K., G.C. and Y.R.; writing-review and editing, M.C.K., G.C. and Y.R. All authors have read and agreed to the published version of the manuscript.

Funding: This research received no external funding.

Conflicts of Interest: The authors declare no conflict of interest.

\section{References}

1. Kyriacou, M.C.; Soteriou, G.A.; Rouphael, Y.; Siomos, A.S.; Gerasopoulos, D. Configuration of watermelon fruit quality in response to rootstock-mediated harvest maturity and postharvest storage. J. Sci. Food Agric. 2016, 96, 2400-2409. [CrossRef] [PubMed]

2. Kyriacou, M.C.; Rouphael, Y.; Colla, G.; Zrenner, R.M.; Schwarz, D. Vegetable grafting: The implications of a growing agronomic imperative for vegetable fruit quality and nutritive value. Front. Plant Sci. 2017, 8, 741. [CrossRef] [PubMed]

3. Colla, G.; Rouphael, Y.; Cardarelli, M.; Temperini, O.; Rea, E.; Salerno, A.; Pierandrei, F. Influence of grafting on yield and fruit quality of pepper (Capsicum annuum L.) grown under greenhouse conditions. Acta Hortic. 2008, 782, 359-363. [CrossRef]

4. Kumar, P.; Rouphael, Y.; Cardarelli, M.; Colla, G. Vegetable grafting as a tool to improve drought resistance and water use efficiency. Front. Plant Sci. 2017, 8, 1130. [CrossRef] [PubMed]

5. Rouphael, Y.; Venema, J.H.; Edelstein, M.; Savvas, D.; Colla, G.; Ntatsi, G.; Ben-Hur, M.; Kumar, P.; Schwarz, D. Grafting as a tool for tolerance of abiotic stress. In Vegetable Grafting: Principles and Practices; Colla, G., Pérez-Alfocea, F., Schwarz, D., Eds.; CAB International: Oxfordshire, UK, 2017; pp. 171-215. [CrossRef]

6. Lee, J.M.; Kubota, C.; Tsao, S.J.; Bie, Z.; Hoyos Echevarria, P.; Morra, L.; Oda, M. Current status of vegetable grafting: Diffusion, grafting techniques, automation. Sci. Hortic. 2010, 127, 93-105. [CrossRef]

7. Pardo-Alonso, J.L.; Carreño-Ortega, Á.; Martínez-Gaitán, C.C.; Callejón-Ferre, Á.J. Combined influence of cutting angle and diameter differences between seedlings on the grafting success of tomato using the splicing technique. Agronomy 2019, 9, 5. [CrossRef]

8. Pardo-Alonso, J.L.; Carreño-Ortega, A.; Martínez-Gaitán, C.C.; Golasi, I.; Gómez Galán, M. Conventional industrial robotics applied to the process of tomato grafting using the splicing technique. Agronomy 2019, 9, 880. [CrossRef]

9. Wei, H.; Zhao, J.; Hu, J.; Jeong, B.R. Effect of supplementary light intensity on quality of grafted tomato seedlings and expression of two photosynthetic genes and proteins. Agronomy 2019, 9, 339. [CrossRef]

10. Noor, R.S.; Wang, Z.; Umair, M.; Yaseen, M.; Ameen, M.; Rehman, S.U.; Khan, M.U.; Imran, M.; Ahmed, W.; Sun, Y. Interactive effects of grafting techniques and scion-rootstocks combinations on vegetative growth, yield and quality of cucumber (Cucumis sativus L.). Agronomy 2019, 9, 288. [CrossRef]

11. Sabatino, L.; Iapichino, G.; Rotino, G.; Palazzolo, E.; Mennella, G.; D’Anna, F. Solanum aethiopicum gr. gilo and its interspecific hybrid with S. melongena as alternative rootstocks for eggplant: Effects on vigor, yield, and fruit physicochemical properties of cultivar 'Scarlatti'. Agronomy 2019, 9, 223. [CrossRef]

12. Sabatino, L.; Iapichino, G.; Consentino, B.P.; D'Anna, F.; Rouphael, Y. Rootstock and arbuscular mycorrhiza combinatorial effects on eggplant crop performance and fruit quality under greenhouse conditions. Agronomy 2020, 10, 693. [CrossRef]

13. Mozafarian, M.; Ismail, N.S.B.; Kappel, N. Rootstock effects on yield and some consumer important fruit quality parameters of eggplant cv. 'Madonna' under protected cultivation. Agronomy 2020, 10, 1442. [CrossRef]

14. Kyriacou, M.C.; Soteriou, G.A.; Rouphael, Y. Modulatory effects of interspecific and gourd rootstocks on crop performance, physicochemical quality, bioactive components and postharvest performance of diploid and triploid watermelon scions. Agronomy 2020, 10, 1396. [CrossRef]

15. Rouphael, Y.; Kyriacou, M.; Colla, G. Vegetable grafting: A toolbox for securing yield stability under multiple stress conditions. Front. Plant Sci. 2018, 8, 2255. [CrossRef] [PubMed]

16. Singh, H.; Kumar, P.; Kumar, A.; Kyriacou, M.C.; Colla, G.; Rouphael, Y. Grafting tomato as a tool to improve salt tolerance. Agronomy 2020, 10, 263. [CrossRef] 
17. Modarelli, G.C.; Rouphael, Y.; De Pascale, S.; Öztekin, G.B.; Tüzel, Y.; Orsini, F.; Gianquinto, G. Appraisal of salt tolerance under greenhouse conditions of a Cucurbitaceae genetic repository of potential rootstocks and scions. Agronomy 2020, 10, 967. [CrossRef]

18. Urlić, B.; Runjić, M.; Mandušić, M.; Žanić, K.; Selak, G.V.; Matešković, A.; Dumičić, G. Partial root-zone drying and deficit irrigation effect on growth, yield, water use and quality of greenhouse grown grafted tomato. Agronomy 2020, 10, 1297. [CrossRef]

19. Allevato, E.; Mauro, R.P.; Stazi, S.R.; Marabottini, R.; Leonardi, C.; Ierna, A.; Giuffrida, F. Arsenic accumulation in grafted melon plants: Role of rootstock in modulating root-to-shoot translocation and physiological response. Agronomy 2019, 9, 828. [CrossRef]

20. Cardarelli, M.; Rouphael, Y.; Kyriacou, M.C.; Colla, G.; Pane, C. Augmenting the sustainability of vegetable cropping systems by configuring rootstock-dependent rhizomicrobiomes that support plant protection. Agronomy 2020, 10, 1185. [CrossRef]

21. Gong, T.; Ray, Z.T.; Butcher, K.E.; Black, Z.E.; Zhao, X.; Brecht, J.K. A novel graft between Pac Choi (Brassica rapa var. chinensis) and Daikon Radish (Raphanus sativus var. longipinnatus). Agronomy 2020, 10, 1464. [CrossRef]

Publisher's Note: MDPI stays neutral with regard to jurisdictional claims in published maps and institutional affiliations.

(C) 2020 by the authors. Licensee MDPI, Basel, Switzerland. This article is an open access article distributed under the terms and conditions of the Creative Commons Attribution (CC BY) license (http://creativecommons.org/licenses/by/4.0/). 



\title{
A Novel Graft between Pac Choi (Brassica rapa var. chinensis) and Daikon Radish (Raphanus sativus var. longipinnatus)
}

\author{
Tian Gong, Zachary T. Ray, Kylee E. Butcher, Zachary E. Black, Xin Zhao * and Jeffrey K. Brecht \\ Horticultural Sciences Department, University of Florida, Gainesville, FL 32611, USA; tiangong@ufl.edu (T.G.); \\ ray.ztyler@ufl.edu (Z.T.R.); kbutcher@ufl.edu (K.E.B.); zackblack@ufl.edu (Z.E.B.); jkbrecht@ufl.edu (J.K.B.) \\ * Correspondence: zxin@ufl.edu; Tel.: +1-352-273-4773
}

Received: 15 August 2020; Accepted: 16 September 2020; Published: 24 September 2020

\begin{abstract}
Vegetable grafting has primarily been used in the commercial production of high-value crops in the Solanaceae and Cucurbitaceae families. In this study, we explored the feasibility of making a novel graft between pac choi (Brassica rapa L. var. chinensis) and daikon radish (Raphanus sativus L. var. longipinnatus) to create a plant with harvestable pac choi leafy vegetable above-ground, and a daikon radish taproot below-ground. 'Mei Qing Choi' pac choi (scion) was grafted onto 'Bora King' daikon radish (rootstock). Grafted pac choi-daikon radish plants did not show a decrease in SPAD value, canopy size, leaf number, leaf area, or above-ground weight compared with self-grafted pac choi plants. However, taproot formation was reduced in grafted pac choi-daikon radish plants, as shown by decreased taproot length, diameter, fresh weight, and dry weight compared with non- and self-grafted daikon radish plants. Surprisingly, grafting with radish increased the photosynthetic rate of the pac choi. This pilot study demonstrated the potential of creating a new pac choi-daikon radish vegetable product to help save growing space and minimize waste at consumption, as pac choi roots are not eaten and radish leaves are usually discarded. The inter-generic grafting between $B$. rapa var. chinensis and $R$. sativus var. longipinnatus could also provide a unique model system to help elucidate scion-rootstock synergy and above- and below-ground sink competition in horticultural crops.
\end{abstract}

Keywords: Brassicaceae; growth; mineral content; photosynthesis; rootstock; taproot

\section{Introduction}

Grafting has become an effective practice in the production of high-value solanaceous and cucurbitaceous vegetables to help overcome biotic and abiotic stresses and improve crop productivity [13]. Although grafting also has been used as a tool in plant physiology studies of Arabidopsis (Arabidopsis thaliana L.) [4], for accelerating the breeding work of common beans (Phaseolus vulgaris L.) [5], and for combating Verticillium wilt of globe artichoke (Cynara cardunculus L. subsp. Scolymus) [6], grafting in other vegetable species beyond Solanaceae and Cucurbitaceae is generally not practiced commercially. Interestingly, some attempts have been made to explore the feasibility of grafting vegetable plants in Brassicaceae. Oda et al. [7] tested inter-varietal, inter-specific, and inter-generic grafting among cabbage (Brassica oleracea L. var. capitata), kale (Brassica oleracea var. sabellica), kohlrabi (Brassica oleracea var. gongylodes), Chinese cabbage (Brassica rapa L. subsp. pekinensis), turnip (Brassica rapa subsp. rapa), Japanese mustard (Takana) (Brassica juncea L. var. integrifolia), and Japanese radish (Raphanus sativus L. var. longipinnatus) and obtained successful grafts. Particularly, an adhesive and hardener system was developed for making grafts between Chinese cabbage (scion) and turnip (rootstock) [8]. Recently, Chen et al. [9] evaluated the survival rate of cabbage grafted onto Chinese kale (B. oleracea Alboglabra group) rootstocks and assessed the feasibility of using grafting to improve cabbage head quality. 
The effort of cruciferous vegetable grafting has not only broadened the potential use of vegetable grafting as a management tool, but also presents the possibility of creating a novel vegetable product with added value. In the case of grafted Chinese cabbage/turnip plants, the above-ground portion of Chinese cabbage- - leafy vegetable, and the below-ground portion of turnip-a root vegetable, can be harvested from the same plant. This type of rootstock-scion combination holds promise for space saving in small-scale intensive cultivation systems. Moreover, the grafted Chinese cabbage/turnip vegetable may possess added economic value with minimal waste, since many consumers may prefer not to eat turnip leaves and could be drawn to the novelty of this new product. However, the Chinese cabbage and turnip grafting study of Oda and Nakajima [8] only reported a 50\% graft survival rate and observed restricted development of the Chinese cabbage head.

In this proof of concept study, we grafted the pac choi (B. rapa var. chinensis) scion onto the daikon radish ( $R$. sativus var. longipinnatus) rootstock to generate a vegetable plant that produced a pac choi leafy vegetable above-ground and an edible daikon radish root below-ground. Pac choi and daikon radish are among specialty vegetables increasingly grown for local markets in the U.S. Although edible, daikon radish leaves are often discarded at consumption. Recent genetic studies supported the feasibility of making successful inter-generic grafts between B. rapa and R. sativus. Yang et al. [10] sequenced the chloroplast noncoding region and found that $R$. sativus was closely related to $B$. rapa/oleracea and proposed that Raphanus was derived from hybridization between $B$. rapa/oleracea and $B$. nigra, the two evolutionary lineages in the genus Brassica. Furthermore, the reciprocal hybridization between $R$. sativus and B. rapa has been proven viable [11]. Vigorous growth was also observed for most of the successful primary hybrids between $B$. rapa and $R$. sativus [12]. On the other hand, according to Tonosaki et al. [13], when hybridized with $R$. sativus, only one particular breeding line of B. rapa ('Shogoin-kabu') successfully produced hybrid seeds, whereas most other lines failed due to embryo breakdown.

By grafting the pac choi scion onto the daikon radish rootstock, the objectives of this pilot experiment were to examine the feasibility of developing successful grafts for harvesting both pac choi leaves and daikon radish taproot from the same plant, and to compare the growth and development of grafted plants with self-grafted and non-grafted pac choi and daikon radish plants.

\section{Materials and Methods}

Two experiments were carried out in this study. The first experiment was a pilot study to test the feasibility of grafting pac choi onto daikon radish. The second experiment was intended to provide a better understanding of above-ground growth and below-ground development of this unique scion-rootstock system over an extended post-grafting period of plant establishment. In both experiments, 'Bora King' (BK), a daikon radish with purple taproots (Johnny's Selected Seeds, Winslow, ME, USA) was used as the rootstock, while 'Mei Qing Choi' (MQ) pac choi (Johnny's Selected Seeds) was used as the scion. They were selected based on our preliminary study in which these two cultivars were found to be compatible for grafting and have similar hypocotyl diameters.

\subsection{Setup of the Pilot Experiment}

Pac choi and daikon radish were seeded on 7 and 13 November 2016, respectively. The pac choi was seeded $6 \mathrm{~d}$ earlier than the daikon radish in order to match the stem diameter of the seedlings at grafting, as the daikon radish germinated and emerged much quicker than the pac choi based on a preliminary seeding test. All the seeds were sown in 72-cell Speedling trays (Speedling Inc., Ruskin, FL, USA) and filled with Fafard-2 potting mix (Sun Gro Horticulture, Agawam, MA, USA) containing a mixture of peat moss, perlite, vermiculite, and dolomite lime. Plants were grown in a greenhouse at the University of Florida campus (Gainesville, FL, USA). Water-soluble fertilizer 20N-8.7P-16.7K (Jack's Classic; Jr Peters Inc., Allentown, PA, USA) was applied on 17 and 28 November at a nitrogen (N) concentration of $200 \mathrm{mg} \mathrm{L}^{-1}$. 
Plants were grafted on 30 November 2016 (0 d after grafting (DAG)) using the splice grafting method [1]. Twenty-four plants were grafted using seedlings with the most consistent growth. With the purpose of ensuring consistent grafting quality, only a small number of plants were grafted in this pilot experiment after earlier attempts at practicing the grafting technique. The daikon radish seedlings were severed using a double edge razor blade at approximately a 45-degree angle below cotyledons to remove the shoots, with pac choi scions cut at the hypocotyl with the same angle just above the soil surface. The cut surfaces of the pac choi scion and the daikon radish seedlings with shoot removal were conjoined using a $1.5 \mathrm{~mm}$ silicone grafting clip (Johnny's Selected Seeds). Grafted plants were then placed in a healing chamber constructed by wrapping a metal shelving unit with thin plastic film (Uline Econo-Wrapper $(0.02 \mathrm{~mm})$, Uline corporation, Pleasant Prairie, WI, USA) in a temperature-controlled room with air temperature set at $23{ }^{\circ} \mathrm{C}$ and relative humidity (RH) at $99 \%$. Light was provided by two, 54-watt T5 fluorescent lights (Philips Lighting Company, Somerset, NJ, USA) at a photosynthetic photon flux density (PPFD) of $56 \mu \mathrm{mol} \mathrm{m}{ }^{-2} \mathrm{~s}^{-1}$ at seedling canopy level for $12 \mathrm{~h}$ each day. An additional plastic tray with a wet sheet of germination paper was placed inside the healing chamber to help maintain humidity.

From 5 DAG, the healing chamber was gradually cut open and the ambient RH setting was reduced to $60 \%$. At $8 \mathrm{DAG}$, the plastic film was completely removed, and grafts remained exposed in the temperature-controlled room until 13 DAG. Water was applied to plants by filling the bottom of the tray for absorption. All the grafted plants were transferred to a greenhouse at $13 \mathrm{DAG}$, and graft survival rate was determined by counting the number of live and dead plants; only plants with turgid leaves were counted as living. At harvest, the number of surviving grafted plants was counted again for calculation of the final graft survival rate, as some plants severely declined following transplanting into pots.

At 16 DAG, surviving grafted plants were transplanted into $11.36 \mathrm{~L}$ black plastic pots (1200C; Hummert International, Earth City, MO, USA) filled with Fafard-2 soilless mix (Sun Gro Horticulture) for continued monitoring of the survival of the grafted plants. In addition, five plants of non-grafted 'Mei Qing Choi' and 'Bora King' were potted as controls. All the plants were placed on the greenhouse bench following a completely randomized design. Organic fertilizer MicroSTART60 3N-0.9P-2.5K (Perdue AgriRecycle, LLC., Seaford, DE, USA) was applied to each pot at the rate of $80 \mathrm{~g} /$ pot. Drip irrigation was used by placing one $1.89 \mathrm{~L} \mathrm{~h}^{-1}$ emitter (Woodpecker pressure compensating junior dripper; Netafim USA, Fresno, CA, USA) in each pot; plants were watered once a day for 3 min. Irrigation increased to twice per day for 2 min each time starting at 56 DAG. Insecticidal soap (Safer Brand; Woodstream Corporation, Lancaster, PA, USA) was sprayed at 56 DAG and lacewing larvae (Chrysoperla rufilabris (Neuroptera: Chrysopidae); Rincon-Vitova Insectaries, Ventura, CA, USA) were released at $64 \mathrm{DAG}$ for aphid control. The average day and night temperatures of the greenhouse during the plant growth were $22.8^{\circ} \mathrm{C}$ and $16.5^{\circ} \mathrm{C}$, respectively.

\subsection{Setup of the Follow-Up Experiment}

A follow-up experiment was conducted in 2019 to further explore the above-ground growth and below-ground taproot development in grafted pac choi-daikon radish plants. 'Mei Qing Choi' (MQ) pac choi was grafted onto 'Bora King' (BK) daikon radish (MQ/BK), while non-grafted pac choi (MQ) and daikon radish (BK) as well as self-grafted pac choi (MQ/MQ) and daikon radish (BK/BK) were used as controls. A randomized complete block design with four replications (blocks) and ten grafted plants per treatment per replication (block) was used in the grafting experiment. MQ and BK were seeded into 72-cell trays on 8 and 14 February 2019, respectively. Fish \& seaweed organic liquid fertilizer 2N-1.3P-0.8K (Neptune's Harvest, Gloucester, MA, USA) and 0N-0P-41.5K potassium sulfate (Big K; JHBiotech, Inc., Ventura, CA, USA) were applied at concentrations of $200 \mathrm{mg} \mathrm{L}^{-1} \mathrm{~N}$ and $200 \mathrm{mg} \mathrm{L}^{-1}$ $\mathrm{K}_{2} \mathrm{O}$ at the seedling growth stage on 18 and 26 Feb. Plants were grafted on 1 March 2019 using the aforementioned grafting method. Grafted plants were healed in an air-conditioned laboratory room with the same set up of healing chamber as in 2016. Supplemental light was provided for $10 \mathrm{~h}$ each 
day during the healing process. The air temperature and $\mathrm{RH}$ of the laboratory room were $23.8 \pm 0.5^{\circ} \mathrm{C}$ and $47.6 \pm 13.1 \%$. The plastic film was completely removed at 8 DAG. Water was gently sprayed onto the soil surface using a wash bottle when needed to avoid wetting foliage. All the grafted plants were moved into a greenhouse at 13 DAG where the average day and night temperatures were $27.1^{\circ} \mathrm{C}$ and $20.7^{\circ} \mathrm{C}$, respectively. Graft survival rate was determined for each grafting treatment in each replication by counting the number of live and dead plants at 17 DAG. At 19 DAG, 24 plants from each treatment with healthy and consistent growth were chosen and randomly reassigned to four blocks with six plants in each block for further evaluation of the growth of the grafted plants in a greenhouse pot study, following a randomized complete block design. Plants were transplanted into $11.36 \mathrm{~L}$ black plastic pots filled with PRO-MIX premium organic vegetable and herb mix (Premier Tech Ltd., Quakertown, PA, USA) which contained 60-75\% peat moss plus peat humus, compost, perlite, gypsum, limestone, organic fertilizer, and mycorrhizae. Drip irrigation was used by placing one $1.89 \mathrm{~L} \mathrm{~h}^{-1}$ emitter in each pot; the plants were watered twice a day for 3 min per cycle between 21 and 39 DAG and irrigation increased to $4 \mathrm{~min}$ per cycle thereafter. Adventitious roots developed from the graft union area were monitored and removed once a week as needed after the plants were transplanted into the pots.

\subsection{Plant Growth Measurements}

In the 2019 follow-up experiment, leaf relative chlorophyll content and canopy size were measured at 33 and 41 DAG. A SPAD 502 Plus Chlorophyll Meter (Spectrum Technologies, Aurora, IL, USA) was used to measure leaf relative chlorophyll content on three randomly chosen plants per treatment per block by averaging four readings obtained from two distal areas of the leaf blade for each of the two most recent mature leaves per plant. The canopy size was measured on 3 plants of $M Q / B K, M Q / M Q$, and MQ for each block using digital photographs processed with ImageJ/Fiji (version 2.0.0) [14]. A ruler held in the frame of each photograph set the scale for pixels per linear $\mathrm{cm}$ and enabled digital measurement of length and width of the plant canopy. The canopy size was then determined by multiplying the canopy length and width.

\subsection{Gas Exchange Measurements}

Gas-exchange was measured in the 2019 follow-up experiment at 34 and 46 DAG between 10:00 am and 3:00 pm by using an open gas exchange system (Li-6800; Li-Cor Inc., Lincoln, NE, USA) on three plants per treatment per block. Leaf transpiration rate $\left(\mathrm{E}, \mathrm{mmol}_{2} \mathrm{O} \mathrm{m}^{-2} \mathrm{~s}^{-1}\right)$, net $\mathrm{CO}_{2}$ assimilation rate $\left(\mathrm{A}, \mathrm{mmol} \mathrm{CO} \mathrm{m}^{-2} \mathrm{~s}^{-1}\right)$, intercellular $\mathrm{CO}_{2}$ concentration $\left(\mathrm{Ci}, \mu \mathrm{mol} \mathrm{CO}_{2} \mathrm{~mol}^{-1}\right.$ air), and stomatal conductance to water ( $\mathrm{gsw}, \mathrm{mmol} \mathrm{H}_{2} \mathrm{O} \mathrm{m}^{-2} \mathrm{~s}^{-1}$ ) were measured at steady-state on the third (fully expanded) leaf from the top of each plant [15]. The PPFD was set at $800 \mu \mathrm{mol} \mathrm{m}^{-2} \mathrm{~s}^{-1}$, with $\mathrm{CO}_{2}$ concentration at $400 \mathrm{ppm}$, vapor pressure deficit at $1.2 \mathrm{kPa}$, and leaf temperature at $27-29^{\circ} \mathrm{C}$. Instantaneous water use efficiency (iWUE) $\left(\mu \mathrm{mol} \mathrm{CO}_{2} \mathrm{mmol}^{-1} \mathrm{H}_{2} \mathrm{O}\right)$ was calculated as $\mathrm{A} / \mathrm{E}$ [16] and stomatal conductance $\left(\mathrm{Gs}, \mathrm{mol} \mathrm{m}^{-2} \mathrm{~s}^{-1}\right)$ was calculated as gsw/1.6 [17].

\subsection{Yield Components and Biomass Accumulation at Harvest}

For the 2016 pilot study, the above-ground part (above soil line) of all the plants of MQ/BK, non-grafted MQ, and non-grafted BK were harvested at 68 DAG. The number of leaves longer than $4 \mathrm{~cm}$ were counted for each plant. The MQ/BK and non-grafted BK were then uprooted, and the taproots were separated and rinsed with water to remove excess potting soil from the roots. Taproot length (from the stem base to the end of the radish taproot) of each harvested plant was recorded, and the diameter of the widest part of each radish taproot was measured with a digital caliper. For the 2019 follow-up experiment, harvest and destructive sampling were carried out at 47 DAG. Five out of six plants per treatment per replication were randomly sampled. The above-ground part (above soil line) of each plant was removed from the pot, and leaves longer than $4 \mathrm{~cm}$ were counted and scanned with a leaf area meter (LI-3100; Li-Cor Inc., Lincoln, NE, USA). Only taproots from MQ/BK, BK, and BK/BK were harvested and cleaned. Pak choi and daikon radish leaves and taproots from the 2016 and 2019 
experiments were first weighed then dried at $65{ }^{\circ} \mathrm{C}$ for $7 \mathrm{~d}$ (until constant weight) to determine the above-ground and below-ground fresh and dry biomass.

\subsection{Mineral Nutrient Contents in Leaf and Root Tissues}

In the 2019 experiment, the dried root samples from the BK, BK/BK, and MQ/BK treatments and dried leaf samples from the $\mathrm{MQ}, \mathrm{MQ} / \mathrm{MQ}$, and $\mathrm{MQ} / \mathrm{BK}$ treatments were ground using a Thomas Wiley Laboratory mill (Model 4; Arthur H. Thomas Company, Philadelphia, PA, USA) and sent to Waters Agricultural Laboratories (Camilla, GA, USA) to measure the concentrations of the macronutrients N, phosphate $(\mathrm{P})$, sulfate $(\mathrm{S})$, potassium $(\mathrm{K})$, calcium $(\mathrm{Ca})$, and magnesium $(\mathrm{Mg})$ and the micronutrients boron $(\mathrm{B})$, zinc $(\mathrm{Zn})$, manganese $(\mathrm{Mn})$, iron $(\mathrm{Fe})$, and copper $(\mathrm{Cu})$. Nutrient accumulation was calculated by multiplying the nutrient concentration by dry tissue biomass.

\subsection{Statistical Analyses}

The pilot study followed a completely randomized design with five replications and one plant per replication. In the follow-up experiment, a randomized complete block design with four replications (blocks) and ten plants per experimental unit was used before plants were transplanted to larger pots, when the number was reduced to six plants per experimental unit. Data were analyzed using a linear mixed model in the GLIMMIX procedure of SAS (SAS Version 9.4 for Windows; SAS Institute, Cary, NC, USA). Some data were transformed by taking the square root to meet the assumptions of the model (normality, homogeneity, linearity) as needed, while results were presented using the original data following statistical analysis. Fisher's least significant difference (LSD) test $(\alpha=0.05)$ was conducted for multiple comparisons of different measurements among treatments.

\section{Results and Discussion}

\subsection{Graft Survival Rate}

In the 2016 pilot study, the survival rate of MQ/BK was $95.8 \%$ at 13 DAG but decreased to $87.5 \%$ at 68 DAG (data not shown). In the 2019 experiment, there was no difference in survival rate $(p=0.483)$ between BK/BK (79\%), MQ/MQ (92\%), and MQ/BK (77\%) at $17 \mathrm{DAG}$ (data not shown). The relatively high survival rates of MQ/BK indicated good graft compatibility between 'Mei Qing Choi' pac choi and 'Bora King' daikon radish. Both the edible pac choi leafy green part of the plant and the radish taproot developed in MQ/BK (Figure 1A-C). According to Oda and Nakajima [8], 'Taibyoh 60-nichi' Chinese cabbage grafted onto 'Taibyoh hikari' turnip had a survival rate of only approximately 50\%; however, it was attributed to the small size of the seedlings at grafting rather than graft incompatibility. In our studies, we also used $1.5 \mathrm{~mm}$ or even smaller grafting clips to graft younger and tender seedlings as the hypocotyl tissue of radish and pac choi plants tend to become more lignified as they grow. The lower survival rate observed in the 2019 experiment may have been due to an issue with properly matching the plant stem diameters at grafting since the hypocotyl of the daikon radish plant had grown thicker than expected at the time of grafting. As stem diameter and alignment of cambial tissues affect the success of grafting [18-20], matching plant stem diameters between these two species, which have thin hypocotyls at the optimum stage for grafting, is a challenge for achieving successful grafts. In this study, daikon radish was seeded $6 \mathrm{~d}$ earlier than pac choi to help match their stem diameters, but with less than desirable results, especially in the 2019 experiment owing to the seasonal variability of greenhouse conditions that led to unpredictable growth rate of plants. As shown by Hayashida et al. [21] and Kwack et al. [22], the hypocotyl growth of pac choi and radish seedlings can be manipulated by light quality and intensity. Employing a more controlled environment for growing seedlings until ready for grafting seems to be advisable for future work. 


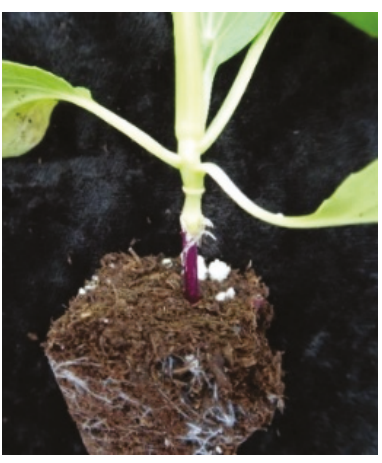

(A)

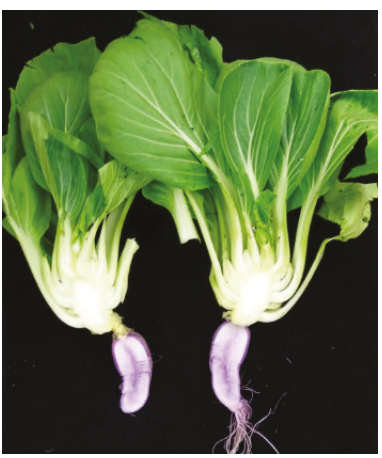

(C)

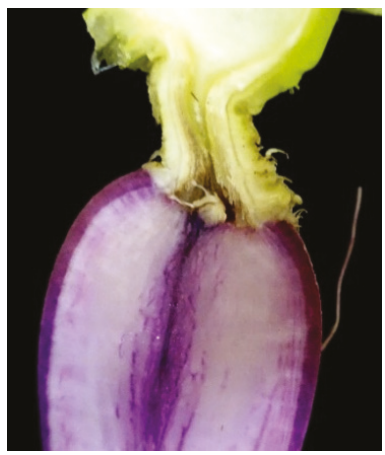

(E)

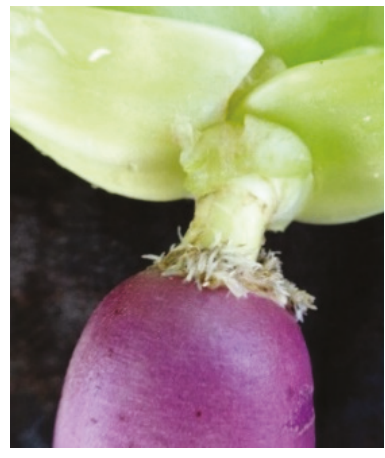

(B)

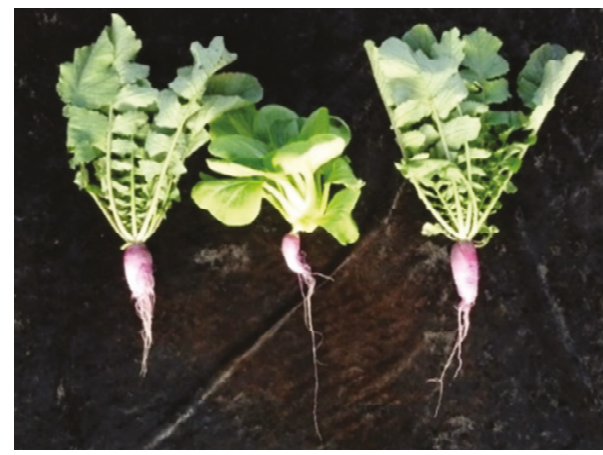

(D)

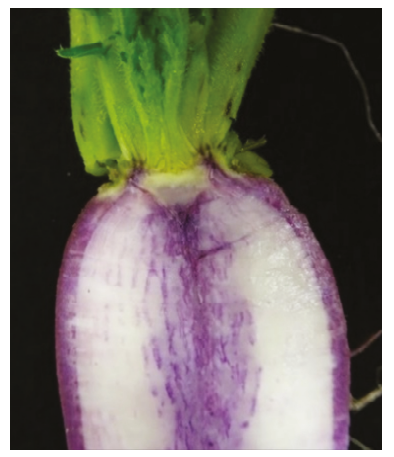

(F)

Figure 1. Cont. 


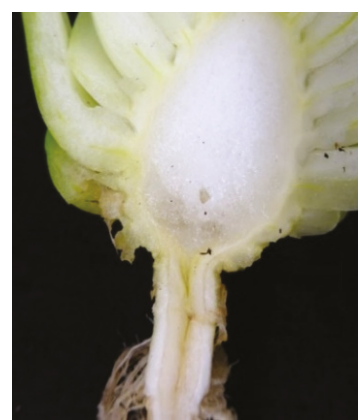

(G)

Figure 1. Grafted plants with 'Mei Qing Choi' pac choi as scion and 'Bora King' daikon radish as rootstock. (A) A well-healed grafted pac choi-daikon radish seedling. (B) Formation of the taproot of daikon radish grafted with pac choi. (C) Longitudinal section of the grafted pac choi-daikon radish plant at harvest. (D) Comparison between self-grafted 'Bora King' (left), 'Mei Qing Choi' pac choi grafted onto 'Bora King' daikon radish (middle), and non-grafted 'Bora King' (right) at harvest. (E) Longitudinal section of the graft union area of grafted pac choi-daikon radish plant at harvest.

(F) Longitudinal section of the graft union area of self-grafted 'Bora King' daikon radish at harvest.

(G) Longitudinal section of the graft union area of self-grafted 'Mei Qing Choi' pac choi plant at harvest.

\subsection{Plant Growth Parameters}

SPAD and canopy size were measured at 33 and 41 DAG in the 2019 experiment (Table 1). There was a significant difference in SPAD among treatments at 33 DAG, but no difference was found at 41 DAG. At 33 DAG, non-grafted pac choi showed lower levels of leaf SPAD values than nonand self-grafted daikon radish. The lack of difference in SPAD between MQ/BK, MQ, and MQ/MQ indicated that $\mathrm{BK}$ as a rootstock did not impair accumulation of chlorophyll by MQ. The similar canopy size between MQ/BK, MQ, and MQ/MQ at both 33 and 41 DAG (Table 1) suggested that grafting with daikon radish did not reduce the leaf growth and expansion of pac choi.

Table 1. Relative chlorophyll content and canopy size of grafted, self-grafted, and non-grafted pac choi and daikon radish plants at $33 \mathrm{~d}$ after grafting (DAG) and 41 DAG in the 2019 experiment.

\begin{tabular}{|c|c|c|c|c|}
\hline \multirow{2}{*}{ Treatment ${ }^{z}$} & \multicolumn{2}{|c|}{$\begin{array}{l}\text { Relative Chlorophyll Content } \\
\text { (SPAD) }\end{array}$} & \multicolumn{2}{|c|}{ Canopy $\left(\mathrm{cm}^{2}\right.$ Plant $\left.^{-1}\right)$} \\
\hline & 33 DAG & 41 DAG & 33 DAG & $41 \mathrm{DAG}$ \\
\hline BK & $37.2 \pm 0.8 a^{y}$ & $40.6 \pm 0.7 \mathrm{a}$ & - & - \\
\hline $\mathrm{BK} / \mathrm{BK}$ & $36.7 \pm 0.8 \mathrm{ab}$ & $40.3 \pm 0.7 \mathrm{a}$ & - & - \\
\hline MQ & $34.1 \pm 0.8 c$ & $40.7 \pm 0.7 \mathrm{a}$ & $54.26 \pm 2.71 \mathrm{a}$ & $78.32 \pm 3.35 a$ \\
\hline MQ/MQ & $34.6 \pm 0.8 b c$ & $42.1 \pm 0.7 \mathrm{a}$ & $58.90 \pm 2.71 \mathrm{a}$ & $76.90 \pm 3.35 a$ \\
\hline MQ/BK & $33.3 \pm 0.8 c$ & $40.0 \pm 0.7 \mathrm{a}$ & $52.32 \pm 2.71 \mathrm{a}$ & $75.42 \pm 3.35 \mathrm{a}$ \\
\hline$p$ value & 0.006 & 0.194 & 0.150 & 0.813 \\
\hline
\end{tabular}

${ }^{z}$ BK = Non-grafted 'Bora King' daikon radish; BK/BK = Self-grafted 'Bora King' daikon radish; MQ = Non-grafted 'Mei Qing Choi' pac choi; MQ/MQ = Self-grafted 'Mei Qing Choi' pac choi; MQ/BK = 'Mei Qing Choi' pac choi grafted onto 'Bora King' daikon radish. ${ }^{y}$ Mean \pm SE (standard error); means followed by the same letter are not significantly different at $p \leq 0.05$ according to Fisher's LSD test.

As shown in Figure 1B, above-ground pac choi and below-ground daikon radish taproot developed normally in $\mathrm{MQ} / \mathrm{BK}$ plants. We observed cavities in the vascular bundle connections at the graft union area in grafted pac choi plants with the daikon radish rootstock but not in self-grafted daikon radish plants (Figure 1E,F), similar to what was reported in grafted Chinese cabbage/turnip plants [8]. In our experiments, grafting was carried out at $16 \mathrm{~d}$ after sowing (DAS) for daikon radish and 23 DAS for pac choi. According to Liu et al. [23], as early as 16 DAS, tuberization began in turnip (B. rapa subsp. Rapa) 
and the center part of the upper hypocotyl which accounted for about $50 \%$ of the cross section area was occupied by pith cells, with an actively dividing cambium circle and a thin xylem ring. When pac choi was grafted at 23 DAS, more than $50 \%$ of the center part of the upper hypocotyl of pac choi consisted of secondary xylem cells with highly lignified cell walls. This discrepancy in hypocotyl structure between scion and rootstock seedlings likely resulted in the formation of the cavity inside the graft union during healing as observed in our study (Figure 1E), especially considering that the cavity did not exist in self-grafted daikon radish (Figure 1F) or pac choi (Figure 1G).

Leaf number and taproot length and diameter were measured at harvest in both experiments (Table 2). In the 2016 pilot study, MQ/BK had more leaves than non-grafted BK, but did not differ significantly from MQ. In the 2019 experiment, MQ/BK had 35\% and $26 \%$ more leaves than selfand non-grafted BK, respectively, but no difference was found between self- and non-grafted BK. Similar leaf numbers were observed for $\mathrm{MQ} / \mathrm{BK}, \mathrm{MQ} / \mathrm{MQ}$, and MQ. Total leaf area was also measured in the 2019 experiment and MQ/BK had smaller leaf area than all other treatments. In both 2016 and 2019, MQ/BK produced significantly shorter and smaller taproots than non-grafted BK and in 2019, $\mathrm{MQ} / \mathrm{BK}$ was also smaller in taproot diameter than BK/BK (Table 2 and Figure 1D). Our results were consistent with Zheng et al. [24], who reported that the diameter of turnip was significantly smaller when grafted with rapeseed (B. rapa subsp. oleifera) than self-grafted turnip. BK/BK did not differ significantly from BK in taproot length but was 7\% smaller in taproot diameter.

Table 2. Total leaf number and area and taproot length and diameter of grafted, self-grafted, and non-grafted pac choi and daikon radish plants at harvest in the 2016 pilot study and the 2019 experiment.

\begin{tabular}{|c|c|c|c|c|}
\hline Treatment $^{z}$ & $\begin{array}{l}\text { Leaf Number (no. } \\
\text { Plant }^{-1} \text { ) }\end{array}$ & $\begin{array}{l}\text { Leaf Area }\left(\mathrm{mm}^{2}\right. \\
\left.\text { Plant }^{-1}\right)\end{array}$ & $\begin{array}{c}\text { Taproot Length } \\
(\mathrm{cm})\end{array}$ & $\begin{array}{l}\text { Taproot Diameter } \\
\qquad(\mathrm{mm})\end{array}$ \\
\hline & \multicolumn{4}{|c|}{2016} \\
\hline BK & $18.9 \pm 2.3 b^{y}$ & - & $10.9 \pm 0.5 \mathrm{a}$ & $68.55 \pm 3.98 \mathrm{a}$ \\
\hline MQ & $26.6 \pm 2.4 \mathrm{ab}$ & - & - & - \\
\hline $\mathrm{MQ/BK}$ & $28.1 \pm 2.4 \mathrm{a}$ & - & $8.2 \pm 0.5 b$ & $51.92 \pm 3.56 b$ \\
\hline \multirow[t]{2}{*}{$p$ value } & 0.020 & & 0.005 & 0.017 \\
\hline & \multicolumn{4}{|c|}{2019} \\
\hline BK & $15.7 \pm 0.6 b$ & $2521.73 \pm 60.62 \mathrm{a}$ & $9.2 \pm 0.5 \mathrm{a}$ & $45.24 \pm 0.71 \mathrm{a}$ \\
\hline $\mathrm{BK} / \mathrm{BK}$ & $14.7 \pm 0.5 b$ & $2401.06 \pm 60.62 \mathrm{ab}$ & $8.4 \pm 0.5 \mathrm{a}$ & $42.20 \pm 0.71 b$ \\
\hline MQ & $20.4 \pm 0.6 \mathrm{a}$ & $2423.26 \pm 60.62 \mathrm{ab}$ & - & - \\
\hline MQ/MQ & $19.5 \pm 0.6 \mathrm{a}$ & $2311.67 \pm 60.62 \mathrm{~b}$ & - & - \\
\hline $\mathrm{MQ} / \mathrm{BK}$ & $19.8 \pm 0.6 \mathrm{a}$ & $2080.12 \pm 60.62 c$ & $6.8 \pm 0.5 b$ & $34.94 \pm 0.71 \mathrm{c}$ \\
\hline$p$ value & $<0.001$ & 0.002 & 0.005 & $<0.001$ \\
\hline
\end{tabular}

${ }^{\mathrm{z}}$ BK = Non-grafted 'Bora King' daikon radish; BK/BK = Self-grafted 'Bora King' daikon radish; MQ = Non-grafted 'Mei Qing Choi' pac choi; MQ/MQ = Self-grafted 'Mei Qing Choi' pac choi; MQ/BK = 'Mei Qing Choi' pac choi grafted onto 'Bora King' daikon radish. ${ }^{y}$ Mean \pm SE (standard error); means followed by the same letter are not significantly different at $p \leq 0.05$ according to Fisher's LSD test.

The primary root axis of radish consists of two anatomically distinct parts. The upper part originates from the hypocotyl whereas the lower part is true root tissue. Both lower and upper regions of the radish root thicken to form succulent tissue by increases in both cell number and cell size $[25,26]$. In this grafting experiment, the cut made on the daikon radish plant was in the thickening region of the hypocotyl as demonstrated by the longitudinal section of the graft union area of self-grafted daikon radish plant (Figure 1F). Very likely, grafting pac choi with radish shortens the hypocotyl part that could contribute to the formation of the taproot, leading to reduced taproot length compared with non-grafted radish, while self-grafting radish does not involve any loss of hypocotyl tissue. Furthermore, it has been found that in turnip the hypocotyl tissue is the main contributor to underground tuber development, and hypocotyl excision led to a lower expression level of genes controlling tuberization, leading to a substantial inhibition of tuber formation [24]. 


\subsection{Gas-Exchange Parameters}

Leaf transpiration rate, net $\mathrm{CO}_{2}$ assimilation rate, intercellular $\mathrm{CO}_{2}$ concentration, stomatal conductance, and instantaneous water use efficiency (iWUE) were compared for $M Q / B K, M Q, M Q / M Q$, $\mathrm{BK}$, and BK/BK at 34 and 46 DAG in the 2019 experiment (Table 3). No difference in leaf transpiration rate was observed at $34 \mathrm{DAG}$, while at $46 \mathrm{DAG}, \mathrm{MQ} / \mathrm{BK}$ had a similar transpiration rate as MQ and $\mathrm{MQ} / \mathrm{MQ}$, and all three treatments showed a $95 \%$ increase of transpiration rate on average than $\mathrm{BK}$ and $\mathrm{BK} / \mathrm{BK}$. Grafting significantly increased the net $\mathrm{CO}_{2}$ assimilation rate of $\mathrm{MQ} / \mathrm{BK}$ compared with $\mathrm{MQ}$ and MQ/MQ by $15 \%$ and $28 \%$, respectively, at 34 DAG, while no difference was observed between $\mathrm{MQ} / \mathrm{BK}$ and $\mathrm{BK} / \mathrm{BK}$. At $46 \mathrm{DAG}, \mathrm{MQ} / \mathrm{BK}$ showed net $\mathrm{CO}_{2}$ assimilation rate that was $48 \%$ and $45 \%$ higher than $\mathrm{MQ}$ and $\mathrm{MQ} / \mathrm{MQ}$, respectively, but it did not differ significantly from $\mathrm{BK} / \mathrm{BK}$. MQ/BK also had a $21 \%$ higher net $\mathrm{CO}_{2}$ assimilation rate than BK at $46 \mathrm{DAG}$. Very likely, MQ/BK had a stronger sink strength than $\mathrm{MQ} / \mathrm{MQ}$ and $\mathrm{MQ}$, which contributed to the higher photosynthetic rate observed [27]. Interestingly, at $34 \mathrm{DAG}, \mathrm{MQ}$ and $\mathrm{MQ} / \mathrm{MQ}$ had similar intercellular $\mathrm{CO}_{2}$ concentrations, which were significantly higher than that of other treatments. At $46 \mathrm{DAG}, \mathrm{MQ} / \mathrm{BK}, \mathrm{MQ}$, and MQ/MQ had higher intercellular $\mathrm{CO}_{2}$ concentration than $\mathrm{BK}$ and $\mathrm{BK} / \mathrm{BK}$ and the same trend was observed for stomatal conductance at $46 \mathrm{DAG}$ although no difference in stomatal conductance was detected at $34 \mathrm{DAG}$. At 34 DAG, MQ/BK had 36\% and 53\% higher iWUE than MQ and MQ/MQ, but did not differ from BK and $\mathrm{BK} / \mathrm{BK}$. However, at $46 \mathrm{DAG}, \mathrm{MQ} / \mathrm{BK}, \mathrm{MQ}$, and MQ/MQ exhibited a similar level of iWUE which was significantly lower than that of $\mathrm{BK}$ and $\mathrm{BK} / \mathrm{BK}$.

Table 3. Leaf transpiration rate (E), net $\mathrm{CO}_{2}$ assimilation rate (A), intercellular $\mathrm{CO}_{2}$ concentration (Ci), stomatal conductance (gs), and instantaneous water use efficiency (iWUE) of grafted, self-grafted, and non-grafted pac choi and daikon radish plants at $34 \mathrm{~d}$ after grafting (DAG) and 46 DAG in the 2019 experiment.

\begin{tabular}{|c|c|c|c|c|c|c|c|c|c|c|}
\hline \multirow{2}{*}{$\underset{\mathrm{y}}{\text { Treatment }}$} & \multicolumn{2}{|c|}{$\mathrm{E}\left(\mathrm{mmol} \mathrm{H}_{2} \mathrm{O} \mathrm{m}^{-2} \mathrm{~s}^{-1}\right)$} & \multicolumn{2}{|c|}{$\mathrm{A}\left(\mu \mathrm{mol} \mathrm{CO} \mathrm{CO}^{-2} \mathrm{~s}^{-1}\right)$} & \multicolumn{2}{|c|}{$\mathrm{Ci}\left(\mu \mathrm{mol} \mathrm{CO} \mathrm{mol}^{-1}\right.$ air $)$} & \multicolumn{2}{|c|}{ Gs $\left(\mathrm{mol} \mathrm{m}^{-2} \mathrm{~s}^{-1}\right)$} & \multicolumn{2}{|c|}{$\begin{array}{c}\text { iWUE }\left(\mu \mathrm{mol} \mathrm{CO}_{2} \mathrm{mmol}^{-1}\right. \\
\left.\mathrm{H}_{2} \mathrm{O}\right)^{z}\end{array}$} \\
\hline & 34 DAG & 46 DAG & 34 DAG & 46 DAG & 34 DAG & 46 DAG & 34 DAG & 46 DAG & 34 DAG & 46 DAG \\
\hline BK & $\begin{array}{c}4.81 \pm 0.71 \mathrm{a} \\
\mathrm{x}\end{array}$ & $2.80 \pm 0.79 \mathrm{~b}$ & $\begin{array}{c}21.41 \pm 0.75 \\
a\end{array}$ & $\begin{array}{c}17.22 \pm 0.89 \\
b\end{array}$ & $\begin{array}{l}298.14 \pm \\
11.10 \mathrm{~b}\end{array}$ & $\begin{array}{l}251.33 \pm \\
10.59 \mathrm{~b}\end{array}$ & $0.28 \pm 0.05 a$ & $0.15 \pm 0.05 b$ & $4.92 \pm 0.56 \mathrm{a}$ & $7.26 \pm 0.54 \mathrm{a}$ \\
\hline $\mathrm{BK} / \mathrm{BK}$ & $4.68 \pm 0.71 \mathrm{a}$ & $4.18 \pm 0.79 \mathrm{~b}$ & $\begin{array}{c}19.66 \pm 0.75 \\
\mathrm{ab}\end{array}$ & $\begin{array}{c}18.93 \pm 0.89 \\
\mathrm{ab}\end{array}$ & $\begin{array}{l}305.43 \pm \\
11.10 \mathrm{~b}\end{array}$ & $\begin{array}{c}273.09 \pm \\
10.59 \mathrm{~b}\end{array}$ & $0.27 \pm 0.05 \mathrm{a}$ & $0.25 \pm 0.05 b$ & $\begin{array}{c}4.55 \pm 0.56 \\
\mathrm{ab}\end{array}$ & $6.27 \pm 0.54 \mathrm{a}$ \\
\hline MQ & $4.95 \pm 0.71 \mathrm{a}$ & $6.61 \pm 0.79 \mathrm{a}$ & $\begin{array}{c}16.10 \pm 0.75 \\
c\end{array}$ & $\begin{array}{c}14.06 \pm 0.89 \\
c\end{array}$ & $\begin{array}{c}330.36 \pm \\
11.10 \mathrm{a}\end{array}$ & $\begin{array}{r}345.22 \pm \\
10.59 \mathrm{a}\end{array}$ & $0.32 \pm 0.05 a$ & $0.41 \pm 0.05 \mathrm{a}$ & $\begin{array}{c}3.59 \pm 0.56 \\
\mathrm{bc}\end{array}$ & $2.49 \pm 0.54 b$ \\
\hline $\mathrm{MQ} / \mathrm{MQ}$ & $5.51 \pm 0.71 \mathrm{a}$ & $6.33 \pm 0.79 a$ & $\begin{array}{c}14.41 \pm 0.75 \\
c\end{array}$ & $\begin{array}{c}14.31 \pm 0.89 \\
c\end{array}$ & $\begin{array}{c}331.63 \pm \\
11.10 \mathrm{a}\end{array}$ & $\begin{array}{c}346.80 \pm \\
10.59 \mathrm{a}\end{array}$ & $0.33 \pm 0.05 a$ & $0.40 \pm 0.05 \mathrm{a}$ & $3.20 \pm 0.56 c$ & $2.51 \pm 0.54 \mathrm{~b}$ \\
\hline $\mathrm{MQ} / \mathrm{BK}$ & $4.35 \pm 0.71 \mathrm{a}$ & $7.47 \pm 0.79 a$ & $\begin{array}{c}18.44 \pm 0.75 \\
b\end{array}$ & $\begin{array}{c}20.76 \pm 0.89 \\
a\end{array}$ & $\begin{array}{l}299.39 \pm \\
11.10 \mathrm{~b}\end{array}$ & $\begin{array}{c}336.66 \pm \\
10.59 \mathrm{a}\end{array}$ & $0.25 \pm 0.05 a$ & $0.45 \pm 0.05 a$ & $4.88 \pm 0.56 \mathrm{a}$ & $2.94 \pm 0.54 b$ \\
\hline$p$ value & 0.564 & $<0.001$ & $<0.001$ & $<0.001$ & 0.011 & $<0.001$ & 0.362 & 0.001 & 0.024 & $<0.001$ \\
\hline
\end{tabular}

${ }^{\mathrm{z}}$ Instantaneous water use efficiency (iWUE) $=$ net $\mathrm{CO}_{2}$ assimilation rate $(\mathrm{A}) /$ transpiration rate $(\mathrm{E})$. ${ }^{\mathrm{y}} \mathrm{BK}=\mathrm{Non}-\mathrm{grafted}$ 'Bora King' daikon radish; BK/BK = Self-grafted 'Bora King' daikon radish; $\mathrm{MQ}=$ Non-grafted 'Mei Qing Choi' pac choi; MQ/MQ = Self-grafted 'Mei Qing Choi' pac choi; MQ/BK = 'Mei Qing Choi' pac choi grafted onto 'Bora King' daikon radish. ${ }^{x}$ Mean \pm SE (standard error); means followed by the same letter are not significantly different at $p \leq$ 0.05 according to Fisher's LSD test.

Lower leaf transpiration rate and intercellular $\mathrm{CO}_{2}$ concentration of radish compared with pac choi observed in the later growth stage could be owing to different leaf structures. Pac choi leaves are fleshy and glossy, while radish has trichomes on both upper and lower leaf surfaces [28]. It has been suggested that trichome density is negatively related to transpiration rate and $\mathrm{CO}_{2}$ diffusion rate as trichomes can increase boundary layer resistance [29-31]. The trichomes on daikon radish leaves might have affected the leaf transpiration rates and intercellular $\mathrm{CO}_{2}$ concentrations measured in this study. Further examination is needed to directly compare the intrinsic leaf structures of pac choi and daikon radish plants for their effects on gas exchange and gas exchange measurements.

Most water loss from leaves of intact plants is generally through open stomatal apertures [32], thus the higher stomatal conductance of MQ/BK was likely the driving factor for its lower iWUE compared with $\mathrm{BK}$ and $\mathrm{BK} / \mathrm{BK}$ despite its higher net $\mathrm{CO}_{2}$ assimilation rate. It has been found in tobacco (Nicotiana tabacum L.) that stomatal conductance did not always parallel photosynthetic capacity 
changes [33,34], which could partially explain the relatively high stomata conductance, but low net $\mathrm{CO}_{2}$ assimilation rate observed in $\mathrm{MQ}$ and $\mathrm{MQ} / \mathrm{MQ}$.

\subsection{Leaf and Taproot Harvest and Biomass Partition}

In the 2016 pilot study, MQ and MQ/BK had 151\% and 104\% higher above-ground fresh weight (FW) than BK, and the former two did not differ significantly (Table 4). No difference was detected in above-ground dry weight (DW) between these three treatments. $\mathrm{MQ} / \mathrm{BK}$ produced significantly lower below-ground FW and DW compared with BK, while similar levels of total FW and DW were observed between $\mathrm{MQ} / \mathrm{BK}$ and $\mathrm{BK}$.

Table 4. Above-ground, below-ground, and total fresh weight (FW) and dry weight (DW) of grafted, self-grafted, and non-grafted pac choi and daikon radish plants at harvest in the 2016 pilot study and the 2019 experiment.

\begin{tabular}{|c|c|c|c|c|c|c|}
\hline Treatment $^{\mathrm{z}}$ & $\begin{array}{l}\text { Above-Ground } \\
\text { FW }\left(\text { g Plant }^{-1}\right)\end{array}$ & $\begin{array}{l}\text { Below-Ground } \\
\text { FW }\left(\text { g Plant }^{-1}\right)\end{array}$ & $\begin{array}{l}\text { Above-Ground } \\
\text { DW }\left(\mathrm{g}_{\text {Plant }}{ }^{-1}\right)\end{array}$ & $\begin{array}{l}\text { Below-Ground } \\
\text { DW }\left(\mathrm{g}_{\text {Plant }}{ }^{-1}\right)\end{array}$ & $\begin{array}{c}\text { Total FW (g } \\
\text { Plant }^{-1} \text { ) }\end{array}$ & $\begin{array}{c}\text { Total DW (g } \\
\left.\text { Plant }^{-1}\right)\end{array}$ \\
\hline & \multicolumn{6}{|c|}{2016} \\
\hline BK & $\underset{y}{240.07 \pm 54.58 b}$ & $332.15 \pm 33.23 \mathrm{a}$ & $20.41 \pm 2.52 \mathrm{a}$ & $19.84 \pm 1.56 \mathrm{a}$ & $572.21 \pm 67.48 \mathrm{a}$ & $41.08 \pm 4.00 \mathrm{a}$ \\
\hline MQ & $602.76 \pm 48.82 \mathrm{a}$ & - & $25.50 \pm 2.25 \mathrm{a}$ & - & - & - \\
\hline $\mathrm{MQ} / \mathrm{BK}$ & $490.63 \pm 48.82 \mathrm{a}$ & $110.44 \pm 29.72 b$ & $24.42 \pm 2.25 \mathrm{a}$ & $7.60 \pm 1.20 b$ & $601.07 \pm 60.36 \mathrm{a}$ & $32.02 \pm 3.10$ \\
\hline \multirow[t]{2}{*}{$p$ value } & 0.001 & $<0.001$ & 0.331 & $<0.001$ & 0.792 & 0.142 \\
\hline & \multicolumn{6}{|c|}{2019} \\
\hline BK & $171.64 \pm 6.62 \mathrm{~d}$ & $103.47 \pm 5.25 \mathrm{a}$ & $12.85 \pm 0.25 \mathrm{a}$ & $6.58 \pm 0.33 a$ & $275.17 \pm 4.44 b$ & $19.45 \pm 0.41$ \\
\hline $\mathrm{BK} / \mathrm{BK}$ & $162.27 \pm 6.62 \mathrm{~d}$ & $77.55 \pm 4.57 b$ & $12.34 \pm 0.25 a$ & $5.33 \pm 0.30 b$ & $239.91 \pm 4.44 c$ & $17.67 \pm 0.41 b$ \\
\hline MQ & $329.83 \pm 6.62 \mathrm{a}$ & - & $10.09 \pm 0.25 b$ & - & - & - \\
\hline $\mathrm{MQ} / \mathrm{MQ}$ & $293.51 \pm 6.62 b$ & - & $8.98 \pm 0.25 c$ & - & - & - \\
\hline $\begin{array}{l}\mathrm{MQ} / \mathrm{BK} \\
p \text { value }\end{array}$ & $\begin{array}{c}269.08 \pm 6.62 c \\
<0.001\end{array}$ & $\begin{array}{c}43.59 \pm 3.45 c \\
<0.001\end{array}$ & $\begin{array}{c}9.43 \pm 0.25 b c \\
<0.001\end{array}$ & $\begin{array}{c}2.24 \pm 0.20 \mathrm{c} \\
\quad<0.001\end{array}$ & $\begin{array}{c}312.93 \pm 4.44 \mathrm{a} \\
<0.001\end{array}$ & $\begin{array}{c}11.68 \pm 0.41 \\
<0.001\end{array}$ \\
\hline
\end{tabular}

In the 2019 study, MQ/BK showed a significant reduction in above-ground FW compared with MQ and MQ/MQ by $18 \%$ and $8 \%$, respectively (Table 4 ). MQ, MQ/MQ, and MQ/BK on average had $78 \%$ higher above-ground FW than the average of BK and BK/BK. However, BK and BK/BK had significantly higher above-ground DW than other treatments and $\mathrm{MQ} / \mathrm{BK}$ did not differ significantly in above-ground DW from MQ and MQ/MQ. Grafting with pac choi significantly decreased the below-ground FW and DW of daikon radish compared with non- and self-grafted daikon radish. $\mathrm{BK}$ had higher below-ground FW and DW than BK/BK by $33 \%$ and $23 \%$, respectively. MQ/BK exhibited a significantly higher total FW but a reduction in total DW compared with BK and BK/BK. The water content of both radish taproots and leaves was about $93 \%$, whereas it reached $97 \%$ in the pac choi leaves, indicating that the pac choi leafy part had a disproportional contribution to the FW of MQ/BK. The differences in total FW and DW between 2016 and 2019 studies may be due to the different growing seasons and the time between grafting and harvest as the period from grafting to harvesting was $45 \%$ longer in 2016 compared with the 2019 study. Overall, the two experiments suggested that grafting between 'Mei Qing Choi' pac choi and 'Bora King' daikon radish had a greater impact on radish taproot development than the influence on pac choi leaf growth as the taproot DW of $\mathrm{MQ} / \mathrm{BK}$ was significantly lower than BK, but the leaf DW was similar to that of MQ.

The grafting procedure per se negatively affected biomass accumulation in edible part in both self-grafted BK/BK and MQ/MQ compared with their non-grafted counterparts. Grafting can be viewed as mechanical wounding that triggers redistribution of the local resources or mobilization of resources from neighboring tissues to the injured part [35], which may divert the resources that could be used for plant growth. Moreover, wounding could induce jasmonic acid production, leading to suppression of mitosis [36], and thus reduce cell number and lead to reduced plant growth. 
Gibberellins (GAs) have long been known to inhibit potato tuberization possibly by their involvement in photoperiodic control of tuber formation [37,38]. Grafting potato (Solanum tuberosum L.) with tomato (Solanum lycopersicum L.) decreased stolon (underground shoot) number and length as well as tuber number, but increased the gibberellic acid $\left(\mathrm{GA}_{3}\right)$ content of stolon and tuber compared with self-grafted potato [39]. The level of GAs has also been reported to play a vital role in carrot (Daucus carota L. var. sativus) elongation and expansion [40]. Leaf application of $\mathrm{GA}_{3}$ inhibited tuberous root growth but improved shoot growth in radish, while leaf application of paclobutrazol, an inhibitor of gibberellin biosynthesis, improved taproot growth [41]. Auxin may also affect hypocotyl-tuber growth in turnip as show in in-vitro studies [23]. Peres et al. [38] grafted tomato mutants, which were incapable of certain hormone biosynthesis or photomorphogenesis, onto potato plants and suggested that failure to produce certain chemicals by the tomato mutant scion may have impeded formation of the potato tuber. Hence, modifications of signal molecules produced in and transported from pac choi may have led to reduced growth of the daikon radish taproot.

In most cases, plants partition photosynthates preferentially to vegetative organs in the early to middle growth stage and to reproductive or storage organs in late growth stage [42]. However, many root vegetable plants grow the vegetative biomass and develop the storage root at the same time, leading to a balance between them [42,43]. Grafting may disturb the source-sink balance between scion and rootstock [44]. Both the leaf apical meristem of pac choi and the taproot part of daikon radish are strong sinks [45] and possibly competed for photosynthates in the pac choi-daikon radish grafts. The source-sink relationship was likely altered to support the growth of pac choi leaves at a cost of reduction in radish taproot development in the grafted plants. The dry mass of the leafy part accounted for $81 \%$ of the total DW of MQ/BK, but for non-grafted daikon radish, the leafy part only accounted for $66 \%$ of the total DW.

For Chinese cabbage grafted onto turnip, the heading of the Chinese cabbage was restricted by the thickening of the turnip taproot, resulting in a small Chinese cabbage head when the turnip taproot was harvested [8]. This imbalance was attributed to the discrepancy in crop maturity and growth cycle requirement as the heading of the Chinese cabbage requires more time than the development of the turnip taproot. In our study, 'Mei Qing Choi' pac choi and 'Bora King' daikon radish were both fast-growing cultivars with 45 and $49 \mathrm{~d}$ to maturity, respectively (Johnny's Selected Seeds). However, we seeded the faster maturing pac choi $6 \mathrm{~d}$ earlier than the slower maturing daikon radish in order to better match their stem diameters for grafting. Further examinations are needed to elucidate the scion-rootstock interactions for grafting scenarios in which accumulated biomass of both scion (shoots) and rootstock (enlarged taproot) are harvested together for economic yield. In this special scenario, competition for water and nutrients, photosynthetic capacity, and photosynthate partitioning between above- and below-ground sinks are of particular importance. Interestingly, the reciprocal grafting experiment by Sugiura et al. [42] using Raphanus sativus genotypes with differential hypocotyl sink activities demonstrated the genotype-dependent autonomous regulation of the hypocotyl sink activity.

\subsection{Mineral Nutrient Contents in Pac Choi Leaves and Daikon Radish Roots of Grafted Plants}

Dried leaves of $\mathrm{MQ}, \mathrm{MQ} / \mathrm{MQ}$, and $\mathrm{MQ} / \mathrm{BK}$, and dried taproots of $\mathrm{BK}, \mathrm{BK} / \mathrm{BK}$, and $\mathrm{MQ} / \mathrm{BK}$ from the 2019 experiment harvest were used to examine the macronutrient and micronutrient concentrations (Table 5) and accumulation (Table 6). Leaf $\mathrm{N}$ concentration did not differ significantly between $\mathrm{MQ} / \mathrm{BK}$ and $\mathrm{MQ}$. Interestingly, MQ/MQ had a significantly higher $\mathrm{N}$ concentration in the leaf tissue compared with $\mathrm{MQ} / \mathrm{BK}$. However, this seems contradictory to the finding that $\mathrm{MQ} / \mathrm{BK}$ had a higher leaf photosynthetic rate (Table 3) than MQ/MQ. It needs to be pointed out that the entire above-ground leaf tissue was sampled for leaf nutrient analysis, whereas the most recently mature leaves were used for photosynthesis measurements. While $\mathrm{MQ} / \mathrm{BK}$ had a lower level of leaf $\mathrm{N}$ concentration in the above-ground biomass, its higher leaf photosynthetic rate could be due to remobilization of $\mathrm{N}$ compounds from the older leaves to the most recently mature leaves that were used for photosynthesis measurement [46]. Compared with non-grafted pac choi, grafting with the daikon radish rootstock 
significantly decreased $\mathrm{K}$ and $\mathrm{S}$ concentrations in the leaf tissue of pac choi (by $21 \%$ and $45 \%$, respectively), but it increased $\mathrm{Zn}$ concentration in the leaf tissue by $37 \%$. MQ/BK had significantly higher concentrations of $\mathrm{N}$ (by $14 \%$ ), K (by 30\%), Mg (by 47\%), Ca (by 38\%), B (by 36\%), and Zn (by $63 \%$ ) in the taproot compared with the average of BK and BK/BK, while there were no differences between $\mathrm{BK}$ and $\mathrm{BK} / \mathrm{BK}$. By contrast, the concentration of $\mathrm{S}$ in the taproot of $\mathrm{MQ} / \mathrm{BK}$ was reduced by $44 \%$ compared with BK and BK/BK. Overall, there was not a clear relationship between plant nutritional status and reduction of taproot in $\mathrm{MQ} / \mathrm{BK}$. Nutrient uptake of grafted pac choi-daikon radish in relation to scion-rootstock interactions is an intriguing area to explore.

Table 5. Mineral nutrient concentrations in leaves of grafted, self-grafted, and non-grafted pac choi and in taproots of grafted, self-grafted, and non-grafted daikon radish plants at harvest in the 2019 experiment.

\begin{tabular}{|c|c|c|c|c|c|c|c|c|c|c|c|}
\hline$\underset{z}{\text { Treatment }}$ & $\mathrm{N}\left(\mathrm{mg} \mathrm{g}^{-1}\right)$ & $P\left(\mathrm{mg} \mathrm{g}^{-1}\right)$ & $\mathrm{K}\left(\mathrm{mg} \mathrm{g}^{-1}\right)$ & $\underset{\left.\mathrm{g}^{-1}\right)}{\mathrm{Mg}(\mathrm{mg}}$ & $\begin{array}{c}\mathrm{Ca}(\mathrm{mg} \\
\left.\mathrm{g}^{-1}\right)\end{array}$ & $\mathrm{S}\left(\mathrm{mg} \mathrm{g}^{-1}\right)$ & B $\left(\mu \mathrm{g} \mathrm{g}^{-1}\right)$ & $\mathrm{Zn}\left(\mu \mathrm{g} \mathrm{g}^{-1}\right)$ & $\begin{array}{c}\mathrm{Mn}(\mu \mathrm{g} \\
\left.\mathrm{g}^{-1}\right)\end{array}$ & $\mathrm{Fe}\left(\mu \mathrm{g} \mathrm{g}^{-1}\right)$ & $\begin{array}{c}\mathrm{Cu}(\mu \mathrm{g} \\
\left.\mathrm{g}^{-1}\right)\end{array}$ \\
\hline & & & & & & Leaves & & & & & \\
\hline MQ & $\underset{y}{51.5 \pm 0.9 \mathrm{ab}}$ & $10.3 \pm 0.3 \mathrm{a}$ & $92.1 \pm 1.7 \mathrm{~b}$ & $6.4 \pm 0.2 \mathrm{a}$ & $30.2 \pm 1.0 \mathrm{a}$ & $15.4 \pm 0.4 \mathrm{a}$ & $44.6 \pm 1.6 \mathrm{a}$ & $77.5 \pm 3.5 \mathrm{~b}$ & $\begin{array}{c}180.4 \pm 7.1 \\
\mathrm{a}\end{array}$ & $\begin{array}{c}103.5 \pm 6.8 \\
\mathrm{a}\end{array}$ & $0.7 \pm 0.1 \mathrm{a}$ \\
\hline $\mathrm{MQ} / \mathrm{MQ}$ & $53.7 \pm 0.9 \mathrm{a}$ & $10.5 \pm 0.3 \mathrm{a}$ & $96.1 \pm 1.7 \mathrm{a}$ & $6.7 \pm 0.2 \mathrm{a}$ & $31.3 \pm 1.0 \mathrm{a}$ & $15.4 \pm 0.4 \mathrm{a}$ & $45.9 \pm 1.6 \mathrm{a}$ & $76.7 \pm 3.5 b$ & $\begin{array}{c}195.3 \pm 7.1 \\
\mathrm{a}\end{array}$ & $\begin{array}{c}101.7 \pm 6.8 \\
\mathrm{a}\end{array}$ & $0.7 \pm 0.1 \mathrm{a}$ \\
\hline $\mathrm{MQ} / \mathrm{BK}$ & $48.4 \pm 0.9 \mathrm{~b}$ & $9.7 \pm 0.3 \mathrm{a}$ & $73.1 \pm 1.7 \mathrm{c}$ & $6.4 \pm 0.2 \mathrm{a}$ & $32.0 \pm 1.0 \mathrm{a}$ & $8.5 \pm 0.4 b$ & $45.6 \pm 1.6 \mathrm{a}$ & $\begin{array}{c}106.5 \pm 3.5 \\
\mathrm{a}\end{array}$ & $\begin{array}{c}180.8 \pm 7.1 \\
\mathrm{a}\end{array}$ & $\begin{array}{c}120.1 \pm 6.8 \\
\mathrm{a}\end{array}$ & $1.1 \pm 0.1 \mathrm{a}$ \\
\hline$p$ value & 0.008 & 0.147 & $<0.001$ & 0.352 & 0.437 & $\begin{array}{l}<0.001 \\
\text { Taproot }\end{array}$ & 0.835 & $<0.001$ & 0.175 & 0.070 & 0.057 \\
\hline BK & $28.2 \pm 0.7 b$ & $7.6 \pm 0.3 \mathrm{a}$ & $51.1 \pm 2.4 \mathrm{~b}$ & $1.5 \pm 0.1 b$ & $3.3 \pm 0.2 \mathrm{~b}$ & $10.3 \pm 0.3 \mathrm{a}$ & $20.7 \pm 0.9 \mathrm{~b}$ & $63.2 \pm 3.8 \mathrm{~b}$ & $27.0 \pm 1.5 \mathrm{a}$ & $\begin{array}{c}105.2 \pm 17.9 \\
\mathrm{a}\end{array}$ & $0.9 \pm 0.2 \mathrm{a}$ \\
\hline $\mathrm{BK} / \mathrm{BK}$ & $28.2 \pm 0.7 b$ & $7.4 \pm 0.3 \mathrm{a}$ & $49.7 \pm 2.4 \mathrm{~b}$ & $1.4 \pm 0.1 \mathrm{~b}$ & $3.3 \pm 0.2 \mathrm{~b}$ & $10.6 \pm 0.3 \mathrm{a}$ & $20.2 \pm 0.9 \mathrm{~b}$ & $65.0 \pm 3.8 \mathrm{~b}$ & $23.4 \pm 1.5 \mathrm{a}$ & $\begin{array}{c}92.2 \pm 16.8 \\
\mathrm{a}\end{array}$ & $1.0 \pm 0.2 \mathrm{a}$ \\
\hline $\mathrm{MQ} / \mathrm{BK}$ & $32.2 \pm 0.7 \mathrm{a}$ & $8.1 \pm 0.3 \mathrm{a}$ & $65.7 \pm 2.4 \mathrm{a}$ & $2.2 \pm 0.1 \mathrm{a}$ & $4.6 \pm 0.2 \mathrm{a}$ & $5.9 \pm 0.3 b$ & $27.8 \pm 0.9 \mathrm{a}$ & $\begin{array}{c}104.3 \pm 3.8 \\
\mathrm{a}\end{array}$ & $25.5 \pm 1.5 \mathrm{a}$ & $\begin{array}{c}90.9 \pm 16.7 \\
a\end{array}$ & $1.1 \pm 0.2 \mathrm{a}$ \\
\hline$p$ value & 0.008 & 0.128 & 0.001 & $<0.001$ & $<0.001$ & $<0.001$ & $<0.001$ & $<0.001$ & 0.201 & 0.664 & 0.677 \\
\hline
\end{tabular}

Table 6. Mineral nutrient contents accumulated in leaves of grafted, self-grafted, and non-grafted pac choi and in taproots of grafted, self-grafted, and non-grafted daikon radish plants at harvest in the 2019 experiment.

\begin{tabular}{|c|c|c|c|c|c|c|c|c|c|c|c|}
\hline$\underset{z}{\text { Treatment }}$ & $\begin{array}{c}\mathrm{N}(\mathrm{mg} \\
\left.\text { Plant }^{-1}\right)\end{array}$ & $\begin{array}{c}\text { P(mg } \\
\left.\text { Plant }^{-1}\right)\end{array}$ & $\begin{array}{c}\mathrm{K}(\mathrm{mg} \\
\left.\text { Plant }^{-1}\right)\end{array}$ & $\begin{array}{l}\mathrm{Mg}(\mathrm{mg} \\
\left.\text { Plant }^{-1}\right)\end{array}$ & $\begin{array}{l}\text { Ca (mg } \\
\left.\text { Plant }^{-1}\right)\end{array}$ & $\begin{array}{c}\text { S (mg } \\
\left.\text { Plant }^{-1}\right)\end{array}$ & $\begin{array}{c}\text { B ( } \mu \mathrm{g} \\
\left.\text { Plant }^{-1}\right)\end{array}$ & $\begin{array}{c}\text { Zn ( } \mu g \\
\left.\text { Plant }^{-1}\right)\end{array}$ & $\begin{array}{l}\text { Mn ( } \mu g \\
\left.\text { Plant }^{-1}\right)\end{array}$ & $\begin{array}{c}\mathrm{Fe}(\mu \mathrm{g} \\
\left.\text { Plant }^{-1}\right)\end{array}$ & $\begin{array}{l}\mathrm{Cu}(\mu \mathrm{g} \\
\left.\text { Plant }^{-1}\right)\end{array}$ \\
\hline \multicolumn{12}{|c|}{$\begin{array}{l}\text { Leaves } \\
\end{array}$} \\
\hline MQ & $519.6 \pm \underset{y}{y}$ & $\begin{array}{c}104.2 \pm 3.8 \\
\mathrm{a}\end{array}$ & $\begin{array}{c}929.3 \pm 25.1 \\
\mathrm{a}\end{array}$ & $64.6 \pm 1.9 \mathrm{a}$ & $\begin{array}{c}304.6 \pm 10.8 \\
\mathrm{a}\end{array}$ & $\begin{array}{c}155.0 \pm 5.2 \\
\mathrm{a}\end{array}$ & $\begin{array}{c}450.0 \pm 21.1 \\
\mathrm{a}\end{array}$ & $\begin{array}{c}781.9 \pm 37.5 \\
\text { b }\end{array}$ & $\begin{array}{c}1819.5 \pm \\
84.7 \mathrm{a}\end{array}$ & $\begin{array}{c}1043.8 \pm \\
69.4 \mathrm{a}\end{array}$ & $6.9 \pm 1.2 \mathrm{a}$ \\
\hline $\mathrm{MQ} / \mathrm{MQ}$ & $\begin{array}{c}481.6 \pm 13.3 \\
\mathrm{ab}\end{array}$ & $93.8 \pm 3.8 \mathrm{a}$ & $\begin{array}{c}862.5 \pm 25.1 \\
\mathrm{a}\end{array}$ & $59.9 \pm 1.9 \mathrm{a}$ & $\begin{array}{c}280.7 \pm 10.8 \\
a\end{array}$ & $\begin{array}{c}138.1 \pm 5.2 \\
\text { b }\end{array}$ & $\begin{array}{c}412.9 \pm 21.1 \\
\mathrm{a}\end{array}$ & $\begin{array}{c}688.1 \pm 37.5 \\
c\end{array}$ & $\begin{array}{c}1753.8 \pm \\
84.7 \mathrm{a}\end{array}$ & $\begin{array}{c}911.5 \pm 69.4 \\
\mathrm{a}\end{array}$ & $6.4 \pm 1.2 \mathrm{a}$ \\
\hline $\mathrm{MQ} / \mathrm{BK}$ & $456.2 \pm 13.3 \mathrm{~b}$ & $91.3 \pm 3.8 \mathrm{a}$ & $\begin{array}{c}690.4 \pm 25.1 \\
b\end{array}$ & $60.1 \pm 1.9 \mathrm{a}$ & $\begin{array}{c}300.7 \pm 10.8 \\
\mathrm{a}\end{array}$ & $79.7 \pm 5.2 \mathrm{c}$ & $\begin{array}{c}429.8 \pm 21.1 \\
\mathrm{a}\end{array}$ & $\begin{array}{c}1003.4 \pm \\
37.5 \mathrm{a}\end{array}$ & $\begin{array}{c}1707.4 \pm \\
84.7 \mathrm{a}\end{array}$ & $\begin{array}{c}1133.1 \pm \\
69.4 \mathrm{a}\end{array}$ & $10.5 \pm 1.2 \mathrm{a}$ \\
\hline \multicolumn{12}{|c|}{ Taproot } \\
\hline BK & $185.3 \pm 5.7 \mathrm{a}$ & $49.9 \pm 1.5 \mathrm{a}$ & $\begin{array}{c}333.8 \pm 11.5 \\
\mathrm{a}\end{array}$ & $9.9 \pm 0.3 \mathrm{a}$ & $21.8 \pm 0.5 \mathrm{a}$ & $67.4 \pm 2.4 \mathrm{a}$ & $\begin{array}{c}135.3 \pm 4.1 \\
\text { a }\end{array}$ & $\begin{array}{c}414.8 \pm 15.9 \\
\text { a }\end{array}$ & $\begin{array}{c}178.4 \pm 10.0 \\
\mathrm{a}\end{array}$ & $\begin{array}{l}723.3 \pm \\
106.9 \mathrm{a}\end{array}$ & $6.0 \pm 1.2 \mathrm{a}$ \\
\hline $\mathrm{BK} / \mathrm{BK}$ & $150.2 \pm 5.7 b$ & $39.3 \pm 1.5 b$ & $\begin{array}{c}264.5 \pm 11.5 \\
b\end{array}$ & $7.7 \pm 0.3 b$ & $17.3 \pm 0.5 b$ & $56.4 \pm 2.4 \mathrm{~b}$ & $\begin{array}{c}107.5 \pm 4.1 \\
\mathrm{~b}\end{array}$ & $\begin{array}{c}346.6 \pm 15.9 \\
b\end{array}$ & $\begin{array}{c}124.4 \pm 10.0 \\
\mathrm{~b}\end{array}$ & $\begin{array}{l}503.8 \pm \\
106.9 \mathrm{ab}\end{array}$ & $5.5 \pm 1.2 \mathrm{a}$ \\
\hline $\mathrm{MQ} / \mathrm{BK}$ & $72.1 \pm 5.7 \mathrm{c}$ & $18.3 \pm 1.5 \mathrm{c}$ & $\begin{array}{c}148.2 \pm 11.5 \\
c\end{array}$ & $4.8 \pm 0.3 c$ & $10.2 \pm 0.5 \mathrm{c}$ & $13.2 \pm 2.4 \mathrm{c}$ & $62.9 \pm 4.1 \mathrm{c}$ & $\begin{array}{c}235.2 \pm 15.9 \\
c\end{array}$ & $57.8 \pm 10.0 c$ & $\begin{array}{l}207.3 \pm \\
106.9 \mathrm{~b}\end{array}$ & $2.5 \pm 1.2 \mathrm{a}$ \\
\hline$p$ value & $<0.001$ & $<0.001$ & $<0.001$ & $<0.001$ & $<0.001$ & $<0.001$ & $<0.001$ & $<0.001$ & $<0.001$ & 0.027 & 0.120 \\
\hline
\end{tabular}

With respect to leaf nutrient accumulation, $\mathrm{MQ} / \mathrm{BK}$ had $37 \%$ greater $\mathrm{Zn}$ accumulation compared with the average of MQ/MQ and MQ (Table 6). However, MQ/BK decreased N, K, and S content by $12 \%, 26 \%$, and $49 \%$, respectively, compared with MQ. In terms of nutrient accumulation in the taproot, $\mathrm{MQ} / \mathrm{BK}$ showed significantly lower accumulation of all measured minerals except $\mathrm{Fe}$ and $\mathrm{Cu}$ relative to $\mathrm{BK}$ and $\mathrm{BK} / \mathrm{BK}$, which was likely associated with the small size of the taproot in $\mathrm{MQ} / \mathrm{BK}$. The lower accumulation of nutrients in the taproot demonstrated that pac choi-daikon radish favored growth of the pac choi leaves at the expense of the radish taproot. 


\section{Conclusions}

Successful grafts were produced between B. rapa var. chinensis and $R$. sativus var. longipinnatus in this study, resulting in a novel 'pac choi-daikon radish' product that may help save growing space and have added-value as perceived by farmers and consumers. More research is needed to optimize the seeding time and management of seedling production to help further improve the graft survival rate. Grafting pac choi with daikon radish did not severely impair the growth of the above-ground parts as grafted pac choi had similar SPAD value, canopy size, leaf number, and above-ground DW compared with non-grafted pac choi. Interestingly, grafting with radish increased the photosynthetic ability of the pac choi. However, grafting the daikon radish with pac choi decreased the taproot formation as reflected by the reduced length, diameter, FW and DW of the taproot. Future studies could explore different approaches such as cultivar selection and nutrient management to better balance the sizes of the above- and below-ground parts of this new pac choi-daikon radish product. Given the wide range of B. rapa var. chinensis and R. sativus var. longipinnatus cultivars, it would be interesting to explore different grafting combinations to characterize the range of graft performance. We only tested the graft performance under greenhouse conditions, and the grafted plants need to be further evaluated in field growing systems where biotic and abiotic stressors can be intensified. Generally, grafting between pac choi and daikon radish showed more negative impacts on mineral nutrient levels in radish taproots than in pac choi leaves. Sensory properties of the 'pac choi-daikon radish' product are unknown, and this aspect deserves further assessment. The inter-generic grafting between B. rapa var. chinensis and $R$. sativus var. longipinnatus could also provide a unique model system to further our understanding of scion-rootstock synergy and above- and below-ground sink competition in horticultural crops toward improving the use of grafting technology in sustainable vegetable production.

Author Contributions: Conceptualization, X.Z.; Data curation, T.G., Z.T.R. and K.E.B.; Formal analysis, T.G.; Funding acquisition, X.Z.; Investigation, T.G., Z.T.R. and K.E.B.; Methodology, T.G., Z.T.R., Z.E.B. and X.Z.; Project administration, X.Z.; Resources, X.Z. and J.K.B.; Supervision, X.Z. and J.K.B.; Writing-original draft, T.G. and X.Z.; Writing-review \& editing, T.G., Z.T.R., K.E.B., Z.E.B., X.Z. and J.K.B. All authors have read and agreed to the published version of the manuscript.

Funding: This work is partly supported by the Specialty Crop Research Initiative grant No. 2016-51181-25404 from the USDA National Institute of Food and Agriculture.

Conflicts of Interest: The authors declare no conflict of interest.

\section{References}

1. Lee, J.M.; Kubota, C.; Tsao, S.J.; Bie, Z.; Echevarria, P.H.; Morra, L.; Oda, M. Current status of vegetable grafting: Diffusion, grafting techniques, automation. Sci. Hortic. 2010, 127, 93-105. [CrossRef]

2. Louws, F.J.; Rivard, C.L.; Kubota, C. Grafting fruiting vegetables to manage soilborne pathogens, foliar pathogens, arthropods and weeds. Sci. Hortic. 2010, 127, 127-146. [CrossRef]

3. Guan, W.; Zhao, X.; Hassell, R.; Thies, J. Defense mechanisms involved in disease resistance of grafted vegetables. HortScience 2012, 47, 164-170. [CrossRef]

4. Chen, A.; Komives, E.A.; Schroeder, J.I. An improved grafting technique for mature Arabidopsis plants demonstrates long-distance shoot-to-root transport of phytochelatins in Arabidopsis. Plant Physiol. 2006, 141, 108-120. [CrossRef]

5. Gurusamy, V.; Bett, K.E.; Vandenberg, A. Grafting as a tool in common bean breeding. Can. J. Plant Sci. 2010, 90, 299-304. [CrossRef]

6. Temperini, O.; Calabrese, N.; Temperini, A.; Rouphael, Y.; Tesi, R.; Lenzi, A.; Carito, A.; Colla, G. Grafting artichoke onto cardoon rootstocks: Graft compatibility, yield and Verticillium wilt incidence. Sci. Hortic. 2013, 149, 22-27. [CrossRef]

7. Oda, M.; Tsuji, K.; Nagaoka, M. Inter-generic, inter-specific and inter-varietal grafting in Cruciferae. Acta Hortic. 1990, 319, 425-430. [CrossRef]

8. Oda, M.; Nakajima, T. Adhesive grafting of Chinese cabbage on turnip. HortScience 1992, 27, 1136. [CrossRef] 
9. Chen, Y.C.; Chang, W.C.; Wang, S.T.; Lin, S.I. Development of a grafting method and healing conditions to improve cabbage head quality. HortTechnology 2019, 29, 57-64. [CrossRef]

10. Yang, Y.W.; Tai, P.Y.; Chen, Y.; Li, W.H. A study of the phylogeny of Brassica rapa, B. nigra, Raphanus sativus, and their related genera using noncoding regions of chloroplast DNA. Mol. Phylogenet. Evol. 2002, 23, 268-275. [CrossRef]

11. Matsuzawa, Y.; Funayama, T.; Kamibayashi, M.; Konnai, M.; Bang, S.W.; Kaneko, Y. Synthetic Brassica rapa-Raphanus sativus amphidiploid lines developed by reciprocal hybridization. Plant Breed. 2000, 119, 357-359.

12. Lange, W.; Toxopeus, H.; Lubberts, J.H.; Dolstra, O.; Harrewijn, J.L. The development of Raparadish (x Brassicoraphanus, 2n =38), a new crop in agriculture. Euphytica 1989, 40, 1-14.

13. Tonosaki, K.; Michiba, K.; Bang, S.W.; Kitashiba, H.; Kaneko, Y.; Nishio, T. Genetic analysis of hybrid seed formation ability of Brassica rapa in intergeneric crossings with Raphanus sativus. Theor. Appl. Genet. 2013, 126, 837-846.

14. Abràmoff, M.D.; Magalhães, P.J.; Ram, S.J. Image processing with ImageJ. Biophotonics Intern. 2004, 11, 36-42.

15. Chen, X.; Wang, J.; Shi, Y.; Zhao, M.Q.; Chi, G.Y. Effects of cadmium on growth and photosynthetic activities in pak choi and mustard. Bot. Stud. 2011, 52, 41-46.

16. He, Y.; Zhu, Z.; Yang, J.; Ni, X.; Zhu, B. Grafting increases the salt tolerance of tomato by improvement of photosynthesis and enhancement of antioxidant enzymes activity. Environ. Exp. Bot. 2009, 66, 270-278.

17. Gago, J.; de Menezes Daloso, D.; Figueroa, C.M.; Flexas, J.; Fernie, A.R.; Nikoloski, Z. Relationships of leaf net photosynthesis, stomatal conductance, and mesophyll conductance to primary metabolism: A multispecies meta-analysis approach. Plant Physiol. 2016, 171, 265-279.

18. Bumgarner, N.R.; Kleinhenz, M.D. Grafting Guide: A Pictorial Guide to the Cleft and Splice Graft Methods as Applied to Tomato and Pepper; The Ohio State University: Columbus, OH, USA, 2013; Available online: https://web.extension.illinois.edu/smallfarm/downloads/50570.pdf (accessed on 19 September 2020).

19. Garner, R.J.; Bradley, S. The Grafter's Handbook; Mitchell Beazley: London, UK, 2013.

20. Melnyk, C.W. Plant grafting: Insights into tissue regeneration. Regeneration 2017, 4, 3-14.

21. Hayashida, T.; Shibato, Y.; Hamachi, Y.; Yamato, Y.; Yamazaki, H.; Miura, H. Effect of light quality with different red/far-red photon flux density ratio on elongation of pak-choi (Brassica chinensis) seedlings grown under high temperatures. J. Jpn. Soc. Hortic. Sci. 2001, 70, 774-776.

22. Kwack, Y.; Kim, K.K.; Hwang, H.; Chun, C. Growth and quality of sprouts of six vegetables cultivated under different light intensity and quality. Hortic. Environ. Biotechnol. 2015, 56, 437-443.

23. Liu, M.; Bassetti, N.; Petrasch, S.; Zhang, N.; Bucher, J.; Shen, S.; Zhao, J.; Bonnema, G. What makes turnips: Anatomy, physiology and transcriptome during early stages of its hypocotyl-tuber development. Hortic. Res. 2019, 6, 38. [CrossRef]

24. Zheng, Y.; Luo, L.; Gao, Z.; Liu, Y.; Chen, Q.; Kong, X.; Yang, Y. Grafting induces flowering time and tuber formation changes in Brassica species involving FT signaling. Plant. Biol. 2019, 21, 1031-1038. [PubMed]

25. Tsuro, M.; Suwabe, K.; Kubo, N.; Matsumoto, S.; Hirai, M. Mapping of QTLs controlling root shape and red pigmentation in radish, Raphanus sativus L. Breed. Sci. 2008, 58, 55-61. [CrossRef]

26. Zaki, H.E.M.; Takahata, Y.; Yokoi, S. Analysis of the morphological and anatomical characteristics of roots in three radish (Raphanus sativus) cultivars that differ in root shape. J. Hortic. Sci. Biotechnol. 2012, 87, 172-178.

27. Bihmidine, S.; Hunter Iii, C.T.; Johns, C.E.; Koch, K.E.; Braun, D.M. Regulation of assimilate import into sink organs: Update on molecular drivers of sink strength. Front. Plant Sci. 2013, 4, 177. [CrossRef] [PubMed]

28. Abdel, C.G. Stomata and trichrome performances of four radish Raphanus sativus L. var. sativus cultivars grown in controlled cabinet under varying temperatures and irrigation levels. Intl. J. Farm. Alli. Sci. 2016, 5, 46-65.

29. Ehleringer, J.; Björkman, O.; Mooney, H.A. Leaf pubescence: Effects on absorptance and photosynthesis in a desert shrub. Science 1976, 191, 376-377.

30. Choinski, J.S., Jr.; Wise, R.R. Leaf growth development in relation to gas exchange in Quercus marilandica Muenchh. J. Plant Physiol. 1999, 154, 302-309. [CrossRef]

31. Hauser, M.T. Molecular basis of natural variation and environmental control of trichome patterning. Front. Plant Sci. 2014, 5, 1-7.

32. Thomson, G.E. Role of harvest technique and injuries in water loss from stored pak choi (Brassica rapa subsp. chinensis) heads. N. Z. J. Crop Hortic. 2005, 33, 111-115. [CrossRef] 
33. Von Caemmerer, S.; Lawson, T.; Oxborough, K.; Baker, N.R.; Andrews, T.J.; Raines, C.A. Stomatal conductance does not correlate with photosynthetic capacity in transgenic tobacco with reduced amounts of Rubisco. J. Exp. Bot. 2004, 55, 1157-1166. [CrossRef]

34. Xu, Z.; Zhou, G. Responses of leaf stomatal density to water status and its relationship with photosynthesis in a grass. J. Exp. Bot. 2008, 59, 3317-3325. [CrossRef] [PubMed]

35. Rosenkranz, H.; Vogel, R.; Greiner, S.; Rausch, T. In wounded sugar beet (Beta vulgaris L.) taproot, hexose accumulation correlates with the induction of a vacuolar invertase isoform. J. Exp. Bot. 2001, 52, 2381-2385. [CrossRef] [PubMed]

36. Zhang, Y.I.; Turner, J.G. Wound-induced endogenous jasmonates stunt plant growth by inhibiting mitosis. PLoS ONE 2008, 3, e3699. [CrossRef] [PubMed]

37. Xu, X.; van Lammeren, A.A.M.; Vermeer, E.; Vreugdenhil, D. The role of gibberellin, abscisic acid, and sucrose in the regulation of potato tuber formation in vitro. Plant Physiol. 1998, 117, 575-584. [CrossRef] [PubMed]

38. Peres, L.E.P.; Carvalho, R.F.; Zsögön, A.; Bermúdez-Zambrano, O.D.; Robles, W.G.R.; Tavares, S. Grafting of tomato mutants onto potato rootstocks: An approach to study leaf-derived signaling on tuberization. Plant Sci. 2005, 169, 680-688. [CrossRef]

39. Zhang, G.; Mao, Z.; Wang, Q.; Song, J.; Nie, X.; Wang, T.; Zhang, H.; Guo, H. Comprehensive transcriptome profiling and phenotyping of rootstock and scion in a tomato/potato heterografting system. Physiol. Plant 2019, 166, 833-847. [CrossRef]

40. Wang, G.L.; Xiong, F.; Que, F.; Xu, Z.S.; Wang, F.; Xiong, A.S. Morphological characteristics, anatomical structure, and gene expression: Novel insights into gibberellin biosynthesis and perception during carrot growth and development. Hortic. Res. 2015, 2, 15028. [CrossRef]

41. Jabir, O.; Mohammed, B.; Benard Kinuthia, K.; Almahadi Faroug, M.; Nureldin Awad, F.; Muleke, E.M.; Ahmadzai, Z.; Liu, L. Effects of gibberellin and gibberellin biosynthesis inhibitor (paclobutrazol) applications on radish (Raphanus sativus) taproot expansion and the presence of authentic hormones. Int. J. Agric. Biol. 2017, 19, 779-786. [CrossRef]

42. Sugiura, D.; Betsuyaku, E.; Terashima, I. Manipulation of the hypocotyl sink activity by reciprocal grafting of two Raphanus sativus varieties: Its effects on morphological and physiological traits of source leaves and whole-plant growth. Plant Cell Environ. 2015, 38, 2629-2640. [CrossRef]

43. Chapin Iii, F.S.; Schulze, E.D.; Mooney, H.A. The ecology and economics of storage in plants. Annu. Rev. Ecol. Syst. 1990, 21, 423-447. [CrossRef]

44. Kyriacou, M.C.; Rouphael, Y.; Colla, G.; Zrenner, R.; Schwarz, D. Vegetable grafting: The implications of a growing agronomic imperative for vegetable fruit quality and nutritive value. Front. Plant Sci. 2017, 8, 741. [PubMed]

45. Yu, R.; Xu, L.; Zhang, W.; Wang, Y.; Luo, X.; Wang, R.; Zhu, X.; Xie, Y.; Karanja, B.; Liu, L. De novo taproot transcriptome sequencing and analysis of major genes involved in sucrose metabolism in radish (Raphanus sativus L.). Front. Plant Sci. 2016, 7, 585. [PubMed]

46. Sugiura, D.; Watanabe, C.K.A.; Betsuyaku, E.; Terashima, I. Sink-source balance and down-regulation of photosynthesis in Raphanus sativus: Effects of grafting, $\mathrm{N}$ and $\mathrm{CO}_{2}$. Plant Cell Physiol. 2017, 58, 2043-2056. [PubMed]

(C) 2020 by the authors. Licensee MDPI, Basel, Switzerland. This article is an open access article distributed under the terms and conditions of the Creative Commons Attribution (CC BY) license (http://creativecommons.org/licenses/by/4.0/). 

Article

\title{
Rootstock Effects on Yield and Some Consumer Important Fruit Quality Parameters of Eggplant cv. 'Madonna' under Protected Cultivation
}

\author{
Maryam Mozafarian, Nazatul Syaima Binti Ismail and Noémi Kappel * \\ Department of Vegetable and Mushroom Growing, Faculty of Horticultural Science, Szent István University, \\ Villányi út 29-43, H-1118 Budapest, Hungary; maryammozafariyan67@gmail.com (M.M.); \\ syaima.unibio@gmail.com (N.S.B.I.) \\ * Correspondence: Kappel.Noemi@szie.hu; Tel.: +36-30-215-8922
}

Received: 14 August 2020; Accepted: 20 September 2020; Published: 22 September 2020

\begin{abstract}
This study aimed to investigate the effect of different rootstocks on the yield and quality of eggplant cv. 'Madonna' in soilless pot culture in an unheated polyethylene greenhouse. The eggplant was grafted onto several rootstocks, including tomato rootstocks Optifort (O) and Emperador $(\mathrm{E})$, and four Solanum rootstocks; Solanum grandiflorum $\times$ Solanum melongena $(\mathrm{SH})$, Solanum torvum $(\mathrm{ST})$, Solanum melongena $\times$ Solanum integrifolium (SI), and Solanum integrifolium (A) compared with self-grafted (SG) and self-rooted (SR) as control. The results showed that the total marketable yield significantly increased by grafting onto ST ( $3.94 \mathrm{~kg} /$ plant), SH (3.36 kg/plant), and A (3.34 kg/plant) relative to SR (1.65 kg/plant). The chromatics characters of skin and pulp are slightly influenced by rootstocks. Our findings confirmed that grafting eggplant decreased firmness (except $\mathrm{SH}$ ) of the flesh. Fruit harvested from the Optifort/Madonna combination had the rounded shape, lowest firmness, and Brix value, while the lowest oxidation potential was observed in this combination. The highest seed number was observed in SH/Madonna and SI/Madonna combinations. During the sensory evaluation, the lightest fruit flesh was found in SR, ST, and O, and the sweetest taste was observed in fruits harvested from ST rootstock.
\end{abstract}

Keywords: eggplant grafting; rootstock; fruit quality; yield; sensory evaluation

\section{Introduction}

The eggplant (Solanum melongena L.) is one of the top ten vegetables that originated from Southeast Asia; it has a high antioxidant capability and nutrient value. Soil-borne diseases, and biotic and abiotic stresses have limited the yield in many commercial eggplant plantations. Vegetable grafting is considered to be a rapid alternative way to slow breeding due to the absence of resistance genotype [1]. Grafting has been found effective not only for resistance advantages but also for the improvement of production and some quality traits of the fruit [2,3]. Eggplant grafting was started in the early 1950s by using Scarlet eggplant as rootstocks [4].

Several studies have already investigated different eggplant scion-rootstock combinations [5-8]. For instance, Solanum paniculatum increased vigour and fruit yield, but did not have any positive effect on fruit quality and composition [6]. Solanum incanum induced tolerance to water and temperature stress [9], while Solanum aethiopicum and Solanum macrocarpon were tolerant to Fusarium oxysporum and resistant to Ralstonia solanacearum [10]. Solanum sisymbriffolium and Solanum integrifolium have been reported effective in controlling bacterial wilt and resulted in higher yield [11]. Solanum torvum is the most commonly used rootstock for eggplant, which has been reported to be resistant to soil-borne diseases; but due to lack of rapid and homogeneous seed germination, there is a need to find other alternative rootstocks [12]. Some tomato rootstocks can be valuable, as well, to improve 
eggplant growth and production. Grafting eggplant onto tomato rootstocks (Solanum lycopersicum L. $\times$ Solanum habrochaites) indicated a positive result on yield and the appearance of fruits, but not equally, and it largely depended on the combination and environment [13]. Overall, some rootstock-scion combinations are moderately compatible, and unfavourable effects may occur; hence, the selection of appropriate rootstock-scion combinations is crucial.

Fruit quality of grafted vegetables can be measured by sensory evaluation and instrumental methods as well [14]. Grieneisen et al. [15] conducted a review of 202 different rootstocks and 1023 experimental treatments related to tomato grafting, and they concluded that fruit quality data based on sensory tests were rare among the published studies. Sensory evaluation of grafted plants of the members of the Cucurbitaceae family, i.e., melon [16], watermelon [17,18], and cucumber [19], and those of the Solanaceae family $[20,21]$ have been conducted, but there is relatively few data for eggplant.

The majority of previous studies investigated eggplant and tomato rootstock compatibility with eggplant scion individually. The objective of the present study was to compare the effect of tomato and eggplant rootstocks on fruit yield and certain quality parameters of eggplant cv. 'Madonna' in soilless pot culture in an unheated plastic greenhouse. Moreover, current research is aimed at identifying the best rootstock type to maximize yield and fruit quality, conducting not only laboratory testing, but sensory evaluation as well.

\section{Materials and Methods}

\subsection{Experimental Site, Plant Material, and Management Practices}

The experiment was conducted from March 2019 until October 2019 at the Experimental and Research Farm, Faculty of Horticultural Science, Szent István University, Budapest, in unheated plastic house $\left(47^{\circ} 23^{\prime} 49^{\prime \prime} \mathrm{N}, 19^{\circ} 09^{\prime} 10^{\prime \prime} \mathrm{E}, 120 \mathrm{~m}\right.$ a.s.l.). The study was arranged based on completely randomized design (CRD) to understand the effect of different rootstocks suitable for eggplant grafting, including Solanum grandiflorum $\times$ Solanum melongena $(\mathrm{SH})$, Solanum torvum $(\mathrm{ST})$, Solanum melongena $\times$ Solanum integrifolium (SI), and Solanum integrifolium (A) and tomato rootstocks (Solanum lycopersicum), including cv. 'Optifort' (O) and cv. 'Emperador' (E). Moreover, self-grafted (SG) cv. 'Madonna' and self-rooted (SR) plants, as control, were used with four replications and five plants in each replication.

The used, popular eggplant cultivar 'Madonna' has evenly coloured, dark-violet fruits. Due to slow seed germination, all four eggplant rootstock seeds (SH, A, ST, and SI) were sown 10 days earlier than cv. 'Madonna' and tomato rootstocks seeds (E and O) (which germinated and developed at the same rate); thus, a uniform stem diameter for grafting was obtained. Eggplant seedlings (with the adequate diameter and $4-5$ leaves) were grafted onto the rootstocks by cleft grafting method and kept in high humidity and low light conditions for one week, and then acclimatized to the natural conditions. Three weeks after grafting, all seedlings were transplanted into $10 \mathrm{~L}$ pots containing peat substrate, in an unheated polyethylene greenhouse. Temperature and relative humidity inside the greenhouse were recorded by the Flower Power Sensor data logger, as shown in Figure 1. All phytotechnical work recommended for eggplant greenhouse cultivation was performed uniformly. Irrigation was applied twice a week with a commercial fertilizer solution.

Mature fruits were harvested once a week between June and October 2019 (15 times) according to fruit size, colour, and glossiness. Right after picking, the weight of each fruit was recorded by using a digital scale, and the marketable or unmarketable fruits had been sorted. Fruit width (at maximum fruit diameter) and fruit length (from stalk to end of fruit) had been measured by a tape line, and fruit index was calculated based on fruit width/fruit length. 


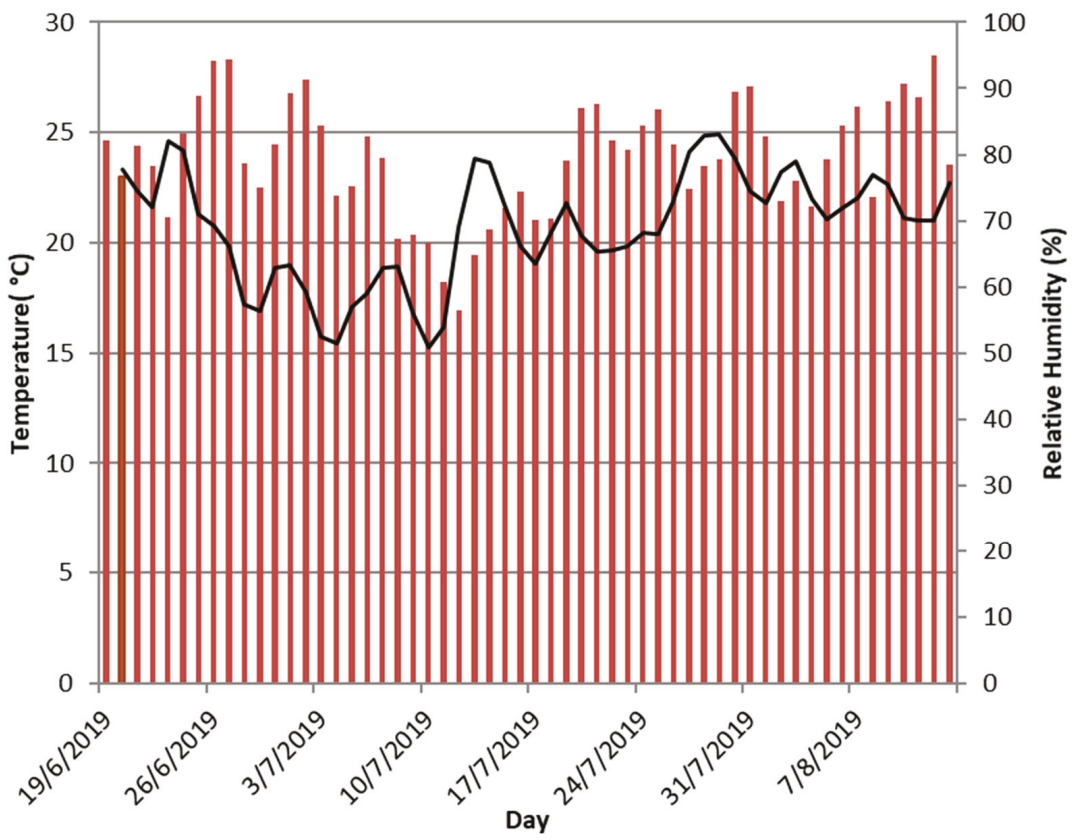

Figure 1. Temperature and relative humidity at the greenhouse during cultivation.

\subsection{Instrumental Measurements}

The fruit flesh acidity $(\mathrm{pH})$ was measured from two sides of each fruit in all combinations by a $\mathrm{pH}$ meter (Hanna HI 98128). The pulp of three fruits from each replication were blended using a kitchen blender. The total soluble solids of the fruit (TSS \%) was measured by using a refractometer (PAL-1 Brix 0-53\% Digital Hand) from the fruit juice. Fruit firmness from each replication (two fruits) were evaluated by a small hand-operated penetrometer. The pressure value was measured in $\mathrm{kg} / \mathrm{cm}^{3}$.

The skin colour of three fruits from each replication was measured on two sides of the skin by using a Minolta Chroma CR-400 colourimeter (Minolta Corporation, Ltd., Osaka, Japan). Fruit chromaticity was expressed in $\mathrm{L}^{*}, \mathrm{a}^{*}, \mathrm{~b}^{*}$ colour space coordinates. Chroma $\left(\mathrm{C}^{*}\right)$ and Hue angles $\left(\mathrm{H}^{\circ}\right)$ were calculated according to the following formula 1 :

$$
\mathrm{C}^{*}=\left(\mathrm{a}^{* 2}+\mathrm{b}^{* 2}\right)^{1 / 2}, \mathrm{H}^{\circ}=\tan ^{-1}\left(\mathrm{~b}^{*} / \mathrm{a}^{*}\right) .
$$

The same colourimeter was used to determine the whitening index (DW), oxidation potential (OP), and colour differences (CD) of the fruit pulp. Two fruits of each replication were cut longitudinally with a straight edge plastic knife. The pulp was measured quickly after being cut $\left(\mathrm{L}_{0}\right)$ and after $30 \mathrm{~min}$ $\left(\mathrm{L}_{30}\right)$ in the central and lateral zone. Colour space had been divided into a three-dimensional ( $\mathrm{L}$, a and b) so that L (lightness; 0 black and 100 white); a (red to green); and b (blue to yellow). The distance of pure white (DW) was measured as Euclidean distance of the colour coordinates to the pure white coordinates $\left(\mathrm{L}^{*}=100 \mathrm{a}^{*}=0 \mathrm{~b}=0\right)$ using the formula 2 [22]:

$$
\mathrm{DW}=\left((100-\mathrm{L})^{2}+\mathrm{a}^{* 2}+\mathrm{b}^{* 2}\right)^{0.5}
$$


The colour differences (CD) were measured as a Euclidean distance between the colour coordinates at 0 and $30 \mathrm{~min}$ and calculated by using formula 3 :

$$
C D=\left[\left(L^{*} 30-L^{*} 0\right)+\left(a^{*} 30-a^{*} 0\right)+\left(b^{*} 30-b^{*} 0\right)\right]
$$

Moreover, the oxidation potential (OP) was measured by International Commission on Illumination (CIE) $\mathrm{L}^{*} \mathrm{a}^{*} \mathrm{~b}^{*}$ values using the following formula 4 [23]:

$$
\mathrm{OP}=\mathrm{L}^{*}{ }_{30}-\mathrm{L}_{0}^{*}
$$

Ten independent slices from the equatorial region of fruits were cut and incubated at $20{ }^{\circ} \mathrm{C}$ to induce seed browning and facilitate seed boundaries identification. Images were used to determine the number of seeds by using the software ImageJ (Version 1.8.0_172; Research Services Branch, National Institute of Mental Health, Bethesda, MD, USA).

\subsection{Sensory Evaluation}

Sensory measurements were made based on questionnaire results. Twelve trained tasting panellists evaluated 10 quality attributes (Table 1) according to ISO 13,299 standard. First, the sensory attributes and their corresponding reference values were determined, to reduce the variation in the resulting dataset. For the sensory test, small pieces of the fruit were boiled for $20 \mathrm{~min}$, placed in numbered plates, and were immediately assessed. The questionnaire results were converted into a grade scale from 0 to 100. The combined results of the properties were plotted on profile diagrams, which were prepared by ProfiSens, a sensory analysis software. Tests were performed according to ISO 8589, and differences between data were evaluated with univariate ANOVA and Fisher least significant difference (LSD) significance level evaluation procedures.

Table 1. Definitions of sensory attributes used in the quantitative descriptive analysis.

\begin{tabular}{cc}
\hline Attributes & Characteristic \\
\hline Flesh Colour & Dark-light \\
Odour & None-very intensive \\
Flesh Firmness & Soft-firm \\
Flesh Juiciness & not very juicy-very juicy \\
Flavour Intensity & not perceptible-intense \\
Tart, Bitter Taste & None-very intensive \\
Pungent Flavour & None-very intensive \\
Sweet Taste & not very intensive-very intensive \\
After Taste & None-very intensive \\
Off-Flavour & None-very intensive \\
\hline
\end{tabular}

\subsection{Statistical Procedures}

The experiment was arranged in a completely randomized design (CRD) with four replications and five plants in each replication. Data were statistically analysed using Statistix 8 software (Tallahassee, FL, USA). Data were subjected to the one-way analysis of variance (ANOVA) and means were separated using the least significant difference (LSD) test at $p<0.05$.

\section{Results}

As shown in Table 1, grafting cv. 'Madonna' onto 'O and E rootstocks caused the lowest fruit length in comparison with the SR and SG rootstocks. Moreover, it has been observed that self-grafting cv. 'Madonna' significantly increased the width of fruit relative to the fruit harvested from control and other combinations (except ST). Statistical analysis showed that fruit shape index was not significantly $(p<0.05)$ influenced by rootstocks. 
Our results showed that the total marketable fruit number significantly increased by grafting in comparison with SR and SG. Average fruit weight decreased by grafting onto O rootstocks in comparison with other treatment (except SG). Grafting cv. 'Madonna' on eggplant rootstocks (SH, ST, $\mathrm{SI}$, and A) significantly increased total marketable fruit yield while tomato rootstocks (E and O) had no significant effect. Total marketable yield of Solanum torvum (ST) rootstock was two times higher than control, self-grafted plants (Table 2).

Table 2. Effect of different rootstock combinations on eggplant fruit shape, fruit number, and yield.

\begin{tabular}{|c|c|c|c|c|c|c|}
\hline Treatment & $\begin{array}{l}\text { Fruit Length } \\
(\mathrm{cm})\end{array}$ & $\begin{array}{l}\text { Fruit Width } \\
\qquad(\mathrm{cm})\end{array}$ & $\begin{array}{l}\text { Fruit Shape } \\
\text { Index }\end{array}$ & $\begin{array}{l}\text { Total Marketable } \\
\text { Fruit Number } \\
\left.\text { (plant-1 }{ }^{-1}\right)\end{array}$ & $\begin{array}{l}\text { Average Fruit } \\
\text { Weight (kg) }\end{array}$ & $\begin{array}{l}\text { Total Marketable } \\
\text { Yield (kg plant- }{ }^{1} \text { ) }\end{array}$ \\
\hline SR & 16.97 a & $8.06 \mathrm{bcd}$ & $2.13 \mathrm{a}$ & $6.35 c$ & $0.28 \mathrm{ab}$ & $1.65 \mathrm{c}$ \\
\hline \multicolumn{7}{|c|}{ Eggplant Rootstocks } \\
\hline SG & $18.10 \mathrm{a}$ & $9.38 \mathrm{a}$ & $1.92 \mathrm{a}$ & $6.70 \mathrm{c}$ & $0.26 \mathrm{bc}$ & $1.89 \mathrm{c}$ \\
\hline $\mathrm{SH}$ & $16.34 \mathrm{ab}$ & $7.94 \mathrm{~cd}$ & $2.06 \mathrm{a}$ & $12.13 \mathrm{ab}$ & $0.29 \mathrm{ab}$ & $3.36 \mathrm{ab}$ \\
\hline ST & $16.58 \mathrm{a}$ & $8.36 \mathrm{ab}$ & $1.99 \mathrm{a}$ & $14.26 \mathrm{a}$ & $0.28 \mathrm{ab}$ & $3.94 \mathrm{a}$ \\
\hline SI & $16.93 \mathrm{a}$ & $8.18 \mathrm{bc}$ & $2.08 \mathrm{a}$ & $10.80 \mathrm{~b}$ & $0.31 \mathrm{a}$ & $3.23 \mathrm{ab}$ \\
\hline A & 16.91 a & $8.19 \mathrm{bc}$ & $2.07 \mathrm{a}$ & $11.14 \mathrm{~b}$ & $0.29 \mathrm{ab}$ & $3.34 \mathrm{ab}$ \\
\hline \multicolumn{7}{|c|}{ Tomato Rootstocks } \\
\hline E & $15.66 \mathrm{bc}$ & $8.11 \mathrm{bcd}$ & $1.95 \mathrm{a}$ & $10.71 \mathrm{~b}$ & $0.28 \mathrm{ab}$ & $2.80 \mathrm{abc}$ \\
\hline $\mathrm{O}$ & $14.94 \mathrm{c}$ & $7.68 \mathrm{~d}$ & $1.96 \mathrm{a}$ & $9.38 \mathrm{~b}$ & $0.24 c$ & $2.39 \mathrm{bc}$ \\
\hline $\mathrm{CV}$ & 10.87 & 11.19 & 12.42 & 15.00 & 26.67 & 20.19 \\
\hline$p$ Value & 0.000 & 0.0005 & 0.003 & 0.000 & 0.009 & 0.0002 \\
\hline Significance & $* * *$ & $* * *$ & $* *$ & $* * *$ & $* *$ & $* * *$ \\
\hline
\end{tabular}

According to ANOVA, L* value and CIRG index (Color index of red) of fruit skin from all combinations was not significantly $(p<0.05)$ different with the self-rooted (SR) plants. Grafting Madonna onto O, E, A, and SH significantly increased the a* value of skin fruit relative to SR and SG (Table 3). Fruit harvested from $\mathrm{O}$ rootstocks had the highest $\mathrm{b}^{*}$ value compared with the SR. Our results showed that the highest Hue value was observed at E and O rootstock in comparison with SR and SG. Chroma value of skin fruit increased when $\mathrm{O}, \mathrm{E}$, and A was used as rootstock compared with either non-grafted or self-grafted (Table 3).

Table 3. Effect of different rootstock combinations on chromatic characteristics of eggplant fruit skin.

\begin{tabular}{ccccccc}
\hline Treatment & $\mathbf{L}^{*}$ & $\mathbf{a}^{*}$ & $\mathbf{b}^{*}$ & Hue & Chroma & CIRG \\
\hline SR & $25.22 \mathrm{a}$ & $3.09 \mathrm{~d}$ & $-0.72 \mathrm{bc}$ & $3.18 \mathrm{~cd}$ & $346.15 \mathrm{~cd}$ & $6.62 \mathrm{a}$ \\
\hline \multicolumn{7}{c}{ Eggplant Rootstocks } \\
\hline SG & $25.07 \mathrm{a}$ & $2.95 \mathrm{~d}$ & $-0.73 \mathrm{bc}$ & $3.05 \mathrm{~d}$ & $345.13 \mathrm{~d}$ & $6.69 \mathrm{a}$ \\
SH & $25.36 \mathrm{a}$ & $3.62 \mathrm{abc}$ & $-0.71 \mathrm{bc}$ & $3.70 \mathrm{abc}$ & $347.70 \mathrm{abc}$ & $6.53 \mathrm{a}$ \\
ST & $25.58 \mathrm{a}$ & $3.32 \mathrm{bcd}$ & $-0.75 \mathrm{bc}$ & $3.40 \mathrm{bcd}$ & $346.68 \mathrm{bcd}$ & $6.51 \mathrm{a}$ \\
SI & $25.08 \mathrm{a}$ & $3.27 \mathrm{~cd}$ & $-0.79 \mathrm{c}$ & $3.72 \mathrm{~cd}$ & $346.03 \mathrm{~cd}$ & $6.65 \mathrm{a}$ \\
\hline A & $25.61 \mathrm{a}$ & $3.65 \mathrm{abc}$ & $-0.69 \mathrm{ab}$ & $3.71 \mathrm{abc}$ & $348.69 \mathrm{ab}$ & $6.47 \mathrm{a}$ \\
\hline \multicolumn{7}{c}{ Tomato Rootstocks } \\
\hline E & $25.53 \mathrm{a}$ & $3.89 \mathrm{ab}$ & $-0.67 \mathrm{ab}$ & $3.95 \mathrm{ab}$ & $348.92 \mathrm{ab}$ & $6.46 \mathrm{a}$ \\
O & $25.45 \mathrm{a}$ & $4.08 \mathrm{a}$ & $-0.611 \mathrm{a}$ & $4.14 \mathrm{a}$ & $349.51 \mathrm{a}$ & $6.46 \mathrm{a}$ \\
\hline CV & 4.35 & 20.15 & -22.19 & 28.66 \\
$p$ Value & 0.47 & 0.001 & 0.006 & 0.001 & 0.002 & 0.084 \\
Significance & NS & $* * *$ & $* *$ & $*$ & NS \\
\hline
\end{tabular}

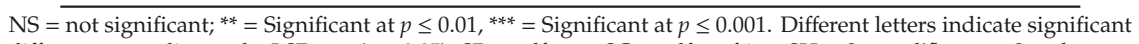
difference according to the LSD test $(p<0.05)$. SR = self-root; $\mathrm{SG}=$ self-grafting; $\mathrm{SH}=S$. grandiflorum $\times S$. melongena; $\mathrm{ST}=$ S. torvum $; \mathrm{SI}=$ S. melongena $\times$ S. integrifolium $; \mathrm{A}=$ S. integrifolium $; \mathrm{E}=$ Emperador; $\mathrm{O}=$ Optifort. 
The results of pulp colour measurements are presented in Table 4. No significant difference was observed in $\mathrm{L}_{0} * \mathrm{a}^{*}, \mathrm{CD}$ and $\mathrm{DW}_{0}$ between grafted and SR plants. Moreover, our results showed that grafting onto tomato rootstocks $(\mathrm{E}$ and $\mathrm{O})$ significantly decreased OP value of pulp fruit relative to SR and SG.

Table 4. Effect of different rootstock combinations on chromatic characteristics, colour difference, whiteness degree, and oxidation potential of eggplant pulp.

\begin{tabular}{ccccccc}
\hline Treatment & $\mathbf{L}_{\mathbf{0}}{ }^{*}$ & $\mathbf{a}^{*}$ & $\mathbf{b}^{*}$ & $\mathbf{C D}$ & $\mathbf{D W}_{\mathbf{0}}$ & OP \\
\hline SR & $84.89 \mathrm{ab}$ & $-4.10 \mathrm{ab}$ & $29.08 \mathrm{a}-\mathrm{c}$ & $12.16 \mathrm{a}-\mathrm{c}$ & $33.10 \mathrm{a}-\mathrm{c}$ & $9.97 \mathrm{a}$ \\
\hline \multicolumn{7}{c}{ Eggplant Rootstocks } \\
\hline SG & $85.43 \mathrm{ab}$ & $-3.71 \mathrm{ab}$ & $26.84 \mathrm{c}$ & $12.62 \mathrm{ab}$ & $30.85 \mathrm{c}$ & $10.66 \mathrm{a}$ \\
SH & $84.62 \mathrm{ab}$ & $-4.01 \mathrm{ab}$ & $29.15 \mathrm{abc}$ & $13.61 \mathrm{a}$ & $33.24 \mathrm{abc}$ & $8.67 \mathrm{ab}$ \\
ST & $84.03 \mathrm{~b}$ & $-2.86 \mathrm{a}$ & $30.14 \mathrm{ab}$ & $11.46 \mathrm{abc}$ & $34.25 \mathrm{ab}$ & $9.67 \mathrm{ab}$ \\
SI & $85.26 \mathrm{ab}$ & $-4.56 \mathrm{~b}$ & $29.05 \mathrm{abc}$ & $12.48 \mathrm{ab}$ & $32.93 \mathrm{abc}$ & $9.38 \mathrm{ab}$ \\
$\mathrm{A}$ & $84.65 \mathrm{ab}$ & $-3.17 \mathrm{ab}$ & $30.32 \mathrm{a}$ & $13.21 \mathrm{a}$ & $34.30 \mathrm{ab}$ & $11.03 \mathrm{a}$ \\
\hline \multicolumn{7}{c}{ Tomato Rootstocks } \\
\hline E & $86.36 \mathrm{a}$ & $-4.71 \mathrm{~b}$ & $27.70 \mathrm{bc}$ & $7.37 \mathrm{c}$ & $31.30 \mathrm{bc}$ & $5.81 \mathrm{~b}$ \\
$\mathrm{O}$ & $83.91 \mathrm{~b}$ & $-3.68 \mathrm{ab}$ & $31.39 \mathrm{a}$ & $8.29 \mathrm{bc}$ & $35.51 \mathrm{a}$ & $5.81 \mathrm{~b}$ \\
\hline CV & 2.71 & -4.82 & 8.88 & 27.58 & 9.25 & 16.90 \\
$p$ value & 0.4 & 0.2 & 0.02 & 0.1 & 0.06 & 0.05 \\
Significance & NS & NS & $*$ & NS & NS & $*$ \\
\hline
\end{tabular}

NS = not significant; ${ }^{*}$ Significant at $p \leq 0.05$. Different letters indicate significant difference according to LSD's test $(p<0.05)$. SR = self-root; $\mathrm{SG}=$ self-grafting; $\mathrm{SH}=S$. grandiflorum $\times S$. melongena; $\mathrm{ST}=\mathrm{S}$. toroum; $\mathrm{SI}=\mathrm{S}$. melongena $\times$ S. integrifolium; $\mathrm{A}=\mathrm{S}$. integrifolium; $\mathrm{E}=$ Emperador; $\mathrm{O}=$ Optifort. $\mathrm{CD}=$ colour difference; $\mathrm{DW}=$ whiteness degree; $\mathrm{OP}=$ oxidation potential.

As shown in Table 5, Brix value of fruit flesh was negatively influenced by grafting onto SI, E, and $\mathrm{O}$ rootstocks, while SG resulted the highest Brix value in the pulp. Fruit firmness significantly decreased by grafting (except grafting onto $\mathrm{SH}$ rootstock). The $\mathrm{pH}$ value of the flesh was not influenced by different rootstocks.

Table 5. Effect of different rootstock combinations on $\mathrm{pH}$, Brix, firmness, and seed number of eggplant fruits.

\begin{tabular}{|c|c|c|c|c|}
\hline Treatment & $\mathrm{pH}$ & T.S.S (Brix) & Firmness $\left(\mathrm{kg} / \mathrm{cm}^{3}\right)$ & Seed Number \\
\hline SR & $5.55 \mathrm{a}$ & $5.28 \mathrm{~b}$ & $4.93 \mathrm{a}$ & $21.81 \mathrm{c}$ \\
\hline \multicolumn{5}{|c|}{ Eggplant Rootstocks } \\
\hline SG & $5.57 \mathrm{a}$ & $5.80 \mathrm{a}$ & $4.18 \mathrm{~b}$ & $29.50 \mathrm{bc}$ \\
\hline $\mathrm{SH}$ & $5.46 \mathrm{ab}$ & $5.26 \mathrm{~b}$ & $4.56 \mathrm{ab}$ & $47.30 \mathrm{a}$ \\
\hline ST & $5.53 \mathrm{a}$ & $5.34 \mathrm{~b}$ & $3.51 \mathrm{c}$ & $38.70 \mathrm{abc}$ \\
\hline SI & $5.44 \mathrm{ab}$ & $4.78 \mathrm{c}$ & $3.56 \mathrm{c}$ & $44.36 \mathrm{ab}$ \\
\hline A & $5.38 \mathrm{~b}$ & $5.62 \mathrm{ab}$ & $4.04 \mathrm{bc}$ & $25.46 \mathrm{c}$ \\
\hline \multicolumn{5}{|c|}{ Tomato Rootstocks } \\
\hline $\mathrm{E}$ & $5.56 \mathrm{a}$ & $4.62 \mathrm{c}$ & $2.77 \mathrm{~d}$ & $27.09 \mathrm{bc}$ \\
\hline $\mathrm{O}$ & $5.53 \mathrm{a}$ & $4.72 \mathrm{c}$ & $2.43 \mathrm{~d}$ & $28.15 \mathrm{bc}$ \\
\hline $\mathrm{CV}$ & 2.45 & 10.59 & 14.42 & 14.03 \\
\hline$p$ Value & 0.06 & 0.000 & 0.000 & 0.000 \\
\hline Significance & NS & $* * *$ & $* * *$ & $* * *$ \\
\hline
\end{tabular}

NS = not significant; ${ }^{* * *}=$ Significant at $p \leq 0.001$. Different letters indicate significant difference according to the $\mathrm{LSD}$ test $(p<0.05)$. SR = self-root; $\mathrm{SG}=$ self-grafting; $\mathrm{SH}=$ S. grandiflorum $\times \mathrm{S}$. melongena; $\mathrm{ST}=\mathrm{S}$. torvum; $\mathrm{SI}=\mathrm{S}$. melongena $\times$ S. integrifolium $; \mathrm{A}=$ S. integrifolium $; \mathrm{E}=$ Emperador $; \mathrm{O}=$ Optifort. 
In the current experiment, grafting eggplant onto SH and SI rootstocks sharply increased the seed number of fruits in comparison with SR (Table 4; Figure 2).

Sensory analysis data showed a significant difference in four parameters (flesh colour, firmness, sweet taste, and intensive odour) between selected rootstocks. Fruits harvested from SR, ST, and O had lighter flesh colour than other rootstock combinations. Respectively, SR and E had the lowest and highest flesh firmness between grafting combinations according to panellists' evaluation. Grafting onto ST showed significantly stronger sweet taste as compared to SR fruits. Fruits harvested from SI showed significantly intensive odour among all combinations (Figure 3). Bitter taste, pungent flavour, off flavour, aftertaste, flesh juiciness, and flavour intensity were not significantly influenced by grafting.

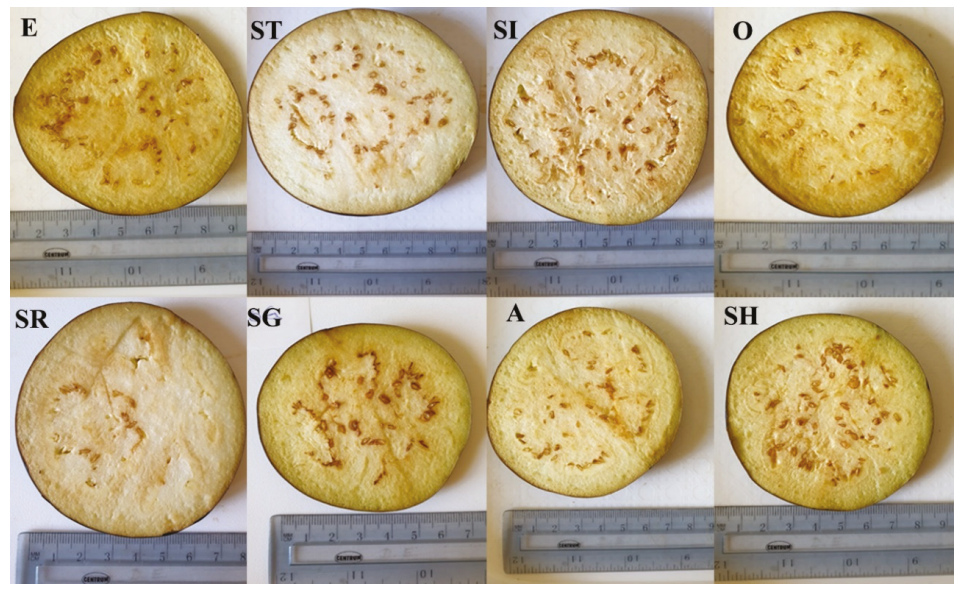

Figure 2. Effect of different rootstock combinations on fruit seed number. SR = self-root; $\mathrm{SG}=$ self-grafting; $\mathrm{SH}=$ S. grandiflorum $\times$ S. melongena; $\mathrm{ST}=$ S. torvum; $\mathrm{SI}=$ S. melongena $\times$ S. integrifolium; $\mathrm{A}=$ S. integrifolium $; \mathrm{E}=$ Emperador $; \mathrm{O}=$ Optifort.

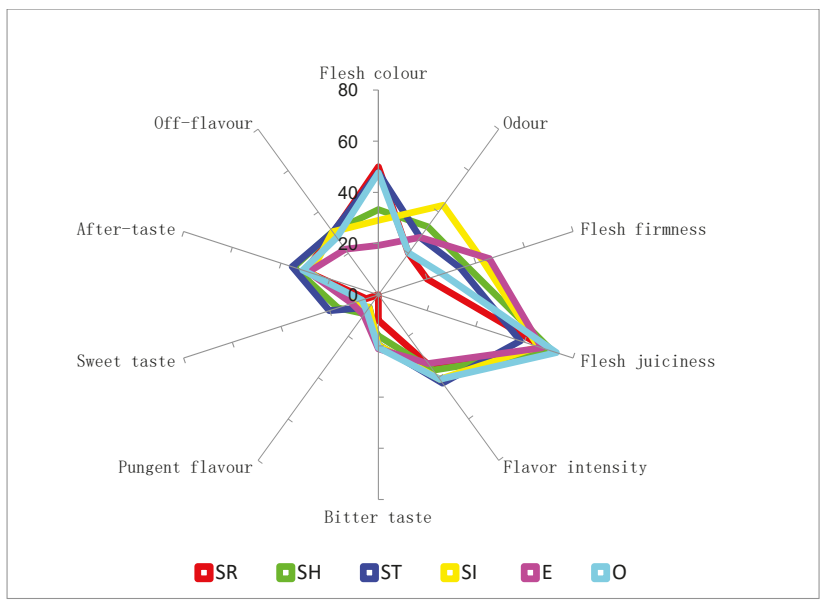

Figure 3. Effect of different rootstock combinations on sensory evaluation of fruit by trained panellists.

\section{Discussion}

Vegetable quality is defined by external attributes, such as colour, shape, size and freshness, as well as internal features, such as texture, flavour, content of mineral, health-promoting compounds, 
and sensory parameters. The quality of grafted vegetables can differ and conflicting from the grower and consumer perspectives. However, consumer demand determines economic value and it is an essential aspect in grafted vegetable productions. In the current experiment, we have tested the 'Madonna' eggplant cultivar grafted onto two groups of rootstocks (tomato and other Solanum spp.) to find the best combination in terms of yield and quality in both laboratory and consumer evaluation.

Our results showed that the lowest fruit length was observed at tomato rootstock (E and O) and highest fruit width was at SG rootstocks. Fruit shape is controlled genetically; however, Sabatino et al. [6,24] and Gisbert et al. [25] demonstrated that eggplant fruit shape (length and width) is affected by the rootstock. In line with our findings, Passam et al. [26] stated that grafting can increase eggplant fruit size. Moreover, Cassaniti et al. [27] harvested longer fruits from cv. 'Black Bell'-S. toroum combination than from self-grafted plants. In cucumber, shape index in grafted plants was higher than non-grafted ones [28], while in watermelon grafting it had no influence on fruit size and shape, according to some studies [29,30]. Therefore, these results are different due to genotype, vigorous rootstocks, and grafting combinations [3]. For instance, grafting tomato onto vigorous rootstocks (i.e., 'Maxifort'; 'Beaufort') increased the fruit size, while grafting onto less vigorous rootstocks (i.e., 'Brigeor'; 'Energy,'; 'Firefly', 'Linea9243,' and 'Nico') reduced tomato fruit size [31-33].

All eggplant rootstocks (SH, ST, A, and SI) improved total fruit yield. Yield, fruit number, and earliness of eggplant cv. 'Cristal F1' grafted onto eggplant rootstocks was higher than tomato rootstocks [25]. In line with our results, Sabatino et al. [19] reported that eggplant cv. 'Scarlatti' F1 grafted onto $S$. melongena $\times$ S. aethiopicum rootstock had higher total and marketable yield than plants grafted onto S. aethiopicum. Earlier, they found that higher marketable yield of grafted eggplant onto S. torvum and S. macrocarpon can be the result of higher fruit numbers, which associate with increasing water and nutrient absorption [6]. Gisbert et al. [25] confirmed that grafted plants with higher yield had earlier fruit harvesting. In the current experiment, the higher marketable yield is due to a higher harvested fruit number in grafted plants. Our results also correlate with Sabatino et al. [5] who confirmed a higher fruit number of grafted plants than on non-grafted. Higher yield of grafted plants may be related to higher water and nutrient absorption [29].

The darkest skin colour is connected to a high concentration of anthocyanin. Results of Moncada et al. [34] showed that grafting eggplant cv. 'Biragh' onto S. torvum caused a darker and less vivid fruit skin colour (lower value of $\mathrm{L}^{*}$ and chroma), while other cultivars ('Black Moon' and 'Black Bell') were not influenced by rootstock. Moreover, the highest Hue value was observed when eggplant cv. 'Scarlatti' was grafted onto S. torvum and S. aethiopicum rootstocks in an experiment by Sabatino et al. [24]. In our study, the most noticeable finding was that grafting cv. 'Madonna' onto O rootstock resulted in low-quality fruit skin, with the Hue value of 4.14, and chroma of 349.51. In tomato, variable results were found in fruit skin colour by grafted plants compared to non-grafted ones [31,35].

A CIRG index of 5 indicates red dark violet skin, and higher than 6 indicates blue-black skin. In the current experiment, 'Madonna' scion normally had dark black skin and grafting did not have any significant influence on CIRG. Kacjan Maršic et al. [13] reported that grafting eggplant cv. 'Blackbell' onto tomato rootstock cv. 'Beaufort' increased CIRG index, while in another cultivar (cv. 'Epic') decreased. It can be explained that scion variety has different responses to grafting according to Kacjan Maršic et al. [13]. Moreover, they concluded that higher vigour of grafted plants negatively influenced the anthocyanins, and the pruning of plants should be carried out during the cultivation to improve the fruit colour [13].

It seems that tomato rootstocks had lower browning degree and colour difference value than self-rooted and self-grafted plants, and fruit harvested from these combinations oxidized less than others (Table 3). High oxidation potential is expected due to the high phenolic compound content of the eggplant. Moreover, it may be influenced by many factors, e.g., scion genotype, rootstocks, and environmental conditions. Moncada et al. [34] and Sabatino et al. [6] reported that grafting eggplant onto S. torvum had little or no effect on pulp browning. However, other rootstocks had different reactions; for instance, S. paniculatum and S. macrocarpon showed lowest [6], while S. aethiopicum gave 
the highest oxidation potential in eggplant [3]. Seed number and fruit size may lead to different colour and oxidization in fruit pulp after cutting. A negative correlation between the browning index and fruit size, and positive relation with seed number, has been reported by Radicetti et al. [36].

Several studies confirmed that fruit quality seldom varied significantly between grafted and non-grafted plants. For instance, previous results by Arvanitoyannis et al. [37] and Cassaniti et al. [27] confirmed a reduction in eggplant flesh firmness by grafting. Similarly, tomato fruits harvested from grafted plants were not firmer than control and self-grafted plants [31,38]. Lower water uptake in non-grafted plant caused lower water content in eggplant fruit and harder texture [37]. The current experiment showed that grafting significantly reduced TSS of eggplant cv. 'Madonna'. In line with our results, lower TSS was observed in eggplant fruits (cv. 'Faselis') obtained from grafted on S. torvum, while no significant difference was found in fruits (cv. 'Rima') obtained from tomato hybrid rootstocks compared to the rest of combinations [39]. Lee et al. [40] reported that grafting eggplant onto S. torvum had no influence on TSS. Previous studies showed that firmness and SSC of non-grafted and self-grafted melon was higher than grafted fruit in the Guan et al. [14] study, and they explained that it is due to the improved water status of grafted melon by enhancing leaf water potential, leaf stomatal conductance, transpiration rate, and amount of xylem sap, which then can reduce TSS of the fruit [14,41]. Fruits obtained from SH and SI $\times$ 'Madonna' combination had the highest seed number and it can be explained that higher nitrogen absorption in the grafted plant may cause a higher seed number in fruit [42].

Combining sensory and instrumental measurements provided a thorough evaluation of the effects of grafting and rootstock combination [14]. Grafting eggplant cv. 'Tsakoniki' onto S. torvum resulted in fewer empty spaces and harder fruits more than in case of other combinations [37]. Moreover, they reported that fruits grafted on S. sisymbriifolium had fewer seeds and less intensive tart flavour than the rest of the treatments. Another interesting finding was that all grafted plants resulted in less sweet fruits and lower acceptability ratings in the panellist test [37]. In our experiment, fruit harvested from ST had a sweeter taste and lighter colour, and fruit harvested from SI showed intensive odour, according to consumer evaluation. In tomato, according to the experiment of Di Gioia et al. [20], grafting onto cv. 'Beaufort' and 'Maxifort' rootstocks did not influence sweetness, sourness, and the tomato-like taste of the fruits. Barrett et al. [21] and Casals et al. [43] reported that grafting had negative effects on acceptability and the tomato flavour descriptors assessed by a consumer test.

In the Cucurbitaceae family, Guan et al. [14] reported that grafting Galia melon onto hybrid squash rootstocks caused lower sensory properties, while Honey Yellow cv. was not influenced by grafting. They explained that lower SSC can be one of the reasons of the lower sensory evaluation results. Similarly, in another experiment, Velkov and Pevicharova [19] confirmed that sensory evaluation of cucumber depended on scion-rootstock combinations and every scion showed a different reaction to the same rootstock.

\section{Conclusions}

In the present study, we examined the effect of grafting onto different rootstocks in case of an eggplant variety favoured by consumers. Either tomato or other Solanum species are recommended for the grafting of eggplant; thus, we also selected the rootstocks to be tested accordingly. Compared to previous studies, we also observed differences between each grafting combination, both in terms of yield and fruit quality.

In our study, Solanum torvum $\times$ Madonna, as well as Solanum grandiflorum $\times$ Solanum melongena $\times$ Madonna combinations, exhibited the highest marketable yield with a higher fruit number per plant and uniform skin colour. Our findings also revealed that tomato rootstocks ( $\mathrm{O}$ and $\mathrm{E}$ ) had the lowest pulp colour difference and oxidation potential.

Our results also confirm that it is very important to choose the right rootstock, primarily according to the goal of grafting to be achieved. 
Author Contributions: All authors contributed to this research. The design of the experiment was done by N.K., M.M., and N.S.B.I.; M.M. and N.S.B.I. did the recording and processing of the data, as well as the result of the evaluation. The manuscript was written by M.M.; N.K. assisted in writing the paper. N.K. contributed to designing the research and revised the manuscript. The work presented in the paper was conceived within research projects led by N.K. All authors have read and agreed to the published version of the manuscript.

Funding: This research was funded by the Ministry for Innovation and Technology within the framework of the Higher Education Institutional Excellence Program (NKFIH-1159-6/2019) in the scope of plant breeding and plant protection research of Szent István University.

Acknowledgments: This publication was founded by EFOP-3.6.1-16-2016-00016. The specialize of the SZIE Campus of Szarvas research and training profile with intelligent specialization in the themes of water management, hydroculture, precision mechanical engineering, alternative crop production.

Conflicts of Interest: The authors declare no conflict of interest.

\section{References}

1. Mozafarian, M.; Kappel, N. The Role of Grafting Vegetable Crops for Reducing Biotic and Abiotic Stresses. In Handbook of Plant and Crop Stress, 4th ed.; Pessarakli, M., Ed.; CRC Press: Boca Raton, FL, USA, 2019; pp. 855-863. [CrossRef]

2. Mozafarian, M.; Kappel, N. Grafting Plants to Improve Abiotic Stress Tolerance. In Plant Ecophysiology and Adaptation under Climate Change: Mechanisms and Perspectives II; Hasanuzzaman, M., Ed.; Springer: Singapore, 2020; pp. 477-490. [CrossRef]

3. Kyriacou, M.C.; Rouphael, Y.; Colla, G.; Zrenner, R.; Schwarz, D. Vegetable grafting: The implications of a growing agronomic imperative for vegetable fruit quality and nutritive value. Front. Plant Sci. 2017, 8, 1-23. [CrossRef] [PubMed]

4. Boyaci, H.F.; Ellialtioglu, S.S. Rootstock usage in eggplant: Actual situation and recent advances. Acta Hortic. 2020, 1271, 403-410. [CrossRef]

5. Sabatino, L.; Iapichino, G.; Maggio, A.; D’Anna, E.; Bruno, M.; D'Anna, F. Grafting affects yield and phenolic profile of Solanum melongena L. landraces. J. Integr. Agric. 2016, 15, 1017-1024. [CrossRef]

6. Sabatino, L.; Iapichino, G.; D’Anna, F.; Palazzolo, E.; Mennella, G.; Rotino, G.L. Hybrids and allied species as potential rootstocks for eggplant: Effect of grafting on vigour, yield and overall fruit quality traits. Sci. Hortic. 2018, 228, 81-90. [CrossRef]

7. Pebriana, E.; Dawam Maghfoer, M.O.C.H.; Widaryanto, E. Effect of grafting using wild eggplant as rootstock on growth and yield of four eggplant (Solanum melongena L.) cultivars. Biosci. Res. 2018, 15, 337-347.

8. Giuffrida, F.; Cassaniti, C.; Agnello, M.; Leonardi, C. Growth and ionic concentration of eggplant as influenced by rootstocks under saline conditions. Acta Hortic. 2015, 1086, 161-166. [CrossRef]

9. Daunay, M.C. Eggplant. In Handbook of Plant Breeding; Prohens, J., Nuez, F., Eds.; Vegetables II; Springer: New York, NY, USA, 2008; pp. 163-220. [CrossRef]

10. Furini, A.; Wunder, J. Analysis of eggplant (Solanum melongena) related germplasm: Morphological and AFLP data contribute to phylogenetic interpretations and germplasm utilization. Theor. Appl. Genet 2004, 108, 197-208. [CrossRef]

11. Rahman, M.A.; Rashid, M.A.; Hossain, M.M.; Salam, M.A.; Masum, A.S.M.H. Grafting compatibility of cultivated eggplant varieties with wild Solanum species. Pak. J. Biol. Sci. 2002, 5, 755-757. [CrossRef]

12. King, S.R.; Davis, A.R.; Zhang, X.; Crosby, K. Genetics, breeding and selection of rootstocks for Solanaceae and Cucurbitaceae. Sci. Hort. 2010, 127, 106-111. [CrossRef]

13. Kacjan Maršić, N.; Mikulič-Petkovšek, M.; Stampar, F. Grafting influences phenolic profile and carpometric traits of fruits of greenhouse-grown eggplant (Solanum melongena L.). J. Agric. Food Chem. 2014, 62, 10504-10514. [CrossRef]

14. Guan, W.; Zhao, X.; Huber, D.J.; Sims, C.A. Instrumental and sensory analyses of quality attributes of grafted specialty melons. J. Sci. Food Agric. 2015, 95, 2989-2995. [CrossRef] [PubMed]

15. Grieneisen, M.L.; Aegerter, B.J.; Scott Stoddard, C.; Zhang, M. Yield and fruit quality of grafted tomatoes, and their potential for soil fumigant use reduction. A meta-analysis. Agron. Sustain. Dev. 2018, 38, 29. [CrossRef]

16. Németh, D.; Balázs, G.; Daood, H.; Kovács, Z.; Bodor, Z.; Zinia Zaukuu, J.-L.; Szentpéteri, V.; Kókai, Z.; Kappel, N. Standard Analytical Methods, Sensory Evaluation, NIRS and Electronic Tongue for Sensing Taste Attributes of Different Melon Varieties. Sensors 2019, 19, 5010. [CrossRef] 
17. Fekete, D.; Balázs, G.; Bőhm, V.; Várvölgyi, E.; Kappel, N. Sensory evaluation and electronic tongue for sensing grafted and non-grafted watermelon taste attributes. Acta Alimentaria 2018, 47, 487-494. [CrossRef]

18. Liu, Q.; Zhao, X.; Brecht, J.K.; Sims, C.A.; Sanchez, T.; Dufault, N.S. Fruit quality of seedless watermelon grafted onto squash rootstocks under different production systems. J. Sci. Food Agric. 2017, 97, 4704-4711. [CrossRef]

19. Velkov, N.; Pevivharova, G. Effects of cucumber grafting on yield and fruit sensory characteristics. Zemdirbyste Agric. 2016, 103, 405-410. [CrossRef]

20. Di Gioia, F.; Serio, F.; Buttaro, D.; Ayala, O.; Santamaria, P. Influence of rootstock on vegetative growth, fruit yield and quality in 'Cuore di Bue', an heirloom tomato. J. Hort. Sci. Biotechnol. 2010, 854, 77-482. [CrossRef]

21. Barrett, C.E.; Zhao, X.; Hodges, A.W. Cost benefit analysis of using grafted transplants for root-knot nematode management in organic heirloom tomato production. HortTechnology 2012, 22, 252-257. [CrossRef]

22. Larrigaudiere, C.; Lentheric, I.; Vendrell, M. Relationship between enzymatic browning and internal disorders in controlled atmosphere stored pears. J. Sci. Food Agric. 1998, 78, 232-236. [CrossRef]

23. Prohens, J.; Rodriguez-Burruezo, A.; Raigon, M.D.; Nuez, F. Total phenolics concentration and browning susceptibility in a collection of different varietal types and hybrids of eggplant: Implications for breeding for higher nutritional quality and reduced browning. J. Am. Soc. Hort. Sci. 2007, 132, 638-646. [CrossRef]

24. Sabatino, L.; D’Anna, F.; D’Anna, F.; Iapichino, G.; Moncada, A.; D'Anna, E.; De Pasquale, C. Interactive effects of genotype and molybdenum supply on yield and overall fruit quality of tomato. Front. Plant Sci. 2019, 9, 19-22. [CrossRef] [PubMed]

25. Gisbert, C.; Prohens, J.; Raigón, M.D.; Stommel, J.R.; Nuez, F. Eggplant relatives as sources of variation for developing new rootstocks: Effects of grafting on eggplant yield and fruit apparent quality and composition. Sci. Hortic. 2011, 128, 14-22. [CrossRef]

26. Passam, H.C.; Stylianou, M.; Kotsiras, A. Performance of eggplant grafted on tomato and eggplant rootstocks. Eur. J. Hort. Sci. 2005, 70, 130-134.

27. Cassaniti, C.; Giuffrida, F.; Scuderi, D.; Leonardi, C. Effect of rootstock and nutrient solution concentration on eggplant grown in a soilless system. J. Food Agric. Environ. 2011, 9, 252-256.

28. Colla, G.; Rouphael, Y.; Jawad, R.; Kumar, P.; Rea, E.; Cardarelli, M. The effectiveness of grafting to improve $\mathrm{NaCl}$ and $\mathrm{CaCl}_{2}$ tolerance in cucumber. Sci. Hortic. 2013, 164, 380-391. [CrossRef]

29. Colla, G.; Rouphael, Y.; Cardarelli, M.; Rea, E. Effect of salinity on yield, fruit quality, leaf gas exchange, and mineral composition of grafted watermelon plants. HortScience 2006, 41, 622-627. [CrossRef]

30. Soteriou, G.A.; Kyriacou, M.C. Rootstock mediated effects on watermelon field performance and fruit quality characteristics. Intern. J. Vegetable. Sci. 2014, 21, 344-362. [CrossRef]

31. Schwarz, D.; Öztekin, G.B.; Tüzel, Y.; Brückner, B.; Krumbein, A. Rootstocks can enhance tomato growth and quality characteristics at low potassium supply. Sci. Hortic. 2013, 149, 70-79. [CrossRef]

32. Turhan, A.; Ozmen, N.; Serbeci, M.S.; Seniz, V. Effects of grafting on different rootstocks on tomato fruit yield and quality. Hortic. Sci. 2011, 38, 142-149. [CrossRef]

33. Romano, D.; Paratore, A.; Vindigni, G. Caratteristiche dei fruttidi pomodoro in rapporto a diversi portinnesti. In Proceedings of the Workshop on 'Applicazione di Tecnologie Innovative per il Miglioramentodell' Orticoltura Meridionale', Consiglio Nazionale delle Ricerche, Rome, Italy, 18 July 2000; pp. 113-114.

34. Moncada, A.; Miceli, A.; Vetrano, F.; Mineo, V.; Planeta, D.; D'Anna, F. Effect of grafting on yield and quality of eggplant (Solanum melongena L.). Sci. Hortic. 2013, 149, 108-114. [CrossRef]

35. Ulukapi, K.; Onus, A.N. Comparison of the productivity and quality of the grafted and ungrafted tomato plants grown in the greenhouse with mycorrhiza application. X Int. Symp. Process. Tomato 2007. [CrossRef]

36. Radicetti, E.; Massantini, R.; Campigliaa, E.; Mancinelli, R.; Ferri, S.; Moscetti, R. Yield and quality of eggplant (Solanum melongena L.) as affected by cover crop species and residues. Sci. Hortic. 2016, 204, 161-171. [CrossRef]

37. Arvanitoyannis, I.S.; Khah, E.; Christakou, E.C.; Bletsos, F.A. Effect of grafting and modified atmosphere packaging on eggplant quality parameters during storage. Int. J. Food Sci. Tech. 2005, 40, 311-322. [CrossRef]

38. Khah, E.M.; Kakava, E.; Mavromatis, A.; Chachalis, D.; Goulas, C. Effect of grafting on growth and yield of tomato (Lycopersicon esculentum Mill.) in greenhouse and open-field. J. Appl. Hortic. 2006, 8, 3-7. [CrossRef]

39. Khah, E.M. Effect of grafting on growth, performance and yield of aubergine (Solanum melongena L.) in greenhouse and open-field. Intern. J. Plant Prod. 2011, 5, 359-366. [CrossRef] 
40. Lee, J.M.; Kubota, C.; Tsao, S.J.; Biel, Z.; Hoyos Echevaria, P.; Morra, L. Current status of vegetable grafting: Diffusion, grafting techniques, automation. Sci. Hortic. 2010, 127, 93-105. [CrossRef]

41. Rouphael, Y.; Schwarz, D.; Krumbein, A.; Colla, G. Impact of grafting on product quality of fruit vegetables. Sci. Hortic. 2010, 127, 172-179. [CrossRef]

42. Akanbi, W.B.; Togun, A.O.; Olaniran, O.A.; Akinfasoye, J.O.; Tairu, F.M. Physico-chemical properties of eggplant (Solanum melongena L.) fruit in response to nitrogen fertilizer and fruit size. Agric. J. 2007, 2, 140-148.

43. Casals, J.; Rull, A.; Bernal, M.; González, R.; del Castillo, R.R.; Simó, J. Impact of grafting on sensory profile of tomato landraces in conventional and organic management systems. Hortic. Environ. Biotech. 2018, 59, 597-696. [CrossRef]

(C) 2020 by the authors. Licensee MDPI, Basel, Switzerland. This article is an open access article distributed under the terms and conditions of the Creative Commons Attribution (CC BY) license (http://creativecommons.org/licenses/by/4.0/). 
Article

\title{
Partial Root-Zone Drying and Deficit Irrigation Effect on Growth, Yield, Water Use and Quality of Greenhouse Grown Grafted Tomato
}

\author{
Branimir Urlić ${ }^{1}$, , Marko Runjić ${ }^{1}$, Marija Mandušić ${ }^{1}$, Katja Žanić ${ }^{1}$, Gabriela Vuletin Selak ${ }^{2}$, \\ Ana Matešković ${ }^{1}$ and Gvozden Dumičić ${ }^{2}$ \\ 1 Department of Applied Sciences, Institute for Adriatic Crops and Karst Reclamation, Put Duilova 11, \\ 21000 Split, Croatia; marko.runjic@krs.hr (M.R.); marija.mandusic@krs.hr (M.M.); katja@krs.hr (K.Ž.); \\ ana.mateskovic@krs.hr (A.M.) \\ 2 Department of Plant Sciences, Institute for Adriatic Crops and Karst Reclamation, Put Duilova 11, \\ 21000 Split, Croatia; gabriela.vuletin.selak@krs.hr (G.V.S.); gvozden.dumicic@krs.hr (G.D.) \\ * Correspondence: branimir@krs.hr; Tel.: +385-21-434478
}

Received: 9 August 2020; Accepted: 26 August 2020; Published: 1 September 2020

\begin{abstract}
The tomato is an important horticultural crop, the cultivation of which is often under influence of abiotic and biotic stressors. Grafting is a technique used to alleviate these problems. Shortage of water has stimulated the introduction of new irrigation methods: deficit irrigation (DI) and partial root-zone drying (PRD). This study was conducted in two spring-summer season experiments to evaluate the effects of three irrigation regimes: full irrigation (FI), PRD and DI on vegetative growth, leaf gas-exchange parameters, yield, water-use efficiency (WUE), nutrients profile and fruit quality of grafted tomatoes. In both years, the commercial rootstocks Emperador and Maxifort were used. In the first year, the scion cultivar Clarabella was grown on one stem and in the second year the cultivar Attiya was grown on two stems. Self-grafted cultivars were grown as a control. In both experiments, higher vegetative traits (leaf area and number, height, shoot biomass) were recorded in the plants grafted on commercial rootstocks. The stomatal conductance and transpiration rate were higher under FI. Under DI, transpiration was lowest and photosynthetic WUE was highest. Photosynthetic rate changed between irrigation treatments depending on plant type. In both years, the total yield was highest in grafted plants as result of more and bigger fruits per plant. In the 2nd year, grafted plants under FI had higher yield compared to PRD, but not to DI, while self-grafted plants did not differ between irrigation treatments. WUE was highest in DI and PRD treatments and in grafted plants. Leaf N, P, K and Ca was highest in tthe plants grafted on Emperador and Maxifort, while more $\mathrm{Mg}$ was measured in self-grafted plants. More $\mathrm{Ca}$ and $\mathrm{Mg}$ were recorded in the plants under DI and PRD. Fruit mineral concentrations were higher in the plants grafted on commercial rootstocks. Total soluble solids differed between irrigation regarding plant types, while fruit total acidity was higher in Emperador and Maxifort. In conclusion, our study showed that grafted plants could be grown under DI with minor yield reduction with $30-40 \%$ less water used for irrigation. Moderate DI could be used before PRD for cultivation of grafted tomato and double stemmed plants did not show negative effect on tomato yield so it can be used as standard under reduced irrigation.
\end{abstract}

Keywords: reduced irrigation; rootstocks; yield traits; leaf gas exchange

\section{Introduction}

The tomato (Solanum lycopersicum L.) is a leading vegetable and one of the most important horticultural crops. The world production of tomatoes is second to only potatoes, with an estimated production of 160 million tons [1]. Tomato production problems with abiotic and biotic stressors as 
results of intensive monoculture often create problems in tomato production. Tomato production losses caused by unfavorable growing conditions can be reduced by grafting onto specific rootstocks. Commercial vegetable grafting started at the beginning of the 20th century, with the primary intention to achieve tolerance to soil pathogens [2]. The substantial proportion of total tomato production in Europe and Asia currently include usage of grafted tomatoes [3]. In addition, the widespread use of grafting was expected to improve crop response to water, salt, nutrient deficiency and temperatures stresses and to improve fruit quality $[4,5]$.

Water availability is decreasing worldwide-especially where agriculture uses between $50 \%$ and $90 \%$ of all water, such as semi-arid Mediterranean areas. In the context of climate change, improvement of irrigation practices is needed, by use of new sources (e.g., wastewater) or by application of new irrigation techniques [6]. Two main methods regarding the use of reduced irrigation are introduced, namely deficit irrigation (DI) and partial rootzone-drying (PRD) to improve water-use efficiency (WUE). These practices expose the plant to moderate drought stress, could increase abscisic acid (ABA) levels that leads to greater increase in WUE [7]. DI supplies less water to the entire rootzone than the amount lost by evapotranspiration, while PRD involves alternate wetting and drying of the root zones. PRD has been shown to improve DI and has resulted in substantial water savings, improved water-use efficiency and it is superior to DI in terms of yield maintenance in greenhouse or processing tomato $[8,9]$.

Grafted plants showed better uptake of minerals and water than un-grafted plants due to vigorous root growth by the chosen rootstock [10]. Grafted tomato under deficit irrigation showed increased yield and WUE [11,12]. The tomato cultivar Boludo grafted on 144 tomato rootstocks showed higher shoot fresh weight under water deficit in $38 \%$ of combinations [13]. Tomato cultivars Belle and Clarabelle grafted on the rootstock He-man had similar vegetative growth and yield under PRD conditions in commercial greenhouse [14]. The breeding of commercial rootstocks like 'Maxifort' on the other hand was more directed to increase growth capacity and to alleviate soilborne diseases, instead of water economy [2], although it showed similar performance compared to drought tolerant cultivars [15]. Sink limitation is more pronounced in grafted tomato plants compared to non-grafted ones. One of the ways to avoid sink limitations is growing double-stemmed grafted plants. Grafting with two stems became the standard growing method for sustaining tomato production, as it decreased the costs per unit area by reducing the number of plants grown in a greenhouse by one-half $[16,17]$.

The effects of grafting on tomato fruit quality are showing inconsistencies in of the results, mostly affected by the rootstock-scion combination [5]. Similarly, scarce reports showed that grafted plants under water stress differ in total soluble solids (TSS) and total acidity (TA) [11,14,18].

In the first study, we evaluated the effect of PRD on the growth, yield and quality of grafted tomato grown in a commercial greenhouse [14]. As proper evaluation of reduced irrigation methods apart PRD include DI, the two-year studies included the deficit irrigation treatments with similar amount of water applied as in PRD, but evenly to the whole root system. Since two stems are the standard practice for cultivation of grafted tomato, we also included stem number as a factor in our experiments. Finally, the purpose of our studies was to compare the responses of grafted tomato plants subjected to PRD or DI by evaluating vegetative growth, leaf gas-exchange parameters, yield traits, WUE and leaf and fruit mineral profile and fruit quality in a greenhouse located in a Mediterranean climate.

\section{Material and Methods}

Two experiments were conducted on tomatoes in spring-summer season in commercial greenhouses in the Split area (Mediterranean area of Croatia). The first experiment used plants grown on one stem, and in the second experiment two-stem plants were used.

\subsection{Experiment I: Single Stem Plants (2016)}

The first experiment was established in an unheated greenhouse in the Trogir $\left(43^{\circ} 31^{\prime} \mathrm{N}, 16^{\circ} 15^{\prime} \mathrm{E}\right)$ used for intensive vegetable production for many years. The soil type was an alkaline clay with $8.09 \mathrm{pH}$ 
$\left(\mathrm{H}_{2} \mathrm{O}\right), 7.51 \mathrm{pH}(\mathrm{KCl}), 4.4 \%$ soil organic matter and $120 \mathrm{mg}$ of available $\mathrm{P}_{2} \mathrm{O}_{5}$, and $48 \mathrm{mg} \mathrm{K} 2 \mathrm{O} / 100 \mathrm{~g}$ of soil. The greenhouse had side ventilation and the roof was $3 \mathrm{~m}$ high.

Tomato (Solanum lycopersicum L., cv. Clarabella F1, Rijk Zwaan, The Netherlands) plants were either self-grafted or grafted onto the rootstocks "Emperador" (S. lycopersicum $\times$ S. habrochaites, Rijk Zwaan) or "Maxifort" (S. lycopersicum $\times$ S. habrochaites, De Ruiter Seeds, Amsterdam North, The Netherlands). Both rootstocks, as noted by the seed companies, have high to medium vigor and are resistant to Fusarium, Verticillium and ToMV.

The scion seeds were sown on 17 January 2016 and rootstock seeds on 20 January 2016 in polystyrene plug trays with cell volume of $40 \mathrm{~mL}$ in an organic substrate (Brill Type 4, Brill Substrate, Georgsdorf, Germany). As scion and rootstocks have variable growth vigor and to ensure optimum stem diameter between scion and rootstock seedlings at grafting time the scion seeds were sown 3 days earlier than the rootstock. The trays with sown seeds were put in a heated greenhouse (day/night $25^{\circ} \mathrm{C}$ ).

The cv. 'Clarabella' seedlings were self-grafted and grafted onto both rootstocks at 25 days after sowing using the "splice grafting" method. Grafted seedlings were maintained under reduced light conditions ( $10 \%$ of the daily light intensity) at a relative humidity above $95 \%$ and temperature from $22{ }^{\circ} \mathrm{C}$ to $25^{\circ} \mathrm{C}$ until callus formation. After callus formation, the seedlings were maintained as standard tomato transplant. Seedlings were grown in research greenhouse at the Institute for Adriatic Crops (Split, Croatia).

Tomato seedlings with four to five true leaves were transplanted 65 days after sowing (24 March 2016) in a two-row system (90 cm apart) with rows $60 \mathrm{~cm}$ apart with plants were spaced $50 \mathrm{~cm}$ in each row, for a total of 2.7 plants $/ \mathrm{m}^{2}$. The plants were drip irrigated with drippers (pressure-compensating emitters) set in opposite lines of row plants (15 cm from plants). After transplanting, plants were irrigated per the standard practice in the area. During the trial, plants were fertilized twice with $\mathrm{Mg}$, as other nutrients had high available soil concentrations, as confirmed by $\mathrm{N}$ and $\mathrm{K}$ petiole sap analysis during growth phases.

Three irrigation treatments were started 30 days after transplanting: full irrigation (FI), deficit irrigation (DI) and partial-root zone drying (PRD). The soil moisture content was measured by tensiometers (Blumat digital, Leingarten, Germany) which were laboratory calibrated for conducted soil. The tensiometers were placed at $25-30 \mathrm{~cm}$ depth. In FI treatment, plants were watered to a soil moisture content of $65-75 \%$ of field capacity. DI treatments received $50 \%$ water used in FI by using drippers with half capacity than in FI. With PRD, half of the root system was irrigated at $65-75 \%$ of field water capacity (FWC), while other half of the roots were dried until soil moisture reached $35-40 \%$ of field capacity and then irrigation was shifted between two sides of the root system. PRD also received $50 \%$ water from FI. Different irrigation treatments were divided by placing PE folia to the depth of 45-50 cm to stop horizontal water movement. Taking into account water supplied before start of irrigation treatment, in total DI and PRD got $60 \%$ water supplied to FI that received $214 \mathrm{~L}$ per plant.

The plant height and the number of leaves (longer than $5 \mathrm{~cm}$ ) were determined for 7 weeks after transplanting. Harvest started 70 days after transplanting (DAT) and lasted for 55 days-including 12 harvests of fruits as they matured (light red color) The average fruit weight and fruit number were recorded. The first four harvests were calculated as early yield. On the day of the last harvest, the aboveground parts of the subsample plants ( 3 plants per treatment) were removed, divided into leaves, stems and green fruits and weighed for fresh biomass (FM). After measuring the leaf area with leaf area meter LI-3000 (LI-COR, Bad Homburg, Germany), samples were put into an oven and dried at $70{ }^{\circ} \mathrm{C}$ to constant weight to obtain the DM. The yield divided by supplied water was used to find the yield WUE (WUEy).

\subsection{Experiment II: Double Stem Plants (2017)}

The greenhouse in the split was used for the second experiment $\left(43^{\circ} 30^{\prime} \mathrm{N}, 16^{\circ} 30^{\prime} \mathrm{E}\right)$. The soil type was a clay loam with $8.71 \mathrm{pH}\left(\mathrm{H}_{2} \mathrm{O}\right), 7.46 \mathrm{pH}(\mathrm{KCl}), 2.9 \%$ soil organic matter, $16.5 \%$ high active lime and $27 \mathrm{mg}$ of available $\mathrm{P}_{2} \mathrm{O}_{5}$ and $31 \mathrm{mg} \mathrm{K} 2 \mathrm{O} / 100 \mathrm{~g}$ of soil. Same rootstocks were used as in 
Experiment I, and scion cultivar was Attiya (Rijk Zwaan, De Lier, the Netherlands) due to resistance to TSWV (Tomato spotted wilt virus) that influenced growth and yield in previous years on different tomato cultivars in used greenhouse. The scion and rootstocks seeds were sown on 19 January 2016 and 23 January 2016, respectively. Grafting was done on 17 February 2016; all other procedures for seedling production were done as in previous year. In this experiment, two types of seedlings were produced: self-grafted Attiya grown on one stem (ATT) and plants grown on two stems: self-grafted Attiya (AT), Attiya grafted on Emperador (EM) and Attiya grafted on Maxifort (MX), which in total gave four plant types. Two-stemmed seedlings were formed from side-shoots of cotyledons.

The tomato seedlings were transplanted 55 days after sowing (16 March 2016) in two systems: one stem seedlings as in previous years in a two-row system and two-stem seedlings in a one-row system with rows $120 \mathrm{~cm}$ apart. In each row, the plants were spaced $50 \mathrm{~cm}$, which in both systems gave $2.7 \mathrm{stems} / \mathrm{m}^{2}$.

Irrigation treatments started 50 DAT and included FI, DI and PRD. In this year, the soil moisture content was controlled by Maxi Rain soil moisture sensors (Elektronik Jeske, Windorf, Germany), which were set up to open electromagnetic valve when soil moisture was lower than $65 \%$ field water capacity and was irrigated until reached $80 \%$ FWC. DI treatment received $60 \%$ water supplied to FI using drippers with lower capacity. To better measure water needs in the PRD, this treatment had its own sensors for controlling irrigation and switching sides. The PRD used $50 \%$ of the water used in FI. In total—including water applied before irrigation treatment start—-the DI used 70\% and PRD 65\% water of the FI. The FI in total received $233 \mathrm{~L} /$ plant, DI $170 \mathrm{~L} /$ plant and PRD $153 \mathrm{~L} /$ plant. House-made lysimeters $(60 \mathrm{~cm} \times 100 \mathrm{~cm} \times 5 \mathrm{~cm})$ were put below every irrigation treatment at depth of $60 \mathrm{~cm}$ to control possible leaching if plants were over-irrigated.

Plants were fertilized by irrigation system with $\mathrm{N}, \mathrm{K}$ and $\mathrm{Mg}$, depending on growth phases and plant needs. Plant height and leaf number were measured each week. Harvest started at 80 DAT (7 June) and lasted 45 days, consisting of 11 harvests. At the end, plants were divided to determine biomass partitioning, as in previous year.

Leaf nutrient concentrations were determined in the youngest fully developed leaves after the leaves were dried at $70{ }^{\circ} \mathrm{C}$ and then ground. The micro-Kjeldahl digestion method (Kjeltec System 1026, Tecator, Höganas, Sweden) was used to measure total leaf N concentration. Dry ash of grounded samples from a muffle furnace were dissolved in $2 \mathrm{~mL} \mathrm{HCl}$ to extract the $\mathrm{P}, \mathrm{K}, \mathrm{Ca}$ and $\mathrm{Mg}$. The $\mathrm{K}$ concentration was measured using a flame photometer (Model 410, Sherwood Scientific, Cambridge, UK). The vanadate-molybdate yellow color method using a UV-visible spectrophotometer was used to determine the $\mathrm{P}$ concentration (Cary 50 Scan, Varian, Palo Alto, CA, USA) at $420 \mathrm{~nm}$. The Ca and $\mathrm{Mg}$ in solution were determined by atomic absorption spectrometry (SpectrAA 220, Varian, Palo Alto, CA, USA).

The quality parameters of fruits from each treatment were analyzed in the second experiment. For the tomato juice, the total soluble solids (TSS) content was determined by a DR 201-95 refractometer (Kruss optronic, Hamburg, Germany) and expressed in Brix at $20^{\circ} \mathrm{C}$. Acidity was determined by juice titration with $0.1-\mathrm{M} \mathrm{NaOH}$ was used for determination of acidity and results were expressed as citric acid. Gas-exchange parameters were measured using LI-6400 infrared gas analyzer (LI-COR, Inc., Lincoln, NE, USA) in youngest fully expanded leaves. Measurements were performed on six leaves per treatment 20 days after different irrigation techniques were applied in whole experiment. Measurements were conducted under constant light (PAR $750 \mu \mathrm{mol} \mathrm{m}^{-2} \mathrm{~s}^{-1}$ ) and $\mathrm{CO}_{2}$ concentration $\left(400 \mu \mathrm{mol} \mathrm{mol}^{-1}\right)$. The environmental conditions in the greenhouse ranged from $22{ }^{\circ} \mathrm{C}$ to $33^{\circ} \mathrm{C}$ for air temperature and from $33 \%$ to $42 \%$ for relative humidity (RH). The greenhouse light conditions (PAR) ranged from 300 to $1100 \mu \mathrm{mol} \mathrm{m}^{-2} \mathrm{~s}^{-1}$. The transpiration rate (E) and photosynthetic rate (A) were determined from gas exchange measurements and were used to determine the photosynthetic/instantaneous water-use efficiency (PWUE) as the ratio between A and E [19].

The experiments were set up in a randomized block design, consisting of three replications. Each treatment (irrigation $\times$ plant type) was comprised of 12 plants. The data were evaluated by 
ANOVA and when F-tests were significant, the means of the main factors (rootstock/plant type and irrigation technique) and their interactions were compared using the least significant difference test at $p \leq 0.05$. The data were statistically analyzed using StatView ver. 5.0 (SAS Institute, Cary, CA, USA).

\section{Results}

\subsection{Plant Growth and Biomass Production}

In the first year of the experiment, plants grown on one stem showed significant differences in vegetative parameters regarding rootstock type used (Table 1). Plants grafted on Emperador rootstock had highest leaf area, number of leaves, plant height and leaf and shoot dry biomass (DM) compared to self-grafted plants. The irrigation method and interaction between irrigation and graft did not show significant differences.

Table 1. Effect of rootstock type and irrigation treatment on tomato vegetative characteristics in the first year of the experiment with plants grown on one stem.

\begin{tabular}{|c|c|c|c|c|c|}
\hline \multirow{2}{*}{ Treatments } & \multicolumn{3}{|c|}{ Leaf } & \multirow{2}{*}{$\frac{\text { Shoot }}{\text { DM }\left(\text { g plant }^{-1}\right)^{*}}$} & \multirow{2}{*}{$\begin{array}{l}\text { Plant Height } \\
\text { (70 DAT) }(\mathrm{cm})\end{array}$} \\
\hline & Number (70 DAT) & Area $\left(\mathrm{cm}^{2}\right.$ plant $\left.^{-1}\right)$ & DM (g plant $\left.{ }^{-1}\right)$ & & \\
\hline \multicolumn{6}{|l|}{ Rootstock (R) } \\
\hline Self-grafted & $24.4 \mathrm{~b}^{\dagger}$ & $10,406 \mathrm{~b}$ & $108.1 \mathrm{~b}$ & $183.7 \mathrm{~b}$ & $172.5 b$ \\
\hline Emperador & $26.7 \mathrm{a}$ & 19,117 a & $188.6 \mathrm{a}$ & $296.9 \mathrm{a}$ & $184.1 \mathrm{a}$ \\
\hline Maxifort & $26.2 \mathrm{ab}$ & $16,521 \mathrm{a}$ & $158.1 \mathrm{ab}$ & $248.7 \mathrm{ab}$ & $177.7 \mathrm{ab}$ \\
\hline \multicolumn{6}{|l|}{ Irrigation (I) } \\
\hline Full & 25.3 & 15,621 & 149.9 & 245.9 & 175.2 \\
\hline Deficit & 26.7 & 14,990 & 144.4 & 234.1 & 180.8 \\
\hline PRD & 26.2 & 15,433 & 160.5 & 249.2 & 178.3 \\
\hline $\mathrm{I} \times \mathrm{R}$ & ns & ns & ns & ns & ns \\
\hline
\end{tabular}

${ }^{*} \mathrm{DM}$-dry mass; ${ }^{\dagger}$ Significant differences between treatments (LSD test at $p \leq 0.05$ ) are indicated with different letters within columns. ns-non-significant.

In the second year, statistical analyses for vegetative growth are presented in Table 2. Results are presented per stem for two-stemmed grafted plants with plants of one stem. Similar to the first experiment year, most measured traits were significantly affected by rootstock type. Additionally, the leaf number showed differences in irrigation technique applied. Leaf and shoot DM per stem was significantly highest in Emperador and lowest in Attiya. No difference in these traits were found between one-stem Attiya and Maxifort. It can be concluded that Maxifort produces two times more DM per whole plant.

Table 2. Effect of rootstock type and irrigation treatment on tomato vegetative characteristics in the second year of the experiment with plants grown on one and two stem.

\begin{tabular}{|c|c|c|c|c|c|}
\hline \multirow{2}{*}{ Treatments } & \multicolumn{3}{|c|}{ Leaf } & \multirow{2}{*}{$\begin{array}{c}\text { Shoot } \\
\text { DM }\left(\text { g stem }^{-1}\right)\end{array}$} & \multirow{2}{*}{$\begin{array}{l}\text { Plant Height } \\
\text { (60 DAT) }(\mathrm{cm})\end{array}$} \\
\hline & Number (60 DAT) & Area $\left(\mathrm{cm}^{2}\right.$ plant $\left.^{-1}\right)$ & DM (g stem $\left.{ }^{-1}\right)$ & & \\
\hline \multicolumn{6}{|l|}{ Rootstock (R) } \\
\hline One-stem SG * & $25.8 \mathrm{~b}^{+}$ & 14,039 a & $118.5 \mathrm{~b}$ & $177.8 \mathrm{~b}$ & $166.2 \mathrm{~b}$ \\
\hline Two-stem SG & $22.2 \mathrm{c}$ & 7758 b & $77.3 \mathrm{c}$ & $124.4 \mathrm{c}$ & $154.8 \mathrm{~b}$ \\
\hline Emperador & $27.3 \mathrm{a}$ & $11,669 \mathrm{a}$ & $147.8 \mathrm{a}$ & $252.4 \mathrm{a}$ & $199.8 \mathrm{a}$ \\
\hline Maxifort & $26.7 \mathrm{ab}$ & $13,916 \mathrm{a}$ & $117.5 \mathrm{~b}$ & $195.5 \mathrm{~b}$ & $192.8 \mathrm{a}$ \\
\hline \multicolumn{6}{|l|}{ Irrigation (I) } \\
\hline Full & $25.5 \mathrm{ab}$ & 12,308 & 117.3 & 189.8 & 178.1 \\
\hline Deficit & $26.1 \mathrm{a}$ & 12,064 & 111.2 & 178.3 & 181.6 \\
\hline PRD & $24.8 \mathrm{~b}$ & 11,164 & 117.3 & 194.6 & 177.9 \\
\hline $\mathrm{I} \times \mathrm{R}$ & ns & ns & ns & ns & ns \\
\hline
\end{tabular}

${ }^{*}$ SG—self-grafted plants; DM—dry mass; ${ }^{+}$significant differences between treatments (LSD test at $p \leq 0.05$ ) are indicated with different letters within columns. ns-non-significant. 


\subsection{Leaf Gas Exchange}

The leaf gas-exchange parameters measured 20 days after initiation of reduced irrigation treatments $(\mathrm{DI}+\mathrm{PRD})$ are in Table 3. Stomatal conductance (gs), intercellular $\mathrm{CO}_{2}(\mathrm{Ci})$, transpiration rate $(\mathrm{E})$ and photosynthetic WUE (PWUE) were significantly affected by irrigation rate. The values of gs, Ci and E were highest under FI and lowest under DI treatment, while PWUE had highest value under DI that differed from FI and PRD. In addition, only stomatal conductance differed $(p \leq 0.05)$ between rootstocks, with plants grafted on Emperador having the highest values. The effect of the interaction of the rootstock/plant type $\times$ irrigation was recorded for photosynthetic rate (A), photosynthetic WUE (Figure 1A,B) and intercellular $\mathrm{CO}_{2}$ (data not shown). The highest $\mathrm{A}$ was measured for one stem self-grafted Attiya under DI, while lowest was found for same plants under FI. On average, PWUE was highest at DI and as shown by interaction did not differed between plant types under DI, while differences in two other irrigation treatments was influenced by rootstock.
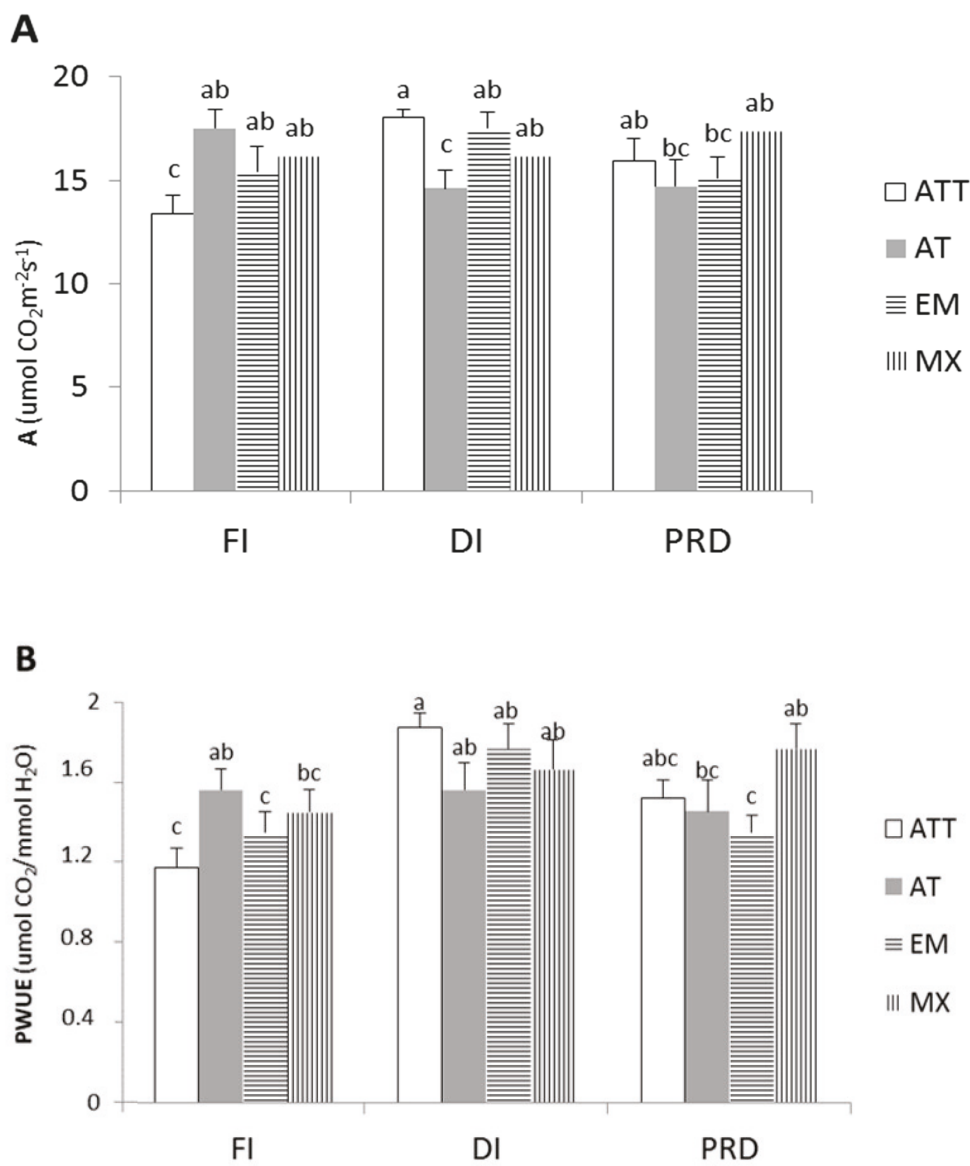

Figure 1. Photosynthetic rate (A,B) photosynthetic water-use efficiency-PWUE of grafted tomato plants grown with one or two stems under three irrigation techniques. Vertical bars represent SE values $(n=6)$. a-significant difference by the LSD test at $p \leq 0.05$ are indicated by different letters above column; ATT—one-stem Attiya; AT-two-stem Attiya; EM-Emperador, MX-Maxifort. 
Table 3. Leaf gas-exchange parameters and photosynthetic water-use efficiency of grafted tomatoes grown with one and two stems under three irrigation techniques in the second year of the experiment.

\begin{tabular}{|c|c|c|c|c|c|}
\hline Treatments & $\begin{array}{l}\text { Photosynthetic Rate (A) } \\
\left(\mu \mathrm{mol} \mathrm{CO} \mathrm{Cm}^{-2} \mathrm{~s}^{-1}\right)\end{array}$ & $\begin{array}{l}\text { Stomatal Conductance } \\
(\mathrm{gs})\left(\mathrm{mol} \mathrm{H}_{2} \mathrm{O} \mathrm{m}^{-2} \mathrm{~s}^{-1}\right)\end{array}$ & $\begin{array}{l}\text { Intercellular } \mathrm{CO}_{2}(\mathrm{Ci}) \\
\left(\mu \mathrm{mol} \mathrm{CO} \mathrm{mol}^{-1}\right)\end{array}$ & $\begin{array}{l}\text { Transpiration Rate (E) } \\
\left(\mathrm{mmol} \mathrm{H}_{2} \mathrm{O} \mathrm{m}^{-2} \mathrm{~s}^{-1}\right)\end{array}$ & $\begin{array}{l}\text { Photosynthetic WUE (PWUE) } \\
\left(\mu \mathrm{mol} \mathrm{CO} \mathrm{C}_{2} / \mathrm{mmol} \mathrm{H}_{2} \mathrm{O}\right)\end{array}$ \\
\hline \multicolumn{6}{|l|}{ Rootstock (R) } \\
\hline One-stem SG & $15.8^{*}$ & $0.81 \mathrm{~b}$ & 336.8 & 10.9 & 1.45 \\
\hline Two-stem SG & 15.6 & $0.85 \mathrm{~b}$ & 339.5 & 10.8 & 1.44 \\
\hline Emperador & 16.0 & $0.92 \mathrm{a}$ & 341.5 & 11.4 & 1.40 \\
\hline Maxifort & 16.6 & $0.84 \mathrm{~b}$ & 335.9 & 10.7 & 1.55 \\
\hline \multicolumn{6}{|l|}{ Irrigation (I) } \\
\hline Full & 15.8 & $0.93 a$ & $342.0 \mathrm{a}$ & $11.7 \mathrm{a}$ & $1.35 \mathrm{~b}$ \\
\hline Deficit & 16.5 & $0.79 \mathrm{~b}$ & $334.7 \mathrm{~b}$ & $10.1 \mathrm{c}$ & $1.63 \mathrm{a}$ \\
\hline PRD & 15.8 & $0.85 \mathrm{~b}$ & $338.7 \mathrm{ab}$ & $10.9 \mathrm{~b}$ & $1.45 \mathrm{~b}$ \\
\hline $\mathrm{I} \times \mathrm{R}$ & $*$ & ns & * & ns & * \\
\hline
\end{tabular}

* Significant differences between treatments (LSD test at $p \leq 0.05$ ) are indicated with different letters within columns. ns-non-significant.

\subsection{Yield and Water-Use Efficiency}

The effects of rootstock type and irrigation technique on tomato yield traits and WUE in the first experiment are presented in Table 4, Average fruit weight, fruit number per plant and total yield were affected by rootstock and were higher in grafted plants than in self-grafted ones. Early yield was significantly affected by irrigation technique and highest values were noted for DI plants differing only with plants cultivated under PRD regime. WUE was affected by rootstock and irrigation. As expected, plants under DI and PRD had almost double values of WUE. Emperador and Maxifort plants significantly differed from self-grafted ones and on average had $40 \%$ higher WUE values.

Table 4. Yield parameters and water-use efficiency of grafted tomato plants grown with one stem under three irrigation techniques in the first year of the experiment.

\begin{tabular}{|c|c|c|c|c|c|}
\hline Treatments & Fruit Mean Weight (g) & Number Plant ${ }^{-1}$ & Early Yield Plant ${ }^{-1}$ (g) & Yield Plant ${ }^{-1}$ (g) & WUEy $\left(\mathrm{g} \mathrm{L}^{-1}\right)$ \\
\hline \multicolumn{6}{|l|}{ Rootstock (R) } \\
\hline Self-grafted & $243 b^{*}$ & $19.3 \mathrm{~b}$ & 761 & $4749 \mathrm{~b}$ & $34.1 \mathrm{~b}$ \\
\hline Emperador & $293 \mathrm{a}$ & $24.1 \mathrm{a}$ & 821 & $7089 a$ & $50.0 \mathrm{a}$ \\
\hline Maxifort & $304 \mathrm{a}$ & $23.1 \mathrm{a}$ & 847 & $7064 \mathrm{a}$ & $40.9 \mathrm{a}$ \\
\hline \multicolumn{6}{|l|}{ Irrigation (I) } \\
\hline Full & 278 & 21.0 & $805 \mathrm{ab}$ & 5953 & $27.8 \mathrm{~b}$ \\
\hline Deficit & 279 & 43853.0 & $938 \mathrm{a}$ & 6583 & $53.5 \mathrm{a}$ \\
\hline PRD & 283 & 43912.0 & $687 \mathrm{~b}$ & 6366 & $51.8 \mathrm{a}$ \\
\hline $\mathrm{I} \times \mathrm{R}$ & ns & ns & ns & ns & ns \\
\hline
\end{tabular}

* Significant differences between treatments (LSD test at $p \leq 0.05$ ) are indicated with different letters within columns. ns-non-significant.

Yield parameters and WUE results for second year are shown in Table 5. As in the first year, plants grafted on commercial rootstocks had significantly $(p \leq 0.001)$ higher fruit mean weight and also number of fruits per stem. Early yield was affected $(p \leq 0.001)$ by plant type and highest was noted for self-grafted Attiya grow with one stem. Yield WUE was significantly $(p \leq 0.001)$ higher for Emperador and Maxifort grafted plants and also for plants grown under both types of reduced irrigation (DI + PRD).

Total yield results for second year are shown in Figure 2. Although, the interaction between factors was not significant, it was important to compare yield of same plant type under different irrigation. This analysis showed that grafted plants with commercial rootstocks grown under FI had highest total yield that differed from same plants type grown under PRD, but not significantly different from DI. In addition, one stem self-grafted plants from all irrigation regimes did not differed to each other and two stem ones had lowest yield had under PRD. 
Table 5. Yield parameters and water-use efficiency of grafted tomato plants grown with one and two stems under three irrigation techniques in the second year of the experiment.

\begin{tabular}{|c|c|c|c|c|c|}
\hline Treatments & Fruit Mean Weight (g) & Number stem $^{-1}$ & Early Yield Stem ${ }^{-1}(\mathrm{~g})$ & Yield Stem $^{-1}(\mathrm{~g})$ & WUEy $\left(\mathrm{g} \mathrm{L}^{-1}\right)$ \\
\hline \multicolumn{6}{|l|}{ Rootstock (R) } \\
\hline One-stem SG & $210 b^{*}$ & $17.6 \mathrm{~b}$ & 1415 a & $3696 \mathrm{~b}$ & $41.1 \mathrm{~b}$ \\
\hline Two-stem SG & $226 \mathrm{~b}$ & $14.8 \mathrm{c}$ & $786 \mathrm{~b}$ & $3347 \mathrm{~b}$ & $36.8 \mathrm{~b}$ \\
\hline Emperador & $261 \mathrm{a}$ & $20.4 \mathrm{a}$ & $604 \mathrm{~b}$ & 5279 a & $58.1 \mathrm{a}$ \\
\hline Maxifort & $271 \mathrm{a}$ & $19.7 \mathrm{a}$ & $699 \mathrm{~b}$ & 5342 a & $59.5 \mathrm{a}$ \\
\hline \multicolumn{6}{|l|}{ Irrigation (I) } \\
\hline Full & 256 & 18.4 & 772 & $4769 \mathrm{a}$ & $40.8 \mathrm{~b}$ \\
\hline Deficit & 239 & 18.7 & 799 & $4436 \mathrm{ab}$ & $52.2 \mathrm{a}$ \\
\hline PRD & 239 & 17.5 & 949 & $4187 \mathrm{~b}$ & $54.9 \mathrm{a}$ \\
\hline $\mathrm{I} \times \mathrm{R}$ & ns & ns & ns & ns & ns \\
\hline
\end{tabular}

* Significant differences between treatments (LSD test at $p \leq 0.05$ ) are indicated with different letters within columns. ns-non-significant.

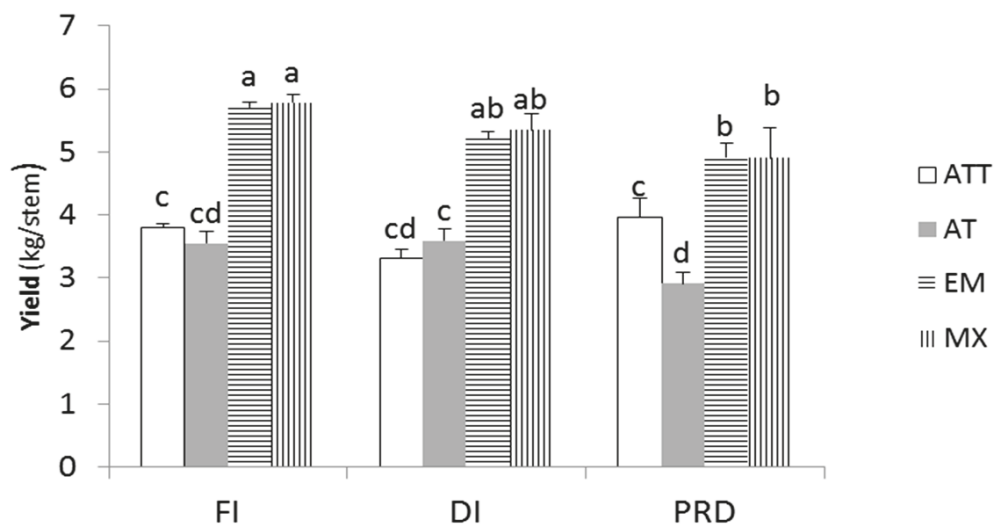

Figure 2. Total yield $\left(\mathrm{kg} \mathrm{stem}^{-1}\right)$ of grafted tomato plants grown with one or two stems under three irrigation techniques. Vertical bars represent SE values $(n=4)$. Different letters above column indicate a significant difference by the LSD test at $p<0.05$. ATT-one-stem Attiya; AT-two-stem Attiya; EM-Emperador; MX-Maxifort.

\subsection{Mineral Content and Fruit Quality}

In the second experiment, all leaf mineral concentrations significantly differed by rootstock type, while $\mathrm{Ca}$ and $\mathrm{Mg}$ were affected also with irrigation method (Table 6). Plants grafted on commercial rootstocks had highest values for $\mathrm{N}, \mathrm{P}$ and $\mathrm{K}(p \leq 0.001)$. Ca was lowest in self-grafted plants grown with one-stem, while $\mathrm{Mg}$ was highest in same plants. Plants grown under both reduced irrigation techniques had significantly $(p \leq 0.01)$ highest $\mathrm{Ca}$ and $\mathrm{Mg}$ leaf concentrations. Fruit mineral concentration in same year was significantly affected by rootstock. Plants grafted on commercial rootstocks had higher values than both types of self-grafted plants (Table 7).

The effects of rootstock and irrigation on fruit quality traits are presented in Table 6. Both TSS and TA differed by rootstock type $(p<0.05)$. There were no differences among irrigation techniques in these traits, but the effect of the interaction of the rootstock $\times$ irrigation was found for TSS $(p<0.05)$ (Figure 3). Highest TSS was recorded in one-stem Attiya grown under DI and differ from values same plants under FI and PRD. Plants grafted on Emperador had higher TSS under PRD than other irrigation treatments. TA was higher in fruits grown on commercial rootstocks. 
Table 6. Leaf mineral concentrations of self-grafted and grafted tomatoes grown under three irrigation techniques in the second year.

\begin{tabular}{cccccc}
\hline \multirow{2}{*}{ Treatments } & $\mathbf{N}$ & $\mathbf{P}$ & $\mathbf{K}$ & $\mathbf{C a}$ & $\mathbf{M g}$ \\
\cline { 2 - 6 } & \multicolumn{5}{c}{$\mathbf{g ~ k g}^{\mathbf{- 1}} \mathbf{D W}$} \\
\hline Rootstock (R) & & & & \\
\hline One-stem SG & $28.9 \mathrm{~b}$ & $2.01 \mathrm{~b}$ & $15.0 \mathrm{~b}$ & $23.1 \mathrm{~b}$ & $5.34 \mathrm{a}$ \\
Two-stem SG & $31.5 \mathrm{~b}$ & $2.32 \mathrm{ab}$ & $14.2 \mathrm{~b}$ & $29.3 \mathrm{a}$ & $4.98 \mathrm{ab}$ \\
Emperador & $36.5 \mathrm{a}$ & $3.23 \mathrm{a}$ & $21.0 \mathrm{a}$ & $28.3 \mathrm{a}$ & $4.5 \mathrm{bc}$ \\
Maxifort & $37.7 \mathrm{ab}$ & $3.31 \mathrm{a}$ & $21.8 \mathrm{a}$ & $28.5 \mathrm{a}$ & $4.45 \mathrm{c}$ \\
\hline Irrigation (I) & & & & & \\
\hline Full & 33.9 & 2.82 & 17.5 & $24.7 \mathrm{~b}$ & $4.41 \mathrm{~b}$ \\
Deficit & 32.8 & 2.73 & 17.6 & $28.3 \mathrm{a}$ & $5.17 \mathrm{a}$ \\
PRD & 34.2 & 2.7 & 18.9 & $29.0 \mathrm{a}$ & $4.87 \mathrm{a}$ \\
I $\times$ R & $\mathrm{ns}$ & $\mathrm{ns}$ & $\mathrm{ns}$ & $\mathrm{ns}$ & $\mathrm{ns}$ \\
\hline
\end{tabular}

Significant differences between treatments (LSD test at $p \leq 0.05$ ) are indicated with different letters within columns. ns-non-significant.

Table 7. Effect of rootstock type and irrigation treatment on tomato fruits mineral concentrations and quality parameters in the second year of the experiment with plants grown on one and two stems.

\begin{tabular}{|c|c|c|c|c|c|c|c|}
\hline \multirow{2}{*}{ Treatments } & $\mathbf{N}$ & $\mathbf{P}$ & $\mathbf{K}$ & $\mathrm{Ca}$ & Mg & \multirow{2}{*}{ TSS $\left(\right.$ Brix $\left.^{0}\right)$} & \multirow{2}{*}{ TA $\left(\mathrm{g} \mathrm{L}^{-1}\right)$} \\
\hline & \multicolumn{5}{|c|}{$\mathrm{g} \mathrm{kg}^{-1} \mathrm{DW}$} & & \\
\hline \multicolumn{8}{|l|}{ Rootstock (R) } \\
\hline One-stem SG & $18.2 \mathrm{~b}$ & $2.08 \mathrm{~b}$ & $29.9 \mathrm{~b}$ & $1.22 \mathrm{~b}$ & $1.37 \mathrm{c}$ & $4.7 \mathrm{a}$ & $4.5 \mathrm{~b}$ \\
\hline Two-stem SG & $18.1 \mathrm{~b}$ & $2.51 \mathrm{~b}$ & $30.5 \mathrm{~b}$ & $1.39 \mathrm{ab}$ & $1.41 \mathrm{bc}$ & $4.4 \mathrm{~b}$ & $4.6 \mathrm{~b}$ \\
\hline Emperador & $22.1 \mathrm{a}$ & $3.26 \mathrm{a}$ & $37.7 \mathrm{a}$ & $1.59 \mathrm{a}$ & $1.61 \mathrm{a}$ & $4.3 \mathrm{~b}$ & $5.6 \mathrm{ab}$ \\
\hline Maxifort & $19.9 \mathrm{a}$ & $3.19 a$ & $35.4 \mathrm{a}$ & $1.51 \mathrm{a}$ & $1.57 \mathrm{ab}$ & $4.4 \mathrm{~b}$ & $5.9 \mathrm{a}$ \\
\hline \multicolumn{8}{|l|}{ Irrigation (I) } \\
\hline Full & 20.1 & 2.81 & 33.9 & 1.46 & 1.55 & 4.3 & 5 \\
\hline Deficit & 19.5 & 3.04 & 33.1 & 1.42 & 1.43 & 4.5 & 5.8 \\
\hline PRD & 19.4 & 2.56 & 33.5 & 1.47 & 1.50 & 4.5 & 4.8 \\
\hline $\mathrm{I} \times \mathrm{R}$ & ns & ns & ns & ns & ns & $*$ & ns \\
\hline
\end{tabular}

* Significant differences between treatments (LSD test at $p \leq 0.05$ ) are indicated with different letters within columns. ns-non-significant.

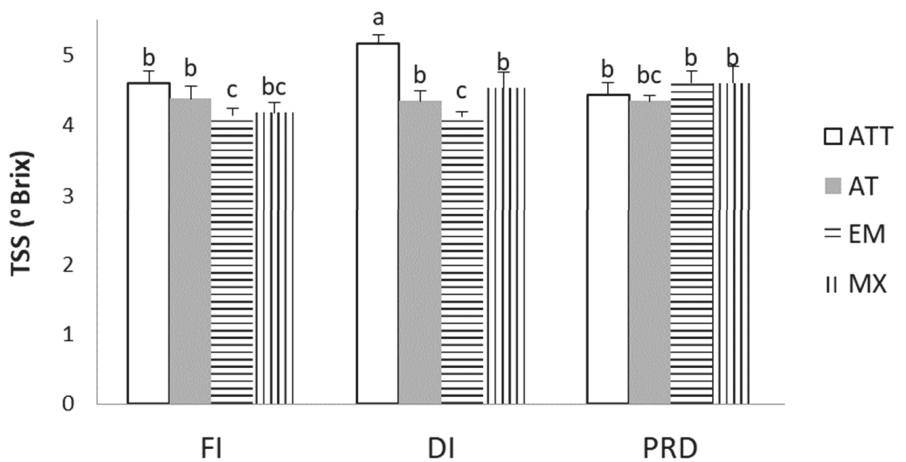

Figure 3. Total soluble solids (TSS) of tomato fruits sampled from different grafted plants grown with three irrigation techniques. Vertical bars represent SE values $(n=4)$. Different letters above column indicate a significant difference by the LSD test at $p \leq 0.05$. ATT-one-stem Attiya; AT-two-stem Attiya; EM-Emperador; MX-Maxifort. 


\section{Discussion}

In general, the use of commercial rootstocks resulted in highly improved plant vigor in terms of excessive vegetative growth. In our studies, the plant height and leaf number measured at 60 or 70 DAT were highest with plants grafted on Emperador and Maxifort rootstocks; the difference was even more pronounced in the second trial. Comparing height with leaf number, it can be assumed that interleaf nodes interval was not influenced by grafting or irrigation. These findings partially differed from other studies [14,20]. Similarly, vegetative biomass production (as leaf area, leaf and shoot DM) was bigger in grafted plants. For example, shoot DM in year one was $40 \%$ and $60 \%$ higher in Maxifort and Emperador grafted plants compared to self-grafted ones. Similar values were found in the second year on stem basis, but when we include all plant production (both stems) vegetative biomass is at least two or three times higher. Vigorous rootstocks had enough capacity to provide satisfactory vegetative growth by roots that can supply needed water and nutrients for assimilates production. On average, leaf area was not influenced by irrigation, as others found that tomato under DI and PRD had smaller leaf area than control and explained as soil drying affected roots reaction and production of chemical signals, i.e., changed ABA concentration or xylem sap $\mathrm{pH}$ that leads to stomatal closure and decreases leaf expansion growth [21].

Interactive effect between rootstock type and irrigation treatment showed that plants grafted on commercial rootstocks did not differ in photosynthetic rate (A), while both types of self-grafted ones differed depending on the applied irrigation technique. It can be concluded that grafted plant had better assimilative processes. The optimization of A under water stress could be modified by the rootstock through action on biochemical and biophysical processes [22]. Stomatal conductance and intercellular $\mathrm{CO}_{2}$ measured 20 days after starting irrigation treatments was lower under DI and PRD. These effects of reduced irrigation in some cases were noted later after initiation of irrigation [23], while in another study differences between treatments disappeared with time [24]. Valerio et al. [23] showed that lower stomatal conductance was related with leaf ABA accumulation, more ABA reduced stomatal conductance. Reducing stomatal conductance is a typical response to soil drying as stomatal closure is primary response to water deficit so plants could better contol water loss due to transpiration [7]. Stomatal closure reduced transpiration rate which was more pronounced in DI. Although, stomatal conductance was similar in both DI and PRD, it was expected that transpiration will be similar in both of them suggesting the response is mostly to the overall amount of water supplied to roots [21]. In contrast, in our study DI received 5\% more water than PRD, so it seems that hydraulic signal is an important factor because plants under PRD on the wet side of the root can absorb enough water to keep higher level of transpiration [23]. Photosynthetic WUE had highest values under DI as result of lowest transpiration rate and similar photosynthetic rate to other irrigation. This can lead to lower biomass production as was noted in our study as reduced shoot biomass (although not significant) under DI and others found similar [21].

Rootstocks may affect tomato productivity positively or negatively, although in most cases yield increased both under non and stress conditions and depended on rootstock/scion combination [24]. In our experiment, plants grafted on commercial rootstocks had highest yield as a result of more and bigger fruits per plant, as was found in other studies $[11,17,25]$. Enhanced fruit production could be clearly related with higher plant biomass [15]. Early yield was different between years, in the first year highest early yield was noted under DI which can be related to a more pronounced water stress that hastened fruit ripening in this treatment. Topcu et al. [26] found higher tomato early yield in PRD than DI plants in experiment with more water reduction (50\%) comparing our $40 \%$. In experiment with two stems (second year), early yield was highest in one-stem-grafted Attiya what is result of longer period of growth for two stems plants because they were trained as side-shoots from cotyledons. In both experiments, cultivars grafted on commercial rootstocks had highest total yield under all irrigation treatments. In the second year comparing yield of these plants, it was found that under FI yield did not differ from DI but differ from PRD (Figure 1). It seems that rootstocks due to its vigor have enough capacity for water uptake to sustain yield under DI. It is important to notice that 
growing on two stems (2nd experiment) did not reduce yield markedly when comparing with one stem plants (1st experiment), although different cultivars were used what should be taken into account. Rahmatian et al. [16] found dry matter allocation was not influenced by grafting or stem numbers and that good balance between vegetative and generative growth can depend on rootstocks. Other studies done with ungrafted greenhouse and processing tomato mostly obtained higher yield using PRD than DI [8] or similar to DI and FI [24].

WUE is the main indicator of plant water relations and is regulated by physiological mechanisms. In both years WUEy calculated as ratio between yield and water applied per treatment was higher in rootstock-grafted plants and as expected under PRD and DI. In these treatments higher fruit yield and lower water use resulted in improved WUE. It was not shown that PRD improved WUE better than DI, which means that irrigation volume is more important than used irrigation technique in determining yield or all crop growth as was suggested before $[21,23,24]$, although other found irrigation technique can be more important [9]. Comparing two experiments it can be seen that in double stemmed plants (2nd experiment) WUE was higher leading to conclusion water use was optimized. In addition, in 1st Experiment WUEy was much lower in FI than in the second year what can be related to use of different soil moisture meters: tensiometers and soil sensors. The tensiometers was used for hand-operated irrigation, which could have led to overirrigation in the first year. It was shown that automatic operated tensiometers was more effective, which can be compared with sensors with automatic valves in our study [27].

The leaf mineral concentrations of $\mathrm{P}$ and $\mathrm{K}$ were under range of sufficiency while others were in range $(\mathrm{N}$ and $\mathrm{Mg}$ ) or above $(\mathrm{Ca})$ as proposed for greenhouse tomato. Grafting is considered as an effective tool for improving nutrient uptake and use efficiency in vegetables, although those were observed under optimal nutrient status in the root zone. N, P and K had higher concentrations in the plants grafted on commercial rootstocks what was expected and already confirmed in other studies that showed that nutrient uptake depends on rootstock-scion combinations [28]. Higher leaf P in grafted plants were reported for grafted eggplant and watermelon $[29,30]$. Grafted plants had more vigorous root system, which could be reason for increase in active uptake of $P$ that has low mobility in soils. Self-grafted and grafted plants had low leaf K (under sufficiency range) because fertilization was not intensive as in commercial production. Potassium is nutrient normally required in the largest amount in tomato production. Grafting promote better growth and K uptake even under low K supply as was shown by Schwarz et al. [31]. These nutrients (N, P, K) concentrations were not affected by water supply rate, although opposite was shown for $\mathrm{N}$ in other studies for PRD or DI in non-grafted tomatoes [32]. Increase in K concentrations under water stress was found in some non-grafted and grafted tomatoes explaining that $\mathrm{K}$ accumulation improves stomatal resistance which improve drought tolerance [33]. In other case, decrease in grafted tomato leaf $\mathrm{K}$ was noted with increase in water stress level [12].

Regarding $\mathrm{Ca}^{2+}$ and $\mathrm{Mg}^{2+}$, a significant increase in tomato Ca leaf concentration was found due to grafting what is in line with other reports [29,31]. In addition, both DI and PRD resulted in more leaf $\mathrm{Ca}$ than plants under FI. It was found that tomatoes under PRD had increased Ca uptake due to higher plant water status and lower stomatal conductance [34]. Higher Ca uptake induced by grafting are important for the tomato fruits due to the possibility of blossom-end rot incidence. Different than $\mathrm{Ca}$, in grafted tomato was found lower leaf $\mathrm{Mg}$ what is in line with previous studies and could be also influenced by rootstock and cultivars used $[5,14]$. It seems that grafting somehow decrease $\mathrm{Mg}$ uptake in grafted vegetables, but reason it is not yet clear. Possible higher Ca uptake reacts antagonistically to $\mathrm{Mg}$ uptake, which could be related to specific transport systems [35]. Under reduced irrigation treatments higher leaf $\mathrm{Mg}$ was measured and same was found for mini watermelons [30]. $\mathrm{Mg}^{2+}$ ion has largest hydrated radius among cations and this property makes $\mathrm{Mg}^{2+}$ bind weakly to negatively charged soil colloids and root cell walls [36], which could lead to decreased Mg uptake under FI conditions due to leching in sub-root zones. The fruit mineral concentrations was influenced 
by rootstock type showing that highest values in the plants grafted on Emperador and Maxifort. Other found effect of rootstock, but also influence of water stress on fruit minerals [18].

Higher TSS was affected by plant type with highest values in one stem plants. Interactive analysis showed it is mostly result of highest values of same plant type under DI. The enhanced TSS in that treatment could be result of water stress, although it is not clear why similar was not found in self-grafted two stem plants. Self-grafted double stemmed plants possible use more assimilates for additional vegetative growth [16]. Grafted plants had lower TSS what is often found even when used different cultivars and rootstocks [25]. For grafted plants vigorous roots can be additional sinks for assimilates and also better water uptake can result in dilution effect of fruits sugars [10]. Under PRD all plant types had similar TSS so it can be concluded that self and grafted plants with this irrigation type changed mechanisms responsible for results recorded under DI. Grafting on commercial rootstocks decreased Mg leaf content, which can possible lead to latent $\mathrm{Mg}$ deficiency influencing carbohydrate partitioning requiring for obtaining maximum yield and ensuring sugar accumulation in fruits [37]. In our study, both rootstocks increased the TA. Their increase by grafting was also found in many other experiments under different conditions [5]. Grafting under regular and low $\mathrm{K}$ resulted in higher TA, independent of $\mathrm{K}$ in fruits [31], while in our study $\mathrm{K}$ in fruits grafted on both rootstocks was higher compared to self-grafted plants. It is known that $\mathrm{K}$ concentration in fruits can be positively related with acid content, although further investigations are needed.

\section{Conclusions}

In the present experiment, we evaluated growth, gas-exchange parameters, yield, WUE and leaf mineral concentrations and fruit quality of self-grafted and tomato grafted on two commercial rootstocks cultivated in greenhouses in Mediterranean climate under three irrigation techniques: FI, DI and PRD. First year plants were grown with one stem and in the second with two stems.

In conclusion, these studies for the first time demonstrates the effects of parallel usage of different reduced irrigation techniques on grafted tomato vegetative and generative traits. Grafting onto commercial rootstocks improved plants growth and yield both in cultivation with one or two stems. Grafted plants under DI had minimal yield reduction compared to FI in double stemmed plants. WUE was highly improved with grafting and application of PRD and DI. That was more pronounced in experiment with two stem plants and could be result of different biomass partitioning and irrigation scheduling based on soil moisture sensors. Leaf mineral concentrations were higher in grafted plants as possible better uptake of vigorous rootstocks while $\mathrm{Mg}$ was reduced what imply contrasting rootstock-scion interactions. These findings indicate that grafted plants can be grown under moderate DI before PRD and that two stem plants could be used under that irrigation regime.

Author Contributions: Conceptualization, B.U., G.D., K.Ž.; methodology, B.U., M.R.; validation, G.D., G.V.S.; formal analysis, B.U., G.D.; investigation, B.U., M.R., G.V.S., M.M., A.M.; resources, B.U., G.D.; data curation, M.R., M.M., A.M.; writing—original draft preparation, B.U.; writing—review and editing, K.Ž., G.D.; visualization, B.U.; supervision, B.U., G.D., M.R.; project administration, B.U.; funding acquisition, B.U. All authors have read and agreed to the published version of the manuscript.

Funding: This work was financed by the Ministry of Agriculture, Croatia through project "Innovative technologies for tomato production enhancement and quality improvement" with project number 2015-13-01.

Acknowledgments: The authors are thankful to Silvia Milišić, Jelena Dumanić and Željko Bilić for their help maintaining experiments, collecting data and providing chemical analyses. In addition, special thanks to families Hrabar and Janković for providing usage of greenhouses and help in conducting experiments.

Conflicts of Interest: The authors declare no conflict of interest.

\section{References}

1. FAOSTAT. 2018. Available online: http://www.fao.org/faostat/en/\#data/QC (accessed on 14 July 2018).

2. Rivard, C.L.; Louws, F.J. Grafting to manage soilborne diseases in heirloom tomato production. HortScience 2008, 43, 2104-2111. [CrossRef] 
3. Grieneisen, M.L.; Aegerter, B.J.; Stoddard, C.S.; Zhang, M. Yield and fruit quality of grafted tomatoes, and their potential for soil fumigant use reduction. A meta-analysis. Agron. Sustain. Dev. 2018, 38, 29. [CrossRef]

4. Schwarz, D.; Rouphael, Y.; Colla, G.; Venema, J.H. Grafting as a tool to improve tolerance of vegetables to abiotic stresses: Thermal stress, water stress and organic pollutants. Sci. Hortic. 2010, 127, 162-171. [CrossRef]

5. Kyriacou, M.C.; Rouphael, Y.; Colla, G.; Zrenner, R.; Schwarz, D. Vegetable grafting: The implications of a growing agronomic imperative for vegetable fruit quality and nutritive value. Front. Plant Sci. 2017, 8, 741. [CrossRef] [PubMed]

6. Lovelli, S.; Perniola, M.; Scalcione, E.; Troccoli, A.; Ziska, L.H. Future climate change in the Mediterranean area: Implications for water use and weed management. Ital. J. Agron. 2012, 7, 44-49. [CrossRef]

7. Liu, F.; Shahnazari, A.; Andersen, M.N.; Jacobsen, S.E.; Jensen, C.R. Effects of deficit irrigation (DI) and partial root drying (PRD) on gas exchange, biomass partitioning, and water use efficiency in potato. Sci. Hortic. 2006, 109, 113-117. [CrossRef]

8. Kirda, C.; Topcu, S.; Cetin, M.; Dasgan, H.Y.; Kaman, H.; Topaloglu, F.; Derici, M.R.; Ekici, B. Prospects of partial root zone irrigation for increasing irrigation water use efficiency of major crops in the Mediterranean region. Ann. Appl. Biol. 2007, 150, 281-291. [CrossRef]

9. Giuliani, M.M.; Nardella, E.; Gagliardi, A.; Gatta, G. Deficit irrigation and partial root-zone drying techniques in processing tomato cultivated under Mediterranean climate conditions. Sustainability 2017, 9, 2197. [CrossRef]

10. Martínez-Ballesta, M.C.; Alcaraz-López, C.; Muries, B.; Mota-Cadenas, C.; Carvajal, M. Physiological aspects of rootstock-scion interactions. Sci. Hortic. 2010, 127, 112-118. [CrossRef]

11. Ibrahim, A.; Wahb-Allah, M.; Abdel-Razzak, H.; Alsadon, A. Growth, yield, quality and water use efficiency of grafted tomato plants grown in greenhouse under different irrigation levels. Life Sci. J. 2014, 11, 118-126.

12. Al-Harbi, A.; Hejazi, A.; Al-Omran, A. Responses of grafted tomato (Solanum lycopersiocon L.) to abiotic stresses in Saudi Arabia. Saudi J. Biol. Sci. 2016, 24, 1274-1280. [CrossRef] [PubMed]

13. Albacete, A.; Andújar, C.; Dodd, I.; Giuffrida, F.; Hichri, I.; Lutts, S.; Thompson, A.; Asins, M. Rootstock-mediated variation in tomato vegetative growth under drought, salinity and soil impedance stresses. Acta Hortic. 2015, 24, 141-146. [CrossRef]

14. Urlić, B.; Runjić, M.; Žanić, K.; Mandušić, M.; Selak, G.V.; Pasković, I.; Dumičić, G. Effect of partial root-zone drying on grafted tomato in commercial greenhouse. Hortic. Sci. 2020, 47, 36-44. [CrossRef]

15. Fullana-Pericàs, M.; Conesa, M.À.; Ribas-Carbó, M.; Galmés, J. The Use of a Tomato Landrace as Rootstock Improves the Response of Commercial Tomato under Water Deficit Conditions. Agronomy 2020, 10, 748. [CrossRef]

16. Rahmatian, A.; Delshad, M.; Salehi, R. Effect of grafting on growth, yield and fruit quality of single and double stemmed tomato plants grown hydroponically. Hortic. Environ. Biotechnol. 2014, 55, 115-119. [CrossRef]

17. Soare, R.; Dinu, M.; Babeanu, C. The effect of using grafted seedlings on the yield and quality of tomatoes grown in greenhouses. Hortic. Sci. 2018, 45, 76-82. [CrossRef]

18. Sánchez-Rodríguez, E.; Leyva, R.; Constán-Aguilar, C.; Romero, L.; Ruiz, J.M. Grafting under water stress in tomato cherry: Improving the fruit yield and quality. Ann. Appl. Biol. 2012, 161, 302-312. [CrossRef]

19. Hatfield, J.L.; Dold, C. Water-use efficiency: Advances and challenges in a changing climate. Front. Plant Sci. 2019, 10, 103. [CrossRef]

20. Khah, E.M.; Kakava, E.; Mavromatis, A.; Chachalis, D.; Goulas, C. Effect of grafting on growth and yield of tomato (Lycopersicon esculentum Mill.) in greenhouse and open-field. J. Appl. Hortic. 2006, 8, 3-7. [CrossRef]

21. Tahi, H.; Wahbi, S.; Wakrim, R.; Aganchich, B.; Serraj, R.; Centritto, M. Water relations, photosynthesis, growth and water-use efficiency in tomato plants subjected to partial rootzone drying and regulated deficit irrigation. Plant Biosyst. 2007, 141, 265-274. [CrossRef]

22. Fullana-Pericàs, M.; Conesa, M.À.; Pérez-Alfocea, F.; Galmés, J. The influence of grafting on crops' photosynthetic performance. Plant Sci. 2019, 295, 110250. [CrossRef]

23. Valerio, M.; Lovelli, S.; Sofo, A.; Perniola, M.; Scopa, A.; Amato, M. Root and leaf abscisic acid concentration impact on gas exchange in tomato (Lycopersicon esculentum Mill) plants subjected to partial root-zone drying. Ital. J. Agron. 2017, 11, 12. [CrossRef] 
24. Nardella, E.; Giuliani, M.M.; Gatta, G.; De Caro, A. Yield response to deficit irrigation and partial root-zone drying in processing tomato (Lycopersicon esculentum Mill.). J. Agric. Sci. Technol. 2012, 2, 209.

25. Turhan, A.; Ozmen, N.; Serbeci, M.S.; Seniz, V. Effects of grafting on different rootstocks on tomato fruit yield and quality. Hortic. Sci. 2011, 38, 142-149. [CrossRef]

26. Topçu, S.; Kirda, C.; Dasgan, Y.; Kaman, H.; Çetin, M.; Yazici, A.; Bacon, M.A. Yield response and N-fertiliser recovery of tomato grown under deficit irrigation. Eur. J. Agron. 2007, 26, 64-70. [CrossRef]

27. Muñoz-Carpena, R.; Li, Y.C.; Klassen, W.; Dukes, M.D. Field comparison of tensiometer and granular matrix sensor automatic drip irrigation on tomato. HortTechnology 2005, 15, 584-590. [CrossRef]

28. Martínez-Andújar, C.; Albacete, A.; Martínez-Pérez, A.; Pérez-Pérez, J.M.; Asins, M.J.; Pérez-Alfocea, F. Root-to-shoot hormonal communication in contrasting rootstocks suggests an important role for the ethylene precursor aminocyclopropane-1-carboxylic acid in mediating plant growth under low-potassium nutrition in tomato. Front. Plant Sci. 2016, 7, 1782. [CrossRef] [PubMed]

29. Leonardi, C.; Giuffrida, F. Variation of plant growth and macronutrient uptake in grafted tomatoes and eggplants on three different rootstocks. Eur. J. Hortic. Sci. 2006, 71, 97-101.

30. Rouphael, Y.; Cardarelli, M.; Colla, G.; Rea, E. Yield, mineral composition, water relations, and water use efficiency of grafted mini-watermelon plants under deficit irrigation. HortScience 2008, 43, 730-736. [CrossRef]

31. Schwarz, D.; Öztekin, G.B.; Tüzel, Y.; Brückner, B.; Krumbein, A. Rootstocks can enhance tomato growth and quality characteristics at low potassium supply. Sci. Hortic. 2013, 149, 70-79. [CrossRef]

32. Wang, Y.S.; Liu, F.L.; Andersen, M.N.; Jensen, C.R. Improved plant nitrogen nutrition contributes to higher water use efficiency in tomatoes under alternate partial root-zone irrigation. Funct. Plant Biol. 2010, 37, 175-182. [CrossRef]

33. Sánchez-Rodríguez, E.; Leyva, R.; Constán-Aguilar, C.; Romero, L.; Ruiz, J.M. How does grafting affect the ionome of cherry tomato plants under water stress? Soil Sci. Plant Nutr. 2014, 60, 145-155. [CrossRef]

34. Sun, Y.; Feng, H.; Liu, F. Comparative effect of partial root-zone drying and deficit irrigation on incidence of blossom-end rot in tomato under varied calcium rates. J. Exp. Bot. 2013, 64, 2107-2116. [CrossRef] [PubMed]

35. Gransee, A.; Führs, H. Magnesium mobility in soils as a challenge for soil and plant analysis, magnesium fertilization and root uptake under adverse growth conditions. Plant Soil 2013, 368, 5-21. [CrossRef]

36. Maguire, M.E.; Cowan, J.A. Magnesium chemistry and biochemistry. Biometals 2002, 15, 203-210. [CrossRef]

37. Verbruggen, N.; Hermans, C. Physiological and molecular responses to magnesium nutritional imbalance in plants. Plant Soil 2013, 368, 87-99. [CrossRef]

(C) 2020 by the authors. Licensee MDPI, Basel, Switzerland. This article is an open access article distributed under the terms and conditions of the Creative Commons Attribution (CC BY) license (http://creativecommons.org/licenses/by/4.0/). 
Article

\title{
Modulatory Effects of Interspecific and Gourd Rootstocks on Crop Performance, Physicochemical Quality, Bioactive Components and Postharvest Performance of Diploid and Triploid Watermelon Scions
}

\author{
Marios C. Kyriacou ${ }^{1, *}$, Georgios A. Soteriou ${ }^{1}$ and Youssef Rouphael ${ }^{2}$ \\ 1 Department of Vegetable Crops, Agricultural Research Institute, Nicosia 1516, Cyprus; soteriou@ari.gov.cy \\ 2 Department of Agricultural Sciences, University of Naples Federico II, 80055 Portici, Italy; \\ youssef.rouphael@unina.it \\ * Correspondence: m.kyriacou@ari.gov.cy; Tel.: +357-2240-3221
}

Received: 28 July 2020; Accepted: 14 September 2020; Published: 15 September 2020

\begin{abstract}
Vegetable grafting has become entrenched as a sustainable tool for addressing biotic and abiotic stresses of vegetable crops, including watermelon. The concerted action of scion-rootstock genotypes in shaping crop performance, fruit quality and postharvest behavior of watermelon is critical. In this respect, scions of different ploidy grafted on interspecific and gourd rootstocks were assessed. Yield traits were strongly influenced by rootstock, as opposed to fruit morphometric characteristics. Interspecific rootstock supported stable yield across seasons with a $20.5 \%$ increase over gourd, and induced thicker rind and higher pulp firmness by $30.1 \%$ over gourd, which constitute advantageous traits for shelf-life. Interspecific rootstock also increased lycopene content, which was further influenced by scion genotype irrespective of ploidy. Triploid cultivars attained higher firmness but lower sugars than diploid, which renders the former particularly prone to loss of sensory quality during postharvest depletion of sugars. Although total and reducing sugars decreased during storage, sucrose increased, which in conjunction with the postharvest accumulation of lycopene sheds new light on the postharvest physiology of watermelon. The marginal rootstock effect on sugars renders interspecific rootstock superior to gourd on account of higher yield, firmness and lycopene content. The present work constitutes a contribution toward understanding rootstock-scion relations and how they mediate crop performance, fruit quality and postharvest behavior of watermelon.
\end{abstract}

Keywords: Citrullus lanatus (Thunb) Matsum and Nakai; functional quality; lycopene; storage; sugars; texture

\section{Introduction}

Grafting has become globally entrenched as an imperative and sustainable tool for overcoming biotic and abiotic stresses confronting vegetable crops [1]. Watermelon (Citrullus lanatus (Thunb) Matsum and Nakai) in particular is the crop that has known the widest application of grafting onto rootstocks resistant to soilborne pathogens or resilient to salinity, water stress, nutrient stress, heat stress, organic pollutants, alkalinity, acidity and contamination of soils by heavy metals [2-4]. Grafting may thus facilitate cultivation of watermelon and other vegetable fruit crops in previously non-arable land and contribute toward global food security. Notwithstanding the importance of grafting for managing biotic and abiotic stress conditions, fruit quality and composition is also modulated by scion-rootstock interaction although it has received comparatively far less attention than the phytoprotection and physiology aspects of crop production [5]. The potential of exploiting wild genetic resources for 
stress-tolerant rootstocks compatible to commercial scions can be a faster route to trait stacking than breeding; moreover, it may bypass undesirable pleiotropic effects on fruit quality traits that befall breeding based on selection of desirable qualitative traits [6]. Toward this end, analytical information is essential on how rootstock-scion interaction under field conditions may impact physical, chemical, bioactive and sensory components of fruit quality. In this respect, it is important to examine how different scion types (e.g., diploid vs. triploid or mini vs. large fruited) may interact with different rootstock types (e.g., interspecific vs. gourd) to configure crop performance and fruit quality.

Changes in fruit physicochemical composition and morphometric characteristics also inevitably bear an impact on the postharvest performance of watermelon, which has received little attention to date $[1,7]$. Yet fruit quality along the horticultural supply chain and ultimately at the customer end is largely influenced by postharvest handling and storage practices. Watermelon is a non-climacteric fruit with a cultivar-dependent but overall brief shelf-life of less than three weeks at $10-15^{\circ} \mathrm{C}$ [8]. Previous work on rootstock-mediated watermelon postharvest performance is limited, but has established that grafting effects on the physicochemical composition of watermelon fruit extend to the postharvest period [1,9]. It is therefore critical to understand how different rootstock types may interact with different scion types to configure postharvest changes in sensory, compositional and functional quality traits that ultimately define shelf-life.

Accordingly, the current work examined how rootstocks TZ148 and Festival, which represent the two major classes of exploited rootstocks-interspecific hybrids (Cucurbita maxima (Duchesne) $\times$ C. moschata (Duchesne ex Poir)) and gourd (Lagenaria siceraria L.), respectively-interacted with two mini triploid (Extazy and Petite), two mini diploid (Vivlos and Esmeralda) and one large-fruited diploid scion cultivar (Pegasus) to impact crop performance and fruit morphometric characteristics. Moreover, fruit sensory quality traits (pulp colorimetry, firmness, sweetness index), chemical composition (fructose, glucose, sucrose) and bioactive components (lycopene and citrulline) were examined at harvest and following postharvest storage at $25^{\circ} \mathrm{C}$ for 10 days. The current work constitutes a contribution toward understanding rootstock-scion relations and how they mediate crop performance, fruit quality and postharvest behavior of watermelon.

\section{Materials and Methods}

\subsection{Location and Plant Material}

The study was carried out for two successive years (2018-2019) between April and July, at the Tohni Experimental Station ( $34^{\circ} 44^{\prime} 00^{\prime \prime} \mathrm{N} ; 33^{\circ} 20^{\prime} 15^{\prime \prime}$ E) of the Agricultural Research Institute of Cyprus. The area has a typical Mediterranean climate with rainfall occurring mainly between November and March. During the study, average day-time temperature ranged from 29 to $40{ }^{\circ} \mathrm{C}$. Transplants of two mini (3-5 kg) diploid cultivars (Esmeralda and Vivlos), two mini triploid cultivars (Extazy and Petite) and a large-fruited $(8-12 \mathrm{~kg}$ ) diploid cultivar (Pegasus) were grafted onto C. maxima $\times$ C. moschata (TZ148) and Lagenaria siceraria (Festival) rootstocks. Grafts were made by approach grafting as described previously by Soteriou and Kyriacou [10]. All transplants were produced at a commercial nursery. Planting was performed in late April, on an alkaline $(\mathrm{pH} 7.5)$ clay-loam soil at a plant density of approximately 3333 plants ha ${ }^{-1}$ with $1.0 \mathrm{~m}$ spacing on the row and $3.0 \mathrm{~m}$ between rows. An amount of $350 \mathrm{~kg} \mathrm{ha}^{-1}$ of compound fertilizer $14 \mathrm{~N}-9.6 \mathrm{P}-7.5 \mathrm{~K}$ was applied into the soil before transplanting. Daily fertigation of 100-120 N: 20-40 P: 110-130 K in $\mathrm{g} \mathrm{m}^{-3}$ was administered through the drip irrigation beginning ten days after transplanting; the higher rates were provided with flowering initiation. Daily inspection and flower tagging at anthesis (fruit setting) secured uniformity in fruit harvest maturity [11]. Applied pest and disease control practices were standard for the region. The postharvest period spanned 10 days of storage in a refrigerated chamber equipped with a Carel, UE001PD000 humidifying system (Carel Industries S.p.A., Brugine PD, Italy) held at $25 \pm 0.5^{\circ} \mathrm{C}$ and $90 \%$ relative humidity. 


\subsection{Measurements and Analyses}

Fruits were weighed and equatorial and meridian diameters were determined with a Vernier caliper at harvest. Yield and number of fruits per hectare were estimated. All underdeveloped fruit were considered unmarketable. Cross-sections of marketable fruit typical for each of the five scion cultivars are presented in Figure 1. Quality assessment was performed by sampling randomly three fruit from each plot. All sampled fruit for quality assessment purposes had been set on the same calendar date \pm 1 day and harvested simultaneously $40 \pm 1$ days later. An electronic caliper was used at two representative points on each cross-sectioned fruit for assessing fruit rind. Watermelon flesh firmness was recorded by a TA.XT plus Texture Analyser (Stable Micro Systems, Surrey, UK) as described previously [11]. The Texture Analyser protocol was set to measure flesh firmness as the maximum resistance force to penetration to a depth of $50 \mathrm{~mm}$ around the heart of each cross-sectioned fruit. A Minolta CR-400 Chroma Meter (Minolta, Osaka, Japan) was used to assess flesh color at two loci in the heart region of each fruit in cross section using the CIELAB color space to record lightness $\left(L^{*}\right)$, chroma coordinates $a^{*}$ and $b^{*}$, chroma $\left(C^{*}\right)$, and hue angle $\left(h^{\circ}\right)$ [12]. A homogenate was obtained from the excised heart of each fruit using a Vita Prep 3 (Vita-Mix Corp., Cleveland, OH, USA) blender under low speed to prevent foaming. Using a digital refractometer (RFM870; Bellingham-Stanley Ltd., Kent, UK), part of the homogenate was used, after double cheesecloth filtration, for determining juice total soluble solids content (TSS) at $20^{\circ} \mathrm{C}$. A pH electrode (SevenMulti, Mettler-Toledo GmbH, Schwerzenbach, Switzerland) was used for measuring the $\mathrm{pH}$ of the juice. Falcon tubes (50 $\mathrm{mL})$, instantly dip-frozen in liquid nitrogen, were used to store part of the homogenate at $-80{ }^{\circ} \mathrm{C}$ for further chemical analyses.

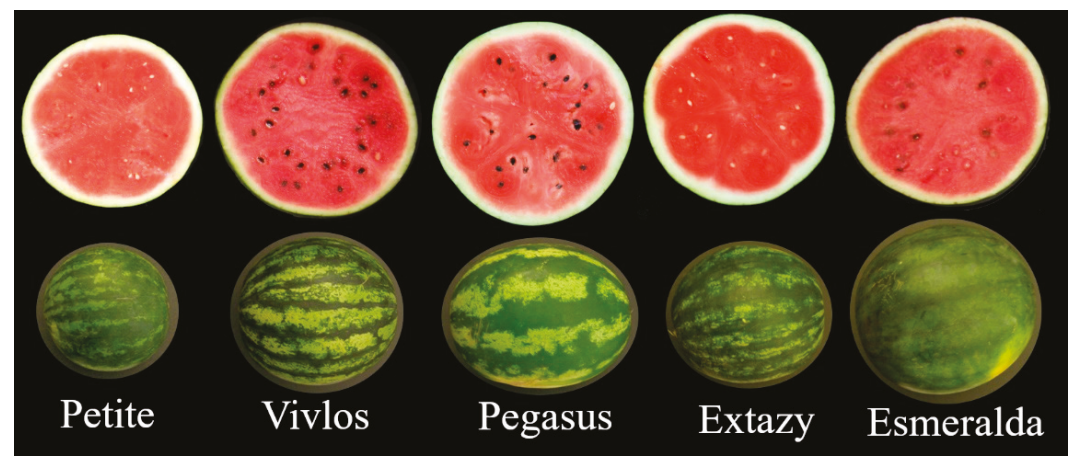

Figure 1. Intact and cross-sectioned watermelon fruit of cvs. Petite, Vivlos, Pegasus, Extazy and Esmeralda.

Lycopene extracted in hexane was determined according to the method of Perkins-Veazie et al. [13]. Lycopene was quantitated against pure hexane on a Jasco V-550 UV-VIS spectrophotometer (Jasco Corp., Tokyo, Japan) at $503 \mathrm{~nm}$ using the extinction coefficient of $17.2 \times 104 \mathrm{M}^{-1} \mathrm{~cm}^{-1}$. Non-structural carbohydrates (glucose, fructose, sucrose) were analyzed by liquid chromatography on an Agilent HPLC system (Agilent Technologies, Santa Clara, CA, USA) equipped with a 1200 Series quaternary pump and a 1260 Series refractive index detector using a $4.6 \times 250 \mathrm{~mm}$ carbohydrate column at $35{ }^{\circ} \mathrm{C}$ (Waters, Milford, MA, USA) and acetonitrile:water (75:25) as mobile phase at $1.4 \mathrm{~mL} \mathrm{~min}^{-1}$ for separation (detailed description provided in Kyriacou et al. [1]). Quantification was performed against external standard calibrating curves with a coefficients of determination $\left(R^{2}\right)>0.9999$. Citrulline was also analyzed on the same HPLC system equipped with an Agilent 1260 Series PDA detector using the method of [1]. 


\subsection{Experimental Design and Statistical Analysis}

The study included two experiments. The first experiment was designed as a factorial two-way completely randomized design, with five cultivars ('Petite', 'Vivlos', 'Pegasus', 'Extazy', 'Esmeralda') and two graft combinations ('TZ148', 'Festival'). In the second experiment, post-harvest storage was also included as a third factor in a factorial three-way completely randomized design. In both experiments, each field plot was replicated 4 times and consisted of 5 plants. Each year was analyzed separately. Data were subjected to analysis of variance (ANOVA) using SAS (SAS Institute, Inc., Cary, NC, USA). Means were separated with the Tukey-Kramer HSD test, provided absence of significant cultivar-by-rootstock interaction.

\section{Results}

\subsection{Crop Performance Characteristics}

Crop performance characteristics such as tradable yield, number of fruits and fruit weight were influenced by both scion and rootstock, whereas variation in fruit shape was dictated strictly by the scion genotype in both years of experimentation (Table 1). The relative effects of scion cultivar and rootstock on all yield characteristics varied between years, with rootstock rendered less influential in the second year. Rootstock effect was most pronounced on tradable yield whereas fruit number, fruit weight and fruit shape were influenced overwhelmingly by cultivar. Cultivar $\times$ rootstock interaction was non-significant for all yield characteristics as scion and rootstock ranking remained unaltered between years. Tradable yield was highest in the large-fruited diploid Pegasus, which did not differ significantly, however, from that of the mini triploid cultivars Petite and Extazy. Yield was notably low in the diploid cultivar Vivlos, which was lower than the average yield of the mini triploid cultivars by $37 \%$ and $38 \%$ in the first and second year, respectively. Fruit weight was lowest for Extazy $(3.2 \pm 0.2 \mathrm{~kg})$ but invariable $(4.2-4.4 \mathrm{~kg})$ across the rest of the mini scions. Inversely, the highest number of fruits per hectare was obtained from Extazy and the lowest from the large-fruited Pegasus. Low fruit weight combined with low number of fruits, tantamount to low yield, was evidenced only in Vivlos. The choice of rootstock had a consistent effect in both years on yield, number of fruits per hectare and fruit weight, which were in all cases higher with TZ148 than Festival. 


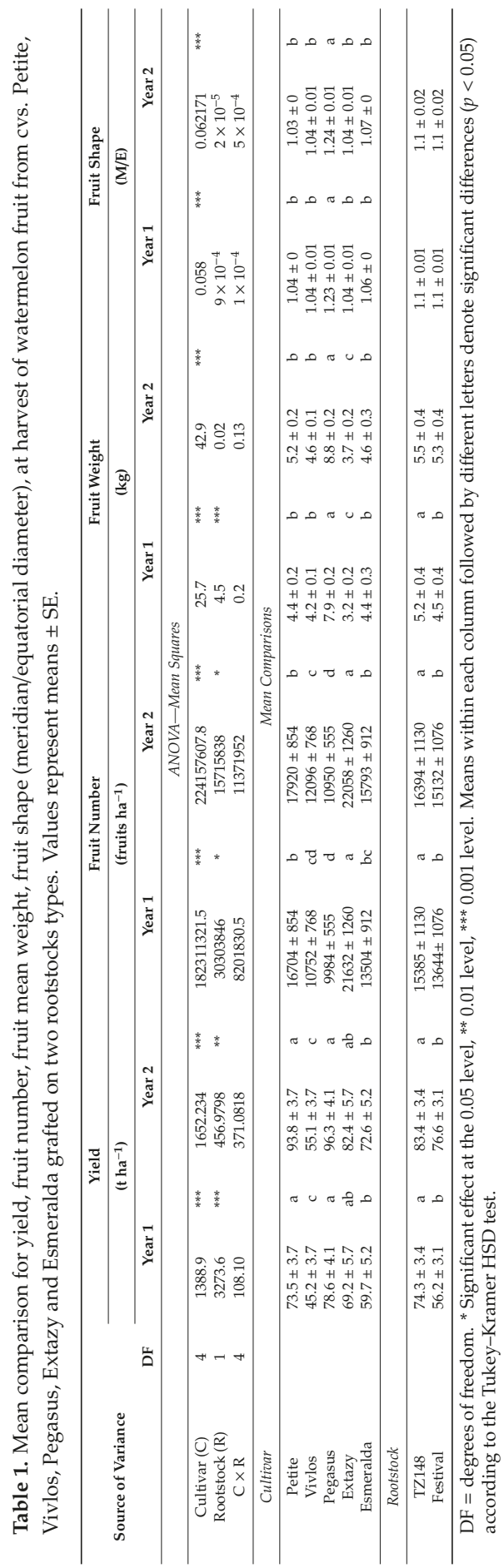




\subsection{Physical Quality Characteristics of Watermelon Fruit}

Physical quality characteristics of watermelon fruit, such as rind thickness, pulp firmness and pulp color, were predominantly determined by the scion cultivar, which accounted for most of the variance observed in these traits (Table 2). Rootstock effect was most pronounced on pulp firmness whereas storage had its greatest effect on rind thickness and the colorimetric values of the pulp. In both years, the thickest watermelon rind was found in the mini triploid cultivar Extazy and the thinnest in the mini diploid Vivlos. Rootstock had a significant effect on rind thickness only in the first year of experimentation whence the interspecific rootstock TZ148 induced a thicker rind than the Lagenaria rootstock Festival. Pulp firmness was highest in the triploid mini cultivars Extazy and Petite and lowest in the diploid cultivars. Rootstock had a significant effect on firmness with TZ148 imparting higher firmness than Festival by $28.9 \%$ and $31.3 \%$ in the first and second year, respectively. The effect of storage on firmness was marginally significant in both years with mean firmness reduced after 10-day storage at $25{ }^{\circ} \mathrm{C}$ by merely $8.0 \%$ and $5.5 \%$ in the first and second year, respectively. The colorimetric variables of the pulp were influenced mainly by scion cultivar and less so by rootstock and storage. Lightness $\left(\mathrm{L}^{*}\right)$ was highest in Pegasus and Vivlos and lowest (darkest pulp) in Extazy and Esmeralda. As denoted by chroma values $\left(C^{*}\right)$, the pulp was most intensely colored in Extazy and Vivlos and least colored in Esmeralda, Petite and Pegasus. Similar cultivar ranking was observed in both years for the intensity of redness denoted by colorimetric parameter a* (data not shown). Chroma was also marginally higher in response to rootstock TZ148 than Festival but only in the first year of experimentation. The narrowest hue angles denoting the most reddish color were obtained from Extazy and Pegasus, while the widest hue angles denoting the least reddish hue were obtained from Esmeralda. During 10-day storage at $25^{\circ} \mathrm{C}$, there was a slight darkening of the pulp (reduced $\mathrm{L}^{*}$ ), but also an increase in chroma and a widening of hue angle denoting a more intense color but also a slight color transition toward orange-red hue. 
Agronomy 2020, 10, 1396

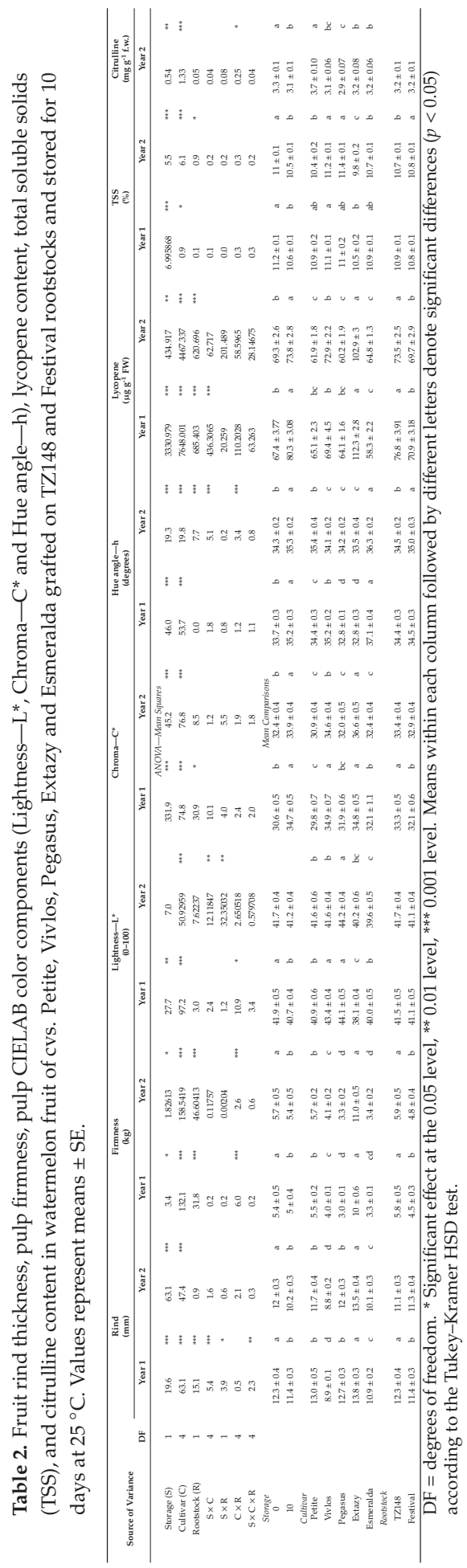




\subsection{Compositional Characteristics of Watermelon Fruit}

Pulp lycopene content correlated significantly with pulp chroma in both years $\left(\mathrm{r}_{\text {year1 }}=0.53\right.$, $p<0.001$ and $r_{\text {year2 }}=0.72, p<0.001$ ). Scion cultivar effect was the most influential on pulp lycopene content compared to rootstock and storage effects (Table 2). The range of lycopene content in the scion cultivars was widened by Extazy, which attained 95\% and 57\% higher lycopene than the mean content of the rest of the cultivars in year1 and year2, respectively. The outstanding lycopene content of Extazy (102.8-112.3 $\mathrm{g} \mathrm{g} \mathrm{g}^{-1}$ ) also rendered the differences among the rest of the cultivars non-significant. Variation among the rest of the cultivars was indeed limited, though it is worth noting that the mini diploid cultivars Esmeralda and Vivlos had the most variable lycopene content between years. With respect to rootstock, in both years the mean lycopene content of the scions grafted onto interspecific rootstock TZ148 was higher than that obtained on the Lagenaria rootstock Festival. Storage at $25^{\circ} \mathrm{C}$ for 10 days increased pulp lycopene in both years, however this effect was more pronounced in the first year. The content of the pulp in the non-essential amino acid citrulline was influenced by the scion cultivar and by storage but not by the choice of rootstock (Table 2). Variation in mean citrulline content among cultivars ranged from $2.9 \pm 0.1 \mu \mathrm{g} \mathrm{g}^{-1}$ f.w. in Pegasus to $3.7 \pm 0.1 \mu \mathrm{g} \mathrm{g}{ }^{-1}$ f.w. in Petite. During storage, the citrulline concentration in the pulp declined, however the reduction was of limited scale, amounting to $6.1 \%$.

The TSS content of the juice was influenced mostly by cultivar and storage and least by rootstock (Table 3). Variation in TSS among cultivars was more limited in the first year compared to the second. In both years, Extazy had the lowest TSS (9.8-10.5\%) whereas Pegasus and Vivlos had the highest (11.0-11.4\%). Overall, diploid cultivars had higher TSS than the seedless cultivars. Rootstock had no effect on TSS during the first year and only a marginal effect during the second when TZ148 resulted in slightly lower TSS than Festival. Very similar effects to those on TSS were observed with respect to the total sugar content of the juice (Table 3). Extazy had the lowest sugars and scions grafted on Festival yielded slightly higher sugars than those on TZ148. Mean total sugar content declined significantly with storage in both years with a sharper drop observed in the first than the second year. Fructose, glucose and sucrose varied significantly in response to storage and scion cultivar and were least affected by rootstock. Fructose was higher in the mini diploid cultivars Vivlos and Esmeralda than the mini seedless Extazy and Petite. Fructose was not affected by rootstock in either year. Storage had a significant effect on fructose which was reduced after 10 days at $25^{\circ} \mathrm{C}$ by $12.4 \%$ as a two-year mean. Glucose was also lowest in Extazy and Petite and highest in Esmeralda and Vivlos. Significant cultivar-rootstock interaction was observed for glucose as Festival induced higher glucose content than TZ148 in the first year whereas the opposite was observed in the second year. Storage reduced glucose by $39.7 \%$ and $42.3 \%$ in the first and second year, respectively. Sucrose was highest in Pegasus and Extazy in the first year and in Pegasus and Petite in the second. Among the mini cultivars, sucrose in proportion to the reducing sugars was more abundant in the seeded than the seedless cultivars. Significant cultivar-rootstock interaction was observed for sucrose as TZ148 induced higher glucose content than Festival in the first year whereas the opposite was observed in the second year. As opposed to the levels of reducing sugars, sucrose levels increase postharvest significantly, amounting to an average increase of $57.2 \%$ between the two years. Variation in the proportions of the three sugars was reflected in the sweetness index of the pulp. The highest sweetness index was observed in Vivlos and Esmeralda and the lowest in Extazy. The watermelon pulp acidity as reflected in the juice $\mathrm{pH}$ showed limited variation across cultivars, with no differences observed in the second year. Rootstock affected juice $\mathrm{pH}$ only in the second year with slightly more acidic juice obtained from watermelons grafted onto TZ148. A significant drop in acidity was observed in both years postharvest. 


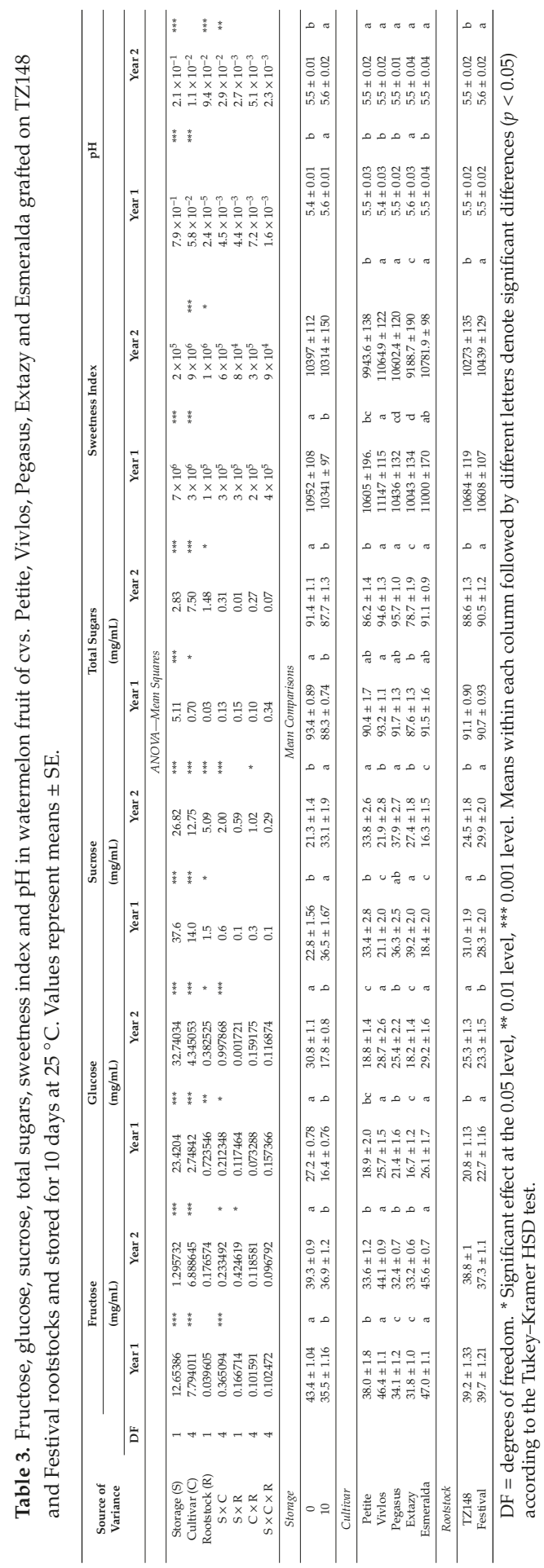




\section{Discussion}

Fruit morphometric characteristics such as weight and shape were the ones affected least by the choice of rootstock. Fruit shape in particular was a trait defined almost exclusively by the scion genotype. These findings corroborate previous works demonstrating the limited variation encountered in these traits in response to different rootstocks and also between grafted and non-grafted material [1]. By contrast, crop performance was strongly influenced by the choice of rootstock. In this respect, the higher yield obtained on Cucurbita maxima $\times$ C. moschata interspecific rootstock TZ148 reflects the vigorous habit of interspecific rootstocks in comparison to the weaker Lagenaria rootstocks, such as Festival. These findings underpin previous reports on the superior crop performance imparted by interspecific rootstocks, provided the absence of physiological incompatibility between scion and rootstock [14-16]. Fruit weight and fruit number incurred a limited rootstock effect. Cultivar genotype largely defined variation in these traits with the large-fruited diploid Pegasus producing higher yield than the mini cultivars, of which the triploid ones were more profuse than the diploid ones. Moreover, watermelon yield may present significant annual variation, as presently demonstrated by all scions on both rootstocks, which has been attributed by previous researchers to the variability of climatic and soil conditions $[17,18]$. It is noteworthy, however, that mean yield varied between years by $12.2 \%$ on TZ148 compared to $36.3 \%$ on Festival, which is an indication of the stable vigor afforded by interspecific rootstocks. Nonetheless, all of the scion-rootstock combinations examined exceeded the regional yield average of 52 tons $\mathrm{ha}^{-1}$ in both years $[19,20]$.

Morphological and visual characteristics of watermelon fruit may substantially influence the perception of quality and ultimately consumer choice. Rind thickness is a morphological trait previously described as responsive to cultural practices that affect maturation, including grafting $[1,11]$. As the rind grows progressively thinner with maturation, watermelon harvest maturity is a defining factor. Contrasting literature on the impact of grafting on rind thickness may thus be interpreted partly in the context of rootstock effects on the ripening process but may also be attributed to the absence of strict maturity standardization during sampling. The current study corroborates that rootstock effect on watermelon rind thickness is generally limited compared to the effect of the scion cultivar [21]. Little emphasis has been given previously on the postharvest change in watermelon rind thickness $[19,22]$. The current study indicates that it is reduced during storage, which renders the impact of rootstocks on rind thickness, presently evidenced in the thicker rind induced by interspecific TZ148 over Lagenaria rootstock Festival, significant for watermelon shelf-life.

Pulp firmness is a significant sensory quality trait of watermelon fruit shown to respond to heterografting on various types of rootstocks. Commercial interspecific (C. maxima $\times$ C. moschata) rootstocks tend to increase pulp firmness, as demonstrated by several previous studies $[10,11,23,24]$. Loss of firmness in response to heterografting has been more often reported with particular Lagenaria siceraria and Cucurbita argyrosperma rootstocks $[25,26]$. The present study focused on the impact of interspecific and Lagenaria gourd rootstocks on scions of differing ploidy, therefore homeograft and self-rooted controls were not used. It was nevertheless observed that the more vigorous interspecific rootstock TZ148 induced notably higher pulp firmness (30.1\% higher as a two-year average) than the Lagenaria rootstock Festival, which underpins previous findings on the superiority of interspecific hybrids for this trait. Gourd rootstocks have had for the most part no effect or very limited and variable effect on pulp firmness $[15,24,25,27]$. Pulp firmness was also found significantly higher in seedless triploid cultivars compared to diploid ones despite the fact that texture analysis was performed not in the locular areas but around the core of the fruit using a set of eight probes in circular $42 \mathrm{~mm}$-diameter arrangement [11]. Pulp firmness has been linked to increased density of parenchymatic cells containing higher alcohol-insoluble and water-insoluble cell wall fractions [28]. The higher firmness presently observed in triploid cultivars, noted also by certain previous researchers [29], might thus be related to higher density of parenchymatic cells bearing more abundant alcohol- and water-insoluble fractions, a hypothesis that warrants further investigation involving cell wall fractionation. Finally, the effect of storage on firmness was significant but limited compared to that of scion cultivar and rootstock. 
Nonetheless, previous work has demonstrated that sensory quality and shelf-life of watermelon is limited to less than two weeks under ambient conditions owing among others to declining pulp firmness, [1]. In light of this, grafting on interspecific hybrid rootstocks might present a significant advantage in terms shelf-life and the same might be the case for triploid over diploid scions.

Watermelon pulp color is configured principally by the accumulation of carotenoids during ripening $[11,30,31]$. Over $90 \%$ of the carotenoid content of red-fleshed cultivars accounts for lycopene, with about $10 \%$ being in the cis isomeric bioavailable form and the rest in the trans form [32]. The highly significant correlation of pulp colorimetry with lycopene content, evidenced in both years of the present study, is common among red-fleshed cultivars; however, pulp chromaticity may not always correlate significantly enough with lycopene content owing to the presence of $\beta$-carotene, which varies with cultivar, maturity and postharvest storage $[1,33]$. The presence of Extazy among the examined scions, which had an outstanding lycopene content $\left(102.8 \mu \mathrm{g} \mathrm{g}^{-1} \mathrm{fw}\right)$, confounded the effects of rootstock and storage compared to the scion effect. Nonetheless, scion genotype is the most determining factor for carotenoid composition of watermelon fruit with lycopene varying widely among red-fleshed cultivars $\left(20-125 \mu \mathrm{g} \mathrm{g}^{-1} \mathrm{fw}\right)$, presently exemplified by the triploid Extazy [32,34]. The current results, moreover, indicate that ploidy is not a determining factor for lycopene content since triploid cultivars diverged significantly (61.9-102.8 $\left.\mathrm{gg} \mathrm{g}^{-1} \mathrm{fw}\right)$. Grafting, on the other hand, especially on C. maxima $\times$ C. moschata interspecific rootstocks $[11,21,35,36]$ and less frequently on L. siceraria cultivars [37], has been found to increase lycopene content in watermelon fruit. In both years of the present study, the lycopene content of the scions grafted onto the interspecific rootstock TZ148 was higher than that obtained on the Lagenaria rootstock Festival. This might be attributed in part to a higher density of parenchymatic cells induced by TZ148 since lycopene is a fat-soluble membrane-bound pigment [11,28]. Finally, postharvest storage at $25^{\circ} \mathrm{C}$ for 10 days increased pulp lycopene in both years of the present study, corroborating previous reports that lycopene synthesis continues and lycopene levels peak postharvest although watermelon is a non-climacteric fruit $[1,19]$. The postharvest increase in chroma $\left(C^{*}\right)$ was accompanied, however, by a wider hue angle signifying a color transition toward the orange-red hue characteristic of over-ripening. This transition might stem from the conversion of lycopene to $\beta$-carotene or from lycopene degradation products [38].

Citrulline is arguably the most important bioactive molecule found in watermelon fruit after lycopene [39]. Previous work has demonstrated that grafting watermelon on interspecific hybrid rootstocks may increase citrulline concentration in the pulp compared to the non-grafted control [1]. The current study indicates that the choice of rootstock between an interspecific hybrid and a Lagenaria rootstock has no effect on citrulline. In fact, the greatest source of variation was the scion cultivar whereas limited decline in citrulline was observed postharvest. It appears therefore that the increase in citrulline content obtained with grafting vs. self-rooted watermelon is largely offset by postharvest decline, which was not previously reported for non-grafted watermelon. However, given the relative abundance of citrulline in watermelon rind, the thicker rind induced by TZ148 may provide more substrate for industrially extracting the non-essential amino acid citrulline that garners significant pharmacological interest [39].

The soluble solids content of watermelon juice is configured primarily by soluble sugars although non-carbohydrate components such as organic acids, water-soluble soluble pectins and pigments may also influence the refractive index of the juice $[40,41]$. In the present study, the TSS and the total sugars of the juice were influenced mostly by cultivar and storage. Diploid cultivars attained overall higher TSS and total sugars than the seedless cultivars, however all scions delivered TSS values near $10 \%$ or higher, which is considered a prerequisite for consumer acceptability [42]. Postharvest storage at ambient temperature resulted in a significant decline in TSS and total sugars, which renders the postharvest handling of watermelons critical for sensory quality, especially for triploid cultivars of lower sweetness. In this respect, Kyriacou et al. [1] highlighted in previous work the importance of optimal harvest maturity for watermelon grafted on vigorous rootstocks that delay ripening, when prolonged postharvest storage ( $>10$ days) at ambient conditions is unavoidable. From a physiological point of 
view, it is noteworthy that glucose and fructose levels decreased during storage as opposed to sucrose, which increased owing most probably to the postharvest activity of ripening-related enzymes such as sucrose synthase. This observation, in conjunction with the postharvest accumulation of lycopene discussed above, sheds new light onto the postharvest physiology of watermelon, otherwise considered a non-climacteric fruit.

The TSS and total sugars of watermelon were generally not decreased by grafting on most commercial C. maxima $\times$ C. moschata rootstocks $[10,23,36]$, whereas scion response to grafting seems more rootstock-specific with Lagenaria siceraria cultivars and landraces [14,37,43]. The marginally lower total sugars content observed with TZ148 in the second year of the current study likely relate to the higher fruit load supported by this rootstock and a possible slight delay in ripening compared to the Lagenaria rootstock Festival. This is further supported by the higher hexoses-to-sucrose ratio observed with TZ148 in the second year, given that the common sugar motif observed during watermelon ripening is that of sucrose accumulating at the expense of hexoses [11]. At any rate, the non-significant or marginal rootstock effect on TSS and total sugars renders interspecific TZ148 an advantageous rootstock over Lagenaria Festival on account of higher yield, firmness and lycopene content.

\section{Conclusions}

Fruit morphometric characteristics were affected least by the choice of rootstock. However, the more vigorous interspecific rootstock delivered higher and more stable yield across seasons than gourd rootstock, which highlights the superior crop performance imparted by interspecific rootstocks, provided the absence of physiological rootstock-scion incompatibility. Interspecific rootstock also induced thicker rind and higher pulp firmness, both of which improve shelf-life. Pulp firmness was higher in seedless triploid cultivars compared to diploid ones, which might relate to higher density of parenchymatic cells. Current results indicate that scion genotype but not ploidy level is the most determining factor for carotenoid composition of watermelon fruit. Moreover, interspecific rootstock induced higher fruit lycopene content than gourd rootstock. Ambient postharvest storage for 10 days increased pulp lycopene, corroborating previous reports that lycopene synthesis continues and lycopene levels peak postharvest although watermelon is a non-climacteric fruit. Diploid cultivars attained overall higher TSS and total sugars than seedless cultivars; storage, however, reduced both, which renders the postharvest handling of triploid cultivars particularly prone to loss of sensory quality. Reducing sugars decreased during storage while sucrose increased. This observation in conjunction with the postharvest accumulation of lycopene sheds new light onto the postharvest physiology of watermelon, otherwise considered a non-climacteric fruit. Minimal reduction in sugars by interspecific rootstock was related to higher fruit load and possible slight delay in ripening compared to gourd, further supported by the higher hexoses-to-sucrose ratio observed with the former. The marginal rootstock effect on sugars renders interspecific rootstock advantageous over gourd on account of higher yield, firmness and lycopene content.

Author Contributions: Conceptualization, G.A.S., M.C.K. and Y.R.; methodology, G.A.S. and M.C.K.; formal analysis, G.A.S. and M.C.K.; investigation, G.A.S. and M.C.K.; writing-review and editing, G.A.S., M.C.K. and Y.R.; supervision, M.C.K. and Y.R.; All authors have read and agreed to the published version of the manuscript.

Funding: This research received no external funding.

Conflicts of Interest: The authors declare no conflict of interest.

\section{References}

1. Kyriacou, M.C.; Soteriou, G.A.; Rouphael, Y.; Siomos, A.S.; Gerasopoulos, D. Configuration of watermelon fruit quality in response to rootstock-mediated harvest maturity and postharvest storage. J. Sci. Food Agric. 2016, 96, 2400-2409. [CrossRef] [PubMed]

2. Savvas, D.; Colla, G.; Rouphael, Y.; Schwarz, D. Amelioration of heavy metal and nutrient stress in fruit vegetables by grafting. Sci. Hortic. 2010, 127, 156-161. [CrossRef] 
3. Schwarz, D.; Rouphael, Y.; Colla, G.; Venema, J.H. Grafting as a tool to improve tolerance of vegetables to abiotic stresses: Thermal stress, water stress and organic pollutants. Sci. Hortic. 2010, 127, 162-171. [CrossRef]

4. Borgognone, D.; Colla, G.; Rouphael, Y.; Cardarelli, M.; Rea, E.; Schwarz, D. Effect of nitrogen form and nutrient solution $\mathrm{pH}$ on growth and mineral composition of self-grafted and grafted tomatoes. Sci. Hortic. 2013, 149, 61-69. [CrossRef]

5. Rouphael, Y.; Kyriacou, M.C.; Colla, G. Vegetable grafting: A toolbox for securing yield stability under multiple stress conditions. Front. Plant Sci. 2018, 8, 2255. [CrossRef]

6. Causse, M.; Saliba-Colombani, V.; Lecomte, L.; Duffé, P.; Rousselle, P.; Buret, M. QTL analysis of fruit quality in fresh market tomato: A few chromosome regions control the variation of sensory and instrumental traits. J. Exp. Bot. 2002, 53, 2089-2098. [CrossRef]

7. Chilsom, D.N.; Picha, D.H. Effect of storage temperature on sugar and organic acid contents of watermelon. HortScience 1986, 21, 1031-1033.

8. Colla, G.; Pérez-Alfocea, F.; Schwarz, D. Vegetable grafting: Principles and practices. CABI 2017. [CrossRef]

9. Kyriacou, M.C.; Soteriou, G.A. Postharvest change in compositional, visual and textural quality of grafted watermelon cultivars. Acta Hortic. 2012, 934, 985-992. [CrossRef]

10. Soteriou, G.A.; Kyriacou, M.C. Rootstock-mediated effects on watermelon field performance and fruit quality characteristics. Int. J. Veg. Sci. 2015, 21, 344-362. [CrossRef]

11. Soteriou, G.A.; Kyriacou, M.C.; Siomos, A.S.; Gerasopoulos, D. Evolution of watermelon fruit physicochemical and phytochemical composition during ripening as affected by grafting. Food Chem. 2014, 165, 282-289. [CrossRef] [PubMed]

12. McGuire, R.G. Reporting of objective color measurements. HortScience 1992, 27, 1254-1255. [CrossRef]

13. Perkins-Veazie, P.; Collins, J.K.; Pair, S.D.; Roberts, W. Lycopene content differs among red-fleshed watermelon cultivars. J. Sci. Food Agric. 2001, 81, 983-987. [CrossRef]

14. Yetisir, H.; Sari, N. Effect of different rootstock on plant growth, yield and quality of watermelon. Aust. J. Exp. Agric. 2003, 43, 1269-1274. [CrossRef]

15. Yetisir, H.; Sari, N.; Yncel, S. Rootstock resistance to Fusarium wilt and effect on watermelon fruit yield and quality. Phytoparasitica 2003, 31, 163-169. [CrossRef]

16. Soteriou, G.A.; Papayiannis, L.C.; Kyriacou, M.C. Indexing melon physiological decline to fruit quality and vine morphometric parameters. Sci. Hortic. 2016, 203, 207-215. [CrossRef]

17. Goreta Ban, S.; Zanic, K.; Dumiciv, G.; Raspudic, E.; Vuletin Selak, G.; Ban, D. Growth and yield of grafted cucumbers in soil infested with root-knot nematodes. Chil. J. Agric. Res. 2014, 74, 29-34. [CrossRef]

18. Huitron, M.V.; Diaz, M.; Dianez, F.; Camacho, F. The effect of various rootstocks on triploid watermelon yield and qualify. J. Food Agric. Environ. 2007, 5, 344-348.

19. Kyriacou, M.C.; Soteriou, G. Quality and postharvest performance of watermelon fruit in response to grafting on interspecific cucurbit rootstocks. J. Food Qual. 2015, 38, 21-29. [CrossRef]

20. Food and Agriculture Organization of the United Nations. FAOSTAT2013; FAO: Rome, Italy, 2010; Available online: http://faostat3.fao.org (accessed on 27 July 2020).

21. Kyriacou, M.C.; Rouphael, Y.; Colla, G.; Zrenner, R.; Schwarz, D. Vegetable grafting: The implications of a growing agronomic imperative for vegetable fruit quality and nutritive value. Front. Plant Sci. 2017, 8, 741. [CrossRef]

22. Corey, K.A.; Schlimme, D.V. Relationship of rind gloss and grounds pot colour to flesh quality of watermelon fruits during maturation. Sci. Hortic. 1988, 34, 211-218. [CrossRef]

23. Huitron, M.V.; Ricárdez, M.; Dianez, F.; Camacho, F. Influence of grafted watermelon plant density on yield and quality in soil infested with melon necrotic spot virus. HortScience 2009, 44, 1838-1841. [CrossRef]

24. Bruton, B.D.; Fish, W.W.; Roberts, W.; Popham, T.W. The influence of rootstock selection on fruit quality attributes of watermelon. Open Food Sci. J. 2009, 3, 15-34. [CrossRef]

25. Cushman, K.E.; Huan, J. Performance of four triploid watermelon cultivars grafted onto five rootstock genotypes: Yield and fruit quality under commercial growing conditions. Acta Hortic. 2008, 82, 335-337. [CrossRef]

26. Davis, A.R.; Perkins-Veazie, P. Rootstock effects on plant vigor and watermelon fruit quality. Cucurbit Genet. Coop. Rep. 2005, 28-29, 39-42. 
27. Özdemir, A.; Çandır, E.; Yetişir, H.; Aras, V.; Arslan, Ö.; Baltaer, Ö. Effects of rootstocks on storage and shelf life of grafted watermelons. J. Appl. Bot. Food Qual. 2016, 9, 191-201. [CrossRef]

28. Soteriou, G.A.; Siomos, A.S.; Gerasopoulos, D.; Rouphael, Y.; Georgiadou, S.; Kyriacou, M.C. Biochemical and histological contributions to textural changes in watermelon fruit modulated by grafting. Food Chem. 2017, 237, 133-140. [CrossRef]

29. Leskovar, D.I.; Bang, H.; Kolenda, K.; Perkins, P.; Franco, J.A. Deficit irrigation influences yield and lycopene content of diploid and triploid watermelon. Acta Hortic. 2004, 628, 147-151. [CrossRef]

30. Bangalore, D.V.; McGlynn, W.G.; Scott, D.D. Effects of fruit maturity on watermelon ultrastructure and intracellular lycopene distribution. J. Food Sci. 2008, 73, S222-S228. [CrossRef]

31. Tadmor, Y.; King, S.; Levi, A.; Davis, A.; Meir, A.; Wasserman, B.; Hirschberg, J.; Lewinsohn, E. Comparative fruit colouration in watermelon and tomato. Food Res. Int. 2005, 38, 837-841. [CrossRef]

32. Perkins-Veazie, P.; Collins, J.K.; Davis, A.R.; Roberts, W. Carotenoid content of 50 watermelon cultivars. J. Agric. Food Chem. 2006, 54, 2593-2597. [CrossRef] [PubMed]

33. Perkins-Veazie, P.; Collins, J.K.; Pair, S.; Roberts, W. December. Watermelon: Lycopene content changes with ripeness stage, germplasm, and storage. Cucurbitaceae 2002, 3, 427-430.

34. Kyriacou, M.C.; Leskovar, D.I.; Colla, G.; Rouphael, Y. Watermelon and melon fruit quality: The genotypic and agro-environmental factors implicated. Sci. Hort. 2018, 234, 393-408. [CrossRef]

35. Perkins-Veazie, P. Ripening events in seeded watermelons. HortScience 2007, 42, 927.

36. Proietti, S.; Rouphael, Y.; Colla, G.; Cardarelli, M.; De Agazio, M.; Zacchini, M.; Moscatello, S.; Battistelli, A. Fruit quality of mini-watermelon as affected by grafting and irrigation regimes. J. Sci. Food Agric. 2008, 88, 1107-1114. [CrossRef]

37. Çandir, E.; Yetişir, H.; Karaca, F.; Üstün, D. Phytochemical characteristics of grafted watermelon on different bottle gourds (Lagenaria siceraria) collected from the Mediterranean region of Turkey. Turk. J. Agric. For. 2013, 37, 443-456. [CrossRef]

38. Schofield, A.; Vasantha Rupasinghe, H.P.; Gopinadhan, P. Isoprenoid Biosynthesis in fruits and vegetables. In Postharvest Biology and Technology of Fruits, Vegetables and Flowers; Paliyath, G., Murr, D.P., Handa, A.K., Lurie, S., Eds.; Wiley-Blackwell Publishing: Ames, IA, USA, 2008.

39. Tarazona-Díaz, M.P.; Viegas, J.; Moldao-Martinsc, M.; Aguayoa, E. Bioactive compounds from flesh and by-product of fresh-cut watermelon cultivars. J. Sci. Food Agric. 2011, 91, 805-812. [CrossRef]

40. Kader, A.A. Flavor quality of fruits and vegetables-Perspective. J. Sci. Food Agric. 2008, 88, 1863-1868. [CrossRef]

41. Magwaza, L.S.; Opara, U.L. Analytical methods for determination of sugars and sweetness of horticultural products-A review. Sci. Hortic. 2015, 184, 179-192. [CrossRef]

42. Maynard, D.N.; Dunlap, A.M.; Sidoti, B.J. Sweetness in diploid and triploid watermelon fruit. Cucurbit Genet. Coop. Rep. 2002, 25, 32-35.

43. Alan, O.; Ozdemir, N.; Gunen, Y. Effect of grafting on watermelon plant growth, yield and quality. J. Agron. 2007, 6, 362-365. [CrossRef]

(C) 2020 by the authors. Licensee MDPI, Basel, Switzerland. This article is an open access article distributed under the terms and conditions of the Creative Commons Attribution (CC BY) license (http://creativecommons.org/licenses/by/4.0/). 


\title{
Augmenting the Sustainability of Vegetable Cropping Systems by Configuring Rootstock-Dependent Rhizomicrobiomes that Support Plant Protection
}

\author{
Mariateresa Cardarelli ${ }^{1}$, Youssef Rouphael ${ }^{2}$, Marios C. Kyriacou ${ }^{3}$, Giuseppe Colla ${ }^{4}$ and \\ Catello Pane ${ }^{1, *}$ \\ 1 Consiglio per la Ricerca in Agricoltura e L'analisi Dell'economia Agraria, Centro di Ricerca Orticoltura e \\ Florovivaismo, 84098 Pontecagnano Faiano, Italy; mteresa.cardarelli@crea.gov.it \\ 2 Department of Agricultural Sciences, University of Naples Federico II, 80055 Portici, Italy; \\ Youssef.rouphael@unina.it \\ 3 Department of Vegetable Crops, Agricultural Research Institute, Nicosia 1516, Cyprus; \\ m.kyriacou@ari.gov.cy \\ 4 Department of Agriculture and Forest Sciences, University of Tuscia, 01100 Viterbo, Italy; giucolla@unitus.it \\ * Correspondence: catello.pane@crea.gov.it
}

Received: 30 June 2020; Accepted: 11 August 2020; Published: 13 August 2020

\begin{abstract}
Herbaceous grafting is a propagation method largely used in solanaceous and cucurbit crops for enhancing their agronomic performances especially under (a)biotic stress conditions. Besides these grafting-mediated benefits, recent advances about microbial networking in the soil/root interface, indicated further grafting potentialities to act as soil environment conditioner by modulating microbial communities in the rhizosphere. By selecting a suitable rootstock, grafting can modify the way of interacting root system with the soil environment regulating the plant ecological functions able to moderate soilborne pathogen populations and to decrease the risk of diseases. Genetic resistance(s) to soilborne pathogen(s), root-mediate recruiting of microbial antagonists and exudation of antifungal molecules in the rhizosphere are some defense mechanisms that grafted plants may upgrade, making the cultivation less prone to the use of synthetic fungicides and therefore more sustainable. In the current review, new perspectives offered by the available literature concerning the potential benefits of grafting, in enhancing soilborne disease resistance through modulation of indigenous suppressive microbial communities are presented and discussed.
\end{abstract}

Keywords: solanaceae; cucurbitaceae; defense mechanisms; soilborne pathogen; genetic resistance; microbial communities; grafting; soil/root interface

\section{Introduction}

Modern agriculture needs innovative strategies inspired by the principles of agroecology, aimed to guarantee soil conservation and fertility, to face the adversities that affect crop productivity and, generally, to increase the sustainability of intensive systems. One of the most important challenges for sustainability concerns the control of soil-borne diseases being considered a major limitation to crop production. The massive use of chemicals against plant pathogens is no longer a viable practice for environmental risks and human health care. The most commonly applied eco-friendly approaches include solarisation, biofumigation, crop rotation, tillage management practices, residue management and organic amendments [1]; additional strategies such as applications of plant growth promoting rhizobacteria (PGPRs), endo- and ectomycorrhizal fungi, cyanobacteria and other organisms can also improve plant resistance to soilborne pathogens. Several studies reported that plants can recruit a specific beneficial rhizosphere microflora which can contribute to reduce the activity of plant pathogens 
and to make plants more resistant to environmental stressors [2,3]. Investigations on rhizosphere microbiome carried out by next-generation sequencing technologies allowed to identify and quantify microorganisms associated with the root apparatus of vegetable crops highlighting an evolutionistic mechanism of microbial recruiting adopted by plants.

Vegetable grafting is a propagation method largely used in solanaceous and cucurbit crops to increase plant resistance to soilborne pathogens as well as other environmental stresses, and to enhance crop productivity and fruit quality [4]. In soils infected by highly destructive plant pathogens, the use of resistant grafted plants represents the main biological-based method that allows cultivation of the highly susceptible cultivars [5]. In the latest years, increasing studies on the ecological role of the grafting revealed new interesting opportunities of this technology to contrast and limit the activity of soilborne pathogens and their damages on vegetable crops, by modifying the presence of beneficial root-associated microbes. For instance, Poudel et al. [6] used a grafted tomato system to study the effect of rootstock genotypes and grafting on soil bacteria communities and their results highlighted an effect of rootstock genotype on bacterial diversity and composition in the rhizosphere. Moreover, Duan et al. [7] reported that some pepper grafting combinations significantly increased the populations of fungi and actinomycetes in the rhizosphere enhancing the activities of peroxidase, catalase, phosphatase, invertase, urease, and nitrate reductase in root rhizosphere soil. Similar results were also reported in grafted eggplants [8]. Besides plant species, additional environmental factors such as soil type can also affect the microbial communities in the rhizosphere indicating the need to evaluate the rootstock-mediated effects on rhizosphere microbiome under different environmental conditions $[9,10]$. The above findings indicate the potential of using plant rootstocks as a mean to recruit specific soil beneficial microorganisms for biotic stress management.

This review offers a novel perspective on the potentialities of vegetable grafting as sustainable practices to enhance crop resistance to environmental stresses through the modulation of microbial community structure in the rhizosphere.

\section{Soil Microorganisms for Biological Control of Plant Diseases}

Rhizosphere and bulk soil around growing plants constitute the habitat for a large number of microbial species with different lifestyles, interacting with one another, with the soil and plants. The culturable bacteria and fungi associated with rhizosphere can contain up to $10^{11}$ microbial cells per gram of roots [11]. Some microorganims have a neutral effect on the plant, but many known microorganisms are beneficial to the plants for nutrient and carbon cycling, soil organic matter formation and stabilization, so influencing agricultural productivity. They are symbiotic nitrogen-fixing bacteria (Rhizobium leguminosarum), endo- and ectomycorrhizal fungi, plant growth-promoting rhizobacteria (PGPR) and other fungi [12]. Many of these microorganisms are even investigated for their ability to prevent or limit soil-borne plant pathogens (fungi and oomycetes are the most important) through mechanisms as hyperparasitism, antibiosis and competition for ecological niches and nutrients [13].

Microbial hyperparasites have a predatory behavior: they enter host cells of fungi and oomycetes helped by secreting cell-wall lytic enzymes (as chitinases, cellulases and proteases) and feed on the pathogen as long as it dies. Parasitic activity is quite common, and well documented for Trichoderma and Gliocladium against fungal pathogens as Rhizoctonia, Sclerotinia, Verticillium and Gaeumannomyces [14-16]. Even Coniothyrium minitans [17] and Sporidesmium sclerotivorum [18] are effective in controlling diseases caused by sclerotia-forming fungi. Chitinolytic activity of Pseudomonas spp. is responsible of antagonistic activity towards $R$. solani [12].

Antibiosis results from the release of low-molecular weight compounds produced by microorganisms in the surrounding environment which are deleterious to the metabolism or growth of plant pathogens $[19,20]$. Fluorescent Pseudomonas spp., Bacillus spp., Streptomyces spp. and Trichoderma spp. produce antibiotic molecules (phenazines, 2,4-diacetylphloroglucinol, pyoluteorin, and pyrrolnitrin) affecting the electron transport chain, metalloenzymes, membrane integrity, or cell membrane and zoospores [20-22]. 
With the competition for space, pathogens are prevented from accessing root surface and plant tissue whereas the competition for nutrients, especially for carbon released as root exudates, affect the saprophytic phase of pathogens, and may cause lacking spore germination and microbiostasis [11]. Siderophore-producing Pseudomonas spp. are involved in the competition for iron, a micronutrient essential for growth and activity of the pathogens and are able to reduce disease incidence or severity of pathogenic fungi [23].

Literature survey reveals many pivotal examples of rhizosphere-competent microbial biocontrol agents of plant pathogens. Fungi belonging to Trichoderma genus, for example, have antagonistic properties towards a plethora of plant pathogens relying on all of the antagonist modes [24]. T. harzianum and T. asperellum showed antagonistic effects against Fusarium oxysporum of tomato [25-27] and melon [28] under field conditions. Gava et al. [28] tested different Trichoderma species (T. harzianum, T. viride, T. koningii, and T. polysporum) in a naturally infested soil and obtained the highest control of melon wilt using T. polysporum.

Malolepsza [29] observed a significant stimulation of systemic defenses (activation of antioxidant enzymes and enhancement of phenols) by T. virens inoculation of tomato plants, leading to lowered Rhizoctonia solani infection. Some authors verified the involvement of the proteins Sm1 and Epl1 in the systemic protection of tomato plants mediated by Trichoderma spp. [30]: in presence of these proteins it was observed an increase in disease resistance against Alternaria solani, Botrytis cinerea, and Pseudomonas syringae due to the increased expression of peroxidase and $\alpha$-dioxygenase encoding genes [30], the elicitation of the salicylic acid pathway [31,32] and the ethylene pathway [31]. Even the accumulation of phenolic acids, flavonoids and de novo synthesis of catechins, enhanced by T. atroviride inoculation, is supposed to contribute to cucumber protection against $R$. solani [33]. In cucumber seedlings inoculated with T. harzianum inoculations, Chen [34] found alterations in nuclear DNA content and cell cycle-related genes expression that might maintain a lower ROS accumulation and higher root cell viability counteracting Fusarium disease in open field. Quantitative proteomics studies on black pepper plants primed with T. harzianum confirmed the plant defense response against the pathogen Phytophthora capsicum through an increase of ethylene synthesis and activating both the isoflavanoid pathway and lignin synthesis [35].

Coating of tomato seeds with T. asperellum and Bacillus subtilis decreased the susceptibility of plants to Pythium aphanidermatum [36]. Frequently the combination of different antagonists in microbial consortia improves their effectiveness for the involvement of diverse biocontrol mechanisms [37]. In watermelon, a systemic acquired resistance against $F$. oxysporum f.sp. niveum was related to the inoculation with a consortium of T. harzianum, Paenibacillus polymyxa and other antagonistic microorganisms that activated defense-related enzymes [38]. T. harzianum and Bacillus amyloliquefaciens together inhibited the growth and production of mycelia and sclerotia protecting over $80 \%$ of tomato, squash and eggplant seedlings against Sclerotinia sclerotiorum [39]. Similarly, to T. asperellum, even the arbuscular mycorrhizal fungus Rhizophagus irregularis (previously known as Glomus intraradices) lowered disease incidence of Fusarium wilt in tomato plants [40]. Both these agents increased plant height, chlorophyll content and $\mathrm{Ca}, \mathrm{Mg}, \mathrm{S}, \mathrm{Mn}, \mathrm{B}$ and Si uptake. T. harzianum combined with Glomus intraradices induced a plant basal resistance attenuating the hormone (ethylene and abscisic acid) disruption induced by F. oxysporum in melon [41] whereas associated with Glomus mossae is useful in cucumber against Phytophthora melonis increasing the transcription level of defensive genes as phenylalanine ammonialyase, cucumber pathogen-induced 4, lipoxygenase and galactinol synthase [42]. In field experiment the consortium mycorrhizae, Trichoderma and plant growth-promoting bacteria enhanced the pepper yield and modulated the activities of defense enzymes as polyphenol oxidase, peroxidase, superoxide dismutase, and catalase [43]. Even arbuscular mycorrhizal fungi alone can control plant soil-borne diseases $[44,45]$ activating a systemic plant immune response. Mycorrhizal fungi reduced the disease severity index of eggplant Verticillium wilt [46]; the disease tolerance was related to a lower proline content and relative electrical conductivity in leaves, and to higher activity of browning related enzymes (phenylalanine ammonia-lyase, polyphenol oxidase and peroxidise). Panda et al. [47] 
found that pre-colonization of tomato roots with mycorrhizal fungus Piriformospora indica systemically induced resistance against early blight by Alternaria solani; after pathogen attack $P$. indica induced a rapid activation of jasmonic acid/ethylene-mediated basal defenses against pathogen infection by altering the expression of JA/ET related genes. Glomus mossae suppresses F. oxysporum development in the roots and rhizosphere of watermelon and modulates the composition of root exudates. Bacterial species of the Bacillus and Pseudomonas genus control plant disease by producing antibiotics or stimulating the host resistance [48]. Tomato plants inoculated with Bacillus amyloliquefaciens exhibited significantly low F. oxysporum f. sp. lycopersici infection compared with the control [49]. Clonostachys rosea counteracted gray mold disease not only by suppressing development and sporulation of Botrytis cinerea but also by inducing the resistance of tomato plants against $B$. cinerea [50].

\section{How Plants Recruit Antagonist Microbes to Prevent the Infection by Pathogens}

The rhizosphere microbiome has been recognized as the second genome of the plants [11], and it may reveal the greater ability of the plant in adapting to the external environment, including the protection degree against pathogenic agents. Plants through their roots are in dynamic communication with the surrounding bulking soil microbial communities [51]. Roots exudates are a main food source for microorganisms and a driving force for their assembling and activities. Carbon and nitrogen are exudates as simple molecules (sugars, organic acids, secondary metabolites) or complex polymers (mucilage) but their composition varies with the plant genotype, developmental stage, and the presence of (a)biotic stresses [52]. It has been seen that microbial communities in the rhizosphere of different plant species growing on the same soil are often different and vice versa $[53,54]$ thus demonstrating that plants modulate exudates profile (alteration of biosynthesis and transport of molecules) and immune system activities to recruit specific beneficial microbes. Moreover, plants can detect communication signals between bacteria in the rhizosphere (quorum sensing signals) and produce molecules that stimulate or deactivate these signals so influencing the outcome of microbe-microbe and/or plant-microbe interactions [55]. L-malic acid is the small signalling molecule exudated from tomato plant roots that is responsible for biofilm formation and root colonization of the antagonistic Bacillus subtilis [56]. Similarly, Tan et al. [57] confirmed the important role of malic and citric acids in tomato root surface colonization of Bacillus amyloliquefaciens. Moreover, different organic acids in watermelon and cucumber roots exudates stimulate the beneficial Paenibacillus polymyxa [58] and Trichoderma harzianum [59], respectively. Glucose, succinic acid, $p$-hydroxybenzoic acid, $p$-coumaric acid and glutamic acid in cucumber root exudates recruit Trichoderma with the most relevant effect from glucose [60].

Recent advances reveal that multiple signals operate in the establishment and the maintenance of arbuscular mycorrhizal symbiosis including calcium spiking, reactive oxygen species and phytohormones [61,62]. The plant hormones strigolactones are actively exuded into rhizosphere as ex-planta signalling molecules that attract arbuscular mycorrhizal fungi affecting both pre-symbiotic and symbiotic phases [63]. Other important hormones involved in the onset of the AM symbiosis are jasmonates [64], gibberellins [65], ethylene [66], and auxins [67]. A possible crosstalk between auxin and strigolactones is also postulated in tomato plants [68]. Martínez-Medina et al. [69] studied the interaction between tomato roots and the AM fungus Rhizophagus irregularis showing a regulatory role of nitric oxide mediated by a specific phytoglobin during the symbiosis.

\section{Defense Mechanisms in Grafted Plants against Soilborne Pathogens}

Disease control-related mechanisms of grafting may rely on the genetic traits of the rootstock-type. Interspecific grafting, for example, is often secured with the non-host resistance of the rootstock against species-specific soil-borne pathogens, such as the wilting causal agents belonging to $F$. oxysporum group that harbour differentially host-compatible formae specialis [70,71]. Limitation in spread of tomato wilting-associated bacteria in resistant cultivars could avoid the generalization of infection to the entire vascular tissues of susceptible scion [72]. Graft-transmissible resistance to airborne disease has been observed for sweet pepper cultivar grafted on a resistant cherry pepper rootstock [73]. In this situation, 
the effects of rootstock on the scion is the major determinant of resistance. Disease resistance of grafted plants may also result from the enhanced vigour for which grafted plants grow more fortified and more efficient in resource utilization, as well as developing vigorous root apparatus that allow them to better withstand pathogenic attacks caused by the parenchymatous parasites [74]. For example, reduction of Verticillium wilting by effective eggplant grafting on S. lycopersicum $\times$ S. habrochaites rootstock is associated to promotion of plant vigour [75]. Another mechanisms of disease resistance promoted by grafting is the release in the rhizosphere of exudates having antifungal activity on pathogen propagules. Liu et al. [76], for example, found root exudates from grafted eggplants, suppressive against the Verticillium dahliae mycelial development, contrarily to those released by the non-grafted ones. Grafting can affect root ability to harbour rhizosphere-competent microbes and to regulate beneficial antagonistic functions by modifying the root-architecture and the exudate profiling $[77,78]$. Rootstock/scion interaction can modulate regulations of transcripts and metabolites affecting disease susceptibility to fungal pathogens [79]. For instance, rootstock can influence disease resistance of scion by modifying secondary metabolites in the sap flow moving through the vascular system [80]. Shibuya et al. [81] attributed the transient reduction of disease symptoms on cucumber scion to changes in morphology or physiology in response to the modified water relations immediately after grafting onto squash. Defense mechanisms in grafted plants against soil-borne pathogens are summarized in Figure 1.

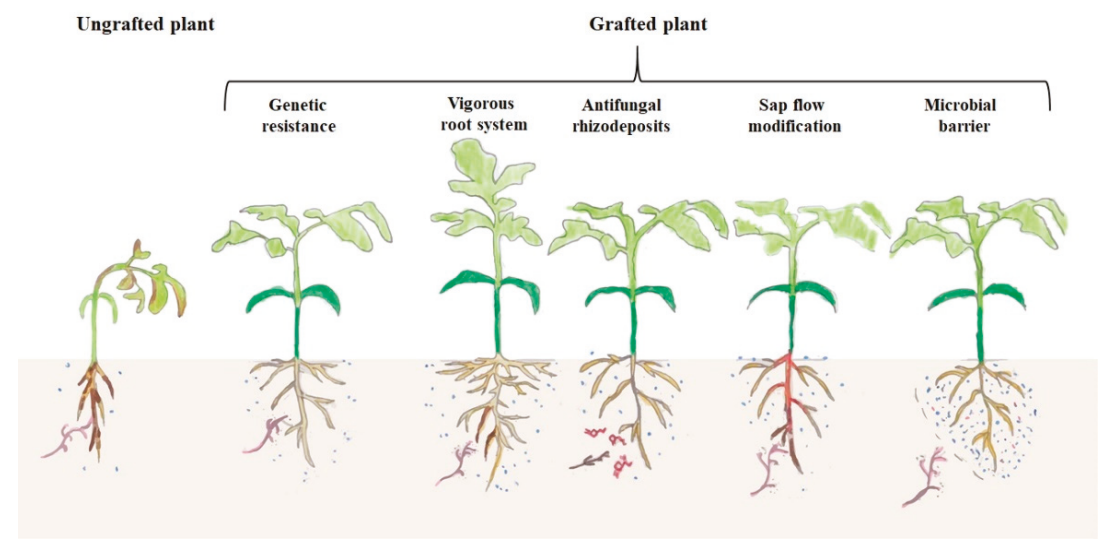

Figure 1. Disease-resistance mechanisms of grafted plants in soil infested by pathogens.

Experimental evidences suggested that the above listed mechanisms act synergistically in the regulation of the disease resistance of grafted roots. Greenhouse trials carried out by Song et al. [77] allowed to define as changes in root exudates from watermelon grafted on Lagenaria siceraria and Cucurbita pepo rootstocks, have promoted the non-host holobiont resistance to F. oxysporum $\mathrm{f}$. sp. niveum infections through additional pathogen exclusion effects. In particular, niche chemical shifts around watermelon grafted roots affected the sheltered microbial diversity, increasing, for example, biocontrol-associated bacteria populations, such as Sphingobacteriia and Bacillus [77]. Biochemical investigations on watermelon/bottle gourd rhizodeposits have allowed to detect the ex-novo formation of bioactive proteins associated with plant resistance to biotic and abiotic stresses [82] and the release of chlorogenic and caffeic acids involved in the microbiostasis against propagules of the wilting causal agent [83]. Findings suggesting that the ungrafted watermelon delivery of molecular signals that are normally used as stimuli by pathogens harbouring the rhizosphere [84], with the grafting, likely, it is interrupted. In this light, combining grafting with environmentally friendly soil treatments (e.g., soil solarization) could slow down the recovery of pathogen recrudescence, often observed in conductive soils with the continuous monoculture cropping [84]. Structural 
variations of a root-associated microbiome after grafting have been also reported in open field tomato production, where Poudel et al. [6] showed rootstock-specific filtering effects driven by vigorous rooting, on endosphere and rhizosphere microbiomes enriched by representatives of Firmicutes, Verrucomicrobia, Planctomycetes, Proteobacteria and Acidobacteria. Under greenhouse, the use of Solanum torvum as rootstook for eggplant, induced an incremental shift in Bacteria and Actinomycetes on the root system, and in the responsive rhizosphere soil enzymes were found both associated to the pathogen population lowering and Verticillium wilting decrease [85].

Plant domestication privileged the selection of agronomic traits strictly related to the edibility, quantity and quality of the yields, leaving on the way all those alleles that gave to wild relatives the ability to profitably deal with soil microorganisms, reducing the potential of modern cultivars to lead rhizosphere microbiome assembly and functions [86]. In order, to bridge this gap, only recently some breeding programs are including, among the genetic improvement objectives, the enhanced ability of crops in recruiting beneficial host-specific root microbiota too [87]. In the meantime, horticultural experiences indicated that, at the moment, grafting better than others available technologies allows to reach this phenotype more quickly depending on the specific influence of rootstock genotype $[84,88]$. The metabolic structure of rootstock-recruited microorganisms, for example, has been implemented for managing tree resistance to the apple replant disease complex in replanted orchards [89]. Thereby, also vegetable productions may alleviate detrimental risks hidden into the intensive cropping systems following a holistic approach, in which grafting improves telluric environment adaptation of cultivar through the reinforcement of partnerships with beneficial and biodiverse microbiota and the enhancement of the efficient resource utilization. A summary of the possible directional interactions occurring in the soil environments shared by grafted roots and microbiome aiming at reducing pathogens pressure is reported in Table 1.

Table 1. Possible directional interactions occurring in the soil between grafted roots and microbiome aiming at reducing pathogens pressure.

\begin{tabular}{ccc}
\hline To & Grafted Roots & Microbiota \\
\hline Grafted roots & $\begin{array}{c}\text { Allelopathy } \\
\text { Microbiota }\end{array}$ & $\begin{array}{c}\text { Selection-filtering effects } \\
\text { C-food providing } \\
\text { Activation of the endophytism }\end{array}$ \\
\hline & $\begin{array}{c}\text { Nutrients availability } \\
\text { Growth promotion }\end{array}$ & $\begin{array}{c}\text { Antibiosis } \\
\text { Induction of resistance to (a)biotic stresses } \\
\text { Niche occupying } \\
\text { Essential food depletion }\end{array}$ \\
\hline
\end{tabular}

Relationships-mediated by rootstock between the vegetable scion and the infected soil open new opportunities for disease risks management in a more environmentally friendly way (Table 2).

Table 2. Soilborne disease risk management using ungrafted and grafted plants.

\begin{tabular}{lll}
\hline \multicolumn{1}{c}{ Management Goal } & \multicolumn{1}{c}{ Ungrafted Plants } & \multicolumn{1}{c}{ Grafted Plants } \\
\hline Reduction of disease risks & $\begin{array}{l}\text { Cultivation of susceptible cultivars } \\
\text { on healthy soils }\end{array}$ & $\begin{array}{l}\text { Grafting of susceptible cultivars on disease } \\
\text { resistant rootstocks }\end{array}$ \\
\hline $\begin{array}{l}\text { Genetic innovation regarding plant } \\
\text { protection objectives }\end{array}$ & $\begin{array}{l}\text { New cultivars resistant/tolerant to } \\
\text { pathogens }\end{array}$ & $\begin{array}{l}\text { New rootstock genotypes resistant/tolerant } \\
\text { to pathogens } \\
\text { New grafting combinations with enhanced root } \\
\text { ability to recruit protective rhizobiome }\end{array}$ \\
\hline $\begin{array}{l}\text { Engineering soil microbiome for } \\
\text { enhancing its antagonistic structure }\end{array}$ & $\begin{array}{l}\text { Soil conditioning techniques } \\
\text { mitigating soil sickness phenomena }\end{array}$ & $\begin{array}{l}\text { Actions for maintenance of ecological bio-barriers } \\
\text { proliferating on the rootstock roots }\end{array}$ \\
\hline $\begin{array}{l}\text { Increased effectiveness of the } \\
\text { chemical control means }\end{array}$ & $\begin{array}{l}\text { Wide-spectrum preventive and } \\
\text { curative applications of fungicides }\end{array}$ & $\begin{array}{l}\text { Targeted use of active molecules both in time and } \\
\text { in dosage }\end{array}$ \\
\hline $\begin{array}{l}\text { Increased effectiveness of the } \\
\text { biological control agents }\end{array}$ & $\begin{array}{l}\text { Mass applications of the bio-based } \\
\text { formulates }\end{array}$ & $\begin{array}{l}\text { Coordinating application of the external microbial } \\
\text { antagonists, with the naturally present rhizobiome } \\
\text { Targeted use of specific microbial strains } \\
\text { characterized by grafted-rhizosphere competence }\end{array}$ \\
\hline
\end{tabular}


Moreover, the integration of grafting technology with other agronomic, chemical and/or biological control means can allow to further reduce the risks of soilborne diseases especially in a long term. However, the use of chemical inputs must be carefully evaluated to avoid depression of beneficial indigenous soil microflora in the rootstock rizhosphere. Under these boosted agroecological conditions monitoring of plant and soil health status over time is crucial.

\section{Conclusion and Future Prospects}

Grafting represents a relatively recent innovation in the vegetable production systems of Western Countries; this advanced technology allowed to reduce the negative impact of soilborne pathogens in solanaceous and cucurbit crops depending on the disease resistance level of rootstock. Grafting can enhance plant disease resistance through several multiple defense mechanisms in plant. Recent studies demonstrated that rootstock-mediated effects on rhizosphere microbiome can contribute to reduce the soilborne diseases by stimulating indigenous microflora able to compete for food and space with plant pathogens and to reduce their activity through antibiosis and hyperparasitism. Moreover, plant-beneficial microbes recruited by rootstock can enhance soilborne disease resistance indirectly through the increase of plant nutrient availability, the stimulation of plant growth and the induction of resistance to biotic stresses. Despite experimental evidences demonstrated a significant role of rhizosphere microbiome in enhancing soilborne disease resistance in grafted plants, more studies are necessary to better understand the scion-rootstock-rhizosphere microbiome interaction under different environmental conditions. Advanced technologies like metagenomics can help to identify and characterize the microbial strains in the rhizosphere of grafting combinations in order to link the changes in rhizosphere microbial community to enhanced plant resistance to specific soilborne pathogens. This knowledge could allow to develop new disease control strategies based on the combined application of selected microbial inoculants and specific grafting combinations.

Author Contributions: Conceptualization, M.C. and C.P.; writing-original draft preparation, M.C. and C.P.; writing-review and editing, M.C., Y.R., M.C.K., G.C. and C.P. All authors have read and agreed to the published version of the manuscript.

Funding: This research received no external funding.

Acknowledgments: This work was partially supported by MIUR (Minister for education, University and Research), Law 232/2016, 'Department of Excellence'.

Conflicts of Interest: The authors declare no conflict of interest.

\section{References}

1. Raaijmakers, J.M.; Paulitz, T.C.; Steinberg, C.; Alabouvette, C.; Moënne-Loccoz, Y. The rhizosphere: A playground and battlefield for soilborne pathogens and beneficial microorganisms. Plant Soil 2009, 321, 341-361. [CrossRef]

2. Tena, G. Recruiting microbial bodyguards. Nat. Plants 2018, 4, 857. [CrossRef] [PubMed]

3. Compant, S.; Samad, A.; Faist, H.; Sessitsch, A. A review on the plant microbiome: Ecology, functions, and emerging trends in microbial application. J. Adv. Res. 2018, 19, 29-37. [CrossRef]

4. Colla, G.; Rouphael, Y.; Cardarelli, M.; Salerno, A.; Rea, E. The effectiveness of grafting to improve alkalinity tolerance in watermelon. Environ. Exp. Bot. 2010, 68, 283-291. [CrossRef]

5. Louws, F.J.; Rivard, C.L.; Kubota, C. Grafting fruiting vegetables to manage soilborne pathogens, foliar pathogens, arthropods and weeds. Sci. Hortic. 2010, 127, 127-146. [CrossRef]

6. Poudel, R.; Jumpponen, A.; Kennelly, M.M.; Rivard, C.L.; Gomez-Montano, L.; Garrett, K.A. Rootstocks shape the rhizobiome: Rhizosphere and endosphere bacterial communities in the grafted tomato system. Appl. Environ. Microbiol. 2018, 85. [CrossRef]

7. Duan, X.; Bi, H.G.; Wei, Y.Y.; Li, T.; Wang, H.T.; Ai, X.Z. Effect of grafting on rhizosphere soil environment and its relationship with disease resistance and yield of pepper. Chin. J. Appl. Ecol. 2016, 27, 3539-3547.

8. Zhou, B.L.; Xu, Y.; Yin, Y.L.; Ye, X.L. Effects of different years continuous cropping and grafting on the biological activities of eggplant soil. Chin. J. Appl. Ecol. 2010, 29, 290-294. 
9. Garbeva, P.; van Elsas, J.D.; Veen, J.A. Rhizosphere microbial community and its response to plant species and soil history. Plant Soil 2008, 302, 19-32. [CrossRef]

10. Viebahn, M.; Doornbos, R.; Wernars, K.; van Loon, L.C.; Smit, E.; Bakker, P.A.H.M. Ascomycete communities in the rhizosphere of fieldgrown wheat are not affected by introductions of genetically modified Pseudomonas putida WCS358r. Environ. Microbiol. 2005, 7, 1775-1785. [CrossRef]

11. Berendsen, R.L.; Pieterse, C.M.J.; Bakker, P.A.H.M. The rhizosphere microbiome and plant health. Trends Plant Sci. 2012, 17, 478-486. [CrossRef] [PubMed]

12. Garbeva, P.; van Veen, J.A.; van Elsas, J.D. Assessment of the diversity and antagonism toward Rhizoctonia solani AG3 of Pseudomonas species in soil from different agricultural regimes. FEMS Microbiol. Ecol. 2004, 47, 51-64. [CrossRef]

13. McSpadden Gardener, B.B. Diversity and ecology of biocontrol Pseudomonas spp. in agricultural systems. Phytopathology 2007, 97, 221-226. [CrossRef] [PubMed]

14. Reithner, B.; Ibarra-Laclette, E.; Mach, R.L.; Herrera-Estrella, A. Identification of mycoparasitism-related genes in Trichoderma atroviride. Appl. Environ. Microbiol. 2011, 73, 4361-4370. [CrossRef]

15. Pinto, Z.V.; Cipriano, M.A.P.; dos Santos, A.S.; Pfenning, L.H.; Patrício, F.R.A. Control of lettuce bottom rot by isolates of Trichoderma spp. Summa Phytopathol. 2014, 40, 141-146. [CrossRef]

16. Salamone, A.L.; Gundersen, B.; Inglis, D.A. Clonostachys rosea, a potential biological control agent for Rhizoctonia solani AG-3 causing black scurf on potato. Biocontrol Sci. Technol. 2018, 28, 895-900. [CrossRef]

17. Jones, E.E.; Clarkson, J.P.; Mead, A.; Whipps, J.M. Effect of inoculum type and timing of application of Coniothyrium minitans on Sclerotinia sclerotiorum: Control of Sclerotinia disease in glasshouse lettuce. Plant Pathol. 2004, 53, 621-623. [CrossRef]

18. Mischke, S. Mycoparasitism of selected sclerotia-forming fungi by Sporidesmium sclerotivorum. Can. J. Bot. 1998, 76, 460-466. [CrossRef]

19. Raaijmakers, J.M.; Vlami, M.; De Souza, T.J. Antibiotic production by bacterial biocontrol agents. Antonie Leeuwenhoek 2002, 81, 537-547. [CrossRef]

20. Haas, D.; Défago, G. Biological control of soil-borne pathogens by fluorescent pseudomonads. Nat. Rev. Microbiol. 2005, 3, 307-319. [CrossRef]

21. Raaijmakers, J.M.; de Bruijn, I.; de Kock, M.J.D. Cyclic lipopeptide production by plant-associated Pseudomonas species: Diversity, activity, biosynthesis and regulation. Mol. Plant-Microbe Interact. 2006, 19, 699-710. [CrossRef] [PubMed]

22. Bae, S.J.; Kumar, T.; Chung, J.Y.; Ryu, M.; Park, G.; Shim, S.; Hong, S.B.; Seo, H.; Bae, D.W.; Bae, I.; et al. Trichoderma metabolites as biological control agents against Phytophthora pathogens. Biol. Control 2016, 92, 128-138. [CrossRef]

23. Alabouvette, C.; Olivain, C.; Steinberg, C. Biological control of plant diseases: The European situation. Eur. J. Plant Pathol. 2006, 114, 329-341. [CrossRef]

24. Kumar, G.; Maharshi, A.; Patel, J.; Mukherjee, A.; Singh, H.B.; Sarma, B.K. Trichoderma: A potential fungal antagonist to control plant diseases. SATSA Mukhapatra 2017, 21, 206-218.

25. Fitrianingsih, A.; Martanto, E.A.; Abbas, B. The effectiveness of fungi Gliocladium fimbriatum and Trichoderma viride to control Fusarium wilt disease of tomatoes (Lycopersicum esculentum). Indian J. Agric. Res. 2019, 53, $57-61$.

26. Li, Z.B.; Zhou, R.J.; Fu, J.F. Allelopathic effects of phenolic acids from ginseng rhizosphere soil on Cylindrocarpon destructans (Zinss) scholten. Allelopath. J. 2018, 43, 53-64. [CrossRef]

27. Mwangi, M.W.; Muiru, W.M.; Narla, R.D.; Kimenju, J.W.; Kariuki, G.M. Management of Fusarium oxysporum f. sp. lycopersici and root-knot nematode disease complex in tomato by use of antagonistic fungi, plant resistance and neem. Biocontrol Sci. Technol. 2019, 29, 207-216. [CrossRef]

28. Gava, C.A.T.; Pinto, J.M. Biocontrol of melon wilt caused by Fusarium oxysporum Schlect f. sp. melonis using seed treatment with Trichoderma spp. and liquid compost. Biol. Control 2016, 97, 13-20. [CrossRef]

29. Małolepsza, U.; Nawrocka, J.; Szczech, M. Trichoderma virens 106 inoculation stimulates defence enzyme activities and enhances phenolic levels in tomato plants leading to lowered Rhizoctonia solani infection. Biocontrol Sci. Technol. 2017, 27, 180-199. [CrossRef] 
30. Salas-Marina, M.A.; Isordia-Jasso, M.I.; Islas-Osuna, M.A.; Delgado-Sánchez, P.; Jiménez-Bremont, J.F.; Rodríguez-Kessler, M.; Rosales-Saavedra, M.T.; Herrera-Estrella, A.; Casas-Flores, S. The Epl1 and Sm1 proteins from Trichoderma atroviride and Trichoderma virens differentially modulate systemic disease resistance against different life style pathogens in Solanum lycopersicum. Front. Plant Sci. 2015, 6. [CrossRef]

31. Martinez, C.; Blanc, F.; Le Claire, E.; Besnard, O.; Nicole, M.; Baccou, J.C. Salicylic acid and ethylene pathways are differentially activated in melon cotyledons by active or heat-denatured cellulase from Trichoderma longibrachiatum. Plant Physiol. 2001, 127, 334-344. [CrossRef] [PubMed]

32. Gomes, E.V.; Ulhoa, U.J.; Cardoza, R.E.; Silva, R.N.; Gutiérrez, S. Involvement of Trichoderma harzianum Epl-1 protein in the regulation of Botrytis virulence- and tomato defense-related genes. Front. Plant Sci. 2017, 8, 1-11. [CrossRef]

33. Nawrocka, J.; Szczech, M.; Małolepsza, U. Trichoderma atroviride enhances phenolic synthesis and cucumber protection against Rhizoctonia solani. Plant Prot. Sci. 2018, 54, 17-23. [CrossRef]

34. Chen, S.; Zhao, H.; Zou, C.; Li, Y.; Chen, Y.; Wang, Z.; Jiang, Y.; Liu, A.; Zhao, P.; Wang, M.; et al. Combined inoculation with multiple arbuscular mycorrhizal fungi improves growth, nutrient uptake and photosynthesis in cucumber seedlings. Front. Microbiol. 2017, 8. [CrossRef] [PubMed]

35. Umadevi, P.; Anandaraj, M. Proteomic analysis of the tripartite interaction between black pepper, Trichoderma harzianum and Phytophthora capsici provides insights into induced systemic resistance mediated by Trichoderma spp. Eur. J. Plant Pathol. 2019, 154, 607-620. [CrossRef]

36. Kipngeno, P.; Losenge, T.; Maina, N.; Kahangi, E.; Juma, P. Efficacy of Bacillus subtilis and Trichoderma asperellum against Pythium aphanidermatum in tomatoes. Biol. Control 2015, 90, 92-95. [CrossRef]

37. Akköprü, A.; Demir, S. Biological control of Fusarium wilt in tomato caused by Fusarium oxysporum $\mathrm{f}$. sp. lycopersici by AMF Glomus intraradices and some Rhizobacteria. J. Phytopathol. 2005, 153, 544-550. [CrossRef]

38. Wu, F.; Liu, B.; Zhou, X. Effects of root exudates of watermelon cultivars differing in resistance to Fusarium wilt on the growth and development of Fusarium oxysporum f.sp. niveum. Allelopath. J. 2010, 25, 403-414.

39. Abdullah, M.T.; Ali, N.Y.; Suleman, P. Biological control of Sclerotinia sclerotiorum (Lib.) de Bary with Trichoderma harzianum and Bacillus amyloliquefaciens. Crop Prot. 2008, 27, 1354-1359. [CrossRef]

40. Bidellaoui, B.; Segarra, G.; Hakkou, A.; Trillas, M.I. Beneficial effects of Rhizophagus irregularis and Trichoderma asperellum strain T34 on growth and Fusarium wilt in tomato plants. J. Plant Pathol. 2019, 101, 121-127. [CrossRef]

41. Martínez-Medina, A.; Pascual, J.A.; Pérez-Alfocea, F.; lbacete, A.; Roldán, A. Trichoderma harzianum and Glomus intraradices modify the hormone disruption in duced by Fusarium oxysporum infection in melon plants. Phytopathology 2010, 100, 682-688. [CrossRef] [PubMed]

42. Sabbagh, S.K.; Roudini, M.; Panjehkeh, N. Systemic resistance induced by Trichoderma harzianum and Glomus mossea on cucumber damping-off disease caused by Phytophthora melonis. Arch. Phytopathol. Plant Prot. 2007, 50, 375-388. [CrossRef]

43. Duc, N.H.; Mayer, Z.; Pék, Z.; Helyes, L.; Posta, K. Combined inoculation of arbuscular mycorrhizal fungi, Pseudomonas Fluorescens and Trichoderma spp. For enhancing defense enzymes and yield of three pepper cultivars. Appl. Ecol. Environ. Res. 2017, 15, 1815-1829. [CrossRef]

44. Azcón-Aguilar, C.; Palenzuela, J.; Roldán, A.; Bautista, S.; Vallejo, R.; Barea, J.M. Analysis of the mycorrhizal potential in the rhizosphere of representative plant species from desertification-threatened Mediterranean shrublands. Appl. Soil Ecol. 2003, 22, 29-37. [CrossRef]

45. Xavier, L.J.C.; Boyetchko, S.M. Arbuscular mycorrhizal fungi as biostimulants and bioprotectants of crops. Appl. Mycol. Biotechnol. 2002, 2, 311-340. [CrossRef]

46. Zhou, B.L.; Zheng, J.D.; Bi, X.H.; Cai, L.L.; Guo, W.W. Effects of mycorrhizal fungi on eggplant Verticillium wilt and eggplant growth. Chin. J. Ecol. 2015, 34, 1026-1030.

47. Panda, S.; Busatto, N.; Hussain, K.; Kamble, A. Piriformospora indica-primed transcriptional reprogramming induces defense response against early blight in tomato. Sci. Hortic. 2019, 255, 209-219. [CrossRef]

48. Gao, P.; Qin, J.; Li, D.; Zhou, S. Inhibitory effect and possible mechanism of a Pseudomonas strain QBA5 against gray mold on tomato leaves and fruits caused by Botrytis cinerea. PLoS ONE 2018, 10, e0190932. [CrossRef]

49. Patakioutas, G.; Dimou, D.; Yfanti, P.; Karras, G.; Ntatsi, G.; Savvas, D. Root inoculation with beneficial micro-organisms as a means to control Fusarium oxysporum $\mathrm{f}$. sp. lycopersici in two Greek landraces of tomato grown on perlite. Acta Hortic. 2017, 1168, 277-286. [CrossRef] 
50. Zheng, N.; Feng, K.; Jingyan, J.; Xuefei, W.; Li, C.W.; Jiahui, L.; Yu, Z.; Zi, Y.; Bin, Z. Growth improvement and salt tolerance mechanisms of tomato seedlings mediated by plant growth-promoting rhizobacteria from contaminated soils. Chin. J. Appl. Environ. Biol. 2018, 24, 47-52.

51. Lareen, A.; Burton, F.; Schäfer, P. Plant root-microbe communication in shaping root microbiomes. Plant Mol. Biol. 2016, 90, 575-587. [CrossRef] [PubMed]

52. Sasse, J.; Martinoia, E.; Northen, T. Feed your friends: Do plant exudates shape the root microbiome? Trends Plant Sci. 2018, 23, 25-41. [CrossRef] [PubMed]

53. Berg, G.; Opelt, K.; Zachow, C.; Lottmann, J.; Gotz, M.; Costa, R.; Smalla, K. The rhizosphere effect on bacteria antagonistic towards the pathogenic fungus Verticillium differs depending on plant species and site. FEMS Microbiol. Ecol. 2006, 56, 250-261. [CrossRef] [PubMed]

54. Miethling, R.; Wieland, G.; Backhaus, H.; Tebbe, C.C. Variation of microbial rhizosphere communities in response to crop species, soil origin, and inoculation with Sinorhizobium meliloti L33. Microb. Ecol. 2000, 40, 43-56. [CrossRef]

55. Faure, D.; Dessaux, Y. Quorum sensing as a target for developing control strategies for the plant pathogen Pectobacterium. In New Perspectives and Approaches in Plant Growth-Promoting Rhizobacteria Research; Bakker, P.A.H.M., Raaijmakers, J.M., Bloemberg, G., Höfte, M., Lemanceau, P., Cooke, B.M., Eds.; Springer: Dordrecht, The Netherlands, 2007; pp. 353-365. [CrossRef]

56. Chen, Y.; Cao, S.; Chai, Y.; Clardy, J.; Kolter, R.; Guo, J.H.; Losick, R. A Bacillus subtilis sensor kinase involved in triggering biofilm formation on the roots of tomato plants. Mol. Microbiol. 2012, 85, 418-430. [CrossRef]

57. Tan, S.; Yang, C.; Mei, X.; Shen, S.; Raza, W.; Shen, Q.; Xu, Y. The effect of organic acids from tomato root exudates on rhizosphere colonization of Bacillus amyloliquefaciens T-5. Appl. Soil Ecol. 2013, 64, 15-22. [CrossRef]

58. Ling, N.; Huang, Q.; Guo, S.; Shen, Q. Paenibacillus polymyxa SQR-21systemically affects root exudates of watermelon to decrease the conidial germination of Fusarium oxysporum f.sp. niveum. Plant Soil 2011, 341, 485-493. [CrossRef]

59. Zhang, F.; Zhu, Z.; Yang, X.; Ran, W.; Shen, Q. Trichoderma harzianum T-E5 significantly affects cucumber root exudates and fungal community in the cucumber rhizosphere. Appl. Soil Ecol. 2013, 72, 41-48. [CrossRef]

60. Zhou, X.G.; Wang, J.; Jin, X.; Li, D.L.; Shi, Y.J.; Wu, F.Z. Effects of selected cucumber root exudates components on soil Trichoderma spp. communities. Allelopath. J. 2019, 47, 257-265. [CrossRef]

61. Pozo, M.J.; Lopez-Raez, J.A.; Azcon-Aguilar, C.; Garcia-Garrido, J.M. Phytohormones as integrators of environmental signals in the regulation of mycorrhizal symbioses. New Phytol. 2015, 205, 1431-1436. [CrossRef]

62. Muller, L.M.; Harrison, M.J. Phytohormones, miRNAs, and peptide signals integrate plant phosphorus status with arbuscular mycorrhizal symbiosis. Curr. Opin. Plant Biol. 2019, 50, 132-139. [CrossRef] [PubMed]

63. López-Ráez, J.A.; Shirasu, K.; Foo, E. Strigolactones in plant interactions with beneficial and detrimental organisms. The Yin and Yang. Trends Plant Sci. 2017, 22, 527-537. [CrossRef]

64. Hause, B. Jasmonates in arbuscular mycorrhizal interactions. Phytochemistry 2007, 68, 101-110. [CrossRef]

65. Foo, E.; Ross, J.J.; Jones, W.T.; Reid, J.B. Plant hormones in arbuscular mycorrhizal symbioses: An emerging role for gibberellins. Ann. Bot. 2013, 111, 769-779. [CrossRef]

66. De Los Santos, R.T.; Vierheilig, H.; Ocampo, J.A.; Garrido, J.M.G. Altered pattern of arbuscular mycorrhizal formation in tomato ethylene mutants. Plant Signal. Behav. 2011, 6, 755-758. [CrossRef]

67. Etemadi, M.; Gutjahr, C.; Couzigou, J.M.; Zouine, M.; Lauressergues, D.; Timmers, A.; Audran, C.; Bouzayen, M.; Becard, G.; Combier, J.P. Auxin perception is required for arbuscule development in arbuscular mycorrhizal symbiosis. Plant Physiol. 2014, 166, 281-292. [CrossRef] [PubMed]

68. Guillotin, B.; Etemadi, M.; Audran, C.; Bouzayen, M.; Becard, G.; Combier, J.P. Sl-IAA27 regulates strigolactone biosynthesis and mycorrhization in tomato (var. MicroTom). New Phytol. 2017, 213, 1124-1132. [CrossRef] [PubMed]

69. Martínez-Medina, A.; Pescador, L.; Fernandez, I.; Rodrıguez-Serrano, M.; Garcıa, J.M.; Romero-Puertas, M.C.; Pozo, M.J. Nitric oxide and phytoglobin PHYTOGB1 are regulatory elements in the Solanum lycopersicum-Rhizophagus irregularis mycorrhizal symbiosis. New Phytol. 2019, 223, 1560-1574. [CrossRef] [PubMed]

70. King, S.R.; Davis, A.R.; Liu, W.; Levi, A. Grafting for disease resistance. HortScience 2008, 43, $1673-1676$. [CrossRef] 
71. Yetışır, H.; Sari, N.; Yücel, S. Rootstock resistance to Fusarium wilt and effect on watermelon fruit yield and quality. Phytoparasitica 2003, 31, 163. [CrossRef]

72. Grimault, V.; Prior, P. Grafting tomato cultivars resistant or susceptible to bacterial wilt: Analysis of resistance mechanisms. J. Phytopathol. 1994, 141, 330-334. [CrossRef]

73. Albert, R.; Künstler, A.; Lantos, F.; Ádám, A.L.; Király, L. Graft-transmissible resistance of cherry pepper (Capsicum annuum var. cerasiforme) to powdery mildew (Leveillula taurica) is associated with elevated superoxide accumulation, NADPH oxidase activity and pathogenesis-related gene expression. Acta Physiol. Plant 2017, 39, 53. [CrossRef]

74. Lee, J.M.; Kubota, C.; Tsao, S.J.; Bie, Z.; Echevarria, P.H.; Morra, L.; Oda, M. Current status of vegetable grafting: Diffusion, grafting techniques, automation. Sci. Hortic. 2010, 127, 93-105. [CrossRef]

75. Johnson, S.; Inglis, D.; Miles, C. Grafting effects on eggplant growth, yield, and Verticillium wilt incidence. Int. J. Veg. Sci. 2014, 20, 3-20. [CrossRef]

76. Liu, N.; Zhou, B.; Zhao, X.; Lu, B.; Li, Y.; Hao, J. Grafting eggplant onto tomato rootstock to suppress Verticillium dahliae infection: The effect of root exudates. HortScience 2009, 44, 2058-2062. [CrossRef]

77. Song, Y.; Zhu, C.; Raza, W.; Wang, D.; Huang, Q.; Guo, S.; Ling, N.; Shen, Q. Coupling of the chemical niche and microbiome in the rhizosphere: Implications from watermelon grafting. Front. Agric. Sci. Eng. 2016, 3, 249-262. [CrossRef]

78. Cichy, K.A.; Snapp, S.S.; Kirk, W.W. Fusarium root rot incidence and root system architecture in grafted common bean lines. Plant Soil 2007, 300, 233-244. [CrossRef]

79. Chitarra, W.; Perrone, I.; Avanzato, C.G.; Minio, A.; Boccacci, P.; Santini, D.; Gilardi, G.; Siciliano, I.; Gullino, M.L.; Delledonne, M.; et al. Grapevine grafting: Scion transcript profiling and defense-related metabolites induced by rootstocks. Front. Plant Sci. 2017, 8, 654. [CrossRef]

80. Wallis, C.M.; Wallingford, A.K.; Chen, J. Grapevine rootstock effects on scion sap phenolic levels, resistance to Xylella fastidiosa infection, and progression of Pierce's disease. Front. Plant Sci. 2013, 4, 502. [CrossRef]

81. Shibuya, T.; Itagaki, K.; Wang, Y.; Endo, R. Grafting transiently suppresses development of powdery mildew colonies, probably through a quantitative change in water relations of the host cucumber scions during graft healing. Sci. Hortic. 2015, 192, 197-199. [CrossRef]

82. Song, Y.; Ling, N.; Ma, J.; Wang, J.; Zhu, C.; Raza, W.; Shen, Y.; Huang, Q.; Shen, Q. Grafting resulted in a distinct proteomic profile of watermelon root exudates relative to the un-grafted watermelon and the rootstock plant. J. Plant Growth Regul. 2016, 35, 778-791. [CrossRef]

83. Ling, N.; Zhang, W.; Wang, D.; Mao, J.; Huang, Q.; Guo, S.; Shen, Q. Root exudates from grafted-root watermelon showed a certain contribution in inhibiting Fusarium oxysporum f. sp. niveum. PLoS ONE 2013, 8, e63383. [CrossRef] [PubMed]

84. Liu, L.; Chen, S.; Zhao, J.; Zhou, X.; Wang, B.; Li, Y.; Zheng, G.; Zhang, J.; Cai, Z.; Huang, X. Watermelon planting is capable to restructure the soil microbiome that regulated by reductive soil disinfestation. Appl. Soil Ecol. 2018, 129, 52-60. [CrossRef]

85. Yin, Y.; Luo, S.; Li, Y.; Zhou, J.; Tang, Y.; Liu, Y. Grafting shaping the microbial community structure to suppress Verticillium dahliae in the rhizosphere of eggplants. Am. J. Agric. For. 2018, 6, 132-140. [CrossRef]

86. Pérez-Jaramillo, J.E.; Mendes, R.; Raaijmakers, J.M. Impact of plant domestication on rhizosphere microbiome assembly and functions. Plant Mol. Biol. 2016, 90, 635-644. [CrossRef]

87. Wei, Z.; Jousset, A. Plant breeding goes Microbial. Trends Plant Sci. 2017, 22, 555-558. [CrossRef]

88. Marasco, R.; Rolli, E.; Fusi, M.; Michoud, G.; Daffonchio, D. Grapevine rootstocks shape underground bacterial microbiome and networking but not potential functionality. Microbiome 2018, 6, 3. [CrossRef]

89. Nicola, L.; Insam, H.; Pertot, I.; Stres, B. Reanalysis of microbiomes in soils affected by apple replant disease (ARD): Old foes and novel suspects lead to the proposal of extended model of disease development. Appl. Soil Ecol. 2018, 129, 24-33. [CrossRef]

(C) 2020 by the authors. Licensee MDPI, Basel, Switzerland. This article is an open access article distributed under the terms and conditions of the Creative Commons Attribution (CC BY) license (http://creativecommons.org/licenses/by/4.0/). 



\title{
Appraisal of Salt Tolerance under Greenhouse Conditions of a Cucurbitaceae Genetic Repository of Potential Rootstocks and Scions
}

\author{
Giuseppe Carlo Modarelli ${ }^{1}$, Youssef Rouphael ${ }^{1}$, Stefania De Pascale ${ }^{1}$, Gölgen Bahar Öztekin ${ }^{2}$, \\ Yüksel Tüzel ${ }^{2}$, Francesco Orsini $^{3, *}$ and Giorgio Gianquinto ${ }^{3}$ \\ 1 Department of Agricultural Sciences, University of Naples Federico II, 80055 Portici, Italy; \\ giuseppecarlo.modarelli@unina.it (G.C.M.); youssef.rouphael@unina.it (Y.R.); depascal@unina.it (S.D.P.) \\ 2 Department of Horticulture, Faculty of Agriculture, Ege University, 35100 Bornova-Izmir, Turkey; \\ golgen.oztekin@ege.edu.tr (G.B.Ö.); yuksel.tuzel@ege.edu.tr (Y.T.) \\ 3 DISTAL-Department of Agricultural and Food Sciences, Alma Mater Studiorum-University of Bologna, \\ 40127 Bologna, Italy; giorgio.gianquinto@unibo.it \\ * Correspondence: f.orsini@unibo.it
}

Received: 7 June 2020; Accepted: 3 July 2020; Published: 5 July 2020

\begin{abstract}
Soil salinization due to climate change and intensive use of water and soil is increasing exponentially. Cucurbitaceae species are cultivated worldwide and the identification of salinity tolerant genotypes to be used as rootstock or scion for securing yield stability in salt affected agricultural areas is a research priority. In the present greenhouse study, we assessed the response to salinity $(0 \mathrm{mM} \mathrm{a}$ non-salt control and $150 \mathrm{mM} \mathrm{NaCl}$ dissolved in the nutrient solution) in the seedlings of 30 genotypes of cucurbits grown in a floating hydroponic system. The species tested included 16 genotypes of Cucumis melo L. (CM1-16), 6 Citrullus vulgaris Schrad. (CV1-6), 2 interspecific hybrids of Cucurbita maxima Duch. $\times$ Cucurbita moschata Duch. (CMM-R1 and 2), 4 bottle gourd (Lagenaria siceraria (Molina) Standl. (LS1-4)), 1 Cucurbita moschata Duch. (CMO51-17), and 1 luffa (Luffa cylindrica Mill. (LC1)) species. Results highlighted different morphological and physiological traits between the species and genotypes and a different response to salt stress. We identified C. maxima $\times$ C.moscata interspecific hybrid CMM-R2, melon genotypes CM6, CM7, CM10, and CM16 together with watermelon genotypes CV2 and CV6 and bottle gourd LS4 as salt tolerant genotypes and possible candidates as salt resistant rootstock to be introduced in grafting programs.
\end{abstract}

Keywords: $\mathrm{NaCl}$; Citrullus vulgaris Schrad; Luffa cylindrica Mill; C. maxima Duch. $\times$ C. moschata Duch.; seedlings; morpho-physiological traits; grafting

\section{Introduction}

Soil and water resource salinization is one of the main abiotic stress factors that reduce plant growth and crop productivity worldwide [1]. It has been estimated that the total land affected by salinization covers approximately 412 million ha and mainly occur in arid and semiarid regions of more than 100 countries in all continents [2]. Generally, a saline environment influences every aspect of crop physiology and growth by causing water deficits due to the low water potential in the root medium, plant toxic ions uptake (e.g., $\mathrm{Na}^{+}, \mathrm{Cl}^{-}, \mathrm{SO}_{4}{ }^{2-}$ ), reduction in the uptake/or transport to the shoot of $\mathrm{K}^{+}, \mathrm{Ca}^{2+}$, and $\mathrm{Mg}^{2+}$ [1]. Moreover, plants grown in saline environments experience reduction of photosynthetic capacity [3] and growth in terms of number of leaves, shoot length, decrease in photosynthetic pigment content due to the negative effect of Na solutes within plant cells, and a decrease in fresh and dry matter content [4]. 
Breeding programs to combine salt resistance traits from different germplasm are increasing among seed companies. However, they currently require complicated evaluation and result in delays in the release of new varieties in the market due to the complexity of the salinity traits [5].

Furthermore, plant responses to salinity derive from complex and multifaceted mechanisms [6] and salt tolerance traits involve several physiological and genetic features that overall limit the success of resistance and/or tolerance trait transfer into commercial varieties [1]. To reduce or avoid production losses due to salt stress, a sustainable and fast solution is grafting highly productive genotypes onto potentially salt tolerant rootstocks [1]. Vegetable grafting is a widely used technique in Japan, Korea, the Mediterranean basin, as well as in several European countries to avoid biotic (i.e., soilborne and foliar pathogens, weeds, and arthropods) or abiotic stressors like drought, flooding, heavy metals contamination, sub optimal temperatures, nutritional deficiencies, and salinity. The salt tolerance of grafted plants is influenced by both scion and rootstock [6]. Generally, the use of salt tolerant rootstocks allows the mitigation of the detrimental effects of salinity and guarantees stable yields during the growing cycle through specific morphological, biochemical, metabolic, and physiological mechanisms. Accordingly, under saline conditions, grafted plants tend to accumulate more biomass in the root system, thus allowing for mitigated salinity effects by increasing the root/shoot ratio [1,7-9]. Additionally, to cope with saline stress, grafted plants adopt strategies like salt exclusion in the shoot and retention of salt ions in the root system $[1,7]$. Besides these strategies, grafting promotes, at the cellular level, a better maintenance of potassium homeostasis, together with accumulation of compatible solutes and osmolytes in the cytosol, along with compartmentation of salt ions in the vacuole through the activation of the antioxidant defense system, and induction of hormones mediated changes in plant growth $[1,7,10,11]$.

Cucurbitaceae species like melon (Cucumis melo L.), cucumber (Cucumis sativus L.), and watermelon (Citrullus vulgaris Schrad.) are generally considered salt sensitive or moderately sensitive crops, while being often cultivated in areas undergoing soil and water salinization [12,13]. In cucurbits, grafting commercial varieties into salt tolerant rootstocks was shown to reduce production losses by improving their photosynthetic capacity $[1,3]$. Watermelon is commonly grafted on bottle gourd (Lagenaria siceraria (Molina) Standl.), interspecific hybrids between C. maxima and C. moschata, and wild watermelon (Citrullus spp.) [14]. Cucumber is generally grafted on bottle gourd, luffa (Luffa cylindrica Mill.), Cucurbita interspecific hybrids, and Cucumis spp [15]. Finally, melon is generally grafted on interspecific hybrids between C. maxima Duch. and C. moschata Duch. and Cucumis melo L. rootstocks and in some cases on luffa [5]. However, their response to salinity, as rootstock vary between the genotypes, and completed screening to identify salt tolerant rootstock varieties to be adopted in commercial grafting program have not yet been carried out.

In the light of these observations, our aim was to evaluate the response to salinity stress in different melons (Cucumis melo L.), watermelon (Citrullus vulgaris Schrad.), interspecific hybrids of C. maxima Duch. $\times$ C. moschata Duch., bottle gourd (Lagenaria siceraria (Molina) Standl.), Cucurbita moschata Duch. co Plovdivski 51-17, and luffa (Luffa cylindrica Mill.) Cucurbitaceae rootstock and scion genotypes, in terms of plant growth and photosynthetic pigments to identify salt tolerant genotypes to be used in commercial grafting programs.

\section{Materials and Methods}

\subsection{Growth Conditions, Plant Material, and Salinity Treatments}

The experiment was carried out in a polyethylene covered double span nursery greenhouse at the Department of Horticulture, Faculty of Agriculture, Ege University ( $38^{\circ} 27^{\prime} 16.2^{\prime \prime}$ N, $27^{\circ} 13^{\prime} 17.8^{\prime \prime}$ E) in Bornova, Izmir Turkey during the spring 2014 growing season.

Plant material included 16 melon varieties (Cucumis melo L.), 6 watermelons (Citrullus vulgaris Schrad.), 2 interspecific hybrids of Cucurbita maxima Duch. $\times$ Cucurbita moschata Duch., 4 bottle gourd (Lagenaria siceraria (Molina) Standl.) varieties, 1 luffa (Luffa cylindrica Mill.) that were obtained 
from the Aegean Agricultural Research Institute Department of Biodiversity and Genetic Resources (Menemen, Izmir-Turkey) and 1 Cucurbita moschata Duch. cv Plovdivski 51-17 obtained from the "Maritsa" Vegetables Crops Research Institute (Plovdiv, Bulgaria) (Table 1). Two salt treatments were considered, by applying 0 (non-saline control) and $150 \mathrm{mM}$ of sodium chloride $(\mathrm{NaCl})$ dissolved in the nutrient solution. Eighty seeds per genotype were sown in polystyrene trays in a mixture of peat and perlite (75:25 v:v) on 5 May 2014 and placed in a germination room for three days (temperature of $24{ }^{\circ} \mathrm{C}, 60 \% \mathrm{RH}$ ) and then placed in an unheated nursery greenhouse (mean daily temperature of $28^{\circ} \mathrm{C}$ ) for two weeks. Seedlings were fertigated with commercial fertilizer twice per day until the start of the experiment.

On 22 May 2014, forty seedlings of each species/genotypes were divided per each salinity treatment and placed in separate floating hydroponic systems. The nutrient solution was composed as follows: nitrate $13.14 \mathrm{mM}$, phosphorus $0.94 \mathrm{mM}$, potassium $5.83 \mathrm{mM}$, calcium $3.79 \mathrm{mM}$, iron $35.8 \mu \mathrm{M}$, boron $37 \mu \mathrm{M}$, copper $1.6 \mu \mathrm{M}$, molybdenum $0.5 \mu \mathrm{M}$. The electrical conductivity (EC) of the nutrient solution was $2.0 \mathrm{dS} \mathrm{m}^{-1}$. The nutrient solution was replaced every two days and aerated with air pumps. In the saline treatment $(150 \mathrm{mM} \mathrm{NaCl})$, salinity stress was induced by progressively dissolving $50 \mathrm{mM}$ of $\mathrm{NaCl}$ every two days in the nutrient solution until the final concentration of $150 \mathrm{mM}$ was achieved within one week.

Table 1. List of the tested species and the relative genotypes used in this study.

\begin{tabular}{|c|c|c|c|c|c|}
\hline \multirow[t]{2}{*}{ Species } & \multicolumn{2}{|c|}{ Genotype } & \multirow[t]{2}{*}{ Species } & \multicolumn{2}{|c|}{ Genotype } \\
\hline & Original Code & Working Code & & Original Code & Working Code \\
\hline \multirow{16}{*}{ Cucumis melo L. } & TR31586 & CM1 & \multirow{6}{*}{ Citrullus vulgaris Schrad. } & TR40374 & CV1 \\
\hline & TR40563 & CM2 & & TR64141 & CV2 \\
\hline & TR43722 & $\mathrm{CM} 3$ & & TR43211 & CV3 \\
\hline & TR45883 & CM4 & & TR66066 & CV4 \\
\hline & TR47822 & CM5 & & TR43342 & CV5 \\
\hline & TR48527 & CM6 & & TR80748 & CV6 \\
\hline & TR48611 & CM7 & \multirow{4}{*}{$\begin{array}{l}\text { Lagenaria sicerania (Molina) } \\
\text { Standl. }\end{array}$} & Macis & LS1 \\
\hline & TR49583 & CM8 & & TR62066 & LS2 \\
\hline & TR51531 & CM9 & & TR79616 & LS3 \\
\hline & TR51763 & CM10 & & TR82049 & $\mathrm{LS} 4$ \\
\hline & TR61583 & CM11 & \multirow{2}{*}{$\begin{array}{l}\text { Cucurbita maxima Duch. } \times \\
\text { Cucurbita moschata Duch. }\end{array}$} & Nun 9075 & CMM-R1 \\
\hline & TR61626 & CM12 & & RS841 & CMM-R2 \\
\hline & TR61851 & CM13 & Cucurbita moschata Duch. & $\begin{array}{l}\text { Plovdivski } \\
51-17\end{array}$ & CMO 51-17 \\
\hline & Kirkagac & CM14 & \multirow[t]{3}{*}{ Luffa cylindrica Mill. } & & \multirow[t]{3}{*}{ LC1 } \\
\hline & Arava & CM15 & & & \\
\hline & Cesme & CM16 & & & \\
\hline
\end{tabular}

\subsection{Plant Growth Measurements}

Plant growth was measured when salinity treatment reached its final concentration of $150 \mathrm{mM}$ (12 days after the start of the $\mathrm{NaCl}$ treatment, at 29 days after sowing, DAS) on 3 plants per Genotype $\times$ $\mathrm{NaCl}$ concentration combination measuring the number of leaves, the shoot diameter, recorded with an electronic caliper, shoot and root length with a ruler. Shoot, root, and leaf fresh weight (FW) were recorded with an electronic balance and dry weight (DW) was recorded after drying the samples for $48 \mathrm{~h}$ at $70^{\circ} \mathrm{C}$. Dry matter (DM) was calculated as percentage of DW/FW.

\subsection{Photosynthetic Pigments Determination}

Chlorophyll $a, b$ and carotenoid contents were determined at 29 DAS on 3 plants per each Genotype $\times \mathrm{NaCl}$ concentration combination by grinding $250 \mathrm{mg}$ of leaf tissue from fully expanded leaves with quartz crystals in $30 \mathrm{~mL}$ of acetone (80\% in vol). Leaf extracts were read at 450,645, and $663 \mathrm{~nm}$ with a Varian Carry 100UV-Vis spectrophotometer (Varian Inc, Palo Alto, CA, USA), pigments content was calculated according to Arnon [16] and values were expressed as $\mathrm{mg} \mathrm{g}^{-1} \mathrm{FW}$. 


\subsection{Electrolyte Leakage Analysis}

Electrolyte leakage (i.e., membrane permeability) was measured at 29 DAS collecting three leaf disks (10 mm diameter each) from fully expanded leaves on 3 plants per Genotype $\times \mathrm{NaCl}$ concentration combination and immersed in $50 \mathrm{~mL}$ of distilled water. EC was measured immediately (1 min -) $\left(\mathrm{EC}_{1}\right)$ and after $60 \mathrm{~min}$ of shaking $\left(\mathrm{EC}_{60}\right)$. The samples were then autoclaved $\left(121^{\circ} \mathrm{C}\right)$ for $25 \mathrm{~min}$, and total conductivity $\left(\mathrm{EC}_{\mathrm{T}}\right)$ of bathing solution was measured after cooling. Electrolyte leakage was calculated and expressed as a percentage (\%) according to Blum and Ebercon [17] using the following Equation:

Electrolyte leakage $(\%)=\left(\mathrm{EC}_{60}-\mathrm{EC}_{1}\right) / \mathrm{EC}_{\mathrm{T}}$.

\subsection{Statistical Analysis}

A completely randomized design was adopted for the experiment. The experiment was conducted on a total of 40 plants per Genotype $\times \mathrm{NaCl}$ concentration combination and each analysis was carried out on at least 3 plants per Genotype $\times \mathrm{NaCl}$ concentration randomly selected. Data were analyzed by ANOVA using SPSS 25 software package (www.ibm.com/software/analytics/spss) and means were compared using Duncan post hoc test $(p \leq 0.05)$. The cluster heatmap was generated using the ClustVis online software [18] using Euclidean distance as the similarity measure and hierarchical clustering with complete linkage on the genotype percent variation, $\log (x+1)$ transformed, between 150 and $0 \mathrm{mM}$ of $\mathrm{NaCl}$ on all the analyzed parameters. The principal component analysis (PCA) was conducted using the Primer 6 software package (PRIMER-e, Albany, New Zealand) on the percentage variation of all the morphological and physiological analyzed parameters to highlight differences between genotypes to the increase of $\mathrm{NaCl}$ concentration in the nutrient solution. Five components were extracted by the PCA analysis. The PCA output includes treatment component scores as well as variable loadings.

\section{Results}

\subsection{Plant Growth and Biomass Production}

The statistical analysis revealed intrinsic genotypic differences, and a genotypic specific response to the $\mathrm{NaCl}$ concentration in the nutrient solution in terms of number of leaves, shoot diameter, shoot length, and root length (Table 2). Compared to non-saline seedlings, under $150 \mathrm{mM} \mathrm{NaCl}$, the number of leaves decreased significantly only in the melon genotype CM5 (-31\%) while it did not vary significantly in the other genotypes (Figure 1a). Shoot diameter between the genotypes grown under $0 \mathrm{mM} \mathrm{NaCl}$ was higher in the interspecific hybrid CMM-R1 (on average $4.6 \mathrm{~mm}$ ) and bottle gourd genotypes LS1, LS3, and LS4 (on average 4.66, 4.73, and $4.73 \mathrm{~mm}$ respectively), whereas bottle gourd LS2, watermelon CV3, and melon (CM9, CM10, CM14, and CM15) seedlings turned out to be thinner (Figure $1 \mathrm{~b}$ ). The genotype and the $\mathrm{NaCl}$ concentration significantly affected shoot diameter (Table 2); as a result, $150 \mathrm{mM}$ of $\mathrm{NaCl}$ increased shoot diameter by $47 \%$ and $36 \%$ in CM10 and CV3 genotypes, respectively, while it decreased by $-26 \%$ in CMM-R1 C. maxima $\times$ C. moscata hybrid and it did not vary in the other genotypes (Figure $1 b$ ). Shoot length was significantly affected by the genotypes (Table 2). Particularly, among seedlings grown in the absence of salt stress, melon genotypes (CM3, CM7, CM8, CM9, CM13, and CM16) produced the longest shoots, while the shortest were observed in bottle gourd LS2, watermelon (CV3, CV4, CV5, CV6) and the interspecific hybrids CMM-R1 and CMM-R2. (Figure 1c). A genotypic response to the $\mathrm{NaCl}$ concentration was also observed in shoot length (Table 2). Accordingly, compared to seedlings grown under $0 \mathrm{mM} \mathrm{NaCl}$, shoot length in saline grown seedlings decreased significantly in all the tested genotypes except for the watermelon (CV3, CV4, and CV6), bottle gourd (LS1, LS2) genotypes, and the luffa (LC1) (Figure 1c). Seedling root length was significantly different among the genotypes. In fact, under $0 \mathrm{mM} \mathrm{NaCl}$, melon $\mathrm{CM} 5$ developed the longest root while melon CM16 and watermelon CV3 the shortest (Figure 1d). On the other hand, when $150 \mathrm{mM} \mathrm{NaCl}$ was applied, no significant differences in root length compared to control conditions were observed in the studied genotypes. 
Table 2. Leaf number $\left(n\right.$ plant $\left.^{-1}\right)$, shoot and root length $(\mathrm{cm})$, shoot diameter $(\mathrm{mm})$, shoot and root dry weight (DW, g plant ${ }^{-1}$ ), and dry matter content (DM, \%) in seedlings of sixteen Cucumis melo L., six Citrullus vulgaris Schrad., two C. maxima $\times$ C. moschata, four Lagenaria siceraria (Molina) Standl. different genotypes, and Cucurbita moschata Duch. cv 51-17 and Luffa cylindrica Mill. grown at 0 or $150 \mathrm{mM}$ of $\mathrm{NaCl}$. (1 week after the beginning of the treatment). Non significance or significance differences at $p \leq 0.05,0.01$, or 0.001 are indicated as: $\mathrm{ns}^{* *}$ and ${ }^{* * *}$ respectively.

\begin{tabular}{ccccccccc}
\hline & $\begin{array}{c}\text { Leaf } \\
\text { Number }\end{array}$ & $\begin{array}{c}\text { Shoot } \\
\text { Length }\end{array}$ & $\begin{array}{c}\text { Shoot } \\
\text { Diameter }\end{array}$ & $\begin{array}{c}\text { Root } \\
\text { Length }\end{array}$ & $\begin{array}{c}\text { Shoot } \\
\text { DW }\end{array}$ & $\begin{array}{c}\text { Root } \\
\text { DW }\end{array}$ & $\begin{array}{c}\text { Shoot } \\
\text { DM }\end{array}$ & $\begin{array}{c}\text { Root } \\
\text { DM }\end{array}$ \\
\hline Genotype $(\mathrm{G})$ & $* *$ & $* * *$ & $* *$ & $* *$ & $* *$ & $* *$ & $* *$ & $* *$ \\
Salt $(\mathrm{NaCl})$ & $* *$ & $* *$ & $\mathrm{~ns}$ & $\mathrm{~ns}$ & $* *$ & $\mathrm{~ns}$ & $* *$ & $\mathrm{~ns}$ \\
$\mathrm{G} \times \mathrm{NaCl}$ & $* *$ & $* *$ & $* *$ & $* *$ & $* *$ & $* *$ & $* *$ & $* *$ \\
\hline
\end{tabular}

(a)

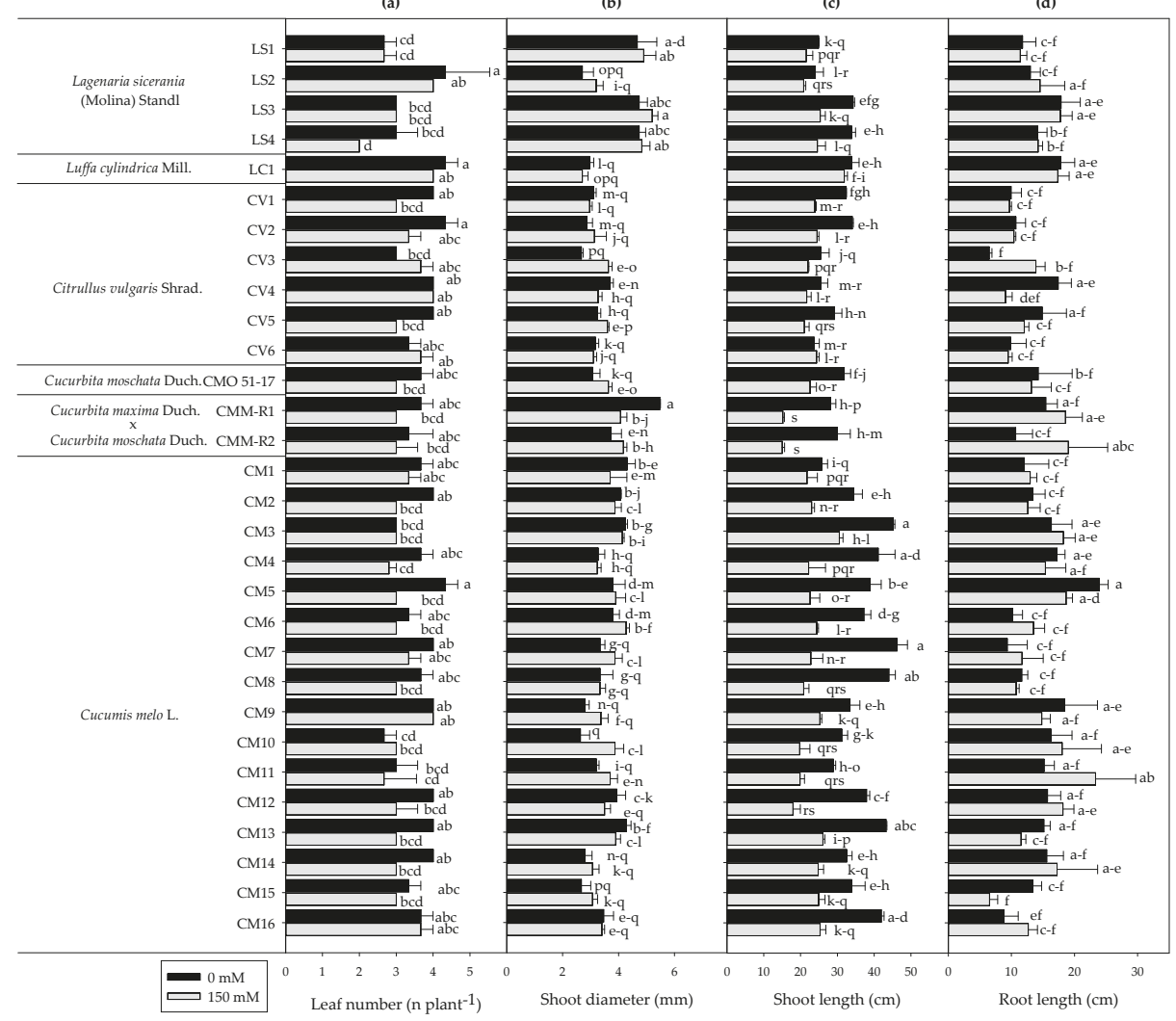

Figure 1. Plant growth, after one week of $\mathrm{NaCl}$ treatment, in term of number of leaves (a), shoot diameter (b), shoot length (c), and root length (d) in seedlings of sixteen Cucumis melo L, six Citrullus vulgaris Schrad., two C. maxima $\times$ C. moschata, four Lagenaria siceraria (Molina) Standl. different genotypes, and Cucurbita moschata Duch. $c v$ 51-17 and Luffa cylindrica Mill. Mean values \pm standard errors; $n=3$ followed by different letters within each parameter are significantly different based on Duncan post hoc $(p<0.05)$.

\subsection{Plant Biomass Production}

The statistical analysis revealed intrinsic genotypic differences, and a genotypic specific response to the $\mathrm{NaCl}$ concentration in terms of shoot and root dry weight and dry matter content (Table 2). Under non-saline conditions, melon genotypes CM12 and CM13, together with CMM-R1, produced 
heavier shoots while watermelon CV3 the lightest (Figure 2a). As compared to $0 \mathrm{mM} \mathrm{NaCl}$, shoot dry weight between the genotypes was differently affected by $150 \mathrm{mM} \mathrm{NaCl}$. A significant decrease in shoot dry weight was observed in melon (CM2, CM3, CM5, CM7, CM8, CM9, CM12, and CM13) as well as in CMM-R1, CMO 51-17, watermelon (CV1, CV2), and bottle gourd LS2, while it increased in CMM-R2, watermelon CV3, and bottle gourd LS1 and did not vary in the other genotypes (Figure 2a). In the absence of salinity, root dry weight was higher in watermelon $\mathrm{CV} 4$, followed by bottle gourd (LS3 and LS4), while the lowest root dry weights were recorded in melon genotypes (CM6, CM15, and CM16) (Figure 2b). When $150 \mathrm{mM} \mathrm{NaCl}$ was applied, root dry weight only decreased in CV4 $(-79 \%)$, while it was not affected in the other genotypes (Figure $2 b)$. Shoot dry matter content differed between the genotypes at both $\mathrm{NaCl}$ concentrations. Under $0 \mathrm{mM} \mathrm{NaCl}$, the highest biomass accumulation was observed in watermelon CV6 while the lowest was associated with melon CM1 (Figure 2c). Furthermore, $150 \mathrm{mM} \mathrm{(NaCl)} \mathrm{resulted} \mathrm{in} \mathrm{significant} \mathrm{increases} \mathrm{in} \mathrm{shoot} \mathrm{dry} \mathrm{matter} \mathrm{in} \mathrm{the}$ bottle gourd genotypes (LS1, LS3, and LS4), together with watermelon (CV2, CV3, and CV5), melon CM1, and both the CMM-R1 and CMM.R1 interspecific hybrids (with the strongest accumulation registered in CMM-R2) (Figure 2c). Differences in root dry matter percentage were associated with genotypes and their interaction with salinity (Table 2). Moreover, under $0 \mathrm{mM} \mathrm{NaCl}$, the highest root biomass content was observed in melon (CM2, CM3, and CM5), while the lowest in bottle gourd (LS1, LS3, and LS4) (Figure 2d). Compared to $0 \mathrm{mM} \mathrm{NaCl}$, root dry matter content decreased in seedlings grown under $150 \mathrm{mM}$ of $\mathrm{NaCl}$ of CMO 51-17 $(-26 \%)$, melon CM3 $(-8 \%), \mathrm{CM} 10(-23 \%), \mathrm{CM} 11(-20 \%)$, and the interspecific hybrids (CMM-R1: $-18 \%$ ) and (CMM-R2: $-48 \%$ ), while it significantly increased in melon (CM1, CM4, CM5, CM6, CM7, CM8, CM15, and CM16), together with watermelon (CV1, CV2, CV3, CV4, and CV5) (Figure 2d).

\subsection{Photosynthetic Pigments}

Intrinsic difference in photosynthetic pigments profile and content were observed between the genotypes (Table 3). Among non-salinized seedlings, chlorophyll ( $a, b$, and total) and carotenoids content was higher in melon (CM11 and CM12), while the lowest concentration was observed in CM5. Compared to non-saline seedlings, chlorophyll $a$ content significantly increased under salt stress in CMM-R1 and CMM-R2 (+47\% and $+61 \%)$, while it decreased in CMO 51-17 $(-40 \%)$ and LC1 $(-49 \%)$ and it did not vary in the other genotypes (Figure 3a). On the other hand, chlorophyll $b$ content increased in CMM-R1 $(+38 \%)$ and CMM-R2 $(+64 \%)$ seedlings grown under saline conditions, while it decreased in LC1 $(-51 \%)$, and was not affected by salinity in any of the other genotypes (Figure 3b). As compared to non-saline conditions, the total chlorophyll and carotenoid content increased under $150 \mathrm{mM} \mathrm{NaCl}$ in CMM-R1 (+44\% and $+52 \%$, respectively), CMM-R2 (+62\% and $+54 \%)$, while they decreased in LC1 $(-50 \%$ and $-28 \%)$ and it did not vary for the other genotypes (Figure $3 \mathrm{c}, \mathrm{d}$ ). 
(a)

(b)

(c)

(d)

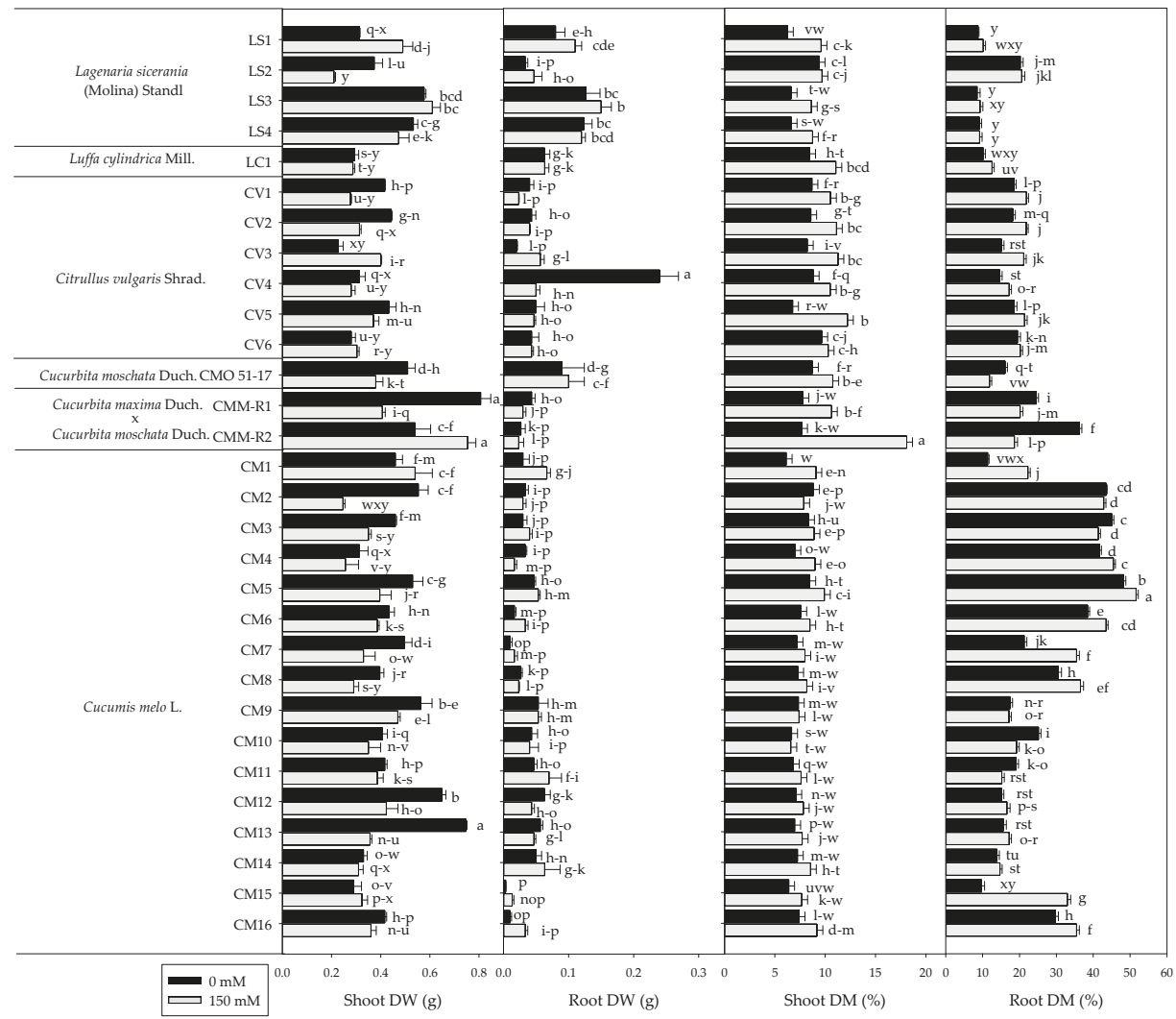

Figure 2. Plant biomass accumulation, after one week of $\mathrm{NaCl}$ treatment, in term of shoot dry weight (a), root dry weight (b), shoot dry matter content (c), and root dry matter content (d) in seedlings of sixteen Cucumis melo L., six Citrullus vulgaris Schrad., two C. maxima $\times$ C. moschata, four Lagenaria siceraria (Molina) Standl. different genotypes, and Cucurbita moschata Duch. cv 51-17 and Luffa cylindrica Mill. Mean values \pm standard errors; $n=3$ followed by different letters within each parameter are significantly different based on Duncan post hoc $(p<0.05)$.

Table 3. Chlorophyll $a, b$, total carotenoids content, and electrolyte leakage in leaves of seedlings of sixteen Cucumis melo L., six Citrullus vulgaris Schrad, two C. maxima $\times$ C. moschata, four Lagenaria siceraria (Molina) Standl. different genotypes, and Cucurbita moschata Duch. cv 51-17 and Luffa cylindrica Mill. grown at 0 or $150 \mathrm{mM}$ of $\mathrm{NaCl}$. (1 week after the beginning of the treatment). Non significance or significance differences at $p \leq 0.05$ or 0.01 are indicated as: $\mathrm{ns}$ and ${ }^{* *}$ respectively.

\begin{tabular}{cccccc}
\hline & $\begin{array}{c}\text { Chlorophyll } a \\
\left(\mathbf{m g ~ g}^{-1}\right)\end{array}$ & $\begin{array}{c}\text { Chlorophyll } b \\
\left(\mathbf{m g ~ g}^{-1}\right)\end{array}$ & $\begin{array}{c}\text { Total Chlorophyll } \\
\left(\mathbf{m g ~ g}^{-1}\right)\end{array}$ & $\begin{array}{c}\text { Carotenoids } \\
\left(\mathbf{m g ~ g}^{-1}\right)\end{array}$ & $\begin{array}{c}\text { Electrolyte Leakage } \\
(\%)\end{array}$ \\
\hline Genotype $(\mathrm{G})$ & $* *$ & $* *$ & $* *$ & $* *$ & $* *$ \\
Salt $(\mathrm{NaCl})$ & $\mathrm{ns}$ & $\mathrm{ns}$ & $\mathrm{ns}$ & $\mathrm{ns}$ & $* *$ \\
$\mathrm{G} \times \mathrm{NaCl}$ & $* *$ & $* *$ & $* *$ & $* *$ \\
\hline
\end{tabular}




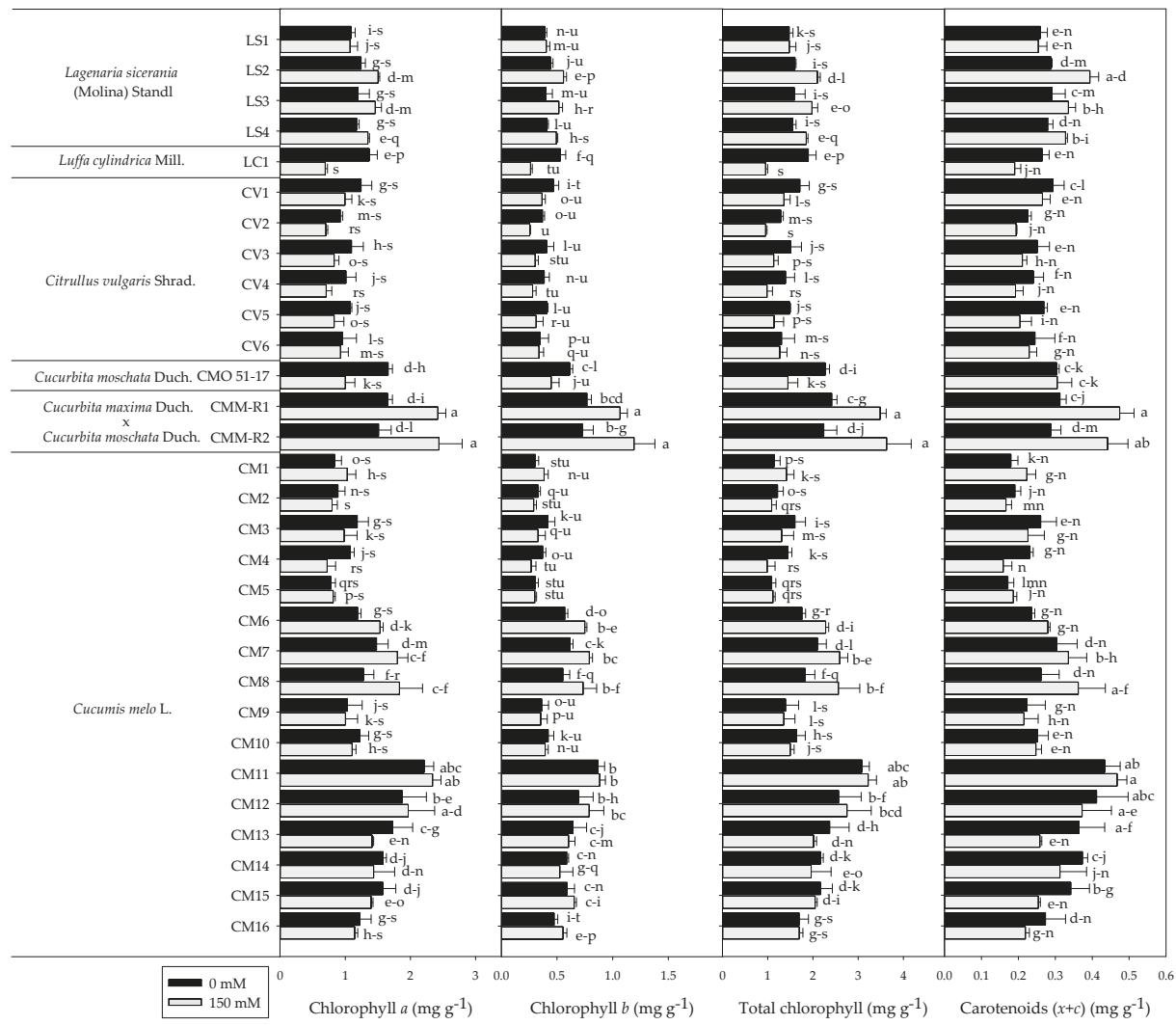

Figure 3. Photosynthetic pigment content, after one week of $\mathrm{NaCl}$ treatment, in term of chlorophyll $a$ (a), chlorophyll $b(\mathbf{b})$, total chlorophyll $(\mathbf{c})$, and carotenoids $(x+n)(\mathbf{d})$ in seedlings of sixteen Cucumis melo L., six Citrullus vulgaris Schrad., two C. maxima $\times$ C. moschata, four Lagenaria siceraria (Molina) Standl. different genotypes, and Cucurbita moschata Duch. cv 51-17 and Luffa cylindrica Mill. Mean values \pm standard errors; $n=3$ followed by different letters within each parameter are significantly different based on Duncan post hoc $(p<0.05)$.

\subsection{Electrolyte Leakage}

Electrolyte leakage was significantly different between the genotypes (Table 3). Under $0 \mathrm{mM} \mathrm{NaCl}$, CMM-R2, LS1, and CM2 showed the highest value of electrolyte leakage, while the lowest electrolyte leakage values were observed in CV4, LC1, LS4, and CM10 (Figure 4). Electrolyte leakage values were generally increased by salinity, although significant differences from control conditions were only observed in LS2 (+184\%), CV13 (+243\%), CM10 (+4662\%), and CM13 (+509\%) (Figure 4). 


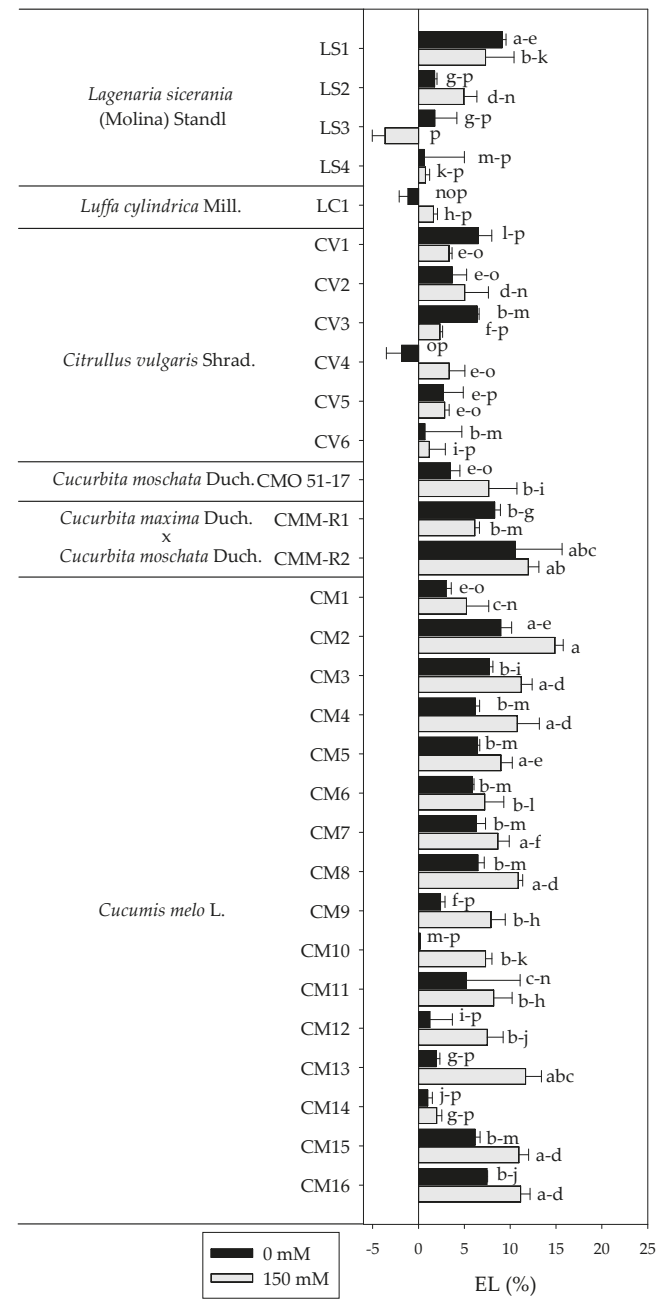

Figure 4. Electrolyte leakage (EL) in leaves, after one week of $\mathrm{NaCl}$ treatment, in seedlings of sixteen Cucumis melo L., six Citrullus vulgaris Schrad., two C. maxima $\times$ C. moschata, four Lagenaria siceraria (Molina) Standl. different genotypes, and Cucurbita moschata Duch. cv 51-17 and Luffa cylindrica Mill. Mean values \pm standard errors; $n=3$ followed by different letters within each parameter are significantly different based on Duncan post hoc $(p<0.05)$.

\subsection{Cluster Heat Map and Principal Component Analysis}

To obtain a detailed overview and to better distinguish the morpho-physiological changes induced by salinity on the tested genotypes, a cluster heat map and a principal component analysis (PCA) were conducted considering the percentage variation between 150 and $0 \mathrm{mM} \mathrm{NaCl}$ for all the aforementioned measured parameters.

The cluster heatmap shows that the main clustering factor was the genotypes regardless of the species, highlighting common response traits to the increase of $\mathrm{NaCl}$ between the different genotypes (Figure 5). The genotypes formed two main clusters. The first was occupied by the watermelon genotype CV2 that clustered alone, mainly as a consequence of an increase in leaf number, root length, 
shoot diameter, and shoot and root dry weight, together with a decrease in electrolyte leakage and photosynthetic pigment content (Figure 5). The second main cluster is split into two sub-groups. In order of distance, the first sub-group arranges bottle gourd LS2, LS3, and LS4 with melon CM8 and the interspecific hybrids CMM-R1 and CMM-R2, together into several further sub-sets characterized by similar positive variations in photosynthetic pigment content and negative variation in electrolyte leakage and root dry matter content (Figure 5). The second sub-group contains most of the genotypes and is organized into two further subsets, one of which has two divisions. The first subset is determined by similar variation in shoot and root dry matter content and electrolyte leakage grouping melon (CM1, CM6, and CM7, CM15 and CM16) and watermelon CV3 and bottle gourd LS1 genotypes together (Figure 5). Furthermore, the CM1 genotype showed the highest positive variation in shoot diameter, while CM6 and CM7 showed the highest increase in dry root weight (Figure 5). The decrease observed under saline conditions in photosynthetic pigments, root length, and dry weight, together with shoot length and diameter and leaf number accounted for the formation of the second subset. This is further subdivided into two divisions, the first of which contains watermelon (CV1, CV4, and CV5), melon (CM4, CM5, CM11, CM12, and CM13), and luffa (LC1) genotypes. Among these genotypes, LC1, CM4, and CV5 showed the highest decrease in photosynthetic pigment contents, shoot diameter and root length, and dry weight. A decrease in root dry weight was also observed in CM11, CM13, and watermelon CV1 (Figure 5). The second and last subdivision is explained mainly by a decrease in shoot and root dry matter and places, together melon (CM2, CM3, CM9, and CM10), watermelon CV6, and C. moscata CMO 51-17. Among the genotypes, melon (CM2, CM3, and CM10) showed the highest decrease in shoot dry matter, while melon CM3, the highest increase in electrolyte leakage and CV6 also showed the highest increase in shoot length (Figure 5).

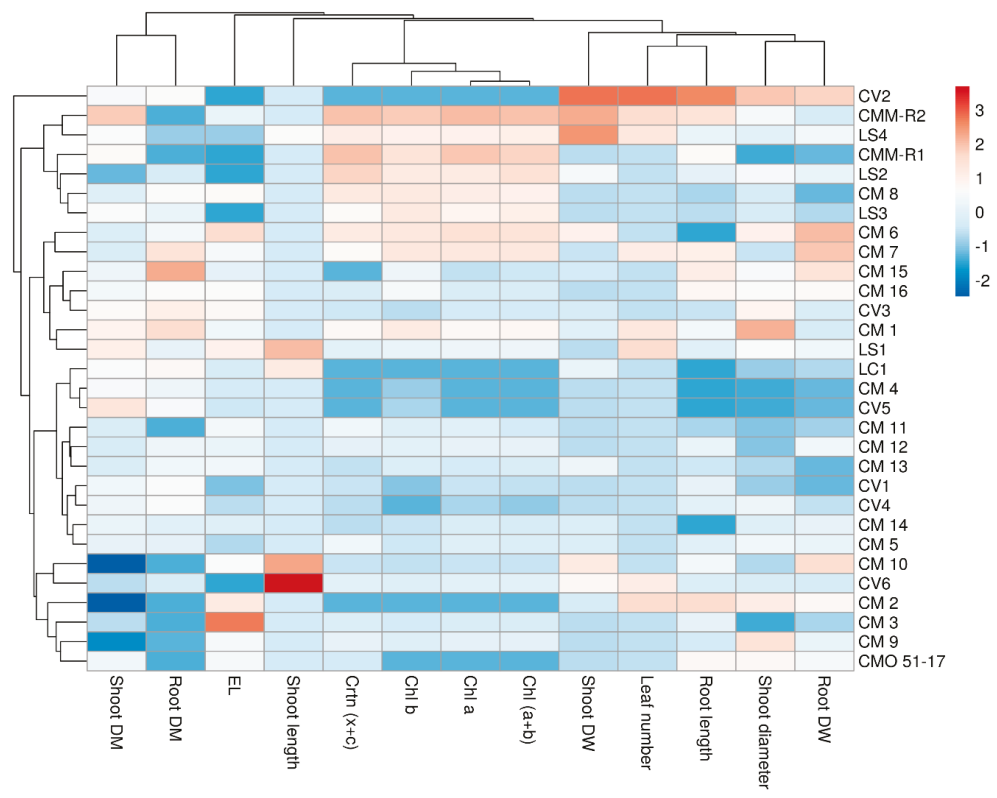

Figure 5. Cluster heat map analysis of the percentage variation to the increase of $\mathrm{NaCl}$ level of all the analyzed parameters in seedlings of sixteen Cucumis melo L, six Citrullus vulgaris Schrad., two C. maxima $\times$ C. moschata, four Lagenaria siceraria (Molina) Standl. different genotypes, and Cucurbita moschata Duch. cv 51-17 and Luffa cylindrica Mill. grown in a floating system in a nursery greenhouse. It was generated using the ClustVis online software [18] with Euclidean distance as the similarity measure and hierarchical clustering with complete linkage. 
The PCA of the relative percentage variation of all the analyzed parameters in seedlings grown at $150 \mathrm{mM} \mathrm{NaCl}$ as compared with the control $(0 \mathrm{mM} \mathrm{NaCl})$ highlighted that the first three principal components (PCs) were related with eigenvalues higher than 1 and explained $64.5 \%$ of the total variance, with PC1, PC2, and PC3 accounting for 32.6\%, 20.1\%, and 11.9\% respectively (data not shown). Both the species and the genotype contributed to the separation of PC1 and PC2, as highlighted in the PCA output, revealing common trait variations among genotypes regardless of the species (Figure 6). The melon genotypes CM3, CM4, CM5, CM11, CM13, and CM14, together with the watermelon genotypes CV1, CV3, and CV4, were concentrated in the upper right quadrant of the PCA output and positively correlated to an increase in electrolyte leakage (Figure 6). The watermelon genotypes CV2 and CV5, together with CMO 51-17, luffa LC1, bottle gourd genotype LS1, and melon genotypes CM2, CM10, and CM15 were concentrated in the negative lower right quadrant of PCA output and were correlated to an increase under saline conditions of shoot length and root dry matter content (Figure 6). The interspecific hybrid CMM-R1, together with melon CM8, CM9, CM12, and bottle gourd LS2 and LS3 were concentrated in the upper left quadrant of the PCA output (Figure 6) and together with the interspecific hybrid CMM-R2 (located in the lower left quadrant), were characterized with an increase in photosynthetic pigment content under saline conditions. In the left lower quadrant depicted genotypes CM1, CM6, CM7, and CM16, together with bottle gourd LS4 and watermelon CV6 and were characterized with increase in leaf number, shoot diameter, shoot dry weight, and dry biomass accumulation and root length under saline conditions (Figure 6).

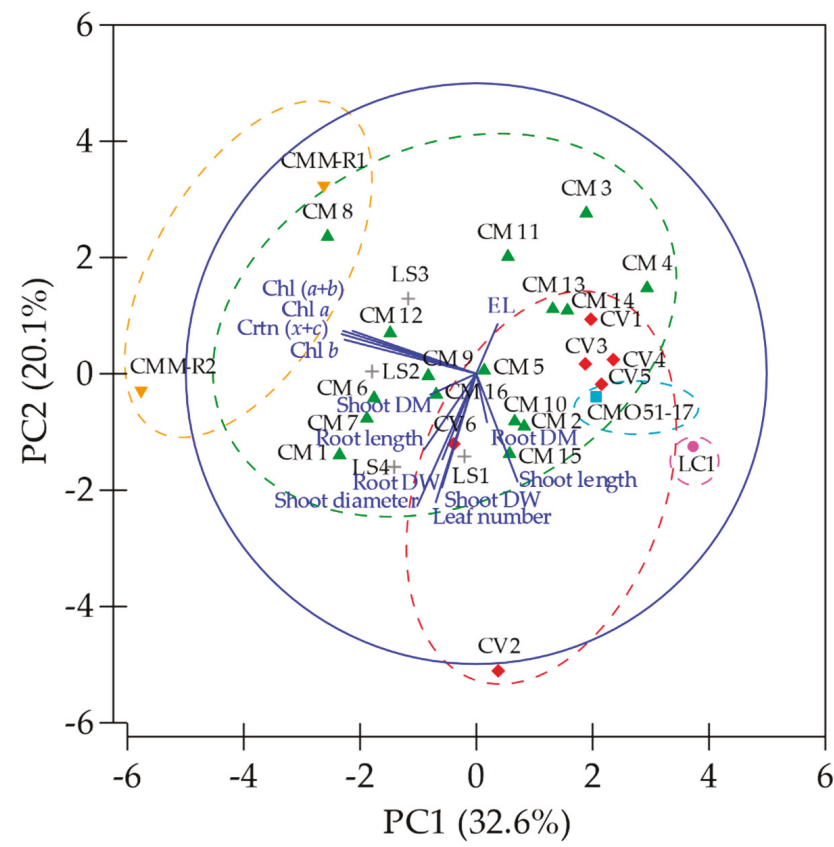

Figure 6. Principal component (PC) loading plot and scores of principal component analysis of the percentage of variation between $150 \mathrm{mM}$ and $0 \mathrm{mM}$ of $\mathrm{NaCl}$ of all the parameter analyzed in seedlings of sixteen Cucumis melo L. (CM), six Citrullus vulgaris Schrad (CV), two C. maxima $\times$ C. moschata (CMM-R), four Lagenaria siceraria (Molina) Standl. (LS) different genotypes, and Cucurbita moschata Duch. cv 51-17 and Luffa cylindrica Mill. grown in a floating system in a nursery greenhouse. 


\section{Discussion}

It is well known that plants' response to different $\mathrm{NaCl}$ concentrations differs between species and even within genotypes of the same species. In this study, high variability in various morphological and physiological traits between the tested genotypes even from the same species were observed. Furthermore, different responses to $\mathrm{NaCl}$ were identified, confirming the high variability within the assessed germplasm collection.

According to Munns [19], a saline environment in the root zone triggers the activation of various mechanisms in plant physiology, morphology, and metabolism. This takes place in two main phases. Firstly, the presence of $\mathrm{NaCl}$ in the soil creates osmotic stress in the roots due to different solute concentration, causing the activation of multiple metabolic pathways that in the short term lead to stomata closure to reduce evapotranspiration and preserve water, and net photosynthesis reduction $[1,20,21]$. Morphological change primarily includes the growth inhibition of aerial organs like shoots and a reduction in the number of leaves. In the current experiment, $150 \mathrm{mM}$ of $\mathrm{NaCl}$ significantly reduced the number of leaves only in melon (CM5), though a decreasing trend was observed in most genotypes. Shoot growth was significantly inhibited by salinity in most genotypes with the exception of watermelon (CV3, CV5, CV6) and luffa (LC1), which turned out to be more salt tolerant for this trait. The root system serves as an interphase between plant and soil, and its anatomy determines root performance [21]. Generally, root growth in a saline environment is inhibited less than the aerial organs [22]. In our study, root growth was not significantly affected by salt stress as the main factor, however, our data highlight a genotypic-specific response to salt concentration since root growth was promoted in salt-treated seedlings of CMM-R1, CMM-R2, and watermelon (CV3) and decreased in watermelon (CV6) and melon (CM14).

Salinity stress leads to a decrease in plant biomass, mainly in the epigean organs and this is ascribed to a decrease in $\mathrm{CO}_{2}$ fixation by photosynthesis due a reduction in stomatal conductance, together with nutrient disorders caused by the toxic action of $\mathrm{Na}^{+}$and $\mathrm{Cl}^{-}$ions inhibiting $\mathrm{Ca}^{2+}$ and $\mathrm{K}^{+}$ uptake [1,21-23]. Under conditions of $150 \mathrm{mM} \mathrm{NaCl}$, shoot dry weight was negatively affected only in melon (CM2, CM5, CM7, CM8, CM12, and CM13), C. moscata (CMO 51-17), watermelon (CV1 and CV2), and in the interspecific hybrid CMM-R1, the latter was the most salt sensitive compared with the other genotypes. In particular, watermelon (CV3), the interspecific hybrid CMM-R2, and bottle gourd (LS1) significantly increased shoot dry weight in response to salinity. On the other hand, shoot dry matter accumulation increased in saline conditions in bottle gourd (LS1, LS3, LS4) and in watermelon (CV2, CV3, and CV5) and melon (CM1) and both the interspecific hybrids CMM-R1 and CMM-R2. Many salinity tolerance traits in grafted plants are associated with the root system. A salt tolerant rootstock genotype alleviates the deleterious shoot growth inhibition, allocating more biomass to the root system, increasing the root surface able to uptake water and nutrients, resulting in a higher growth rate and biomass accumulation [24,25]. Accordingly, with $150 \mathrm{mM} \mathrm{NaCl}$, root dry weight did not decrease in any of the genotypes except for watermelon (CV5), and root dry matter accumulation was significantly enhanced in melon (CM1, CM4, CM5, CM6, CM7, CM8, CM15, and CM16) as well as watermelon (CV1, CV2, CV3, CV4, and CV5), while it decreased in melon (CM3, CM10, and CM11) and CMM-R1 and CMM-R2. Several studies have reported the growth depressing effect of salt on melon [26-28], cucumber [3,29], mini-watermelon [30], tomato [31], and lettuce [32] grown hydroponically under greenhouse conditions. The second phase of the salt stress starts with the accumulation of sodium and chloride ions in the leaves and their degrading action on cell membranes and chloroplast membranes. This degrades the tonoplast together with chlorophyll molecules because of chlorophyllase enzyme [33] as well as the interference of salt ions with pigment-protein complexes which accelerate leaf senescence and abscission [34]. Contradictory information is available in literature on salt stress related to chlorophyll contents among the same species and to others. In fact, studies on melon cv. Parnon and cv. "Tempo F1", under saline conditions, reported a decrease in chlorophyll content $[35,36]$ in line with studies on pumpkin [37], cucumber [38], tomato [31], canola and wheat [39,40]. Conversely, other 
authors observed an increase of photosynthetic pigments in different melon genotypes [41-43] in line with studies on other species like hot pepper [44], sunflower [45], and sesame [46].

Sanoubar and collaborators in 2016 [47] indicated that chlorophyll concentration in stressed tissues can be construed as an index of tissue tolerance to $\mathrm{NaCl}$. Accordingly, our results indicate a good tolerance in most of the genotypes, in particular in the interspecific hybrids CMM-R1 and CMM-R2, where photosynthetic pigments significantly increased under saline condition. Contrarily, in luffa, the decreasing chlorophyll content in response to salinity could be associated with greater sensitivity to salt stress [21]. Adaptation mechanisms induced by salt stress generally influence the light harvesting complex due to a faster decrease of chlorophyll $a$ content as compared to chlorophyll $b$, which leads to an increase in the chlorophyll $a / b$ ratio [34]. In our experiment, the chlorophyll $a / b$ ratio was modified under saline condition only in CMO 51-17 and watermelon (CV1) where chlorophyll $a$ decreased and chlorophyll $b$ did not vary. Different hypotheses have been formulated to explain the increase in photosynthetic pigments in response to salinity. The first considers the morphological modifications associated with the decrease of leaf area due the smaller cell size, resulting in an enhancement of photosynthetic pigments concentration [45,46]. A second hypothesis, proposed by Garcia-Valenzuela and collaborators [48], associated the increase of photosynthetic pigments to the faster response that is generally observed in the biosynthesis of pigments as compared to the cell growth rate [48]. To date, however, most the credited hypothesis relates the increase observed in photosynthetic pigments to a short term acclimatization response to salinity and that a prolonged exposure would in any case be detrimental [49]. The ability to isolate or exclude sodium and chloride is a key factor to consider as a salt tolerance trait $[27,28]$. The longer the salt stress is prolonged, the higher the accumulation of sodium and chloride inside the plant is. To cope with this osmotic disorder, plants exclude uptake of these compounds primarily through root exclusion, and subsequently through compartmentation, by isolating salt in vacuoles. However, the higher the ability to isolate (salt) in the vacuole is, the less the cell membrane is damaged. Moreover, if the concentration increases inside the cytosol, plants start to synthesize different organic solutes to maintain the osmotic turgor and to reduce the deleterious effect of salt due to cell membrane degradation and the increase of reactive oxygen species (ROS) $[19,21,50]$. In our experiment, electrolyte leakage increased dramatically only in LS2, CV4, CM10, and CM13, revealing a high index of internal damage due to the presence of sodium and chloride inside the leaf cells of these genotypes which must be considered a sensitive response to salt stress.

\section{Conclusions}

Salinity stress leads to a decrease in plant growth with more pronounced deleterious effect in the shoot rather than the roots. Similar physiological and morphological salt adaptation traits were observed in different genotypes from different species. In light of the above consideration, we identified C. maxima $\times$ C. moscata interspecific hybrid CMM-R2, melon genotypes (CM6, CM7, CM10, and CM16), together with watermelon (CV2 and CV6) and bottle gourd (LS4) as salt tolerant genotypes and possible candidates as salt resistant rootstock to be introduced in grafting programs. Contrarily, luffa and melon (CM1, CM2, CM3, CM4, CM5 CM8, CM9, CM11, CM12, CM13, CM14, and CM15), watermelon (CV1, CV3, CV4, and CV5), together with CMO 51-17 and bottle gourd LS1 proved salt sensitive. In conclusion, this study provides information to growers, scientists, extension specialists, and breeders on the behavior of the tested genotypes. Further research on these genotypes is needed to clarify their performance in saline environments in the long term and their compatibility with commercial grafted varieties.

Author Contributions: Conceptualization, G.C.M., F.O., Y.T., G.B.Ö., G.G.; methodology, G.C.M., G.B.Ö., Y.T., F.O.; validation, G.C.M., Y.R., F.O.; formal analysis, G.C.M.; investigation, G.C.M., Y.R., F.O.; resources, F.O., G.B.Ö., Y.T.; data curation, G.C.M., Y.R., F.O.; writing-original draft preparation, G.C.M.; writing-review and editing, F.O., Y.R., S.D.P.; visualization, G.C.M., Y.R., F.O.; supervision, S.D.P., Y.R., Y.T., G.B.Ö., G.G.; project administration, G.B.Ö.; funding acquisition, Y.R., G.G., S.D.P. All authors have read and agreed to the published version of the manuscript. 
Funding: This work was carried out during an internship mobility agreement between the University of Bologna and the Ege University financed by the LLP Erasmus Placement Program (2014) and supported by Ege University Scientific Research Projects Coordination Unit with project number 2013-ZRF-001.

Acknowledgments: The authors are thankful to Sofia Siepi, Elyar Saeedi and Gamze Çılgın for their help collecting data and technical assistance during the experiment.

Conflicts of Interest: The authors declare no conflict of interest.

\section{References}

1. Colla, G.; Rouphael, Y.; Leonardi, C.; Bie, Z. Role of grafting in vegetable crops grown under saline conditions. Sci. Hortic. 2010, 127, 147-155. [CrossRef]

2. Montanarella, L.; Badraoui, M.; Chude, V.; Baptista Costa, I.D.S.; Mamo, T.; Yemefack, M.; Singh Aulakh, M.; Yagi, K.; Young Hong, S.; Vijarnsorn, P.; et al. Status of the World's Soil Resources: Main Report; FAO: Rome, Italy, 2015.

3. Rouphael, Y.; Cardarelli, M.; Rea, E.; Colla, G. Improving melon and cucumber photosynthetic activity, mineral composition, and growth performance under salinity stress by grafting onto Cucurbita hybrid rootstocks. Photosynthetica 2012, 50, 180-188. [CrossRef]

4. Balkaya, A.; Yildiz, S.; Horuz, A.; Doğru, S.M. Effects of Salt Stress on Vegetative Growth Parameters and Ion Accumulations in Cucurbit Rootstock Genotypes. J. Crop Breed. Genet. 2016, 2, 11-24.

5. King, S.R.; Davis, A.R.; Zhang, X.; Crosby, K. Genetics, breeding and selection of rootstocks for Solanaceae and Cucurbitaceae. Sci. Hortic. 2010, 127, 106-111. [CrossRef]

6. Edelstein, M.; Ben-Hur, M.; Cohen, R.; Burger, Y.; Ravina, I. Boron and salinity effects on grafted and non-grafted melon plants. Plant Soil 2005, 269, 273-284. [CrossRef]

7. Singh, H.; Kumar, P.; Kumar, A.; Kyriacou, M.C.; Colla, G.; Rouphael, Y. Kumar Grafting Tomato as a Tool to Improve Salt Tolerance. Agronomy 2020, 10, 263. [CrossRef]

8. Schwarz, D.; Öztekin, G.B.; Tüzel, Y.; Brückner, B.; Krumbein, A. Rootstocks can enhance tomato growth and quality characteristics at low potassium supply. Sci. Hortic. 2013, 149, 70-79. [CrossRef]

9. Barbieri, G.; Vallone, S.; Orsini, F.; Paradiso, R.; De Pascale, S.; Zakharov, F.; Maggio, A. Stomatal density and metabolic determinants mediate salt stress adaptation and water use efficiency in basil (Ocimum basilicum L.). J. Plant Physiol. 2012, 169, 1737-1746. [CrossRef]

10. Zhu, J.; Bie, Z.; Huang, Y.; Han, X. Effect of grafting on the growth and ion concentrations of cucumber seedlings under $\mathrm{NaCl}$ stress. Soil Sci. Plant Nutr. 2008, 54, 895-902. [CrossRef]

11. Huang, Y.; Bie, Z.; Liu, P.; Niu, M.; Zhen, A.; Liu, Z.; Lei, B.; Gu, D.; Lu, C.; Wang, B. Reciprocal grafting between cucumber and pumpkin demonstrates the roles of the rootstock in the determination of cucumber salt tolerance and sodium accumulation. Sci. Hortic. 2013, 149, 47-54. [CrossRef]

12. Xiong, M.; Zhang, X.; Shabala, S.; Shabala, L.; Chen, Y.; Xiang, C.; Nawaz, M.A.; Bie, Z.; Wu, H.; Yi, H.; et al. Evaluation of salt tolerance and contributing ionic mechanism in nine Hami melon landraces in Xinjiang, China. Sci. Hortic. 2018, 237, 277-286. [CrossRef]

13. Sarabi, B.; Bolandnazar, S.; Ghaderi, N.; Ghashghaie, J. Genotypic differences in physiological and biochemical responses to salinity stress in melon (Cucumis melo L.) plants: Prospects for selection of salt tolerant landraces. Plant Physiol. Biochem. 2017, 119, 294-311. [CrossRef] [PubMed]

14. Davis, A.R.; Perkins-Veazie, P.; Sakata, Y.; López-Galarza, S.; Maroto, J.V.; Lee, S.-G.; Huh, Y.-C.; Sun, Z.; Miguel, A.; King, S.R.; et al. Cucurbit Grafting. Crit. Rev. Plant Sci. 2008, 27, 50-74. [CrossRef]

15. Sakata, Y.; Ohara, T.; Sugiyama, M. The hystory of melon and cucumber grafting in Japan. Acta Hortic. 2008, 767, 217-228. [CrossRef]

16. Blum, A.; Ebercon, A. Cell Membrane Stability as a Measure of Drought and Heat Tolerance in Wheat. Crop Sci. 1981, 21, 43-47. [CrossRef]

17. Arnon, D.I. Copper enzymes in isolated chloroplasts. Polyphenoloxidase in beta vulgaris. Plant Physiol. 1949, 24, 1-15. [CrossRef]

18. Metsalu, T.; Vilo, J. ClustVis: A web tool for visualizing clustering of multivariate data using Principal Component Analysis and heatmap. Nucleic Acids Res. 2015, 43, W566-W570. [CrossRef]

19. Munns, R.; Passioura, J.; Colmer, T.D.; Byrt, C. Osmotic adjustment and energy limitations to plant growth in saline soil. New Phytol. 2019, 225, 1091-1096. [CrossRef] 
20. Moradi, F.; Ismail, A.M. Responses of Photosynthesis, Chlorophyll Fluorescence and ROS-Scavenging Systems to Salt Stress During Seedling and Reproductive Stages in Rice. Ann. Bot. 2007, 99, 1161-1173. [CrossRef]

21. Acosta-Motos, J.R.; Ortuño, M.F.; Bernal-Vicente, A.; Diaz-Vivancos, P.; Sánchez-Blanco, M.J.; Hernández, J.A. Plant Responses to Salt Stress: Adaptive Mechanisms. Agronomy 2017, 7, 18. [CrossRef]

22. Yetişir, H.; Uygur, V. Plant growth and mineral element content of different gourd species and watermelon under salinity stress. Turk. J. Agric. For. 2009, 33, 65-77.

23. Carillo, P.; Raimondi, G.; Kyriacou, M.C.; Pannico, A.; El-Nakhel, C.; Cirillo, V.; Colla, G.; De Pascale, S.; Rouphael, Y. Morpho-physiological and homeostatic adaptive responses triggered by omeprazole enhance lettuce tolerance to salt stress. Sci. Hortic. 2019, 249, 22-30. [CrossRef]

24. Geilfus, C.-M.; Zörb, C.; Mühling, K.H. Salt stress differentially affects growth-mediating $\beta$-expansins in resistant and sensitive maize (Zea mays L.). Plant Physiol. Biochem. 2010, 48, 993-998. [CrossRef]

25. Ahmed, I.M.; Dai, H.; Zheng, W.; Cao, F.; Zhang, G.; Sun, D.; Wu, F. Genotypic differences in physiological characteristics in the tolerance to drought and salinity combined stress between Tibetan wild and cultivated barley. Plant Physiol. Biochem. 2013, 63, 49-60. [CrossRef] [PubMed]

26. Colla, G.; Rouphael, Y.; Cardarelli, M.; Massa, D.; Salerno, A.; Rea, E. Yield, fruit quality and mineral composition of grafted melon plants grown under saline conditions. J. Hortic. Sci. Biotechnol. 2006, 81, 146-152. [CrossRef]

27. Orsini, F.; Sanoubar, R.; Öztekin, G.B.; Kappel, N.; Tepecik, M.; Quacquarelli, C.; Tüzel, Y.; Bona, S.; Gianquinto, G. Improved stomatal regulation and ion partitioning boosts salt tolerance in grafted melon. Funct. Plant Boil. 2013, 40, 628-636. [CrossRef] [PubMed]

28. Sanoubar, R.; Orsini, F.; Gianquinto, G. Ionic partitioning and stomatal regulation. Plant Signal. Behav. 2013, 8, e27334. [CrossRef]

29. Colla, G.; Rouphael, Y.; Rea, E.; Cardarelli, M. Grafting cucumber plants enhance tolerance to sodium chloride and sulfate salinization. Sci. Hortic. 2012, 135, 177-185. [CrossRef]

30. Colla, G.; Rouphael, Y.; Cardarelli, M.; Rea, E. Effect of Salinity on Yield, Fruit Quality, Leaf Gas Exchange, and Mineral Composition of Grafted Watermelon Plants. HortScience 2006, 41, 622-627. [CrossRef]

31. Gong, B.; Wen, D.; Vandenlangenberg, K.; Wei, M.; Yang, F.; Shi, Q.; Wang, X. Comparative effects of NaCl and $\mathrm{NaHCO} 3$ stress on photosynthetic parameters, nutrient metabolism, and the antioxidant system in tomato leaves. Sci. Hortic. 2013, 157,1-12. [CrossRef]

32. Lucini, L.; Rouphael, Y.; Cardarelli, M.; Canaguier, R.; Kumar, P.; Colla, G.; Lucini, L. The effect of a plant-derived biostimulant on metabolic profiling and crop performance of lettuce grown under saline conditions. Sci. Hortic. 2015, 182, 124-133. [CrossRef]

33. Parida, A.K.; Das, A.B.; Das, P. NaCl stress causes changes in photosynthetic pigments, proteins, and other metabolic components in the leaves of a true mangrove,Bruguiera parviflora, in hydroponic cultures. J. Plant Boil. 2002, 45, 28-36. [CrossRef]

34. Munns, R. Plant Adaptations to Salt and Water Stress. Adv. Bot. Res. 2011, 57, 1-32.

35. Mavrogianopoulos, G.; Spanakis, J.; Tsikalas, P. Effect of carbon dioxide enrichment and salinity on photosynthesis and yield in melon. Sci. Hortic. 1999, 79, 51-63. [CrossRef]

36. Kaya, C.; Tuna, A.L.; Ashraf, M.; Altunlu, H. Improved salt tolerance of melon (Cucumis melo L.) by the addition of proline and potassium nitrate. Environ. Exp. Bot. 2007, 60, 397-403. [CrossRef]

37. Sevengor, S.; Yasar, F.; Kusvuran, S.; Ellialtioglu, S. The effect of salt stress on growth, chlorophyll content, lipid peroxidation and antioxidative enzymes of pumpkin seedling. Afr. J. Agric. Res. 2011, 6, 4920-4924.

38. Tiwari, J.K.; Munshi, A.D.; Kumar, R.; Pandey, R.N.; Arora, A.; Bhat, J.S.; Sureja, A.K. Effect of salt stress on cucumber: $\mathrm{Na}+-\mathrm{K}+$ ratio, osmolyte concentration, phenols and chlorophyll content. Acta Physiol. Plant. 2009, 32, 103-114. [CrossRef]

39. Shahbaz, M.; Noreen, N.; Perveen, S. Triacontanol modulates photosynthesis and osmoprotectants in canola (Brassica napus L.) under saline stress. J. Plant Interact. 2013, 8, 350-359. [CrossRef]

40. Shahbaz, M.; Ashraf, M.; Athar, H.-R. Does exogenous application of 24-epibrassinolide ameliorate salt induced growth inhibition in wheat (Triticum aestivum L.)? Plant Growth Regul. 2008, 55, 51-64. [CrossRef]

41. Romero, L.; Belakbir, A.; Ragala, L.; Ruiz, J.M. Response of plant yield and leaf pigments to saline conditions: Effectiveness of different rootstocks in melon plants (Cucumis melo L.). Soil Sci. Plant Nutr. 1997, 43, 855-862. [CrossRef] 
42. Akrami, M.; Arzani, A. Physiological alterations due to field salinity stress in melon (Cucumis melo L.). Acta Physiol. Plant. 2018, 40,1-14. [CrossRef]

43. Sivritepe, H. Özkan; Sivritepe, N.; Eris, A.; Turhan, E. The effects of $\mathrm{NaCl}$ pre-treatments on salt tolerance of melons grown under long-term salinity. Sci. Hortic. 2005, 106, 568-581. [CrossRef]

44. Ziaf, K.; Amjad, M.; Pervez, M.A.; Iqbal, Q.; Rajwana, I.A.; Ayyub, M. Evaluation of different growth and physiological traits as indices of salt tolerance in hot pepper (Capsicum annuum L.). Pak. J. Bot. 2009, 41, 1797-1809.

45. Rivelli, A.R.; De Maria, S.; Pizza, S.; Gherbin, P. Growth and physiological response of hydroponically-grown sunflower as affected by salinity and magnesium levels. J. Plant Nutr. 2010, 33, 1307-1323. [CrossRef]

46. Bazrafshan, A.H.; Ehsanzadeh, P. Growth, photosynthesis and ion balance of sesame (Sesamum indicum L.) genotypes in response to $\mathrm{NaCl}$ concentration in hydroponic solutions. Photosynthetica 2014, 52, 134-147. [CrossRef]

47. Sanoubar, R.; Cellini, A.; Veroni, A.M.; Spinelli, F.; Masia, A.; Antisari, L.V.; Orsini, F.; Gianquinto, G. Salinity thresholds and genotypic variability of cabbage (Brassica oleracea L.) grown under saline stress. J. Sci. Food Agric. 2015, 96, 319-330. [CrossRef]

48. García-Valenzuela, X.; Garcìa-Moya, E.; Rascón-Cruz, Q.; Herrera-Estrella, L.; Aguado-Santacruz, G. Chlorophyll accumulation is enhanced by osmotic stress in graminaceous chlorophyllic cells. J. Plant Physiol. 2005, 162, 650-661. [CrossRef]

49. Wang, X.; Chang, L.; Wang, B.; Wang, D.; Li, P.; Wang, L.; Yi, X.; Huang, Q.; Peng, M.; Guo, A. Comparative proteomics of Thellungiella halophila leaves from plants subjected to salinity reveals the importance of chloroplastic starch and soluble sugars in halophyte salt tolerance. Mol. Cell. Proteomics 2013, 12, 2174-2195. [CrossRef]

50. Shalata, A.; Neumann, P.M. Exogenous ascorbic acid (vitamin C) increases resistance to salt stress and reduces lipid peroxidation. J. Exp. Bot. 2001, 52, 2207-2211. [CrossRef]

(C) 2020 by the authors. Licensee MDPI, Basel, Switzerland. This article is an open access article distributed under the terms and conditions of the Creative Commons Attribution (CC BY) license (http://creativecommons.org/licenses/by/4.0/). 
Article

\title{
Rootstock and Arbuscular Mycorrhiza Combinatorial Effects on Eggplant Crop Performance and Fruit Quality under Greenhouse Conditions
}

\author{
Leo Sabatino ${ }^{1, *}$, Giovanni Iapichino ${ }^{1, *}$, Beppe Benedetto Consentino ${ }^{1}$, Fabio D'Anna ${ }^{1}$ \\ and Youssef Rouphael ${ }^{2}$ \\ 1 Dipartimento Scienze Agrarie, Alimentari e Forestali (SAAF), Università di Palermo, 90128 Palermo, Italy; \\ beppebenedetto.consentino@unipa.it (B.B.C.); fabio.danna@unipa.it (F.D.) \\ 2 Dipartimento di Agraria, Università degli Studi di Napoli Federico II, 80055 Portici, Italy; \\ youssef.rouphael@unina.it \\ * Correspondence: leo.sabatino@unipa.it (L.S.); giovanni.iapichino@unipa.it (G.I.); \\ Tel.: +39-091-2386-2252 (L.S.); +39-091-2386-2215 (G.I.)
}

Received: 24 March 2020; Accepted: 11 May 2020; Published: 13 May 2020

\begin{abstract}
The herbaceous grafting of fruiting vegetables is considered a toolbox for safeguarding yield stability under various distresses and for improving fruit quality. Inoculation with arbuscular mycorrhiza (AM) fungi seems also to be an efficient tool for increasing the assimilation, uptake and translocation of macroelements and microelements, for modulating plant secondary metabolism and for overcoming several forms of plant distress. The present work evaluated the combined effect of grafting the "Birgah" (B) eggplant onto its wild/allied relatives' rootstocks (Solanum torvum (T), S. macrocarpon $(\mathrm{M})$ and S. paniculatum $(\mathrm{P})$ ) and AM fungi (R. irregularis) on the yield, fruit quality, nitrogen use efficiency, mineral profile, and nutritional and functional quality. The B/T, B/M and B/P grafting combinations significantly increased the marketable fruit and fruit number compared with those in the ungrafted control. Furthermore, irrespective of the grafting combinations, AM fungi significantly enhanced the marketable fruit, fruit number and nitrogen use efficiency (NUE) by $13.3 \%$, $12.7 \%$ and $13.3 \%$, respectively compared to those in the untreated control. Exposing the B/T and B/P grafted plants to the +AM treatment significantly increased the ascorbic acid contents by $17.2 \%$ and $10.4 \%$, respectively, compared with those in the ungrafted control. Fruits from the combination B/P $\times$ $+\mathrm{AM}$ had a higher chlorogenic acid content than fruits from the ungrafted control plots. Finally, the $\mathrm{B} / \mathrm{T} \times+\mathrm{AM}$ and $\mathrm{B} / \mathrm{P} \times+\mathrm{AM}$ combinations decreased glycoalkaloids by $58.7 \%$ and $63.7 \%$, respectively, compared with those in the ungrafted control, which represents a highly important target for eggplant fruit healthiness.
\end{abstract}

Keywords: vegetable grafting; Solanum melongena L.; grafting combinations; arbuscular micorrhizal fungi; yield traits; NUE; mineral profile; functional properties

\section{Introduction}

Eggplant (Solanum melongena L.) is a major solanaceous vegetable crop cultivated worldwide [1]. Eggplant originated in the Old World, evolved from S. insanum, and it was self-sufficiently domesticated in India and China [2,3]. With a global production around $49.5 \mathrm{Mt}$, predominantly in Asia [4], eggplant is a relevant source of minerals and vitamins, and in terms of total nutritional value, it has been compared to tomato [1]. S. macrocarpon L., also known as African eggplant, and S. aethiopicum L., also known as Aethiopicum eggplant, are closely related to S. melongena and are mainly distributed in the African continent. In the eggplant cultivation scenario, the Mediterranean Basin represents an important area and Sicily is counted as a secondary eggplant diversification zone [5]. In Italy, 
eggplant is grown under either greenhouse or outdoor conditions, and due to the intensive cropping systems commonly used in the vegetable production farms, soilborne diseases and pests widely spread, limiting the yield and growth traits in eggplant [6]. At present, the absence of resistant genotypes, together with the ban on methyl bromide [7], has increased interest in the use of grafted eggplant. There are reports underlining the advantages derived from adopting grafting both in terms of plant biotic/abiotic stress tolerance and yield stability [8-10]. Solanum torvum Sw. is the most used rootstock for eggplant as it allows several soilborne diseases to be overcome, such as Verticilium dahliae Klebahn, Ralstonia solanacearum (Smith) Yabuuchiet al., Fusarium oxysporum (Schlechtend:Fr.) f. sp. Melongenae Matuoand Ishigami, and Meloidogyne spp. root-knot nematodes [6,11]. However, both eggplant's wild and allied relatives and interspecific hybrids are proposed as alternative eggplant rootstocks [12-14]. The use of tomato rootstock is also suggested to improve yield, fruit visual quality and plant vigor in eggplant [15].

Crop rotations and biological diversity long have been the key factors in successful traditional agricultural production systems. Rotation is essential for minimizing the build up of pest and soil borne disease problems. However, intensive greenhouse production often precludes vegetable growers from applying rotation. The lack of rotation and tendency towards monocropping in intensive protected vegetable production systems not only increase the prevalence of insects, soil plant pathogens and nematodes but, along with high nutrient levels, can suppress arbuscular mycorrhizal fungi (AMF). AMF are obligate symbionts between plants and fungi belonging to the monophyletic phylum Glomeromycota [16]. AMF symbiosis is extremely important for enhancing the assimilation of key macroelements and microelements ( $\mathrm{P}, \mathrm{Cu}$ and $\mathrm{Zn}$ ) and improving nutrient uptake and efficiency due to its ability to develop an extended external hypha up to 40-50 times their length [17]. Another prominent and sustainable means of boosting yield is the inoculation of beneficial AMF in specific environments such as soil greenhouses where these fungi are generally suppressed.

Moreover, recent findings demonstrated that AM may modulate plant secondary metabolism, enhancing antioxidant activity as well as the accumulation of antioxidant molecules known as phytochemicals (i.e., carotenoids, flavonoids, glucosinolates and phenolic acids) with health-promoting properties [18]. AM fungi have been reported to not only enhance nutritional status and the quality of the produce but also to be able to reduce several forms of plant distress such as thermal stress [19], salinity stress [20], drought stress [21] and soil heavy metal stress [22-25]. Furthermore, there are reports showing an increased resistance to certain diseases in mycorrhized plants [26]. Although there are several studies on the synergistic effects of grafting and other agronomical or chemical means commonly applied in vegetable crop production $[27,28]$, few experiments have been conducted on the interactive effects of grafting and AM on plant performance and the nutritive value of vegetables. In particular, Kumar et al. [24], studying the combined role of grafting and AM on Cd stress tolerance in tomato, observed that vigorous rootstock such as Maxifort successfully alleviate $\mathrm{Cd}$ stress symptoms via several physiological and biochemical mechanisms, such as (i) better nutrient absorption and translocation, (ii) higher synthesis of pigments linked to photosynthetic activity and (iii) better capability of producing enzymes (CAT and APX), proline and key metabolites (phytochelatin, fructans and inulins). Furthermore, Oztekin et al. [29], after studying the effect of grafting and AM on the performance of tomato plants cultivated under different salinity conditions in two growing seasons, conclude that grafting and AM have synergistic effects on tomato plant salinity tolerance. Nevertheless, no specified research has been conducted to study the co-operative effects between using wild and allied eggplant relatives as rootstocks and AM application in improving eggplant crop performance and nutritive value. On the aforesaid basis, the aims of our investigation were to appraise the concerted action of eggplant wild/allied relatives' rootstocks and AM inoculation on the yield, fruit quality and nitrogen use efficiency of "Birgah" eggplant grown under greenhouse conditions. The outcome of this study should provide useful information on the performance of new eggplant rootstocks and on their response to $\mathrm{AMF}$ inoculation. 


\section{Materials and Methods}

\subsection{Trial Site, Nursery Production and Growing Settings}

The investigation was conducted in 2016 at the experimental farm of the University of Palermo. Seeds of the Solanum torvum, Solanum macrocarpon and Solanum paniculatum rootstocks were sown in 44-cell seedling trays, containing pasteurized peat moss (FAP, Padova, Italia), in a protected environment with a day/night temperature cycle of $25^{\circ} \mathrm{C} / 18^{\circ} \mathrm{C}$. Twenty days after rootstock sowing, seeds of the "Birgah" eggplant cultivar were seeded in 104-cell trays and maintained under the same climatic conditions and with the same planting method as the rootstocks. "Birgah" is an eggplant $\mathrm{F}_{1}$ hybrid belonging to the violet round shape group, and it is one of the most cultivated eggplants, both in open fields and in protected environments, in Sicily. Seventy-five days after planting, all seedlings attained a hypocotyl diameter of at least $2 \mathrm{~mm}$ (the minimum recommended for the tube grafting method). The grafting of "Birgah" scions was performed as reported by Sabatino et al. [12,13]. Briefly, the rootstock was cut off, $0.5 \mathrm{~cm}$ below the cotyledons, at a $45^{\circ}$ angle, and a similar cut was performed on the scion. Care was taken to ensure that the cut surfaces fitted perfectly. To complete the grafting procedure, a plastic clip was attached at the grafting point to guarantee that the correct amount of pressure was applied. The grafted plantlets were placed in a greenhouse equipped with a fog system in order to maintain a humidity of $95 \%$ and an air temperature of $20^{\circ} \mathrm{C}$ for 7 days. After that, the grafted transplants were subjected, for 3 days, to a slow dropping of the humidity, useful for plant acclimatization. Then, they were ready for transplantation. Ungrafted and self-grafted eggplants were also included.

Prior to transplanting, half of the ungrafted, self-grafted and grafted plantlets were treated with $10 \mathrm{~g} \mathrm{plant}^{-1}$ of micorrhizal inoculum carrying 40 spores $\mathrm{g}^{-1}$ of Rhizophagus irregularis (formerly Glomus intraradices). All plantlets were transplanted on 9 February, 2016 and maintained till the end of May, 2016 in an unheated greenhouse in Typic Rhodoxeralf soil, characterized by the following soil texture: $46.5 \%$ sand, $22.3 \%$ silt and $31.2 \%$ clay. The soil $\mathrm{pH}$ was 7.2 . Before the experiment, a brassica crop was cultivated. Mulching with a black polyethylene film of $20 \mu \mathrm{m}$ was installed. Eggplant plantlets were spaced in order to obtain a plant density of 2 plants $\mathrm{m}^{-2}$. Plants were periodically drip irrigated, receiving $250 \mathrm{~kg}$ of nitrogen ha ${ }^{-1}, 150 \mathrm{~kg}$ of phosphorous pentoxide ha ${ }^{-1}$ and $250 \mathrm{~kg}$ of potassium oxide ha ${ }^{-1}$. The cultivation practices reported by Baixauli [30], suggested for eggplant growth in Mediterranean conditions, were applied regularly subject to crop requirements.

\subsection{Yield, Nitrogen Use Efficiency, Nutritional Traits and Functional Compounds}

Immediately after harvest, the fruits were weighed and separated into marketable and waste production categories. The number of marketable fruits per plant was recorded, and average fruit weight was also calculated. In total, ten harvests were realized, starting on 21 March, 2016.

A digital penetrometer (Trsnc, Forli, Italy) was used to determine fruit firmness. Fruit firmness was measured based on three replicates of five fruits per scion/rootstock combination. Each fruit was perforated, using a $6 \mathrm{~mm}$ diameter stainless steel cylinder probe, on two opposite sides of the fruit equatorial zone. Firmness was expressed in newtons (N).

Soluble solids content (SSC) was recorded based on three replicates of five fruits and was determined using a refractometer (MTD-045nD, Three-In-OneEnterprises Co. Ltd. Taiwan). Prior to the SSC determinations, the fruit juice was adequately clarified.

Three to five commercially mature fruits for each replicate, from the second and third harvests, were used for the analytical determinations. Each sample consisted of the same quantity of apical, equatorial and distal parts of the fruits. Nutritional and functional determinations were performed on fruits harvested from labelled flowers at the fruit set stage, and all the fruits were harvested 35 days after labelling (fruit commercial maturity stage).

Fruit dry weight was measured via the dehydration of the sample in a heater at $80{ }^{\circ} \mathrm{C}$ until a constant weight was achieved. The fruit dry matter percentage was calculated using the fruit fresh and 
dry weights. For protein determination, the Kjeldal method was applied. Specifically, sample was exposed to acid-catalyzed mineralization to convert the organic nitrogen into ammoniacal nitrogen. Subsequently, the ammoniacal nitrogen was distilled under alkaline $\mathrm{pH}$. The ammonia produced via the distillation was collected in a boric acid solution and measured through titrimetric dosage. The ammoniacal nitrogen value was multiplied by 6.25 .

For $\mathrm{Ca}, \mathrm{Mg}$, $\mathrm{K}$ and Fe determinations, atomic absorption spectroscopy following wet mineralization was adopted as reported by Morand and Gullo [31]. Phosphorus values were assessed using colorimetry as reported by Fogg and Wilkinson [32].

The nitrogen use efficiency $(\mathrm{NUE}=$ yield/ $\mathrm{N}$ application rate) was calculated and expressed as $\mathrm{t} \cdot \mathrm{kg}^{-1}$.

The ascorbic acid content was determined as described by Sabatino et al. [33] for tomato. Therefore, the determinations were made with a reflectometer (Merck RQflex*10 m) using Reflectoquant Ascorbic Acid Test Strips. Thus, one gram of eggplant fruit juice was mixed with distilled water to a $10 \mathrm{~mL}$ total volume. Subsequently, an appropriate test strip was immersed into the prepared sample then inserted into the meter. The results were expressed as $\mathrm{mg}$ of ascorbic acid per $100 \mathrm{~g}$ of fresh weight.

The anthocyanin extraction procedure applied was that described by Mennella et al. [34]. The determination was conducted on a lyophilized and powdered sample of $200 \mathrm{mg}$. The flow rate and absorbance units full scale adopted were $0.8 \mathrm{~mL} \mathrm{~min}^{-1}$ and at 0.1 , respectively. For RP-HPLC analyses, purified delphinidin-3-rutinoside (D3R, Polyphenols Laboratories AS, Sandnes, Norway) was used as an external standard with a dissimilar retention time (23.9 $\mathrm{min}$ ) compared to delphinidin-3-(p-coumaroyl rutinoside)-5-glucoside (nasunin), which was eluted with a longer retention time (25.8 $\mathrm{min}$ for cis-nasunin and $26.1 \mathrm{~min}$ for trans-nasunin, respectively). Regarding the nasunin determination, in agreement with Lo Scalzo et al. [35], a partially purified standard was used. Total anthocyanins were expressed as mg.100 g-1 dry weight $(\mathrm{dw})$, highlighting that the detection limit was $2.00 \mathrm{mg} 100 \mathrm{~g}^{-1}$ of $\mathrm{dw}$.

For chlorogenic acid determination, the extraction and analysis procedure described by Stommel and Whitaker [36], with slight variations, was applied. Therefore, a binary mobile phase gradient of methanol in $0.01 \%$ aqueous phosphoric acid was provided according to this procedure: $0-15 \mathrm{~min}$, linear increase from 5\% to $25 \%$ methanol; $15-28 \mathrm{~min}$, linear increase from $25 \%$ to $50 \%$ methanol; $28-30 \mathrm{~min}$, linear increase from $50 \%$ to $100 \%$ methanol; $30-32 \mathrm{~min}, 100 \%$ methanol; 32-36 min, linear decrease from $100 \%$ to $5 \%$ methanol; $36-43 \mathrm{~min}, 5 \%$ methanol. The flow rate was $0.8 \mathrm{~mL} \cdot \mathrm{min}^{-1}$. The chlorogenic acid quantification, subsequently conducted by RP-HPLC separation, was based on the absorbance at $325 \mathrm{~nm}$ relative to the external standard of chlorogenic acid (Sigma-Aldrich, St.Louis, MO) and expressed as $\mathrm{mg} \cdot 100 \mathrm{~g}^{-1}$ of $\mathrm{dw}$.

For glycoalkaloids, the extraction method adopted was that reported by Birner [37] with some adjustments. Thus, $0.5 \mathrm{~g}$ of lyophilized and powdered flesh tissue sample was extracted with $95 \%$ ethanol. For glycoalkaloids (expressed as $\mathrm{mg} \cdot 100 \mathrm{~g}^{-1} \mathrm{dw}$ ) analyses, the method described by Kuronen et al. [38] was applied. Therefore, the analyses were conducted by means of RP-HPLC using purified solasonine and solamargine as the external standards. The detection limit was $0.03 \mathrm{mg} 100 \mathrm{~g}^{-1} \mathrm{of} \mathrm{dw}$.

\subsection{Root Colonization Assessment}

To evaluate mycorrhizal colonization, the method described by Phillips and Haymann [39] and revised by Torta et al. [40] was adopted. Briefly, three lateral root samples from mychorrhized plants were collected and marked with acid fuchsin. As reported by Kormanik and McGraw [41], mycorrhizal colonization (Mycorrhization Index (MI = \% of marked tissue, with respect to the hyaline portion, on the unit of the length of the root)) was evaluated on three fragments, attaining the average value.

\subsection{Experimental Design and Statistical Analysis}

The trial was organized in a randomized complete block design with 3 replicates per treatment. Each replicate consisted of 10 plants. Consequently, the total number of plants was 300 (10 treatments $\times 30$ plants per treatment $=300$ plants). The data were subjected to GLM (General Linear Model) 
analysis using the SPSS software package version 20.0. For data expressed in percentages, an arcsin transformation before ANOVA analysis $\left(\varnothing=\arcsin (\mathrm{p} / 100)^{1 / 2}\right)$ was performed. Tukey's HSD test $(p<0.05)$ was used to compare means. Principal component analysis (PCA) was conducted on the whole yield, fruit quality and nitrogen use efficiency data set.

\section{Results}

\subsection{Root Colonization by AM Fungi}

AM fungi root colonization was significantly affected by mycorrhizal inoculation (M), whereas the grafting combination $(G)$ did not significantly influence AM root colonization. ANOVA showed no significant interaction $(\mathrm{G} \times \mathrm{M})$ (Figure $\mathrm{S} 1)$. Irrespective of the grafting combination, the percentage of root colonization was higher with the inoculated treatment $(71.8 \%)$ compared to with the non-inoculated one $(2.5 \%)$ (Figure S1).

\subsection{Effect of Grafting Combination and Mycorrhizal Inoculation on Yield, Yield Components and NUE}

The marketable yield, number of marketable fruit per plant and percentage of unmarketable production were significantly influenced by the $\mathrm{G} \times \mathrm{M}$ interaction (Table 1 ).

Table 1. Main effects of the grafting combination and arbuscular mycorrhiza (AM) inoculation on yield and the yield components of greenhouse eggplant.

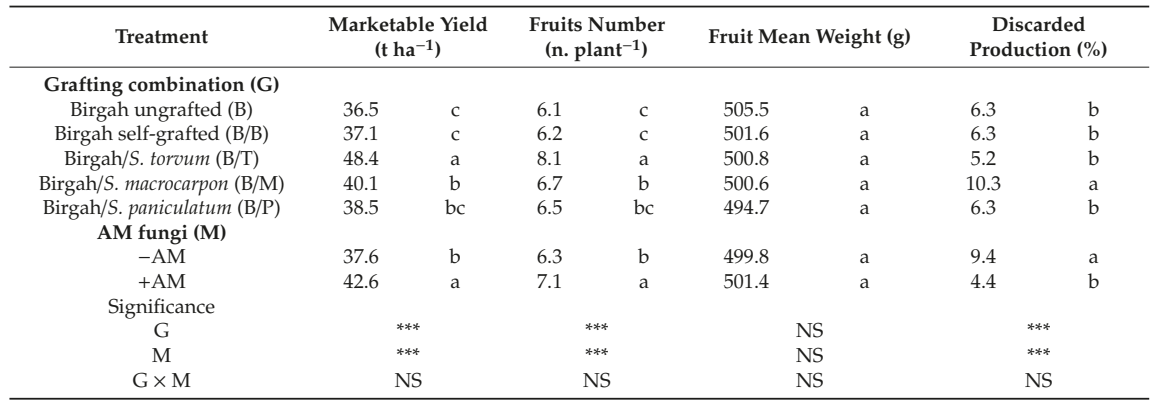

NS, ${ }^{* * *}$ non-significant or significant at $p \leq 0.001$. Data represent mean values of three replicates. Values within a column followed by the same letter are not significantly different at $p \leq 0.05$ according to Tukey's HSD Test. NS = not significant. +AM, $-\mathrm{AM}=$ mycorrhizal and non-mycorrhizal eggplants, respectively.

On the other hand, neither the grafting combination nor mycorrhizal treatment had a significant effect on fruit mean weight (avg. $500.6 \mathrm{~g}_{\text {fruit }}{ }^{-1}$ ). When averaged across mycorrhizal treatments, the marketable yield production reached a maximum value with Brigah grafted onto S. torvum (B/T), followed by both the $\mathrm{B} / \mathrm{M}$ and $\mathrm{B} / \mathrm{P}$ grafting combinations, while the lowest crop productivity was recorded for ungrafted and self-grafted crops (Table 1). Interestingly, the higher marketable fresh yield observed for eggplants grafted onto $S$. toroum and to a lesser extent onto $S$. macrocarpon and S. paniculatum, in comparison to both the ungrafted and self-grafted plants, was associated with an increase in the number of eggplant fruits per plant and not with a change in the mean fruit weight (Table 1). Moreover, the highest discarded production was observed with the B/M grafting combination (Table 1). A significant effect of mycorrhizal treatment on the yield and yield components was also observed (Table 1). Irrespective of grafting combinations, the inoculation of eggplant at the transplantation stage with $R$. irregularis elicited significant increases in the marketable yield and number of fruits per plant of $13.3 \%$ and $12.6 \%$, respectively, compared to for the non-inoculated control (Table 1).

Similarly to the effects on the yield and yield components, the nitrogen use efficiency (NUE) for the $\mathrm{B} / \mathrm{T}$ grafting combination $\left(0.242 \mathrm{t} \mathrm{kg}^{-1}\right)$ was significantly higher, by $31.2 \%$, than that obtained from the ungrafted and self-grafted eggplant (avg. $0.184 \mathrm{t} \mathrm{kg}^{-1}$; Table 1). Finally, the inoculation of eggplant 
with $R$. irregularis, when averaging across grafting combinations, induced a significant increase in the NUE, which was $13.3 \%$ higher than for the non-inoculated control treatment (Figure 1).

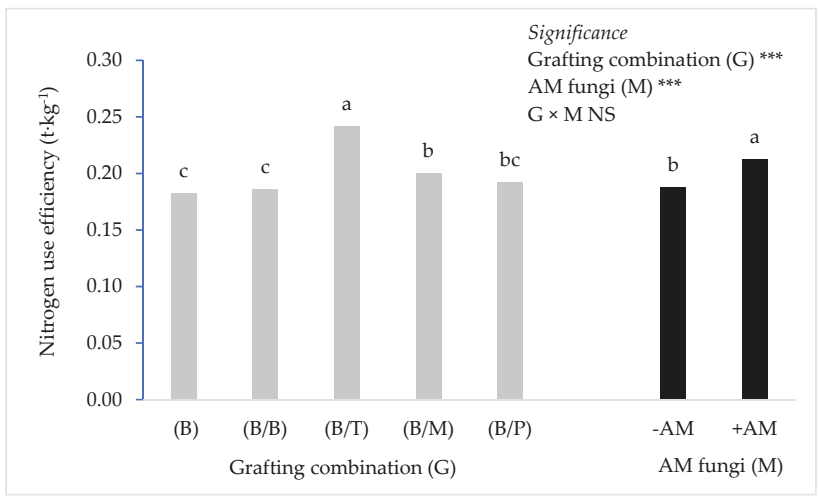

Figure 1. Main effects of grafting combination and AM inoculation on the nitrogen use efficiency (NUE) of greenhouse eggplant. (B): Birgah ungrafted; (B/B): Birgah self-grafted; (B/T): Birgah/S. torvum; (B/M): Birgah/S. macrocarpon; (B/P): Birgah/S. paniculatum.

\subsection{Effects of Grafting Combination and Mycorrhizal Inoculation on the Mineral Profile and Nutritional and Functional Quality}

Neither the grafting combination nor mycorrhizal inoculation had a significant effect on the fruit dry matter content (DM). The soluble solids content (SSC) and K content of eggplant fruits in the B/T and $\mathrm{B} / \mathrm{M}$ plots, averaged across mycorrhizal inoculation status, were higher than those for the other grafting combinations (Table 2).

Table 2. Main effects of the grafting combination and AM inoculation on the fruit dry matter (DM) percentage, soluble solids content (SSC) and macromineral content of greenhouse eggplant.

\begin{tabular}{|c|c|c|c|c|c|c|c|c|c|c|}
\hline \multirow{2}{*}{$\begin{array}{c}\text { Treatment } \\
\text { Grafting combination }(\mathrm{G})\end{array}$} & \multicolumn{2}{|c|}{ Dry Matter (\%) } & \multicolumn{2}{|c|}{ SSC $\left({ }^{\circ}\right.$ Brix $)$} & \multicolumn{2}{|c|}{$\mathrm{K}\left(\mathrm{mg} 100 \mathrm{~g}^{-1} \mathrm{dw}\right)$} & \multicolumn{2}{|c|}{$\mathrm{Ca}\left(\mathrm{mg} 100 \mathrm{~g}^{-1} \mathrm{dw}\right)$} & \multicolumn{2}{|c|}{$\mathrm{Mg}\left(\mathrm{mg} 100 \mathrm{~g}^{-1} \mathrm{dw}\right)$} \\
\hline & & & & & & & & & & \\
\hline Birgah ungrafted (B) & 6.0 & $\mathrm{a}$ & 4.3 & $\mathrm{~b}$ & 4.3 & $\mathrm{~b}$ & 309.2 & c & 18.0 & $\mathrm{a}$ \\
\hline Birgah self-grafted (B/B) & 5.9 & $\mathrm{a}$ & 4.3 & $\mathrm{~b}$ & 4.3 & $\mathrm{~b}$ & 311.5 & c & 17.0 & $\mathrm{a}$ \\
\hline Birgah/S. torvum $(\mathrm{B} / \mathrm{T})$ & 6.0 & $\begin{array}{l}\mathrm{d} \\
\mathrm{a}\end{array}$ & $\begin{array}{l}4.0 \\
5.1\end{array}$ & a & 5.1 & $\mathrm{a}$ & 311.4 & c & 12.3 & c \\
\hline Birgah/S. macrocarpon (B/M) & 5.9 & a & 5.1 & $\mathrm{a}$ & 5.1 & $\mathrm{a}$ & 335.5 & $\mathrm{~b}$ & 16.8 & $\mathrm{a}$ \\
\hline Birgah/S. paniculatum $(\mathrm{B} / \mathrm{P})$ & 5.9 & $\mathrm{a}$ & 4.4 & $\mathrm{~b}$ & 4.4 & $\mathrm{~b}$ & 347.5 & $\mathrm{a}$ & 14.5 & $\mathrm{~b}$ \\
\hline \multicolumn{11}{|l|}{ AM fungi (M) } \\
\hline$-\mathrm{AM}$ & 5.9 & $\mathrm{a}$ & 4.4 & $\mathrm{~b}$ & 4.4 & $\mathrm{~b}$ & 324.0 & $\mathrm{a}$ & 16.1 & $\mathrm{a}$ \\
\hline$+\mathrm{AM}$ & 6.0 & $\mathrm{a}$ & 4.9 & a & 4.9 & $\mathrm{a}$ & 322.0 & $\mathrm{a}$ & 15.6 & $\mathrm{a}$ \\
\hline \multicolumn{11}{|l|}{ Significance } \\
\hline G & \multicolumn{2}{|c|}{ NS } & \multicolumn{2}{|c|}{$* * *$} & \multicolumn{2}{|c|}{$* * *$} & \multicolumn{2}{|c|}{$* * *$} & \multicolumn{2}{|c|}{$* * *$} \\
\hline M & \multicolumn{2}{|c|}{ NS } & \multicolumn{2}{|c|}{$* * *$} & \multicolumn{2}{|c|}{$* * *$} & \multicolumn{2}{|c|}{ NS } & \multicolumn{2}{|c|}{ NS } \\
\hline $\mathrm{G} \times \mathrm{M}$ & \multicolumn{2}{|c|}{ NS } & \multicolumn{2}{|c|}{ NS } & \multicolumn{2}{|c|}{ NS } & \multicolumn{2}{|c|}{ NS } & \multicolumn{2}{|c|}{ NS } \\
\hline
\end{tabular}

NS, ${ }^{* * *}$ non-significant or significant at $p \leq 0.001$. Data represent mean values of three replicates. Values within a column followed by the same letter are not significantly different at $p \leq 0.05$ according to Tukey's HSD Test. $\mathrm{NS}=$ not significant. $+\mathrm{AM},-\mathrm{AM}=$ mycorrhizal and non-mycorrhizal eggplants, respectively.

The highest and lowest $\mathrm{Ca}$ and mg fruit contents were recorded in the B/P and B/T plots, respectively. Regardless of the grafting combination, the SSC and K fruit contents in the inoculated plots were $11.4 \%$ and $11.4 \%$ higher than in the non-inoculated ones, respectively. No significant interaction was observed between the grafting combination and mycorrhizal inoculation in terms of the DM percentage; SSC; and K, Ca and mg fruit contents (Table 2).

The grafting combination and mycorrhizal inoculation significantly affected the $\mathrm{P}$ and Fe fruit contents, protein content, firmness, ascorbic acid, total anthocyanins, chlorogenic acid and glycoalkaloids (Table 3). 
Agronomy 2020, 10, 693

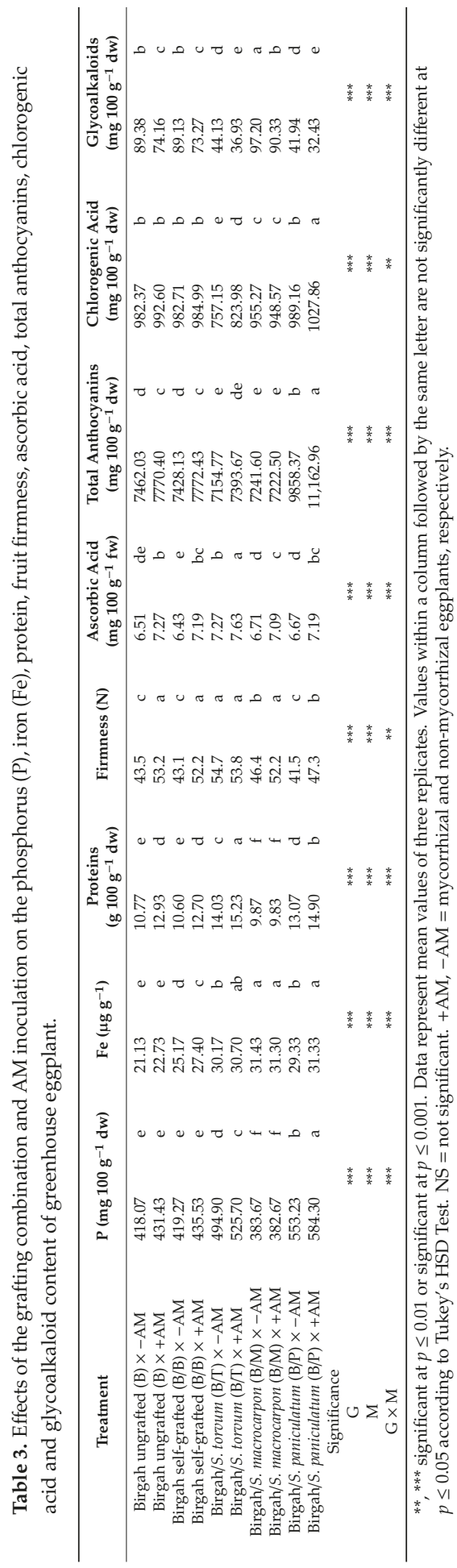


The inoculation treatment elicited a significant increase in the $\mathrm{P}$ fruit content in the $\mathrm{B} / \mathrm{P}$ and $\mathrm{B} / \mathrm{T}$ plots compared to in the non-inoculated ones. However, this effect was not apparent with the other grafting combinations.

A similar positive effect was also observed in eggplant grafted onto S. paniculatum, since mycorrhizal inoculation increased Fe concentration in inoculated plants compared to in the non-inoculated ones (Table 3). Moreover, eggplant "Birgah" grafted onto S. torvum and inoculated with AM fungi displayed the highest total protein value (Table 3). Except for the B/T grafting combination where no significant changes in fruit firmness were observed, the inoculation of eggplant with AM fungi in all the other grafting combinations (ungrafted, B/B, B/M and B/P) incurred a significant increase in fruit firmness (Table 3). Contrarily, for the latter quality parameters ( $\mathrm{P}, \mathrm{Fe}$, protein and firmness), the beneficial effect of AM fungi inoculation on ascorbic acid in eggplant fruits was apparent with all the grafting combinations tested, with the highest values recorded for "Birgah" grafted onto S. torvum (Table 3).

The total anthocyanin and chlorogenic acid contents ranged from 7154 to 11,162 and 757 to $1027 \mathrm{mg} 100 \mathrm{~g}^{-1} \mathrm{dw}$, respectively. Interestingly, the B/P grafting combination inoculated with AM fungi produced a major amplification of total anthocyanins and chlorogenic acid in comparison to the rest of the treatments (Table 3). Finally, the results indicated that the highest glycoalkaloid content was observed in the non-inoculated $\mathrm{B} / \mathrm{M}$ grafting combination, whereas the lowest values were recorded in the $\mathrm{B} / \mathrm{P}$ and $\mathrm{B} / \mathrm{T}$ combinations inoculated with $R$. irregularis (Table 3).

\subsection{Principal Component Analysis of All Agronomic and Qualitative Parameters}

The principal component analysis (PCA) on the agronomic and qualitative traits of greenhouse eggplant in response to the grafting combination and mycorrhizal inoculation is reported in Figure 2.

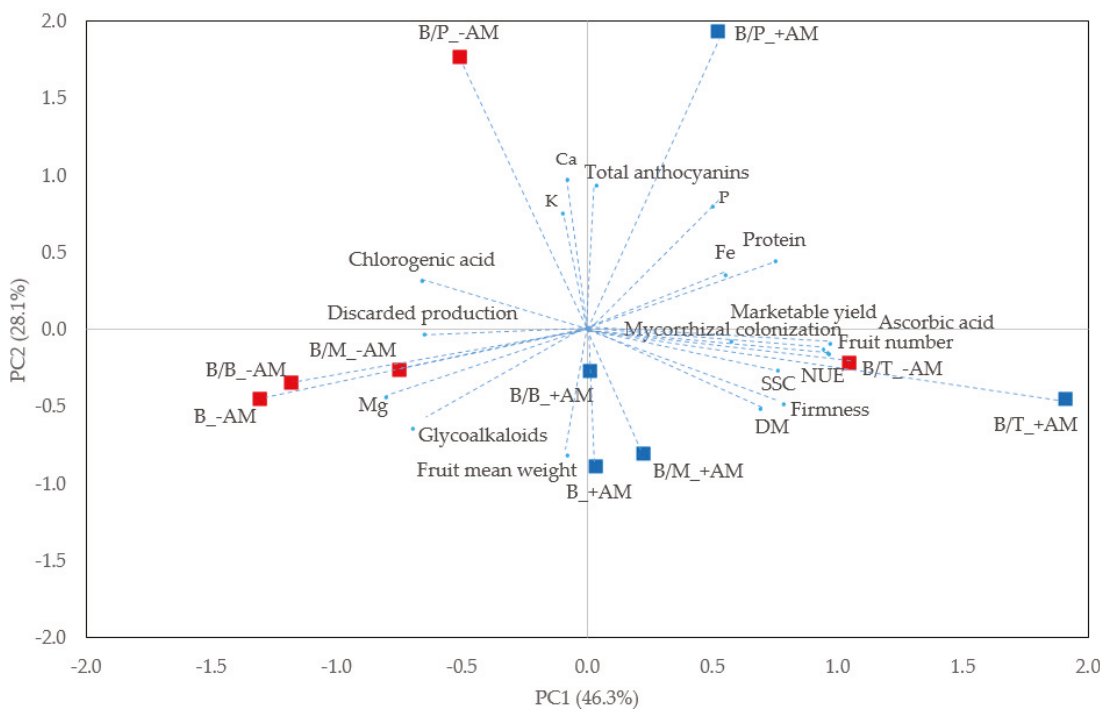

Figure 2. Principal component loading plot and scores of the principal component analysis (PCA) of the yield, yield components, nitrogen use efficiency (NUE), dry matter percentage (DM), protein, firmness, soluble solids content (SSC), minerals (P, K, Ca, mg and Fe), bioactive molecules (ascorbic acid, anthocyanins and chlorogenic acid) and glycoalkaloids of eggplant cv. "Birgah" as a function of grafting combination (ungrafted B and self-grafted B/B, B/T, B/M and B/P) and AM inoculation (+ AM and -AM). 
The first four PCs (i.e., principal components) were related with eigenvalues higher than 1 and explained $94.7 \%$ of the total variance (Table 4 ).

Table 4. Correlation coefficients for each agronomic and qualitative traits, eigenvalues, variance and cumulative proportions of total variance of the four principal components (PCs).

\begin{tabular}{ccccc}
\hline Variable & PC1 & PC2 & PC3 & PC4 \\
\hline Marketable yield & 0.961 & -0.157 & -0.129 & -0.003 \\
Fruit number & 0.969 & -0.090 & -0.156 & -0.012 \\
Fruit mean weight & -0.080 & -0.813 & 0.377 & -0.041 \\
Discarded production & -0.657 & -0.029 & -0.727 & -0.082 \\
Protein & 0.747 & 0.444 & 0.360 & -0.295 \\
K & -0.097 & 0.752 & -0.394 & 0.463 \\
P & 0.498 & 0.798 & 0.193 & -0.261 \\
Ca & -0.083 & 0.972 & 0.078 & 0.046 \\
Mg & -0.809 & -0.435 & 0.243 & 0.290 \\
Fe & 0.550 & 0.359 & -0.644 & 0.345 \\
NUE & 0.959 & -0.155 & -0.130 & -0.017 \\
Fruit dry matter & 0.691 & -0.509 & -0.001 & -0.001 \\
Firmness & 0.780 & -0.488 & 0.088 & 0.146 \\
SSC & 0.757 & -0.262 & -0.365 & 0.425 \\
Ascorbic acid & 0.940 & -0.125 & 0.210 & 0.162 \\
Total anthocyanins & 0.034 & 0.936 & 0.268 & 0.189 \\
Chlorogenic acid & -0.659 & 0.319 & 0.431 & 0.517 \\
Glycoalkaloids & -0.698 & -0.635 & -0.155 & 0.285 \\
Mycorrhizal colonization & 0.571 & -0.077 & 0.500 & 0.636 \\
Eigenvalue & 8.793 & 5.348 & 2.247 & 1.601 \\
Variance (\%) & 46.281 & 28.148 & 11.825 & 8.427 \\
Cumulative (\%) & 46.281 & 74.429 & 86.254 & 94.681 \\
\hline
\end{tabular}

In the current greenhouse experiment, the loading matrix indicates that variation in $\mathrm{Ca}$ and $\mathrm{K}$ was most closely aligned with the total anthocyanins, whereas the variation in the glycoalkaloids was not correlated to the SSC (Figure 2). The score plot of the PCA superimposed on the agronomic and qualitative parameters demonstrated a strong clustering of the two mycorrhizal treatments along PC1 (with the exception of $S$. torvum $\times$-AM), with +AM plants concentrating marketable yield, NUE, DM, SSC, mineral composition and ascorbic acid (Figure 2). Particularly, the B/T grafting combination inoculated with AM fungi was positioned on the positive side of PC1 in the lower right quadrant of the PCA score plot, and it exhibited the highest crop performance (high yield, number of fruits and NUE) with premium quality due to high concentrations of DM, SSC and ascorbic acid (Figure 2). Moreover, eggplant grafted onto S. paniculatum and inoculated with AM was characterized by higher P, Fe and total anthocyanin content (Figure 2). Finally, non-inoculated ungrafted and self-grafted plants were positioned in the lower left quadrant, characterized by higher glycoalkaloid content (Figure 2).

\section{Discussion}

In the present work we tested the use of various eggplant grafting combinations and AM fungi, alone or in combination, to boost crop performance and fruit quality in "Birgah" eggplant cultivated in a protected environment. Our results showed that enhancements in terms of yield, yield related traits, NUE, and fruit nutritional and functional quality can be accomplished by harnessing the combined effects of specific grafting combinations and AM fungi. These results are in line with those reported by Sabatino et al. [12,13], who-exploring the effects of using eggplant hybrids and allied species as rootstocks on eggplant yield, plant vigor and overall fruit quality-found that S. paniculatum and the interspecific hybrid of S. melongena $\times$ S. aethiopicum gr. Gilo provided a higher yield performance and a better fruit quality compared to the ungrafted or self-grafted plants. Similarly, our results are in line with those observed by Oztekin et al. [29], who, studying the influence of AM fungi on salinity 
tolerance in tomato grafted plants, stated that AM fungi significantly increased the total and marketable yields as well as the average fruit weight. Several authors $[42,43]$ report that the phytostimulating effect of the AM fungi could be attributed to numerous mechanisms such as enhancing the uptake and translocation of major and trace elements, inducing a more developed root system, improving the water status and photosynthetic efficiency, bolstering the antioxidative defense system, balancing plant hormones, upregulating nutrient transporter action and promoting the production of enzymes such as phosphatases. Therefore, we might hypothesize that the higher yield and yield related traits of mycorrhized plants could have similar explanations. Our outcomes regarding the NUE are in agreement with those reported by Djidonou et al. [44], who-investigating the yield, water status and NUE in field-grown, grafted tomato-found that grafting the "Florida 47" tomato onto "Beaufort" or "Multifort" significantly increased N use. Our findings are also consistent with those of Colla et al. [45], who, studying the influence of selected rootstocks on the plant performance and nitrogen use efficiency of the "Proteo" melon, report that the use of melon grafted onto designated rootstocks would represent a prospective plan for increasing crop productivity and NUE. In the present study, AM fungi increased the NUE of eggplant plants. This accords with the results of Zhu et al. [46], who-evaluating the effects of AM fungi on growth, nitrogen uptake and NUE in wheat-found that AM symbiosis increased NUE. Our findings are also in line with those presented by Liu et al. [47], who, studying the influence of AM on NUE in soybean, concluded that AM fungi play an imperative function in increasing NUE. Likewise, Rouphael et al. [43], in a review, report that plant biostimulants, including microbial plant biostimulants, can enhance NUE. Our study showed that both the S. torvum and S. macrocarpon rootstocks increased SSC values. This is in congruence with the results of Sabatino et al. [12], who used the "Birgah" eggplant $\mathrm{F}_{1}$ hybrid as a scion. However, these findings are in contrast to the outcomes reported by Sabatino et al. [13], who tested the "Scarlatti" eggplant $\mathrm{F}_{1}$ hybrid as an eggplant scion. Furthermore, our results for SSC revealed that AM fungi increase the SSC level in eggplant. However, this is in contrast with previous reports [29] indicating that AM symbiosis does not affect SSC in tomato fruit. Our results on firmness are corroborated by the results of Sabatino et al. [12], who found that $S$. torvum rootstock increased fruit firmness in "Birgah" hybrid and by those reported by Miceli et al. [48], who, assessing the effect of AM fungi and grafting on yield and fruit quality in mini-watermelon, noted that AM symbiosis increases pulp firmness. In our study, at the end of the experiment, the mean mycorrhizal colonization rates were $71.8 \%$ and $2.5 \%$ in +AM and -AM plants, respectively. There are reports that mycorrhizal hyphae extending into the soil or substrate increase nutrient uptake $[43,49]$ thanks to the mycorrhizal hyphae's capacity to penetrate into very small particles [50]. Our results on fruit mineral composition showed that the $\mathrm{B} / \mathrm{T}, \mathrm{B} / \mathrm{M}$ and $\mathrm{B} / \mathrm{P}$ scion/rootstock combinations improved the $\mathrm{K}, \mathrm{Ca}$ and $\mathrm{Fe}$ fruit contents. Meanwhile, fruits from the $\mathrm{B} / \mathrm{M}$ grafts revealed a decrease in terms of $\mathrm{P}$ content compared to the fruits from the control plots (ungrafted or self-grafted plants). Moreover, the present study showed that AM fungi treatment increased the $\mathrm{K}$ fruit content, without affecting the $\mathrm{Ca}$ and $\mathrm{mg}$ fruit content. In addition, our results highlighted that the $\mathrm{B} / \mathrm{T}$ and $\mathrm{B} / \mathrm{P}$ grafts benefit significantly from AM fungi in terms of $\mathrm{P}$ and Fe fruit concentrations. These outcomes are in accord with those of Kaya et al. [51] and Oztekin et al. [29], who supposed that a higher fruit mineral (macro and micro) concentration in grafted and mycorrhized plants could be attributed to a positive impact on water and nutrient uptake. Our trial showed that the S. torvum and S. paniculatum rootstocks increased fruit protein concentrations. This is in agreement with the results of Sabatino et al. [12] but in contrast to those of Sabatino et al. [13], who found no significant differences in terms of fruit protein content between ungrafted, self-grafted or S. torvum grafted plants. These results mark the important role played by the scion in terms of nutritional fruit quality in grafted plants. In addition, our results showed that AM fungi augmented the protein concentration in eggplant fruits. This seems to be in accord with the study of Baum et al. [52], who asserted that mycorrhizal inoculation induces a higher accumulation of proteins in onion. Contemporary outcomes exposed that AM symbioses are capable to adjust host plant primary and secondary metabolism, encouraging the synthesis of phytochemicals in the root system and shoots of mycorrhized plants [53]. Our data showed that the S. toroum rootstock 
significantly increased ascorbic acid in eggplant fruit, whereas fruits from the $\mathrm{B} / \mathrm{M}$ and $\mathrm{B} / \mathrm{P}$ grafts did not show significant differences in terms of ascorbic acid compared to the fruits from the control plots, demonstrating that the rootstock plays an imperative role in eggplant fruit quality. This results are partially in accord with those reported by Oztekin et al. [29], who observed that the rootstock factor did not affect vitamin $C$ in tomato fruits, and with those of Miceli et al. [48], who reported that grafting increases fruit ascorbic acid content in mini-watermelon. Conversely, our results on the positive effect of the AM fungi on fruit ascorbic acid content are fully in accord with those of Oztekin et al. [29] and Miceli et al. [48]. There is evidence that the increase in secondary metabolites in mycorrhized plants could be correlated to the higher contents of mineral nutrients [25]. In this regard, overall, our study indicated that AM fungi positively affected total anthocyanins and chlorogenic acid, with the sole exception of with the B/M scion/rootstock combination. Our findings seem to be in line with those reported by Walter et al. [54], who revealed that some graminaceous crops inoculated with AM fungi produce undergo important biochemical modulation leading to phenolic acid accumulation. Our results are in accord with those of other authors [55-57], who, investigating the influence of AM symbiosis on the production of phytochemicals in Ocimum basilicum, found higher concentrations of antioxidants when plants were treated with diverse AM fungi species. Baslam et al. [58] remarked that mycorrhized lettuce leaves display higher anthocyanin, carotenoid and phenolic contents than plants from control plots. Castellanos-Morales et al. [59] found that the strawberry mycorrhized plants produced fruits with a higher content of anthocyanidin cyanidin-3-glucoside. Ceccarelli et al. [60] state that artichoke, when treated with two AM fungi species, have increased leaf polyphenolic concentrations and antioxidant activity. Our results on glycoalkaloids support the findings reported by Sabatino et al. [12], who, although not showing a statistically significant effect of the rootstock on glycoalkaloids, highlighted a certain effect of rootstocks on glycoalkaloid content, remarking on the effectiveness of S. torvum and S. paniculatum in reducing glycoalkaloid concentrations. Furthermore, our results evidenced that $+\mathrm{AM}$ treatment had a positive effect on glycoalkaloid reduction which in turn could positively influence human health.

The effectiveness of PCA in interpreting species/cultivar differences across several agronomic and qualitative attributes in response to a wide range of pre-harvest factors such as the genetic material and agricultural practices (i.e., AM inoculation) has been reported previously by several researchers [61-63]. This was also evident in the present study, conducted under protected environment conditions, as the score plot of PCA integrated information on the yield, yield components, NUE, mineral profile and nutritive value of eggplant from five grafting combinations with or without inoculation with AM.

\section{Conclusions}

In the present work, eggplant wild/allied relatives' rootstocks and AMF significantly interacted, improving the crop performance and quality traits of "Birgah" eggplant. However, the B/T and B/P grafts combined with AMF stood out as producing the best results in terms of the yield traits, NUE, mineral profile, and nutritional and functional quality. Our findings could be useful information for vegetable crop nurseries interested in introducing new eggplant rootstocks that successfully respond when combined with AMF.

Supplementary Materials: The following are available online at http://www.mdpi.com/2073-4395/10/5/693/s1, Figure S1: Main effects of arbuscular mycorrhizal inoculation on root colonization.

Author Contributions: Conceptualization, L.S., F.D. and G.I.; methodology, L.S. and Y.R.; validation, L.S. and G.I.; formal analysis, B.B.C. and L.S.; investigation, L.S.; resources, F.D.; data curation, B.B.C. and L.S.; writing-original draft preparation, L.S.; writing - review and editing, L.S., G.I. and Y.R.; visualization, L.S., G.I. and Y.R.; supervision, F.D., G.I. and Y.R.; project administration, F.D.; funding acquisition, F.D. All authors have read and agreed to the published version of the manuscript.

Funding: This research received no external funding.

Conflicts of Interest: The authors declare no conflict of interest. 


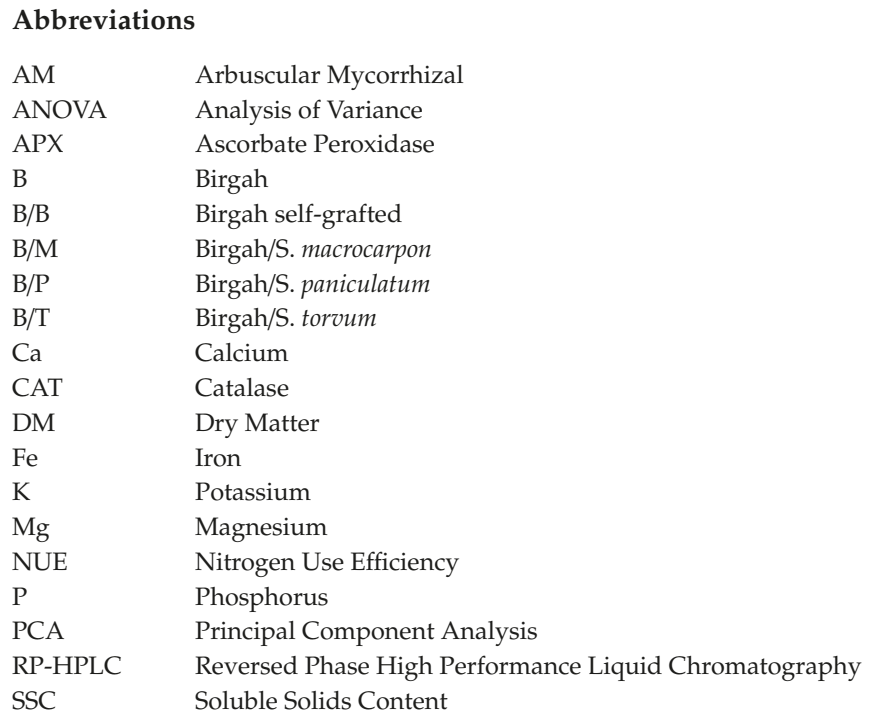

\section{References}

1. Kalloo, G. Eggplant Solanum melongena L. In Genetic Improvement of Vegetable Crops; Kalloo, G., Bergh, B.O., Eds.; Pergamon Press: Oxford, UK, 1993; pp. 587-604.

2. Vavilov, N.I. The Origin, Variation, Immunity and Breeding of Cultivated Plants. Soil Sci. 1951, 72, 482. [CrossRef]

3. Cericola, F.; Portis, E.; Toppino, L.; Barchi, L.; Acciarri, N.; Ciriaci, T.; Sala, T.; Rotino, G.L.; Lanteri, S. The Population Structure and Diversity of Eggplant from Asia and the Mediterranean Basin. PLoS ONE 2013, 8, e73702. [CrossRef] [PubMed]

4. Toppino, L.; Barchi, L.; Scalzo, R.L.; Palazzolo, E.; Francese, G.; Fibiani, M.; D'Alessandro, A.; Papa, V.; Laudicina, V.A.; Sabatino, L.; et al. Mapping Quantitative Trait Loci Affecting Biochemical and Morphological Fruit Properties in Eggplant (Solanum melongena L.). Front. Plant Sci. 2016, 7, 3017. [CrossRef] [PubMed]

5. D'Anna, F.; Sabatino, L. Morphological and agronomical characterization of eggplant genetic resources from the Sicily area. J. Food Agri. Environ. 2013, 11, 401-404.

6. Bletsos, F.; Thanassoulopoulos, C.; Roupakias, D. Effect of Grafting on Growth, Yield, and Verticillium Wilt of Eggplant. HortScience 2003, 38, 183-186. [CrossRef]

7. Maier, J. UNEP-United Nations Environment Programme. In A Concise Encyclopedia of the United Nations; Brill: Caton, The Netherlands, 2010; pp. 712-714.

8. Daunay, M.-C. Eggplant. In Vegetables II; Springer Science and Business Media LLC: Berlin, Germany, 2008; pp. 163-220.

9. King, S.R.; Davis, A.R.; Zhang, X.; Crosby, K. Genetics, breeding and selection of rootstocks for Solanaceae and Cucurbitaceae. Sci. Hortic. 2010, 127, 106-111. [CrossRef]

10. Rouphael, Y.; Kyriacou, M.C.; Colla, G. Vegetable Grafting: A Toolbox for Securing Yield Stability under Multiple Stress Conditions. Front. Plant Sci. 2018, 8, 2255. [CrossRef]

11. Bogoescu, M.; Doltu, M.; Sora, D. Hybrids and allied species as potential rootstocks for eggplant: Effect of grafting on vigour, yield and overall fruit quality traits. Acta Hortic. 2014, 331-336. [CrossRef]

12. Sabatino, L.; Iapichino, G.; D’Anna, F.; Palazzolo, E.; Mennella, G.; Rotino, G.L. Hybrids and allied species as potential rootstocks for eggplant: Effect of grafting on vigour, yield and overall fruit quality traits. Sci. Hortic. 2018, 228, 81-90. [CrossRef] 
13. Sabatino, L.; Iapichino, G.; Rotino, G.L.; Palazzolo, E.; Mennella, G.; Anna, D.; D'Anna, F. Solanum aethiopicum gr. gilo and Its Interspecific Hybrid with S. melongena as Alternative Rootstocks for Eggplant: Effects on Vigor, Yield, and Fruit Physicochemical Properties of Cultivar 'Scarlatti'. Agronomy 2019, 9, 223. [CrossRef]

14. Gisbert, C.; Prohens, J.; Raigón, M.D.; Stommel, J.R.; Nuez, F. Eggplant relatives as sources of variation for developing new rootstocks: Effects of grafting on eggplant yield and fruit apparent quality and composition. Sci. Hortic. 2011, 128, 14-22. [CrossRef]

15. Maršić, N.K.; Mikulič-Petkovšek, M.; Štampar, F. Grafting Influences Phenolic Profile and Carpometric Traits of Fruits of Greenhouse-Grown Eggplant (Solanum melongenaL.). J. Agric. Food Chem. 2014, 62, 10504-10514. [CrossRef] [PubMed]

16. Schüßler, A.; Schwarzott, D.; Walker, C. A new fungal phylum, the Glomeromycota: Phylogeny and evolution. Mycol. Res. 2001, 105, 1413-1421. [CrossRef]

17. Rouphael, Y.; Cardarelli, M.; Colla, G. Role of arbuscular mycorrhizal fungi in alleviating the adverse effects of acidity and aluminium toxicity in zucchini squash. Sci. Hortic. 2015, 188, 97-105. [CrossRef]

18. Avio, L.; Turrini, A.; Giovannetti, M.; Sbrana, C. Designing the Ideotype Mycorrhizal Symbionts for the Production of Healthy Food. Front. Plant Sci. 2018, 9, 9. [CrossRef] [PubMed]

19. Zhu, X.-C.; Song, F.-B.; Liu, S.-Q.; Liu, T.-D. Effects of arbuscular mycorrhizal fungus on photosynthesis and water status of maize under high temperature stress. Plant Soil 2011, 346, 189-199. [CrossRef]

20. Cantrell, I.C.; Linderman, R.G. Preinoculation of lettuce and onion with VA mycorrhizal fungi reduces deleterious effects of soil salinity. Plant Soil 2001, 233, 269-281. [CrossRef]

21. Püschel, D.; Rydlová, J.; Vosátka, M. Can mycorrhizal inoculation stimulate the growth and flowering of peat-grown ornamental plants under standard or reduced watering? Appl. Soil Ecol. 2014, 80, 93-99. [CrossRef]

22. Ouziad, F.; Hildebrandt, U.; Schmelzer, E.; Bothe, H. Differential gene expressions in arbuscular my-corrhizal-colonized tomato grown under heavy metal stress. J. Plant Physiol. 2005, 162, 634-649. [CrossRef]

23. Shahabivand, S.; Maivan, H.Z.; Goltapeh, E.M.; Sharifi, M.; Aliloo, A.A. The effects of root endophyte and arbuscular mycorrhizal fungi on growth and cadmium accumulation in wheat under cadmium toxicity. Plant Physiol. Biochem. 2012, 60, 53-58. [CrossRef]

24. Kumar, P.; Lucini, L.; Rouphael, Y.; Cardarelli, M.; Kalunke, R.M.; Colla, G. Insight into the role of grafting and arbuscular mycorrhiza on cadmium stress tolerance in tomato. Front. Plant Sci. 2015, 6, 477. [CrossRef] [PubMed]

25. Rouphael, Y.; Franken, P.; Schneider, C.; Schwarz, D.; Giovannetti, M.; Agnolucci, M.; De Pascale, S.; Bonini, P.; Colla, G. Arbuscular mycorrhizal fungi act as biostimulants in horticultural crops. Sci. Hortic. 2015, 196, 91-108. [CrossRef]

26. Dugassa, G.D.; Von Alten, H.; Schönbeck, F. Effects of arbuscular mycorrhiza (AM) on health ofLinum usitatissimum L. infected by fungal pathogens. Plant Soil 1996, 185, 173-182. [CrossRef]

27. Ioannou, N. Integrating soil solarization with grafting on resistant rootstocks for management of soil-borne pathogens of eggplant. J. Hortic. Sci. Biotechnol. 2001, 76, 396-401. [CrossRef]

28. Katan, J. Physical and cultural methods for the management of soil-borne pathogens. Crop. Prot. 2000, 19, 725-731. [CrossRef]

29. Oztekin, G.B.; Tuzel, Y.; Tuzel, I.H. Does mycorrhiza improve salinity tolerance in grafted plants? Sci. Hortic. 2013, 149, 55-60. [CrossRef]

30. Baixauli, C. Berenjena. In La Horticultura Espãnola; Nuez, F., Llácer, G., Eds.; Ediciones de Horticultura: Reus, Spain, 2001; pp. 104-108.

31. Morand, P.; Gullo, J.L. Mineralisation des tissus vegetaux en vue du dosage de P, Ca, Mg, Na, K. Ann. Agron. 1970, 21, 229-236.

32. Fogg, D.N.; Wilkinson, N.T. The colorimetric determination of phosphorus. Analist 1958, 83, 406. [CrossRef]

33. Sabatino, L.; D'Anna, F.; Iapichino, G.; Moncada, A.; D'Anna, E.; De Pasquale, C. Interactive Effects of Genotype and Molybdenum Supply on Yield and Overall Fruit Quality of Tomato. Front. Plant Sci. 2019, 9, 9. [CrossRef] 
34. Mennella, G.; Scalzo, R.L.; Fibiani, M.; D’Alessandro, A.; Francese, G.; Toppino, L.; Acciarri, N.; De Almeida, A.E.; Rotino, G.L. Chemical and Bioactive Quality Traits During Fruit Ripening in Eggplant (S. melongena L.) and Allied Species. J. Agric. Food Chem. 2012, 60, 11821-11831. [CrossRef]

35. Scalzo, R.L.; Fibiani, M.; Mennella, G.; Rotino, G.L.; Sasso, M.D.; Culici, M.; Spallino, A.; Braga, P.C. Thermal Treatment of Eggplant (Solanum melongenaL.) Increases the Antioxidant Content and the Inhibitory Effect on Human Neutrophil Burst. J. Agric. Food Chem. 2010, 58, 3371-3379. [CrossRef] [PubMed]

36. Stommel, J.R.; Whitaker, B.D. Phenolic Acid Content and Composition of Eggplant Fruit in a Germplasm Core Subset. J. Am. Soc. Hortic. Sci. 2003, 128, 704-710. [CrossRef]

37. Birner, J. A method for the determination of total steroid bases. J. Pharm. Sci. 1969, 58, 258-259. [CrossRef] [PubMed]

38. Kuronen, P.; Väänänen, T.; Pehu, E. Reversed-phase liquid chromatographic separation and simultaneous profiling of steroidal glycoalkaloids and their aglycones. J. Chromatogr. A 1999, 863, 25-35. [CrossRef]

39. Phillips, J.; Hayman, D. Improved procedures for clearing roots and staining parasitic and vesicular-arbuscular mycorrhizal fungi for rapid assessment of infection. Trans. Br. Mycol. Soc. 1970, 55, 158-168. [CrossRef]

40. Torta, L.; Mondello, V.; Burruano, S. Valutazione delle caratteristiche morfo-anatomiche di alcune simbiosi micorriziche mediante tecniche colorimetriche usuali e innovative. Micol. Ital. 2003, 2, 53-59.

41. Kormanik, P.P.; McGraw, A.C. Quantification of vesicular-arbuscular mycorrhizae in plant roots. In Methods and Principles of Mycorrhizal Research; Schenck, N.C., Ed.; APS Press: St. Paul, MN, USA, 1991; pp. $37-45$.

42. De Pascale, S.; Rouphael, Y.; Colla, G. Plant biostimulants: Innovative tool for enhancing plant nutrition in organic farming. Eur. J. Hortic. Sci. 2018, 82, 277-285. [CrossRef]

43. Rouphael, Y.; Colla, G. Synergistic Biostimulatory Action: Designing the Next Generation of Plant Biostimulants for Sustainable Agriculture. Front. Plant Sci. 2018, 9, 9. [CrossRef]

44. Djidonou, D.; Zhao, X.; Simonne, E.H.; Koch, K.E.; Erickson, J.E. Yield, Water-, and Nitrogen-use Efficiency in Field-grown, Grafted Tomatoes. HortScience 2013, 48, 485-492. [CrossRef]

45. Colla, G.; Suárez, C.M.C.; Cardarelli, M.; Rouphael, Y. Improving Nitrogen Use Efficiency in Melon by Grafting. HortScience 2010, 45, 559-565. [CrossRef]

46. Zhu, X.; Song, F.; Liu, S.; Liu, F. Arbuscular mycorrhiza improve growth, nitrogen uptake, and nitrogen use efficiency in wheat grown under elevated $\mathrm{CO}_{2}$. Mycorrhiza 2015, 26, 133-140. [CrossRef]

47. Liu, H.; Song, F.; Liu, S.; Li, X.; Liu, F.; Zhu, X. Arbuscular mycorrhiza improves nitrogen use efficiency in soybean grown under partial root-zone drying irrigation. Arch. Agron. Soil Sci. 2018, 65, 269-279. [CrossRef]

48. Miceli, A.; Romano, C.; Moncada, A.; Piazza, G.; Torta, L.; D’Anna, F.; Vetrano, F. Yield and quality of mini-watermelon as affected by grafting and mycorrhizal inoculum. J. Agric. Sci. Technol. 2016, 18, 505-516.

49. Colla, G.; Rouphael, Y.; Di Mattia, E.; El-Nakhel, C.; Cardarelli, M. Co-inoculation of Glomus intraradices and Trichoderma atroviride acts as a biostimulant to promote growth, yield and nutrient uptake of vegetable crops. J. Sci. Food Agric. 2015, 95, 1706-1715. [CrossRef] [PubMed]

50. Al-Karaki, G.N. Nursery inoculation of tomato with arbuscular mycorrhizal fungi and subsequent performance under irrigation with saline water. Sci. Hortic. 2006, 109, 1-7. [CrossRef]

51. Kaya, C.; Ashraf, M.; Sonmez, O.; Aydemir, S.; Tuna, A.L.; Cullu, M.A. The influence of arbuscular mycorrhizal colonisation on key growth parameters and fruit yield of pepper plants grown at high salinity. Sci. Hortic. 2009, 121, 1-6. [CrossRef]

52. Baum, C.; El-Tohamy, W.; Gruda, N. Increasing the productivity and product quality of vegetable crops using arbuscular mycorrhizal fungi: A review. Sci. Hortic. 2015, 187, 131-141. [CrossRef]

53. Sbrana, C.; Avio, L.; Giovannetti, M. Beneficial mycorrhizal symbionts affecting the production of health-promoting phytochemicals. Electrophoresis 2014, 35, 1535-1546. [CrossRef]

54. Walter, M.; Fester, T.; Strack, D. Arbuscular mycorrhizal fungi induce the non-mevalonate methylerythritol phosphate pathway of isoprenoid biosynthesis correlated with accumulation of the 'yellow pigment' and other apocarotenoids. Plant J. 2000, 21, 571-578. [CrossRef]

55. Copetta, A.; Lingua, G.; Berta, G. Effects of three AM fungi on growth, distribution of glandular hairs, and essential oil production in Ocimum basilicum L. var. Genovese. Mycorrhiza 2006, 16, 485-494. [CrossRef]

56. Toussaint, J.P.; Smith, F.A.; Smith, S.E. Arbuscular mycorrhizal fungi caninduce the production of phytochemicals in sweet basil irrespective of phosphorus nutrition. Mycorrhiza 2007, 17, 291-297. [CrossRef] [PubMed] 
57. Rasouli-Sadaghiani, M.; Hassani, A.; Barin, M.; Rezaee Danesh, Y.; Sefidkon, F. Effects of arbuscular mycorrhizal (AM) fungi on growth, essential oil production and nutrients uptake in basil. J. Med. Plant Res. 2010, 4, 2222-2228.

58. Baslam, M.; Garmendia, I.; Goicoechea, N. Arbuscular Mycorrhizal Fungi (AMF) Improved Growth and Nutritional Quality of Greenhouse-Grown Lettuce. J. Agric. Food Chem. 2011, 59, 5504-5515. [CrossRef] [PubMed]

59. Castellanos-Morales, V.; Villegas, J.; Wendelin, S.; Vierheilig, H.; Eder, R.; Cardenas-Navarro, R. Root colonization by the arbuscular mycorrhizal fungus Glomus intraradices alters the quality of strawberry fruit (Fragaria $\times$ ananassa Duch) at different nitrogen levels. J. Sci. Food Agric. 2010, 90, 1774-1782. [PubMed]

60. Ceccarelli, N.; Curadi, M.; Martelloni, L.; Sbrana, C.; Picciarelli, P.; Giovannetti, M. Mycorrhizal colonization impacts on phenolic content and antioxidant properties of artichoke leaves and flower heads two years after field transplant. Plant Soil 2010, 335, 311-323. [CrossRef]

61. Colonna, E.; Rouphael, Y.; Barbieri, G.; De Pascale, S. Nutritional quality of ten leafy vegetables harvested at two light intensities. Food Chem. 2016, 199, 702-710. [CrossRef]

62. Kyriacou, M.C.; Soteriou, G.A.; Rouphael, Y.; Siomos, A.S.; Gerasopoulos, D. Configuration of watermelon fruit quality in response to rootstock-mediated harvest maturity and postharvest storage. J. Sci. Food Agric. 2015, 96, 2400-2409. [CrossRef]

63. Carillo, P.; Colla, G.; El-Nakhel, C.; Bonini, P.; D'Amelia, L.; Dell'Aversana, E.; Pannico, A.; Giordano, M.; Sifola, M.I.; Kyriacou, M.C.; et al. Biostimulant application with a tropical plant extract enhances Corchorus olitorius adaptation to sub-optimal nutrient regimens by improving physiological parameters. Agronomy 2019, 9, 249. [CrossRef]

(C) 2020 by the authors. Licensee MDPI, Basel, Switzerland. This article is an open access article distributed under the terms and conditions of the Creative Commons Attribution (CC BY) license (http://creativecommons.org/licenses/by/4.0/). 



\title{
Grafting Tomato as a Tool to Improve Salt Tolerance
}

\author{
Hira Singh ${ }^{1}$, Pradeep Kumar ${ }^{2, *}$, Ashwani Kumar ${ }^{3}$, Marios C. Kyriacou ${ }^{4}$, Giuseppe Colla ${ }^{5}$ and \\ Youssef Rouphael ${ }^{6, *}$ \\ 1 Department of Vegetable Science, Punjab Agricultural University, Ludhiana 141004, India; hira@pau.edu \\ 2 ICAR-Central Arid Zone Research Institute, Jodhpur 342003, India \\ 3 ICAR-Central Soil Salinity Research Institute, Karnal 132001, India; Ashwani.Kumar1@icar.gov.in \\ 4 Department of Vegetable Crops, Agricultural Research Institute, 1516 Nicosia, Cyprus; \\ m.kyriacou@ari.gov.cy \\ 5 Department of Agriculture and Forest Sciences, University of Tuscia, 01100 Viterbo, Italy; giucolla@unitus.it \\ 6 Department of Agricultural Sciences, University of Naples Federico II, 80055 Portici, Italy \\ * Correspondence: pradeephort@gmail.com (P.K.); youssef.rouphael@unina.it (Y.R.)
}

Received: 16 December 2019; Accepted: 11 February 2020; Published: 12 February 2020

\begin{abstract}
Salinity in soil or water is a serious threat to global agriculture; the expected acreage affected by salinity is about $20 \%$ of the global irrigated lands. Improving salt tolerance of plants through breeding is a complex undertaking due to the number of traits involved. Grafting, a surgical mean of joining a scion and rootstock of two different genotypes with the desired traits, offers an alternative to breeding and biotechnological approaches to salt tolerance. Grafting can also be used to circumvent other biotic and abiotic stresses. Increasing salinity tolerance in tomato (Solanum lycopresicum L.), a highly nutritious and economical vegetable, will have greater impact on the vegetable industry, especially in (semi) arid regions where salinity in soil and water are more prevalent. Besides, plants also experience salt stress when water in hydroponic system is recycled for tomato production. Grafting high yielding but salt-susceptible tomato cultivars onto salt-resistant/tolerant rootstocks is a sustainable strategy to overcome saline stress. Selection of salt-tolerant rootstocks though screening of available commercial and wild relatives of tomato under salt stress conditions is a pre-requisite for grafting. The positive response of grafting exerted by tolerant rootstocks or scion-rootstock interactions on yield and fruit characteristics of tomato under saline conditions is attributed to several physiological and biochemical changes. In this review, the importance of tomato grafting, strategies to select appropriate rootstocks, scion-rootstock interaction for growth, yield and quality characteristics, as well as the tolerance mechanisms that (grafted) plants deploy to circumvent or minimize the effects of salt stress in root zones are discussed. The future challenges of grafting tomato are also highlighted.
\end{abstract}

Keywords: Tomato grafting; salinity tolerance; rootstock; physio-biochemical mechanisms; Solanum lycopresicum L.

\section{Introduction}

Salinity in soil or water is a serious threat to plant growth that prevents plants in achieving their genetic potential. Salinity annually damages about $20 \%$ of the world's crops grown under irrigation [1]. The high salt content of productive arable lands could render half of this land unusable for agriculture by 2050 [1]. In the world's arid and semiarid areas, less rain, high evaporation, saline irrigation water and inefficient management of water leads to salinity problems. Approximately $20 \%$ of the total cultivated lands and $33 \%$ of the irrigated agricultural lands worldwide are afflicted by high salinity and such areas are increasing at a rate of $10 \%$ per year [2]. It is estimated that about 3 ha of productive land per minute is lost due to salinity [3]. Thus, it is imperative to take appropriate measures timely to improve the salt tolerance of crops [4], especially tomato (Solanum lycopersicum 
L.), which enjoys the prime position worldwide among different vegetables owing to having high nutritional and economical significance.

Tomato is a member of the nightshade family and cultivated for fresh and processing purposes as an annual crop [5]. Additionally, this crop is used as a model plant to study physiology to molecular genetics and genomics in the angiosperms [6,7]. Salinity represents a substantive threat to tomato production [8]; it causes considerable reductions in tomato growth and yield [2]. Most commercial cultivars of tomato are considered to be moderately sensitive to salt stress, which affects seed germination and the vegetative and reproductive stages of growth $[5,9,10]$. Ongoing efforts to improve salt tolerance in tomato using plant breeding, biotechnological approaches and other management practices have met with limited success due to the genetic and physiological complexity of the traits involved in salt tolerance $[4,7,10,11]$. According to Rao et al. [12], improvement of salt tolerance using plant breeding is an intricate task because of the high number of traits involved, their quantitative nature, epistatic gene action, low to moderate heritability and high sensitivity to the environment. Genetic engineering has been used to increase salt tolerance in plants and has claimed some success [11,12], but its commercial success is still to be witnessed.

An environmentally friendly, sustainable and effective method is grafting that enables to exploit the benefit of resistant genotypes (as rootstocks) to improve the performance of commercial cultivars (as scion) that are susceptible to (a)biotic stresses [13]. Grafting offers an alternative to breeding and biotechnological approaches to rapidly enhance salt tolerance in vegetable plants $[8,11,14-16]$. This technique in woody perennial fruit plants has been a routine practice in Asia for more than 2000 years [14]. In herbaceous vegetables, grafting initially was practiced in 1920s in watermelon to increase resistance to soil-borne diseases [17]. After the first scientific publication about grafting [14,17], use of the technique spread to other cucurbitaceous and solanaceous vegetable crops to address soil-borne diseases and other environmental stresses [18,19]. Commercial tomato grafting became popular in the 1960s in East Asia, Europe and later in North America [20,21]. Application of vegetable grafting has spread in many countries by the end of the 1990s, but it got momentum only after the banning of methyl bromide (MB) in the Montreal protocol in 2005, particularly in developed countries. Although, the protocol was authorized until 2015 in developing countries, with the efforts of United Nations Industrial Development Organization (UNIDO), United Nations Development Program (UNDP), World Bank and lateral agencies from Europe, many developing countries (some of Latin America, Africa, Middle East and Asia) were able to control the use of MB well before 2015, and started using grafting as an alternative to MB [18]. MB was the most commonly used soil fumigant against deadly soil borne pathogens prevailing in intensive vegetables production in protected cultivation [22]. Besides, being a sustainable practice, grafting is a useful component of organic vegetable production, particularly of tomato. In recent pasts, the horizon of grafting use expanded to abiotic stresses too and among which, salinity got the most priority. For instance, watermelon produced in countries like Japan, Korea, Turkey, Greece and parts of Spain and Italy with almost $100 \%$ grafted seedlings, and the use of grafted plants is also increasing immensely in other vegetables like tomato, eggplant, pepper, cucumber and melons across the world [23]. In major countries where grafting is a popular technique, out of the total tomato cultivation proportion share of grafted tomato seedlings use is around 1\% in China, though it also ranks first in the number of grafted seedlings used, 25\% in Korea, 33\% in Vietnam, 40\% in Japan, 50\% in France and 75\% in Netherlands. In other countries like the USA, Italy, Morocco and Spain the uses of grafted seedlings were available in numbers, i.e., 18, 15.1, 44, 72.8 and millions [24,25]. In this review, we present an outline of the potential of a grafting tool to enhance salt tolerance in a tomato based on recent researches done across the world. We also propose a strategy for future research as well as adoption for its better exploitation for the growth of the agriculture sector. 


\section{Effect of Salinity on Tomato Plants}

Salinity is the most serious of all environmental stresses [26] and poses a great threat to agricultural sustainability [27]. It occurs when there is an excessive accumulation of salts (especially high $\mathrm{Na}^{+}$, $\mathrm{Cl}^{-}$and $\mathrm{SO}_{4}{ }^{-}$) in the soil [28] or irrigation water [11,16]. The elevated level of salts generally causes a reduction of water potential in the root medium, thereby leading to a water deficit within plants [5,29], besides their excess level can cause ion-toxicity and nutrient imbalance, especially of $\mathrm{K}^{+}, \mathrm{Ca}^{2+}$ and $\mathrm{Mg}^{2+}$ by disturbing their uptake and/or transport to the shoots [30].

In general, the main factor of inhibiting growth of salt stressed plants is elevated levels of $\mathrm{Na}^{+}$and $\mathrm{Cl}^{-}$; with roots remaining the primary sites for stress perception [31] and the subsequent responses at the cell, organ or whole plant levels [32]. According to the two-phase model of salt-induced growth reduction, plants suffer initially due to osmotic stress impairing their ability to absorb sufficient water, and then from salt specific injuries ascribed to, in general, toxic levels of $\mathrm{Na}^{+}$and $\mathrm{Cl}^{-}$interfering with key cellular processes and causing damage to the cell membranes and organelles; altering nutrient ratios, endogenous growth regulator concentrations and enzymatic activities and suppressing photosynthetic assimilation and causing plant death in the extreme cases [33]. In fact, the second phase of salinity stress, i.e., ion-specific toxicity, is a long-term process and depends on the intracellular salt ion levels, which mostly tend to increase with an increase in the magnitude and duration of salinity stress.

Salinity has been reported to disturb plants physiological and biochemical processes and induce changes in morphological characteristics that finally lead to losses in yield $[2,27,28,34]$. Salt stress causes decrease in plant height, shoot and root biomass and root length in tomato plants [35]. According to Najla et al. [36] salinity adversely affected plant height and leaf area, and the overall development process of tomato plants. However, the salinity induced decrease in plant height was more related to reduced internodal length than the number of nodes, and lower plant growth rate was associated with a decrease in leaflet growth and the number of leaflets per leaf in salt stressed plants [36]. The adverse effects of salinity on shoot and root morphology were the result of an alteration of plant physiology that includes altered absorption of water and nutrients, hormonal production and disrupted root to shoot signals [37]. Salt induced inhibition in photosynthesis and oxidative stress has been widely documented. Salt stress can also alter leaf metabolites concentrations as have been reported by Khavari-Nejad and Mostofi [38]. They observed a notable decrease in the level of chlorophyll and $\beta$-carotene contents, along with an increase of soluble sugars and total saccharides in the leaves of tomato plants treated with $100 \mathrm{mM} \mathrm{NaCl}$. In addition, aggregated chloroplasts and distorted and wrinkled cell membranes were also noticed in tomato leaves by these researchers. In spite of inhibiting plant height and shoots and roots dry matter contents, excess salt concentration in water reduced water use efficiency (WUE) and amount of $\mathrm{K}^{+}$and $\mathrm{K} / \mathrm{Na}$ ratio in all studied tomato cultivars [39]. The accumulation of monovalent and bivalent $\mathrm{Na}^{+}, \mathrm{K}^{+}$and $\mathrm{Ca}^{2+}$ ions in foliage and roots under saline conditions was, though, genotype-dependent [40]. Further, salinity affects almost all the plant growth stages, but the severity depends on the growth stage, salinity level and cultivar [35]. However, despite the inhibitory effects of salinity on growth and yield, the enhancement of some fruit quality characteristics (i.e., higher levels of sugars and organic acids) in tomato have been reported [41]. An increase of up to $40 \%$ carotenoid content in fruits of tomato plants exposed to moderate salinity has also been observed $\left(4.4 \mathrm{dS} \mathrm{m}^{-1}\right)$ [42].

\section{Grafting to Improve Salt Tolerance in Tomato}

\subsection{Growth and Yield}

The persuasive response of grafting on plant growth and yield characteristics under saline conditions can vary; this can be the result of intrinsic characteristics of scion, rootstock and their functional interactions, and severity of saline stress. A wide range of studies suggests that the adverse effects of salt stress on vegetable plants can be mitigated by grafting. Improved plant growth and yield performance of susceptible tomato cultivars under salt stress is the manifestation of positive response 
of grafting; these ascribed to the right choice of scion-rootstocks combination [11]. Concerning the response of scion-rootstock combination on tomato growth and yield, grafting 'Cuore di Bue' scion onto 'Arnold' rootstock was found superior to either non-grafted or those grafted onto other rootstocks ('Maxifort' and 'Armstrong') under a moderate salinity level $(20 \mathrm{mM} \mathrm{NaCl})$, while the response of rootstock grafting was not evident at higher $\mathrm{NaCl}$ concentration (40 mM) [43]. The response of different rootstocks to salt susceptible scion 'Moneymaker' varied for yield and fruit parameters under saline conditions; graft combination involving 'Beaufort' and 'He-man' rootstocks was more productive under a mild saline condition. However, between two, only 'He-man' rootstock could provide sustenance to susceptible scion 'Moneymaker' for fruit yield under a high level of salinity. Contrarily, 'HPG' and 'Energy' rootstocks grafted tomatoes showed negative effect and produced lower yields [15].

Salt stress decreased both vegetative growth (i.e., stem diameter, plant height and shoot fresh weight) and fruit yield of both grafted and non-grafted plants. At this salinity level $\left(3.76 \mathrm{dS} \mathrm{m}^{-1}\right)$, no significant decrease in fruit yield was noticed in grafted plants ('Faridah' scion onto 'Unifort' rootstock) [10]. Concerning scion-rootstock combinations, a significant variation in plant growth (e.g., stem growth rate) was observed under saline conditions by Balliu et al. [44], who revealed that 'Charlotte' grafted onto 'Cyndia' exhibited higher mean stem growth rate than non-grafted plants. However, no difference in this parameter was noted between grafted and non-grafted tomato plants under normal (non-saline) condition. These authors, further stated that 'Bona' plants grafted onto 'Energy' rootstock produced higher mean yield compared to non-grafted plants, while this combination displayed lowest stem growth rate. The other scion, 'Charlotte', gave the maximum yield with rootstock 'Prospero' under saline conditions. The performance of salt sensitive cultivar 'Moneymaker' improved in terms of both plant growth and fruit yield under salt stress ( $50 \mathrm{mM} \mathrm{NaCl})$, when it was grafted onto the salt tolerant rootstock 'Pera' [45]. Santa-Cruz et al. [46] reported that the 'UC-82B'/'Kyndia' (scion/rootstock) combination showed a tolerance response to excess salt (100 mM $\mathrm{NaCl}$ ) by producing higher shoot growth and fruit yield than the rest of the other graft combinations. Among yield-contributing traits, fruit weight was found to be the single factor to determine yield, while the number of fruits affected was not significantly affected by salt stress; as also was obvious in this study where graft combination 'UC-82B'/'Kyndia' exhibited higher fruit weight. Al-Harbi et al. [10] concluded that tomato could be grown successfully with a satisfactory yield by grafting onto suitable rootstock under salt stress (EC $3.76 \mathrm{dS} \mathrm{m}^{-1}$ ). While comparing the response of tomato grafting onto different rootstocks under saline conditions in indoor or outdoor grown plants, Voutsela et al. [47] revealed that tomato fruit yield was significantly higher in grafted plants than non-grafted plants in both indoor and outdoor grown plants under salt stress $(6.0 \mathrm{mS} / \mathrm{cm})$. The benefit of grafting for increased fruit yield over non-grafted plants under salt stress was more pronounced in indoor condition (from $208 \%$ to $259 \%$ ) than outdoor condition (from $0 \%$ to $149 \%$ ). These workers have also reported significantly higher fruit yield in salt stressed self-grafted plants than non-grafted plants regardless of growing conditions. However, Iseri et al. [48] stated that enhanced salt tolerance and adaptive response of tomato scions was rootstock dependent rather than graft-induced changes per se. These reports indicate that selection of rootstocks and scion cultivars to be made reasonably for harnessing the benefit of grafting in tomato under saline conditions.

\subsection{Fruit Quality}

Despite the reduction of the fruit yield, enhancement of fruit quality traits is a general response of mild stress (i.e., water and salt); these are due to the accumulation of more metabolite contents under stress conditions. The interaction between grafting and salinity for fruit quality traits may be positive, negative or even neutral under stress conditions. The response of grafting on growth and fruit yield was positive when tomato cultivar 'Cuore di Bue' grafted onto 'Arnold' rootstock, whereas no obvious effect of grafting was observed in this graft combination on fruit quality traits (i.e., total soluble solids, fruit dry matter percentage, titratable acidity and TA) at any of the levels of $\mathrm{NaCl}$ (i.e., 0,20 or $40 \mathrm{mM}$ ) added medium [43]. Similarly, grafting 'Durinta' onto 'He-man' rootstock showed promising 
response for yield traits, especially under high saline medium $\left(8.8 \mathrm{dS} \mathrm{m}^{-1}\right)$, but the fruits of this graft combination had low titratable acidity content [15]. Turhan et al. [49] have also reported a reduction in the tomato fruit quality in grafted plants than non-grafted plants under salt stress. Contrary to these, findings of Balliu et al. [44] reported positive response of both grafting and salinity level; the fruit quality characteristics namely fruit dry matter percentage, vitamin $C$ and total soluble solids contents increased in grafted plants with the increase of $\mathrm{NaCl}$ concentration from 0 to $5 \mathrm{mM}$. Flores et al. [50] noticed that grafting 'Moneymaker' onto 'UC82B' did not increase fruit yield either under optimal or saline condition, fruit yield rather decreased in grafted plants, but fruit quality parameters (i.e., soluble solid content and titratable TA) were higher in grafted plants, more conspicuously under salt stress condition ( $50 \mathrm{mM}$ ). However, grafting 'Moneymaker' onto 'Radja' rootstock was found as promising as both fruit yield and quality were increased in this graft combination under a saline condition ( 25 and $50 \mathrm{mM} \mathrm{NaCl}$ [ [50]. The inference drawn from these is that the combination of scion and rootstock should be selected carefully to get the maximum benefit of the grafting technique.

\section{Mechanisms of Salt Tolerance in Grafted Plants}

In order to overcome the harmful effects of salinity, grafted tomato plants employ certain adaptive strategies such as salt exclusion or retention, osmotic adjustment, activation of antioxidant defense system, nutrient homeostasis, plant hormonal balances and a gene expression led favorable response. Roots being the primary plant organ have to face any soil related stress (e.g., salinity); their intrinsic characteristics would determine overall plants performance.

\subsection{Morpho-Physiological Traits}

\subsubsection{Root System Architecture and Salt Tolerance}

Performance of grafted plants compared to non-grafted or self-grafted plants under a stressful condition is often dependent on the rootstock's root system characteristics; a vigorous root system could be the most important criterion for increasing salt tolerance [44]. The rootstock's root systems architecture specified by root length and density, root hairs and root surface area plays a critical role in ion and water uptake, thus determining salt tolerance of grafted plants [11,51]. A vigorous root system, for instance, produced more cytokinins and transported water to the shoot system by xylem sap, which positively affected plant growth and crop yield [44,52]. Furthermore, hydraulic conductivity of the roots may control plant growth by manipulation of the water supply to epigeous plant parts [53]; however, this process is still not clear. Roots being the primary organ exposed to salt stress, salt induced inhibition of root growth is quite obvious. For instance, salt stress (100 and $150 \mathrm{mM} \mathrm{NaCl})$ invariably reduced root growth of both control and grafted tomato plants, but the rate of root dry mass reduction was lesser in grafted plants (on 'ZhezhenNo.1' rootstock) than non-grafted plants. However, no effect of grafting was observed on either epigeous or hypogeous dry mass under non-saline $(0 \mathrm{mM}$ $\mathrm{NaCl}$ ) conditions [51]. Martínez-Rodríguez et al. [54] studied tomato rootstocks 'Radja' and 'Pera' for salt tolerance and they found that 'Radja' had a unique root genotype for salt tolerance with the ability to decrease salt ion transportation to the shoot system, as indicated by a lower ion concentration in the leaves. 'Pera' has the ability to improve salt tolerance in plants cultivated at any salt stress level. Tomato scion (cv. 'Faridah') grafted onto rootstock 'Unifort' was less affected by excess salt than the non-grafted scion; reflecting that 'Unifort' roots had a better capacity to limiting the transport of $\mathrm{Na}^{+}$and $\mathrm{Cl}^{-}$to above-ground parts [10]. Similar results were also recorded in cucumber grafted onto a figleaf gourd differing in their ability to regulate water and salt absorption and subsequent translocation to the scion [55].

\subsubsection{Plant Water Relations}

Plant water relations can be measured through root hydraulic conductance by estimating the nutrient and water uptake in grafted plants [56]. Rootstocks confer to grafted plants a stronger 
and larger root system, which provide an increase in minerals and water uptake in comparison to non-grafted plants [57]. Rootstocks mainly set roots physical characteristics, such as its enhanced uptake capacity or vertical and lateral expansion, rendering water uptake more facilitated. Water and nutrients uptake have been found more efficiently in a vigorous rootstock than scion roots [58]. Root hydraulic conductance was higher in grafted plants due to higher resistance of the graft union to water-flow [59]. Shalhevet et al. [60], Munns and Passioura [61] and Evlagon et al. [62] reported that hyperosmotic stress and ionic imbalance caused by the high apoplastic concentrations of $\mathrm{Na}+$ and $\mathrm{Cl}^{-}$. The decrease in root hydraulic conductance could be closely related to the decrease in the activity or concentration of aquaporins in the root plasma membrane due to increased salinity [63]. An experiment conducted by Estañ et al. [64] on tomato illustrated that, in order to exclude salts, various tomato genotypes' roots were used as rootstocks for a commercial tomato hybrid (cv. 'Jaguar'). Estañ and his collaborators noted that especially at 50 and $75 \mathrm{mM} \mathrm{NaCl}$, the 'Jaguar'/'Jaguar' combination plants demonstrated equal or paradoxically higher leaf water contents than the other grafting combinations, indicating that the 'Jaguar' rootstock was capable in salinity conditions to maintain water uptake. The rootstock-scion vascular connection played an important role in determining water and nutrient translocation, which mainly depends on the rootstock's vigorous root system [58,65], enhanced production of endogenous-hormones [66] and enhancement of scion vigor [67].

\subsubsection{Ion Uptake}

Studies have shown that rootstocks protect the scion shoots from salt damage mainly by reducing the ionic stress, and to some extent, by increasing the translocation of $\mathrm{K}^{+}, \mathrm{Ca}^{2+}$ and $\mathrm{Mg}^{2+}$ to the shoots and leaves; whereas they have little role in reducing the osmotic stress $[68,69]$. Reduced translocation of $\mathrm{Na}^{+}$and/or $\mathrm{Cl}^{-}$to the shoot system is achieved either by exclusion or restricted absorption by the roots [54,64]. Pérez-Alfocea et al. [70] opined that depending on the salt source plants employ its intrinsic potential to exclude $\mathrm{Na}^{+}$and/or $\mathrm{Cl}^{-}$from shoots by maintaining energy consuming the root toxic ion efflux. The positive effects of grafting on salt tolerance in a tomato was widely attributed to restricted entry of $\mathrm{Na}^{+}$and $\mathrm{Cl}^{-}$ion in epigeous biomass [10,64,71], though grafted plants were able to accumulate more nutrient elements (e.g., $\mathrm{Ca}^{2+}$ and $\mathrm{K}^{+}$) in the leaves than normal plants under saline stress [10]. Similarly, tomato cultivars 'Fanny' and 'Goldmar' grafted onto rootstock 'AR-9704' showed differential accumulation of $\mathrm{Na}^{+}$and $\mathrm{Cl}^{-}$, with $\mathrm{Cl}^{-}$and $\mathrm{Na}^{+}$concentrations being significantly higher in non-grafted than in grafted plants in both the cultivars and 'Fanny', respectively [72]. Semiz and Suarez [73] reported improved performance of tomato scion cv. 'Big Dena' grafted onto 'Maxifort' rootstock across five tested salinity levels; the positive response of grafting was attributed to a lesser concentration of $\mathrm{Na}^{+}$in the leaves of a grafted tomato than non-grafted plants. However, these researchers could not find any relation between $\mathrm{Cl}^{-}$in irrigation water and yield in a tomato. Apart from osmotic balance and root exclusion or restricted root-to-shoot translocation of the toxic ion (i.e., $\mathrm{Na}^{+}$), the third strategy that plants employ is ion accumulation and subsequent partitioning among the plant organs or compartmentalization in cellular organs such as vacuoles that eases toxic effects of salts. For instance, tomato scions grafted onto rootstock 'Arnold' tended to partition a bulk of shoot $\mathrm{Na}^{+}$into older leaves and thus reduced $\mathrm{Na}^{+}$levels in the actively growing younger leaves. This allowed the grafted plants to maintain favorable $\mathrm{K}^{+} / \mathrm{Na}^{+}, \mathrm{Ca}^{2+} / \mathrm{Na}^{+}$and $\mathrm{Mg}^{2+} / \mathrm{Na}^{+}$ratios in actively growing leaves [43].

The response of salt stress varies widely among Solanum species [37], besides salt concentration and exposure period also exert a severity response [64,74] In contrast to cultivated tomatoes (Solanum lycopersicum L.) that are moderately sensitive to salt stress, certain wild species are reportedly salt resistant. Unlike the cultivated tomato that generally excludes the salt ions $[2,54,75,76]$, most of the wild types (e.g., S. peruvianum [77], S. cheesmaniae [78], Lycopersicon pimpinellifolium, L. hirsutum and L. pennellii [79]) accumulate higher concentrations of $\mathrm{Na}^{+}$and $\mathrm{Cl}^{-}$in the leaves. However, there are some salt tolerant tomato ecotypes (e.g., 'Edkawy' and 'Pera') $[75,80,81]$ that exhibit a pronounced salt inclusion capacity similar to the salt-loving wild species. This implies that tolerance or sensitivity to 
salt would depend on the ability of a genotype (excluder or includer) to maintain benign ion levels through mechanisms like root exclusion, phloem recirculation and dilution such that physiological homeostasis is not disturbed [82]. If ion levels exceed the critical threshold, salt tolerance capacity diminishes, adversely affecting growth and fruiting. Use of salt tolerant types as rootstocks can protect the sensitive types from deleterious effects of salinity [54,64].

He et al. [51] found that with the enhancement of $\mathrm{NaCl}$ concentration, the $\mathrm{Na}^{+}$levels in leaves and roots increased considerably. They estimated that non-grafted, self-grafted and plants of scion-rootstock combinations elicited the same levels of $\mathrm{Na}^{+}$in leaves and roots under similar salt concentrations, whereas $\mathrm{K}^{+}$concentration in both leaves and roots decreased considerably with higher $\mathrm{NaCl}$ levels. Nevertheless, the roots of scion-rootstock grafted plants showed more $\mathrm{K}^{+} / \mathrm{Na}^{+}$ratio and water use efficiency (WUE) at $150 \mathrm{mM} \mathrm{NaCl}$ concentration than non-grafted and self-grafted plants.

In another study, Santa-Cruz et al. [46] selected tomato cultivars 'Moneymaker' (indeterminate growth habit, shows excluder character under salt stress) and 'UC-82B' (determinate growth habit and shows includer behavior) as scions, and tomato hybrid 'Kyndia' as a rootstock for the study of grafting behavior under 50 and $100 \mathrm{mM} \mathrm{NaCl}$ salt stress. Grafting had a positive effect on salt tolerance of scion 'UC-82B' grafted onto 'Kyndia' rootstock in terms of the shoot biomass at a $100 \mathrm{mM} \mathrm{NaCl}$ concentration. The same combination was noted for higher water content in leaves under salt stress compared to self-grafted 'UC-82B' plants. Accumulation of $\mathrm{Na}^{+}$and $\mathrm{Cl}^{-}$ions in leaves varied with the graft combination. Lower $\mathrm{Na}^{+}$and similar $\mathrm{Cl}^{-}$concentration was found in the 'Moneymaker' and 'Kyndia' combination as compared to self-grafted 'Moneymaker' plants. However, this response was different for the 'UC-82B' and 'Kyndia' combination, which elicited lower accumulation of both $\mathrm{Na}^{+}$ and $\mathrm{Cl}^{-}$ions. $\mathrm{Na}^{+} / \mathrm{K}^{+}$ratio in leaves of this combination decreased three times compared to self-grafted plants of 'UC-82B'. The toxic effect of ions was mitigated by the 'UC-82B' and 'Kyndia' combination.

The improvement in salt tolerance of tomato plants was related to a high leaf $\mathrm{K}^{+}$content in many studies $[51,83,84]$, though the direct relationship between leaf $\mathrm{K}^{+}$homeostasis and salinity tolerance of grafted plants has not been yet adequately worked out [11]. Studying the response of tomato cv. 'Faridah' onto 'Unifort' rootstock under saline conditions, fruit yield, $\mathrm{Ca}^{2^{+}}$and $\mathrm{K}^{+}$ions were noticeably higher in grafted plants compared to non-grafted plants. Besides, accumulation of $\mathrm{Na}^{+}$and $\mathrm{Cl}^{-}$was lower than in non-grafted tomato plants, under salt stress condition [10].

\subsection{Gas Exchange Attributes}

One of the early responses of glycophytes to salt stress is manifested as a reduction in leaf growth that seems to be caused by a decrease in stomatal conductance in tomato [85]. Stomatal factors decrease the photosynthetic rate in salt treated grafted and non-grafted plants by adversely affecting $\mathrm{CO}_{2}$ diffusion into leaves as a result of impaired stomatal and mesophyll conductance [86]. Salt stress blocks photosynthesis by suppressing the electron transport chain, which leads to the photoinhibition of photosynthesis. The inhibition of photosynthesis causes a reduction in the plant growth. In previous reports, it is established that grafting of salt tolerant rootstocks can enhance the photosynthetic rate by protecting the structure of chloroplast and alleviating the oxidative damage, which ultimately leads to the delay in the rate of photoinhibition $[87,88]$.

The rate of net photosynthesis under salt stress was higher in tomato plants (cv. 'Durinta') grafted onto 'Energy', 'He-man' and 'Resistar' rootstocks, though no significant effect of grafting on epigeous dry matter was noticed [15]. High photosynthetic rates as well as WUE were reported by He et al. [51] in tomato plants (cv. 'Hezuo903') grafted onto 'Zhezhen No.1' rootstock under severe salt stress. However, comparing the response of four tomato cultivars ('Jenin1,' 'Hebron,' 'Ramallah' and 'Maramand') under four salinity levels (0, 50, 100 and $150 \mathrm{mM} \mathrm{NaCl})$, Sholi [5] reported that the higher salt tolerance (up to $100 \mathrm{mM} \mathrm{NaCl}$ ) in cultivar 'Ramallah' was attributed to the highest photosynthesis rate along with $\mathrm{K}^{+} / \mathrm{Na}^{+}$ratio than the others.

Two commercial hybrid tomato cultivars, 'Belle' and 'Gardel' scions grafted on two interspecific hybrids, 'Beaufort' and 'Maxifort' rootstock showed no significant effect on net photosynthesis and 
stomatal conductance when exposed to $\mathrm{NaCl}$ compared to the non-grafted plants [89]. Feng et al. [90] also found that salinity treated tomato scion grafted on wolfberry (Lycium chinense) rootstock displayed higher net photosynthesis, transpiration, stomatal conductance, Fv/Fm and electron transport rate in comparison with non-grafted tomato plants.

\subsection{Molecular Responses}

Salt stress sets in motion a chain of events-reduced stomatal conductance, decreased photosynthetic electron transport and increased production of harmful reactive oxygen species (ROS) — that lead eventually to plant damage and death. ROS (e.g., hydrogen peroxide and superoxide radicals), by causing oxidative damage to the proteins, nucleic acid and lipids, disturbs the plant metabolism. Both enzymatic (i.e., ascorbate peroxidase (APX), catalase (CAT), superoxide dismutase (SOD), monodehydro ascorbate reductase, dehydro ascorbate reductase and glutathione reductase (GR)) and non-enzymatic (i.e., reduced glutathione, reduced ascorbate, carotenoids and tocopherols) antioxidant systems are activated by the plants to minimize ROS-induced oxidative damage. In grafted plants, salt-induced production of ROS generally remains quite low than in non-grafted plants as evidenced by a significant increase in the antioxidant activity in salt-treated (grafted) tomatoes. While SOD and CAT activities tended to increase with an increase in salinity in grafted plants, the reverse was true for non-grafted and self-grafted plants [51]. Besides enzymatic antioxidants, a non-enzymatic antioxidant system (ascorbate peroxidase, monodehydro ascorbate reductase, reduced glutathione, etc.) is also known to remove the excess ROS [91]. Higher expression of CAT mRNA, $\mathrm{Cu} / \mathrm{Zn}-\mathrm{SOD}, \mathrm{Mn}-\mathrm{SOD}$ and higher activities of CAT, Cu/Zn-SOD, Mn-SOD and SOD have been observed in salt stressed grafted plants [92]. Grafted eggplant produced lower $\mathrm{O}_{2-}, \mathrm{H}_{2} \mathrm{O}_{2}$ and MDA compared to non-grafted seedlings when subjected to $\mathrm{Ca}\left(\mathrm{NO}_{3}\right)_{2}$ stress. Higher activities of SOD, APX and GR were also seen in grafted than in non-grafted seedlings [93]. Ruiz et al. [94] explored a salt tolerance ability in another solanaceous species: tobacco (Nicotiana spp.) and a tomato-tobacco (scion-rootstock) combination (named as 'Tomacco' by Yasinok et al. [95]). Tobacco roots, in fact, were able to restrain the concentration of $\mathrm{Na}^{+}$and $\mathrm{Cl}^{-}$, and lipid peroxidation in their leaves, besides inducing an accumulation of proline and sucrose concentrations under saline conditions [94]. The ability of tobacco roots in conferring better adaptive responses to salt stress in comparison to tomato was supported by the upregulation of proline and antioxidant enzymes (APOX and CAT) levels in grafted plants [48].

The commercial cultivars of tomato show more or less sensitivity to salt stress [96] and undergo drastic losses due to salts [97]. The genetics of this trait specific in tomato have also been discussed nicely by Cuartero et al. [34]. In tomato, a universal stress protein gene (SpUSP) cloned from S. pennellii, which is a wild relative of tomato and functionally characterized in commercial tomato genotype revealed enhanced expression under stress conditions such as dehydration, salt, oxidative and abscisic acid (ABA) treatment. About 15 primers were synthesized using fifteen salinity responsive candidate genes. The results from these primers displayed that the genotype UC82B showed the maximum vegetative growth parameters and yield, so, exploitation of this identified genotype could be as used for the salt tolerance [97]. Most recently in 2020, Yveline et al. [98] noticed that the salinity tolerant accessions collected from the Islands of Galapagos use different mechanisms to survive under salt stress conditions, which exhibited natural diversity among the Galapagos tomatoes for high salinity tolerance. They found some accessions namely LA0317, LA1449 and LA1403, which showed significantly higher tolerance under salt stress at the seedling stage. Their tolerance mechanism at the genetic and molecular level need to be studied intensively and comprehensively so that it could be helpful to develop salt tolerant commercial tomato cultivars to sustain tomato production under changing climate scenario across the globe. Such identified genotypes can be used as rootstocks in tomato grafting to raise the salinity tolerance of commercial scion cultivars after investigating their graft compatibility and subsequent effects on fruit characteristics.

Asins et al. [99] reported the genetic dissection of tomato rootstock effects on scion traits under moderate salinity. They documented that the rootstock HKT1 genotype affects the $\mathrm{Na}^{+}$level in fruits, 
which was found higher when the rootstock genotype was homozygote for SpHKT1. Along with this, they found the 37 QTLs, which controls the important rootstock-mediated scion traits such as the leaf concentration of nutrients, fruit yield, soluble-solids content of fruits and harvest time under moderate salinity.

In the salt-tolerance mechanism, it is now well established that calcium has an important role. The exogenous application of calcium can protect the plant from the negative effect of salinity [100]. The high amount of $\mathrm{Na}^{+}$can induce a calcium signaling cascade, which leads to the activation of the salt-overly-sensitive (SOS) pathway and stimulation of $\mathrm{Na}^{+} / \mathrm{H}^{+}$exchange [101]. An ER chaperone protein, Calreticulin, is considered as a regulating protein for the $\mathrm{Ca}^{2+}$ homeostasis by binding to $\mathrm{Ca}^{2+}$. Salt stress causes the calreticulin to bind with the $\mathrm{Ca}^{2+}$ ions, which later accumulated in the cell. The accumulated calcium ions act as a secondary messenger for ABA resulting into the ameliorations of salt stress [102]. Shaterian et al. [103] reported the effect of grafting and ABA on calreticulin gene expression in a potato. They observed an increase in the expression of calreticulin in salt stressed grafted plants and showed a positive association in the presence of abscisic acid.

\subsection{Growth Regulators}

During the past few decades, the role of phytohormones in modulating the union between shoot (scion) and root (rootstock) components in grafted plants has become a focal point of research: in addition to regulating key metabolic processes at the graft union, endogenous plant bio-regulators (e.g., auxins, gibberellins, cytokinins and ethylene) are also involved in signal transduction across the graft union [104]. Functions of some important phytohormones in grafted plants are briefly summarized in the following sections:

Auxins: While other phytohormones play minor roles, auxins, both alone and in interaction with other phytohormones, remain central to vascular tissue regeneration and connection, and thus to the growth and development of vascular tissues [105]. Two main protein families (PIN-FORMED auxin transport proteins (PINs) and proteins of ATP-binding cassette subfamily B (ABCB)) regulate a process called 'polar auxin transport' (PAT) that ensures the maintenance of adequate auxin levels for the proper development of xylem tissues [106]. For example, increased expression of CcPIN1b and CcLAX3 genes encoding the efflux carriers for PAT was found to induce graft union development in Carya cathayensis [107]. Similarly, Sauer et al. [108] found higher PIN1 expression at damaged stem portions to activate the process of xylem cell differentiation in pea (Pisum sativum). Transcriptome analysis of grafted Torreya grandis plants indicated that auxins modulate the key MAPK signaling pathway during graft development [109]. Auxins are also believed to enhance graft union by regulating metabolic pathways linked to phenylpropanoids, cytochrome P450 and carbohydrates. Available evidence suggests that besides promoting the formation of lateral roots, auxins also regulate xylem development and cambium growth, processes critical to the success of grafting in plants [104].

Cytokinins: The significant role of cytokinins (CKs) in callus proliferation at the graft union can be ascribed to their increased biosynthesis during the process of wound healing and to the elevated zeatin riboside levels at the graft unions [105]. CKs are known to stimulate the regeneration of vessels and sieve tubes. Moreover, CKs interact with the auxins to promote the vascular differentiation and increase the phloem/xylem ratio [110]. Increased levels of CKs in the rootstock xylem tend to induce auxin translocation from the aerial parts that in turn promotes the development of graft union [111]. Exogenously applied CKs accelerate the graft union and growth by enhancing the callus formation, phloem regeneration and soil nutrient supply to the scion [112,113]. While CKs alone are often less effective in modulating the development of vascular tissues, they act synergistically with other phytohormones (e.g., auxins) to enhance the cell division, xylem fiber development, cambium activity and regeneration of phloem/xylem tissues at the site of injury [114].

Since salinity stress decreased plant CK status, increasing root-to-shoot CK transport by using a rootstock overexpressing the CK biosynthesis genes such as isopentenyltransferase improved tomato salt tolerance by increasing vegetative and fruit growth and also delaying leaf senescence and 
maintaining stomatal conductance and PSII efficiency, thereby avoiding or delaying the accumulation of toxic ions [115].

Gibberellins: Gibberellins (GAs) are known to regulate the processes like cambium activity, xylem fiber differentiation and expansion, and secondary growth. Frequent movement of GAs across the graft union is believed to contribute to the union of shoot and root components, and to the normal development of vascular tissues; as evidenced by their involvement in the reunion of cortex in cucumber and tomato $[116,117]$. Since they hasten xylogenesis, GAs might also trigger vascular bundles formation at the graft union [118]. Experiments with mutants lacking GA-biosynthetic enzymes and wild type pea plants pointed to the role of GAs in regulating the normal growth of vascular tissues, induce the processes of wood formation, xylem expansion and cambial activity [119]. Development of a particular vascular tissue also depends on the ratio of auxins and GAs; while a higher IAA:GA ratio hastens xylem formation, low IAA:GA ratio promotes phloem formation [120]. These two hormones also act synergistically to regulate the cell division and secondary growth of the vascular tissues. For instance, GAs stimulate PAT by up-regulating the key auxin transporter PIN1 in the cambial region [119]. Up-regulation of the expression of GA20OX, a gene involved in GA-biosynthesis, points to increased biosynthesis of GAs at the site of graft union. Up-regulation of Cla015407, a gene encoding enzyme gibberellin 3-beta-hydroxylase involved in the conversion of GA20 to GA1, in grafted watermelons also supports the positive role of GAs in the growth and development of composite plants [121].

Abscisic acid: There is little evidence for any direct role of ABA in the growth and development of grafted plants; however, ABA seems to be indirectly involved in the processes of wound formation and vascular differentiation: abiotic stresses in general including wounding tend to hasten ABA biosynthesis [122]. In contrast to ABA-deficient mutants, wild type plants display increased expression of wound-activated genes in response to ABA application [122,123]. Salinity enhances ABA concentration in shoot limiting water loss through transpiration (by inducing stomatal closure) and maintaining leaf water relations in plants grown under saline conditions. Chen et al. [124] reported that the scion genotype, and its ABA level, played the major role in the growth of grafted plants, regardless of the rootstock genotype and the salinity of the growth medium. Although ABA has been suggested to restrict the synthesis of the potential growth inhibitor ethylene, thus maintaining growth, in other circumstances such as citrus leaf abscission under salinity, ABA apparently stimulates 1-aminocyclopropane-1-carboxylic acid (ACC) synthesis [85]; these authors also reported that ratios between CKs and the ethylene precursor ACC were most closely correlated with both leaf biomass and PSII efficiency $(\mathrm{Fv} / \mathrm{Fm})$ of tomato grown under saline conditions whereas the ratio ACC/ABA was negatively correlated with leaf biomass.

Ethylene: Although ethylene signaling is implicated in tissue reunion in the wounded stems, it is hardly of any significance in the grafted hypocotyls, suggesting that differential roles of ethylene might be due to the differences in tissue age and type. Transcriptomic analyses of grafted Arabidopsis hypocotyls showed that ethylene biosynthesis genes are activated at the point of graft union [125]. However, mutating ANAC071 reduced the formation of vascular tissues at the graft junction [126]. Under salinity, ethylene production is quickly stimulated in plant tissues [127]. Ungrafted tomato genotype cv. Boludo F1 had 40\% higher ACC concentration in the xylem sap in comparison with plants grafted onto some low and high vigor rootstocks (derived from the recombined inbred line (RIL) population of Solanum lycopersicum $\times$ Solanum cheesmaniae) after growing for 50 days under moderate salinity $(75 \mathrm{mM} \mathrm{NaCl})$. Accumulation of the ethylene precursor ACC indicated the onset of salt-induced oxidative damage in the leaves, preceding leaf senescence induction and leaf growth impairment under salinity [85].

A summary of the main agronomic effects and physiological and molecular mechanisms of tomato grafted plants in comparison to non-grafted or self-grafted plants grown under non-saline and saline conditions is reported in Table 1 and Figure 1. 
Agronomy 2020, 10, 263

\begin{tabular}{|c|c|c|c|c|c|c|}
\hline 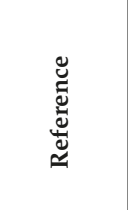 & 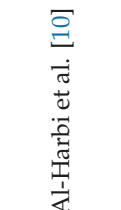 & 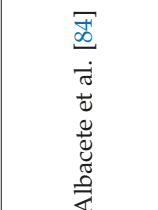 & 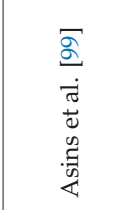 & 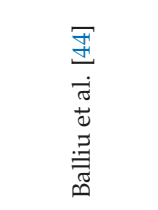 & 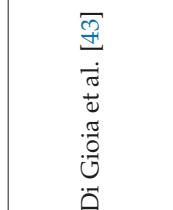 & 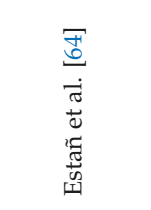 \\
\hline 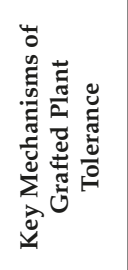 & 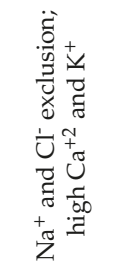 & 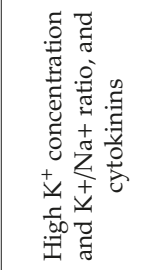 & & 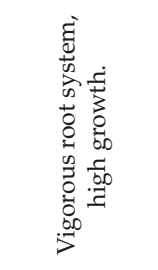 & 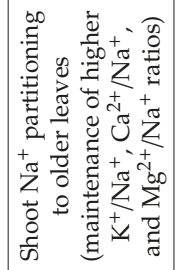 & 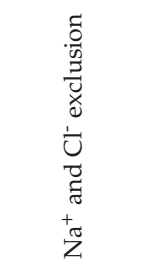 \\
\hline 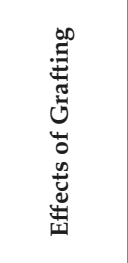 & 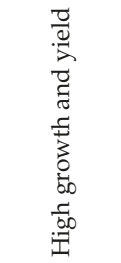 & 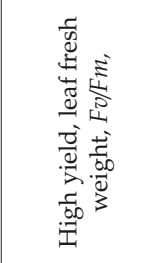 & 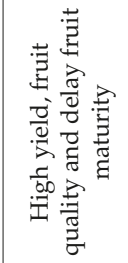 & 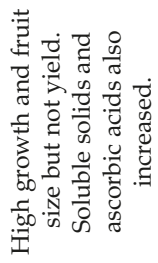 & 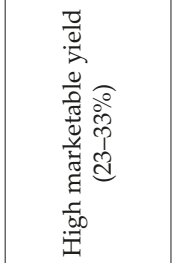 & 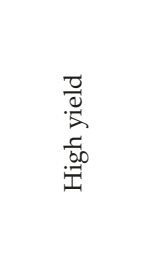 \\
\hline 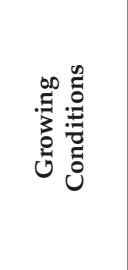 & 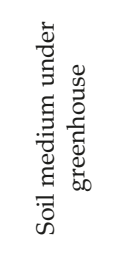 & 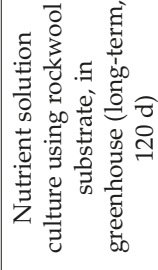 & 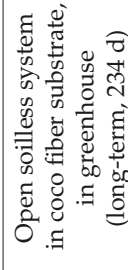 & 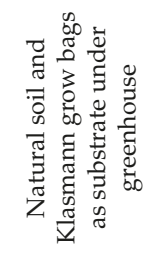 & 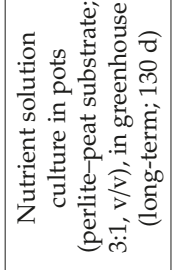 & 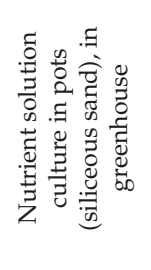 \\
\hline 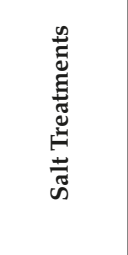 & 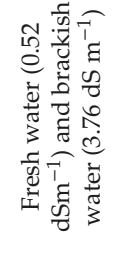 & 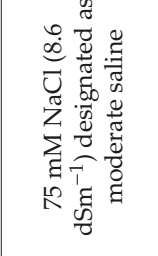 & 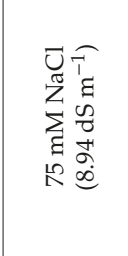 & 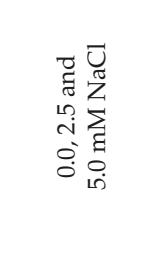 & 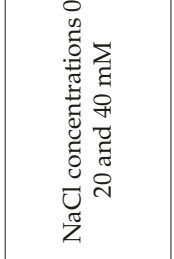 & 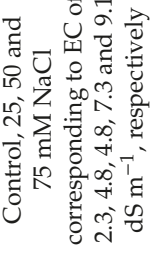 \\
\hline 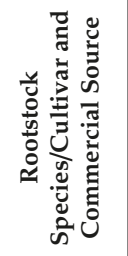 & 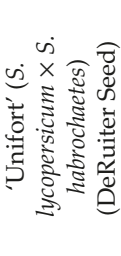 & 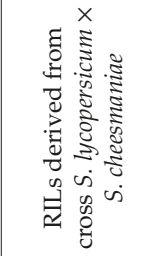 & 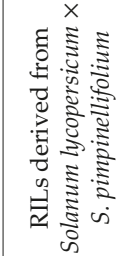 & 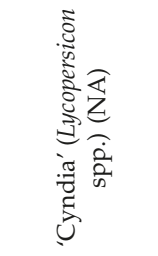 & 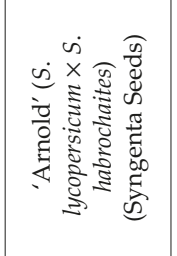 & 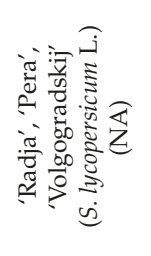 \\
\hline 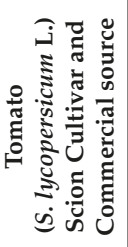 & 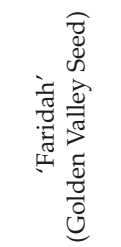 & 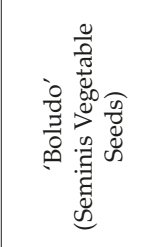 & 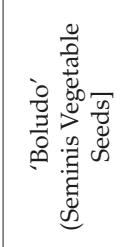 & 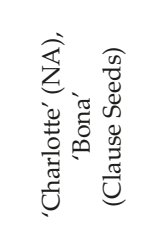 & 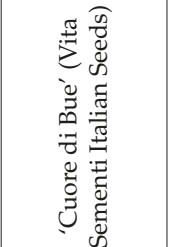 & 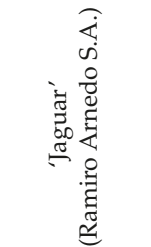 \\
\hline
\end{tabular}


Agronomy 2020, 10, 263

\begin{tabular}{|c|c|c|c|c|c|}
\hline 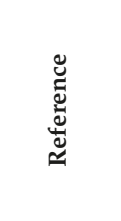 & 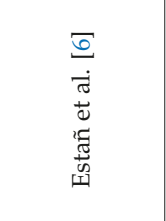 & 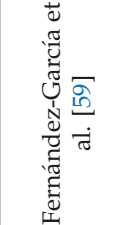 & 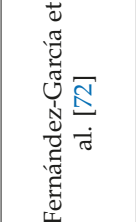 & 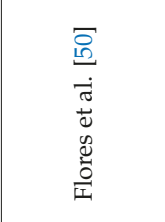 & 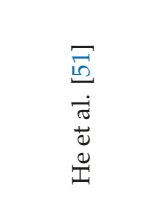 \\
\hline 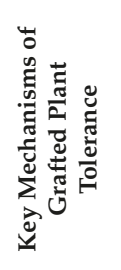 & 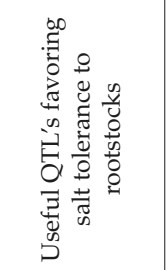 & 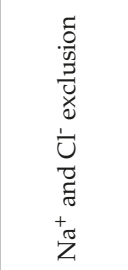 & 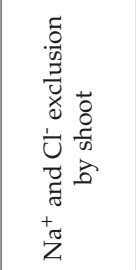 & & 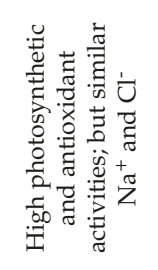 \\
\hline 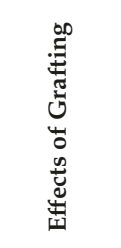 & 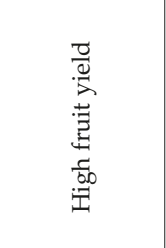 & 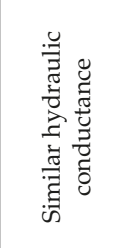 & 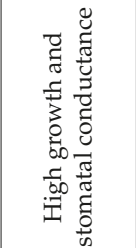 & 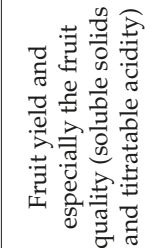 & 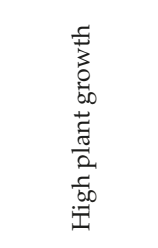 \\
\hline 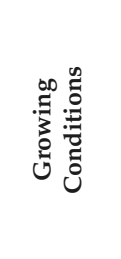 & 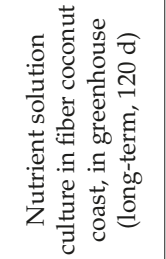 & 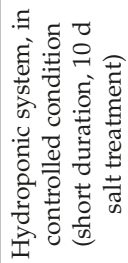 & 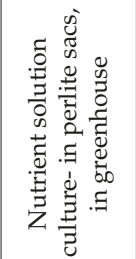 & 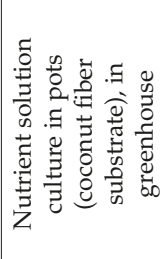 & 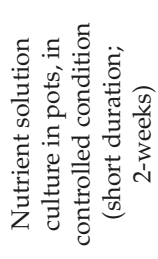 \\
\hline 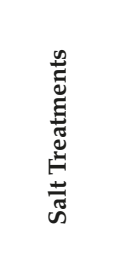 & 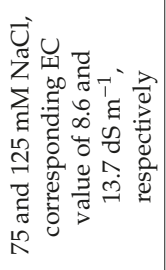 & 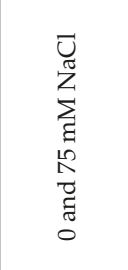 & 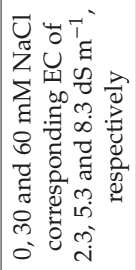 & 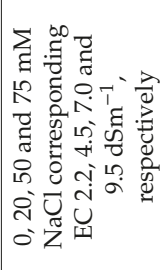 & 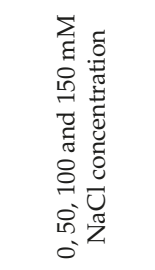 \\
\hline 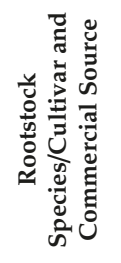 & 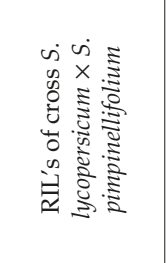 & 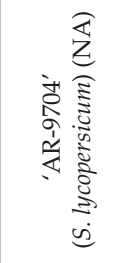 & 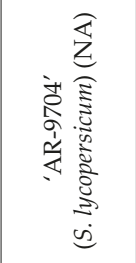 & 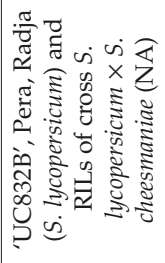 & 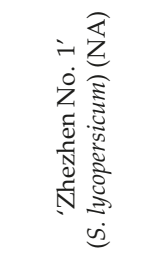 \\
\hline 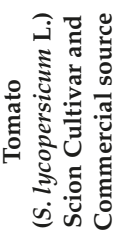 & 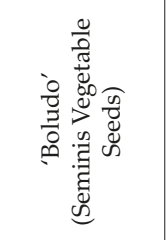 & 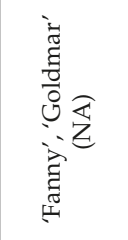 & 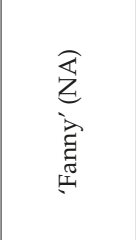 & 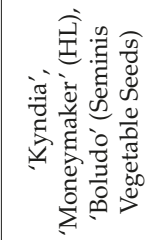 & 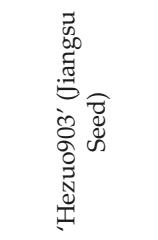 \\
\hline
\end{tabular}


Agronomy 2020, 10, 263

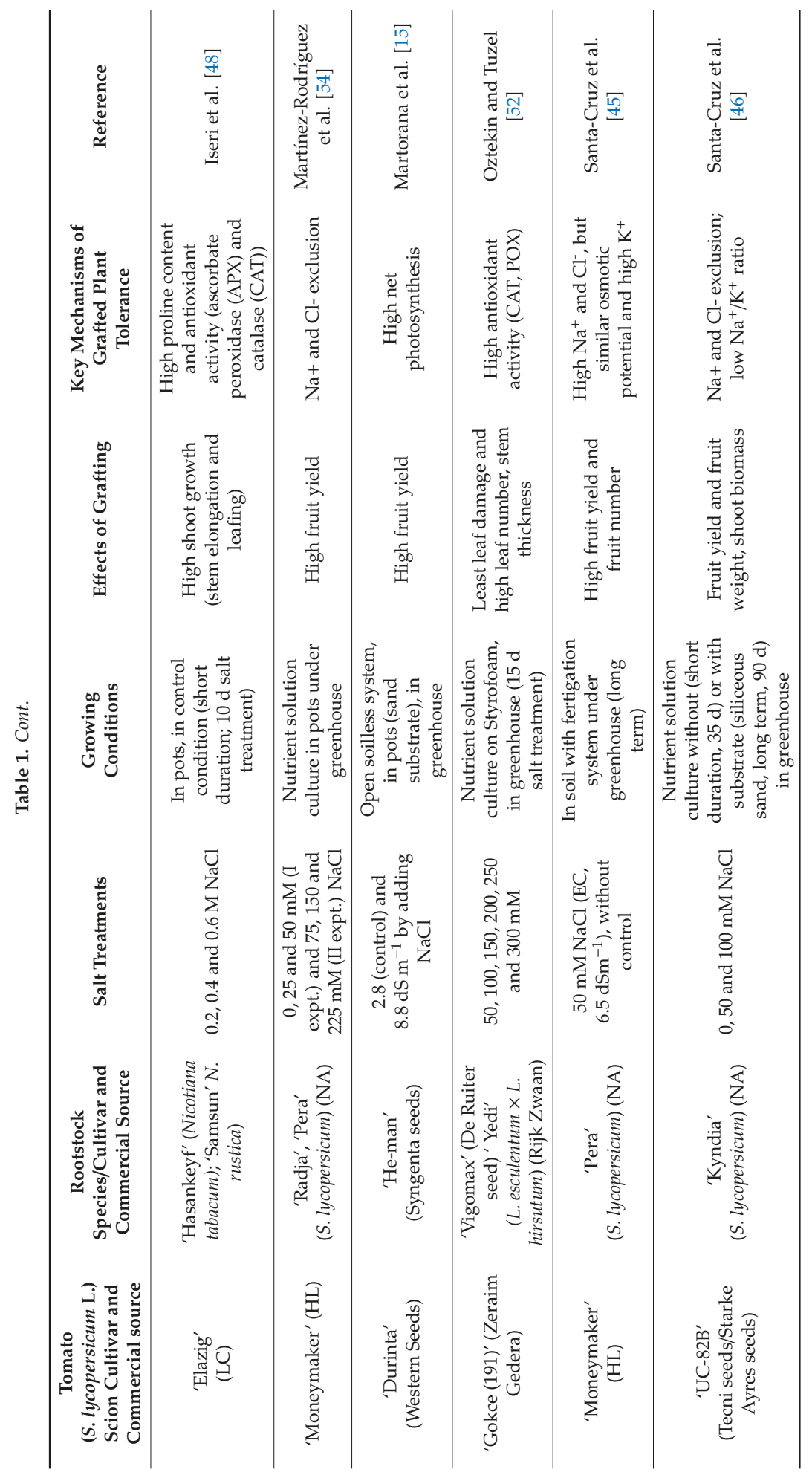




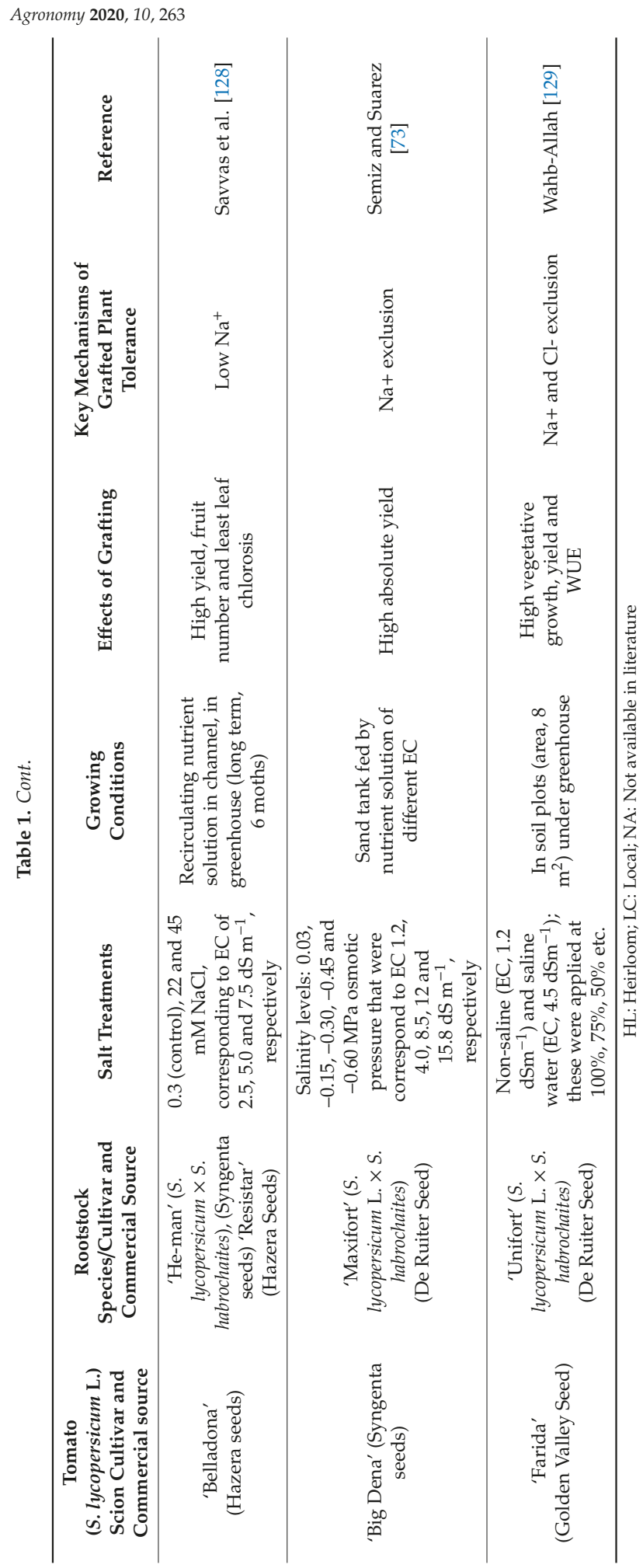




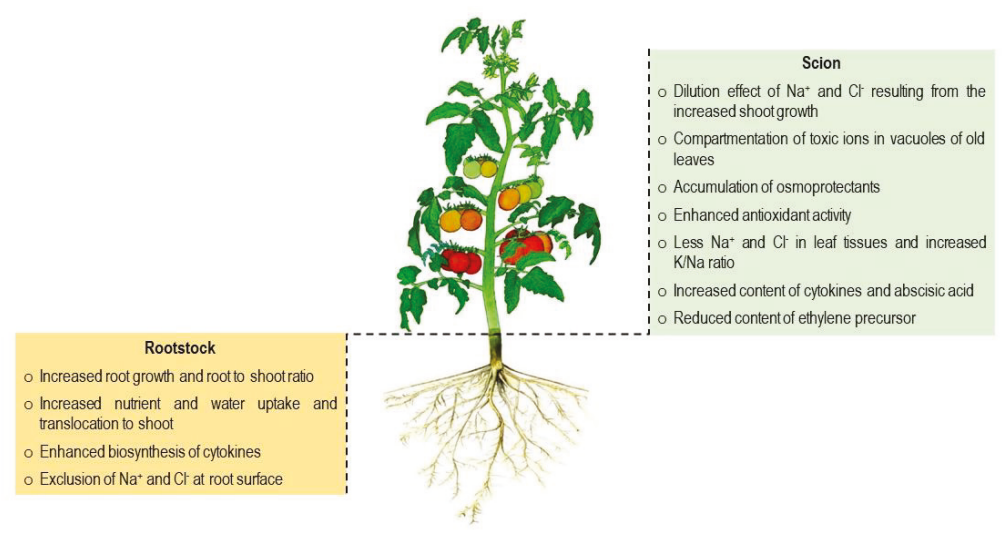

Figure 1. Physiological adaptive traits to mitigate the effect of salt stress in grafted plants.

\section{Potential Use of Wild Tomato Species as Rootstocks for Improving Salt Tolerance in Tomato}

Selection of salt-tolerant rootstocks is an important strategy to enhance salt tolerance. Testing and screening of available commercial and wild relatives under salt stress conditions is a prerequisite for grafting. Natural genetic variation with specific root characters can be utilized effectively through grafting [14]. Various wild tomato/Solanum species including S. cheesmaniae, S. chmielewskii, S. habrochaites, S. pennellii, S. pimpinellifolium and S. peruvianum demonstrate salt tolerance $[12,85]$. Due to incompatibility in crossing and linkage drag, it is cumbersome to transfer salt tolerant genes from wild to cultivated tomato cultivars [12]. However, these wild species could be exploited as salt-resistant rootstocks for grafting susceptible but high yielding commercial tomato cultivars. Compared to commercially grown tomato (S. lycopersicum) that usually excludes toxic ions [47], several wild relatives possess an ionic inclusion mechanism. These genotypes have the capability to accumulate higher $\mathrm{Na}^{+}$ and $\mathrm{Cl}^{-}$concentrations in the leaves [85]. Breeding new rootstocks with tolerance or resistance to a spectrum of biotic and abiotic stresses is a focus of the private [19] as well as public sectors [11].

Use of interspecific hybrids as rootstocks for salt tolerance is well documented [6,64,85]. In this technique, recombinant inbred lines (RILs) created from interspecific crosses are directly used as rootstocks to enhance salinity tolerance. Evaluation of RILs as rootstocks derived from interspecific crosses under salt stress was demonstrated by Albacete et al. [85]. A commercial tomato hybrid cv. 'Boludo' was used to graft onto rootstocks (RILs derived from the cross of S. lycopersicum and S. cheesmaniae) and grown on soil with $75 \mathrm{mM} \mathrm{NaCl}$ salt concentration. These RILs showed good performance under salt stress by affecting growth, and target ionic and hormonal factors in the leaves. They displayed the correlation of rootstock-altered leaf area with $20 \%$ more fruit yield compared to self-grafted plants of the scion hybrid under salt pressure, but not under the control [7,75], indicating that canopy development only limited yield under salt stress [14]. For high salt tolerance, rootstock plants should capable of decreasing the salt load in the foliage cells by excluding the salt ions or accumulating salt in the roots, resulting in a reduction of salt transportation to the shoot system of the plant [21].

While intraspecific grafting is a common practice, efforts also have been made to use interspecific grafting to alleviate wide-spectrum pathogen and environmental pressure without affecting scion fruit yield and quality. Accessions of wild tomato species S. pimpinellifolium were screened for salt tolerance by Rao et al. [12], who suggested the species could be a potential salt tolerance source for tomato breeding and at the same time be used for interspecific grafting to enhance salt tolerance in commercial cultivars. Their results indicated that shoot dry weight and the ratio of $\mathrm{K}^{+}$and $\mathrm{Na}^{+}$are the two most critical factors for survival, while fruit number is critical for yield per plant under saline 
conditions. Two genotypes exhibited high survival rates and produced more fruit under salt stress, and these accessions showed tolerance to $40 \mathrm{dS} \mathrm{m}^{-1}$ EC level.

\section{Conclusions and Challenges Ahead}

Climate change, water scarcity and human activities are increasing soil salinity and depleting arable land. High salinity in soil or water is a serious threat to plant growth and prevents plants from reaching their genetic potential, which reduces yields and threatens food security. Grafting can reduce the negative effects of salinity on tomato scions and thus provides an alternative way to enhance salt tolerance and maintain fruit yield and quality under salt stress. The selection of salt-tolerant rootstocks is an important strategy for enhancing salt tolerance. Testing and screening of available commercial cultivars, landraces and wild relatives, and inbred lines or hybrids involving a resistant parent under salt stress conditions is a prerequisite for successful grafting. This technique can cause both positive and negative effects on yield and fruit characteristics when tomatoes are grown under saline conditions. Weather, salinity level, soil type, cultural practices and consumer preferences also vary in different locations or countries, so the combination of scion and rootstock should be selected carefully at plants morphometric, physio-biochemical and molecular planes to get the maximum benefit from grafting.

Author Contributions: H.S. Wrote the initial draft of the review including yield and quality of grafted tomatoes under salinity; A.K. First draft of physio-biochemical and molecular aspects. P.K. Improved the first draft, contributed to the morphological, physio-biochemical mechanism, and prepared the graph. M.C.K., G.C. and Y.R. critically revised and improved the review paper. All authors have read and agreed to the published version of the manuscript.

Acknowledgments: The authors acknowledge Punjab Agricultural University, Ludhiana and ICAR-Central Arid Zone Research Institute, Jodhpur, India for providing supports.

Conflicts of Interest: The authors declare no conflict of interest.

\section{References}

1. Roychoudhury, A.; Paul, S.; Basu, S. Cross-talk between abscisic acid-dependent and abscisic acid-independent pathways during abiotic stress. Plant Cell Rep. 2013, 32, 985-1006. [CrossRef] [PubMed]

2. Foolad, M.R. Recent advances in genetics of salt tolerance in tomato. Plant Cell Tissue Organ. Cult. 2004, 76, 101-119. [CrossRef]

3. Arzani, A. Improving salinity tolerance in crop plants: A biotechnological view. In Vitro Cell. Dev. Biol. Plant 2008, 44, 373-383. [CrossRef]

4. Zheng, Q.; Liu, J.; Liu, R.; Wu, H.; Jiang, C.; Wang, C.; Guan, Y. Temporal and spatial distributions of sodium and polyamines regulated by brassinosteroids in enhancing tomato salt resistance. Plant Soil 2016, 400, 147-164. [CrossRef]

5. Sholi, N.J. Effect of salt stress on seed germination, plant growth, photosynthesis and ion accumulation of four tomato cultivars. Am. J. Plant Physiol. 2012, 7, 269-275. [CrossRef]

6. Estañ, M.T.; Villalta, I.; Bolarin, M.C.; Carbonell, E.A.; Asins, M.J. Identification of fruit yield loci controlling the salt tolerance conferred by Solanum rootstocks. Theor. Appl. Genet. 2009, 118, 305-312. [CrossRef]

7. Lim, M.Y.; Jeong, B.R.; Jung, M.; Harn, C.H. Transgenic tomato plants expressing strawberry d-galacturonic acid reductase gene display enhanced tolerance to abiotic stresses. Plant Biotechnol. Rep. 2016, 10, 105-116. [CrossRef]

8. Keatinge, J.D.H.; Lin, L.J.; Ebert, A.W.; Chen, W.Y.; Hughes, J.A.; Luther, G.C.; Wang, J.F.; Ravishankar, M. Overcoming biotic and abiotic stresses in the Solanaceae through grafting: Current status and future perspectives. Biol. Agric. Hortic. 2014, 30, 272-287. [CrossRef]

9. Dehyer, R.; Gordon, I. Irrigation water quality. I-salinity and soil structure stability. Nat. Res. Sci. 2005, 55, 55-60.

10. Al-Harbi, A.; Hejazi, A.; Al-Omran, A. Responses of grafted tomato (Solanum lycopersiocon L.) to abiotic stresses. Saudi, J. Biol. Sci. 2016, 24, 1274-1280. [CrossRef]

11. Colla, G.; Rouphael, Y.; Leonardi, C.; Bie, Z. Role of grafting in vegetable crops grown under saline conditions. Sci. Hortic. 2010, 127, 147-155. [CrossRef] 
12. Rao, E.S.; Kadirvel, P.; Symonds, R.C.; Ebert, A.W. Relationship between survival and yield related traits in Solanum pimpinellifolium under salt stress. Euphytica 2013, 190, 215-228. [CrossRef]

13. Kumar, P.; Rouphael, Y.; Cardarelli, M.; Colla, G. Vegetable Grafting as a Tool to Improve Drought Resistance and Water Use Efficiency. Front. Plant Sci. 2017, 8, 1130. [CrossRef] [PubMed]

14. Albacete, A.; Martínez-Andújar, C.; Martínez-Pérez, A.; Thompson, A.J.; Dodd, I.C.; Pérez-Alfocea, F.R. Unravelling rootstock-scion interactions to improve food security. J. Exp. Bot. 2015, 66, 2211-2226. [CrossRef]

15. Martorana, M.; Giuffrida, F.; Leonardi, C.; Kaya, S. Influence of rootstock on tomato response to salinity. Acta Hortic. 2007, 747, 555-561. [CrossRef]

16. Colla, G.; Rouphael, Y.; Jawad, R.; Kumar, P.; Rea, E.; Cardarelli, M. The effectiveness of grafting to improve $\mathrm{NaCl}$ and $\mathrm{CaCl}_{2}$ tolerance in cucumber. Sci. Hortic. 2013, 164, 380-391. [CrossRef]

17. Tateishi, K. Grafting watermelon onto pumpkin. J. Jpn. Hortic. 1927, 39, 5-8.

18. Besri, M. Current situation of tomato grafting as alternative to methyl bromide for tomato production in Morocco. In Proceedings of the Annual International Research Conference on Methyl Bromide Alternatives and Emission Reductions, San Diego, CA, USA, 28-31 October 2007; pp. 62.1-62.5.

19. King, S.R.; Davis, A.R.; Zhang, X.; Crosby, K. Genetics, breeding and selection of rootstocks for Solanaceae and Cucurbitaceae. Sci. Hortic. 2010, 127, 106-111. [CrossRef]

20. Kubota, C.; McClure, M.A.; Kokalis-Burelle, N.; Bausher, M.G.; Rosskopf, E.N. Vegetable grafting: History, use, and current technology status in North America. Sci. Hortic. 2008, 43, 1644-1669. [CrossRef]

21. Edelstein, M.; Cohen, R.; Baumkoler, F.; Ben-Hur, M. Using grafted vegetables to increase tolerance to salt and toxic elements. Isr. J. Plant Sci. 2016, 1-18. [CrossRef]

22. Cohen, R.; Omari, N.; Porat, A.; Edelstein, M. Management of Macrophomina wilt in melons using grafting or fungicide soil application: Pathological, horticultural and economical aspects. Crop Prot. 2012, 35, 58-63. [CrossRef]

23. Kubota, C. How to Produce Grafted Vegetable Plants; Kubota, C., Miles, C., Zhao, X., Eds.; Grafting manual: Washington, DC, USA, 2016; pp. 1-5.

24. Besri, M. Economic aspects of grafting tomato in some Mediterranean countries. In Proceedings of the Annual International Research Conference on Methyl Bromide Alternatives and Emissions Reductions proceedings, San Diego, CA, USA, 29 October-1 November 2007; p. 62-1-5.

25. Singh, H.; Kumar, P.; Chaudhari, S.; Edelstein, M. Tomato grafting: A Global perspective. HortScience 2017, 52, 1328-1336. [CrossRef]

26. Sardoo, M.; Fatemeh, S. Evaluation of salt tolerance of tomato (Lycopersicon esculentum). Agric. Adv. 2016, 5, 221-226.

27. Abbasi, H.; Jamil, M.; Haq, A.; Ali, S.; Ahmad, R.; Malik, Z. Salt stress manifestation on plants, mechanism of salt tolerance and potassium role in alleviating it: A review. Zemdirbyste Agric. 2016, 103, 229-238. [CrossRef]

28. Parida, AK.; Das, A.B. Salt tolerance and salinity effects on plants. Ecotox. Environ. Saf. 2005, 60, 324-349. [CrossRef]

29. Rivero, R.M.; Ruiz, J.M.; Romero, L. Role of grafting in horticultural plants under stress conditions. J. Food Agric. Environ. 2003, 1, 70-74.

30. Colla, G.; Kumar, P.; Cardarelli, M.; Rouphael, Y. Grafting an effective tool for abiotic stress alleviation in vegetables. In Horticulture for Food and Environment Security; Chadha, K.L., Singh, A.K., Singh, S.K., Dhillon, W.S., Eds.; Westville Publishing House: New Delhi, India, 2012; pp. 15-28.

31. Rajaei, S.M.; Niknam, V.; Seyedi, S.M.; Ebrahimzadeh, H.; Razavi, K. Contractile roots are the most sensitive organ in Crocus sativus to salt stress. Biol. Plant. 2009, 53, 523. [CrossRef]

32. Chaves, M.M.; Costa, J.M.; Saibo, N.J.M. Recent advances in photosynthesis under drought and salinity. Adv. Bot. Res. 2011, 57, 49-104.

33. Mahajan, S.; Tuteja, N. Cold, salinity and drought stresses: An overview. Arch. Biochem. Biophys. 2005, 444, 139-158. [CrossRef]

34. Cuartero, J.; Bolarin, M.C.; Asins, M.J.; Moreno, V. Increasing salt tolerance in the tomato. J. Exp. Biol. 2006, 57, 1045-1058. [CrossRef]

35. Hajer, A.S.; Malibari, A.A.; Al-Zahrani, H.S.; Almaghrabi, O.A. Responses of three tomato cultivars to sea water salinity 1. Effect of salinity on the seedling growth. Afr. J. Biotechnol. 2006, 5, 855-861. 
36. Najla, S.; Vercambre, G.; Page's, L.; Grasselly, D.; Gautier, H.; Ge'nard, M. Tomato plant architecture as affected by salinity: Descriptive analysis and integration in a 3-D simulation model. Botany 2009, 87, 893-904. [CrossRef]

37. Cuartero, J.; Fernández-Muñoz, R. Tomato and salinity. Sci. Hortic. 1999, 78, 83-125. [CrossRef]

38. Khavari-Nejad, R.A.; Mostofi, Y. Effects of $\mathrm{NaCl}$ on photosynthetic pigments, saccharides, and chloroplast ultrastructure in leaves of tomato cultivars. Photosynthetica 1998, 35, 151-154. [CrossRef]

39. Al-Karaki, G.N. Growth, water use efficiency, and sodium and potassium acquisition by tomato cultivars grown under salt stress. J. Plant. Nutr. 2000, 23, 1-8. [CrossRef]

40. Turhan, A.; Seniz, V.; Kusçu, H. Genotypic variation in the response of tomato to salinity. Afr. J. Biotechnol. 2009, 8, 1062-1068.

41. Gao, Z.; Sagi, M.; Lips, S.H. Carbohydrate metabolism in leaves and assimilate partitioning in fruits of tomato (Lycopersicon esculentum L.) as affected by salinity. Plant Sci. 1998, 135, 149-159. [CrossRef]

42. De Pascale, S.; Maggio, A.; Fogliano, V.; Ambrosino, P.; Ritieni, A. Irrigation with saline water improves carotenoids content and antioxidant activity of tomato. J. Hortic. Sci. Biotechnol. 2001, 76, 447-453. [CrossRef]

43. Di Gioia, F.; Signore, A.; Serio, F.; Santamaria, P. Grafting improves tomato salinity tolerance through sodium partitioning within the shoot. HortScience 2013, 48, 855-862. [CrossRef]

44. Balliu, A.; Vuksani, G.; Nasto, T.; Haxhinasto, L.; Kaçiu, S. Grafting effects on tomato growth rate, yield and fruit quality under saline irrigation water. Acta Hortic. 2007, 801, 1161-1166. [CrossRef]

45. Santa-Cruz, A.; Martínez-Rodríguez, M.M.; Cuartero, J.; Bolarin, M.C. Response of plant yield and ion contents to salinity in grafted tomato plants. Acta Hortic. 2001, 559, 413-417. [CrossRef]

46. Santa-Cruz, A.; Martínez-Rodríguez, M.M.; Pérez-Alfocea, F.; Romero-Aranda, R.; Bolarin, M.C. The rootstock effect on the tomato salinity response depends on the shoot genotype. Plant Sci. 2002, 162, 825-831. [CrossRef]

47. Voutsela, S.; Yarsi, G.; Petropoulos, S.A.; Khan, E.A. The effect of grafting of five different rootstocks on plant growth and yield of tomato plants cultivated outdoors and indoors under salinity stress. Afr. J. Agric. Res. 2012, 7, 5553-5557. [CrossRef]

48. Iseri, O.D.; Körpe, D.A.; Sahin, F.I.; Haberal, M. High salt induced oxidative damage and antioxidant response in tomato grafted on tobacco. Chil. J. Agric. Res. 2015, 75, 192-201.

49. Turhan, A.; Ozmen, N.; Serbeci, M.S.; Seniz, V. Effects of grafting on different rootstocks on tomato fruit yield and quality. Sci. Hortic. 2011, 38, 142-149. [CrossRef]

50. Flores, F.B.; Sanchez-Bel, P.; Estañ, M.T.; Martinez-Rodriguez, M.M.; Moyano, E.; Morales, B.; Campos, J.F.; Garcia-Abellán, J.O.; Egea, M.I.; Fernández-García, N.; et al. The effectiveness of grafting to improve tomato fruit quality. Sci. Hortic. 2010, 125, 211-217. [CrossRef]

51. He, Y.; Zhu, Z.; Yang, J. Grafting increases the salt tolerance of tomato by improvement of photosynthesis and enhancement of antioxidant enzymes activity. Environ. Exp. Bot. 2009, 66, 270-278. [CrossRef]

52. Oztekin, G.B.; Tuzel, Y. Salinity response of some tomato rootstocks at seedling stage. Afr. J. Agric. Res. 2011, 6, 4726-4735.

53. Gregory, P.J.; Atkinson, C.J.; Bengough, A.G.; Else, M.A.; Fernández-Fernández, F.; Harrison, R.J.; Schmidt, S. Contributions of roots and rootstocks to sustainable, intensified crop production. J. Exp. Bot. 2013, 64, 1209-1222. [CrossRef]

54. Martínez-Rodríguez, M.M.; Estañ, M.T.; Moyano, E.; Garcia-Abellan, J.O.; Flores, F.B.; Campos, J.F.; Al-Azzawi, M.J.; Flower, T.J.; Bolarin, M.C. The effectiveness of grafting to improve salt tolerance in tomato when an 'excluder' genotype is used as scion. Environ. Exp. Bot. 2008, 63, 392-401. [CrossRef]

55. Zhen, A.; Bie, Z.; Huang, Y.; Liu, Z.; Li, Q. Effects of scion and rootstock genotypes on the anti-oxidant defense systems of grafted cucumber seedlings under $\mathrm{NaCl}$ stress. Soil Sci. Plant Nutr. 2010, 56, 263-271. [CrossRef]

56. Turquois, N.; Malone, M. Non-destructive assessment of developing hydraulic connections in the graft union of tomato. J. Exp. Bot. 1996, 298, 701-707. [CrossRef]

57. Huang, Y.; Zhao, L.Q.; Kong, Q.S.; Cheng, F.; Niu, M.L.; Xie, J.J.; Nawaz, M.A.; Bie, Z.L. Comprehensive mineral nutrition analysis of watermelon grafted onto two different rootstocks. Hort. Plant J. 2016, 2, 105-113. [CrossRef]

58. Ruiz, D.; Martínez, V.; Cerda, A. Citrus response to salinity, growth and nutrient uptake. Tree Physiol. 1997, 17, 141-150. [CrossRef] [PubMed] 
59. Fernández-García, N.; Martinez, V.; Cerdá, A.; Carvajal, M. Water and nutrient uptake of grafted tomato plants grown under saline conditions. J. Plant Physiol. 2002, 159, 899-905. [CrossRef]

60. Shalhevet, J.; Maas, E.V.; Hoffman, G.J.; Ogata, G. Salinity and the hydraulic conductance of roots. Physiol. Plant. 1976, 38, 224-232. [CrossRef]

61. Munns, R.; Passioura, J.B. Hydraulic resistance of plants. III. Effects of $\mathrm{NaCl}$ in barley and lupin. Aust. J. Plant Physiol. 1984, 11, 351-359. [CrossRef]

62. Evlagon, D.; Ravina, Y.; Neumann, P.M. Interactive effects of salinity and calcium on hydraulic conductivity, osmotic adjustment and growth in primary roots of maize seedlings. Isr. J. Bot. 1990, 39, 239-247.

63. Carvajal, M.; Martínez, V.; Alcaraz, C.F. Physiological function of water-channels, as affected by salinity in roots of paprika pepper. Physiol. Plant. 1999, 105, 95-101. [CrossRef]

64. Estañ, M.T.; Martinez-Rodriguez, M.M.; Perez-Alfocea, F.; Flowers, T.J.; Bolarin, M.C. Grafting raises the salt tolerance of tomato through limiting the transport of sodium and chloride to the shoot. J. Exp. Bot. 2005, 56, 703-712. [CrossRef]

65. Lee, J.M. Cultivation of grafted vegetables I. Current status, grafting methods, and benefits. HortScience 1994, 29, 235-239. [CrossRef]

66. Zijlstra, S.; Groot, S.P.C.; Jansen, J. Genotypic variation of rootstocks for growth and production in cucumber; possibilities for improving the root system by plant breeding. Sci. Hortic. 1994, 56, 185-196. [CrossRef]

67. Leoni, S.; Grudina, R.; Cadinu, M.; Madeddu, B.; Carletti, M.G. The influence of four rootstocks on some melon hybrids and a cultivar in greenhouse. II Inter. Sym. Protec. Culti. Veg. Mild Winter Clim. 1990, 287, 127-134. [CrossRef]

68. Moya, J.L.; Primo-Millo, E.; Talón, M. Morphological factors determining salt tolerance in citrus seedlings: The shoot to root ratio modulates passive root uptake of chloride ions and their accumulation in leaves. Plant Cell. Environ. 1999, 22, 1425-1433. [CrossRef]

69. Zhu, J.; Bie, Z.; Huang, Y.; Han, X. Effect of grafting on the growth and ion concentrations of cucumber seedlings under $\mathrm{NaCl}$ stress. Soil Sci. Plant Nutr. 2008, 54, 895-902. [CrossRef]

70. Pérez-Alfocea, F.; Albacete, A.; Ghanem, M.E.; Dodd, I.C. Hormonal regulation of source-sink relations to maintain crop productivity under salinity: A case study of root-to-shoot signalling in tomato. Funct. Plant Biol. 2010, 37, 592-603. [CrossRef]

71. Martinez-Rodriguez, M.M.; Santa-Cruz, A.; Estan, M.T.; Caro, M.; Bolarin, M.C. Influence of rootstock in the tomato response to salinity. Acta Hortic. 2002, 573, 455-460. [CrossRef]

72. Fernández-García, N.; Martínez, V.; Carvajal, M. Effect of salinity on growth, mineral composition, and water relations of grafted tomato plants. J. Plant Nutr. Soil Sci. 2004, 167, 616-622. [CrossRef]

73. Semiz, G.D.; Suarez, D.L. Tomato salt tolerance: Impact of grafting and water composition on yield and ion relations. Turk. J. Agric. For. 2015, 39, 876-886. [CrossRef]

74. Munns, R. Genes and salt tolerance: Bringing them together. New Phytol. 2005, 167, 645-663. [CrossRef]

75. Pérez-Alfocea, F.; Estañ, M.T.; Caro, M.; Bolarín, M.C. Response of tomato cultivars to salinity. Plant Soil. 1993, 150, 203-211. [CrossRef]

76. Pérez-Alfocea, F.; Balibrea, M.E.; Santa Cruz, A.; Estañ, M.T. Agronomical and physiological characterization of salinity tolerance in a commercial tomato hybrid. Plant Soil. 1996, 180, 251-257. [CrossRef]

77. Tal, M. Salt tolerance in the wild relatives of the cultivated tomato: Responses of Lycopersicon esculentum, L. peruvianum, and L. esculentum minor to sodium chloride solution. Aust. J. Agric. Res. 1971, 22, 631-638. [CrossRef]

78. Rush, D.W.; Epstein, E. Comparative studies on the sodium, potassium, and chloride relations of a wild halophytic and a domestic salt-sensitive tomato species. Plant Physiol. 1981, 68, 1308-1313. [CrossRef]

79. Bolarin, M.C.; Fernandez, F.G.; Cruz, V.; Cuartero, J. Salinity tolerance in four wild tomato species using vegetative yield-salinity response curves. J. Am. Soc. Hort. Sci. 1991, 116, 286-290. [CrossRef]

80. Cuartero, J.; Yeo, A.R.; Flowers, T.J. Selection of donors for salt-tolerance in tomato using physiological traits. New Phytol. 1992, 121, 63-69. [CrossRef]

81. Shannon, M.C. Adaptation of plants to salinity. In Advances in Agronomy; Academic Press: Cambridge, MA, USA, 1997; Volume 60, pp. 75-120.

82. Sacher, R.F.; Staples, R.C.; Robinson, R.W. Saline tolerance in hybrids of Lycopersicon esculentum X Solanum penellii and selected breeding lines. Environ. Sci. Res. 1982, 325-336. 
83. Huang, Y.; Zhu, J.; Zhen, A.; Chen, L.; Bie, Z.L. Organic and inorganic solutes accumulation in the leaves and roots of grafted and ungrafted cucumber plants in response to $\mathrm{NaCl}$ stress. J. Food Agric. Environ. 2009, 7, 703-708.

84. Albacete, A.; Martínez-Andújar, C.R.; Ghanem, M.E.; Acosta, M.; Sánchez-bravo, J.O.; Asins, M.J.; Cuartero, J.; Lutts, S.; Dodd, I.C.; Pérez-Alfocea, F.R. Rootstock-mediated changes in xylem ionic and hormonal status are correlated with delayed leaf senescence, and increased leaf area and crop productivity in salinized tomato. Plant Cell Environ. 2009, 32, 928-938. [CrossRef]

85. Xu, H.L.; Gauthier, L.; Gosselin, A. Photosynthetic responses of greenhouse tomato plants to high solution electrical conductivity and low soil water content. J. Hortic. Sci. 1994, 69, 821-832. [CrossRef]

86. Flexas, J.; Bota, J.; Loreto, F.; Cornic, G.; Sharkey, T.D. Diffusive and metabolic limitations to photosynthesis under drought and salinity in $C_{3}$ plants. Plant Biol. 2004, 6, 269-279. [CrossRef] [PubMed]

87. Zhen, A.; Bie, Z.; Huang, Y. Effects of salt-tolerant rootstock grafting on ultrastructure, photosynthetic capacity, and $\mathrm{H}_{2} \mathrm{O}_{2}$-scavenging system in chloroplasts of cucumber seedlings under $\mathrm{NaCl}$ stress. Acta Physiol. Plant. 2011, 33, 2311. [CrossRef]

88. Liu, Z.; Bie, Z.; Huang, Y. Rootstocks improve cucumber photosynthesis through nitrogen metabolism regulation under salt stress. Acta Physiol. Plant. 2013, 35, 2259-2267. [CrossRef]

89. Marsic, N.K.; Vodnik, D.; Mikulic-Petkovsek, M.; Veberic, R.; Sircelj, H. Photosynthetic Traits of Plants and the Biochemical Profile of Tomato Fruits Are Influenced by Grafting, Salinity Stress, and Growing Season. J. Agric. Food Chem. 2018, 66, 5439-5450. [CrossRef]

90. Feng, X.; Guo, K.; Yang, C.; Li, J.; Chen, H.; Liu, X. Growth and fruit production of tomato grafted onto wolfberry (Lycium chinense) rootstock in saline soil. Sci. Hortic. 2019, 255, 298-305.

91. Bartoli, C.G.; Buet, A.; Grozeff, G.G. Ascorbate-glutathione cycle and abiotic stress tolerance in plants. In Ascorbic Acid in Plant. Growth, Development and Stress Tolerance; Springer: Cham, Germany, 2017; pp. 177-200.

92. Gao, J.J.; Zhang, L.; Qin, A.G.; Yu, X.C. Relative expression of SOD and CAT mRNA and activities of SOD and CAT in grafted cucumber leaves under $\mathrm{NaCl}$ stress. Ying yong sheng tai xue bao. J. Appl. Ecol. 2008, 19, 1754-1758.

93. Wei, G.P.; Yang, L.F.; Zhu, Y.L.; Chen, G. Changes in oxidative damage, antioxidant enzyme activities and polyamine contents in leaves of grafted and non-grafted eggplant seedlings under stress by excess of calcium nitrate. Sci. Hortic. 2009, 120, 443-451. [CrossRef]

94. Ruiz, J.M.; Ríos, J.J.; Rosales, M.A.; Rivero, R.M.; Romero, L. Grafting between tobacco plants to enhance salinity tolerance. J. Plant Physiol. 2006, 163, 1229-1237. [CrossRef]

95. Yasinok, A.E.; Feride, S.I.; Eyidogan, F.; Kuru, M.; Haberal, M. Grafting tomato plant on tobacco plant and its effect on tomato plant yield and nicotine content. J. Sci. Food Agric. 2009, 89, 1122-1128. [CrossRef]

96. Singh, J.; Sastry, E.V.D.; Singh, V. Effect of salinity on tomato (Lycopersicon esculentum Mill.) during seed germination stage. J. Plant Physiol. Molecular Biol. 2012, 18, 45-50. [CrossRef] [PubMed]

97. Ja'afar, U.; Aliero, A.A.; Shehu, K.; Abubakar, L. Genetic diversity in tomato genotypes (Solanum lycopersicum) based on salinity responsive candidate gene using simple sequence repeats. International Lett. Nat. Sci. 2018, 72, 37-46. [CrossRef]

98. Yveline, P.; Awlia, M.; Julkowska, M.; Passone, L.; Zemmouri, K.; Negrão, S.; Schmöckel, S.M.; Tester, M. Diverse traits contribute to salinity tolerance of wild tomato seedlings from the Galapagos Islands. Plant. Physiol. 2020, 182, 534-546.

99. Asins, M.J.; Raga, V.; Roca, D.; Belver, A.; Carbonell, E.A. Genetic dissection of tomato rootstock effects on scion traits under moderate salinity. Theor. Appl Genet. 2015, 128, 667-679. [CrossRef]

100. Nedjimi, B. Calcium application enhances plant salt tolerance: A review. Essent. Plant Nutr. Springer 2017, 367-377.

101. Zhao, N.; Wang, S.; Ma, X. Extracellular ATP mediates cellular $\mathrm{K}+/ \mathrm{Na}+$ homeostasis in two contrasting poplar species under $\mathrm{NaCl}$ stress. Trees. 2016, 30, 825-837. [CrossRef]

102. Mahajan, S.; Pandey, G.K.; Tuteja, N. Calcium-and salt-stress signaling in plants: Shedding light on SOS pathway. Arch. Biochem. Bioph. 2008, 471, 146-158. [CrossRef]

103. Shaterian, J.; Georges, F.; Hussain, A. Root to shoot communication and abscisic acid in calreticulin (CR) gene expression and salt-stress tolerance in grafted diploid potato clones. Environ. Exp. Bot. 2005, 53, 323-332. [CrossRef] 
104. Sharma, A.; Zheng, B. Molecular responses during plant grafting and its regulation by auxins, cytokinins, and gibberellins. Biomolecules 2019, 9, 397. [CrossRef]

105. Nanda, A.K.; Melnyk, C.W. The role of plant hormones during grafting. J. Plant Res. 2018, 131, 49-58. [CrossRef]

106. Ruzicka, K.; Ursache, R.; Hejatko, J.; Helariutta, Y. Xylem development-from the cradle to the grave. New Phytol. 2015, 207, 519-535. [CrossRef] [PubMed]

107. Kumar, R.M.S.; Ji, G.; Guo, H.; Zhao, L.; Zheng, B. Over-expression of a grafting-responsive gene from hickory increases abiotic stress tolerance in Arabidopsis. Plant Cell Rep. 2018, 37, 541-552. [CrossRef] [PubMed]

108. Sauer, M.; Balla, J.; Luschnig, C.; Wisniewska, J.; Reinohl, V.; Friml, J.; Benkova, E. Canalization of auxin flow by Aux/IAA-ARF-dependent feedback regulation of PIN polarity. Genes Dev. 2006, 20, 2902-2911. [CrossRef]

109. Yuan, H.; Zhao, L.; Qiu, L.; Xu, D.; Tong, Y.; Guo, W.; Yang, X.; Shen, C.; Yan, D.; Zheng, B. Transcriptome and hormonal analysis of grafting process by investigating the homeostasis of a series of metabolic pathways in Torreya grandis cv. Merrillii. Ind. Crops Prod. 2017, 108, 814-823. [CrossRef]

110. Aloni, R. The role of cytokinin in organised differentiation of vascular tissues. Funct. Plant Biol. 1993, 20, 601-608. [CrossRef]

111. Shehata, S.; El-Shraiy, A.M. Regulating cucumber grafting by interactions of cytokinins in xylem exudates of rootstock and basipetol polar auxin transport of scion at graft union. Aus. J. Basic Appl. Sci. 2010, 4, 6179-6184.

112. Aloni, B.; Cohen, R.; Karni, L.; Aktas, H.; Edelstein, M. Hormonal signaling in rootstock-scion interactions. Sci. Hortic. 2010, 127, 119-126. [CrossRef]

113. Ghanem, M.E.I.; Hichri, A.C.; Smigocki, A.; Albacete, M.L.; Fauconnier, E.; Diatloff, C.; Martı'nez-Andu'jar, M.; Acosta, J.; Sanchez-Bravo, S.; Lutts, I.C.; et al. Root-targeted biotechnology to mediate hormonal signaling and improve crop stress tolerance. Plant Cell Rpt. 2011, 30, 807-823. [CrossRef]

114. Aloni, R.; Aloni, E.; Langhans, M.; Ullrich, C.I. Role of cytokinin and auxin in shaping root architecture: Regulating vascular differentiation, lateral root initiation, root apical dominance and root gravitropism. Ann. Bot. 2006, 97, 883-893. [CrossRef]

115. Ghanem, M.E.; Albacete, A.; Smigocki, A.C.; Frébort, I.; Pospíšilová, H.; Martínez-Andújar, C.; Acosta, M.; Sánchez-Bravo, J.; Lutts, S.; Dodd, I.C.; et al. Root-synthesized cytokinins improve shoot growth and fruit yield in salinized tomato (Solanum lycopersicum L.) plants. J. Exp. Bot. 2011, 62, 125-140. [CrossRef]

116. Asahina, M.; Gocho, Y.; Kamada, H.; Satoh, S. Involvement of inorganic elements in tissue reunion in the hypocotyl cortex of Cucumis sativus. J. Plant Res. 2006, 119, 337-342. [CrossRef] [PubMed]

117. Asahina, M.; Yamauchi, Y.; Hanada, A.; Kamiya, Y.; Kamada, H.; Satoh, S.; Yamaguchi, S. Effects of the removal of cotyledons on endogenous gibberellin levels in hypocotyls of young cucumber and tomato seedlings. Plant Biotechnol. 2007, 24, 99-106. [CrossRef]

118. Mo, Z.; Feng, G.; Su, W.; Liu, Z.; Peng, F. Transcriptomic Analysis Provides Insights into Grafting Union Development in Pecan (Carya illinoinensis). Genes 2018, 9, 71. [CrossRef] [PubMed]

119. Bjorklund, S.; Antti, H.; Uddestrand, I.; Moritz, T.; Sundberg, B. Cross-talk between gibberellin and auxin in development of Populus wood: Gibberellin stimulates polar auxin transport and has a common transcriptome with auxin. Plant J. 2007, 52, 499-511. [CrossRef] [PubMed]

120. Dayan, J.; Voronin, N.; Gong, F.; Sun, T.P.; Hedden, P.; Fromm, H.; Aloni, R. Leaf-induced gibberellin signaling is essential for internode elongation, cambial activity, and fiber differentiation in tobacco stems. Plant Cell. 2012, 24, 66-79. [CrossRef]

121. Liu, N.; Yang, J.; Fu, X.; Zhang, L.; Tang, K.; Guy, K.M.; Hu, Z.; Guo, S.; Xu, Y.; Zhang, M. Genome-wide identification and comparative analysis of grafting-responsive mRNA in watermelon grafted onto bottle gourd and squash rootstocks by high-throughput sequencing. Mol. Genet. Genom. 2016, 291, 621-633. [CrossRef]

122. Peña-Cortés, H.; Sánchez-Serrano, J.J.; Mertens, R. Abscisic acid is involved in the wound-induced expression of the proteinase inhibitor II gene in potato and tomato. Proc. Natl. Acad. Sci. USA 1989, 86, 9851-9855. [CrossRef]

123. Peña-Cortés, H.; Fisahn, J.; Willmitzer, L. Signals involved in wound-induced proteinase inhibitor II gene expression in tomato and potato plants. Proc. Natl. Acad. Sci. USA 1995, 92, 4106-4113. [CrossRef] 
124. Chen, G.; Fu, X.; Lips, S.H.; Sagi, M. Control of plant growth resides in the shoot, and not in the root, in reciprocal grafts of flacca and wild-type tomato (Lysopersicon esculentum), in the presence and absence of salinity stress. Plant Soil 2003, 256, 205-215. [CrossRef]

125. Yin, H.; Yan, B.; Sun, J.; Jia, P.; Zhang, Z.; Yan, X.; Chai, J.; Ren, Z.; Zheng, G.; Liu, H. Graft-union development: A delicate process that involves cell-cell communication between scion and stock for local auxin accumulation. J. Exp. Bot. 2012, 63, 4219-4232. [CrossRef]

126. Matsuoka, K.; Sugawara, E.; Aoki, R.; Takuma, K.; Terao-Morita, M.; Satoh, S.; Asahina, M. Differential Cellular Control by Cotyledon-Derived Phytohormones Involved in Graft Reunion of Arabidopsis Hypocotyls. Plant Cell Physiol. 2016, 57, 2620-2631. [CrossRef] [PubMed]

127. Tao, J.J.; Chen, H.W.; Ma, B.; Zhang, W.K.; Chen, S.Y.; Zhang, J.S. The role of ethylene in plants under salinity stress. Front. Plant Sci. 2015, 6, 1059. [CrossRef] [PubMed]

128. Savvas, D.; Savva, A.; Ntatsi, G.; Ropokis, A.; Karapanos, I.; Krumbein, A.; Olympios, C. Effects of three commercial rootstocks on mineral nutrition, fruit yield, and quality of salinized tomato. J. Plant Nutr. Soil Sci. 2011, 174, 154-162. [CrossRef]

129. Wahb-Allah, M.A. Effectiveness of grafting for the improvement of salinity and drought tolerance in tomato (Solanum lycopersicum L.). Asian J. Crop. Sci. 2014, 6, 112-122.

(C) 2020 by the authors. Licensee MDPI, Basel, Switzerland. This article is an open access article distributed under the terms and conditions of the Creative Commons Attribution (CC BY) license (http://creativecommons.org/licenses/by/4.0/). 


\title{
Conventional Industrial Robotics Applied to the Process of Tomato Grafting Using the Splicing Technique
}

\author{
José-Luis Pardo-Alonso ${ }^{1}$, Ángel Carreño-Ortega ${ }^{1, *}$, Carolina-Clara Martínez-Gaitán ${ }^{2}$, \\ Iacopo Golasi ${ }^{3}$ and Marta Gómez Galán ${ }^{1}$ \\ 1 Department of Engineering, University of Almería, Research Center CIMEDES, Agrifood Campus of \\ International Excellence (CeiA3), La Cañada de San Urbano, 04120 Almería, Spain; jolupa@ual.es (J.-L.P.-A.); \\ mgg492@ual.es (M.G.G.) \\ 2 Tecnova, Technological Center: Foundation for Auxiliary Technologies for Agriculture; Parque Tecnológico \\ de Almería, Avda. de la Innovación, 23, 04131 Almería, Spain; cmartinez@fundaciontecnova.com \\ 3 DIAEE-Area Fisica Tecnica, Università degli Studi di Roma "Sapienza", 00184 Rome, Italy; \\ iacopo.golasi@uniroma1.it \\ * Correspondence: acarre@ual.es; Tel.: +34-950-214-098
}

Received: 10 November 2019; Accepted: 9 December 2019; Published: 12 December 2019

\begin{abstract}
Horticultural grafting is routinely performed manually, demanding a high degree of concentration and requiring operators to withstand extreme humidity and temperature conditions. This article presents the results derived from adapting the splicing technique for tomato grafting, characterized by the coordinated work of two conventional anthropomorphic industrial robots with the support of low-cost passive auxiliary units for the transportation, handling, and conditioning of the seedlings. This work provides a new approach to improve the efficiency of tomato grafting. Six test rates were analyzed, which allowed the system to be evaluated across 900 grafted units, with gradual increases in the speed of robots work, operating from 80 grafts/hour to over 300 grafts/hour. The results obtained show that a higher number of grafts per hour than the number manually performed by skilled workers could be reached easily, with success rates of approximately $90 \%$ for working speeds around 210-240 grafts/hour.
\end{abstract}

Keywords: tomato grafting; splice grafting technique; agricultural robot; automated grafting; agricultural machinery

\section{Introduction}

The herbaceous graft is a growing technique that allows two pieces of living plant tissue to be joined together in such a way that they will unite and later grow and develop as a single composite plant [1]. This technique is widespread in Southeast Asia, the Mediterranean basin, and Europe for intensive cultivation in tomato greenhouses. With the use of grafting, plants with properties of agronomic interest are created, fundamentally seeking greater resistance to soil diseases and higher productivity in high-quality cultivars [2]. One of the technique's main disadvantages is its high cost of production. The seeds (of both the scions used and the added cost of the rootstock), the cost of labor, the supplies for each graft, the use of machinery and work tools, and post-graft care in the healing chambers are considered the most important factors in price determination [3-5].

It is estimated that the work of the grafting process itself can amount to approximately a quarter of the total costs associated per grafted plant; a third of these costs represent the total cost of the seeds, and the rest is essentially equally divided between the costs of materials and tools, the cost of the clip and the stay in the healing chamber, the energy costs, and the costs of the work of handling and 
transplantation personnel [6,7]. Proportionally, and with respect to the cost of the seeds, the scion represents $80 \%$ of the cost, compared to the $20 \%$ cost of the rootstock (Figure 1 ).

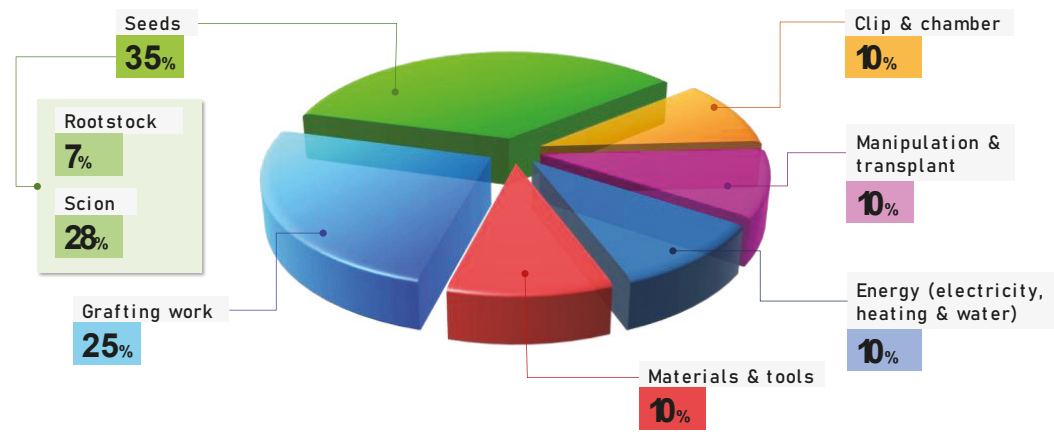

Figure 1. Estimated average cost distribution for a grafted plant. Average data assessed according to data collected in nurseries in Almería (Spain), [6,7].

On the other hand, the average cost of grafted tomato plants versus non-grafted plants varies considerably depending on several factors, mainly the productive scale of the nursery, the cost of labor, the production practices, and the cost of seeds employed, which can sometimes amount to more than $50 \%$ of the total costs [7]. In nurseries with a medium-high production volume, the costs of hand-grafted plants are estimated at approximately $\$ 0.67$ for the USA, compared to $\$ 0.15$ for non-grafted plants [8-10]. Similar prices are maintained for Asian countries, such as Japan and Korea [5], while for Spain and other European countries, the costs vary between $€ 0.54$ for hand-grafted plants compared to $€ 0.18$ for non-grafted plants [11]. These data corroborate that grafted plants can accumulate extra costs 3 to 4 times their cost without grafting.

Even so, the advantages of using grafted plants versus non-grafted plants, which include eliminating the common problems of soil pathogens that have traditionally been controlled by fumigation, have made the technique's use widespread and common in large regions of the world. Grafting has become the most effective and economically viable technique to address this problem [12], compared to other alternatives that have failed to provide a convincing ability to control these diseases, such as genetic improvement with resistance genes, greater crop rotation, soil solarization, the use of plastic mulch, biofumigation, the use of water vapor, crops without soil, the fallow technique, the use of trap plants, or the use of integrated biological control [13]. In Japan, Korea, and the rest of Southeast Asia, grafting is a common technique for the production of Solanaceae, especially in greenhouses, which constitute approximately $100 \%$ of the cultivated area [14]. Although its introduction in Europe and the Mediterranean basin occurred somewhat later, similar graft percentages are reached today. It is estimated that the cost/benefit ratio is 4.6 for grafted tomatoes, compared to 3.5 for non-grafted tomatoes [15].

Grafting is a task that requires considerable time, concentration, and dexterity, even for skilled workers. The delicate characteristics of the process and the biological requirements of the work seedlings, which need to be specially manipulated in a clean, warm, and humid environment, cause growing concern for plant producers due to the lack of available specialized personnel who are capable of facing intense workloads during short campaigns and with a high productive demand. Grafting requires up to three or four people and dedicated specific tasks within the process [3]. The shortage of skilled workers, along with an ageing agricultural population and an increasing demand for grafted plants, has made it necessary to automate grafting [16].

The need to use machinery in plant production to reduce the demand for human labor, expand production capacities, and improve product uniformity has been recognized for a long time [17]. In advanced agricultural countries, efforts are being made to develop and use automatic graft equipment 
due to the lack of labor in rural areas $[18,19]$. An improvement in grafting methods and techniques that reduce the cost of labor in grafting, its subsequent management, and transplants will contribute to the increased use of grafted plants worldwide [5,17].

There is an important tendency towards developing graft robots with a market potential, as opposed to manual grafting [18]. Splice grafting is a widely used method for Solanaceae, with the advantages of being easily mechanized and having well-defined and clear operations. The stem of the rootstock is cut, preferably below the cotyledons, at a specific angle. The scion, cut with the same angle, has a section that is more or less similar to the rootstock. Finally, by means of a special clamp or clip in the form of a tube, the two cuts are joined [1,20-22] (Figure 2).

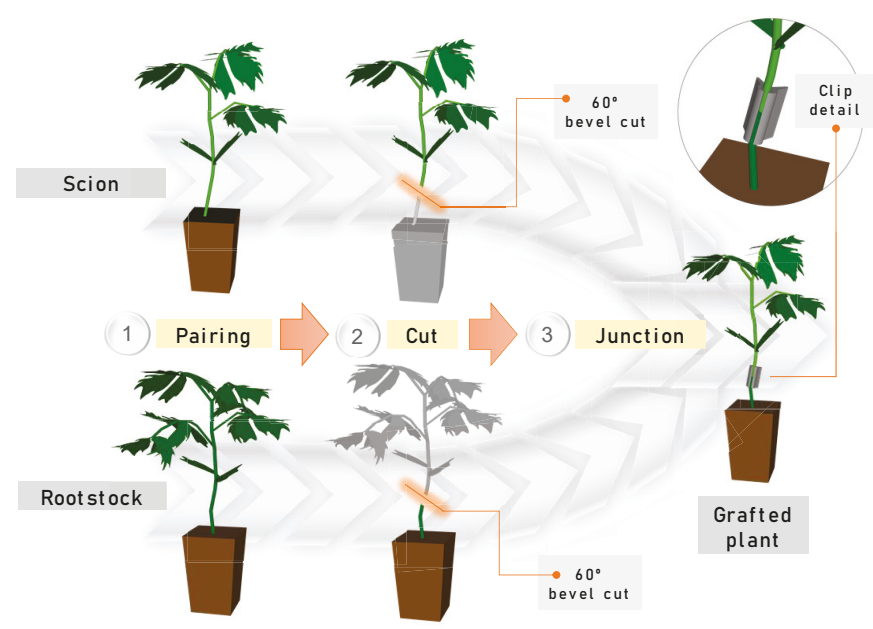

Figure 2. Sketch of the tomato grafting technique known as "tube grafting", "Japanese top-grafting", or "splice grafting".

Since the late 1980s and in the last three decades, there have been numerous attempts to invent equipment that reasonably succeeds in the automated grafting of horticultural plants. In the first two decades, the majority of developments came from Southeast Asia, while in the last decade, developments of mainly European origin have also been added $[3,17,23]$. This equipment has fundamentally been a semi-automated technology system, which facilitates the grafting task but requires up to two or three operators to function. Other developed systems are completely autonomous but enormously rigid in their performance, while at the same time being complex in their adaptability and operational requirements. Faced with these developments, and based on dedicated and specific automation, a study is presented herein of equipment based on conventional industrial robotic technology, supported by simple auxiliary equipment, which allows the productive requirements of the graft task to be met and can be easily adapted to other tasks and productive needs.

The price trend experienced in recent years in industrial robotics, which allows for the acquisition of small robotic units with similar initial investments at a cost no higher than the biannual cost associated with the minimum wage in developed countries [24,25], together with the use of passive auxiliary units with a low cost for transporting, cutting, and placing the binding clip on the seedlings, would allow for a rapid amortization of investment, which makes the study of this development alternative an area of interest.

The objective of this article was centred on the study and feasibility of automated grafting using a robotic cell based on the use of conventional industrial robotics, which allowed the grafting task to be faced with a greater system configurability and flexibility against the natural biological variability of the seedlings being used. This grafting system is supported by the use of simple and low-cost auxiliary 
equipment, which allows the task to be completed with tools external to the logistical tasks of the seedling trays, the cutting of the seedlings, and the dispensing and placement of the graft clip.

\section{Materials and Methods}

\subsection{Device Description and Productive Process}

The robotic equipment for grafting consists of transport devices, the manipulator itself, cutting mechanisms, and devices that facilitate bonding and grip [26]. True to this premise, the study equipment consisted of two anthropomorphic robots equipped with clips adapted for manipulating seedlings, with two seedling bevel cutting devices and a device for the forming, dispensing, and placement of the graft clips (Figure 3).

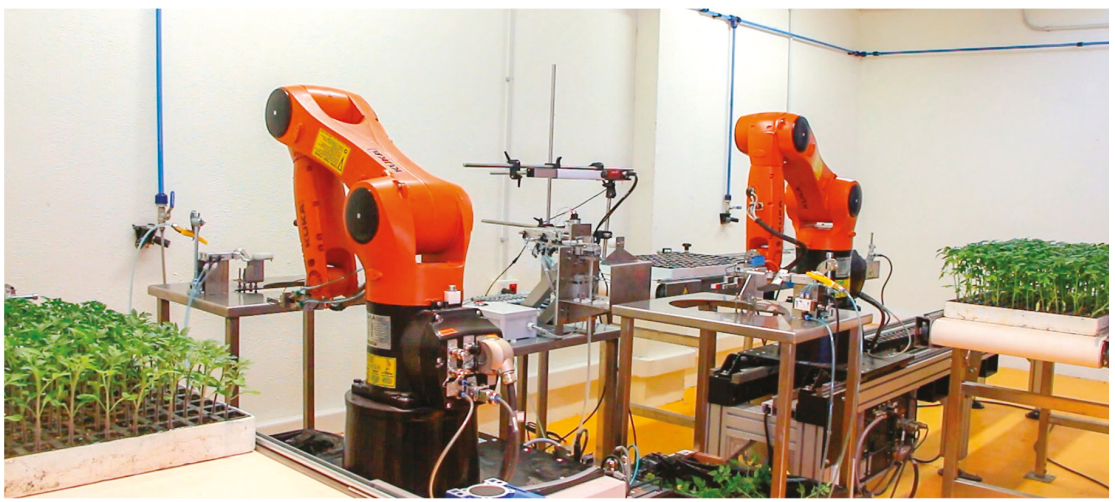

(a)

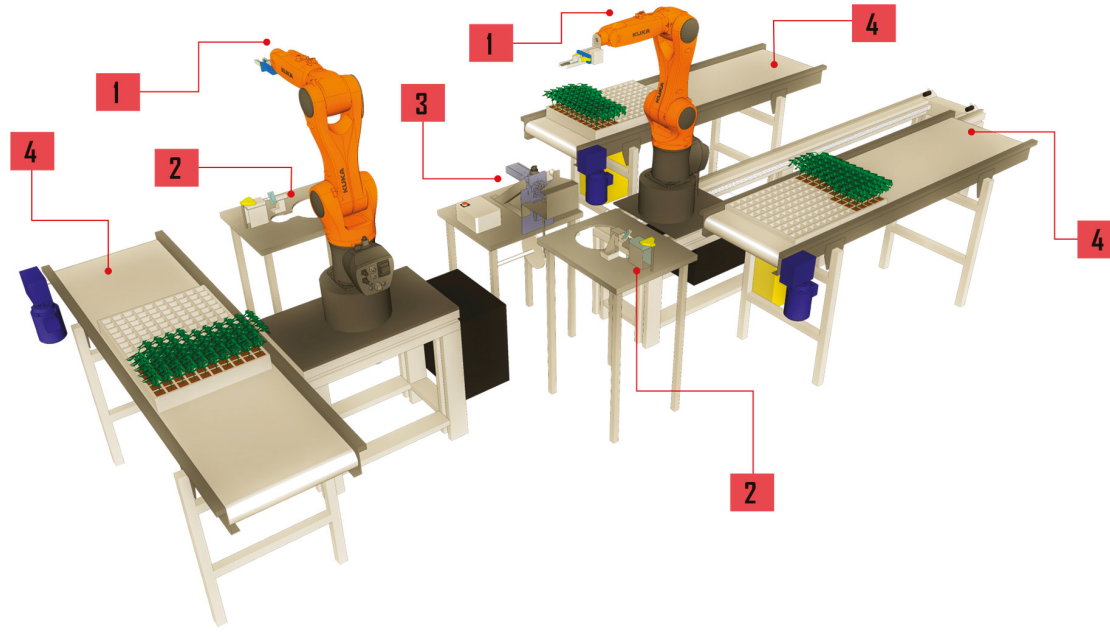

(b)

Figure 3. (a) General view of the robotic cell developed for grafting plants using the splicing technique. (b) Work cell sketch. (1) KUKA KR6 900 robots for manipulating the seedlings. (2) Cutting devices for rootstock and scion seedlings. (3) Forming, dispensing, and placement graft clip device. (4) Conveyor belts for seedling trays (rootstock, scion, and grafted plants). Demonstrative video of the system: https://youtu.be/9GvIDyrBBfo (accessed on 10 December 2019). 
The seedling trays are loaded at the beginning of the process into conveyor belts suitable for this purpose, so that two seedling starter trays, loaded with rootstock and scion seedlings will be properly positioned in front of the working robots.

Each completed row of work is followed by an advance of the belt, which relocates the next row into the appropriate collection area. This process happens until the rows in the seedling starter trays (rootstock and scion) are finished. Likewise, there is a third conveyor belt with an empty output tray for the resulting seedlings to be placed on once grafted. This output conveyor belt also performs partial advances per row while working on that tray.

Once the trays reach the required locations, the two industrial robots, Kuka model Agilus R6 900 (developed by KUKA Roboter $\mathrm{GmbH}$ ), work from their home position in a coordinated manner on the rootstock and scion to achieve graft completion. These robots have equivalent commercial equipment from other large manufacturers worldwide, such as the robot model IRB1200 (developed by ABB), the model MH5F (developed by Yaskawa), or the model LR Mate 200iD/7 L (developed by FANUC). All of them have similar load capacities, degrees of freedom, speeds, and working spaces, so their replacement would not lead to significant differences.

Each robot operates independently by handling each of the seedlings, which are obtained from the input trays. The rootstock and scion seedlings are approached in a simultaneous and coordinated manner: (1) approach the input trays (AIT). This displacement is followed by a precision operation that separates the seedlings from their trays: (2) grip and extraction (GE).

The final elements for the seedling manipulation consist of clamps composed of two fingers with an opening and closing parallel model MHZ2-32D from SMC, equipped with a padded extension zone of low-density (150-200 kg/m³ ) polyurethane foam (neoprene) with high resilience for precise and firm seedling attachment. A photocell is located between the ends of these fingers, and a Sick LL3-TB02 optical fibre sensor detects the precise location of the stems of the seedlings, which can emerge at any position within the alveolus of the tray. The individual seedlings have a unique growth morphology, and the alveoli can even be empty (Figure 4).

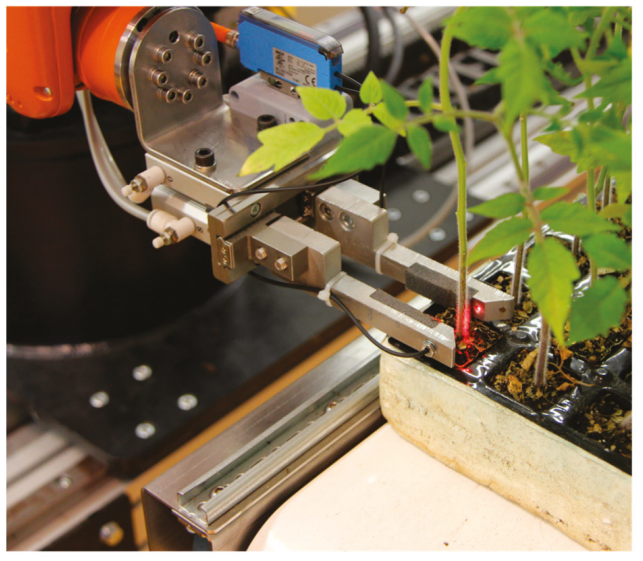

(a)

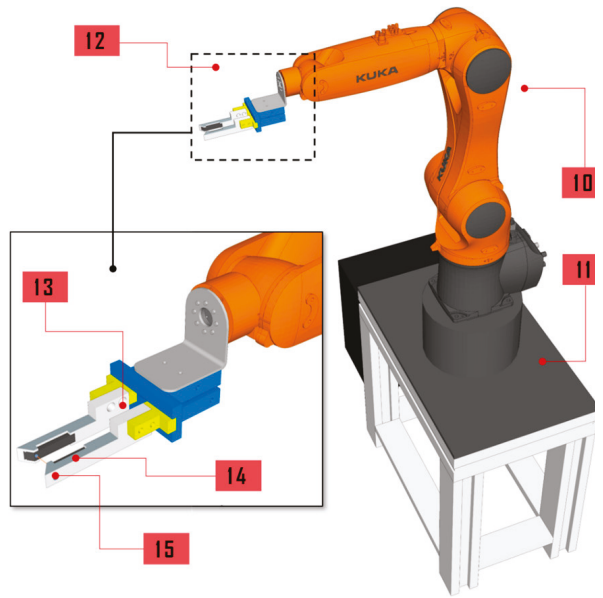

(b)

Figure 4. (a) Detailed view of the clamp or terminal element of the robots. (b) Robot and clamp sketch. (10) Industrial robots. (11) Clamping base. (12) Robot clamp. (13) Fingers with parallel opening and closing operation. (14) Padded area for holding seedlings. (15) Sensor for seedling detection.

After extracting the seedlings from their alveoli in the trays, the robotic arms carry the seedlings to the point where the cut will be made: (3) approach the cutting zone (AC). The system uses two equal 
pieces of equipment for cutting the seedlings to guarantee precision in the required cutting angle and the integrity of the dissected seedling. Both pieces of equipment are responsible for acting, one on the rootstock and another on the scion, allowing the cutting angle to be regulated and complementary between both plants. Prior to cutting, the robots insert the seedlings into a slot or channel located in front of the blade, where the stems are embedded to ensure the verticality of the stems during cutting. The cut is executed by activating a double-shank pneumatic cylinder, SMC model CXSM15-15, coupled to a terminal tool of a sharpened, disinfected, and interchangeable blade of stainless steel with a precise cut angle [27]. The cut is performed by a dry shock stroke of the blade against the seedling, which cleanly bisects the stem and ensures a clean cut: (4) cutting process (C). Meanwhile, an external blower separates the non-useful part of the treated seedling (Figure 5).

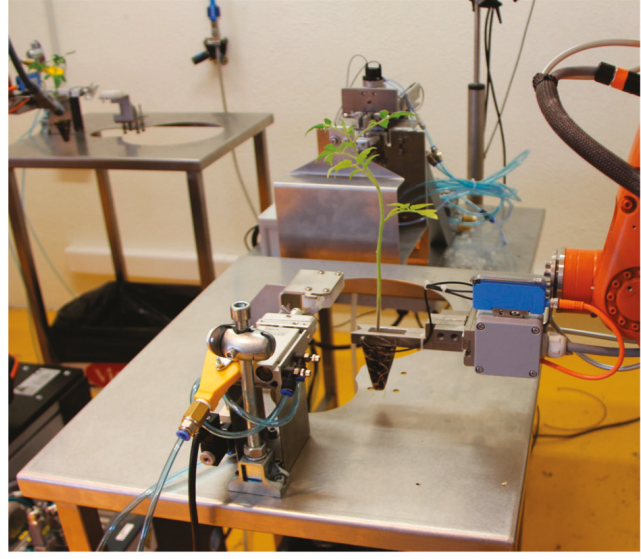

(a)

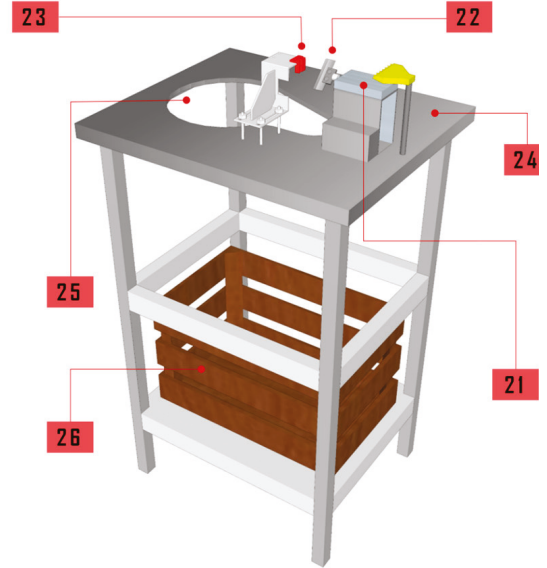

(b)

Figure 5. (a) Detailed view of the cutting device. (b) Cutting device sketch. (21) Pneumatic cylinder to drive the blade. (22) Cutting blade. (23) Slot for seedling lace. (24) Worktable. (25) Hole for waste disposal. (26) Waste accumulation box. (26) Blower.

After the cut, the robotic arms carry the useful parts of the seedlings for the graft towards the bonding area: (5) approach the clip dispensing zone (ACD). The graft equipment that creates the bond is responsible for cutting plastic clips from a continuous roll and then dispensing and placing a clip on the seedlings to be grafted. Thus, this device contains two subsystems: one in charge of preparing the clip and another in charge of placing it.

The first clip preparation subsystem consists of a series of electropneumatic devices that act in a coordinated and sequential manner to perform the clip cutting process from a continuous roll of plastic tube, regulating the advance and thus controlling the length of the cut clips. To obtain a clip with the desired length, an SMC model CJPB10-5 microcylinder presses the plastic tube against the end of a second cylinder, an SMC model CXSM15-15, which advances in the vertical direction the exact length that the clip is desired to have. Finally, an SMC model CXSM15-15 cylinder, equipped with a sharp blade at its end, makes a clean cut with a sharp blow, creating the clip to be used.

The second subsystem contains a rotating cylinder, a Festo model DM-6-90-PA, which grips the cut clip, then tightens its wings and thus clamps and fully opens the clip. Finally, with an SMC model CXSM25-70 cylinder, the clip is brought closer by a precise horizontal movement to the junction point where the two seedlings to be grafted are located. At the point of clip placement, a passive fitting device is adapted to accommodate and locate the seedlings in front of the clip. To ensure a precise bond without unwanted seedling displacement, both parts remain in contact and can thus fasten the 
bond. Once the clip is placed on the seedlings, the device that kept the graft clip pinched loosens and moves away from the junction point, returning to its resting position (Figure 6).

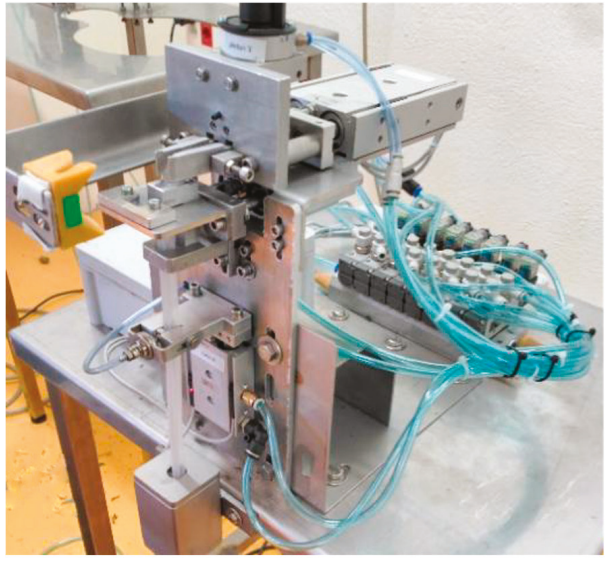

(a)

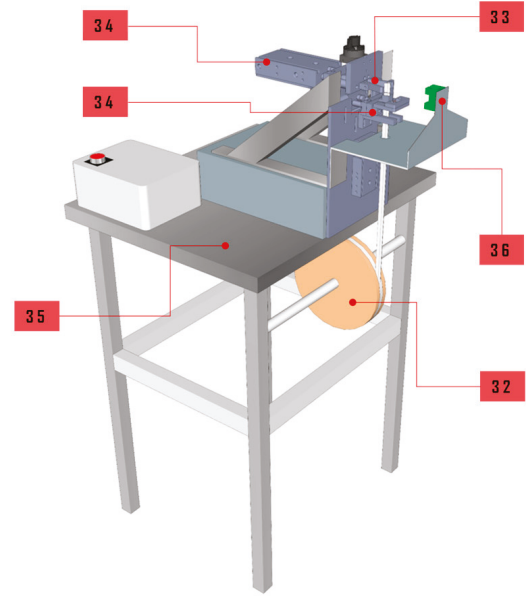

(b)

Figure 6. (a) Detailed view of the device that dispenses and places the graft clip. (b) Sketch of the device that dispenses graft clips. (31) Pneumatic cylinders and blade to make the grafting clip. (32) Continuous silicone roll for clip manufacture. (33) Tweezers for the grip and clip opening. (34) Pneumatic cylinder responsible for bringing the grafting clip closer to the junction point. (35) Worktable. (36) Plant placement device and grafting clip insertion point.

The graft is accomplished when both plants are placed in intimate contact with one another and the graft clip is pressed onto them: (6) clip preparation and placement (CPP). Once the clip is placed, the robot holding the scion releases the graft and withdraws, leaving the bonding area, while the other robot, which holds the completed graft by its lower part, moves the graft by the rootstock to the tray where the grafts will be left once finished: (7) approach the output trays (AOT). The graft is deposited in an alveolus of the output tray: (8) insertion on trays and release of plants (ITR).

Once the process is finished, both robots return to their resting positions, either as an end point or as a point of passage from where a new work cycle begins: (9) return home (RH). The process is repeated until the work trays are completed. The tray with the grafted seedlings is removed, and the grafted seedlings are subjected to a post-grafting process of healing, where their success is examined over 14 days: (10) post-graft losses (PGL). The entire system and grafting equipment described, as well as other secondary elements and auxiliary equipment, are managed and coordinated in a global manner through a central control unit, consisting of a PLC model CJ2 M, with an Omron CPU32.

During the grafting operation, 10 control points were established as singular intermediate points of reference in the process, which allowed us to record the partial times used and a distribution of failures during grafting (Figure 7).

The flowchart describing the operations and process described above allowed us to evaluate the validity and efficacy of conventional industrial robotics applied to tomato seedling grafting using external low-cost passive devices that facilitate grafting completion. The external devices act as a tool both in cutting the seedlings and in the dispensing and placing of the graft clip (Figure 8). 


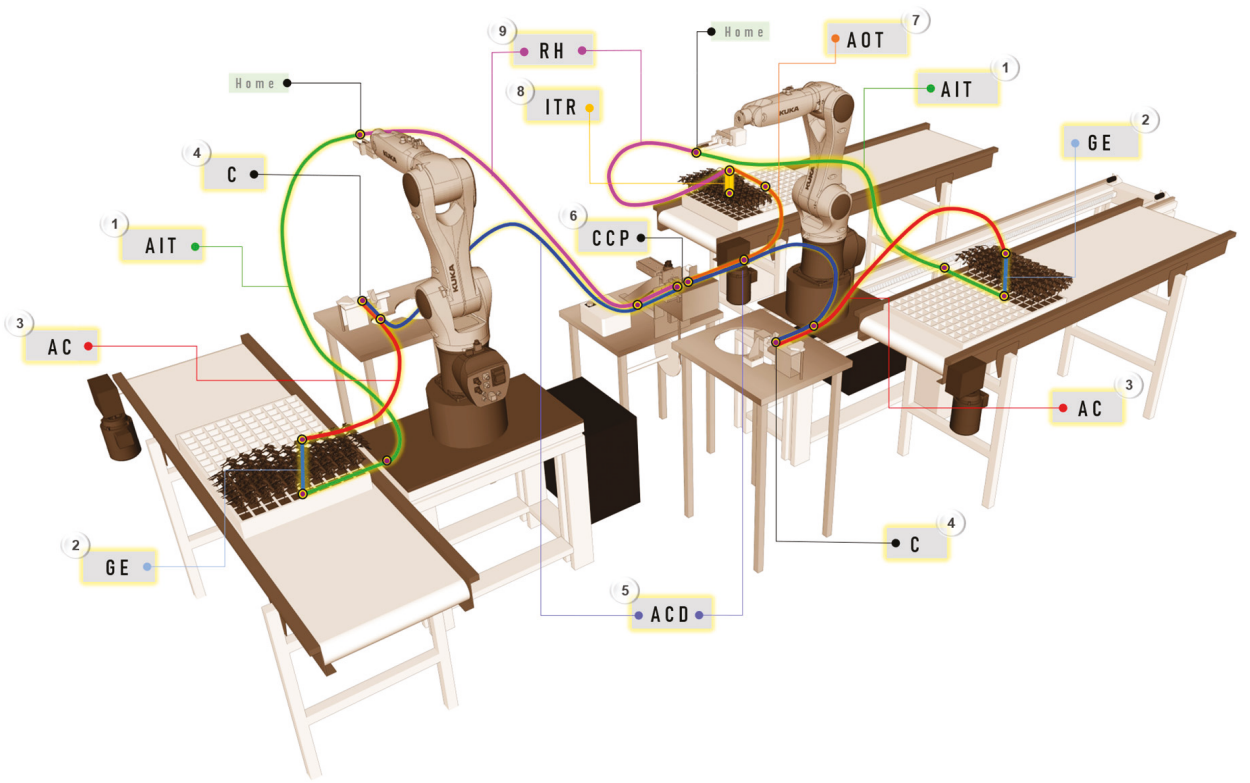

Figure 7. Travel details. Singular points: (1) approach the input trays (AIT); (2) grip and extraction (GE); (3) approach the cutting zone (AC); (4) cutting process (C); (5) approach the clip dispensing zone (ACD); (6) clip preparation and placement (CPP); (7) approach the output trays (AOT); (8) insertion on trays and release of plants (ITR); (9) return home (RH).

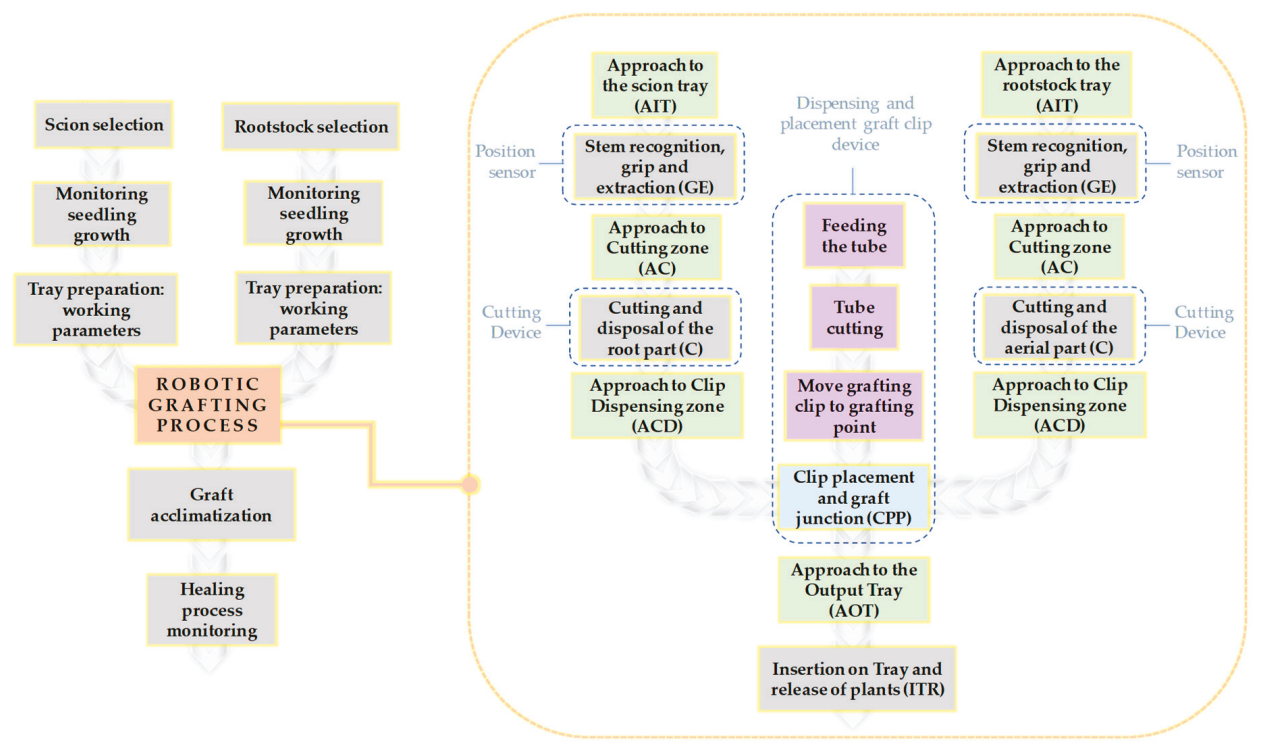

Figure 8. Flowchart of the developed automated grafting process. 


\subsection{Definition of Operating Conditions}

The experiment was conducted at the Tecnova Technological Center (Centro Tecnológico Tecnova): Foundation for Agricultural Technologies of Agriculture, in Almería ( $36^{\circ} 52^{\prime} 38^{\prime \prime} \mathrm{N}, 2^{\circ} 19^{\prime} 59^{\prime \prime} \mathrm{W}$ ) between the months of April and June 2017. The environment of Almería is a model of agricultural exploitation. Greenhouse growth of arable fruit crops has a high technical and economic performance, with tomato cultivation being of particular importance.

The rootstock used in the experiment was the interspecific hybrid "Maxifort" from De Ruiter Seed $^{\mathrm{TM}}$, which is recommended for crops with better behavior at low temperatures and under high salinity conditions. The "Ventero" variety from De Ruiter Seed ${ }^{\mathrm{TM}}$ was used as an indeterminate hybrid tomato for branch harvest. Both types of seeds are routinely used in seedbeds to perform manual grafts using the "tomato on tomato" (T/T) technique, which demonstrates their prior compatibility with the robotic system.

The growth protocol developed in the nursery attempted to obtain plants that were grown and cared for until reaching a similar growth state between the rootstock and scion, with mature plants and those prepared for the graft having two-four well-defined true compound leaves [28] and stem diameters of at least $1.5 \mathrm{~mm}$ for the splicing method [29]. Therefore, stems with some natural variability characteristic of the development of each plant (between 1.5 and $2.5 \mathrm{~mm}$ in diameter in the area close to the cut for the scion, and between 2 and $3 \mathrm{~mm}$ in diameter for the area close to the cut for the rootstock) were worked with. Usually, in the automatic graft, the requirements in terms of growth and uniformity required for the rootstock and scion seedlings are as critical as in the manual graft [30], demanding an arduous previous task of pre-selection and pairing similar diameters between the linked seedlings. In our experiment, this work was eliminated because the seedlings were cut with a bevel at a $60^{\circ}$ angle. From a certain cutting angle, between $50^{\circ}$ and $70^{\circ}$, and provided that one works within the margins of natural variability between the previously established stems, the success rate of the graft was acceptable and higher than $95 \%$. Therefore, the need to seek equal diameters of the workplaces was of lessened importance [27,31].

Prior to each experiment and for each tray, it was ensured that all the alveoli slots contained seedlings that met the previously established rootstock size criteria. The environmental conditions were regulated during the grafting process, with temperatures between $20^{\circ} \mathrm{C}$ and $25{ }^{\circ} \mathrm{C}$, conditions of relative humidity that were sometimes forced and were guaranteed to be above $75 \%$, and stable, non-direct daylight luminosity conditions.

The data were collected for each test via filming and were then timed; the times until reaching each control point of the process until the graft was completed or the point of generation of each failure were evaluated.

Regarding the post-grafting conditions, the plants began to wilt immediately after cutting and grafting, so once each graft tray was finished, it was immediately introduced into a small healing chamber consisting of a tunnel slightly larger than the dimension of each tray and a low height, covered by a transparent film. This tunnel was placed inside a chamber in which the climatic conditions were controlled throughout the healing process. During the first $48 \mathrm{~h}$, the plants were kept without illumination to reduce transpiration and evaporation. On the following days, the intensity of the light was increased, and a $14 \mathrm{~h}$ light photoperiod with a value $\approx 100 \mu \mathrm{mol} \cdot \mathrm{m}^{-2} \cdot \mathrm{s}^{-1}$ of PAR, $(\sim 3000 \mathrm{lux})$ of non-direct and diffuse light was established during the callus formation stage, from LED lights, corresponding to a value slightly above the compensation point because there is evidence that a high intensity of light prevents callus formation [1]. The level of illumination was gradually increased after several days. The temperature was established with a variable set point in the healing chamber between $23^{\circ} \mathrm{C}$ and $30^{\circ} \mathrm{C}$, with an average of approximately $26^{\circ} \mathrm{C}$, slightly varying between the diurnal and nocturnal conditions. The relative humidity was initially established between $75 \%$ and $95 \%$ in an attempt to reduce the transpiration rate of the scions, avoiding high stress and thus preventing the drying of the graft [32]. The humidity level was gradually reduced in successive days to condition the grafts to the outdoors. The vapor pressure deficit (VPD), during the critical graft healing phase was 
around $0.8 \mathrm{kPa}$ in the tunnel inside of the healing chamber, with the aim of decreasing transpiration. This value was gradually increased in the following days.

The success or failure of the final graft was evaluated by estimation and visual assessment performed daily across the 14 days after grafting, assessing the natural evolution of the graft, and analyzing other symptoms and external evidence that would determine its classification as either a success or a failure. In making this determination, key intermediate points were considered to mark an inflection of the task or singularity within the process, so that the successful or unsuccessful completion of this phase of the robotic process could be evaluated.

\subsection{Experiments}

In the process, different robot working speeds were tested, with the objective of determining the influence on the graft success. The robot speeds were constant within each test and ranged from $100 \mathrm{~mm} / \mathrm{s}$ to $600 \mathrm{~mm} / \mathrm{s}$, with gradual increments of $100 \mathrm{~mm} / \mathrm{s}$. In total, six working speeds were tested.

A total of 900 grafts were prepared, divided into three experimental blocks consisting of a total of 300 grafted seedlings each, where a total of 50 grafts were performed for each of the six test rates. The sum of the experimental blocks, equal to one another, therefore consisted of a total of 150 resulting grafts for each of the six tested velocities.

Only the work times of the external processes on the seedlings (manipulations on the trays, cutting, and dispensing of the clip) were kept constant between the tests. It was understood that since the work times are based on pneumatic technology, they were optimized for the corresponding work speed at 3.5 bar (0.35 MPa).

Each experimental block, when was developed on a specific date, was treated under the same cultivation, manipulation, and post-graft healing conditions, with the aim of matching the development conditions between the three experimental blocks. In addition, for each of the experimental blocks, the positional order of each test rate was altered, thereby neutralizing the dependence of said factor.

The statistical analysis of the collected data was performed using the software Minitab v.18.1. The obtained results were subjected to an analysis of variance with a confidence level of $95 \%$, and contrast tests were applied using Tukey's test (honestly significant difference, HSD test).

\section{Results and Discussion}

After performing the hypothesis test, we estimated that there were statistically significant differences between the grafting times used for the different tested work rates (Table 1).

For each velocity tested (between TS1 and TS6), the variability of time used in each test unit was mainly due to singularities that facilitated the manipulation and the development of the grafting work, to a greater or lesser extent. Singularities included the position of the alveolus in each row of work, the natural variability of the seedling emergence point within each alveolus, and the unique growth morphology of each seedling, among others. At low velocities, the difference for each work velocity was clear, given that the time taken to solve these singularities was less significant compared to the time spent in tasks not affected by these singularities. However, at high speeds, these factors became increasingly important and, to some extent, determined the time spent in each test unit.

Grouping the data by test speed, analyzing the failures associated with each control point that were recorded for the different velocities, and performing the hypothesis test, we estimated that, based on the Tukey's tests, there were statistically significant differences between the groups of different assay speeds (Table 2).

At low test rates, the success rate was higher, greater than $90 \%$ for speeds equal to or lower than TS3, and there was a significantly increasing graft failure for operating speeds equal to or greater than TS4. Low speeds, between TS1 and TS3, had similar behavior in terms of failures; therefore, we consider that their differences were derived from chance and not from the working speed itself. Therefore, it is clear that the TS3 production speeds are more attractive, given that they had a higher production ratio associated with a low failure rate. 
The relationship linking the number of grafts/hour for each of the tested rates (TS1 to TS6) can be considered practically linear and was only altered by the random parameters derived, to a great extent, from the natural variability of the work seedling growth. Such nuances of correction barely affected the speed, which was largely marked by that established for both robots for each test, although the working speed of the auxiliary devices was kept constant. In addition, the percentage of successes/failures associated with each of the test rates (TS1 to TS6), considering their evolution, allowed us to observe a behavior similar to a quadratic function (Figure 9).

Table 1. Comparison between the mean times spent in grafting task for the six tested speeds. Grouping of comparisons applying Tukey's HSD test (honestly significant difference). Significance level $p<0.05$.

\begin{tabular}{ccccccccc}
\hline $\begin{array}{c}\text { TS } \\
\text { (Test Speed) }\end{array}$ & $N$ & Mean Time (s) & Variance & St. Dev & SS & St. Error & 95\% CI & $\begin{array}{c}\text { Grouping } \\
\text { (Tukey's HDS) }\end{array}$ \\
\hline TS1 & 150 & 40.641 & 185.078 & 13.600 & 27576.61 & 0.617 & $(39.43 ; 41.85)$ & A \\
TS2 & 150 & 21.521 & 56.582 & 7.522 & 8430.76 & 0.617 & $(20.31 ; 22.73)$ & B \\
TS3 & 150 & 15.430 & 27.691 & 5.262 & 4125.97 & 0.617 & $(14.22 ; 16.64)$ & C \\
TS4 & 150 & 13.320 & 30.922 & 5.561 & 4607.40 & 0.617 & $(12.11 ; 14.53)$ & C \\
TS5 & 150 & 9.416 & 19.950 & 4.467 & 2972.62 & 0.617 & $(8.20 ; 10.63)$ & D \\
TS6 & 150 & 6.993 & 22.708 & 4.765 & 3383.49 & 0.617 & $(5.78 ; 8.20)$ & D \\
\hline
\end{tabular}

The different letters show significative differences.

Table 2. Comparison between the means for grafting failures for the six speeds tested. Grouping of comparisons applying Tukey's HSD test (honestly significant difference). Significance level $p<0.05$.

\begin{tabular}{cccccccc}
\hline $\begin{array}{c}\text { TS } \\
\text { Test Speed) }\end{array}$ & $\begin{array}{c}\text { Speed } \\
(\mathbf{m m} / \mathbf{s})\end{array}$ & $\begin{array}{c}\text { Check } \\
\text { Points }\end{array}$ & $\begin{array}{c}\text { Mean } \\
\text { (Fails) }\end{array}$ & Variance & St. Dev & 95\% CI & $\begin{array}{c}\text { Grouping } \\
\text { (Tukey HDS) }\end{array}$ \\
\hline TS1 & 100 & 10 & 1.50 & 3.16667 & 1.780 & $(0.022 ; 2.978)$ & A \\
TS2 & 200 & 10 & 1.60 & 3.37778 & 1.838 & $(0.122 ; 3.078)$ & A \\
TS3 & 300 & 10 & 1.50 & 3.16667 & 1.780 & $(0.022 ; 2.978)$ & A \\
TS4 & 400 & 10 & 2.20 & 6.17778 & 2.486 & $(0.722 ; 3.678)$ & AB \\
TS5 & 500 & 10 & 2.70 & 5.37778 & 2.319 & $(0.922 ; 3.878)$ & AB \\
TS6 & 600 & 10 & 4.70 & 11.34444 & 3.370 & $(3.220 ; 6.180)$ & B \\
\hline
\end{tabular}

The different letters show significative differences.

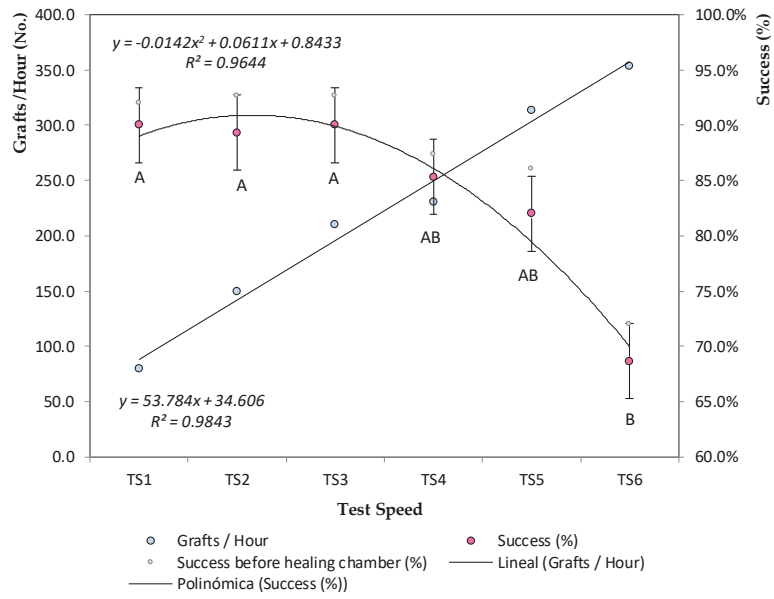

Figure 9. Grafts/hour versus grafting success for different test speeds (TS1 to TS6). Success rate includes the typical error. "Success before healing chamber" has been included to evaluate the influence on the global success of the grafting process. 
At the working speeds of the TS3 and TS4 robots (210 and 240 grafts/hour, respectively), the number of grafts estimated for manual expert workers was already surpassed, i.e., a maximum of $150-240$ grafts/hour $[7,15]$, and an average of approximately no more than 1000 grafts per person per day $[30,33,34]$. In addition, the success rates for manual grafting are not usually very high, between $81 \%$ and $91 \%$ [35]. In part, this rate of failure may come from long hours in a hostile work environment, characterized by high humidity and temperature. The success rates achieved by the robotic graft were quite similar to those achieved by manual workers, reaching $90.0 \%$ for the TS3 speed of $300 \mathrm{~mm} / \mathrm{s}$ and $85.3 \%$ for the TS4 speed of $400 \mathrm{~mm} / \mathrm{s}$.

For large cutting angles in splicing grafts, the difference between the diameters of the linked stems became less important as long as they stayed within certain a range [31]. For cuts at a $60^{\circ}$ bevel, failure in the healing and grafting of the middle graft was between $3 \%$ and $6 \%$ of failures [27]. The difference between the number of successes considered after grafting and the number of successes recorded after the healing period in the chamber confirmed this parameter (less than $4 \%$ ), and except for errors not visually detected in the grafting process, we associated the percentage of losses in the chamber to random problems in the healing process itself.

The established isolated intermediate control points allowed us to record the cause for each failed graft. Studying the origin of the graft failures associated with each velocity in detail, we determined that at low test rates, the failures detected in the grafting process in the GE phase (grip and extraction) were slightly more significant. This result may be because the seedling, when extracted from its alveolus at a lower velocity, experiences lower extraction acceleration, with a consequently greater resistance and grip to the alveolus walls. As a result, the roots tend to remain adhered and occasionally incur damage and tears; traction damage to the stem or alterations to the other plants in the tray may also occur, among other problems.

However, it was observed that, as the test speed increased, the number of failures in this phase decreased, as did the number of failures in the operations of adaptation and placement of the seedlings, such as the AC (approach the cutting zone) and ACD (approach the clip dispensing zone) phases, and in the tasks properly conducted by these tools: $\mathrm{C}$ (cutting process) and CPP (clip preparation and placement). In part, this was due to seedling management from certain working speeds, where there was a substantial acceleration in the displacements between points, and with it, the inertia experienced on the seedlings, which, together with their root ball (semi-compressed coconut fibre substrate) could suffer greater damage and tearing when experiencing such sudden changes of state. In addition, it was observed that high accelerations led to excessive seedling balance by the ends not held by the robot clamp (root ball and stem), causing the robot to lose its reference point at rest or to not return to it in time, thus spoiling the graft. The development of the grafting process is shown in Figure 10.

As the working speed increased, the times spent in the tasks performed by the external working tools became more important compared to the times spent in the displacement and pre-positioning of the seedlings in front of the tools. This factor is due to the fixed value of the velocities of the pneumatic devices in response to an incremental increase in the robot velocities (Figure 11).

At speeds equal to or lower than TS3, the recorded success rate was relatively good at approximately $90 \%$, but it decreased substantially at higher speeds. The next tested speed, TS4, had a significantly different percentage of recorded failure, five points lower or $85.3 \%$. It is important to assess the success associated with each work rate, because it is the factor that makes it feasible as an alternative to manual grafting, because the system evaluated is scalable in terms of systems and tools operating in parallel. That is, the clamp or end element could be adapted by cloning two or more gripping systems in parallel for the seedlings, and, to the same extent, the auxiliary devices or tools acting on the seedlings could be cloned, thus multiplying the number of plants grafted per hour, maintaining similar success rates. In addition, regarding these working speeds (TS3 and TS4), the number of grafts capable of being developed manually began to be exceeded. Therefore, when evaluating the grafts/success ratio, we estimated a better average behavior for velocities close to TS3 (210 grafts/hour). 


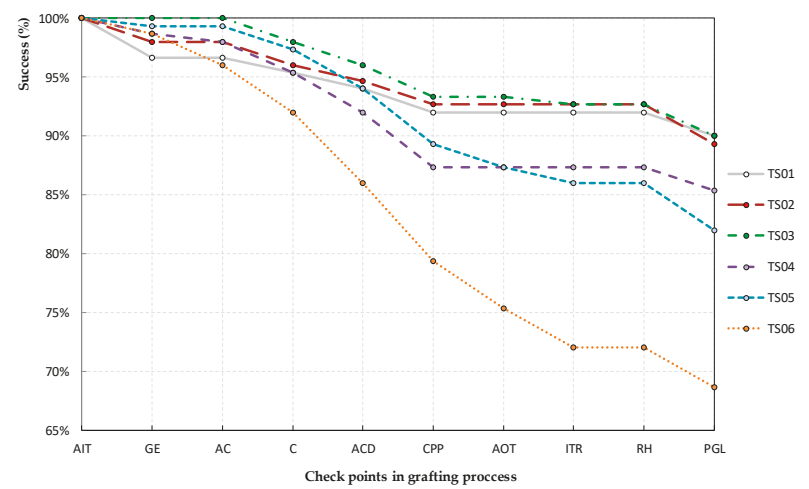

Figure 10. Success associated with each check point for the different test speeds, reflected in a percentage of successful plants in the grafting process. Check Points: approach the input trays (AIT), grip and extraction (GE), approach the cutting zone (AC), cutting process (C), approach the clip dispensing zone (ACD), clip preparation and placement (CPP), approach the output trays (AOT), insertion on trays and release of plants (ITR), return home (RH), and post-graft losses (PGL).

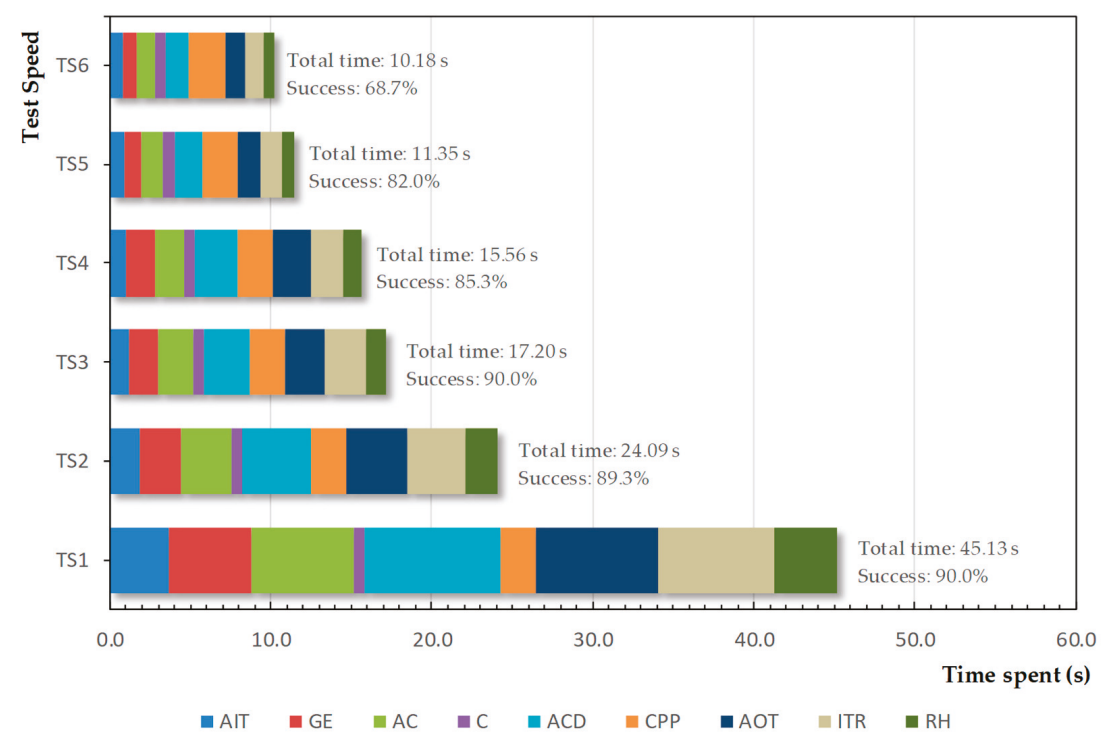

Figure 11. Average time spent in the development of each phase between control points. Check Points: approach the input trays (AIT), grip and extraction (GE), approach the cutting zone (AC), cutting process $(C)$, approach the clip dispensing zone (ACD), clip preparation and placement (CPP), approach the output trays (AOT), insertion on trays and release of plants (ITR), and return home (RH).

Numerous studies have collected the test results of prototypes and commercial devices for the automated grafting of horticultural seedlings over the last three decades $[3,5,7,23,36-44]$, and the results for dozens of pieces of equipment have been collected, mainly from Southeast Asia (Japan, Korea, and China mainly) and Europe.

Comparatively, we can refer to four factors that determine the convenience of and interest in the study equipment compared to other existing equipment: (a) the flexibility in terms of the horticultural family of work and the grafting method developed; (b) the degree of automation and the number of 
operators involved in the process; (c) system velocity (grafts/hour) and system efficiency; and (d) the price of the equipment.

(a) There are devices prepared exclusively for use with Solanaceae and others that allow working with Solanaceae and Cucurbitaceae. These pieces of equipment are mostly characterized by being inflexible. The study equipment, based on industrial robotics supported by low-cost external equipment, is specifically intended for splicing grafts, but enables easy and economic reconversion and readaptability, as it is able to work with other horticultural families and to apply other grafting methods. It even has the ability to perform other tasks in the seedbeds or productive environments.

(b) The existing prototypes and commercial devices present a different degree of automation, ranging from simple tools to help with grafting (cutting or dispensing the clip), to semi-automated equipment that requires the participation of two to three operators, to fully equipped devices. These are all automated and can be managed by a single operator. Nevertheless, they claim a high homogeneity in the work seedlings, requiring the important tasks of pre-sorting and pairing between seedlings, which to some extent tarnishes the autonomy of the system. The study equipment, by working with a high cutting angle, allowed us to avoid these previous tasks of searching and matching between the diameters of the workplaces and therefore enjoys a high degree of autonomy.

(c) Regarding the number of grafts per hour, the majority of studies present equipment ranging between 200 and 1200 grafts/hour. These values are much higher than those achieved using this equipment (210-240 grafts/hour), but these results are sufficient compared to manual grafting, and improvement is feasible by replicating terminal systems, allowing for working in parallel and over several plants simultaneously. In contrast, the system has a high success rate or efficiency of approximately $90 \%$.

(d) The current price trend of industrial robotics, together with the use of simple, low-cost auxiliary equipment, allows us to estimate that the studied system is a rapidly amortizable system, with an initial investment in robots no greater than the biannual cost associated with the minimum interprofessional wage in countries [25], and an additional base cost of auxiliary and control equipment which is not higher than other interprofessional minimum wages (MW). This implies a total base investment of $5 \mathrm{MW}(\sim € 60,000)$. Faced with this, the estimated costs of high automation systems robotic equipment in high productivity environments (100 million plants per year) are estimated at investments above $\sim \$ 7,500,000$ [45]. Comparatively, and estimating our system working at approximately 230 grafts/hour, we would yield approximately 2 million grafts per year per piece of equipment, which would imply approximately 50 systems working in parallel to reach 100 million grafts. Such scaling would involve an investment of $\sim € 3,000,000$, well below the investment necessary for other robotic equipment.

\section{Conclusions}

The splicing technique, widely used for Solanaceae such as tomato, has the advantage of being simple and methodical, and therefore easily automatable. In the last three decades, there have been numerous attempts to develop equipment to deal with the automated grafting of horticultural plants, and the challenge of using conventional industrial robotics to perform the splicing graft process can provide a great opportunity. The robotic cell tested herein is based on two industrial robots and low-cost passive auxiliary units.

The use of low speeds, between $100 \mathrm{~mm} / \mathrm{s}$ and $300 \mathrm{~mm} / \mathrm{s}$, allows ratios close to a $90 \%$ success rate to be maintained. At medium-high velocities, between $400 \mathrm{~mm} / \mathrm{s}$ and $500 \mathrm{~mm} / \mathrm{s}$, success ratios were still acceptable above $80 \%$. However, at a test speed of $600 \mathrm{~mm} / \mathrm{s}$, there was a considerable decrease in the success rate to less than $70 \%$.

Consequently, we conclude that it is advisable to use a velocity close to $300 \mathrm{~mm} / \mathrm{s}(90.0 \%$ success), which allows working at speeds higher than those estimated for manual expert workers, approximately $150-240$ grafts/hour (with success rates between $81 \%$ and $91 \%$ ). Decreasing the work rate below that point did not substantially improve the success rate. 
Author Contributions: J.-L.P.-A. conceived and designed the experiments, performed the experiments, collected and analyzed the data, interpreted the results and developed the manuscript. Á.C.-O. conceived and designed the experiments, analyzed the data, interpreted the results and developed the manuscript. C.-C.M.-G. conceived, designed and performed the experiments. I.G. and M.G.G. provided constructive suggestions on experiment analysis.

Funding: This research received no external funding.

Acknowledgments: This study was supported by Tecnova, Technological Center: Foundation for Auxiliary Technologies for Agriculture. The authors would like to acknowledge all the employees involved for their contributions to the experimental setting and data collection.

Conflicts of Interest: The authors declare no conflicts of interest.

\section{References}

1. Hartmann, H.; Kester, D.E.; Davies, F.T.; Geneve, R.L. Principles of grafting and budding. In Plant Propagation: Principles and Practices, 8th ed.; Prentice Hall: Upper Saddle River, NJ, USA, 2010; Chapter 11.

2. Camacho-Ferre, F. El injerto en tomate como alternativa al bromuro de metilo. Experiencias con esta técnica en San Quintín. B.C.-México. II Agro Simp. Int. Téc. Empres. Prod. y Tendencias 2013, 1-3. Available online: http://203.187.160.132:9011/simm.cicese.mx/c3pr90ntc0td/horta/docs/camachoFerre.pdf (accessed on 15 July 2019).

3. Lee, J.-M.; Oda, M. Grafting of Herbaceous Vegetable and Ornamental Crops, Horticultural Reviews. Hortic. Rev. 2003, 28, 61-124. [CrossRef]

4. Sakata, Y.; Ohara, T.; Sugiyama, M. The history and present state of the grafting of Cucurbitaceous vegetables in Japan. III Int. Symp. Cucurbits 2007, 159-170. [CrossRef]

5. Lee, J.-M.; Kubota, C.; Tsao, S.J.; Bie, Z.; Echevarria, P.H.; Morra, L.; Oda, M. Current status of vegetable grafting: Diffusion, grafting techniques, automation. Sci. Hortic. 2010, 127, 93-105. [CrossRef]

6. Rivard, C.L.; Sydorovych, O.; O'Connell, S.; Peet, M.M.; Louws, F.J. An economic analysis of two grafted tomato transplant production systems in the United States. Horttechnology 2010, 20, 794-803. [CrossRef]

7. Lin, H.-S.; Chang, C.-Y.; Chien, C.-S.; Chen, S.-F.; Chen, W.-L.; Chu, Y.-C.; Chang, S.-C. Current Situation of Grafted Vegetable Seedling Industry and Its Mechanization Development in Taiwan. 2016, pp. 65-76. Available online: http://www.fftc.agnet.org/activities.php?func=view\&id=20160113155600 (accessed on 15 July 2019).

8. Djidonou, D.; Gao, Z.; Zhao, X. Economic analysis of grafted tomato production in sandy soils in northern Florida. Horttechnology 2013, 23, 613-621. [CrossRef]

9. Rysin, O.; Rivard, C.; Louws, F.J. Is vegetable grafting economically viable in the United States: Evidence from four different tomato production systems. Acta Hortic. 2015, 1086, 79-86. [CrossRef]

10. Singh, H.; Kumar, P.; Chaudhari, S.; Edelstein, M. Tomato Grafting: A Global Perspective. HortScience 2017, 52, 1328-1336. [CrossRef]

11. De Miguel, A. Use of Grafted Plants and I.P.M. Methods for the Production of Tomatoes in the Mediterranean Region; Instituto Valenciano de Investigaciones Agrarias: Valencia, Spain, 2004; Available online: http: //ec.europa.eu/clima/events/docs/0014/tomato_4_en.pdf (accessed on 15 July 2019).

12. De Miguel, A. Evolución del injerto de hortalizas en España. Technol. Hortícola Hortic. Int. 2009, 10, 72. Available online: http://www.horticom.com/revistasonline/horticultura/rhi72/10_17.pdf (accessed on 15 July 2019).

13. González, F.M.; Hernández, A.; Casanova, A.; Depestre, T.; Gómez, L.; Rodríguez, M.G. El injerto herbáceo: Alternativa para el manejo de plagas del suelo. Rev. Protección Veg. 2008, 23, 69-74, ISSN 2224-4697. Available online: http://www.shorturl.at/klAKU (accessed on 15 July 2019).

14. Hoyos Echevarria, P. Situación del injerto en horticultura en España: especies, zonas de producción de planta, portainjertos. Ind. Hortícola 2007, 199, 12-25. Available online: http://www.horticom.com/revistasonline/ horticultura/rh199/12_25.pdf (accessed on 15 July 2019).

15. Ngo, Q.V. Grafted Tomato in Vietnam, From 0 to 7000 Ha/Year. 2016. Available online: http://www.fftc.agnet: htmlarea_file/activities/20160113155600/2016P032-7VN.pdf (accessed on 15 July 2019).

16. Kobayashi, K.; Suzuki, M.C. Grafting Robot. J. Robot. Mechatron. 1999, 11, 213-219. [CrossRef] 
17. Tian, S.; Xu, D. Current status of grafting robot for vegetable. In Proceedings of the 2011 International Conference on Electronic \& Mechanical Engineering and Information Technology, Harbin, China, 12-14 August 2011; Volume 4, pp. 1954-1957. [CrossRef]

18. Chiu, Y.C.; Chen, S.; Chang, Y.C. Development of a circular grafting robotic system for watermelon seedlings. Appl. Eng. Agric. 2011, 10, 95-102. [CrossRef]

19. Kim, H.M.; Hwang, S.J. Comparison of Pepper Grafting Efficiency by Grafting Robot. Prot. Hortic. Plant Fact. 2015, 24, 57-62. [CrossRef]

20. Oda, M. Grafting of Vegetables to Improve Greenhouse Production. Ph.D. Thesis, Food \& Fertilizer Technology Center: College of Agriculture, Osaka Prefecture University, Sakai Osaka, Japan, 1998; pp. 1-11. Available online: http://www.agnet:library.php?func=view\&id=20110803135029/ (accessed on 15 July 2019).

21. De Miguel, A.; Cebolla, V. Unión del injerto. Terralia 2005, 53, 50-60. Available online: https://www.terralia. com/terralias/view_report?magazine_report_id=365 (accessed on 15 July 2019).

22. Chiu, Y.; Chen, S.; Chang, Y.; Chou, L. Development of Robotic Grafting Systems for Fruit Vegetable Seedlings. In Proceedings of the FFTC \& Tainan-DARES International Workshop on Grafting to Improve Fruit Vegetable Production, Tainan, Taiwan, 16-20 May 2016; pp. 77-85. Available online: http://www.fftc.agnet: library.php?func=view\&style=type\&id=20170331104933 (accessed on 15 July 2019).

23. Jinyuan, Z.; Yunsheng, T. Development Status of Internal and External Graft Machinery. Council Agric. For. 2015, 99-106. Available online: https://book.tndais.gov.tw/Other/2015seedling/speech10.pdf (accessed on 15 July 2019).

24. Kuka Robots Ibérica. In Proceedings of the Conference Universidad de Vigo, Vigo, Spain, 27 October 2008; Available online: http://shorturl.at/yUVY9 (accessed on 15 July 2019).

25. Chiacchio, F.; Petropoulos, G.; Pichler, D. The Impact of Industrial Robots on EU Employment and Wages: A Local Labour Market Approach; Bruegel: Brussel, Belgium, 2018; pp. 1-18.

26. Feng-feng, W. Study on Grafting Machine of Camellia Seedling for Cleft Grafting. Ph.D. Thesis, Chinese Academy of Sciences, Beijing, China, 2011. Available online: https://www.dissertationtopic.net/doc/149228 (accessed on 15 July 2019).

27. Pardo-Alonso, J.-L.; Carreño-Ortega, Á.; Martínez-Gaitán, C.-C.; Callejón-Ferre, Á.-J. Combined Influence of Cutting Angle and Diameter Differences between Seedlings on the Grafting Success of Tomato Using the Splicing Technique. Agronomy 2018, 9, 5. [CrossRef]

28. Miles, C.; Flores, M.; Estrada, E. Injerto de Verduras Berenjenas y Tomates. In Hoja de Datos de la Extensión, FS052ES; Washington State University: Washington, DC, USA, 2013; pp. 1-4. Available online: https://s3.wp. wsu.edu/uploads/sites/2071/2014/04/Grafting-Eggplants-and-Tomatoes-SPAN-FS052ES.pdf (accessed on 15 July 2019).

29. Bumgarner, N.R.; Kleinhenz, M.D. Grafting Guide: A Pictorial Guide to the Cleft and Splice Graft Methods as Applied to Tomato and Pepper; Ohio State University, Research and Development Center: Columbus, OH, USA, 2014; Available online: http://www.walterreeves.com/wp-content/uploads/2010/11/tomato-grafting-guide. compressed.pdf (accessed on 15 July 2019).

30. Hassell, R.L.; Memmott, F.; Liere, D.G. Grafting methods for watermelon production. HortScience 2008, 43, 1677-1679. [CrossRef]

31. Bausher, M.G.; Road, S.R.; Pierce, F. Graft Angle and Its Relationship to Tomato Plant Survival. HortScience 2013, 48, 34-36. [CrossRef]

32. Johnson, S.J.; Miles, C.A. Effect of healing chamber design on the survival of grafted eggplant, tomato, and watermelon. Horttechnology 2011, 21, 752-758. [CrossRef]

33. Rivard, C.L. Tomato Grafting for High Tunnel Production; Kansas State University, Research and Extension: Manhattan, KS, USA, 2012; Available online: https://www.slideshare.net/UMNfruit/rivard-mn-ht2012a (accessed on 15 July 2019).

34. Tirupathamma, T.L.; Ramana, C.V.; Naidu, L.N.; Sasikala, K. Vegetable Grafting: A Multiple Crop Improvement Methodology. Curr. J. Appl. Sci. Technol. 2019, 33, 1-10. [CrossRef]

35. Sarah, A. Masterson. Propagation and Utilization of Grafted Tomatoes in the Great Plains; University of Alabama: Tuscaloosa, AL, USA, 2010; Available online: https://core.ac.uk/download/pdf/18529369.pdf (accessed on 15 July 2019).

36. Al-Razaq, A.H.A. Grafting techniques in vegetables crops: A review. Plant Arch. 2019, 19, 49-51. Available online: http://plantarchives:PDF\%2019-1/49-51\%20(4756).pdf (accessed on 15 July 2019). 
37. Tian, S.; Ashraf, M.A.; Kondo, N.; Shiigi, T.; Momin, M.A. Optimization of Machine Vision for Tomato Grafting Robot. Sens. Lett. 2013, 11, 1190-1194. [CrossRef]

38. Yinghui, M.; Xiwen, L. Root Pruning and Hole-Oblique Insertion Hypocotyl Automatic Grafting of Cucurbitaceous Vegetables; Chinese Society of Agricultural Engineering: Beijing, China, 2011; pp. 2-7. Available online: http://www.tcsae.org/nygcxb/ch/reader/view_abstract.aspx?file_no=X201102006\&flag=1 (accessed on 15 July 2019).

39. Song, G.; Linbin, J. Development of domestic and foreing vegetable grafting robot. J. Northeast Agric. Univ. 2007, 38, 847-851.

40. Oda, M. Use of Grafted Seedlings for Vegetable Production in Japan. Acta Hortic. 2008, 770, 15-20. [CrossRef]

41. Yamada, H. Research for Development of the Grafting Robot for Solanaceae. Tech. Pap. Agric. Mach. Res. Assoc. 2003, 65, 142-149. [CrossRef]

42. Lee, J.-M.; Bang, H.J.; Ham, H.S. Grafting of Vegetables. Jpn. Soc. Agric. Mach. Food Eng. 1998, 67, 1098-1104. [CrossRef]

43. Hwang, H.H. Study on Development of Automatic Grafting System for Fruit Bearing Vegetable Seedling; Escuela de Silvicultura de La Universidad Sungkyunkwan-Ministro de Agricultura y Silvicultura, Sungkyunkwan: Seoul, Korea, 1997.

44. Kurata, K. Cultivation of grafted Vegetables 2. Development of Grafting Robots in Japan. HortScience 1994, 29, 240-244. [CrossRef]

45. Lewis, M.D.; Kubota, C.; Tronstad, R. Scenario-Based Economic Analyses of Different Grafting Operation Sizes. Poster, (Table 2), 1000. 2012. Available online: http://www.vegetablegrafting:wp/wp-content/uploads/ 2012/11/Lewis_poster.pdf (accessed on 15 July 2019).

(C) 2019 by the authors. Licensee MDPI, Basel, Switzerland. This article is an open access article distributed under the terms and conditions of the Creative Commons Attribution (CC BY) license (http://creativecommons.org/licenses/by/4.0/). 

Article

\title{
Arsenic Accumulation in Grafted Melon Plants: Role of Rootstock in Modulating Root-To-Shoot Translocation and Physiological Response
}

\author{
Enrica Allevato ${ }^{1, \dagger}{ }^{\text {, }}$ Rosario Paolo Mauro ${ }^{2,+}$, Silvia Rita Stazi ${ }^{3, *}$, Rosita Marabottini ${ }^{1}$, \\ Cherubino Leonardi ${ }^{2}$, Anita Ierna ${ }^{4}$ and Francesco Giuffrida ${ }^{2}$ \\ 1 DIBAF, University of Tuscia, Via S.C. De Lellis snc, 01100 Viterbo, Italy; eallevato@unitus.it (E.A.); \\ marabottini@unitus.it (R.M.) \\ 2 Di3A, University of Catania, Via Valdisavoia 5, 95123 Catania, Italy; rosario.mauro@unict.it (R.P.M.); \\ cherubino.leonardi@unict.it (C.L.); francesco.giuffrida@unict.it (F.G.) \\ 3 DSCF, University of Ferrara, Via Borsari 46, 44121 Ferrara, Italy \\ 4 CNR-IBE, Via P. Gaifami 18, 95126 Catania, Italy; anita.ierna@cnr.it \\ * Correspondence: silviarita.stazi@unife.it \\ + The authors share the first Authorship.
}

Received: 6 October 2019; Accepted: 26 November 2019; Published: 1 December 2019

\begin{abstract}
The bio-agronomical response, along with the arsenic (As) translocation and partitioning were investigated in self-grafted melon "Proteo", or grafted onto three interspecific ("RS841", "Shintoza", and "Strong Tosa") and two intraspecific hybrids ("Dinero" and "Magnus"). Plants were grown in a soilless system and exposed to two As concentrations in the nutrient solution (0.002 and $3.80 \mathrm{mg} \mathrm{L}^{-1}$, referred to as As- and As+) for 30 days. The As+ treatment lowered the aboveground dry biomass $(-8 \%$, on average), but the grafting combinations differed in terms of photosynthetic response. As regards the metalloid absorption, the rootstocks revealed a different tendency to uptake As into the root, where its concentration varied from 1633.57 to $369.10 \mathrm{mg} \mathrm{kg}^{-1} \mathrm{DW}$ in "Magnus" and "RS841", respectively. The high bioaccumulation factors in root (ranging from 97.13 to 429.89 ) and the low translocation factors in shoot (from 0.015 to 0.071 ) and pulp (from 0.002 to 0.008 ) under As+, showed a high As mobility in the substrate-plant system, and a lower mobility inside the plants. This tendency was higher in the intraspecific rootstocks. Nonetheless, the interspecific "RS841" proved to be the best rootstock in maximizing yield and minimizing, at the same time, the As concentration into the fruit.
\end{abstract}

Keywords: Cucumis melo L.; arsenic; grafting; translocation; bioaccumulation

\section{Introduction}

Melon (Cucumis melo L.) is one of the major Cucurbit species, playing an important role in irrigated farmlands of the Mediterranean area [1]. In these regions, the water intended for irrigation could be contaminated with heavy metals as result of weathering of soil minerals and human activities [2]. Irrigation with contaminated water can affect food quality and safety for the presence of metalloids and/or heavy metals harmful for human health [3,4]. Among these, arsenic (As) is a persistent, non-degradable metalloid widely present in the environment both for geogenic or anthropogenic reasons [5]. Most As compounds are odorless, tasteless, and water-soluble, creating a serious health risk because of their carcinogenic potential [6]. This metalloid exists in plant organs both as inorganic and organometallic species, whose concentration and oxidation states are dependent on the type and amounts of sorbents in the substrate, $\mathrm{pH}$, redox potential (Eh), and soil microbial activity $[7,8]$.

Arsenic is non-essential and generally toxic to plants. At high concentrations (depending on the species) it interferes with multiple metabolic processes, leading to growth and yield disturbance, 
and even plant death $[9,10]$. The As(III) root uptake (i.e., the dominating form in anaerobic root environments) occurs by passive transmembrane transport involving members of the nodulin 26-like intrinsic protein family of plant aquaporins [11]. As(V), which dominates in aerobic root environments, enters plant roots via phosphate $(\mathrm{Pi})$ transporters, as the oxyanion chemical structure of $\mathrm{As}(\mathrm{V})$ is analogous to $\mathrm{Pi}[12]$. As a consequence, $\mathrm{As}(\mathrm{V})$ compete with Pi absorption and P-dependent metabolic processes during ATP synthesis, with subsequent disturbance of major biological functions $[13,14]$.

The efficiency of As translocation from roots to shoots via xylem loading affects the plants' As tolerance and their proneness to accumulate this metalloid into the edible fraction, so posing potential risks to human health [14].

In horticultural systems, vegetable grafting is a multipurpose technique improving crops performances and product quality under both optimal and suboptimal growth conditions [15-17]. It has been proposed as a means to reduce the heavy metals uptake and translocation to the shoots and the edible parts [18,19], although the mechanisms underlying such impediment are still unclear [20]. Thus, investigating the use of melon rootstocks could be useful for understanding the behavior of different grafting combinations, with the view to improve crop performances and product safety in As-polluted areas.

Considering the above, the objective of this research was to study the effects of different rootstock genotypes on As uptake, accumulation, and partitioning, as well as on agronomical and physiological response of melon plants subjected to a high concentration of the metalloid in the root environment. To this end, the present experiment was performed to investigate: (i) If As concentration in the nutrient solution influences its uptake and translocation in melon plants; (ii) if and how the different rootstocks can mitigate the As accumulation within plant organs; (iii) the possible role of different rootstock genotypes in modulating the bio-agronomical response of melon plants to the elevated As concentration in the root zone.

\section{Materials and Methods}

\subsection{Experimental Site, Plant Material, and Management Practices}

The experiment was conducted in 2014, in a greenhouse situated in the coastal area of Eastern Sicily $\left(37^{\circ} 24^{\prime} 26^{\prime \prime} \mathrm{N}, 15^{\circ} 03^{\prime} 37^{\prime \prime} \mathrm{E}, 6 \mathrm{~m}\right.$ a.s.l.). The local climate is semi-arid/Mediterranean, with mild and wet winters, and hot, dry summers. A $1000 \mathrm{~m}^{2}$, east-west-oriented, multi-aisle greenhouse was used, having a steel tubular structure and covered with polycarbonate slabs. Mean air temperature, relative humidity and global radiation inside the greenhouse (two sets of sensors in the center of each experimental plot) were recorded on a data logger (CR10 X; Campbell Scientific Ltd., Loughborough, UK). Melon cv. "Proteo" $F_{1}$ (Syngenta Seed, Basel, Switzerland) belonging to the Reticulatus group was used as scion. Five $F_{1}$ rootstock genotypes were included in the study, of which 2 were intraspecific, namely "Dinero" (Syngenta Seed) and "Magnus" (Agris), and 3 were interspecific (Cucurbita maxima Duchesne $\times$ C. moschata Duchesne ex Poir.), namely "RS841" (DeRuiter Seeds, Oxnard, CA, USA) "Shintoza" (Fenix, Belpasso, Italy) and 'Strong Tosa' (Syngenta Seed). Self-grafted "Proteo" was used as control. Splice-grafted plantlets were used, whereas plastic clips were applied to secure the creation of the graft union. Plantlets were obtained from a specialized nursery and transplanted at the stage of 3 true leaves on April 22, in $5 \mathrm{~L}$ pots filled with perlite $(3-5 \mathrm{~mm})$. Pots were placed in troughs (5 per main plot) of an open soilless system, placed at $5 \mathrm{~cm}$ from the soil surface and with a distance of 50 $\mathrm{cm}$ between pots and $100 \mathrm{~cm}$ between troughs, obtaining a plant density of 2 plants $\mathrm{m}^{-2}$. During the trial, the crop was fertigated with a nutrient solution having the following composition, including the starting well water $\left(\mathrm{mmol} \mathrm{L}^{-1}\right)$ : $11.2 \mathrm{NO}_{3}{ }^{-}, 0.3 \mathrm{NH}_{4}{ }^{+}, 1.3 \mathrm{H}_{2} \mathrm{PO}_{4}{ }^{-}, 6.6 \mathrm{~K}^{+}, 0.9 \mathrm{SO}_{4}{ }^{2-}, 3.4 \mathrm{Ca}^{2+}$, $2.5 \mathrm{Mg}^{2+}$. The concentration of microelements $\left(\mu \mathrm{mol} \mathrm{L}{ }^{-1}\right)$ was: $15 \mathrm{Fe}^{3+}, 10 \mathrm{Mn}^{2+}, 0.75 \mathrm{Cu}^{2+}, 5 \mathrm{Zn}^{2+}$, $30 \mathrm{~B}^{3+}, 0.5 \mathrm{Mo}^{6+}$. The $\mathrm{pH}$ was maintained at 5.9 by adding $\mathrm{H}_{2} \mathrm{SO}_{4}\left(95 \%\right.$ concentration, $\left.1.83 \mathrm{~kg} \mathrm{~L}^{-1}\right)$. Bumblebees were introduced into the greenhouse to maximize pollination. Stems were left to grow horizontally, whereas plants were pruned by removing the lateral shoots. Only 1 lateral ramification 
per plant was left, bearing 2 fruits. In order to evaluate the effects of studied factors at the same date, the trial was stopped when the first fruit was fully ripe (i.e., 45 days after transplant). Fifteen days after transplanting, the nutrient solution was differentiated to obtain 2 As concentrations, a control solution $\left(0.002 \mathrm{mg} \mathrm{L}^{-1}\right.$ As, which was the concentration in the starting fertigation solution, hereafter As-) and an As-enriched one ( $3.8 \mathrm{mg} \mathrm{L}^{-1} \mathrm{As}$, hereafter As+) obtained by adding sodium arsenate $\left(\mathrm{Na}_{2} \mathrm{HAsO}_{4}\right.$ $7 \mathrm{H}_{2} \mathrm{O}, 24 \%$ As content). The As+ treatment was chosen to simulate the working condition of a soil having 55 ppm of As, $7.0 \%$ of which was bioavailable (a common situation in As contaminated soils). The nutrient solutions were supplied using a drip irrigation system with one emitter per plant $\left(4 \mathrm{~L} \mathrm{~h}^{-1}\right)$. The amount of nutrient solution supplied at each irrigation was quantified on a weekly basis, according to the volume of the substrate exploited by the roots and the corresponding water contained in the substrate at the intervals from -10 to $-50 \mathrm{hPa}$ of matrix potential $\left(12 \mathrm{~mL} 100 \mathrm{~mL}^{-1}\right)$.

The experiment was arranged in a randomized split-plot design with three replicates, assigning the As concentration of the nutrient solution to the main plots, and the rootstock combination to the subplots. The overall experimental area inside the greenhouse was $450 \mathrm{~m}^{2}(15.0 \times 30.0 \mathrm{~m})$, including 900 plants (324, excluding border plants), divided into 36 net experimental units ( 2 As levels $\times 6$ grafting combinations $\times 3$ replicates) each containing 9 plants.

\subsection{Leaf Relative Chlorophyll (Chl) Content and Gas Exchange Measurements}

Forty-five days after transplanting plants were checked for leaf relative Chl content, through a portable Chl meter (SPAD 502; Minolta Camera, Osaka, Japan). Before measurements, the instrument was calibrated according to manufacturer's instructions. All readings were taken from the adaxial side of the tallest fully expanded leaf. To minimize possible interactions with either plant water status and natural irradiance level [21,22], measurements were made in the morning, starting at 08:00 $\mathrm{h}$ (local solar time). Instantaneous leaf photosynthetic rate $\left(\mathrm{A}_{\mathrm{N}}\right)$, stomatal conductance (gs), and leaf transpiration rate (E) were also measured from 11:00 to 13:00 inside a $6.25 \mathrm{~cm}^{2}$ leaf chamber of a portable photosynthesis system (LCi; ADC BioScientific Ltd., Hoddesdon, UK). Photosynthetic water use efficiency (WUE) was calculated as the ratio $A_{N} / E$ [23]. During measurements, leaf temperature was $27.4 \pm 2{ }^{\circ} \mathrm{C}$, while mean photosynthetic photon flux density was in the range of $1500 \pm 100 \mu \mathrm{mol}$ photons $\mathrm{m}^{-2} \mathrm{~s}^{-1}$. Duplicate measurements were taken from four plants per sub-plot.

\subsection{Plant Growth and Development Measurements}

On the same date of physiological measurements, all the plants within each replicate were harvested and their main fractions (leaves, stem and fruits, regardless of the ripening stage) weighed separately. The number of leaves per plant $\left(\mathrm{L}_{\mathrm{N}}\right)$ was determined, while plant leaf area $\left(\mathrm{L}_{\mathrm{A}}\right)$ was measured using an Image Analysis System (DeltaT Devices Ltd., Cambridge, UK), then subsamples of raw materials were kept in a thermo-ventilated oven at $70{ }^{\circ} \mathrm{C}$ (Binder, Milan, Italy) until constant weight, in order to determine their dry weight (DW). From the original data frame, the leaf area ratio (LAR, the ratio between the area and total plant biomass) and leaf weight ratio (LWR, the dry weight of leaves to whole plant dry weight) were calculated.

\subsection{Arsenic and Phosphorous Determination in Plant Tissues}

Roots, shoots, and fully ripe fruits (1 per plant) were analyzed to determine the quantity of the total As and phosphorus (P). To this end, about $200 \mathrm{mg}$ of samples were subjected to acid digestions and to As and P determinations, which were performed according to Stazi et al. [19]. The reagents were super pure for trace analysis. The accuracy of the measurements was assessed using SRM 1573a as standard reference materials trace metals. Total As quantification were performed using an inductively-coupled plasma optical emission spectrometer (ICP-OES) with an axially viewed configuration (8000 DV, PerkinElmer, Shelton, CT, USA) equipped with an ultrasonic nebulizer. The As detection limit for employed technique was $0.1 \mu \mathrm{g} \mathrm{L} \mathrm{L}^{-1}$. With the aim of understanding the metabolic pathway followed by this element once absorbed by the plant, we measured the amount of trivalent and pentavalent 
As. Inorganic As species were extracted without the addition of hydrogen peroxide according to Rintala et al. [24] with some modifications. In brief, $200 \mathrm{mg}$ of roots were homogenized and digested with $10 \mathrm{~mL}$ of a mixture of $\mathrm{HNO}_{3}(1 \%, \mathrm{v} / \mathrm{v})$ and left to react overnight. The samples were subjected to microwave-assisted extraction according to the following program-3 min from 25 to $55^{\circ} \mathrm{C}$ (step 1), $10 \mathrm{~min}$ at $55^{\circ} \mathrm{C}$ (step 2), $2 \mathrm{~min}$ from 55 to $75^{\circ} \mathrm{C}$ (step 3), $10 \mathrm{~min}$ at $75^{\circ} \mathrm{C}$ (step 4 ), 2 min from 75 to $95^{\circ} \mathrm{C}$ (step 5) and $30 \mathrm{~min}$ at $95^{\circ} \mathrm{C}$ (step 6). Samples were then quantitatively transferred into tubes and centrifuged for $15 \mathrm{~min}$ at $10,000 \mathrm{rpm}$ at $4{ }^{\circ} \mathrm{C}$. The supernatant was filtered with a $0.22 \mu \mathrm{m}$ PVDF filter. The concentration of As(III) was determined directly with an ICP-OES equipped with a hydride generation system. The total concentration of inorganic arsenic species $[\mathrm{As}(\mathrm{III})+\mathrm{As}(\mathrm{V})]$ were obtained after reducing $\mathrm{As}(\mathrm{V})$ to $\mathrm{As}(\mathrm{III})$ through $5.0 \%(\mathrm{w} / \mathrm{v})$ ascorbic acid and potassium iodide in hydrochloric acid, and the content of $\mathrm{As}(\mathrm{V})$ was calculated from the difference between total As concentration and that of As(III) [25].

\subsection{Bioaccumulation and Translocation Factors}

Arsenic bioaccumulation factor (BAF) (i.e., the ability of a plant to accumulate this element from water) was calculated on a DW basis, as the ratio among its concentration in root (BAF root), shoot $\left(\mathrm{BAF}_{\text {shoot }}\right)$, and pulp $\left(\mathrm{BAF}_{\text {pulp }}\right)$ and the corresponding concentration in the nutrient solution. The root-to-plant translocation factor (TF) defines the movement and distribution of As from roots to the aerial part of the plant. The TF was calculated on a DW basis, as the ratio between the As concentration in shoot $\left(\mathrm{TF}_{\text {shoot }}\right)$ and fruit pulp $\left(\mathrm{TF}_{\text {pulp }}\right)$, and the corresponding concentration in roots at the end of the experiment [26-28].

\subsection{Statistical Procedures}

All data were subjected to Shapiro-Wilk and Levene's test, in order to check for normal distribution and homoscedasticity, respectively, then to a 'As concentration $\times$ rootstock' analysis of variance (ANOVA), according to the split-plot experimental layout adopted in the greenhouse. Percentage data were Bliss' transformed before the ANOVA (untransformed data are reported and discussed), while multiple means comparison was performed through Fisher's protected least significant difference (LSD) test $(p=0.05)$. The As concentrations in root, shoot, and pulp were subjected at principal component analysis (PCA) to verify the interaction between the different factors able to synthetize the considered variables. All calculations were performed using the Excel (Microsoft Corporation, Redmond, WA, USA) and JMP 11.0 statistical software package (SAS Institute, Cary, NC, USA).

\subsection{Microclimate Conditions Inside the Greenhouse}

During the experiment, the average mean temperature progressively increased from 18.6 to $26.4^{\circ} \mathrm{C}$ (on day 12 and 36 after transplanting, respectively), while relative humidity showed an opposite trend, as it passed from $63.7 \%$ to $40.5 \%$ (on day 11 and 33 after transplanting, respectively). Solar radiation amply paralleled the trend of mean temperature, as it progressively increased passing from 10.45 to $15.02 \mathrm{MJ} \mathrm{m}^{-2}$ (on day 11 and 36 after transplanting, respectively). As regards the spatial variability among main plots, the differences in terms of mean temperature, relative humidity, and solar radiation never exceeded $0.2{ }^{\circ} \mathrm{C}, 2.1 \%$, and $0.8 \mathrm{MJ} \mathrm{m}^{-2}$, respectively.

\section{Results}

\subsection{Aboveground Plant Biomass and Partitioning}

Whole plant biomass was affected by the main factors and their interaction (Table 1). In Astreatment this variable was higher in "Proteo" grafted onto "Strong Tosa" and "RS841" (309 g plant ${ }^{-1}$, on average), whereas in response to As+ treatment it significantly decreased in "Proteo" grafted onto "Dinero" (from 251.7 to 198.7 g plant $^{-1},-21 \%$ ) and "Strong Tosa" (from 317.0 to 239.3 g plant $^{-1},-25 \%$ ) (Table 1). Among the plant components, stem biomass resulted 30 and $24 \mathrm{~g} \mathrm{plant}^{-1}$ in As- and As+, 
respectively (-20\%) (Table 1). Passing from As- to As+, there was a general decrease of the leaf biomass too. This response was more marked in "Proteo" grafted onto "Dinero" (from 66.4 to $42.0 \mathrm{~g}$ plant $^{-1},-37 \%$ ), 'Magnus' (from 56.7 to $44.5 \mathrm{~g} \mathrm{plant}^{-1},-22 \%$ ), 'RS841' (from 66.3 to $52.1 \mathrm{~g} \mathrm{plant}^{-1}$, $-21 \%$ ), and "Strong Tosa" (from 58.0 to 44.4 g plant $^{-1},-23 \%$ ), whereas no significant difference was recorded when "Proteo" was self-grafted or grafted onto "Shintoza" (Table 1). When grown in the As+, fruit biomass showed a significant variation in "Proteo" grafted onto 'Magnus' and "Strong Tosa", where it varied by $+33 \%$ (from 119.9 to $159.1 \mathrm{~g} \mathrm{plant}^{-1}$ ) and $-26 \%$ (from 231.1 to $170.9 \mathrm{~g} \mathrm{plant}^{-1}$ ), respectively (Table 1 ).

Table 1. Aboveground biomass production and partitioning ( $g$ dry weight plant ${ }^{-1}$ ) in melon plant as affected by As concentration in the nutrient solution and rootstock. Different letters within main factors indicate significance at Fisher's protected least significant difference (LSD) test $(p=0.05)$. NS—not significant.

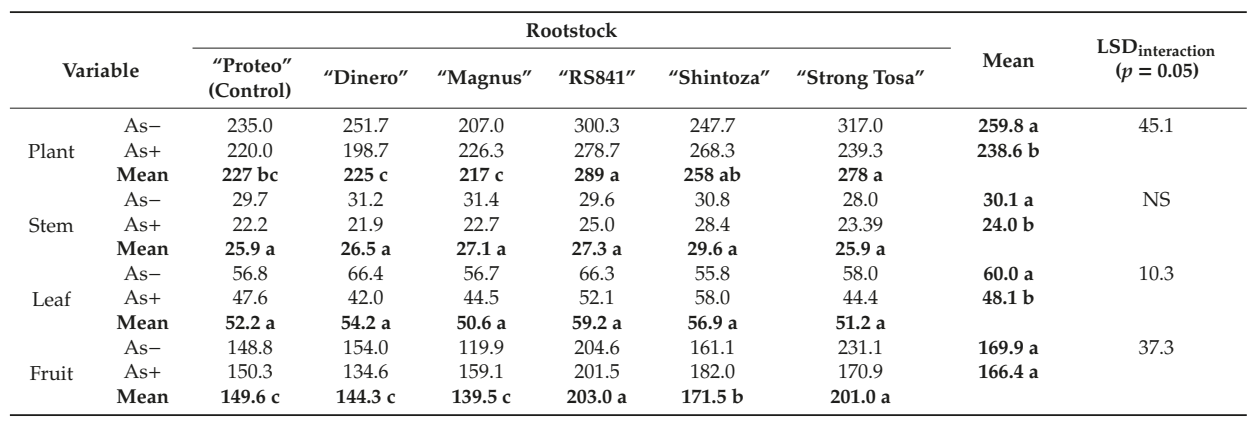

\subsection{Leaf Growth Variables}

All leaf growth variables were significantly affected by the 'As concentration $\times$ rootstock' interaction (Table 2). With the As increase in the nutrient solution, both $\mathrm{L}_{\mathrm{N}}$ and $\mathrm{L}_{\mathrm{A}}$ showed the strongest reduction in the grafting combinations "Proteo"/"Dinero" (-43 leaves plant ${ }^{-1}$ and $-34.4 \mathrm{dm}^{2}$ plant $^{-1}$, respectively), "Proteo"/"Magnus" (-42 leaves plant ${ }^{-1}$ and $-27.2 \mathrm{dm}^{2}$ plant $^{-1}$ ), and "Proteo"/'Strong Tosa' (-27 leaves plant $^{-1}$ and $-19.3 \mathrm{dm}^{2}$ plant $^{-1}$ ) (Table 2). Similarly, LAR and LWR showed a significant reduction passing from As- to As+ solution, with the strongest drops recorded in the grafting combinations "Proteo"/"Dinero" (-7.6 $\mathrm{cm}^{2} \mathrm{~g}^{-1} \mathrm{DW}$ and $-0.054 \mathrm{~g} \mathrm{~g}^{-1} \mathrm{DW}$, respectively) and "Proteo"/ "Magnus" $\left(-16 \mathrm{~cm}^{2} \mathrm{~g}^{-1} \mathrm{DW}\right.$ and $\left.-0.073 \mathrm{~g} \mathrm{~g}^{-1} \mathrm{DW}\right)$ (Table 2).

Table 2. Leaf growth variables in melon plant as affected by As concentration in the nutrient solution and rootstock. Different letters within main factors indicate significance at Fisher's LSD test ( $p=0.05)$.

\begin{tabular}{|c|c|c|c|c|c|c|c|c|c|}
\hline \multirow{2}{*}{\multicolumn{2}{|c|}{ Variable }} & \multicolumn{6}{|c|}{ Rootstock } & \multirow[b]{2}{*}{ Mean } & \multirow{2}{*}{$\begin{array}{l}\text { LSD }_{\text {interaction }} \\
\quad(p=0.05)\end{array}$} \\
\hline & & $\begin{array}{l}\text { "Proteo" } \\
\text { (Control) }\end{array}$ & "Dinero" & "Magnus" & "RS841" & "Shintoza" & "Strong Tosa" & & \\
\hline \multirow{3}{*}{$\begin{array}{c}\mathrm{L}_{\mathrm{N}} \\
\text { (n. } \text { plant }^{-1} \text { ) }\end{array}$} & As- & 163 & 178 & 187 & 158 & 157 & 176 & 170 a & 22 \\
\hline & As+ & 159 & 135 & 145 & 140 & 162 & 149 & $148 \mathrm{~b}$ & \\
\hline & Mean & 161 a & 156 a & 166 a & $149 a$ & $160 \mathrm{a}$ & 162 a & & \\
\hline \multirow{3}{*}{$\begin{array}{c}\mathrm{L}_{\mathrm{A}} \\
\left(\mathrm{dm}^{2} \text { plant }^{-1}\right)\end{array}$} & As- & 74.1 & 91.5 & 86.9 & 75.9 & 83.6 & 86.3 & 83.1 a & 14.5 \\
\hline & As+ & 66.9 & 57.1 & 59.7 & 63.3 & 83.3 & 67.0 & $66.2 \mathrm{~b}$ & \\
\hline & Mean & $70.5 \mathrm{a}$ & $74.3 \mathrm{a}$ & $73.3 \mathrm{a}$ & $69.6 \mathrm{a}$ & 83.4 a & $76.7 \mathrm{a}$ & & \\
\hline \multirow{3}{*}{$\begin{array}{c}\text { LAR } \\
\left(\mathrm{cm}^{2} \mathrm{~g}^{-1} \mathrm{DW}\right)\end{array}$} & As- & 31.7 & 36.4 & 42.4 & 25.3 & 34.2 & 27.2 & $32.9 \mathrm{a}$ & 7.1 \\
\hline & As+ & 30.7 & 28.8 & 26.4 & 22.7 & 31.5 & 28.3 & $28.1 \mathrm{~b}$ & \\
\hline & Mean & $31.2 \mathrm{ab}$ & $32.6 \mathrm{ab}$ & $34.4 \mathrm{a}$ & $24.0 \mathrm{c}$ & 32.8 a & $27.7 \mathrm{bc}$ & & \\
\hline \multirow{3}{*}{$\begin{array}{c}\text { LWR } \\
\left(\mathrm{g} \mathrm{g}^{-1} \mathrm{DW}\right)\end{array}$} & As- & 0.243 & 0.267 & 0.270 & 0.223 & 0.230 & 0.183 & $0.236 a$ & 0.034 \\
\hline & As+ & 0.217 & 0.213 & 0.197 & 0.190 & 0.217 & 0.187 & $0.203 \mathrm{~b}$ & \\
\hline & Mean & $0.230 \mathrm{ab}$ & $0.240 \mathrm{a}$ & $0.233 \mathrm{a}$ & $0.207 \mathrm{ab}$ & $0.223 b c$ & $0.185 \mathrm{c}$ & & \\
\hline
\end{tabular}

LN-number of leaves; LA — leaf area; LAR_leaf area ratio; LWR-leaf weight ratio. 


\subsection{Leaf Relative Chl Content and Gas Exchanges}

Leaf relative $\mathrm{Chl}$ content did not differ in relation to rootstock, while in all grafting combinations it increased by 7\% (from 55.3 to 59.3 SPAD units) in the As+ solution (Table 3). The highest $\mathrm{A}_{\mathrm{N}}$ values in As- solution were recorded in "Proteo" grafted onto "Magnus", "RS841", and 'Strong Tosa' (27.4 $\mu \mathrm{mol} \mathrm{CO} 2 \mathrm{~m}^{-2} \mathrm{~s}^{-1}$, on average). Nevertheless under As+ treatment, the grafting combination "Proteo" / "RS841" showed a significant $\mathrm{A}_{\mathrm{N}}$ reduction (from 27.7 to $22.7 \mu \mathrm{mol} \mathrm{CO}_{2} \mathrm{~m}^{-2} \mathrm{~s}^{-1},-18 \%$ ), whereas an opposite trend was recorded in self-grafted "Proteo" (from 25.3 to $27.7 \mu \mathrm{mol} \mathrm{CO} 2 \mathrm{~m}^{-2} \mathrm{~s}^{-1}$, $+10 \%$ ) (Table 3). Passing from As- to As+, gs significantly varied in the grafting combinations "Proteo"/ "Dinero" (from 273 to $385 \mu \mathrm{mol} \mathrm{CO} \mathrm{m}^{-2} \mathrm{~s}^{-1},+41 \%$ ), "Proteo" / Shintoza" (from 190 to $245 \mu \mathrm{mol} \mathrm{CO} \mathrm{m}^{-2} \mathrm{~s}^{-1},+29 \%$ ), and "Proteo"/ "Magnus" (from 275 to $207 \mu \mathrm{mol} \mathrm{CO} \mathrm{m}^{-2} \mathrm{~s}^{-1},-25 \%$ ), with the control showing stable gs values across nutrient solutions (Table 3). "RS841" rootstock maximized the WUE values in As-, but showed the highest decrease in response to As+ (being reduced from 3.5 to $3.0 \mu \mathrm{mol} \mathrm{CO} 2 \mu \mathrm{mol}^{-1} \mathrm{H}_{2} \mathrm{O} \mathrm{m}^{-2} \mathrm{~s}^{-1},-12 \%$ ), while an opposite trend was recorded in self-grafted "Proteo" (from 3.0 to $3.4 \mu \mathrm{mol} \mathrm{CO} 2 \mu \mathrm{mol}^{-1} \mathrm{H}_{2} \mathrm{O} \mathrm{m}^{-2} \mathrm{~s}^{-1},+14 \%$ ). A similar response was recorded when "Proteo" was grafted onto 'Strong Tosa' (from 2.8 to $3.3 \mu \mathrm{mol} \mathrm{CO} \mu_{2} \mathrm{~mol}^{-1} \mathrm{H}_{2} \mathrm{O}$ $\mathrm{m}^{-2} \mathrm{~s}^{-1},+17 \%$ ) and "Magnus" (from 2.8 to $3.6 \mu \mathrm{mol} \mathrm{CO} \mathrm{Cmol}^{-1} \mathrm{H}_{2} \mathrm{O} \mathrm{m}^{-2} \mathrm{~s}^{-1},+26 \%$ ) (Table 3).

Table 3. Leaf relative Chl content and gas exchange variables in melon plant as affected by As concentration in the nutrient solution and rootstock. Different letters within main factors indicate significance at Fisher's LSD test $(p=0.05)$. NS-not significant.

\begin{tabular}{|c|c|c|c|c|c|c|c|c|c|}
\hline \multirow[b]{2}{*}{ Variable } & & \multicolumn{6}{|c|}{ Rootstock } & \multirow[b]{2}{*}{ Mean } & \multirow{2}{*}{$\begin{array}{l}\text { LSD }_{\text {interaction }} \\
\quad(p=0.05)\end{array}$} \\
\hline & & $\begin{array}{l}\text { "Proteo" } \\
\text { (Control) }\end{array}$ & "Dinero" & "Magnus" & "RS841" & "Shintoza" & “Strong Tosa" & & \\
\hline \multirow{3}{*}{ SPAD } & As- & 55.7 & 56.4 & 54.7 & 56.1 & 52.9 & 55.9 & $55.3 \mathrm{~b}$ & NS \\
\hline & As+ & 57.5 & 59.3 & 58.1 & 61.7 & 58.6 & 60.8 & $59.3 \mathrm{a}$ & \\
\hline & Mean & $56.6 \mathrm{a}$ & $57.8 \mathrm{a}$ & 56.4 a & 58.9 a & 55.7 a & $58.4 \mathrm{a}$ & & \\
\hline \multirow{3}{*}{$\begin{array}{c}\mathrm{A}_{\mathrm{N}} \\
\left(\mu \mathrm{mol} \mathrm{CO} \mathrm{m}^{-2} \mathrm{~s}^{-1}\right)\end{array}$} & As- & 25.3 & 25.0 & 26.7 & 27.7 & 25.1 & 27.7 & $26.2 \mathrm{a}$ & 2.2 \\
\hline & As+ & 27.7 & 23.2 & 25.6 & 22.7 & 25.4 & 29.1 & $25.6 \mathrm{a}$ & \\
\hline & Mean & $26.5 \mathrm{~b}$ & $24.1 \mathrm{c}$ & $26.1 \mathrm{~b}$ & $25.2 \mathrm{bc}$ & $25.2 \mathrm{bc}$ & $28.4 \mathrm{a}$ & & \\
\hline \multirow{3}{*}{$\begin{array}{c}\mathrm{Gs} \\
\left(\mu \mathrm{mol} \mathrm{CO} 2 \mathrm{~m}^{-2} \mathrm{~s}^{-1}\right)\end{array}$} & As- & 240 & 273 & 275 & 255 & 190 & 330 & 261 a & 43 \\
\hline & As+ & 247 & 385 & 207 & 230 & 245 & 300 & $269 a$ & \\
\hline & Mean & $243 \mathrm{~b}$ & 329 a & $241 b$ & $243 \mathrm{~b}$ & $218 \mathrm{~b}$ & 315 a & & \\
\hline WUE & As- & 3.0 & 3.0 & 2.8 & 3.5 & 3.0 & 2.8 & $3.0 \mathrm{~b}$ & 0.3 \\
\hline$\left(\mu \mathrm{mol} \mathrm{CO}{ }_{2} \mu \mathrm{mol}^{-1}\right.$ & As+ & 3.4 & 2.8 & 3.6 & 3.0 & 3.2 & 3.3 & $3.2 \mathrm{a}$ & \\
\hline $\left.\mathrm{H}_{2} \mathrm{O} \mathrm{m}^{-2} \mathrm{~s}^{-1}\right)$ & Mean & $3.2 \mathrm{a}$ & $2.9 \mathrm{~b}$ & $3.2 \mathrm{a}$ & $3.3 \mathrm{a}$ & $3.1 \mathrm{ab}$ & $3.1 \mathrm{ab}$ & & \\
\hline
\end{tabular}

\subsection{Arsenic Accumulation in Plant Fractions}

Arsenic accumulation in plant fractions was significantly affected by the main factors and their interaction (Table 4). In As- treatment, the highest As root was recorded in the rootstocks "Magnus" and "Proteo" (11.75 mg kg DW ${ }^{-1}$, on average), while the lowest one in "RS841" (6.26 mg kg DW $\left.\mathrm{mb}^{-1}\right)$. In the As+ treatment, As root increased in all the tested rootstocks, with the highest concentration recorded in "Magnus" (1633.57 mg kg ${ }^{-1} \mathrm{DW},+131$ fold than control), while the lowest one in "RS841" (369.10 $\mathrm{mg} \mathrm{kg}^{-1} \mathrm{DW},+58$ fold) (Table 4). The As+ treatment promoted As shoot in a rootstock-dependent way too, since passing from As- to As+, "RS841" showed the highest As shoot increase (by $25.61 \mathrm{mg} \mathrm{kg}^{-1}$ $\mathrm{DW},+43$ fold than control), whereas 'Strong Tosa' showed the least one (by $21.75 \mathrm{mg} \mathrm{kg}^{-1} \mathrm{DW},+36$ fold) (Table 4). By increasing the As concentration in the nutrient solution, Aspulp increased in all the grafting combinations, with the highest rise recorded in "Proteo" grafted onto "Shintoza" and "Dinero" (by $3.09 \mathrm{mg} \mathrm{kg}^{-1} \mathrm{DW}$, on average, equal to +14 fold than control) and the least one recorded in self-grafted "Proteo" (by $1.86 \mathrm{mg} \mathrm{kg}^{-1} \mathrm{DW},+2$ fold) (Table 4). 
Table 4. Total arsenic accumulation $\left(\mathrm{mg} \mathrm{kg}^{-1} \mathrm{DW}\right)$ in different organs of melon plant as affected by As concentration in the nutrient solution and rootstock. Different letters within main factors indicate significance at Fisher's LSD test $(p=0.05)$.

\begin{tabular}{|c|c|c|c|c|c|c|c|c|c|}
\hline & & \multicolumn{6}{|c|}{ Rootstock } & \multirow[b]{2}{*}{ Mean } & \multirow{2}{*}{$\begin{array}{l}\text { LSD }_{\text {interactio }} \\
\quad(p=0.05)\end{array}$} \\
\hline \multicolumn{2}{|c|}{ Variable } & $\begin{array}{l}\text { "Proteo" } \\
\text { (Control) }\end{array}$ & "Dinero" & "Magnus" & “RS841" & "Shintoza" & "Strong Tosa" & & \\
\hline \multirow[t]{3}{*}{ As root } & As+ & 1031.53 & 1090.73 & 1633.57 & 369.10 & 732.75 & 805.88 & $943.93 \mathrm{a}$ & \\
\hline & Mean & $521.68 \mathrm{~b}$ & $548.91 \mathrm{~b}$ & 822.61 a & $187.68 \mathrm{~d}$ & $370.42 \mathrm{c}$ & $407.12 \mathrm{c}$ & & \\
\hline & As- & 0.71 & 0.86 & 0.77 & 0.59 & 0.47 & 0.60 & $0.67 \mathrm{~b}$ & 1.73 \\
\hline \multirow{3}{*}{$A s_{\text {pulp }}$} & As- & 0.86 & 0.14 & 0.46 & 0.29 & 0.30 & 0.60 & $0.44 b$ & 0.25 \\
\hline & As+ & 2.72 & 3.16 & 2.99 & 2.98 & 3.46 & 3.19 & $3.08 \mathrm{a}$ & \\
\hline & Mean & $1.79 \mathrm{ab}$ & $1.65 \mathrm{~b}$ & $1.72 \mathrm{ab}$ & $1.64 \mathrm{~b}$ & $1.88 \mathrm{a}$ & $1.89 \mathrm{a}$ & & \\
\hline
\end{tabular}

\subsection{Arsenic Speciation in Root}

Arsenic speciation in root was significantly affected by 'As concentration $\times$ rootstock' interaction (Table 5). In As- treatment, As sinorganic in root accounted from 40.1\% ("Shintoza") to 60.1\% ("Proteo"); however, in the As+ solution, this variable significantly decreased in the intraspecific rootstocks, namely "Proteo", "Dinero", and "Magnus" (-14.57\%, on average), while it increased in the interspecific hybrids "RS841", "Shintoza", and 'Strong Tosa' (+34.93\%, on average) (Table 5). In As- treatment,

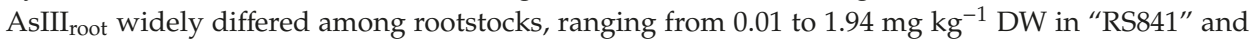
"Proteo", respectively. In the As+ treatment it showed the highest rise in 'Strong Tosa' (+577.24 mg $\mathrm{kg}^{-1}$ DW; i.e., +3207 fold than control) and "Shintoza" (+287.39 $\mathrm{mg} \mathrm{kg}^{-1}$ DW; i.e., +3193 fold), and the least one in "RS841" (+82.25 mg kg ${ }^{-1}$ DW; i.e., +8225 fold) (Table 5). In As- treatment, AsV root showed the highest value in "Proteo" (5.17 $\left.\mathrm{mg} \mathrm{kg}^{-1} \mathrm{DW}\right)$ and the least one in "Dinero" and "RS841" (2.88 $\mathrm{mg} \mathrm{kg}^{-1} \mathrm{DW}$, on average) (Table 5). When plants were grown in the As+ solution, such variable showed the highest increase in "Magnus" (by $345.94 \mathrm{mg} \mathrm{kg}^{-1} \mathrm{DW}$; i.e., +80 fold than control), followed by "Proteo" and "Dinero" (by $255.88 \mathrm{mg} \mathrm{kg}^{-1} \mathrm{DW}$, on average; i.e., +64 fold), and the least one in 'Strong Tosa' (by $41.85 \mathrm{mg} \mathrm{kg}^{-1}$ DW; i.e., +14 fold) (Table 5).

Table 5. Inorganic As (percentage of total), $\mathrm{As}(\mathrm{III})$, and $\mathrm{As}(\mathrm{V})\left(\mathrm{mg} \mathrm{kg}^{-1} \mathrm{DW}\right)$ in root of melon plant as affected by As concentration in the nutrient solution and rootstock. Different letters within main factors indicate significance at Fisher's LSD test $(p=0.05)$.

\begin{tabular}{|c|c|c|c|c|c|c|c|c|c|}
\hline & & \multicolumn{6}{|c|}{ Rootstock } & \multirow[b]{2}{*}{ Mean } & \multirow{2}{*}{$\begin{array}{l}\text { LSD }_{\text {interaction }} \\
\quad(p=0.05)\end{array}$} \\
\hline \multicolumn{2}{|c|}{ Variable } & $\begin{array}{l}\text { "Proteo" } \\
\text { (Control) }\end{array}$ & "Dinero" & "Magnus" & "RS841" & "Shintoza" & "Strong Tosa" & & \\
\hline \multirow[t]{2}{*}{$\mathrm{As}_{\text {inorganic }}$} & As+ & 48.6 & 38.9 & 31.0 & 80.7 & 71.2 & 77.2 & $57.9 \mathrm{~b}$ & \\
\hline & Mean & $54.3 \mathrm{bc}$ & $46.5 \mathrm{~cd}$ & $39.5 \mathrm{~d}$ & $63.4 \mathrm{a}$ & $55.6 \mathrm{ab}$ & $57.7 \mathrm{ab}$ & & \\
\hline AsIII $_{\text {root }}$ & As- & 1.94 & 0.96 & 1.25 & 0.01 & 0.09 & 0.18 & $0.74 \mathrm{~b}$ & 71.89 \\
\hline \multirow{3}{*}{$\mathrm{AsV}_{\text {root }}$} & As- & 5.17 & 2.88 & 4.35 & 2.87 & 3.15 & 3.01 & $3.57 \mathrm{~b}$ & 102.15 \\
\hline & As+ & 264.86 & 254.95 & 350.29 & 215.72 & 233.87 & 44.86 & 227.42 a & \\
\hline & Mean & $135.02 \mathrm{a}$ & 128.91 a & 177.32 a & $109.30 \mathrm{a}$ & 118.51 a & $23.94 \mathrm{~b}$ & & \\
\hline
\end{tabular}

\subsection{Arsenic Bioaccumulation and Translocation Factors}

All the bioaccumulation and translocation factors proved to be higher under the control growing conditions, displaying a sharp decrease in response to the As+ treatment (Table 6). Shifting from As- to As+, the strongest BAF root reduction was found in "Proteo" and "Magnus" (-5646.22 and -5394.68 , respectively, corresponding to $-95 \%$ and $-93 \%$ ), while the least one in "Dinero" and "RS841" (-3260.82 and -3033.38, respectively, corresponding to $-92 \%$ and $-97 \%$ ) (Table 6). Differently, "Dinero" caused the sharper $\mathrm{BAF}_{\text {shoot }}$ decrease in response to As+ treatment $(-422.82$, i.e., $-98 \%)$, followed by "Magnus" (-377.37, i.e., -98\%), while "Shintoza" generated the smallest variation (-229.6, i.e., 
-97\%) (Table 6). With reference to BAF pulp, "Proteo" and "Strong Tosa" generated the strongest drop in response to As+ (by -426.92 and -298.47 , respectively, corresponding to $-99.8 \%$ and $-99.7 \%$ ), whereas a less marked decrease was recorded when "Proteo" was grafted onto "Shintoza" (-150.45, i.e., $-99.4 \%)$, "RS841" (-145.92; i.e., $-99.5 \%$ ) and "Dinero" (-68.05, i.e.; $-98.8 \%)$ (Table 6). The increase in As concentration in the root environment caused the highest $\mathrm{TF}_{\text {shoot }}$ reductions in "Proteo" grafted onto "Dinero" (-0.097; i.e., $-80.2 \%)$ and "Magnus" $(-0.051$, i.e., $-77.3 \%)$, while the least ones in the grafting combinations "Proteo"/“Shintoza" (-0.025; i.e., $-43.1 \%)$ and "Proteo"/“RS841" (-0.024; i.e., $-25.3 \%$ ) (Table 6). "Strong Tosa", "Magnus" and "Shintoza" proved the highest TF response to the As stress $(-0.069,-0.038$, and -0.032 , respectively, corresponding to $-94.5 \%,-95.0 \%$, and $-86.5 \%)$, whereas "Dinero" showed the least one $(-0.007$; i.e., $-84.2 \%)($ Table 6$)$.

Table 6. Arsenic bioaccumulation and translocation factors (adimensional) in shoot and pulp of melon plants as affected by As concentration in the nutrient solution and rootstock. Different letters within main factors indicate significance at Fisher's LSD test $(p=0.05)$.

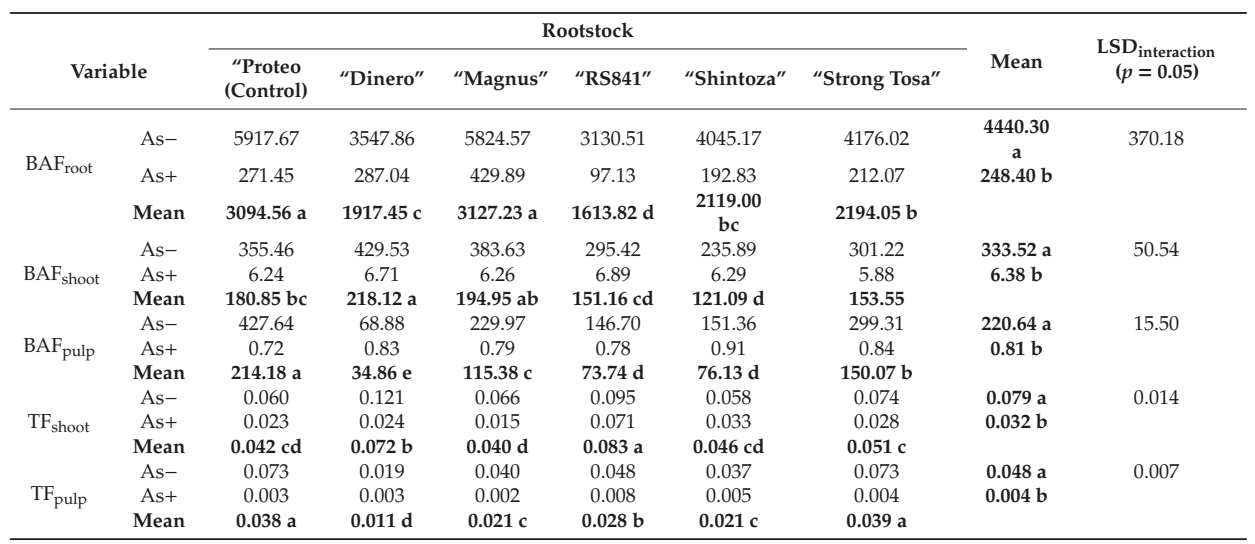

\subsection{Phosphorus Accumulation in Plant Fractions}

Phosphorus accumulation in plant fractions was significantly affected by the main factors and their interaction (Table 7). Passing from As- to As+ treatment, $P_{\text {root }}$ increased mostly in self-grafted "Proteo" (from 3527 to 31,390 $\mathrm{mg} \mathrm{kg}^{-1} \mathrm{DW},+790 \%$ ), followed by "Dinero" (from 3566 to 17,059 mg $\mathrm{kg}^{-1} \mathrm{DW},+378 \%$ ), "Magnus" (from 14,362 to $22,938 \mathrm{mg} \mathrm{kg}^{-1} \mathrm{DW},+60 \%$ ), and "Shintoza" (from 12,535 to $19,210 \mathrm{mg} \mathrm{kg}^{-1} \mathrm{DW},+53 \%$ ) (Table 7). Conversely, the As+ treatment significantly reduced $\mathrm{P}_{\text {shoot }}$ as compared to the standard nutrient solution, with the highest drop recorded in "Proteo" grafted onto "Dinero" and "Magnus" (from 7001 to $4923 \mathrm{mg} \mathrm{kg}^{-1} \mathrm{DW}$, on average, $-30 \%$ ) (Table 7). Passing from As- to As+, $P_{\text {pulp }}$ significantly increased in "Proteo" grafted onto "Dinero", "Magnus", and 'Strong Tosa' (by 4472, 1334, and $1203 \mathrm{mg} \mathrm{kg}^{-1} \mathrm{DW}$, respectively, corresponding to $+758 \%,+35 \%$, and $+30 \%$ ), whereas did not show any significant variation in the other graft combinations (Table 7). 
Table 7. Phosphorus accumulation $\left(\mathrm{mg} \mathrm{kg}^{-1} \mathrm{DW}\right)$ in different organs of melon plants as affected by As concentration in the nutrient solution and rootstock. Different letters within main factors indicate significance at Fisher's LSD test $(p=0.05)$.

\begin{tabular}{|c|c|c|c|c|c|c|c|c|c|}
\hline & & \multicolumn{6}{|c|}{ Rootstock } & \multirow[b]{2}{*}{ Mean } & \multirow{2}{*}{$\begin{array}{l}\text { LSD }_{\text {interactio }} \\
\quad(p=0.05)\end{array}$} \\
\hline \multicolumn{2}{|c|}{ Variable } & $\begin{array}{l}\text { "Proteo" } \\
\text { (Control) }\end{array}$ & "Dinero" & "Magnus" & "RS841" & "Shintoza" & "Strong Tosa" & & \\
\hline \multirow[t]{3}{*}{$P_{\text {root }}$} & As+ & 31390 & 17059 & 22938 & 10379 & 19210 & 22343 & 20553 a & \\
\hline & Mean & 17458 bc & $10312 \mathrm{~d}$ & $18650 \mathrm{~b}$ & $11669 \mathrm{~d}$ & 15872 c & 21609 a & & \\
\hline & As- & 7038 & 7131 & 6871 & 6039 & 6465 & 6538 & 6681 a & 564 \\
\hline \multirow{3}{*}{$P_{\text {pulp }}$} & As- & 4745 & 590 & 3827 & 4119 & 4110 & 3996 & $3565 \mathrm{~b}$ & 521 \\
\hline & As+ & 5151 & 5062 & 5161 & 3797 & 4561 & 5199 & 4822 a & \\
\hline & Mean & 4948 a & $2826 \mathrm{~d}$ & $4494 \mathrm{~b}$ & $3958 \mathrm{c}$ & $4335 \mathrm{~b}$ & $4597 \mathrm{ab}$ & & \\
\hline
\end{tabular}

\subsection{Principal Component Analysis}

The first two principal components gave eigenvalues equal to 2.75 (PC1) and 0.21 (PC2), and together accounted for $98.9 \%$ of the total variance (Table 8 ). The As accumulation into the different plant fractions positively contributed to PC1, with correlation coefficient ranging from 0.556 to 0.589 , while PC2 was strongly and positively correlated to $\mathrm{As}_{\text {root }}(0.830)$ and negatively correlated to $\mathrm{As}_{\text {shoot }}$ and $\mathrm{As}_{\text {pulp }}$ (-0.367 and -0.419 , respectively). The resulting PCA scatterplot showed a clear separation among plants grown in As- (on the negative side of PC1) and those grown in As+ (on the right side of PC1). The first group clustered together, with no separation between different plant organs, while the second group showed a further separation in two sub-clusters, in the second and fourth quadrant of the centroid, respectively (Figure 1). The first sub-cluster grouped on the positive side of PC2 the grafting combinations (self-grafted "Proteo", "Proteo"/“Magnus", and "Proteo"/"Dinero") accumulating As mainly in root, while the second sub-cluster grouped those combinations ("Proteo"/'Strong Tosa', "Proteo"/"Shintoza", and "Proteo"/ "RS841"), accumulating As in the aerial parts of the plant, namely shoot and pulp (Figure 1).

Table 8. Correlation coefficients for each trait with respect to the first two principal components, eigenvalues, and relative and cumulative proportions of the explained variance.

\begin{tabular}{ccc}
\hline \multirow{2}{*}{ Trait } & \multicolumn{2}{c}{ Principal Component Coefficients } \\
\cline { 2 - 3 } & First & Second \\
\hline As soot & 0.556 & 0.830 \\
As $s_{\text {shoot }}$ & 0.589 & -0.367 \\
Aspulp & 0.586 & -0.419 \\
Eigenvalue & 2.75 & 0.21 \\
Explained Variability $(\%)$ & 91.91 & 7.07 \\
\hline
\end{tabular}




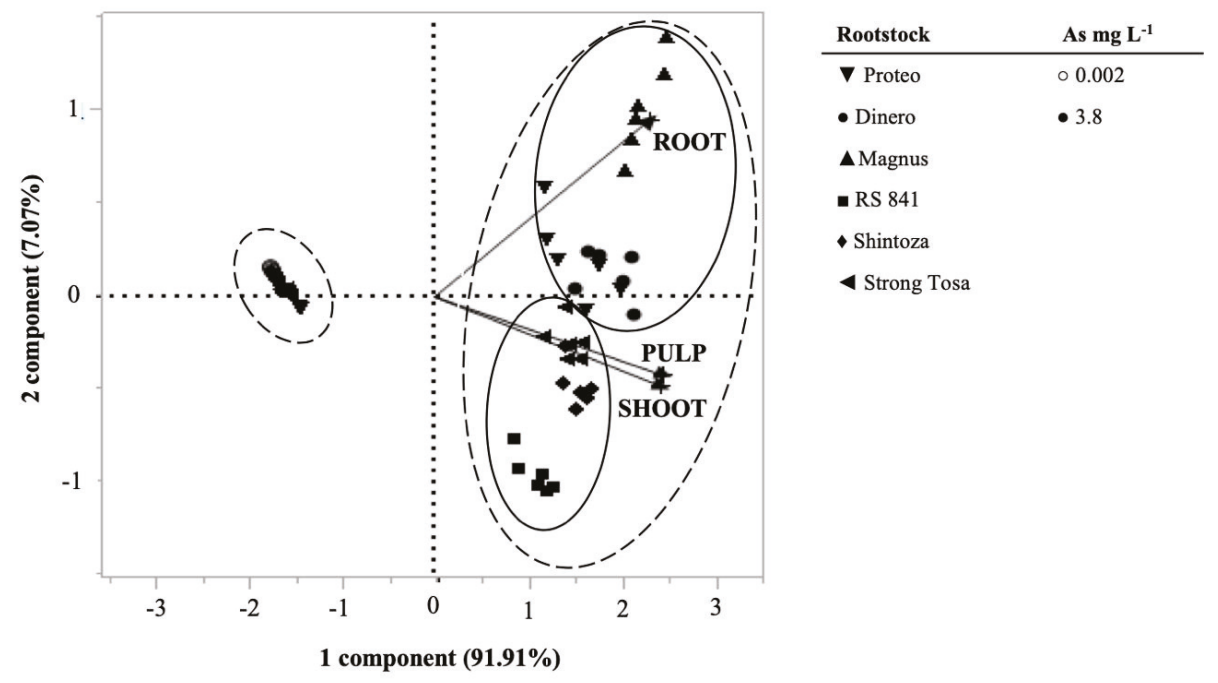

Figure 1. Principal Component Analysis scatter-plot based on total As concentration in root, shoot and pulp of melon plant "Proteo" as a function of the grafting combination and As concentration of the nutrient solution. Dotted lines group together treatments at different concentrations of As in the nutrient solution, while solid lines group together the grafting combinations.

\section{Discussion}

The environmental As contamination is a worldwide health threat due to the toxic and carcinogenic nature of this metalloid [29]. From an agricultural viewpoint, plants exposure to As- stress can cause morphological, physiological, and biochemical changes, leading to altered photosynthesis, stunted growth, reduced crop productivity, and worsened toxicological profile of the edible fractions [30]. In our experiment, the bioaccumulation factors values revealed that, even at a low As concentration in the nutrient solution, melon behaves as an hyperaccumulator plant, following the gradient root $>$ shoot $>$ fruit generally reported in literature [31]. However, when exposed to an As+ solution, all the grafting combinations acted to limit the As entrance into the plant, as can be inferred from the average reduction of $\mathrm{BAF}_{\text {root }}(-94.4 \%), \mathrm{BAF}_{\text {shoot }}(-98.1 \%)$, and $\mathrm{BAF}_{\text {pulp }}(-99.6 \%)$. Nonetheless plants exposure to As stress highlighted evidences of systemic stress, consisting in a decrease of the whole aboveground dry biomass per plant, which mainly mirrored the reduction of both, stem and leaf dry biomass per plant. The reduced plant growth in response to As toxicity originates from complex alterations involving enzymes activity, induction of oxidative stresses, or altered nutrient uptake and balance into the plant [32,33]. In the present experiment melon plants subjected to As stress showed a decreased ability to maintain the normal growth equilibrium among plant fractions, by partially losing $(\sim 20 \%)$ the ability of photosynthates investment into leaf biomass, so indicating the main photosynthetic organs as an elective target of As-induced alterations. Leaf area, leaf area ratio, and leaf weight ratio were predominantly affected by the As toxicity, more than leaf number, indicating leaf cells proliferation and elongation as primarily affected by the As stress, more than leaf cells differentiation. According to Koyama and Kikuzawa [34] and Ropokis et al. [35], leaf area is a trait having a central role in determining the level of nutrient uptake, via the rate of whole plant photosynthesis and transpiration. In this sense, the decreased leaf area we recorded suggests the triggering of morpho-physiological modifications reducing the As entrance inside the plant, probably by modulating the plant's transpiration and nutrient demand.

Regarding photosynthesis, As accumulation in leaf tissues is responsible for key physiological events such as chlorophyll degradation and leaf necrosis, decreased activity of the enzymes involved 
in photosynthetic metabolism, disturbance of photosynthates transport, and stomatal behavior [36,37]. This, apparently, was not reflected in our experiment where, besides the absence of any leaf necrosis (data not shown), there was a general increase in leaf relative chlorophyll content, as can be inferred from SPAD readings. This result is consistent with those of $\mathrm{Zu}$ et al. [37], which have reported that As is able to promote chlorophyll content in leaf tissues, becoming harmful only above a threshold concentration.

The analysis of net photosynthetic rate revealed different degrees of sensibility to the As toxicity among grafting combinations, with self-grafted "Proteo" experiencing a slight stimulation under As stress, a feature opposite to that displayed by "Proteo"--RS841" combination. Both trends were associated to correspondingly similar patterns of water use efficiency, but not to any correlated change in stomatal conductance, indicating that mechanisms beyond stomatal behavior are involved in determining the photosynthetic response of As-stressed melon plants. Interestingly, under severe As stress, the $A_{N}$ variations induced by the different rootstocks were not correlated to any corresponding variation of the aboveground biomass per plant, so that $A_{N}$ and plant growth were apparently not related to each other. Indeed, under As+ treatment, both whole plant and fruit biomass resulted generally higher in "Proteo" grafted onto the C. maxima $\times$ C. moschata hybrids (namely "RS841", "Shintoza" and "Strong Tosa"; i.e., those rootstocks conferring no $\mathrm{A}_{\mathrm{N}}$ enhancement under As-enriched nutrient solution). This seems to suggest a differential alteration of the energy balance of the plants, likely attributable to different energy dissipation pathways involved in the As stress response [38]. The data of As speciation and partitioning we found seem to confirm such hypothesis. Indeed, when exposed to the As+ treatment, the intraspecific rootstocks showed the highest total As concentration in roots, but the lowest one under its inorganic form (from 31\% to $49 \%$ ), meaning that up to $69 \%$ of their $\mathrm{As}_{\text {root }}$ was present in organic and complexed form. This is the As form whose translocation from root is hampered, because of bonds with thiol groups of root-synthetized phytochelatins and subsequent sequestration into root cells vacuole [39]. On the contrary, the interspecific rootstocks subjected to the As+ treatment, showed the lowest total As concentration in their root, demonstrating their superior ability to buffer the As entrance into the plant from the nutrient solution. However, they showed also the highest inorganic $\mathrm{As}_{\text {root }}$ incidence (up to $81 \%$; i.e., the most mobile As form from the root organ) [39,40]. Inorganic As(III) is the main species suitable for transport trough xylem vessels and/or root efflux, while $\mathrm{As}(\mathrm{V})$ is rapidly reduced in roots to $\mathrm{As}(\mathrm{III})$ and then transported from the root cortical cells to the xylem vessels [40,41]. Accordingly, when growing under conditions of As stress, all the interspecific rootstocks had the highest $\mathrm{TF}_{\text {shoot }}$ and $\mathrm{TF}_{\text {pulp }}$ values, with "Shintoza" and "Strong Tosa" having also the highest concentration of As(III) in their roots. On the contrary, "Magnus" and "Dinero" confirmed the lowest $\mathrm{TF}_{\text {shoot }}$ and $\mathrm{TF}_{\text {pulp }}$ values, respectively, since the highest incidence of organic As into their roots.

Several authors have reported that the As uptake and translocation kinetics are mainly dependent on its concentration in the root environment and plant species [42,43], with the diversity of the root systems having a central role in determining differences among genotypes [44]. The PCA scatter plot highlighted that the As concentration in the root environment had a pivotal role in triggering different behaviors among rootstocks. Indeed, when exposed to the standard nutrient solution, all the grafting combinations clustered together on the negative side of PC1 (indicating lower values of As accumulation in plant tissues), without differences in terms of As partitioning inside the plant fractions. The opposite was noticed under conditions of imposed As stress, so that the grafting combinations clustered on the positive side of PC1, with a further distinction along the PC2 between rootstocks promoting the As accumulation mainly in roots (i.e., the intraspecific rootstocks) and those promoting its accumulation in shoot and pulp, namely "Shintoza" and "Strong Tosa". "RS841" slightly diverged from these latter owing to its ability to contain the As accumulation into the pulp.

The present study took into account the uptake and translocation of $\mathrm{P}$ too, given its peculiar interaction with As, as well as for its role in improving the conversion of solar energy into new plant biomass [45]. The complex interrelation between arsenate and phosphate in the substrate-plant systems has brought, up to now, no univocal results in literature, since their interaction can be either 
synergistic or antagonistic, depending on the growing conditions [46]. In our experiment, both $\mathrm{P}$ concentration and partitioning inside the plant were significantly modified by the As level in the nutrient solution, so that in As-stressed plants prevailed an increased P concentration in root and pulp, while a lowered one in shoot. This tendency was more marked when "Proteo" was grafted onto the intraspecific combinations. To this end, the protective role of $\mathrm{P}$ against the As-induced lipid peroxidation of cellular membranes has been suggested [47]. In this view, the selective increase in $P$ concentration inside the plant fractions could be the result of a melon response aimed at protecting both root (the plant organ firstly exposed to the As pollution) and reproductive structures from the As injury, this latter feature having been formerly described in rise [48]. On the other hand, the decreased $P$ concentration in shoot tissues seems well related to the decreased $L_{A}$, LAR, and LWR per plant recorded under conditions of As stress, so suggesting a possible role of P metabolism in buffering the transpiration-driven As entrance inside the plant.

\section{Conclusions}

The outcome of this experiment shows that As uptake and translocation into melon plants were both influenced by its concentration in the nutrient solution and by the genetic background of the rootstock. All tested plants, when grown in an As-enriched solution, showed a high As mobility in the substrate-plant continuum, resulting As accumulators most of all in root and shoot. Intraand interspecific rootstocks differently influenced the As root accumulation inside the plant, with the interspecific hybrids proving a superior ability to limit the metalloid entrance into the roots. When subjected to As stress, melon plants acted to limit the metalloid translocation from root to shoot and pulp, so indicating the triggering of physiological mechanisms aimed at limiting the As diffusion inside the plant. To this end, the intraspecific rootstocks displayed a better ability to retain the toxic metalloid into the root system, most of all in an organic form. This feature suggests a higher efficiency of the root chelation mechanisms of As, occurring, in turn, at the expenses of the photosynthetic balance. The interspecific $C$. maxima $\times$ C. moschata rootstocks gave the best results in terms of fruit biomass under conditions of As stress, so suggesting the possibility to exploit their superior bio-agronomical potential with the aim to improve melon performances in heavily As-polluted areas. "RS841" proved to be the best rootstock in the view of maximizing yield and minimizing, at the same time, the As concentration into the fruit. Thus, the significant differences we found suggest the possibility to deepen this area of research, with the aim of identifying rootstocks genotypes for their superior agronomic and toxicological response to high As contamination in the root zone.

Author Contributions: C.L. and S.R.S. conceived the experiments and proposed the experimental design. F.G. and R.P.M. carried out the experiments. R.M. and E.A. carried out chemical experiments. R.P.M., A.E., S.R.S., R.M. interpreted data and wrote the manuscript. F.G. and A.I. critically revised the manuscript.

Funding: The research activity was co-funded by the Italian Ministry of University and Research (PRIN project "Health of agroecosystems: chemical, biochemical and biological processes that regulate the mobility of As in the soil-water-plant compartments" code 2010JBNLJ7_006).

Conflicts of Interest: The authors declare no conflict of interest. The funder had no role in the design of the study; in the collection, analyses, or interpretation of data; in the writing of the manuscript, or in the decision to publish the results.

\section{References}

1. Calatayud, Á.; San Bautista, A.; Pascual, B.; Maroto, J.V.; López-Galarza, S. Use of Chlorophyll Fluorescence Imaging as Diagnostic Technique to Predict Compatibility in Melon Graft. Sci. Hortic. (Amsterdam) 2013, 149, 13-18. [CrossRef]

2. Gupta, S.; Satpati, S.; Nayek, S.; Garai, D. Effect of Wastewater Irrigation on Vegetables in Relation to Bioaccumulation of Heavy Metals and Biochemical Changes. Environ. Monit. Assess. 2010, 165, 169-177. [CrossRef] [PubMed] 
3. Muchuweti, M.; Birkett, J.W.; Chinyanga, E.; Zvauya, R.; Scrimshaw, M.D.; Lester, J.N. Heavy Metal Content of Vegetables Irrigated with Mixtures of Wastewater and Sewage Sludge in Zimbabwe: Implications for Human Health. Agric. Ecosyst. Environ. 2006, 112, 41-48. [CrossRef]

4. Verkleij, J.A.C.; Golan-Goldhirsh, A.; Antosiewisz, D.M.; Schwitzguébel, J.P.; Schröder, P. Dualities in Plant Tolerance to Pollutants and Their Uptake and Translocation to the Upper Plant Parts. Environ. Exp. Bot. 2009, 67, 10-22. [CrossRef]

5. Meharg, A.A.; Macnair, M.R. Relationship between Plant Phosphorus Status and the Kinetics of Arsenate Influx in Clones of Deschampsia cespitosa (L.) Beauv. That Differ in Their Tolerance to Arsenate. Plant Soil 1994, 162, 99-106. [CrossRef]

6. Hughes, M.F.; Beck, B.D.; Chen, Y.; Lewis, A.S.; Thomas, D.J. Arsenic Exposure and Toxicology: A Historical Perspective. Toxicol. Sci. 2011, 123, 305-332. [CrossRef]

7. Carbonell-Barrachina, A.A.; Aarabi, M.A.; DeLaune, R.D.; Gambrell, R.P.; Patrick, W.H. The Influence of Arsenic Chemical Form and Concentration on Spartina Patens and Spartina Alterniflora Growth and Tissue Arsenic Concentration. Plant Soil 1998, 198, 33-43. [CrossRef]

8. Stazi, S.R.; Marabottini, R.; Papp, R.; Moscatelli, M.C. Arsenic in Soil: Availability and Interactions with Soil Microorganisms. In Heavy Metal Contamination of Soils; Sherameti, I., Varma, A., Eds.; Springer International Publishing: Cham, Switzerland, 2015; pp. 113-126. [CrossRef]

9. Garg, N.; Singla, P. Arsenic Toxicity in Crop Plants: Physiological Effects and Tolerance Mechanisms. Environ. Chem. Lett. 2011, 9, 303-321. [CrossRef]

10. Finnegan, P.M.; Chen, W. Arsenic Toxicity: The Effects on Plant Metabolism. Front. Physiol. 2012, 3, 1-18. [CrossRef]

11. Maurel, C.; Verdoucq, L.; Luu, D.T.; Santoni, V. Plant Aquaporins: Membrane Channels with Multiple Integrated Functions. Annu. Rev. Plant Biol. 2008, 59, 595-624. [CrossRef]

12. Allevato, E.; Stazi, S.R.; Marabottini, R.; D'Annibale, A. Mechanisms of arsenic assimilation by plants and countermeasures to attenuate its accumulation in crops other than rice. Ecotoxicol. Environ. Saf. 2019, 185, 109701. [CrossRef]

13. Abbas, G.; Murtaza, B.; Bibi, I.; Shahid, M.; Niazi, N.K.; Khan, M.I.; Amjad, M.; Hussain, M.; Natasha. Arsenic Uptake, Toxicity, Detoxification, and Speciation in Plants: Physiological, Biochemical, and Molecular Aspects. Int. J. Environ. Res. Public Health 2018, 15, 59. [CrossRef] [PubMed]

14. Verbruggen, N.; Hermans, C.; Schat, H. Mechanisms to Cope with Arsenic or Cadmium Excess in Plants. Curr. Opin. Plant Biol. 2009, 12, 364-372. [CrossRef] [PubMed]

15. Kyriacou, M.C.; Rouphael, Y.; Colla, G.; Zrenner, R.; Schwarz, D. Vegetable Grafting: The Implications of a Growing Agronomic Imperative for Vegetable Fruit Quality and Nutritive Value. Front. Plant Sci. 2017, 8, 1-23. [CrossRef]

16. Rouphael, Y.; Kyriacou, M.C.; Colla, G. Vegetable Grafting: A Toolbox for Securing Yield Stability under Multiple Stress Conditions. Front. Plant Sci. 2018, 8, 10-13. [CrossRef] [PubMed]

17. Sabatino, L.; Iapichino, G.; D'Anna, F.; Palazzolo, E.; Mennella, G.; Rotino, G.L. Hybrids and Allied Species as Potential Rootstocks for Eggplant: Effect of Grafting on Vigour, Yield and Overall Fruit Quality Traits. Sci. Hortic. Amsterdam 2018, 228, 81-90. [CrossRef]

18. Kumar, P.; Edelstein, M.; Cardarelli, M.; Ferri, E.; Colla, G. Grafting Affects Growth, Yield, Nutrient Uptake, and Partitioning under Cadmium Stress in Tomato. HortScience 2015, 50, 1654-1661. [CrossRef]

19. Stazi, S.R.; Cassaniti, C.; Marabottini, R.; Giuffrida, F.; Leonardi, C. Arsenic Uptake and Partitioning in Grafted Tomato Plants. Hortic. Environ. Biotechnol. 2016, 57, 241-247. [CrossRef]

20. Savvas, D.; Colla, G.; Rouphael, Y.; Schwarz, D. Amelioration of Heavy Metal and Nutrient Stress in Fruit Vegetables by Grafting. Sci. Hortic. 2010, 127, 156-161. [CrossRef]

21. Hoel, B.O.; Solhaug, K.A. Effect of irradiance on chlorophyll estimation with the Minolta SPAD-502 leaf chlorophyll meter. Ann. Bot. 1998, 82, 389-392. [CrossRef]

22. Martínez, D.E.; Guiamet, J.J. Distortion of the SPAD 502 chlorophyll meter readings by changes in irradiance and leaf water status. Agronomie 2004, 24, 41-46. [CrossRef]

23. Al-hamdani, S.H.; Murphy, J.M.; Todd, G.W. Stomatal conductance and $\mathrm{CO}_{2}$ assimilation as screening tools for drought resistance in sorghum. Can. J. Plant Sci. 1991, 71, 689-694. [CrossRef] 
24. Rintala, E.M.; Ekholm, P.; Koivisto, P.; Peltonen, K.; Venäläinen, E.R. The intake of inorganic arsenic from long grain rice and rice-based baby food in Finland-Low safety margin warrants follow up. Food Chem. 2014, 150, 199-205. [CrossRef] [PubMed]

25. Welna, M.; Pohl, P.; Szymczycha-Madeja, A. Non-chromatographic Speciation of Inorganic Arsenic in Rice by Hydride Generation Inductively Coupled Plasma Optical Emission Spectrometry. Food Anal. Methods 2019, 12, 581-594. [CrossRef]

26. Liu, J.; Zhang, X.H.; Li, T.Y.; Wu, Q.X.; Jin, Z.J. Soil characteristics and heavy metal accumulation by native plants in a Mn mining area of Guangxi, South China. Environ. Monit. Assess. 2014, 186, 2269-2279. [CrossRef]

27. de Campos, F.V.; de Oliveira, J.A.; da Silva, A.A.; Ribeiro, C.; dos Santos Farnese, F. Phytoremediation of arsenite-contaminated environments: Is Pistia stratiotes L. a useful tool? Ecol. Indic. 2019, 104, 794-801. [CrossRef]

28. Pandey, J.; Verma, R.K.; Singh, S. Screening of most potential candidate among different lemongrass varieties for phytoremediation of tannery sludge contaminated sites. Int. J. Phytoremediat. 2019, 21, 600-609. [CrossRef]

29. Saldaña-Robles, A.; Abraham-Juárez, M.R.; Saldaña-Robles, A.L.; Saldaña-Robles, N.; Ozuna, C.; Gutiérrez-Chávez, A.J. The Negative Effect of Arsenic in Agriculture: Irrigation Water, Soil and Crops, State of the Art. Appl. Ecol. Environ. Res. 2018, 16, 1533-1551. [CrossRef]

30. Stazi, S.R.; Allevato, E.; Marabottini, R. Contaminazione Dei Prodotti Agricoli Da Arsenico: Assimilazione e Strategie Di Mitigazione. Italus Hortus 2016, 23, 19-32.

31. Ma, L.Q.; Komar, K.M.; Tu, C.; Zhang, W.; Cai, Y.; Kennelley, E.D. A Fern That Hyperaccumulates Arsenic. Nature 2001, 409, 579. [CrossRef]

32. Gomes, M.P.; Carvalho, M.; Carvalho, G.S.; Marques, T.C.L.L.S.M.; Garcia, Q.S.; Guilherme, L.R.G.; Soares, A.M. Phosphorus Improves Arsenic Phytoremediation by Anadenanthera peregrina by Alleviating Induced Oxidative Stress. Int. J. Phytoremediat. 2013, 15, 633-646. [CrossRef] [PubMed]

33. Mehmood, T.; Bibi, I.; Shahid, M.; Niazi, N.K.; Murtaza, B.; Wang, H.; Ok, Y.S.; Sarkar, B.; Javed, M.T.; Murtaza, G. Effect of Compost Addition on Arsenic Uptake, Morphological and Physiological Attributes of Maize Plants Grown in Contrasting Soils. J. Geochem. Explor. 2017, 178, 83-91. [CrossRef]

34. Koyama, K.; Kikuzawa, K. Is Whole-Plant Photosynthetic Rate Proportional to Leaf Area? A Test of Scalings and a Logistic Equation by Leaf Demography Census. Am. Nat. 2009, 173, 640-649. [CrossRef] [PubMed]

35. Ropokis, A.; Ntatsi, G.; Kittas, C.; Katsoulas, N.; Savvas, D. Impact of Cultivar and Grafting on Nutrient and Water Uptake by Sweet Pepper (Capsicum annuum L.) Grown Hydroponically Under Mediterranean Climatic Conditions. Front. Plant Sci. 2018, 9, 1-12. [CrossRef] [PubMed]

36. Rahman, A.M.; Hasegawa, H.; Mahfuzur Rahman, M.; Nazrul Islam, M.; Majid Miah, M.A.; Tasmen, A. Effect of Arsenic on Photosynthesis, Growth and Yield of Five Widely Cultivated Rice (Oryza sativa L.) Varieties in Bangladesh. Chemosphere 2007, 67, 1072-1079. [CrossRef]

37. Zu, Y.Q.; Sun, J.J.; He, Y.M.; Wu, J.; Feng, G.Q.; Li, Y. Effects of Arsenic on Growth, Photosynthesis and Some Antioxidant Parameters of Panax Notoginseng Growing in Shaded Conditions. Int. J. Adv. Agric. Res. 2016, 4, 78-88.

38. Srivastava, S.; Akkarakaran, J.J.; Sounderajan, S.; Shrivastava, M.; Suprasanna, P. Arsenic Toxicity in Rice (Oryza sativa L.) Is Influenced by Sulfur Supply: Impact on the Expression of Transporters and Thiol Metabolism. Geoderma 2016, 270, 33-42. [CrossRef]

39. Zhao, F.J.; Ma, J.F.; Meharg, A.A.; McGrath, S.P. Arsenic Uptake and Metabolism in Plants. New Phytol. 2009, 181, 777-794. [CrossRef]

40. Raab, A.; Schat, H.; Meharg, A.A.; Feldmann, J. Uptake, Translocation and Transformation of Arsenate and Arsenite in Sunflower (Helianthus annuus): Formation of Arsenic-Phytochelatin Complexes during Exposure to High Arsenic Concentrations. New Phytol. 2005, 168, 551-558. [CrossRef]

41. Pickering, I.J.; Prince, R.C.; George, M.J.; Smith, R.D.; George, G.N.; Salt, D.E. Reduction and Coordination of Arsenic in Indian Mustard 1. Plant Physiol. 2000, 122, 1171-1177. [CrossRef]

42. Ouyang, Y. Phytoextraction: Simulating Uptake and Translocation of Arsenic in a Soil-Plant System. Int. J. Phytoremediat. 2005, 7, 3-17. [CrossRef]

43. Wang, J.; Zhao, F.J.; Meharg, A.A.; Raab, A.; Feldmann, J.; McGrath, S.P. Mechanisms of Arsenic Hyperaccumulation in Pteris Vittata. Uptake Kinetics, Interactions with Phosphate, and Arsenic Speciation. Plant Physiol. 2002, 130, 1552-1561. [CrossRef] [PubMed] 
44. Chaturvedi, I. Effects of Arsenic Concentration and Forms on Growth and Arsenic Uptake and Accumulation by Indian Mustard (Brassica juncea L.) Genotyopes. J. Cent. Eur. Agric. 2006, 7, 31-40.

45. Ierna, A.; Mauro, R.P.; Mauromicale, G. Improved Yield and Nutrient Efficiency in Two Globe Artichoke Genotypes by Balancing Nitrogen and Phosphorus Supply. Agron. Sustain. Dev. 2012, 32, 773-780. [CrossRef]

46. Tu, C.; Ma, L.Q. Effects of Arsenate and Phosphate on Their Accumulation by an Arsenic-Hyperaccumulator Pteris vittata L. Plant Soil 2003, 249, 373-382. [CrossRef]

47. Gunes, A.; Pilbeam, D.J.; Inal, A. Effect of Arsenic-Phosphorus Interaction on Arsenic-Induced Oxidative Stress in Chickpea Plants. Plant Soil 2009, 314, 211-220. [CrossRef]

48. Suriyagoda, L.D.B.; Dittert, K.; Lambers, H. Mechanism of Arsenic Uptake, Translocation and Plant Resistance to Accumulate Arsenic in Rice Grains. Agric. Ecosyst. Environ. 2018, 253, 23-37. [CrossRef]

(C) 2019 by the authors. Licensee MDPI, Basel, Switzerland. This article is an open access article distributed under the terms and conditions of the Creative Commons Attribution (CC BY) license (http://creativecommons.org/licenses/by/4.0/). 

Article

\title{
Effect of Supplementary Light Intensity on Quality of Grafted Tomato Seedlings and Expression of Two Photosynthetic Genes and Proteins
}

\author{
Hao Wei ${ }^{1,+}$, Jin Zhao ${ }^{1,+}$, Jiangtao $\mathrm{Hu}^{1}$ and Byoung Ryong Jeong ${ }^{1,2,3, *}$ \\ 1 Department of Horticulture, Division of Applied Life Science (BK21 Plus Program), Graduate School of \\ Gyeongsang National University, Jinju 52828, Korea; oahiew@gmail.com (H.W.); jzhao9006@gmail.com (J.Z.); \\ jiangtaoh@yahoo.com (J.H.) \\ 2 Institute of Agriculture \& Life Science, Gyeongsang National University, Jinju 52828, Korea \\ 3 Research Institute of Life Science, Gyeongsang National University, Jinju 52828, Korea \\ * Correspondence: brjeong@gmail.com; Tel.: +82-010-6751-5489 \\ + These authors contributed equally to this work.
}

Received: 4 May 2019; Accepted: 21 June 2019; Published: 25 June 2019

\begin{abstract}
Lower quality and longer production periods of grafted seedlings, especially grafted plug seedlings of fruit vegetables, may result from insufficient amounts of light, particularly in rainy seasons and winter. Supplemental artificial lighting may be a feasible solution to such problems. This study was conducted to evaluate light intensity's influence on the quality of grafted tomato seedlings, 'Super Sunload' and 'Super Dotaerang' were grafted onto the 'B-Blocking' rootstock. To improve their quality, grafted seedlings were moved to a glasshouse and grown for 10 days. The glasshouse had a combination of natural lighting from the sun and supplemental lighting from LEDs $\left(W_{1} R_{2} B_{2}\right)$ for $16 \mathrm{~h} /$ day. Light intensity of natural lighting was $490 \mu \mathrm{mol} \cdot \mathrm{m}^{-2} \cdot \mathrm{s}^{-1}$ photosynthetic photon flux density (PPFD) and that of supplemental lighting was 50, 100, or $150 \mu \mathrm{mol} \cdot \mathrm{m}^{-2} \cdot \mathrm{s}^{-1}$ PPFD. The culture environment had $30 / 25^{\circ} \mathrm{C}$ day/night temperatures, $70 \% \pm 5 \%$ relative humidity $(\mathrm{RH})$, and a natural photoperiod of $14 \mathrm{~h}$ as well. Compared with quality of seedlings in supplemental lighting of $50 \mu \mathrm{mol} \cdot \mathrm{m}^{-2} \cdot \mathrm{s}^{-1} \mathrm{PPFD}$, that of seedlings in supplement lighting of $100 \mathrm{or} 150 \mu \mathrm{mol} \cdot \mathrm{m}^{-2} \cdot \mathrm{s}^{-1} \mathrm{PPFD}$ improved significantly. With increasing light intensity, diameter, fresh weight, and dry weight, which were used to measure shoot growth, greatly improved. Leaf area, leaf thickness, and root biomass were also greater. However, for quality of seedlings, no significant differences were discovered between supplement lighting of $100 \mu \mathrm{mol} \cdot \mathrm{m}^{-2} \cdot \mathrm{s}^{-1} \mathrm{PPFD}$ and supplement lighting of $150 \mu \mathrm{mol} \cdot \mathrm{m}^{-2} \cdot \mathrm{s}^{-1}$ PPFD. Expressions of PsaA and PsbA (two photosynthetic genes) as well as the corresponding proteins increased significantly in supplement lightning of 100 and $150 \mu \mathrm{mol} \cdot \mathrm{m}^{-2} \cdot \mathrm{s}^{-1} \mathrm{PPFD}$, especially in $100 \mu \mathrm{mol} \cdot \mathrm{m}^{-2} \cdot \mathrm{s}^{-1} \mathrm{PPFD}$. Overall, considering quality and expressions of two photosynthetic genes and proteins, supplemental light of $100 \mu \mathrm{mol} \cdot \mathrm{m}^{-2} \cdot \mathrm{s}^{-1} \mathrm{PPFD}\left(\mathrm{W}_{1} \mathrm{R}_{2} \mathrm{~B}_{1}\right)$ would be the best choice to cultivate grafted tomato seedlings.
\end{abstract}

Keywords: LED; PPFD; PsaA; PsbA; Western Blot

\section{Introduction}

Light, temperature, humidity, concentration of $\mathrm{CO}_{2}$, and nutrition supply are vital factors that influence photosynthesis of plants. Light intensity, quality, photoperiod, and direction influence plant growth, development, photomorphogenesis, and anatomical structure as energy sources and regulatory signals [1-3]. Previous studies have proven that light intensity can adjust formation of the chloroplast protein complex, electron transport, and quantum yield between photosystems I (PSI) and II (PSII) $[4,5]$. 
Grafting as an efficient technique can be applied to overcome the obstacles of continuous cropping and improve yield, quality, and stress resistance in various plant species including fruit trees, vegetables, and ornamental flowers [6]. In addition to rootstock, affinity of the scion, and grafted methods, the surviving rates, formation of new vascular bundles, and biological properties of grafted seedlings are also related to environmental conditions and management in healing and acclimatization processes [7]. Light-emitting diodes (LEDs) are widely used in facility horticulture as an artificial light source for production of high-quality seedlings. LEDs have shown promising foreground applications because of their advantages of being light-weight, having a small volume, having a specific wavelength, they are easy to integrate, and they have low heat dissipation. Previous studies have shown that the LEDs play a vital role in toughening grafted seedlings in healing and acclimatization processes $[8,9]$.

Generally, stocky plug seedlings are preferred by crop growers for the convenience of transportation and to insure a higher survival ratio and enhanced development after transplanting. Each country has different standards for evaluating the quality of seedlings. In South Korea, it is generally agreed that high-quality seedlings are those without overgrowth, with short and not lodging stems and leaves, and with well-developed roots that hold the medium in the plug tray. Light intensity has been proven to affect plant height and biomass growth $[10,11]$. Leaf area also changes with light intensity as plants use leaves to absorb light energy [12,13]. Moreover, higher light intensities may result in more root biomass so the absorption of water and mineral elements could be promoted [14]. Therefore, seedlings with good quality could be obtained by supplementing them with optimal light intensity.

This study was carried out aimed at finding an optimal light intensity to improve the quality of two kinds of grafted tomato seedlings. After grafting, well-healed grafted seedlings were moved to and cultivated for an additional 10 days in a glasshouse, which had natural lighting and supplemental lighting. The supplementary light intensities were set at 50,100 , or $150 \mu \mathrm{mol} \cdot \mathrm{m}^{-2} \cdot \mathrm{s}^{-1}$ photosynthetic photon flux density (PPFD) supplied from mixed LEDs $\left(W_{1} R_{2} B_{1}\right)$ to further improve the quality of seedlings. After treatment, expressions of two photosynthesis-related genes ( $P s a A$ and $P s b A)$ and the corresponding proteins were analyzed to evaluate the capacity of photosynthesis.

\section{Materials and Methods}

\subsection{Plant Materials}

Two cultivars of tomato (Solanum lycopersicum L.) 'Super Sunload (SS)' and 'Super Dotaerang (SD)' were selected as the scions and tomato 'B-Blocking' as a common rootstock. Cultivars 'SS' and 'SD', widely used for grafting, were purchased from Sakata Seed Korea Co., Ltd. (Seoul, Korea) and Koregon Co., Ltd. (Anseong, Korea), respectively. The 'SS' has high fruit firmness with an average fruit weight of 220-240 g. The primary advantages of 'SS' are a low ratio of fruit deformity and resistance to high temperatures. The ' $\mathrm{SD}^{\prime}$ ' is a cultivar with disease resistance and has a high sugar content, firm flesh, and a low deformity ratio. The seeds of these cultivars were sown into 40 square cell plug trays at the same time they were filled with commercial growing medium (Super Mix, NongKyung Co., Jincheon, Korea). The scion and rootstock were cleft-grafted at $20 \mathrm{~d}$ after sowing when both scion cultivars had two same sizes of compound leaves. After grafting, the grafted seedlings were immediately transported to a healing chamber, which had a temperature of $23^{\circ} \mathrm{C}$ and relative humidity of $95 \%$ to $100 \%$ throughout the healing period. Five days later, the well-healed grafted seedlings were moved from the healing chamber to the greenhouse for light treatment when the average plant height was about $8 \pm 0.7 \mathrm{~cm}$ and each seedling had two and a half true leaves.

\subsection{Light Treatments}

Mixed LEDs $\left(\mathrm{W}_{1} \mathrm{R}_{2} \mathrm{~B}_{1}\right)$ (Custom made, Sung Kwang LED Co., Ltd., Incheon, Korea), which were selected as the best artificial light source in precedent research [15], were used as the sole light source. The grafted seedlings were cultivated for an additional $10 \mathrm{~d}$ in a glasshouse with a daily light integral (DLI) of $11.59 \mathrm{~mol} \cdot \mathrm{m}^{-2} \cdot \mathrm{d}^{-1}$ from the sun and supplemental lighting for $16 \mathrm{~h} / \mathrm{d}$. The supplementary 
light intensities were set at 50,100, or $150 \mu \mathrm{mol} \cdot \mathrm{m}^{-2} \cdot \mathrm{s}^{-1}$ PPFD (henceforth shortened as 50, 100, and 150). The DLIs of the three supplementary light treatments were $2.88,5.76$, and $8.64 \mathrm{~mol} \cdot \mathrm{m}^{-2} \cdot \mathrm{d}^{-1}$, respectively. The distance between the LEDs and seedlings was $50 \mathrm{~cm}$. Light intensity was measured at the horizontal position at the seedling stem. The culture environment had $30 / 25{ }^{\circ} \mathrm{C}$ day/night temperatures, $70 \% \pm 5 \%$ relative humidity $(\mathrm{RH})$, with a natural photoperiod of $14 \mathrm{~h}$. A portable photo/radiometer (Type specification: HD-2102.2, Delta, OHM, Padova, Italy) was used to measure the photon flux density. Different light intensities were controlled by adjustable electric currents.

\subsection{Stomatal Conductance}

Mature and expanded leaves were selected for the measurement of stomatal conductance. Measurements were carried out during the day (9:00-10:00) on a porometer (Type specification: Sc-1 Porometer, Decagon Devices Inc., Pullman, WA, USA).

\subsection{Quantitative Real-Time PCR Analysis}

Tomato leaves were ground under RNase-free conditions after being frozen in liquid nitrogen. An Easy-Spin total RNA extraction kit (Type Specification: iNtRON Biotechnology, Seoul, Republic of Korea) and a GoScript Reverse Transcription System (Specification: Promega, Madison, WI, USA) were used for RNA extraction and cDNA synthesis, respectively, following the manufacturer's instructions. The Rotor-Gene Q detection system (Qiagen, Hilden, Germany) was applied in the examination of gene expression. Reaction volumes $(20 \mu \mathrm{L})$ contained $1 \mu \mathrm{L}$ cDNA, $0.5 \mu \mathrm{L}$ primer $(10 \mu \mathrm{M}), 10 \mu \mathrm{L}$ of $2 \times$ AMPIGENE qPCR Green Mix Lo-ROX (Enzo life Sciences Inc., Farmingdale, NY, USA), and $8 \mu \mathrm{L}$ $\mathrm{ddH}_{2} \mathrm{O}$. The $2^{-\triangle \Delta \mathrm{Ct}}$ method was applied to determine the relative gene expressions, and the $18 \mathrm{~S}$ gene was used as housekeeping gene. All primers used are shown in Supplementary Table S1.

\subsection{Protein Extraction and Western Blotting}

Protein extraction was conducted following the method described elsewhere [16], with slight modifications. An extraction buffer was used to homogenize approximately $500 \mathrm{mg}$ tomato leaves. The buffer contained $100 \mathrm{mM}$ Tris- $\mathrm{HCl}(\mathrm{pH} 8.0), 0.5 \mathrm{mM}$ EDTA $\cdot \mathrm{Na}_{2}, 1 \%(\mathrm{v} / \mathrm{v})$ polyvinylpyrrolidone, $10 \mathrm{mM} \beta$-mercaptoethanol, and $200 \mathrm{mM}$ sucrose. At $4{ }^{\circ} \mathrm{C}$, the mixture was centrifuged at $12,000 \mathrm{rpm}$ for $10 \mathrm{~min}$. Subsequent to determination of protein concentrations, the supernatant $(10 \mu \mathrm{L})$ was mixed together with protein loading buffer and then separated on 12\% SDS-PAGE gel. After that, proteins were moved to a polyvinylidene fluoride (PVDF) blotting membrane (Type specification: Millipore, Bedford, MA, USA) using an electrotransfer instrument (Type specification: Bio-Rad, Hercules, CA, USA). Following electrotransfer, the PVDF blotting membrane was transferred into 5\% nonfat skimmed milk, dissolved in tris buffered saline tween (TBST) overnight at $4{ }^{\circ} \mathrm{C}$ to prevent nonspecific adsorption, washed with TBST, and incubated by using the following polyclonal primary antibodies: 1:3000 dilution of anti-PsaA (Specification: Agrisera AS06 172, Vännäs, Sweden) for PsaA, 1:10,000 dilution of anti-PsbA (Specification: Agrisera AS05 084, Vännäs, Sweden) for PsbA, and 1:10,000 dilution of anti-RbcL (Specification: Agrisera AS03 037, Vännäs, Sweden) for loading control overnight at $4{ }^{\circ} \mathrm{C}$, respectively. After that, PVDF blotting membranes were incubated in 1:10,000 dilution of HRP (horseradish peroxidase)-linked anti-rabbit 1gG (Bethyl A120 101P, Montgomery, TX, USA) for $1 \mathrm{~h}$ at ambient temperature as a secondary antibody before visualization of immunoreactive proteins using Clarity ${ }^{\mathrm{TM}}$ Western ECL Substrate (\#6883, Bio-Rad, Hercules, CA, USA) on an iBright ${ }^{\mathrm{TM}}$ Imaging Systems (Type specification: Thermo Fisher Scientific, Waltham, MA, USA).

\subsection{Data Collection and Analysis}

After supplemental lighting treatments for $10 \mathrm{~d}$, this study measured the following parameters: lengths of scion and root, diameters of scions, number of leaves, leaf length, leaf width, leaf area and thickness, chlorophyll (SPAD), fresh weight of root, dry weight of root, specific weight of leaf, and dry weight to height ratio of scion. 
The experiment was carried out in three replicates with a design of randomized complete block, using 9 seedlings in each replication. Locations of replications were randomly mixed to eliminate position effect within a controlled environment. One-way analysis of variance ANOVA by SAS program Statistical Analysis System (V.9.1, Cary, NC, USA), was applied to statistically analyze the collected data. Duncan's multiple range test was adopted to test significant differences between different means.

\section{Results}

\subsection{Growth and Development of Tomato Seedlings as Affected by Supplemental Lighting Treatment in} the Glasshouse

After cultivation in a glasshouse for $10 \mathrm{~d}$, growth and development parameters of the grafted tomato seedlings were measured. Results of the measurements showed that the characteristics of the seedlings' morphologies were significantly influenced by light intensities. The two cultivars of grafted tomato cultivated in 100 and those in 150 showed the greatest scion length and root fresh weight. No significant differences were discovered in scion stem diameter and leaf length between supplementary lighting of 50,100, or 150. Leaf area and width, number of leaves, and root length of 'SS' were significantly greater in supplementary lighting of 100 and 150 than in supplementary lighting 50. The greatest root length was observed in light intensity of $150 \mathrm{in}$ 'SD'. In general, there were little differences between supplementary lighting of 100 and 150. Compared with supplementary lighting of 50 , both of these two treatments significantly improved quality of the two types of grafted tomato seedlings (Table 1 ).

Dry weight of shoot and dry weight of root are shown in Figure 1. Considering these two weights, there were no significant differences between light intensity of 100 and light intensity of 150 . However, compared to the treatment of light intensity of 50 , these two treatments significantly improved dry weight of the two types of tomato cultivars.
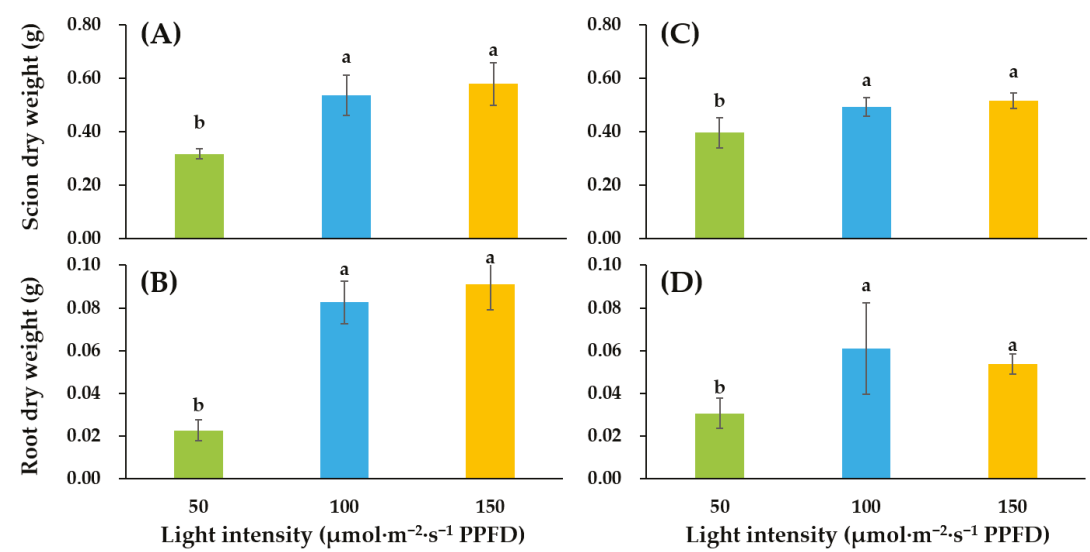

Figure 1. Influence of supplementary lighting intensity on dry weight of shoots and dry weight of roots of two cultivars of tomato 'Super Sunload' ('SS') (A,B) and 'Super Dotaerang' ('SD') (C,D) grafted onto the 'B-Blocking' rootstock. Error bars represent SEs of nine biological replicates $(n=9)$. According to the Duncan test, lowercase letters at $p \leq 0.05$ indicate significant differences between different treatments. 
Agronomy 2019, 9, 339

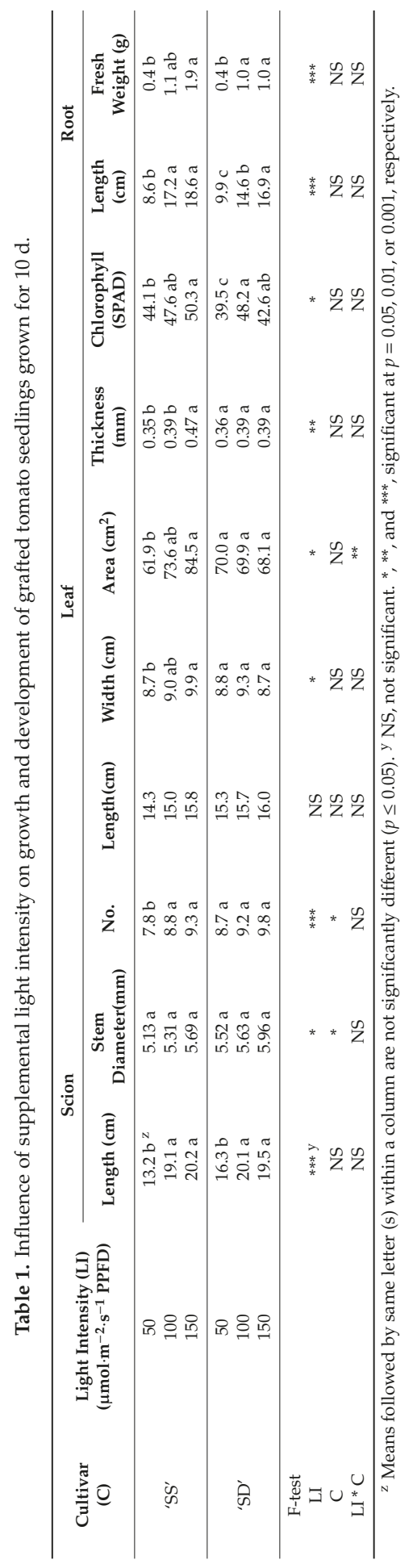


Growing compact and sturdy seedlings is an objective of high-quality seedling production. Dry weight to height ratio of scion (WHR) was conducted to indicate the quality of seedlings. For 'SS', supplementary lighting of 100 and 150 significantly improved WHR as compared to supplementary lighting of 50. There were no significant differences in WHRs between supplementary lighting of 100 and 150. For 'SD', the greatest WHRs showed in supplementary light of 150. For both tomato cultivars, the specific leaf weight (a leaf fresh weight per unit leaf area) was significantly improved in light intensities of 100 and 150 as compared to light intensity of 50. There were no significant differences in the specific leaf weight between light intensity of 100 and 150 (Figure 2).
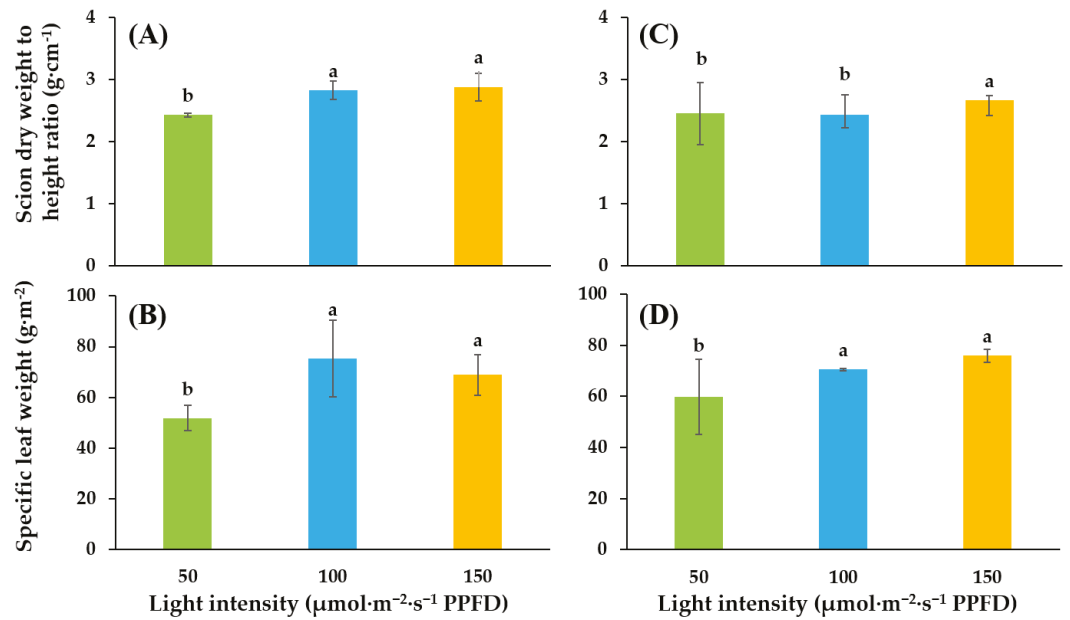

Figure 2. Influence of supplementary lighting intensity on dry weight to height ratio of scion and specific leaf weight of two cultivars of tomato 'SS' (A,B) and 'SD' (C,D) grafted onto 'B-Blocking' rootstock. The error bars represent SEs of biological replicates $(n=9)$. According to the Duncan test, lowercase letters at $p \leq 0.05$ indicate significant differences between different treatments.

Moreover, we determined the effect of lighting intensity on stomatal conductance of the two tomato cultivars. Results showed, compared with light intensity of 50, light intensity of 100 increased stomatal conductance of the two cultivars. Interestingly, stomatal conductance in light intensity of 150 was similar to that in light intensity of 50 treatment (Figure 3).
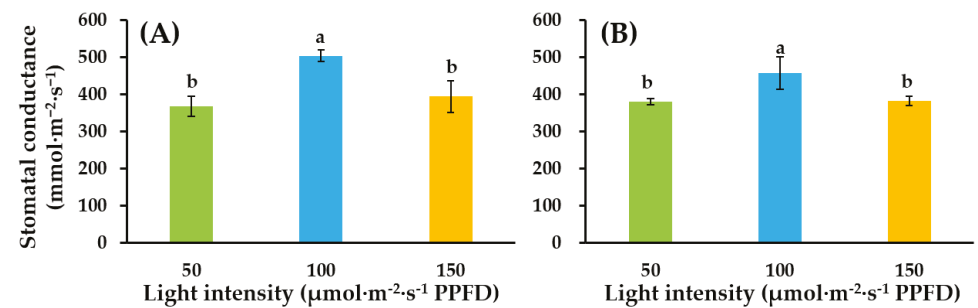

Figure 3. Influence of supplementary lighting intensity on stomatal conductance of two cultivars of tomato 'SS' (A) and 'SD' (B) grafted onto the 'B-Blocking' rootstock. The error bars represent SEs of three biological replicates $(n=3)$. According to the Duncan test, lowercase letters at $p \leq 0.05$ indicate significant differences between treatments.

Figure 4 illustrated seedling morphologies of 'SS' and 'SD' after treating for $10 \mathrm{~d}$ by using supplementary lighting with a different light intensity. It showed that tomato seedlings grown in supplementary lighting of 100 and 150 had more biomass and were sturdier. 

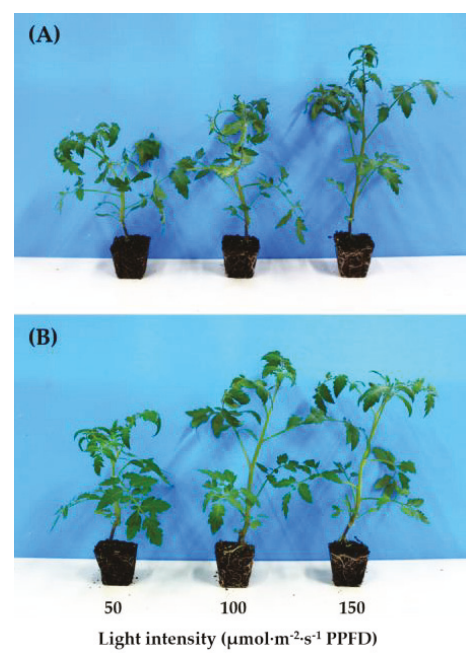

Figure 4. Influence of supplementary light intensity on morphology of 'SS' (A) and 'SD' (B) after $10 \mathrm{~d}$ of cultivation.

\subsection{Expressions of Photosynthesis-Related Genes}

Light intensity significantly influenced $P s a A$ and $P s b A$ genes (Figure 5). Light intensity of 100 enhanced expressions of $P_{S} a A$ and $P_{s} b A$. Relative expressions of $P_{s} a A$ in 'SS' and 'SD' were 1.37- and 2.27-fold, while that of $P s b A$ was 4.01- and 10.29-fold, as compared to that in the light intensity of 50 . However, a dramatic decrease in expression was observed in light intensity of 150 in 'SS' and 'SD'. Particularly, the relative expression of $P s a A$ in 'SS' was only 0.44-fold compared to the expression level in 50 .
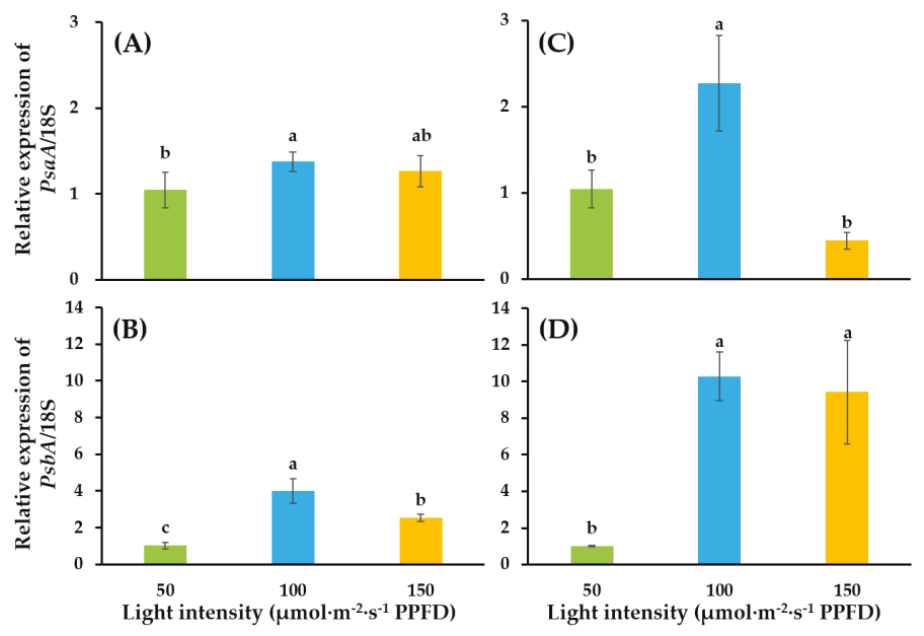

Figure 5. Relative expressions of $P s a A$ and $P s b A$ genes in 'SS' $(\mathbf{A}, \mathbf{B})$ and 'SD' $(\mathbf{C}, \mathbf{D})$ grafted onto the 'B-Blocking' rootstock. The bars among treatments represent the mean \pm SEs of technological replicates $(n=3)$. According to the Duncan test, lowercase letters at $p \leq 0.05$ indicate significant differences between different treatments. 


\subsection{PsaA and PsbA Immunoblots}

The PsaA gene is located in chloroplast genome (cpDNA). It encodes a core protein of a protein-pigment complex in PSI [17] and encodes D1 protein, which is a core component of PSII [18]. Figure 6 shows the protein expressions of PsaA and PsbA in 'SD' and 'SS' cultivated in supplementary lighting with different light intensities $(50,100$, or 150). For both tomato cultivars, expression levels of PsaA and PsbA in light intensities of 100 and 150 increased as compared to those in light intensity of 50. The highest expression levels of the PsaA and PsbA proteins appeared in light intensity of 100.

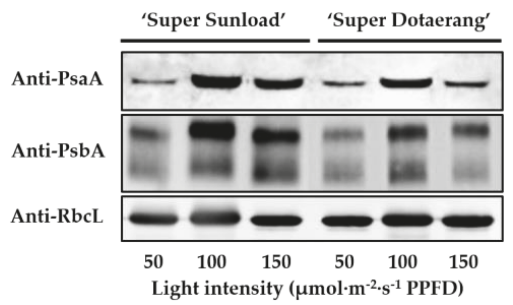

Figure 6. Expressions of PsaA and PsbA protein in 'SD' and 'SS' grafted onto the 'B-Blocking' rootstock. Equal loading was verified by the Rubisco large subunit (RbcL) level.

\section{Discussion}

Among regulatory factors for light condition, light intensity as an essential element is involved in regulation of growth, yield, and nutritional quality of vegetables [19]. Previous studies have proven that increased light intensity within a certain range may promote growth in lettuce [20,21]. Light condition is the foundation and guarantees healthy growth and yield of tomatoes [22]. Recent studies have shown that tomato seedlings under low-light conditions showed elongated internodes and petioles as well as a larger leaf area, which were caused by a shade-avoidance response $[23,24]$. Low-light conditions also affect the differentiation time and quality of flower buds in tomatoes [25]. For tomato cultivars 'Matador' and 'Blizzard', plant height, leaf width, number of leaves, and dry weight of aerial plant parts significantly improved due to increased levels of supplementary light $\left(30,60\right.$, and $90 \mu \mathrm{mol} \cdot \mathrm{m}^{-2} \cdot \mathrm{s}^{-1}$ PPFD) [26]. However, these findings do not mean the higher light intensities are always better. Tomato seedlings treated with $150 \mu \mathrm{mol} \cdot \mathrm{m}^{-2} \cdot \mathrm{s}^{-1}$ PPFD using white and blue LEDs showed continuous light-induced injuries, and the degree of the injury was more serious under white and blue LEDs than under orange and red LEDs of the same intensity [27]. This study showed that, compared with stem diameter of grafted tomato seedlings in supplementary lighting of 50, that of grafted tomato seedlings increased in supplementary lighting of 100 and 150. Leaf width and leaf thickness were also greater with treatments of light intensity of 100 and 150 (Table 1). Higher over-ground biomass and activeness of antioxidant enzymes were discovered in treatments with increased light intensity $\left(100,200\right.$, and $\left.400 \mu \mathrm{mol} \cdot \mathrm{m}^{-2} \cdot \mathrm{s}^{-1} \mathrm{PPFD}\right)$ in lettuce [28]. For Nicotiana tabacum, seedling biomass, soluble sugar concentrations, and primary root growth increased dramatically with light intensity of $300 \mu \mathrm{mol} \cdot \mathrm{m}^{-2} \cdot \mathrm{s}^{-1} \mathrm{PPFD}$ as compared to $60 \mu \mathrm{mol} \cdot \mathrm{m}^{-2} \cdot \mathrm{s}^{-1}$ PPFD [14]. It had been proven that low light intensity decreased above- and below- ground biomass in radish [29]. The results also showed, compared with light intensity of 100 and 150, dry weight of scion and dry weight of root were much lower in light intensity of 50 (Figure 1). Additionally, light intensity influences the development of stomata as well. According to the study of Lee [30], the stomatal conductance and the number of stomata per unit area of leaf increased with light intensity, increasing up to $60 \mu \mathrm{mol} \cdot \mathrm{m}^{-2} \cdot \mathrm{s}^{-1}$ PPFD in Withania somnifera. However, width and length of stomata declined in light intensity of $90 \mu \mathrm{mol} \cdot \mathrm{m}^{-2} \cdot \mathrm{s}^{-1}$ PPFD. These findings were consistent with our results in Figure 3 . The 100 promoted stomatal conductance of both tomato cultivars, while 150 affected it adversely.

The aim of supplementary lighting in greenhouses are as follows: to increase the light intensity in greenhouse and enable crops to receive proper light, to provide crops with light with specific 
wavelengths, to alter the time of flowering and fruiting, and to increase time for photosynthesis via changing the lighted period [31,32]. Advantages of light-emitting diodes (LEDs) include their small volume, longer service life, energy savings, and use of a single wavelength, which are efficient to encourage plant growth by producing the type of light with the specific wavelength needed by plants [33]. Studies have shown that red and blue lights absorbed by plants account for $90 \%$ of total light absorption [34], which are involved in regulating gene expression in photomorphogenesis [35]. Our previous study showed that compared with high pressure sodium (HPS), far-red (FR), metal halide $(\mathrm{MH})$, and white LEDs $(\mathrm{W})$, mixed LEDs $\left(\mathrm{W}_{1} \mathrm{R}_{2} \mathrm{~B}_{1}\right)$ as a supplementary light source had the best effect to improve the quality of grafted tomato seedlings [15]. The application of monochromatic light may cause physiological defects of plants such as disturbance of photosynthetic mechanisms [36], damage to the granule and thylakoid [37], and restrained synthesis of chlorophyll [38], which can be overcome or relieved by the mixture of red and blue light.

Photosynthesis is one of the supreme chemical reactions in plants. Photoreaction takes place in the chloroplast thylakoid membrane. Two light energy-driven systems, PSI and PSII, synergistically function in primary energy conversion reactions. Driven by light, plants and other photoautotrophs are able to synthesize carbon compounds directly from $\mathrm{CO}_{2}$ and $\mathrm{H}_{2} \mathrm{O}$ and release $\mathrm{O}_{2}$. Processes of consumption and formation in photosynthesis are related to photosynthetic phosphorylation coupled with electron transport. Electrons generated from splitting of $\mathrm{H}_{2} \mathrm{O}$ by the oxygen-evolving complex $(\mathrm{OEC})$ are used to reduce $\mathrm{NADP}^{+}$to NADPH. At the same time, synthesis of ATP is driven by a transmembrane electrochemical proton gradient $[39,40]$. The PSII, a multi-subunit protein-pigment complex, is associated with the photolysis of water and synthesis of ATP [41]. Within the core of the complex, PsbC and PsbB are bond to the photosynthetic pigments and transfer the excitation energy to reaction center proteins $\mathrm{D} 1(\mathrm{Qb}, \mathrm{PsbA})$ and D2 (Qa, PsbD) [42]. D1 dimerize with D2 as a heterodimer. Studies have suggested that synthesis of $\mathrm{D} 1$ is coordinated with linear photosynthetic electron transport as well as the relative activities of PSI and PSII [43]. Light has an important role in the translation of Dl protein [44]. The PSI complex contains reaction center P700, as well as five electron transfer centers (A0, A1, FX, FA, and FB) bound to PsaA and PsaB proteins [45]; it mediates electron transfer and is involved in light-driven conversion of $\mathrm{NADP}^{+}$to NADPH [46]. The two largest polypeptides, PsaA and PsaB, carrying P700 are believed to form the center Fx through dimerization [47]. In higher plants, the genes $P_{s} a A$ and $P_{s} a B$ encode the two polypeptides respectively and are located adjacent to each other in the plastid genome [48].

A previous study proved that expression of the PsaA gene product during rice plastid development was light-regulated on the translational or post-translational level [49]. In Synechococcus, blue light photoreceptor regulates expressions of $P s b A$ genes [50]. Moreover, in Synechocystis the transcription levels of promoters of $P s b a$ gene changed in response to dark and light conditions [51].

Expression levels of $P_{s} a A$ and $P s b A$ genes in light intensities of 100 and 150 increased as compared to those in light intensity of 50 in both cultivars. Compared with those in light intensity of 100 , lower expression levels of genes appeared in light intensity of 150 (Figure 5). Western blotting showed the same tendency of variation in protein expression as shown in Figure 6. Previous studies pointed that high light intensities caused degradation and phosphorylation of PSII core protein and damaged the photosynthetic machinery [52]. It could be speculated that the photosynthetic apparatuses suffered slight damage in light intensity of 150.

Although light is the basic energy for photosynthesis, light that is too strong will cause light stress for plants, which has side effects for photosynthesis, especially under low temperatures, drought, or other unfavorable conditions [53]. In 1956, Kok firstly proposed the concept of photoinhibition and defined it as 'the photochemical inactivation of complete pigment complexes or photosynthetic units' [54]. Powles (1984) pointed that excessive light energy absorbed by the photosynthetic apparatus caused photoinhibition with the characteristic of reduced photosynthetic capacity [55]. PSII is very sensitive to strong light, and it is the main occurrence site of photoinhibition [40]. There are two mechanisms of photoinhibition in PSII, acceptor-side photoinhibition and donor-side 
photoinhibition [56]. In the former situation, the hindered assimilation of $\mathrm{CO}_{2}$ will cause the reduction of the plastoquinone pool. Consequently, the double-reduced form of $\mathrm{QA}^{-}$accumulates and promotes the formation of the triplet state of the primary donor $\left({ }^{3} \mathrm{P} 680\right)$. The ${ }^{1} \mathrm{O}_{2}$ generated from the reaction between ${ }^{3} \mathrm{P} 680$ and $\mathrm{O}_{2}$ will cause damage to proteins and pigments, especially the amino acid residue sites in the D1 protein. In another mechanism, electron transport is impaired due to the hindered oxidation of water and prolonged half-life period of $\mathrm{P} 60^{+}$resulting in high oxidation potential on the donor side. Adjacent proteins and pigments are damaged as a consequence [57].

In 1994, Terashima firstly reported photoinhibition in PSI [58]. High-light intensity [59,60], low temperatures [61], and fluctuating light conditions $[62,63]$ will cause PSI photoinhibition. Studies have shown that changes of reducing state and production of ROS (reactive oxygen species) and hydroxyl peroxide on the acceptor side are the main causes of PSI photoinhibition $[64,65]$.

Plants have developed various mechanisms to prevent photoinhibition under high-light intensities because of their long-term evolution and development. The main mechanisms of photoprotection are as follows: to reduce the light absorption via movements of leaf and chloroplast [66]; to increase photosynthetic efficiency via increased levels of the photosynthetic electron transport carriers and contents of the photosynthetic key enzymes [67,68]; to protect the photosynthetic apparatus by photochemical and non-photochemical pathway such as the xanthophyll cycle, photorespiration, and the Mehler reaction [69-71]; to strengthen the active oxygen eliminating enzyme system [72,73]; and to distribute excitation energy and heat dissipation equally via state transition between PSII and PSI $[74,75]$.

Usually, sun and shade plants possess different morphological, physiological, and biochemical characteristics to adapt to different light conditions. Chloroplasts with distinctive characteristics will contribute to levels of photosynthesis. As compared to sun plants, shade plants have higher thylakoid stack areas, fewer grana stacks, and smaller widths of grana stacks to inhibit degradation of the D1 protein [76]. The levels of photosynthetic electron transport carriers and activities of photosynthesis-related enzymes, especially Rubisco, are higher in sun plants [77,78]. When light intensity is changed, the activities of RuBP and Rubisco do respond to the fluctuating environment [79]. Studies in mulberry showed that the leaves, which were at the daily maximum photosynthetic state, showed higher reversibility of photosynthetic quantum conversion, confronting the environment with changing light intensity [80]. After being transferred to an intercropping shaded environment, the lodging-resistant soybean genotypes showed elongated main stems and internodes as well as decreased biomass to the length of the stem ratio. The reasons may be due to downregulated gene expressions related to biosynthesis of structural carbohydrates [81]. Additionally, shade conditions influenced the photosynthetic rate by altering the chlorophyll fluorescence performance in soybean [82] and Athyrium pachyphlebium [83]. Shade treatment changed concentrations of chlorophyll and chlorophyll $\mathrm{a} / \mathrm{b}$ ratios in soybeans [84] and wheat [85]. These studies suggested that light capture and utilization, PSII activity, and the transfer of electron and energy between PSII and PSI may involve the regulation of photosynthetic capacity in shade and light conditions. Phenotypic plasticity of plants refers to the ability to conform their morphology and physiology to the environment [86]. Even though studies have shown that the phenotypic plasticity of some shade plant species is lower $[87,88]$, the mechanism of optimizing light energy capture should be lucubrated. To illustrate that, the mechanism of photosynthesis in natural growth condition with fluctuating light can help plants to adapt to sun and shade conditions and increase yields as a consequence [86]. Additionally, more attention should be paid to the relationship between genotype plasticity and productivity as well as the intraspecific variation in plasticity to fluctuating light [89].

Light required by plants is related to different species, cultivars, growth stages, developmental stages, and environmental factors as well as target of production [19]. Although light has a vital function in photosynthesis, excess light may depress photosynthetic efficiency, which is referred to as photoinhibition [55]. Therefore, to maximize economic benefits of grafted seedlings with high quality and quantity, detailed studies on optimizing light intensity are in urgent need. 


\section{Conclusions}

When moved to and cultivated in a glasshouse having supplementary lighting, light intensities of 100 and 150 had significantly improved qualities of grafted tomato seedlings as compared to light intensity of 50. However, considering improvement of quality of grafted seedlings, there were no significant differences between light intensities of 100 and 150. Owing to enhanced photosynthesis, the upregulated gene expression levels of $P_{s} a A$ and $P s b A$ and the corresponding protein expression levels indicated that light intensity of 100 might be the most suitable supplementary lighting to improve the quality of grafted tomato seedlings. That is, supplementary lighting with a light intensity of 100 would be the best choice to improve the quality of grafted vegetable seedlings when both power consumption and economic benefits are taken into account. This study provides new thoughts on supplemental lighting strategies that might be applied in greenhouses and lays the foundation for further studies on the utilization of light energy during early development stages of tomato seedlings.

Supplementary Materials: The following are available online at http://www.mdpi.com/2073-4395/9/6/339/s1, Table S1: Sequences of Primers used in the expressions of photosynthesis-related genes.

Author Contributions: Conceptualization, B.R.J.; Methodology, B.R.J. and H.W.; Formal Analysis, H.W., J.Z., and J.H.; Resources, B.R.J.; Data Curation, H.W. and J.Z.; Writing-Original Draft Preparation, H.W.; Writing-Review \& Editing, B.R.J.; Project Administration, B.R.J.; Funding Acquisition, B.R.J.

Funding: This research was funded by Korea Institute of Planning and Evaluation for Technology in Food, Agriculture, and Forestry, Project No.319008-01. H.W., J.Z., and J.H. were supported by a scholarship from the BK21 Plus Program, Ministry of Education, Republic of Korea.

Acknowledgments: This study was carried out with support from the Korea Institute of Planning and Evaluation for Technology in Food, Agriculture, and Forestry (Project No.319008-01). H.W., J.Z., and J.H. were supported by a scholarship from the BK21 Plus Program, Ministry of Education, Republic of Korea.

Conflicts of Interest: The authors declare no conflict of interest.

\section{References}

1. Muneer, S.; Kim, E.J.; Park, J.S.; Lee, J.H. Influence of green, red and blue light emitting diodes on multiprotein complex proteins and photosynthetic activity under different light intensities in lettuce leaves (Lactuca sativa L.). Int. J. Mol. Sci. 2014, 15, 4657-4670. [CrossRef] [PubMed]

2. Berta, M.; Giovannelli, A.; Sebastiani, F.; Camussi, A.; Racchi, M.L. Transcriptome changes in the cambial region of poplar (Populus alba L.) in response to water deficit. Plant Biol. 2010, 12, 341-354. [CrossRef] [PubMed]

3. Baba, K.; Karlberg, A.; Schmidt, J.; Schrader, J.; Hvidsten, T.R.; Bako, L.; Bhalerao, R.P. Activity-dormancy transition in the cambial meristem involves stage-specific modulation of auxin response in hybrid aspen. Proc. Natl. Acad. Sci. USA 2011, 108, 3418-3423. [CrossRef] [PubMed]

4. Sorce, C.; Giovannelli, A.; Sebastiani, L.; Anfodillo, T. Hormonal signals involved in the regulation of cambial activity, xylogenesis and vessel patterning in trees. Plant Cell Rep. 2013, 32, 885-898. [CrossRef] [PubMed]

5. Lee, J.M.; Kubota, C.; Tsao, S.; Bie, Z.; Echevarria, P.H.; Morra, L.; Oda, M. Current status of vegetable grafting: Diffusion, grafting techniques, automation. Sci. Hortic. 2010, 127, 93-105. [CrossRef]

6. Vu, N.T.; Kim, Y.S.; Kang, H.M.; Kim, I.S. Effect of red LEDs during healing and acclimatization process on the survival rate and quality of grafted tomato seedlings. Prot. Hortic. Plant Fact. 2014, 23, 43-49. [CrossRef]

7. Yorio, N.C.; Goins, G.D.; Kagie, H.R.; Wheeler, R.M.; Sager, J.C. Improving spinach, radish, and lettuce growth under red light-emitting diodes (LEDs) with blue light supplementation. HortScience 2001, 36, 380-383. [CrossRef]

8. Yano, A.; Fujiwara, K. Plant lighting system with five wavelength-band light-emitting diodes providing photon flux density and mixing ratio control. Plant Methods 2012, 8, 46. [CrossRef]

9. Kim, K.; Kook, H.S.; Jang, Y.J.; Lee, W.H.; Kamala-Kannan, S.; Chae, J.C.; Lee, K.J. The effect of blue-light-emitting diodes on antioxidant properties and resistance to Botrytis cinerea in tomato. J. Plant Pathol. Microbiol. 2013, 4, 203. [CrossRef]

10. Beon, M.S.; Bartsch, N. Early seedling growth of pine (Pinus densiflora) and oaks (Quercus serrata, Q. mongolica, Q. variabilis) in response to light intensity and soil moisture. Plant Ecol. 2003, 167, 97-105. [CrossRef] 
11. Du, Y.X.; Xin, J.; Zhang, J.; Li, J.Z.; Sun, H.Z.; Zhao, Q.Z. Research progress on the impacts of low light intensity on rice growth and development. Chin. J. Eco-Agric. 2013, 11, 1307-1317. (In Chinese) [CrossRef]

12. Perrin, P.M.; Mitchell, F.J. Effects of shade on growth, biomass allocation and leaf morphology in European yew (Taxus baccata L.). Eur. J. For. Res. 2013, 132, 211-218. [CrossRef]

13. Shao, Q.; Wang, H.; Guo, H.; Zhou, A.; Huang, Y.; Sun, Y.; Li, M. Effects of shade treatments on photosynthetic characteristics, chloroplast ultrastructure, and physiology of Anoectochilus roxburghii. PLoS ONE 2014, 9 , e85996. [CrossRef] [PubMed]

14. Nagel, K.A.; Schurr, U.; Walter, A. Dynamics of root growth stimulation in Nicotiana tabacum in increasing light intensity. Plant Cell Environ. 2006, 29, 1936-1945. [CrossRef] [PubMed]

15. Wei, H.; Hu, J.T.; Liu, C.; Wang, M.Z.; Zhao, J.; Kang, D.I.; Jeong, B.R. Effect of supplementary light source on quality of grafted tomato seedlings and expression of two photosynthetic genes. Agronomy 2018, 8, 207. [CrossRef]

16. Li, Y.Y.; Mao, K.; Zhao, C.; Zhao, X.Y.; Zhang, H.L.; Shu, H.R.; Hao, Y.J. MdCOP1 ubiquitin E3 ligases interact with MdMYB1 to regulate light-induced anthocyanin biosynthesis and red fruit coloration in apple. Plant Physiol. 2012, 160, 1011-1022. [CrossRef]

17. Choquet, Y.; Goldschmidt-Clermont, M.; Girard-Bascou, J.; Kück, U.; Bennoun, P.; Rochaix, J.D. Mutant phenotypes support a trans-splicing mechanism for the expression of the tripartite psaA gene in the C. reinhardtii chloroplast. Cell 1988, 52, 903-913. [CrossRef]

18. Singh, M. Turnover of D1 protein encoded by $P s b A$ gene in higher plants and cyanobacteria sustains photosynthetic efficiency to maintain plant productivity under photoinhibitory irradiance. Photosynthetica 2000, 38, 161-169. [CrossRef]

19. Kang, J.H.; Krishna, K.S.; Atulba, S.L.S.; Jeong, B.R.; Hwang, S.J. Light intensity and photoperiod influence the growth and development of hydroponically grown leaf lettuce in a closed-type plant factory system. Hortic. Environ. Biotechnol. 2013, 54, 501-509. [CrossRef]

20. Hunter, D.C.; Burritt, D.J. Light quality influences adventitious shoot production from cotyledon explants of lettuce (Lactuca sativa L). In Vitro Cell Dev. Biol. 2004, 40, 215-220. [CrossRef]

21. Li, Q.; Kubota, C. Effects of supplemental light quality on growth and phytochemicals of baby leaf lettuce. Environ. Exp. Bot. 2009, 67, 59-64. [CrossRef]

22. Franklin, K.A.; Larner, V.S.; Whitelam, G.C. The signal transducing photoreceptors of plants. ITLE Int. J. Dev. Biol. 2005, 49, 653-664. [CrossRef] [PubMed]

23. Fan, X.X.; Xu, Z.G.; Liu, X.Y.; Tang, C.M.; Wang, L.W.; Han, X.L. Effects of light intensity on the growth and leaf development of young tomato plants grown under a combination of red and blue light. Sci. Hortic. 2013, 153, 50-55. [CrossRef]

24. Chitwood, D.H.; Kumar, R.; Ranjan, A.; Pelletier, J.M.; Townsley, B.T.; Ichihashi, Y.; Martinez, C.C.; Zumstein, K.; Harada, J.J.; Maloof, J.N.; et al. Light-Induced Indeterminacy Alters Shade-Avoiding Tomato Leaf Morphology. Plant Physiol. 2015, 169, 2030-2047. [CrossRef] [PubMed]

25. Samach, A.; Lotan, H. The transition to flowering in tomato. Plant Biotechnol. 2007, 24, 71-82. [CrossRef]

26. McCall, D. Effect of supplementary light on tomato transplant growth, and the after-effects on yield. Sci. Hortic. 1992, 51, 65-70. [CrossRef]

27. Matsuda, R.; Yamano, T.; Murakami, K.; Fujiwara, K. Effects of spectral distribution and photosynthetic photon flux density for overnight LED light irradiation on tomato seedling growth and leaf injury. Sci. Hortic. 2016, 198, 363-369. [CrossRef]

28. Fu, W.G.; Li, P.P.; Wu, Y.Y.; Tang, J. Effects of different light intensities on anti-oxidative enzyme activity, quality and biomass in lettuce. Sci. Hortic. 2012, 39, 129-134.

29. Hole, C.C.; Dearman, J. The effect of photon flux density on distribution of assimilate between shoot and storage root of carrot, red beet and radish. Sci. Hortic. 1993, 55, 213-225. [CrossRef]

30. Lee, S.H.; Tewari, R.K.; Hahn, E.J.; Paek, K.Y. Photon flux density and light quality induce changes in growth, stomatal development, photosynthesis and transpiration of Withania somnifera (L.) Dunal. plantlets. Plant Cell Tissue Organ Cult. 2007, 90, 141-151. [CrossRef]

31. Seginer, I.; Albright, L.D.; Ioslovich, I. Improved strategy for a constant daily light integral in greenhouses. Biosyst. Eng. 2006, 93, 69-80. [CrossRef]

32. Warner, R.M.; Erwin, J.E. Effect of photoperiod and daily light integral on flowering of five Hibiscus sp. Sci. Hortic. 2003, 97, 341-351. [CrossRef] 
33. Brown, C.S.; Schuerger, A.C.; Sager, J.C. Growth and photomorphogenesis of pepper plants under red light-emitting diodes with supplemental blue or far-red lighting. J. Am. Soc. Hortic. Sci. 1995, 120, 808-813. [CrossRef] [PubMed]

34. Terashima, I.; Fujita, T.; Inoue, T.; Chow, W.S.; Oguchi, R. Green light drivesleaf photosynthesis more efficiently than red light in strong white light: Revisiting the enigmatic question of why leaves are green. Plant Cell Physiol. 2009, 50, 684-697. [CrossRef] [PubMed]

35. Barnes, C.; Bugbee, B. Morphological responses of wheat to changes in phytochrome photoequilibrium. Plant Physiol. 1991, 97, 359-365. [CrossRef] [PubMed]

36. Hogewoning, S.W.; Douwstra, P.; Trouwborst, G.; van Ieperen, W.; Harbinson, J. An artificial solar spectrum substantially alters plant development compared with usual climate room irradiance spectra. Exp. Bot. 2010, 61, 1267-1276. [CrossRef] [PubMed]

37. Wang, X.Y.; Xu, X.M.; Cui, J. The importance of blue light for leaf area expansion, development of photosynthetic apparatus, and chloroplast ultrastructure of Cucumis sativus grown under weak light. Photosynthetica 2015, 53, 213-222. [CrossRef]

38. Bach, A.; Krol, A. Effect of light quality on somatic embryogenesis in Hyacinthus orientalis L. 'Delft's Blue'. Biol. Bull. Pozn. 2001, 38, 103-107.

39. Lander, G.C.; Estrin, E.; Matyskiela, M.E.; Bashore, C.; Nogales, E.; Martin, A. Complete subunit architecture of the proteasome regulatory particle. Nature 2012, 482, 186-191. [CrossRef]

40. Huang, W.; Zhang, S.B.; Liu, T. Moderate photoinhibition of photosystem II significantly affects linear electron flow in the shade-demanding plant Panax notoginseng. Front. Plant Sci. 2018, 9, 250-256. [CrossRef]

41. Raymond, J.; Blankenship, R.E. The evolutionary development of the protein complement of photosystem II. Biochim. Biophys. Acta Bioenerg. 2004, 1655, 133-139. [CrossRef] [PubMed]

42. Grotjohann, I.; Jolley, C.; Fromme, P. Evolution of photosynthesis and oxygen evolution: Implications from the structural comparison of Photosystems I and II. Phys. Chem. Chem. Phys. 2004, 6, 4743-4753. [CrossRef]

43. Trebitsh, T.; Danon, A. Translation of chloroplast $p s b A$ mRNA is regulated by signals initiated by both photosystems II and I. Proc. Natl. Acad. Sci. USA 2001, 98, 12289-12294. [CrossRef] [PubMed]

44. Gruissem, W. Chloroplast gene expression: How plants turn their plastids on. Cell 1989, 56, 161-170. [CrossRef]

45. Chitnis, P.R.; Xu, Q.; Chitnis, V.P.; Nechushtai, R. Function and organization of photosystem I polypeptides. Photosynth. Res. 1995, 44, 23-40. [CrossRef] [PubMed]

46. Altman, A.; Cohen, B.N.; Weissbach, H.; Brot, N. Transcriptional activity of isolated maize chloroplasts. Arch. Biochem. Biophys. 1984, 235, 26-33. [CrossRef]

47. Webber, A.N.; Malkin, R. Photosystem I reaction-centre proteins contain leucine zipper motifs: A proposed role in dimer formation. FEBS Lett. 1990, 264, 1-4. [CrossRef]

48. Hiratsuka, J.; Shimada, H.; Whittier, R.; Ishibashi, T.; Sakamoto, M.; Mori, M.; Kondo, C.; Honji, Y.; Sun, C.R.; Meng, B.Y.; et al. The complete sequence of the rice (Oryza sativa) chloroplast genome: Intermolecular recombination between distinct tRNA genes accounts for a major plastid DNA inversion during the evolution of the cereals. Mol. Gen. Genet. 1989, 217, 185-194. [CrossRef]

49. Chen, S.G.; Cheng, M.C.; Chung, K.R.; Yu, N.J.; Chen, M.C. Expression of the rice chloroplast $p s a A-p s a B-r p s 14$ gene cluster. Plant Sci. 1992, 81, 93-102. [CrossRef]

50. Tsinoremas, N.F.; Schaefer, M.R.; Golden, S.S. Blue and red light reversibly control $p s b A$ expression in the cyanobacterium Synechococcus sp. strain PCC 7942. J. Biol. Chem. 1994, 269, 16143-16147.

51. Albers, S.C.; Peebles, C.A. Evaluating light-induced promoters for the control of heterologous gene expression in Synechocystis sp. PCC 6803. Biotechnol. Prog. 2017, 33, 45-53. [CrossRef] [PubMed]

52. Chen, L.; Jia, H.; Tian, Q.; Du, L.; Gao, Y.; Miao, X.; Liu, Y. Protecting effect of phosphorylation on oxidative damage of $\mathrm{D} 1$ protein by down-regulating the production of superoxide anion in photosystem II membranes under high light. Photosynth. Res. 2012, 112, 141-148. [CrossRef] [PubMed]

53. Antal, T.K.; Kovalenko, I.B.; Rubin, A.B.; Tyystjärvi, E. Photosynthesis-related quantities for education and modeling. Photosynth. Res. 2013, 117, 1-30. [CrossRef] [PubMed]

54. Kok, B. On the inhibition of photosynthesis by intense light. Biochim. Biophys. Acta. 1956, 21, $234-244$. [CrossRef]

55. Powles, S.B. Photoinhibition of photosynthesis induced by visible light. Annu. Rev. Plant Physiol. 1984, 35, 15-44. [CrossRef] 
56. Aro, E.M.; Virgin, I.; Andersson, B. Photoinhibition of photosystem II. Inactivation, protein damage and turnover. Biochim. Biophys. Acta 1993, 1143, 113-134. [CrossRef]

57. Henmi, T.; Yamasaki, H.; Sakuma, S.; Tomokawa, Y.; Tamura, N.; Shen, J.R.; Yamamoto, Y. Dynamic Interaction between the D1 protein, CP43 and OEC33 at the lumenal side of photosystem II in spinach chloroplasts: Evidence from light-induced cross-Linking of the proteins in the donor-side photoinhibition. Plant Cell Physiol. 2003, 44, 451-456. [CrossRef]

58. Terashima, I.; Funayama, S.; Sonoike, K. The site of photoinhibition in leaves of Cucumis sativus L. at low temperatures is photosystem I, not photosystem II. Planta 1994, 193, 300-306. [CrossRef]

59. Huang, W.; Yang, Y.J.; Zhang, J.L.; Hu, H.; Zhang, S.B. PSI photoinhibition is more related to electron transfer from PSII to PSI rather than PSI redox state in Psychotria rubra. Photosynth. Res. 2016, 129, 85-92. [CrossRef]

60. Gollan, P.J.; Lima-Melo, Y.; Tiwari, A.; Tikkanen, M.; Aro, E.M. Interaction between photosynthetic electron transport and chloroplast sinks triggers protection and signalling important for plant productivity. Philos. Trans. R. Soc. B 2017, 372, 20160390. [CrossRef]

61. Tjus, S.E.; Moller, B.L.; Scheller, H.V. Photosystem I is an early target of photoinhibition in barley illuminated at chilling temperatures. Plant Physiol. 1998, 116, 755-764. [CrossRef] [PubMed]

62. Suorsa, M.; Järvi, S.; Grieco, M.; Nurmi, M.; Pietrzykowska, M.; Rantala, M.; Kangasjärvi, S.; Paakkarinen, V.; Tikkanen, M.; Jansson, S.; et al. PROTON GRADIENT REGULATION5 is essential for proper acclimation of Arabidopsis photosystem I to naturally and artificially fluctuating light conditions. Plant Cell 2012, 24, 2934-2948. [CrossRef]

63. Tikkanen, M.; Grebe, S. Switching off photoprotection of photosystem I-A novel tool for gradual PSI photoinhibition. Physiol. Plant. 2018, 162, 156-161. [CrossRef] [PubMed]

64. Munekage, Y.; Hojo, M.; Meurer, J.; Endo, T.; Tasaka, M.; Shikanai, T. PGR5 is involved in cyclic electron flow around photosystem I and is essential for photoprotection in Arabidopsis. Cell 2002, 110, 361-371. [CrossRef]

65. Tikkanen, M.; Mekala, N.R.; Aro, E.M. Photosystem II photoinhibition-repair cycle protects Photosystem I from irreversible damage. Biochim. Biophys. Acta 2014, 1837, 210-215. [CrossRef]

66. Kagawa, T.; Sakai, T.; Suetsugu, N.; Oikawa, K.; Ishiguro, S.; Kato, T.; Tabata, S.; Okada, K.; Wada, M. Arabidopsis NPL1: A phototropin homolog controlling the chloroplast high-light avoidance response. Science 2001, 291, 2138-2141. [CrossRef] [PubMed]

67. Anderson, J.M.; Osmond, C.B. Shade-sun responses: Compromises between acclimation and photoinhibition. In Photoinhibition; Kyle, D.J., Osmond, C.B., Arntzen, C.J., Eds.; Elsevier Science BV: Amsterdam, The Netherlands, 1987; Volume 96, pp. 2-38.

68. Demmig-Adams, B.; Adams Iii, W.W. Photoprotection and other responses of plants to high light stress. Annu. Rev. Plant Biol. 1992, 43, 599-626. [CrossRef]

69. Sacharz, J.; Giovagnetti, V.; Ungerer, P.; Mastroianni, G.; Ruban, A.V. The xanthophyll cycle affects reversible interactions between PsbS and light-harvesting complex II to control non-photochemical quenching. Nat. Plants 2017, 3, 16225. [CrossRef]

70. Bräutigam, A.; Gowik, U. Photorespiration connects C3 and C4 photosynthesis. J. Exp. Bot. 2016, 67, 2953-2962. [CrossRef] [PubMed]

71. Badger, M.R.; Caemmerer, S.; Ruuska, S.; Nakano, H. Electron flow to oxygen in higher plants and algae: Rates and control of direct photoreduction (Mehler reaction) and rubisco oxygenase. Philos. Trans. R. Soc. B 2000, 355, 1433-1446. [CrossRef]

72. Guo, Y.Y.; Tian, S.S.; Liu, S.S.; Wang, W.Q.; Sui, N. Energy dissipation and antioxidant enzyme system protect photosystem II of sweet sorghum under drought stress. Photosynthetica 2018, 56, 861-872. [CrossRef]

73. Li, J.; Cang, Z.; Jiao, F.; Bai, X.; Zhang, D.; Zhai, R. Influence of drought stress on photosynthetic characteristics and protective enzymes of potato at seedling stage. J. Saud. Soc. Agric. Sci. 2017, 16, 82-88. [CrossRef]

74. Takahashi, H.; Iwai, M.; Takahashi, Y.; Minagawa, J. Identification of the mobile light-harvesting complex II polypeptides for state transitions in Chlamydomonas reinhardtii. Proc. Natl. Acad. Sci. USA 2006, 103, 477-482. [CrossRef] [PubMed]

75. Falkowski, P.G.; Chen, Y.B. Photoacclimation of light harvesting systems in eukaryotic algae. In Light Harvesting Antennas in Photosynthesis; Green, B.R., Parson, W.W., Eds.; Springer: Dordrecht, The Netherlands, 2003; Volume 13, pp. 423-447.

76. Lichtenthaler, H.K.; Meier, D.; Buschmann, C. Development of chloroplasts at high and low light quanta fluence rates. Isr. J. Bot. 1984, 33, 185-194. 
77. Pastenes, C.; Horton, P. Effect of high temperature on pho to synthesis in beans. Plant Physiol. 1996, 11, 1253-1260. [CrossRef] [PubMed]

78. Mathur, S.; Jain, L.; Jajoo, A. Photosynthetic efficiency in sun and shade plants. Photosynthetica 2018, 56, 354-365. [CrossRef]

79. Pearcy, R.W.; Osteryoung, K.; Calkin, H.W. Photosynthetic responses to dynamic light environments by Hawaiian trees: Time course of $\mathrm{CO}_{2}$ uptake and carbon gain during sunflecks. Plant Physiol. 1985, 79, 896-902. [CrossRef] [PubMed]

80. Hu, Y.B.; Sun, G.Y.; Wang, X.C. Induction characteristics and response of photosynthetic quantum conversion to changes in irradiance in mulberry plants. J. Plant Physiol. 2007, 164, 959-968. [CrossRef] [PubMed]

81. Hussain, S.; Iqbal, N.; Rahman, T.; Ting, L.; Brestic, M.; Safdar, M.E.; Asghar, M.A.; Farooq, M.U.; Shafiq, I.; Ali, A.; et al. Shade effect on carbohydrates dynamics and stem strength of soybean genotypes. Environ. Exp. Bot. 2019, 162, 374-382. [CrossRef]

82. Hussain, S.; Iqbal, N.; Brestic, M.; Raza, M.A.; Pang, T.; Langham, D.R.; Safdar, M.E.; Ahmed, S.; Wen, B.; Gao, Y.; et al. Changes in morphology, chlorophyll fluorescence performance and Rubisco activity of soybean in response to foliar application of ionic titanium under normal light and shade environment. Sci. Total Environ. 2019, 658, 626-637. [CrossRef]

83. Huang, D.; Wu, L.; Chen, J.R.; Dong, L. Morphological plasticity, photosynthesis and chlorophyll fluorescence of Athyrium pachyphlebium at different shade levels. Photosynthetica 2011, 49, 611-618. [CrossRef]

84. Yao, X.; Li, C.; Li, S.; Zhu, Q.; Zhang, H.; Wang, H.; Yu, C.; Martin, S.K.S.; Xie, F. Effect of shade on leaf photosynthetic capacity, light-intercepting, electron transfer and energy distribution of soybeans. In Plant Growth Regulation; Springer: Berlin/Heidelberg, Germany, 2017; Volume 83, pp. 1-8.

85. Kunderlikova, K.; Brestic, M.; Zivcak, M.; Kusniarova, P. Photosynthetic responses of sun-and shade-grown chlorophyll b deficient mutant of wheat. J. Cent. Eur. Agric. 2016, 17, 950-956. [CrossRef]

86. Valladares, F.; Niinemets, Ü. Shade tolerance, a key plant feature of complex nature and consequences. Annu. Rev. Ecol. Syst. 2008, 39, 237-257. [CrossRef]

87. Portsmuth, A.; Niinemets, U. Structural and physiological plasticity in response to light and nutrients in five temperate deciduous woody species of contrasting shade tolerance. Funct. Ecol. 2007, 21, 61-77. [CrossRef]

88. Valladares, F.; Wright, S.J.; Lasso, E.; Kitajima, K.; Pearcy, R.W. Plastic phenotypic response to light of 16 congeneric shrubs from a Panamanian rainforest. Ecology 2000, 81, 1925-1936. [CrossRef]

89. Aspinwall, M.J.; Loik, M.E.; Resco de Dios, V.; Tjoelker, M.G.; Payton, P.R.; Tissue, D.T. Utilizing intraspecific variation in phenotypic plasticity to bolster agricultural and forest productivity under climate change. Plant Cell Environ. 2015, 38, 1752-1764. [CrossRef]

(C) 2019 by the authors. Licensee MDPI, Basel, Switzerland. This article is an open access article distributed under the terms and conditions of the Creative Commons Attribution (CC BY) license (http://creativecommons.org/licenses/by/4.0/). 

Article

\title{
Interactive Effects of Grafting Techniques and Scion-Rootstocks Combinations on Vegetative Growth, Yield and Quality of Cucumber (Cucumis sativus L.)
}

\author{
Rana Shahzad Noor ${ }^{1,2}$, Zhi Wang ${ }^{1}$, Muhammad Umair ${ }^{2}$, Muhammad Yaseen ${ }^{3}$, \\ Muhammad Ameen ${ }^{4}$, Shoaib-Ur Rehman ${ }^{5}$, Muzammil Usman Khan ${ }^{5}$, Muhammad Imran ${ }^{6}$, \\ Waqar Ahmed ${ }^{7}$ and Yong Sun ${ }^{1, *}$ \\ 1 Department of Agriculture, Biological, Environment and Energy Engineering, College of Engineering, \\ Northeast Agricultural University, Harbin 150030, China; engr.rsnoor@uaar.edu.pk (R.S.N.); \\ wangzhi@neau.edu.cn (Z.W.) \\ 2 Faculty of Agricultural Engineering \& Technology, PMAS-Arid Agriculture University, \\ Rawalpindi 46000, Pakistan; umairkpr@uaar.edu.pk \\ 3 Department of Agricultural Extension, College of Agriculture, University of Sargodha, \\ Sargodha 40100, Pakistan; yaseen.baksh@uos.edu.pk \\ 4 College of Engineering, Nanjing Agricultural University, Nanjing 210031, China; ameenkhan114@yahoo.com \\ 5 Institute of Horticultural Sciences, University of Agriculture, Faisalabad 38040, Pakistan; \\ shoaibhort@gmail.com (S.-U.R.); khancoca0@gmail.com (M.U.K.) \\ 6 Faculty of Water Resources and Hydroelectric Engineering, Xi'an University of Technology, \\ Xi'an 710048, China; 180414001@stu.xaut.edu.cn \\ 7 Key Laboratory of Soybean Biology, Chinese Ministry of Education, Northeast Agricultural University, \\ Harbin 150030, China; khuhrowaqar@gmail.com \\ * Correspondence: sunyong@neau.edu.cn; Tel.: +86-138-36145034
}

Received: 13 April 2019; Accepted: 31 May 2019; Published: 5 June 2019

\begin{abstract}
The density of herbaceous crops creates a suitable environment to produce pathogens in the soil that intensify the attack of pathogens traditionally controlled by disinfectant, which are mostly prohibited and unlisted because of their toxicity. Grafting is an alternative technique to enhance abiotic stress tolerance and reduce root diseases due to soil-borne pathogens, thus enhancing crop production. This research study was conducted during the crop season of 2017 and 2018 in order to investigate the interactive effect of different grafting techniques of hybrid scion onto local rootstocks on plants survival, plant phenological growth, fruit yield and fruit quality under a controlled environment. The hybrid cucumber was also planted self-rooted. The cucumber (Cucumis satious L.) cv. Kalaam $\mathrm{F}_{1}$, Syngenta was grafted onto four local cucurbitaceous rootstocks; ridge gourd (Luffa operculate Cogn.), bitter gourd (Momordica charantia L.), pumpkin (Cucurbita pepo L.), bottle gourd (Lagenaria siceraria (Molina) Standl.) using splice grafting, tongue approach, single cotyledon and hole insertion grafting techniques and self-rooted hybrid cucumber under greenhouse conditions. The experimental results indicated that all local cucurbitaceous rootstocks showed a high compatibility with hybrid cucumber scion in the splice grafting method compared to other grafting and non-grafted methods. Lagenaria siceraria rootstocks were found highly compatible with cucumber cv Kalaam scion which gave significantly maximum plant survival rates (95\%) due to high sap contents, high SPAD value, better vegetative growth and maximum fruit yield when compared with other rootstocks by employing the splice grafting method followed by tongue approach, single cotyledon and hole insertion grafting while the fruit quality of all rootstocks was observed to be similar. The non-grafted cucumber $\mathrm{cv}$. Kalaam $\mathrm{F}_{1}$ showed significant results of plant vegetative growth, fruit development and fruit quality and encountered grafting methods while the lowest result were associated with the hole insertion grafting method in all scion/rootstock combinations. The grafted plants have no significant effect on cucumber fruit dry matter and fruit quality while the
\end{abstract}


fruit mineral compositions ( $\mathrm{N}, \mathrm{P}, \mathrm{K}, \mathrm{Ca}$ and $\mathrm{Mg}$ ) were higher among grafted and non-grafted plant fruits. The results indicate that grafting hybrid cucumber onto four local cucurbitaceous rootstocks influenced growth, yield and fruit quality. Grafting can be alternative and control measure for soil-borne disease and to enhance cucumber production.

Keywords: cucumber; grafting techniques; rootstock-scion; soil-borne disease; resistant; tolerant crop growth; fruit yield; fruit quality

\section{Introduction}

Grafting entails a deliberate combination of parts of different plants of the same species by which vascular continuity is established [1]. The crown of the plant (Scion) adheres to the root part of the plant (rootstock) resulting in composite plant growth and development of a single plant (graft) [2]. The callus related to parenchyma cells develops from the plant tissue of the rootstock and scion around the joint portion to develop vascular connection [3]. Grafting is a horticultural technique applied in the sustainable agricultural practice for the protection of cucurbitaceous crops from soil-borne pathogens, nematodes, soil $\mathrm{pH}$ and salinity. This problem has been globally important since 2005 when the application of methyl bromide was prohibited [4]. The rapid multiplication of soil-borne pathogens and nematodes is due to the intensive use of soil and absence of crop rotation. This affects vegetable growth particularly under greenhouse conditions [5]. It is a big challenge to reduce the impact of soil pathogens for a sustainable agriculture production system [6] and monoculture is more susceptible than a diversified agricultural system [7]. The rootstocks resistant for nematodes are not available; nematodes cause $11 \%$ annual average yield loss [8].

Grafting has become a technique with a high potential to improve the efficiency of modern and intelligent vegetable cultivation, and indicates adoptability and resistance under different stress situations [9]. The grafting of plants is carried out to develop tolerance against temperature variation, salt stress and heavy metal contents in the soil. The grafting scion on appropriate local rootstocks can medicate these issues [10-12]. The structural and biological development of graft between scion and rootstock has been studied and three basic phases have been observed, namely: combining scion and rootstock, callus creation around the joint and establishing continuity at joint through vascular re-differentiation $[1,3,13,14]$. These discussed events determine the success of the scion-rootstock combination, considering the role of plant growth hormones (auxin) in the grafting technique [15]. The graft may grow through the wound healing mechanism and formation of conductive vessels [16]. Therefore, the formation of vascular connection represents the last and most critical stage in wound healing because after healing, the transportation of water and solute start from the rootstock to the scion and the graft union develops a strength $[13,17]$. The time required for the completion of grafting stages is a little unpredictable [17] because an appropriate method for the assessment of development in grafting does not exist [18]. However, the development can be predicted by destructive and non-destructive methods, including the visual determination of graft [19], thermal camera image [19], cutting graft vertically at union to observe vascular system [20], electrical resistance measurement from scion to rootstock [19] asses tensile strength at scion-rootstock union [21,22], disruptive evaluation of hydraulic connection [23] and the nuclear magnetic resonance (NMR) method to show water flux inside vessels [23].

Cucurbitaceous crops are mostly grown during the warm season (greenhouse conditions, $21^{\circ} \mathrm{C}$ to $32{ }^{\circ} \mathrm{C}$ ). The temperature below $16^{\circ} \mathrm{C}$ is not suitable for the germination of cucumber seeds [24]. Cucumber is grown during the warm season when vegetables produce good crops when grown under protection [24]. The above discussed problems severely influence the area and production under greenhouse conditions [25]. The grafting of scion on local rootstocks is the most effective solution to this problem. Cucumber (Cucumis sativus L.) grafted on different cucurbitaceous crop rootstocks are 
Cucurbita maxima Duchesne, C. moschata, C. ficifilia, Lagenaria spp., Luffa spp. [26-28]. The selective method of grafting considerably depends upon crop type, grower decision and experience, as well as facilities availability [29]. Splice grafting [30,31], tongue grafting [32], single cotyledon [4,33] and hole insertion grafting [19,34]. Several studies indicated that the grafting technique showed productive findings such as increase growth, yield and tolerance against stress conditions [35-37]. These plant characteristics majorly linked with genotype of rootstock particularly plant growth and yield effected by rootstock $[37,38]$. The grafting of cucumber crop on different rootstock reduces precocity but the total yield significantly increased as compared with non-grafted plants [39].

The grafting had some undesirable effects such as deterioration in taste, changes in the fruit color, bigger fruit size. The grafting also resulted the increment in fructose content and sweetness of cucumber which indicates the significance of rootstock [40]. The collar size of grafted plants varies depending upon rootstock. Frequently, the diameter of the collar of the grafted plants is higher [39]. The concerning, uncertainties regarding scion-rootstock and environmental instructions. The best selection for rootstock based on production area, rootstock species and scion cultivars used under different conditions [41]. The combination of rootstock and scion must be carefully selected according to the specific calamitic and soil condition [42]. The adequate rootstock-scion combination could help to regulate the soil borne diseases, increase yield and improve fruit quality.

This motivates us to carry out a more detailed study of these significant parameters such as yield, earliness, taste and some fruit sensory characteristics of grafted cucumber plants on different cucurbit rootstocks. This study was carried out to investigate the effect of grafting a hybrid cucumber scion onto four local cucurbitaceous rootstocks by four different grafting technique under greenhouse conditions on plants survival, plant phenological growth, fruit yield and fruit quality in order to establish the most tolerant scion-rootstock combination and favorable method for cucumber grafting. The hybrid scion cucumber $\mathrm{cv}$ Kalaam $\mathrm{F}_{1}$ and four rootstocks, namely ridge gourd (Luffa operculata), bitter gourd (Momordica charantia), pumpkin (Cucurbita pepo), bottle gourd (Lagenaria siceraria) were used as scion-rootstock combinations in order to check the compatibility of tongue grafting, splice grafting, single cotyledon grafting and hole insertion grafting.

\section{Materials and Methods}

This experimental study was conducted during the crop season of 2017 and 2018 at Floriculture Research Station, University of Agriculture, Faisalabad to evaluate the compatibility and suitability of grafting techniques for hybrid cucumber cv. Kalaam $\mathrm{F}_{1}$ scion grafted onto four local cucurbitaceous rootstocks (Pumpkin, Ridge gourd, Bottle Gourd and Bitter gourd) under greenhouse conditions (Temperature $28^{\circ} \mathrm{C}$ and $90 \%$ humidity). Screening and determining the resistant and tolerant rootstock against soil pathogenic characteristics were performed.

\subsection{Grafting Plant Materials}

The hybrid cucumber cv. Kalaam $\mathrm{F}_{1}$ from Syngenta seed company was used as a scion. Four local rootstocks from cucurbitaceous species; ridge gourd (Luffa operculata), bitter gourd (Momordica charantia), pumpkin (Cucurbita pepo), bottle gourd (Lagenaria siceraria) were used as shown in Table 1.

\subsection{Nursery of Scion and Rootstocks}

Cucumber cv Kalaam $\mathrm{F}_{1}$ scion were grafted on four local cucurbitaceous rootstocks by tongue grafting, splice grafting, single cotyledon grafting and hole insertion grafting. Scions were sown in a nursery greenhouse on 25th and 28th of July in 2017 and 2018 in a 200-hole tray and rootstocks were grown in seedling trays with 128 cells $(280 \times 540 \times 40 \mathrm{~mm})$. The seeds of four different rootstocks named as Luffa operculata, Momordica charantia, Cucurbita pepo and Lagenaria siceraria were sown after five days of scion seed sowing. Peat moss and vermiculite ratio 1:1 (v/v) was used as growing media because it sustained better equilibrium of moisture and air which was best for seedlings. $100 \mathrm{~g}$ ammonium sulphate, $150 \mathrm{~g}$ potassium sulphate, $400 \mathrm{~g}$ calcium superphosphate, $50 \mathrm{~mL}$ nutrient solution and $50 \mathrm{~g}$ 
of fungicide were mixed for each $50 \mathrm{~kg}$ of peat moss. The characteristics of the growing media before seed sowing were: $\mathrm{pH}-6.7$, electrical conductivity EC-0.14 mS cm${ }^{-1}, \mathrm{NO}_{3}-15 \mathrm{mg} \mathrm{dm}^{3}, \mathrm{P}-4 \mathrm{mg} \mathrm{dm}$, $\mathrm{K}-31 \mathrm{mg} \mathrm{dm}{ }^{3}, \mathrm{Ca}-28 \mathrm{mg} \mathrm{dm}^{3}, \mathrm{Mg}-17 \mathrm{mg} \mathrm{dm}^{3}$ and total nitrogen $0.25 \%$ [43]. Nitrogen, phosphate and potassium fertilizer were also applied. The seeds were sown under $28{ }^{\circ} \mathrm{C}$ mean temperature and $80 \%$ relative humidity. The 400 scion plants and 400 rootstocks (100 for each rootstock) were prepared and 200 plants (100 scion and 100 rootstocks) were used in each grafting technique. The experimental treatments, their levels and replication were presented in Table 1. The scion-rootstock were shifted into plastic pots of $8 \mathrm{~cm}$ diameter with the same growing media. Before grafting, a laminar flow UV light was used to kill the microbes in the working place [43].

\subsection{Grafting Techniques and Procedure}

The four grafting techniques used were splice grafting, tongue grafting, single cotyledon and hole insertion grafting. The different aged seedlings were grafted under the different grafting methods. Grafting method required selection of seedlings that mainly based on its stem diameter. Each grafting technique was applied on 100 scion and 100 rootstocks ( 25 for each rootstock) with four treatments and five replications.

The scion and rootstock plants were taken out from the seedling tray. The grafting was performed and then the plants were shifted into disposable plastic pots with same growing media and characteristics. In tongue grafting technique (TAG), the plants were 17 and 15 days old ( $4 \mathrm{~mm}$ stem diameter) taken for root-stock and scion gave the best diameter match. The downward and upward slanting cut were made on scion stock and rootstock respectively [32,44,45]. In splice grafting, the 15 day old plants were preferably matched stem diameter that can fits with each other were best fits for that graft union. The rootstock and scion stock were cut slanted at $35^{\circ}-45^{\circ}$ downward and upward respectively [33,34]. The 14 days rootstock and 13 days scion stock fit best for this graft combination in single cotyledon grafting method. The scion was grafted on the stem of rootstock plant [36,37]. The hybrid cucumber scions of 13 days and pumpkin rootstocks of 10 days were best match for grafting. Rootstock was removed just above the false leaf, and the sharpened scion was inserted in it after making a hole between the false leaf interjections with the help of small narrow sterilized wooden sticks [20,38]. The union point was sealed with aluminum wrap and grafting clips. The plastic pots were enveloped with transparent plastic sheet in order to maintain the humidity level around the graft. The plastic sheet was cut from top side after three days in order to allow vertical growth. Grafting plants healing begun after five days and plastic sheet was taken off completely after six days. Plants were supplied water and fertilizer accordingly.

The plants were kept in screen house for eight days after twelve days of grafting. This whole procedure took 30-35 days after transplanting. Transplantation of grafted plants was performed on September 9th and 12th, 2017 and 2018. The grafted plants rows were of $10 \mathrm{~m}$ in length and $1.2 \mathrm{~m}$ in width with $0.5 \mathrm{~m}$ distance between plants. Each single treatment consisted of twenty (20) plants in a row. The plants were transplanted keeping union of graft above the soil surface to prevent the development of roots from graft union that may cause infection and plant wilting. The conventional agricultural practices were adopted during the entire cucumber crop production. The cucumber fruit was harvest after 70 days from grafting ( 35 days after transplanting) and then cucumber fruit was harvested with two days interval. The following parameters were studied during this research study.

\subsection{Studied Characteristics}

The plant and fruit growth characteristics were studied to evaluate the compatibility of different grafting techniques applied on four local cucurbitaceous rootstocks and one hybrid cucumber scion.

\subsubsection{Plant Vegetative Growth}

The plant sustainability after grafting was measured till 30 days after grafting and the measurements were taken for plant vegetative growth 75 days after transplanting. Three plants were randomly 
selected from each treatment. The mean leaf area $\left(\mathrm{cm}^{2}\right)$ was measured through fresh weight method. The collected leaves were cleaned and weighted $0.001 \mathrm{~g}$. The 20 disks with known weight were taken and the area of each disk was $1.0 \mathrm{~cm}^{2}$.

$$
\text { Leaf area }\left(\mathrm{cm}^{2}\right)=\frac{\text { fresh weight of leaf No.10 }}{\text { fresh weight of } 20 \text { diske }} \times 20 \times \text { area of disk }
$$

The other plant vegetative parameter measured number of leaves, plant height $(\mathrm{cm})$, shoot length $(\mathrm{cm})$, stem diameter/thickness $(\mathrm{cm})$, number of plant branches and chlorophyll content/SPAD values were using SPAD-501 (leaf chlorophyll meter) to estimate the leaves pigments or green color of leaves of 5th leaf (fully expanded) from the top of canopy [46]. At flowering stage flowering time (days), fruiting harvesting time (days) and survival rates (\%) were observed. The plant survival rates and mortality were observed after 12 days from the grating by counting the number of plants wilted. The survival rates were recorded till harvesting stage.

\subsubsection{Fruit Growth and Quality Analysis}

The parameters studied for fruit growth and quality were total number of fruits/plants, fruit weight per cucumber $(\mathrm{g})$, fruit shape index, total soluble solids (\%), fruit dry matter $(\%)$, fruit chemical contents, mineral composition and fruit fresh weight $(\mathrm{g})$, length of fruit $(\mathrm{cm})$ \& fruit diameter $(\mathrm{cm})$.

The fruit shape index was a ratio between cucumber fruit length and diameter. Total soluble solids (T.S.S \%) in fruit juice was measured using hand refractometer. Five samples were analyzed from each scion-rootstock combination [47]. Fruit dry matter (\%) was measured through drying $100 \mathrm{~g}$ of fresh fruit weight in an oven at $70{ }^{\circ} \mathrm{C}$ till no further weight reduction condition reached. The contents of ascorbic acid in all grafted and non-grafted fruit were measured by 2,6-dichlorophenol-indophenol method [48]. Bradford G-250 reagent was used to calculate the soluble protein [49] while ninhydrin technique was used to measure total amino acids [50]. Soluble sugar was calculated by anthrone [51]. Fruit mineral composition by the atomic absorption spectrometer (Varian spectra 220) to calculate after dry fruit ashes $\left(550^{\circ} \mathrm{C}\right)$ and mixed in $1 \mathrm{~N} \mathrm{HCl}$. The $\mathrm{N}$ and $\mathrm{P}$ were observed by Kjeldahl technique and vanado-molybdate phosphoric yellow color method. The fruit fresh weight $(\mathrm{g})$, fruit length $(\mathrm{cm})$ and fruit diameter $(\mathrm{cm})$ were measured right after the first day of fruit development to harvesting (day 1-9).

\subsection{Data Processing and Experimental Design}

The experimental data collected were than analyzed statistically using one-way analysis of variance (ANOVA) to evaluate the level of significance. Tukey HSD at $5 \%$ level of significance was applied to check the significant difference between values of studied parameter. The complete statistical analysis was performed using Minitab 17 statistical software (Minitab Pty Ltd., Sydney, Australia).

Table 1. Treatments, their level and replication for different grafting techniques.

\begin{tabular}{ccc}
\hline Grafting Technique & Cucurbitaceous Crop & Treatment Description (Scion-Rootstock) \\
\hline & & $\mathrm{T}_{1}=$ Cucumber-Ridge gourd \\
& & $\mathrm{T}_{2}=$ Cucumber-Bitter gourd \\
$\mathrm{G}_{1}=$ Tongue grafting & Scion; & $\mathrm{T}_{3}=$ Cucumber-Pumpkin \\
$\mathrm{G}_{2}=$ Splice grafting & Cucumber cv. Kalaam $\mathrm{F}_{1}$ & $\mathrm{~T}_{4}=$ Cucumber-Bottle gourd \\
$\mathrm{G}_{3}=$ Single cotyledon grafting & Rootstock; & $\mathrm{T}_{\mathrm{C}}=\mathrm{Kalam} \mathrm{F}_{1}$ (real rooted) \\
$\mathrm{G}_{4}=$ Hole insertion & Ridge gourd (Luffa operculata) & $\mathrm{R}_{1}$ \\
Grafting & Bitter gourd (Momordica charantia) & $\mathrm{R}_{2}$ \\
$\mathrm{G}_{\mathrm{n}}=$ Non-grafted & Pumpkin (Cucurbita pepo) & $\mathrm{R}_{3}$ \\
& Bottle gourd (Lagenaria siceraria) & $\mathrm{R}_{4}$ \\
& & $\mathrm{R}_{5}$ \\
& & \\
\end{tabular}




\section{Results and Discussion}

\subsection{Plant Vegetative Growth}

The results of vegetative growth and survival rate of cucumber (Cucumis sativus) plants grafted on different cucurbitaceous rootstocks were observed after 15 and 30 days of grafting in two crop season 2017 and 2018. The leaf area, number of leaves and SPAD values after the first 15 days of grafting, during both crop seasons of 2017 and 2018, were observed in all combination of cucumber $\left(\right.$ Kalaam $\mathrm{F}_{1}$ ) scion and four local rootstocks; ridge gourd, bitter gourd, pumpkin and bottle gourd were presented in Figure 1. The mean leaf area $\left(\mathrm{cm}^{2}\right)$ of cucumber $\mathrm{cv}$. Kalaam $\mathrm{F}_{1}$ was found significantly maximum during both crop seasons 2017 and 2018 when grafted onto bottle gourd rootstock followed by ridge gourd, bitter gourd and pumpkin rootstock with the splice grafting $(36.10,37.65)$, single cotyledon grafting $(32.40,33.23)$, tongue grafting $(28.23,29.98)$ and hole insertion grafting $(25.80,26.13)$ respectively. The leaf area $(21.43,22.70)$ was found non-significant in non-grafting cucumber $\mathrm{cv}$. Kalaam $F_{1}$. The results observed in both seasons didn't show any significant difference. The plants with bottle gourd rootstocks showed significantly maximum five plant leaves in tongue grafting, splice grafting and single cotyledon grafting during both crop seasons. The real rooted plants produced four plant leaves while the lowest figures were associated with pumpkin rootstock. Figure 1 illustrates that the SPAD values (chlorophyll content) were found significantly different in all grafting techniques and non-grafted plants during the vegetative growth stage. The splice grafting technique gave optimum results of chlorophyll content than other grafting methods. The significantly different SPAD values $(49.31,46.6)$ were found in cucumber $c v$. Kalaam $F_{1}$ grafted onto bottle gourd with splice grafting during 2017 and 2018 crop season respectively. The SPAD values in plant leaf of real rooted Kalaam $\mathrm{F}_{1}$ and pumpkin rootstock in hole insertion grafting method were statistically non-significant.

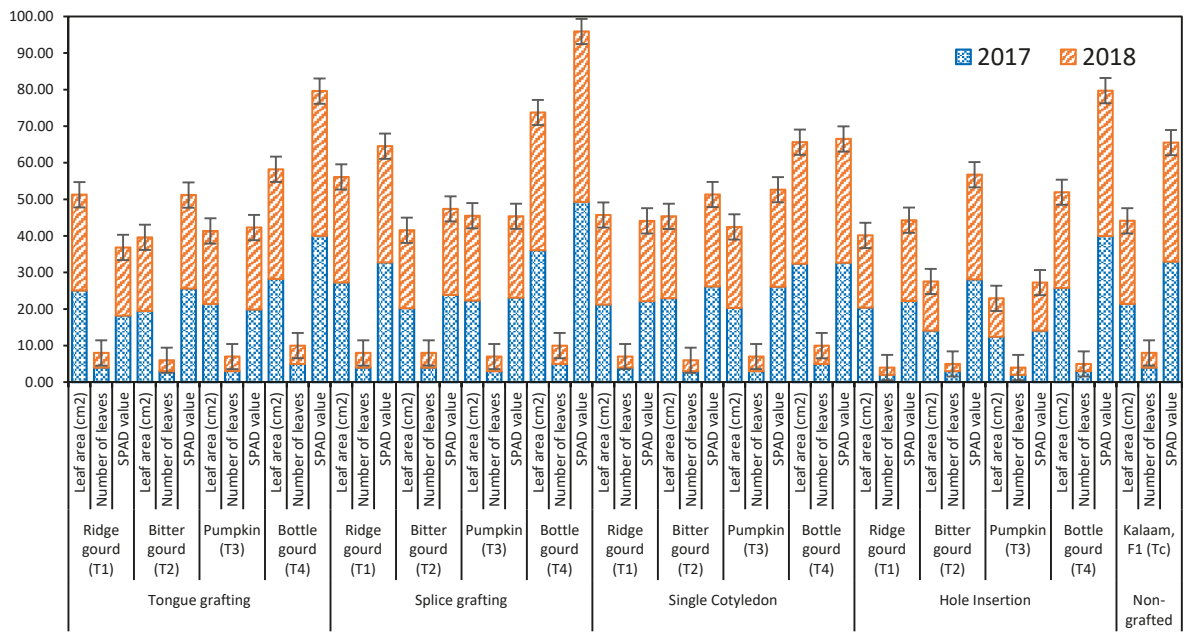

Figure 1. Evaluating the effect of Scion/rootstocks combinations (grafting) on vegetative growth of Cucumber fruit after 15 days during crop season 2017 and 2018.

After 30 days, the bottle gourd rootstock in splice grafting showed significantly higher mean leaf area $\left(82.40,85.28 \mathrm{~cm}^{2}\right)$, number of leaves $(8,8)$ and SPAD contents $(49.31,56.22)$ during both crop season 2017 and 2018 respectively as shown in Figure 2 . The real rooted cucumber didn't show significant difference of leaf area $\left(40.95,44.65 \mathrm{~cm}^{2}\right)$, number of leaves $(7,7)$ and SPAD value $(39.98,42.8)$ during crop season of 2017 and 2018 while the rootstocks in hole insertion grafting showed non-significant results. 
It could be found that the SPAD values and chlorophyll content have a strong correlation [42] and the combinations of scion/rootstocks had significantly affected the vegetative growth of cucumber [52].

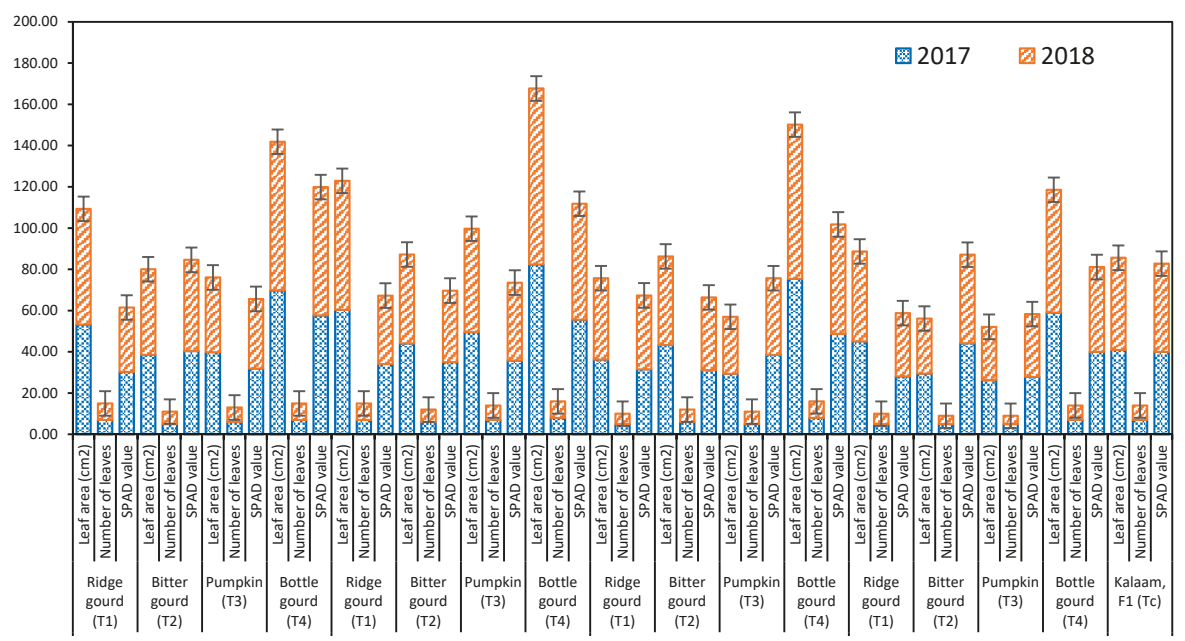

Figure 2. Evaluating the effect of Scion/rootstocks combinations (grafting) on vegetative growth of Cucumber fruit after 30 days during crop season 2017 and 2018.

Table 2 indicates plant mortality and the percentage of plant survival in the real rooted and grafted treatment of hybrid cucumber cv. Kalaam $\mathrm{F}_{1}$ grafted on four local cucurbitaceous rootstocks (ridge gourd, bitter gourd, pumpkin and bottle gourd) with different grafting techniques during the 2017 and 2018 crop growing seasons. The statistical analysis presented in Table 2 shows that pumpkin rootstock in the hole insertion grafting method had a lower plant survival (42.00 \pm 0.81 and $44.00 \pm 1.29)$ in the 2017 and 2018 seasons respectively. These results showed unsuitability of hybrid Kalam $\mathrm{F}_{1}$ with local rootstock. The significantly maximum plant survival rate of $(96.00 \pm 2.77)$ was obtained when grafted plants onto bottle gourd $\left(\mathrm{T}_{4}\right)$ in splice grafting during the first crop season, while in the second crop season bottle gourd $\left(T_{4}\right)$ and ridge gourd $\left(T_{1}\right)$ showed the same $(95.00 \pm 0.55)$ survival rates of grafted plants. Ridge gourd $\left(\mathrm{T}_{1}\right)$ and bitter gourd $\left(\mathrm{T}_{2}\right)$ in tongue grafting $\left(\mathrm{G}_{1}\right)$ and real rooted Kalaam, $\mathrm{F}_{1}\left(\mathrm{~T}_{\mathrm{c}}\right)$ didn't show any significant difference during first growing season while, in second crop season ridge gourd $\left(\mathrm{T}_{1}\right)$ and bottle gourd $\left(\mathrm{T}_{4}\right)$ in tongue grafting $\left(\mathrm{G}_{1}\right)$ and non-grafted Kalaam, $\mathrm{F}_{1}\left(\mathrm{~T}_{\mathrm{c}}\right)$ didn't show any significant difference in cucumber plants survival. The rootstocks under single cotyledon grafting method show significantly different results for plants survival. These results agreed with [53] who reported that the survival rate of cucumber plants increased under different grafting techniques.

The shoot length, plant height and stem diameter of cucumber (Cucumis sativus) plants grafted onto four local cucurbitaceous rootstocks with different grafting methods were presented in Figure 3. The bottle gourd rootstock had significant shoot length $(\mathrm{cm})$ in tongue grafting $(13.50,13.30)$, splice grafting $(12.20,12.10)$ and single cotyledon grafting $(11.34,11.28)$ after first 15 days of grafting during 2017 and 2018 respectively while the hole insertion grafting showed non-significant results $(4.15,4.1)$ onto ridge gourd. The real rooted plant has $(9.0,9.20)$ shoot lengths. The plants with bottle gourd rootstock developed a significantly thick plant stem $(0.19,0.18 \mathrm{~cm})$ in splice grafting and didn't show any significant difference of stem diameter during season 2017 and 2018 respectively. The real rooted hybrid cucumber had $(0.15$ and $0.16 \mathrm{~cm})$ stem diameter after first 15 days of 2017 and 2018 seasons. In tongue grafting and single cotyledon grafting, the bottle gourd showed significant plant height $(15.34,15.50 \mathrm{~cm}),(16.10,15.73 \mathrm{~cm})$ while the pumpkin rootstock in hole insertion grafting had non-significant $(6.55,6.49 \mathrm{~cm})$ plant height during 2017 and 2018 respectively. 


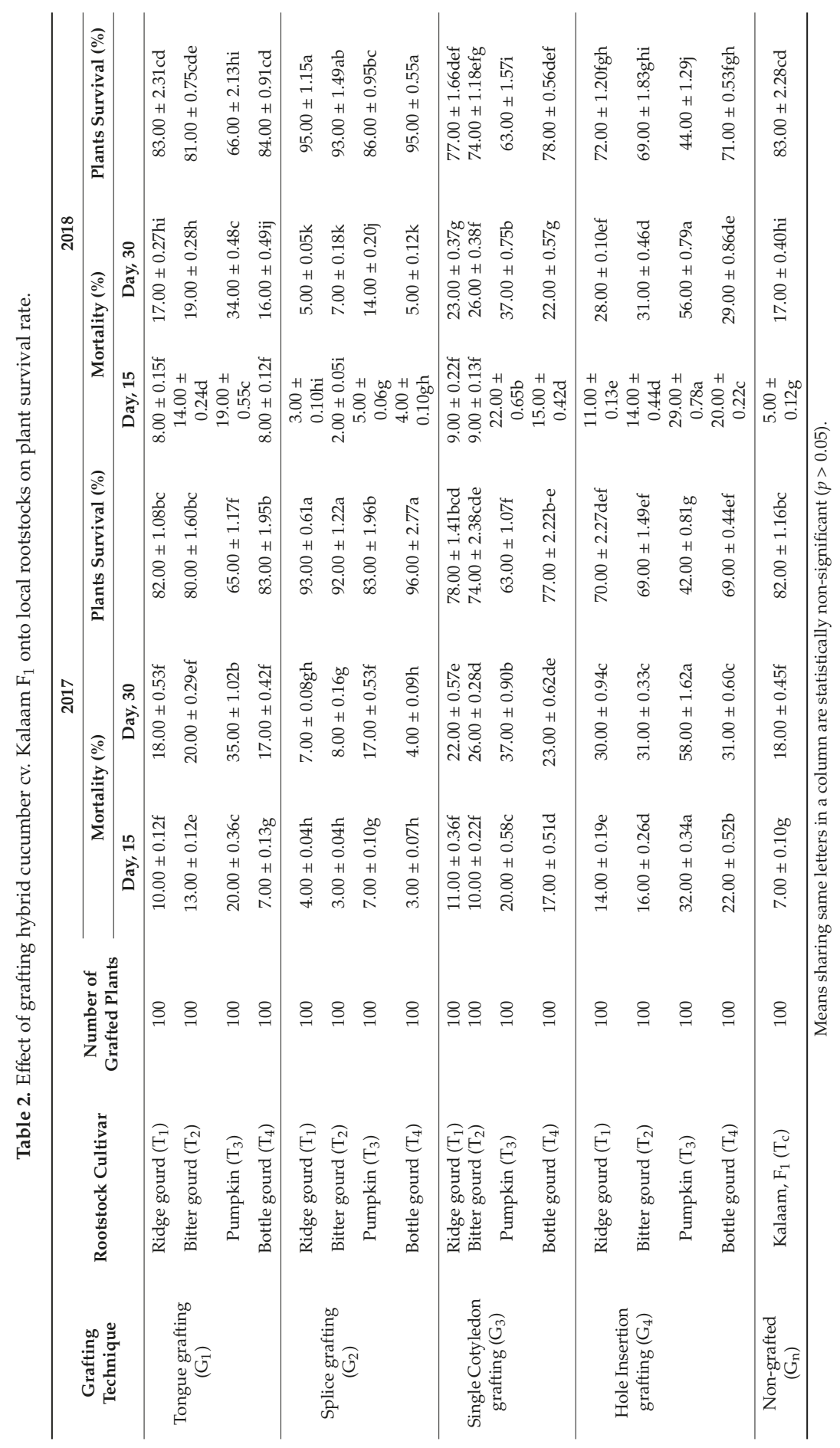




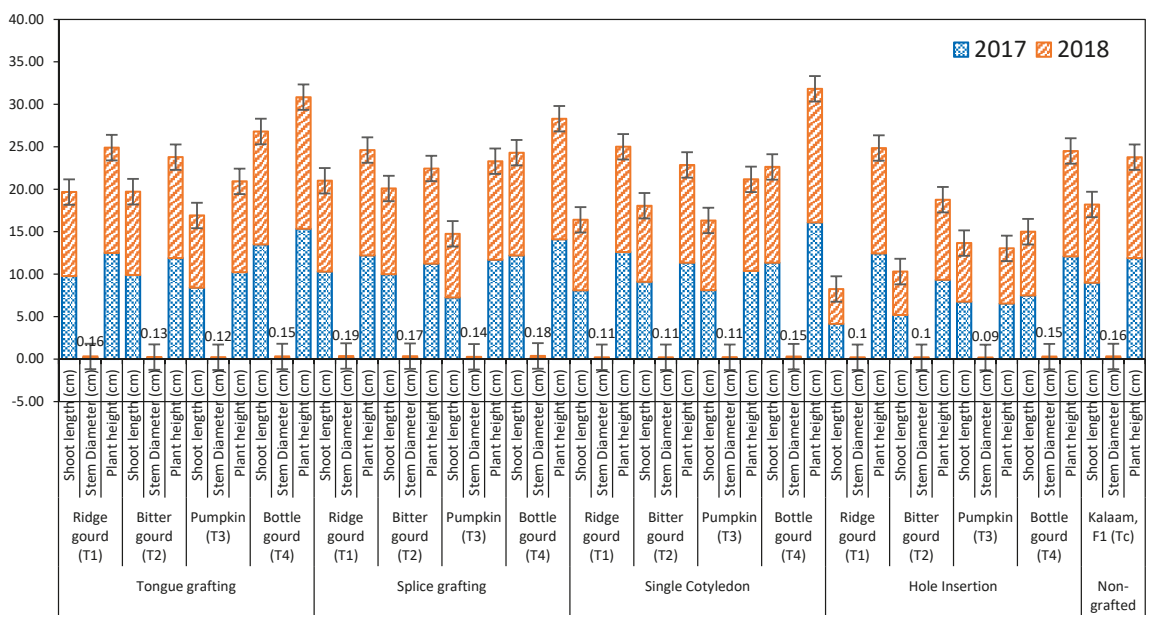

Figure 3. Effect of Scion/rootstocks combinations (grafting) on vegetative growth parameters of Cucumber fruit after 15 days during crop season 2017 and 2018.

Figure 4 presents shoot length, plant height and stem diameter of grafted cucumber (Cucumis sativus) plants onto cucurbitaceous rootstocks during the crop seasons of 2017 and 2018. After 30 days of grafting, The bottle gourd and ridge gourd rootstocks in splice grafting showed significant shoot length $(21.90,21.80 \mathrm{~cm})$ and $(20.98,21.10 \mathrm{~cm})$ while the hole insertion grafting showed non-significant results $(9.10,8.67 \mathrm{~cm})$ onto pumpkin rootstock after 30 days of grafting during 2017 and 2018 respectively. The non-grafted plants didn't show any significant difference. The plants with bottle gourd rootstock developed significantly thick plant stems $(0.37,0.38 \mathrm{~cm})$ in splice grafting. The bottle gourd in tongue grafting, ridge gourd and bitter gourd in splice grafting, bottle gourd in single cotyledon grafting and real rooted plants didn't show any significant difference of stem diameter during the seasons 2017 and 2018. The pumpkin rootstock in hole insertion grafting had $(0.15$ and $0.16 \mathrm{~cm}$ ) non-significant stem diameter after 30 days of grafting during both 2017 and 2018 crop seasons. In splice grafting and single cotyledon grafting, the bottle gourd showed significant plant height $(24.65,24.50 \mathrm{~cm}),(24.0,23.63 \mathrm{~cm})$. The bottle gourd rootstock in tongue grafting, ridge gourd in splice grafting, bottle gourd in single cotyledon and real rooted plants didn't show any significant change of plant height while the rest of the rootstocks showed non-significant plant height during 2017 and 2018 respectively.

The data in Table 3 indicate that the scion/rootstock combinations (grafting) promoted cucumber plant growth and significantly increased the vigor of grafts plants compared to real rooted hybrid cucumber during both 2017 and 2018 crop periods. That was shown in plant height $(\mathrm{cm})$, number of plant branches \& leaves, stem thickness/diameter $(\mathrm{cm})$, flowering time (days) and first fruit harvesting time (days). Grafting cucumber cv. Kalaam $\mathrm{F}_{1}$ on cucurbitaceous rootstock (Bottle gourd) produced significantly maximum plant height, stem diameter and No. of leaves \& nodes than rootstocks (Ridge gourd, Bitter gourd and Pumpkin). The sequence found between the grafting techniques was splice grafting, tongue grafting, single cotyledon grafting and hole insertion grafting. The splice grafting showed significantly maximum plant heights $(622.0 \pm 4.06$ and $619.0 \pm 4.58 \mathrm{~cm})$, number of leaves $(194.0 \pm 6.32$ and $183.0 \pm 4.62)$, number of branches (13.00 \pm 0.40 and $13.00 \pm 0.58)$ and stem diameter $(1.13 \pm 0.03$ and $1.10 \pm 0.03 \mathrm{~cm})$ for Lagenaria siceraria (bottle gourd) during crop season 2017 and 2018 respectively while, the lowest values were associated with pumpkin rootstock. Ridge gourd $\left(\mathrm{T}_{1}\right)$ and bitter gourd $\left(T_{2}\right)$ in tongue grafting $\left(G_{1}\right)$ \& single Cotyledon grafting $\left(G_{3}\right)$, ridge gourd $\left(T_{1}\right)$ and bottle gourd $\left(T_{4}\right)$ in hole insertion grafting $\left(G_{4}\right)$ and real rooted Kalaam, $F 1\left(T_{C}\right)$ didn't show any significant difference in plant height during first season while, in the second season most of the rootstocks didn't 
show any significant difference. Bitter gourd $\left(T_{2}\right)$ pumpkin $\left(T_{3}\right)$ bottle gourd $\left(T_{4}\right)$ in hole Insertion grafting $\left(\mathrm{G}_{4}\right)$ showed maximum time for flowering during both 2017 and 2018 crop seasons respectively. Fruit harvesting time didn't show any significant difference for all grafting technique under both crop seasons. This could be interpreted that cultivation of grafted cucumber produced better plant vegetative growth compared with non-grafted plants in infested soil with nematode and soil salinity. The results are in line with [54] who described that vegetative growth (plant height, branches and leaves) was significantly higher in grafting than that of non-grafting. Hormone synthesis controlled by plant root could lead the plant growth and root to shoot ratios [55]. Zhang [56] stated that the vegetative growth (plant height, leaves, branches, leaf area and stem diameter), photosynthesis rate, yield, wilt resistance and root-knot nematode immunity were higher in scion/rootstock combination plants. The statistical analysis presented in Table 3 indicate the earliness of first female flower on grafted plants.

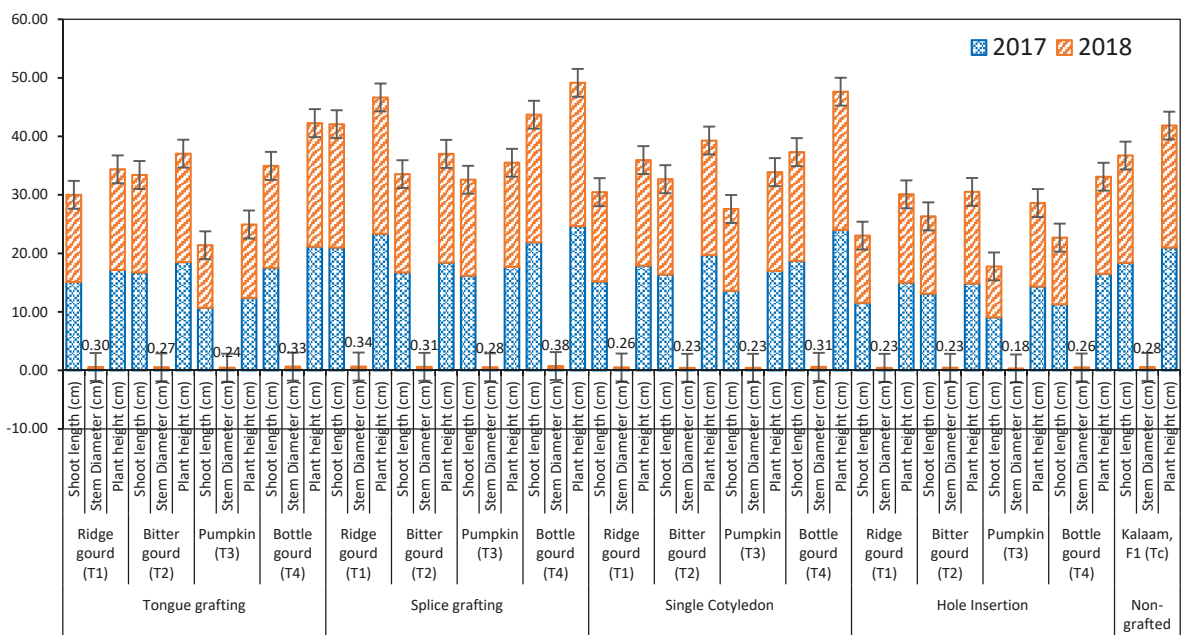

Figure 4. Effect of Scion/rootstocks combinations (grafting) on vegetative growth parameters of Cucumber fruit after 30 days during crop season 2017 and 2018.

The Lagenaria siceraria, Luffa operculata and Momordica charantia started flowering at 33rd day while pumpkin started on 34th day in splice grafting technique as shown in Table 3. The significantly different 62 days were taken by the plants for flowering in hole insertion grafting method. The non-grafted cucumber cv. Kalaam $\mathrm{F}_{1}$ showed flowers after 60 days. Therefore, splice grafted plants showed early and high vigor compared with other grafts and non-grafted plants. The first fruit harvested after 12 days of flowering. The harvesting was carried out at the same time from all kind of grafted plants.

Ozarslandan [57] observed that all genotypes of Lagenaria siceraria (Bottle gourd) were liable to root-knot nematodes. The grafting of scion (Watermelon) onto rootstock (Bottle gourd) gave higher plant growth and fruit yield as compared to non-grafted fruit root-knot nematodes carry soil. It was concluded that bottle gourd rootstock tolerated nematodes with their rapid growth. In this study, splice grafted plants using all scion/rootstock combinations had significantly higher vegetative growth and fruit yield. According to our results, Lee [5] and Ioannou [58] observed that growth of scion/rootstocks were better than that of real rooted plants.

Cansev and Ozgur [42] described that, generally the growth and yield reduced significantly in real rooted (non-grafted) plants as compared with grafting techniques used for scion/rootstock combinations. The results suggested grafting of cucurbitaceous plants avoid yield reduction due to intensive cropping and soil borne disease. Cucumber grafting onto resistant rootstock was recommended technique in soil with high root-knot nematodes infestation and to produce more fruit yield from grafted plants [59]. 


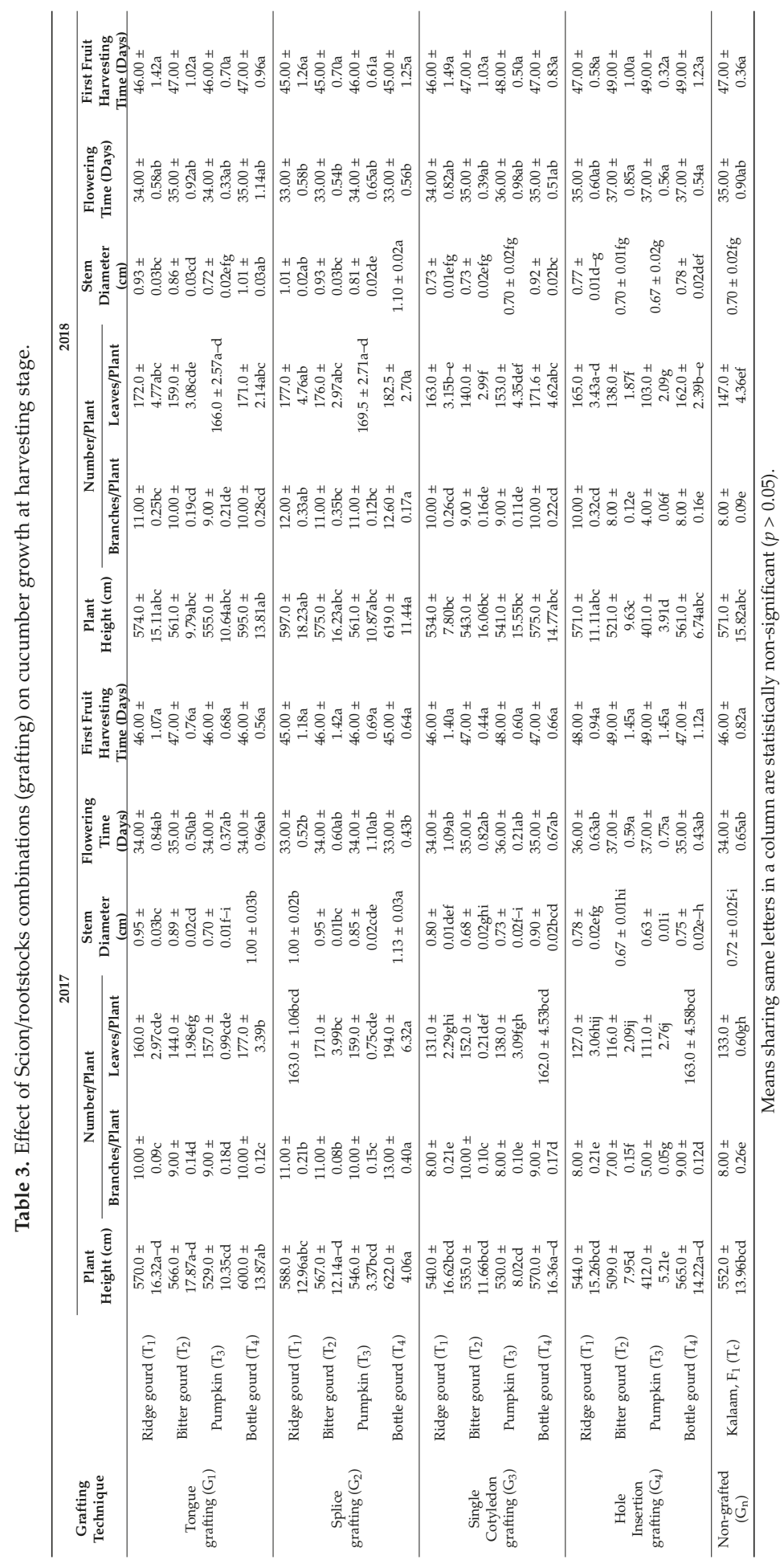


The maximum early yield was produced by grafted plants rather than non-grafted plants [60]. Walters and Wehner [61] declared that root-knot nematodes were a major reason of cucumber yield reduction. Zhang [56] observed that grafted cucumber plants onto resistant rootstocks showed earlier flowering and first harvesting time than those of other rootstock and non-grafted plants.

Chen [62] reported that grafted cucumber onto local and resistant rootstocks had higher yields, better quality and a good control on soil pathogenic characteristics. The yield was significantly reduced cucumber fruit yield grown in non-treated soil compared to treated soil [46].

The damage of root-knot nematodes was highest in warm areas which resulted wilting plants under moisture stress [60]. These results agreed with Miguel and Maroto [63], they reported maximum yield in hybrid watermelon grafting and nematodes infested soil than self-rooted planed in fumigated (nematicide) soils. The local and resistant rootstock had enhanced the plant growth, flowering and yield of cucumber fruit [59]. The use of resistant cucurbitaceous rootstocks could increase the cucumber plant growth and fruit yield while the fruit quality was not different [64]. The grafted plants have no significant effect on fruit dry matter but improved nutritional concentration [65].

\subsection{Fruit Growth and Quality}

The effect of four different Scion/rootstocks combinations (grafting) on cucumber fruit, fruit fresh weight, fruit shape index, TSS and fruit dry matter was presented in Table 4 . The splice grafting showed significantly maximum number of fruit per plant (14.60 \pm 0.20 and $15.60 \pm 0.38)$, Fruit weight/cucumber (122.50 \pm 2.42 and $121.29 \pm 3.05 \mathrm{~g})$, Fruit shape index (7.88 \pm 0.22 and $7.84 \pm 0.10)$, TSS (5.20 \pm 0.11 and $5.11 \pm 0.15 \%)$ and Fruit dry matter (4.62 \pm 0.11 and $4.50 \pm 0.12 \%$ ) for Lagenaria siceraria (bottle gourd) during crop season 2017 and 2018 respectively while, the lowest values were associated with pumpkin rootstock. Ridge gourd $\left(T_{1}\right)$ and bottle gourd $\left(T_{4}\right)$ in tongue grafting $\left(G_{1}\right)$, single Cotyledon grafting $\left(G_{3}\right)$ and hole Insertion grafting $\left(G_{4}\right)$ while ridge gourd $\left(T_{1}\right)$ and bitter gourd $\left(T_{2}\right)$ in splice grafting $\left(G_{2}\right)$ didn't show any significant difference in number of fruits/plants. The real rooted cucumber showed significant different $(10.30 \pm 0.23)$ number of fruits per plant during both seasons. This could be concluded that grafting hybrid cucumber onto local rootstocks gave significant increment in fruit length and diameter (fruit shape index) which results in more fruit yield. These results agreed with Al-Debei [43] who observed that when grafted cucumber cultivar on cucurbitaceous rootstock resulted in more vigorous cucumber plants. Ridge gourd $\left(T_{1}\right)$, bitter gourd $\left(T_{2}\right)$ and pumpkin $\left(T_{3}\right)$ in tongue grafting $\left(G_{1}\right)$, pumpkin $\left(T_{3}\right)$ in splice grafting $\left(G_{2}\right)$, ridge gourd $\left(T_{1}\right)$, bottle gourd $\left(T_{4}\right)$ in single cotyledon grafting $\left(\mathrm{G}_{3}\right)$, bitter gourd $\left(\mathrm{T}_{2}\right)$ in hole insertion grafting $\left(\mathrm{G}_{4}\right)$ and Kalaam, $\mathrm{F} 1\left(\mathrm{~T}_{\mathrm{c}}\right)$ in non-grafting $\left(G_{n}\right)$ didn't show any significant difference in fruit weight during first season while in second season bottle gourd $\left(\mathrm{T}_{4}\right)$ in all grafting techniques showed significantly different results. The Kalaam, $\mathrm{F}_{1}\left(\mathrm{~T}_{\mathrm{c}}\right)$ also showed significant results for fruit weight. 


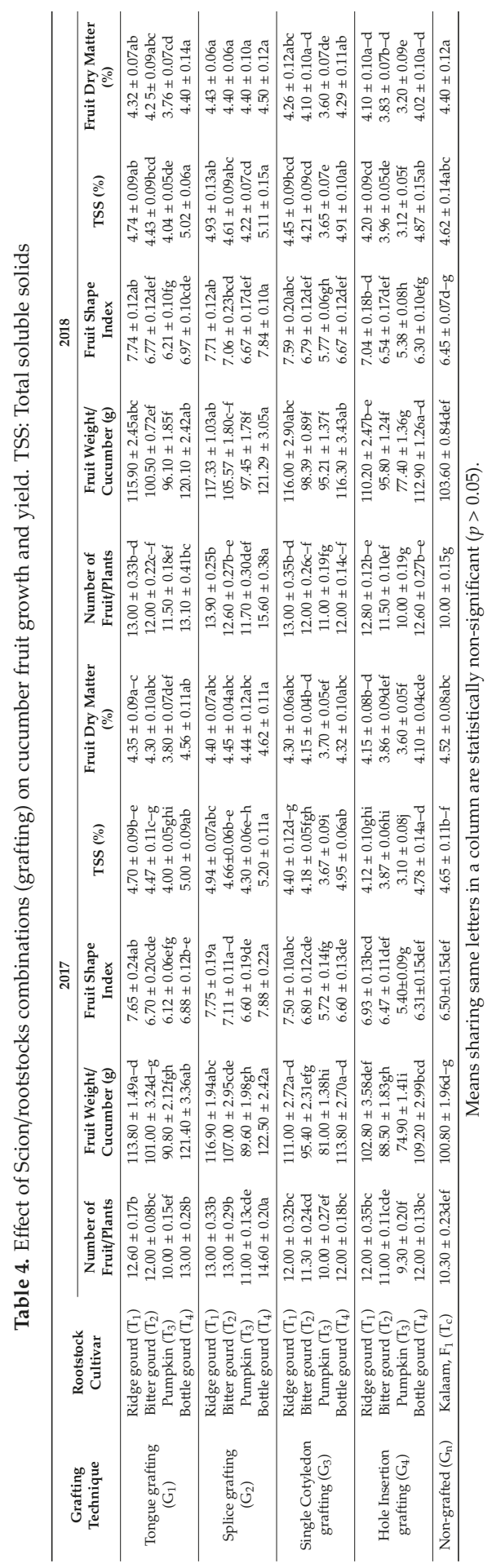


The results of fruit dry matter obtained from ridge gourd $\left(T_{1}\right)$, bitter gourd $\left(T_{2}\right)$ and pumpkin $\left(T_{3}\right)$ in tongue grafting $\left(G_{1}\right)$ and splice grafting $\left(G_{2}\right)$, ridge gourd $\left(T_{1}\right)$ and bottle gourd $\left(T_{4}\right)$ in single cotyledon grafting $\left(\mathrm{G}_{3}\right)$, bitter gourd $\left(\mathrm{T}_{2}\right)$ in hole insertion grafting $\left(\mathrm{G}_{4}\right)$ and real rooted Kalaam, F1 $\left(\mathrm{T}_{\mathrm{c}}\right)$ during first crop season 2017 were not statistically different. During second season, all rootstocks in splice grafting and real rooted Kalaam, $F_{1}$ didn't show any significant difference. These results are in line with Yetistir and Sari [66] who reported that grafted cucumber fruit with higher fruit fresh weight and dry matter had more nutritional concentration compared with low fresh weight cucumber fruit. Grafting of cucumber scion onto bottle gourd rootstock can enhance the reduction of cucumber fruit dry matter [67]. Ridge gourd $\left(T_{1}\right)$ in tongue grafting $\left(G_{1}\right)$, bitter gourd $\left(T_{2}\right)$ in splice grafting $\left(G_{2}\right)$ didn't show any significant difference. Bottle gourd $\left(T_{4}\right)$ in tongue grafting $\left(G_{1}\right)$ and single cotyledon grafting $\left(G_{3}\right)$ similarly pumpkin $\left(T_{3}\right)$ in tongue grafting $\left(G_{1}\right)$ and ridge gourd $\left(T_{1}\right)$ in hole insertion grafting $\left(\mathrm{G}_{4}\right)$ didn't show any significant difference for TSS in fruit juice during first crop season while in the second season, ridge gourd $\left(T_{1}\right)$ in tongue grafting $\left(G_{1}\right)$ and splice grafting $\left(G_{2}\right)$ and bottle gourd $\left(\mathrm{T}_{4}\right)$ in single cotyledon grafting $\left(\mathrm{G}_{3}\right)$ and hole insertion grafting $\left(\mathrm{G}_{4}\right)$ didn't show any significant TSS contents but real rooted plants showed statistically significant TSS [54]. During first crop season bottle gourd $\left(T_{4}\right)$ and ridge gourd $\left(T_{1}\right)$ in splice grafting $\left(G_{2}\right)$ didn't show any significant difference. The real rooted plants showed statistically different results in season 2018 but not in 2017.

Plant hormones regulate plant vegetative growth and reproductive development and are responsible for built root-shoot communication [68]. Plant with healthy rootstock produce more cytokinins into rising xylem sap which enhanced fruit yield [68]. The grafting changed hormones production and their impact on grafted plants. Flowering are controlled by plant hormones. It could be concluded that grafting increased the fruit yield since grafted plants have strong root system which improved disease immunity and photosynthesis. The plant growth of grafted cucumber and the resemblance of protective isozymes between grafted and non-grafted plants had a positive correlation [69].

The Table 5 indicated the effect of scion (cucumber $\mathrm{cv}$. Kalaam $\mathrm{F}_{1}$ ) grafted onto four local rootstocks (ridge gourd, bitter gourd, pumpkin and bottle gourd) with different grafting techniques on quality of cucumber fruit. The fruit quality was evaluated at 3,6 and 9 days after pollination. It is clear from the Table that the contents of ascorbic acid in fruit decreased significantly with the fruit growth. The ascorbic acid, soluble protein and free amino acid decreased with periodically while soluble sugar content increased. The contents of ascorbic acid in cucumber $\mathrm{cv}$. Kalaam $\mathrm{F}_{1}$ fruit were higher initial days and then decrease gradually. Bottle gourd gave statistically significant results while the pumpkin showed lowest values. The ridge gourd, bitter gourd and real rooted plants didn't show any significant difference during both seasons. The cucumber cv. Kalaam $\mathrm{F}_{1}$ fruit grafted onto bottle gourd had statistically significant soluble protein content during first and second seasons while pumpkin rootstock showed least values. The statistical difference was not found in other rootstocks. Free amino acid and soluble sugar didn't show any significant difference in all rootstocks during both seasons. 


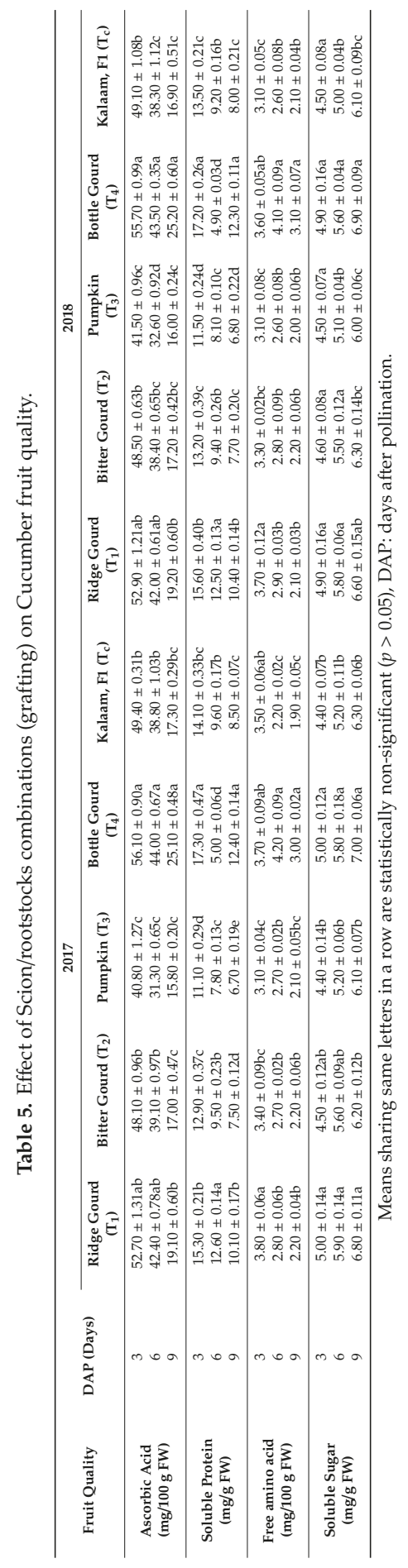


The Table 6 indicated the mineral composition of scion/rootstock combinations (grafts) and non-grafted cucumber cv. Kalaam $\mathrm{F}_{1}$. Fruit N, P, K, Ca and Mg of hybrid cucumber grafted onto bottle gourd were significantly more among other rootstock and self-rooted cucumber fruits. The lowest values were associated with pumpkin rootstock. Scion/rootstock enhanced mineral circulation in plants. The contents of Potassium $(\mathrm{K})$ and magnesium $(\mathrm{Mg})$ in grafted fruits were statistically significant as compared to non-grafted fruits which was based on vigorous rootstock development responsible for absorbing water and nutrients effectively than other real roots [5]. The bottle gourd rootstock showed significantly maximum N, P, K, Ca and Mg contents during both crop seasons. Bitter gourd $\left(\mathrm{T}_{2}\right)$ and Kalaam, $\mathrm{F}_{1}\left(\mathrm{~T}_{\mathrm{c}}\right)$ didn't show any significantly difference during first season while, during second season all rootstocks had statistically different nitrogen contents. Ridge and bottle gourd didn't show any significant difference of phosphorus content during 2017 while results were statistically different for all rootstock in second season. Statistically no different results of $\mathrm{K}$, Ca and $\mathrm{Mg}$ were found between both seasons. Although the scion/rootstock combinations determine fruit quality and nutritional contents, there was a significant influence of grafting found on fruit quality as compared to the original rooted plants. Therefore, the cucumber cv. Kalaam F1 grafted on four local root stocks (ridge gourd, bitter gourd, pumpkin and bottle gourd) have an improved mineral composition that can be used for commercial production.

Salehi-Muhammadi [70] described how the impact of rootstock on mineral composition depended upon the development of root genotypes which improved water and mineral transfer. The low performance of other rootstocks and non-grafted plants compared to the bottle gourd rootstock were justified by unsuitable grafting, which can cause improper scion growth or depression and mineral transfer from the union of grafting [42,71,72]. Several studies have been conducted to explain that effect in scion due to grafting techniques and the transport of genes from the local root system and hybrid scion through vascular bundles [73-75]. The rate of mineral transfer was higher in bottle gourd than other grafted and non-grafted plants, and tolerated a high crop load [76].

The fresh weight, length and diameter of cucumber fruit grafted on different cucurbitaceous rootstocks were presented in Figure 5. The observation carried out at the time of harvesting didn't show any significant difference in fruit weight, fruit length and fruit diameter during both crop seasons 2017 and 2018. The splice grafting of cucurbitaceous rootstock with hybrid cucumber fruit showed significantly maximum physical properties of cucumber fruit. The splice grafting showed significant fresh fruit weight $(\mathrm{g})$ in bottle gourd $(280.50 \pm 3.39$ and $277.00 \pm 5.32)$, ridge gourd (252.00 \pm 4.29 and $265.00 \pm 7.31)$, bitter gourd $(243.00 \pm 3.34$ and $252.00 \pm 5.33)$ and pumpkin $(227.00 \pm 5.43$ and $234.00 \pm 1.68)$. All rootstocks showed significantly different fruit fresh weight during 2017 and 2018. The fruit length of cucumber showed statistically different results. Ridge gourd in tongue grafting and single cotyledon grafting while bitter gourd and pumpkin and ridge gourd and bottle gourd in splice grafting didn't show significant difference during first season but in second season the complete results obtained were statistically different. The fruit diameter was not statistically different during the first season but in the second season the results of fruit diameter were statistically different. 


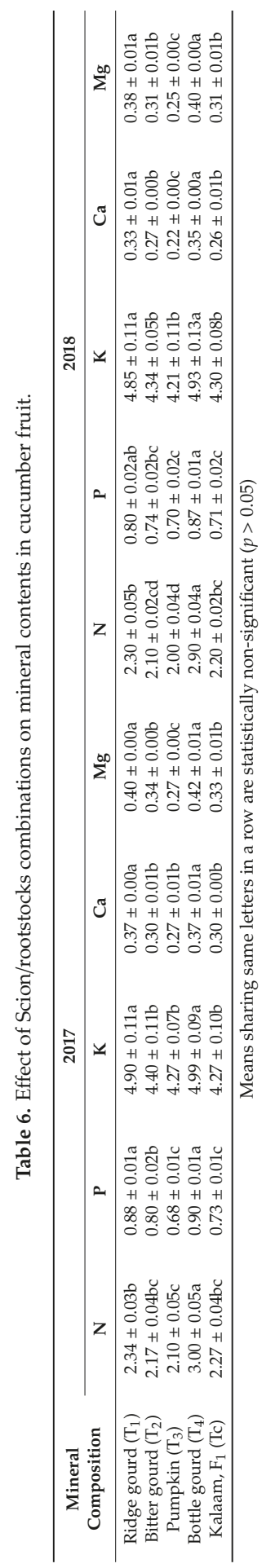




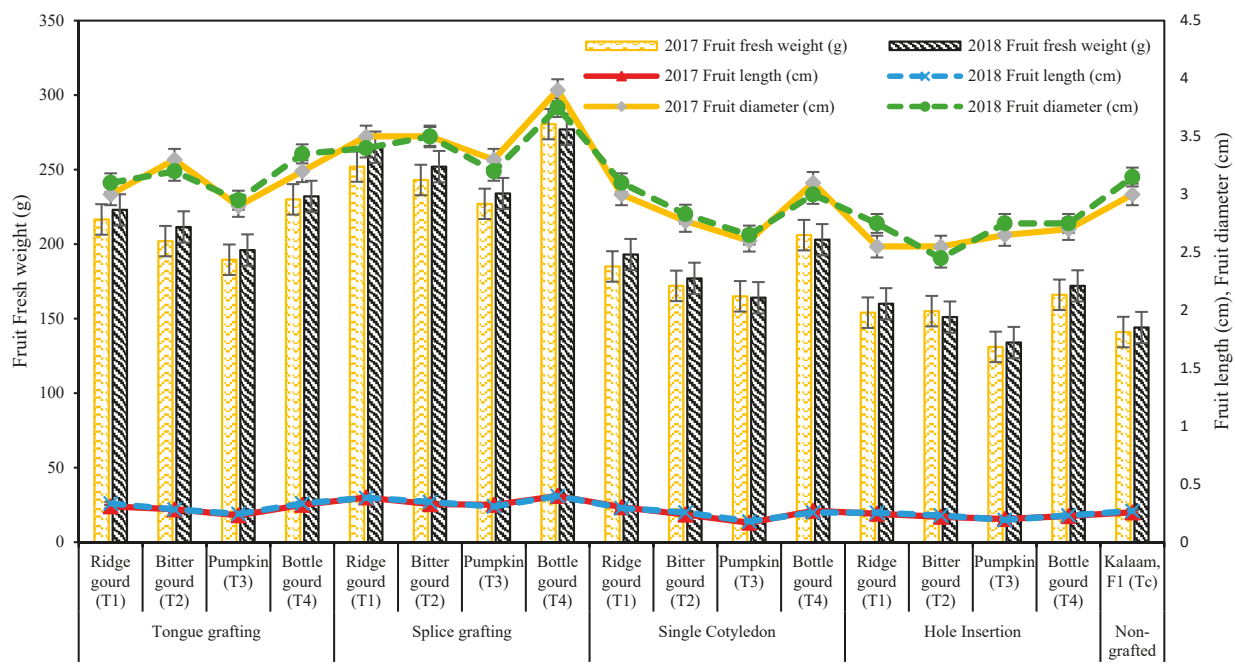

Figure 5. Effect of scion/rootstocks combinations (grafting) on physical properties of Cucumber fruit.

The effect of grafting cucumber $\mathrm{cv}$. Kalaam $\mathrm{F}_{1}$ onto local rootstocks on daily mean fresh weight of fruit, average length and average diameter of cucumber fruit during crop seasons 2017 and 2018 is presented in Figures 6-8. Figure 6 illustrates that after 4 days of pollination, the mean weight of fruit was increased significantly as shown in the Figure 6A-D. The fresh fruit weights $(\mathrm{g})$ of all scion/rootstock combination in splice grafting were found significantly maximum than other grafted and real rooted cucumber plants during both 2017 and 2018 crop seasons. At day 9 after pollination, the fresh weight of splice grafting was $(270 \mathrm{~g})$ statistically significant for bottle gourd while the ridge gourd and bitter gourd (261 g and $24 \mathrm{7g}$ ) didn't show significant differences in fruit fresh weight. The pumpkin rootstock and real rooted cucumber $\mathrm{cv}$. Kalaam $\mathrm{F}_{1}$ had non-significant fruit fresh weight 161 and 138.25 grams. During both 2017 and 2018 crop seasons length of cucumber fruit $(\mathrm{cm})$ improved significantly after pollination while from 3-8 days showed maximum fruit length in all scion/rootstock combinations as shown in Figure 7A-D. The fruit lengths in splice grafting were significantly longer as compared to that in other grafting and non-grafting methods. After 9 days of pollination for two years, bottle gourd had significantly higher length of cucumber while ridge gourd and bitter gourd didn't show significant differences of fruit length. The pumpkin and real rooted plants had non-significant mean fruit length. The diameter of cucumber fruit $(\mathrm{cm})$ didn't increased significantly from day 1-3 and enhanced significantly from day 3-9 after pollination as shown in Figure 8A-D. Grafted plants had a significantly larger diameter of cucumber fruit while real rooted plants showed non-significant fruit diameter. After day 9 the diameter of cucumber plants in splice grafting were significantly higher $3.5,3.3,3.4$ and $3.7 \mathrm{~cm}$. The diameter of non-grafted cucumber fruit $(3.1 \mathrm{~cm})$ didn't show significant difference while the non-significant diameters of cucumber fruits were found 2.7, 2.6, 2.7 and $2.7 \mathrm{~cm}$ in hole insertion grafting of ridge gourd, bitter gourd, pumpkin and bottle gourd respectively. It could be concluded that the grafted plants had significantly higher weight, length and diameter of fresh fruit than those of fresh fruit in non-grafting. The results agreed with studies on citrus [77], grapes [78], lemon [79], mango [80] and melon [81] grafted on appropriate rootstocks. 

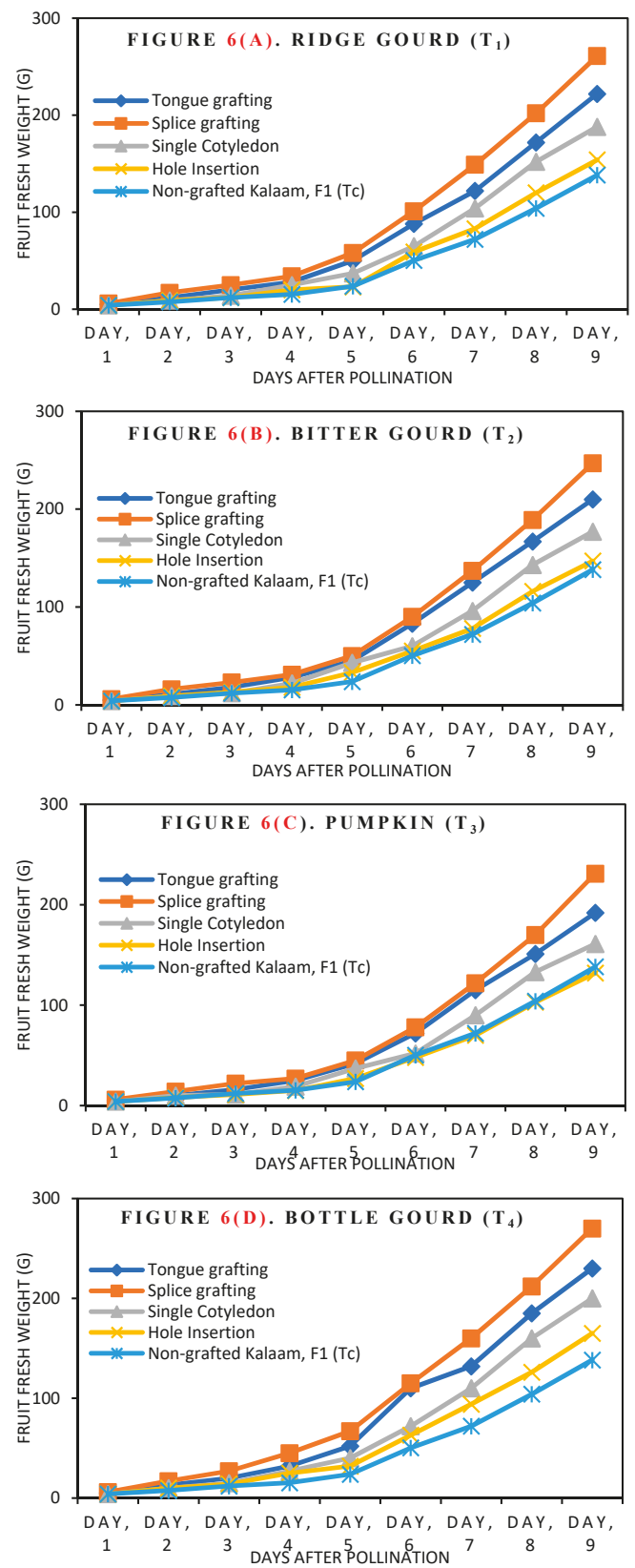

Figure 6. (A-D). Effect of scion/rootstocks combinations (grafting) on fresh weight of Cucumber fruit. 

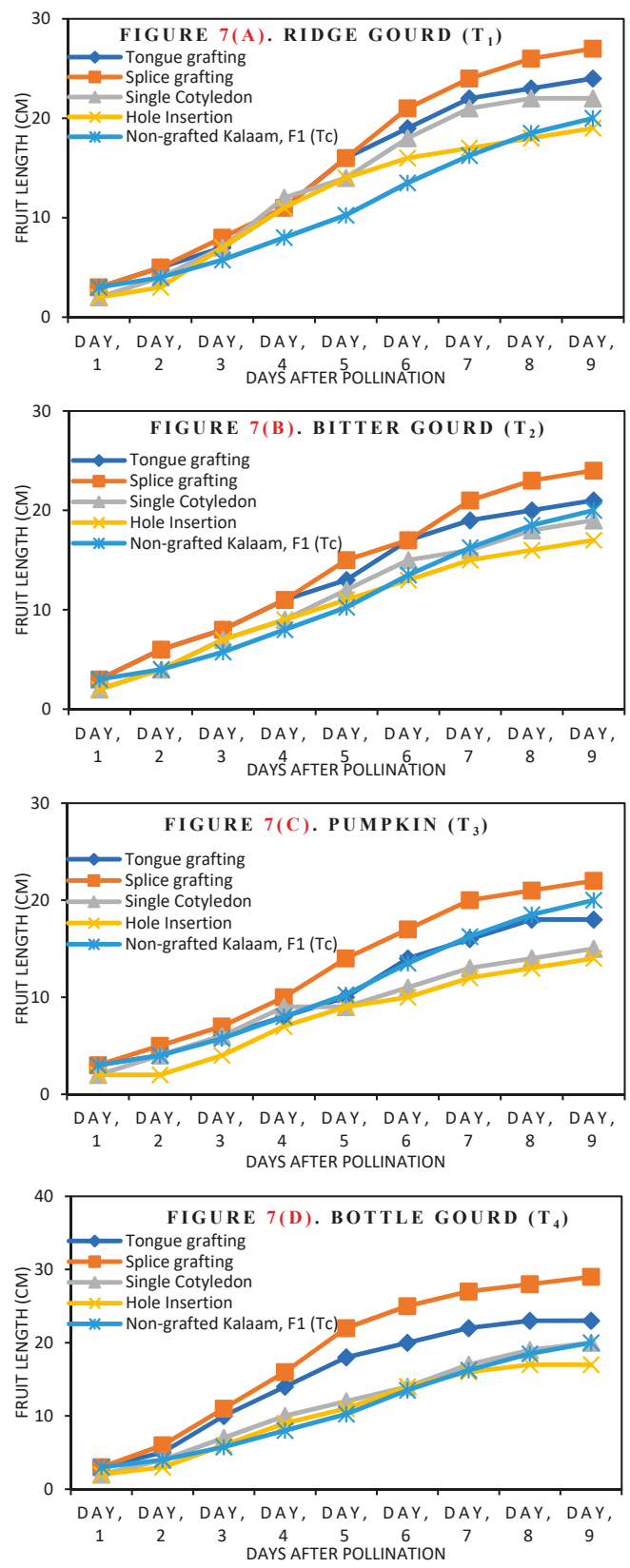

Figure 7. (A-D). Effect of grafting on Cucumber fruit development (fruit length) after pollination. 

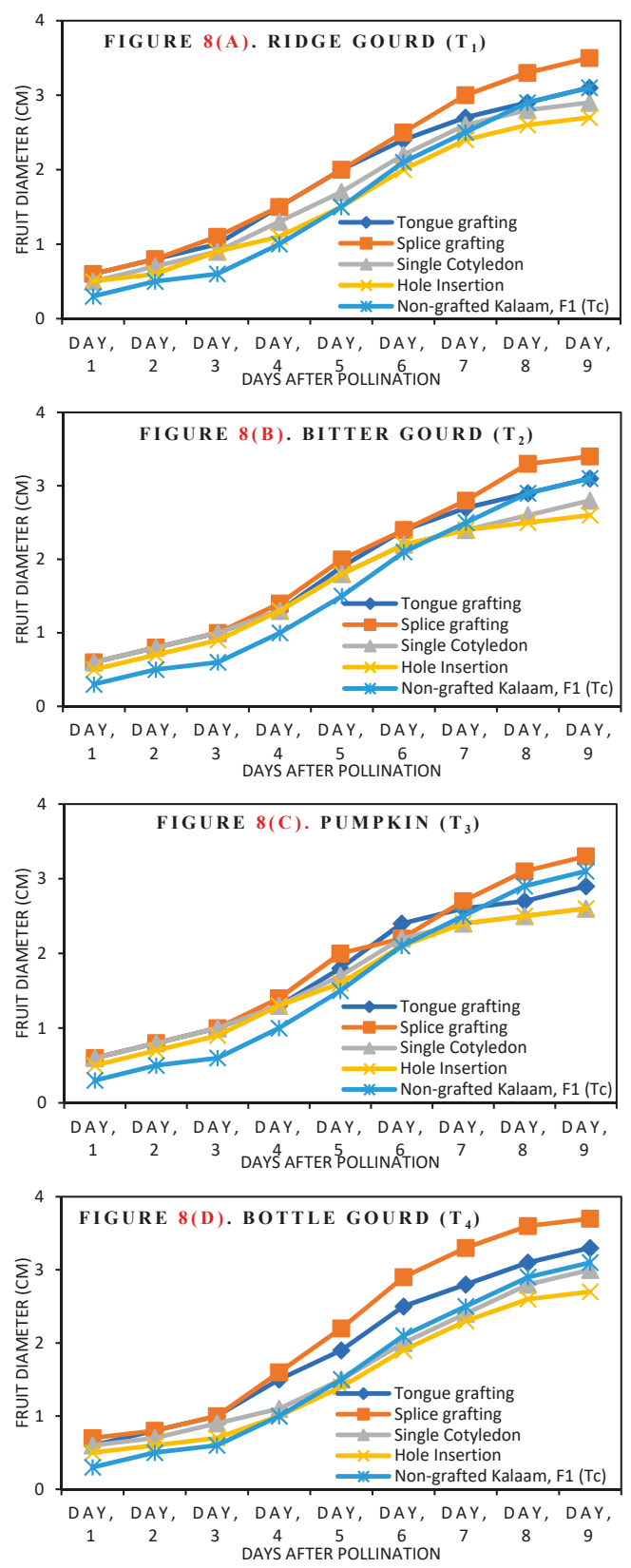

Figure 8. (A-D). Effect of grafting on Cucumber fruit development (fruit diameter) after pollination.

\section{Conclusions}

The pathological and soil-borne diseases particularly root-knot nematode represent major constraints for good seed germination, plant survival and growth, fruit development and fruit quality in cucumber production. There is no cucumber hybrid variety tolerant to nematode while fumigation of nematicides are expensive and can damage a sustainable agriculture system. Therefore, 
grafting is a real agricultural practice to control disease, and to improve cucumber production and quality in a suitable growing environment. The optimum plant vegetative growth, yield and fruit quality are based on both shoot and root genotypes. This study aimed to select and evaluate the resistant and tolerant scion/rootstock combination. The scion of hybrid cucumber cv. Kalaam $\mathrm{F}_{1}$ and four local cucurbitaceous rootstocks were combined through tongue grafting (TAG), splice grafting, single cotyledon grafting and hole insertion grafting during 2017 and 2018. All scion/rootstocks combinations showed significantly maximum results in splice grafting than other grafting and non-grafted (self-rooted) plants. The hybrid cucumber cv. Kalaam $\mathrm{F}_{1}$ grafted on bottle gourd rootstock gave significantly highest survival rate, plant vegetative growth, yield, fruit quality and resistance against soil-borne disease in splice grafting method followed by tongue approach, single cotyledon and hole insertion grafting. The non-significant values were associated with hole insertion grafting method in all scion/rootstock combinations. Grafting had no effect on cucumber fruit matter and fruit quality but fruit mineral composition ( $\mathrm{N}, \mathrm{P}, \mathrm{K}, \mathrm{Ca}$ and $\mathrm{Mg}$ ) was improved significantly. Thus, grafting hybrid cucumber onto local rootstocks improved the growth, yield and quality of fruit, as well as the development of immunity to disease. The studies suggested that grafting of hybrid cucumber $\mathrm{cv}$. Kalaam $\mathrm{F}_{1}$ on local rootstocks grow well in infested soil to control soil-borne disease and to enhance cucumber production.

Author Contributions: Conceptualization, Design and Development, R.S.N.; Data collection, R.S.N., W.A. and M.I.; Formal Analysis, R.S.N., M.U.K. and M.A.; Investigation and Methodology, R.S.N., S.-U.R. and Z.W.; Supervision, M.U. and Y.S.; Visualization, R.S.N. and M.U.; Writing—original draft, R.S.N.; Writing review, Y.S., M.Y. and M.U.K.; Write-up editing, R.S.N.

Funding: This research received no external funding.

Acknowledgments: The authors would like to acknowledge to all the services and technical support of Horticultural research station, University of Agriculture Faisalabad, Faculty of Agricultural Engineering and Technology PMAS-Arid Agriculture University Rawalpindi and Department of Agriculture, Biological, Environment and Energy Engineering, College of Engineering, Northeast Agricultural University, Harbin provided during research work setting, instrumentation, data collection and write-up compilation.

Conflicts of Interest: The authors declared no conflict of interest.

\section{References}

1. Pina, A.Y.; Errea, P. A review of new advances in mechanism of graft compatibility-incompatibility. Sci. Hortic. 2005, 106, 1-11. [CrossRef]

2. Mudge, K.; Janick, J.; Scoffield, S.; Goldschmidt, E.E. A history of grafting. Hortic. Rev. 2009, 35, 437-494.

3. Hartmann, H.T.; Kester, D.E.; Davies, F.T.; Geneve, R.L. Principles of grafting and budding. In Plant Propagation: Principles and Practices, 8th ed.; Pearson: London, UK, 2010; Chapter 11; pp. 415-463. ISBN 978-0-13-501449-3.

4. Lee, J.M.; Kubota, C.; Tsao, S.J.; Bie, Z.; Hoyos, E.P.; MorraL, O.M. Current status of vegetable grafting: diffusion, grafting techniques, automation. Sci. Hortic. 2010, 127, 93-105. [CrossRef]

5. Lee, J.M. Cultivation of grafted vegetables I. Current status, grafting methods, and benefits. Hortic. Sci. 1994, 29, 235-239.

6. Hartman, G.; Pawlowski, M.; Herman, T.; Eastburn, D. Organically Grown Soybean Production in the USA: Constraints and Management of Pathogens and Insect Pests. Agronomy 2016, 6, 16. [CrossRef]

7. Diacono, M.; Persiani, A.; Fiore, A.; Montemurro, F.; Canali, S. Agro-Ecology for Potential Adaptation of Horticultural Systems to Climate Change: Agronomic and Energetic Performance Evaluation. Agronomy 2017, 7, 35. [CrossRef]

8. St. Amand, P.C.; Wehner, T.C. Crop loss to 14 diseases in cucumber in North Carolina for 1983 to 1988. Cuc. Genet. Coop. Rep. 1999, 14, 15-17.

9. Pradeep, K.; Youssef, R.; Mariateresa, C.; Giuseppe, C. Vegetable Grafting as a Tool to Improve Drought Resistance and Water Use Efficiency. Front. Plant Sci. 2017, 8, 1130. [CrossRef]

10. Huang, Y.; Bie, Z.; He, S.; Hua, B.; Zhen, A.; Liu, Z. Improving cucumber tolerance to major nutrients induced salinity by grafting onto Cucurbita ficifolia. Environ. Exp Bot. 2010, 69, 32-38. [CrossRef] 
11. Schwarz, D.; Rouphael, Y.; Colla, G.; Venema, J.H. Grafting as a tool to improve tolerance of vegetables to abiotic stresses: Thermal stress, water stress and organic pollutants. Sci. Hortic. 2010, 127, 162-171. [CrossRef]

12. Colla, G.; Rouphael, Y.; Rea, E.; Cardarelli, M. Grafting cucumber plants enhance tolerance to sodium chloride and sulfate salinization. Sci. Hortic. 2012, 135, 177-185. [CrossRef]

13. Moore, R. A model for graft compatibility-incompatibility in higher plants. Am. J. Bot. 1984, 71, 751-758. [CrossRef]

14. De Miguel, A.; Cebolla, V. Terralia 53, Unión del Injerto; Terralia: Madrid, Spain, October 2005; pp. 50-60. Available online: https://www.terralia.com/terralias/view_report?magazine_report_id=365 (accessed on 5 January 2018)

15. Kumar, R.M.S.; Gao, L.X.; Yuan, H.W.; Xu, D.B.; Liang, Z.; Tao, S.C.; Guo, W.B.; Yan, D.L.; Zheng, B.S.; Edqvist, J. Auxin enhances grafting success in Carya cathayensis (Chinese hickory). Planta 2018, 247, 761-772. [CrossRef]

16. Melnyk, C.W. Plant grafting: Insights into tissue regeneration. Regeneration 2017, 4, 3-14. [CrossRef]

17. De Velasco Alvarado, M.J. Anatomía y Manejo Agronómico de Plantas Injertadas en Jitomate. Master's Thesis, Universidad Autónoma de Chapingo, Chapingo, Mexico, May 2013. Available online: https: //chapingo.mx/horticultura/pdf/tesis/TESISMCH2013050810128186.pdf (accessed on 1 June 2018).

18. Leonardi, C.; Romano, D. Recent issues on vegetable grafting. Acta Hortic. 2004, 631, 163-174. [CrossRef]

19. Yang, S.; Xiang, G.; Zhang, S.; Lou, C. Electrical resistance as a measure of graft union. J. Plant Physiol. 1993, 141, 98-104. [CrossRef]

20. Bletsos, F.A.; Olympios, C.M. Rootstocks and Grafting of Tomatoes, Peppers and Egg plants for Soil-borne Disease Resistance, Improved Yield and Quality. Eur. J. Plant Sci. Biotechnol. 2008, 2, 62-73. Available online: http://www.globalsciencebooks.info/Online/GSBOnline/images/0812/EJPSB_2(SI1)/EJPSB_2(SI1)6273o.pdf (accessed on 1 June 2018).

21. Torii, T.; Kasiwazaki, M.; Okamoto, T.; Kitani, O. Evaluation of graft-take using a thermal camera. Acta Hortic. 1992, 319, 631-634. [CrossRef]

22. Oda, M.; Maruyama, M.; Mori, G. Water Transfer at Graft Union of Tomato Plants Grafted on to Solanum Rootstocks. J. Jpn. Soc. Hortic. Sci. 2005, 74, 458-463. [CrossRef]

23. De Miguel, A.; Cebolla, V. Terralia 53, Pages 50-60. Octubre 2005. Unión del Injerto. Available online: https://sci-hub.tw/http://hortsci.ashspublications.org/content/48/1/34.short (accessed on 5 May 2018).

24. Bausher, M.G. Road, South Rock, Pierce, Fort Graft Angle and Its Relationship to Tomato Plant Survival. Hort. Sci. 2013, 48, 34-36. Available online: http://hortsci.ashspublications.org/content/48/1/34.short (accessed on 6 June 2018).

25. Turquois, N.; Malone, M. Non-destructive assessment of developing hydraulic connections in the graft union of tomato. J. Exp. Bot. 1996, 47, 701-707. [CrossRef]

26. Xia, Y.; Sarafis, V.; Campbell, E.O.; Callaghan, P.T. Noninvasive imaging of water flow in plants by NMR microscopy. Protoplasma 1993, 173, 170-176. [CrossRef]

27. Hochmuth, R.; Davis, L.L.; Laughlin, W.L.; Simonne, E.H. Evaluation of Organic Nutrient Sources in the Production of Greenhouse Hydroponic Basil; Research Report 2003-08; University of Florida: Gainesville, FL, USA, June 2008; pp. 1-7.

28. Goh, K.M. Evaluation of potting media for commercial nursery production of container-grown plants. V. Patterns of release of nitrogen fertilizers in different media. N. Z. J. Agr. Res. 1979, 22, 163-171. [CrossRef]

29. Agricultural Statistics of Pakistan, 2017-2018. Available online: http://www.finance.gov.pk/survey/chapters_ 14/ (accessed on 1 December 2018).

30. Oda, M. Grafting of Vegetable Crops; Scientific Report of Agriculture and Biological Sciences; Osaka Prefecture University: Osaka, Japan, 2002; Volume 54, pp. 49-72.

31. Davis, A.R.; Perkins-Veazie, P.; Sakata, Y.; López-Galarza, S.; Maroto, J.V.; Lee, S.G.; Huh, Y.C.; Sun, Z.; Miguel, A.; King, S.R.; et al. Cucurbit grafting. Criti. Rev. Plant Sci. 2008, 27, 50-74. [CrossRef]

32. Sakata, Y.; Ohara, T.; Sugiyama, M. The history of melon and cucumber grafting in Japan. Acta Hortic. 2008, 767, 217-228. [CrossRef] 
33. Ito, T. Present state of transplant production practices in Japanese horticultural industry. In Proceedings of the International Symposiumon Transplant Production Systems, Transplantant Production Systems, Yokohama, Japan, 21-26 July 1992; Kurata, K., Kozai, T., Eds.; Kluwer Academic Publishers: Amsterdam, The Netherlands, 1992.

34. Kurata, K.; Kozai, T. Transplant Production Systems. In Proceedings of the International Symposium on Transplant Production Systems, Yokohama, Japan, 21-26 July 1992; Kluwer Academic Publishers: Dordrecht, The Netherlands; Boston, MA, USA; London, UK; p. 335. Available online: http://www.springer.com/us/ book/9780792317975 (accessed on 15 September 2018).

35. Lee, J.M.; Oda, M. Grafting of Herbaceous Vegetable and Ornamental Crops. In Horticulture Reviews; Janick, J., Ed.; John Wiley \& Sons: Hoboken, NJ, USA, 2003; Volume 28, p. 453.

36. Nishiura, Y.; Murase, H.; Honami, N.; Taira, T. Development of Plug-in Grafting Robotic System Osaka Prefecture University. In Proceedings of the IEEE International Conference on Robotics and Automaton, Nagoya, Japan, 25-27 May 1995; pp. 2510-2517. Available online: http://ieeexplore.iee.org/abstract/ document/525636/ (accessed on 19 September 2018).

37. Oda, M. Grafting of Vegetable Crops; Osaka Prefecture University: Osaka, Japan, March 2002; Volume 54, pp. 49-72. Available online: http://repository.osakafu-u.ac.jp/dspace/bitstream/10466/1053/1/KJ00000052064. pdf (accessed on 22 June 2018).

38. Oda, M. Use of Grafted Seedlings for Vegetable Production in Japan. Acta Hortic. 2008, 770, 15-20. [CrossRef]

39. Lee, J.M.; Bang, H.J.; Ham, H.S. Grafting of Vegetables. Jpn. Soc. Agric. Mach. Food Eng. 1998, 67, 1098-1104. Available online: https://www.jstage.jst.go.jp/article/jjshs1925/67/6/67_6_1098/_pdf (accessed on 22 June 2018). [CrossRef]

40. Pavlou, G.; Vakalounakis, D.; Ligoxigakis, E. Control of root and stem rot of cucumber, caused by Fusarium oxysporum f. sp. radicis-cucumerinum, by grafting onto resistant rootstocks. Plant Dis. 2002, 86, 379-382. [CrossRef]

41. Huang, Y.; Tang, R.; Cao, Q.; Bie, Z. Improving the fruit yield and quality of cucumber by grafting onto the salt tolerant rootstock under $\mathrm{NaCl}$ stress. Sci. Hortic. 1999, 122, 26-31. [CrossRef]

42. Cansev, A.; Ozgur, M. Grafting cucumber seedlings on Cucurbita spp.: comparison of different grafting methods, scions and their performance. J. Food Agric. Environ. 2010, 8, 804-809.

43. Uysal, N.; Tuzel, Y.; Oztekin, G.B.; Tuzel, I.H. Effects of different rootstocks on greenhouse cucumber production. Acta Hortic. 2012, 927, 281-289. [CrossRef]

44. Moradipour, F.; Dashti, F.; Zahedi, B. Effect of grafting on yield and some vegetative characteristics of two greenhouse cucumber cultivar. Iran. J. Hortic. Sci. 2010, 41, 291-300.

45. Hoyos, P. Influence of different rootstocks on the yield and quality of greenhouses grown cucumbers. Acta Hortic. 2001, 559, 139-143. [CrossRef]

46. Lee, J.; Bang, H.; Ham, H. Quality of cucumber fruit as affected by rootstock. Acta Hortic. 1999, 483, 117-124. [CrossRef]

47. Sakata, Y.; Ohara, T.; Sugiyama, M. The history and present state of the grafting of Cucurbitaceous vegetables in Japan. Acta Hortic. 2007, 731, 159-170. [CrossRef]

48. Davis, A.R.; Perkins-Veazie, P.; Hassell, R.; Levi, A.; King, S.R.; Zhang, X. Grafting effects on vegetable quality. HortScience 2008, 43, 1670-1672. [CrossRef]

49. Sonneveld, C. Estimating quantities of water-soluble nutrients using a specific 1:2 by volume extract. Soil Sci. Plant Anal. 1990, 21, 1257-1265. [CrossRef]

50. Oda, M. Grafting of Vegetables to Improve Greenhouse Production; Extension Bulletin 480; Food and Fertilizer Technology Center: Taipei city, China, 1 December 1999; p. 11.

51. Ishibashi, K. Tongue-approach grafting in cucurbits. Agr. Hort. 1965, 40, 1899-1902. (In Japanese)

52. Lee, J.M.; Oda, M. Grafting of herbaceous vegetable and ornamental crops. In Horticultural Reviews; Janick, J., Ed.; John Wiley and Sons: New York, NY, USA, 2003; Volume 28, pp. 61-124.

53. Davis, R.F. Effect of Meloidogyne incognita on watermelon yield. Nematropica 2007, 37, 287-293.

54. Yadava, I.L. A rapid and nondestructive method to determine chlorophyll in intact leaves. HortScience 1986, 21, 1449.

55. Association of Official Analytical Chemists. Official Methods of Analysis of the Association of Official Agriculture Chemists, 12th ed.; Association of Official Agricultural Chemists: Washington, DC, USA, 1975; p. 870. 
56. Ranganna, S. Manual of Analysis of Fruit and Vegetable Products; Tata McGraw-Hill Publishing: New Delhi, India, 1977; Volume 6, pp. 151-160.

57. Özarslandan, A.; Söğüt, M.A.; Yetișir, H.; Elekcıŏlu, I.H. Screening of bottle gourds (Lagenaria siceraria (Molina) Standley) genotypes with rootstock potential for watermelon production for resistance against Meloidogyne incognita (Kofoid \& White, 1919) Chitwood and Meloidogyne javanica (Treub, 1885) Chitwood. Turk. Entomol. Derg. 2011, 35, 687-697.

58. Ioannou, N. Integrating soil solarization with grafting on resistant rootstocks for management of soil-borne pathogens of eggplant. J. Hortic. Sci. Biotechnol. 2001, 7, 396-401. [CrossRef]

59. Salata, A.C.; Bertolini, E.V.; Magro, F.O.; Cardoso, A.; Wilcken, S.R.S. Effect of grafting on cucumber production and reproduction of Meloidogyne javanica and M. incognita. Hortic Bras. 2012, 30, 590-594. [CrossRef]

60. Netscher, C.; Sikora, R.A. Nematode parasites of vegetables. In Plant Parasitic Nematodes in Subtropical and Tropical Agriculture; CAB International: Wallingford, UK, 1990; pp. 237-283.

61. Walters, S.A.; Wehner, T.C. 'Lucia', 'Manteo', and 'Shelby' root-knot nematode-resistant cucumber inbred lines. HortScience 1997, 32, 1301-1303. [CrossRef]

62. Chen, Z.D.; Wand, P.S.; Zhou, Y.; Ji, Y.L.; Wan, Z.J.; Peng, L. Effects of rootstock grafting on yield, quality and control of Meloidogyne incognita of cucumber (Cucumis sativus L.). China Veget. 2012, 8, 57-62.

63. Miguel, A.; Maroto, J.V. El injerto herbáceo en la sandía (Citrullus lanatus) como alternativa a la desinfecció n química del suelo. Invest. Agrar. Prod. Prot. Veg. 1996, 11, 239-253.

64. Zhu, J.; Bie, Z.L.; Huang, Y.; Han, X.X. Effect of grafting on the growth and ion concentrations of cucumber seedlings under $\mathrm{NaCl}$ stress. Soil Sci. Plant Nutr. 2008, 54, 895-902. [CrossRef]

65. Zhong, Y.Q.; Bie, Z.L. Effects of grafting on the growth and quality of cucumber fruits. Acta Hortic. 2007, 761, 341-347. [CrossRef]

66. Yetisir, H.; Sari, N. Effect of different rootstock on plant growth, yield and quality of watermelon. Aust. J. Exp. Agric. 2003, 43, 1269-1274. [CrossRef]

67. Huang, Y.; Bie, Z.L.; Liu, Z.X.; Zhen, A.; Wang, W.J. Protective role of proline against salt stress is partially related to the improvement of water status and peroxidase enzyme activity in cucumber. Soil Sci. Plant Nutr. 2009, 55, 698-704. [CrossRef]

68. Aloni, B.; Cohen, R.; Karni, L.; Aktas, H.; Edelstein, H. Hormonal signaling in rootstock-scion interactions. Sci Hortic. 2010, 127, 119-126. [CrossRef]

69. Zhang, J.; Shu, W.S. Mechanisms of heavy metal cadmium tolerance in plants. J. Plant. Physiol. Mol. Biol. 2006, 32, 1-8.

70. Salehi-Mohammadi, R.; Khasi, A.; Lee, S.G.; Huh, Y.C.; Lee, J.M.; Delshad, M. Assessing survival and growth performance of Iranian melon to grafting onto Cucurbita rootstocks. Korean J. Hortic. Sci. Technol. 2009, 27, 1-6.

71. Hartmann, H.T.; Kester, D.E.; Davies, F.T.; Geneve, R.L. Plant Propagation: Principles and Practices; Prentice Hall: Upper Saddle River, NJ, USA, 1997; p. 770.

72. Martínez-Ballesta, M.C.; Alcaraz-López, C.; Muries, B.; Mota-Cadenas, C.; Carvajal, M. Physiological aspects of rootstock-scion interactions. Sci. Hortic. 2010, 127, 112-118. [CrossRef]

73. Molnar, A.; Melnyk, C.W.; Bassett, A.; Hardcastle, T.J.; Dunn, R.; Baulcombe, D.C. Small silencing RNAs in plants are mobile and direct epigenetic modification in recipient cells. Science 2010, 328, 872-875. [CrossRef] [PubMed]

74. Dunoyer, P.; Brosnan, C.A.; Schott, G.; Wang, Y.; Jay, F.; Alioua, A.; Himber, C.; Voinnet, O. An endogenous, systemic RNAi pathway in plants. Embryol. J. 2010, 29, 1699-1712. [CrossRef]

75. Harada, T. Grafting and RNA transport via phloem tissue in horticultural plants. Sci. Hortic. 2010, 125, 545-550. [CrossRef]

76. Yamasaki, A.; Yamashita, M.; Furuya, S. Mineral concentrations and cytokinin activity in the xylem exudates of grafted watermelons as affected by rootstocks and crop load. J. Jpn. Soc. Hortic. Sci. 1994, 62, 817-826. [CrossRef]

77. Zekri, M. Citrus rootstocks affect scion nutrition, fruit quality, growth, yield and economical return. Fruits 2000, 55, 231-239. [CrossRef]

78. Economides, C.V.; Gregoriou, C. Growth, yield and fruit quality of nucellar frost 'Marsh' Grapefruit on fifteen rootstocks in Cyprus. J. Amer. Soc. Hort. 1993, 118, 326-329. [CrossRef] 
79. Al-Jaleel, A.; Zekri, M.; Hammam, Y. Yield, fruit quality, and tree health of 'Allen Eureka' lemon on seven rootstocks in Saudi Arabia. Sci. Hort. 2005, 105, 457-465. [CrossRef]

80. Reddy, Y.T.N.; Kurian, R.M.; Ramachander, P.R.; Singh, G.; Kohli, R.R. Long-term effects of rootstocks on growth and fruit yielding patterns of 'Alphonso' mango (Mangifera indica L.). Sci. Hort. 2003, 97, 95-108. [CrossRef]

81. Traka-Mavronaa, E.; Metaxia, K.S.M.; Pritsaa, T. Response of squash (Cucurbita spp.) as rootstock for melon (Cucumis melo L.). Sci. Hort. 2000, 83, 353-362.

(C) 2019 by the authors. Licensee MDPI, Basel, Switzerland. This article is an open access article distributed under the terms and conditions of the Creative Commons Attribution (CC BY) license (http://creativecommons.org/licenses/by/4.0/). 
Article

\title{
Solanum aethiopicum gr. gilo and Its Interspecific Hybrid with S. melongena as Alternative Rootstocks for Eggplant: Effects on Vigor, Yield, and Fruit Physicochemical Properties of Cultivar 'Scarlatti'
}

\author{
Leo Sabatino ${ }^{1, *}$, Giovanni Iapichino ${ }^{1}$, Giuseppe Leonardo Rotino ${ }^{2}$, Eristanna Palazzolo ${ }^{1}$, \\ Giuseppe Mennella ${ }^{3}$ and Fabio D'Anna ${ }^{1}$ \\ 1 Dipartimento Scienze Agrarie, Alimentari e Forestali, Università di Palermo, Viale delle Scienze, \\ 90128 Palermo, Italy; giovanni.iapichino@unipa.it (G.I.); eristanna.palazzolo@unipa.it (E.P.); \\ fabio.danna@unipa.it (F.D.) \\ 2 Consiglio per la Ricerca in Agricoltura e l'Analisi dell'Economia Agraria CREA-GB, Centro di Ricerca \\ Genomica e Bioinformatica, Via Paullese, 26836 Montanaso Lombardo (LO), Italy; \\ giuseppeleonardo.rotino@crea.gov.it \\ 3 Consiglio per la Ricerca in Agricoltura e l'Analisi dell'Economia Agraria CREA-OF, Centro di Ricerca \\ Orticoltura e Florovivaismo, Via Cavalleggeri, 84098 Pontecagnano-Faiano, Italy; \\ giuseppe.mennella@crea.gov.it \\ * Correspondence: leo.sabatino@unipa.it; Tel.: +39-329-801-6975
}

Received: 26 February 2019; Accepted: 29 April 2019; Published: 30 April 2019

\begin{abstract}
Grafting is generally considered effective in ameliorating vegetable crop tolerance to biotic and abiotic stresses. The use of interspecific hybrid as rootstock for eggplant may represent a valid alternative approach to enhance eggplant performance. However, studies on the effects of different rootstocks on eggplant plant vigor, yield, and fruit quality traits often show conflicting results. Thus, an experiment was performed in two spring-summer growing seasons (2014 and 2015) by grafting eggplant 'Scarlatti' $F_{1}$ hybrid on two accessions of S. aethiopicum gr. gilo and on the interspecific hybrid S. melongena $\times$ S. aehtiopicum gr. gilo in comparison to the most common eggplant rootstock S. torvum. Results indicate that $S$. melongena $\times$ S. aethiopicum gr. gilo interspecific hybrid and S. toroum improved grafting success, plant vigor, early flowering and yield in 'Scarlatti' $F_{1}$ scion. All rootstocks tested did not negatively influence fruit apparent quality traits and fruit quality composition. Moreover, fruit glycoalkaloids content remained below the recommended threshold value. These findings suggest that the use of S. melongena $\times$ S. aethiopicum gr. gilo interspecific hybrid as rootstock may be a good alternative to the most commonly used $S$. torvum.
\end{abstract}

Keywords: wild eggplant relative; interspecific hybrid; scion/rootstock combination; plant vigour; yield; fruit quality attributes

\section{Introduction}

Eggplant (Solanum melongena L.) is the world's sixth most important vegetable after tomato, watermelon, onion, cabbage, and cucumber [1] and the most important Solanum crop native to the Old World [2]. Sicily is one of the most important production areas within the Mediterranean Basin that is considered a secondary center of diversification [3]. Soilborne diseases arising from continuous cropping are major problems that limit productivity in eggplant [4]. Therefore, improving soilborne resistance is one of the major scientific and economic challenges in eggplant. Grafting has been attempted as an effective mean to control soilborne diseases and abiotic stresses while simultaneously not adversely affect plant growth or even to improve vigor and yield [4]. Among the abiotic stresses 
that affect vegetable crops, salinity continues to be a main factor in reducing vegetable crop yield and profits in many arid and semi-arid regions. In this respect, Colla et al. [5] demonstrated the effectiveness of grafting to improve salinity tolerance in cucumber. However, the use of specific rootstocks may offer many other advantages such as drought resistance [6] or heavy metal tolerance [7].

Solanum torvum $\mathrm{Sw}$. is the rootstock commonly used for grafting, especially in the most intensive protected cultivation. However, its use has been limited due to lack of rapid and homogeneous synchronized seed germination [8]. Studies have shown that grafting can affect yield and fruit quality in eggplant [9,10]. Kyriacou et al. [11], in their review, reassessed that grafting itself and the prevalence of particular type of commercial rootstocks influence vegetable fruit quality and, partially, storability. They also reported that grafting significantly affects morphometric traits, textural characteristics, sweetness and acidity, as well as functional compounds in eggplant. However, according to Kyriacou et al. [11], current reports on the changes conferred by grafting on eggplant fruit quality provide conflicting information probably due to the environment in which experiment were run. In particular, they stressed both possible rootstock-scion interactions, underscoring graft combinations and different stemming from failure to standardize fruit harvest maturity. In this respect, Gisbert et al. [9] and Sabatino et al. [10] found that the use of interspecific hybrid rootstocks derived from compatible crosses of eggplant with related species can be a valuable approach to improve/preserve eggplant production.

Solanum aethiopicum gr. gilo (scarlet eggplant), a close relative species of S. melongena, has been considered a noticeable resource for eggplant genetic improvement and as potential rootstock. It presents traits of interest, including resistance to F. oxysporum f. sp. melongenae, R. solanacearum [12,13], and root-knot nematodes [14]. Since scarlet eggplant is a cultivated species, it does not display those undesirable traits that are commonly present in the wild relatives of eggplant such as small fruit production, presence of prickles, and high saponins and glycoalcaloids concentrations [15]. A great genetic and morphological variability has been evidenced in S. aethiopicum [16]; therefore, it is particularly relevant to characterize the accessions for the presence and expressivity of the traits of interest before starting a breeding program. Interspecific sexual and somatic hybrids between S. melongena and S. aethiopicum gr. gilo have been produced and although they present a high degree of sterility, recombination between the two genomes has been demonstrated [17] and backcross generations to $S$. melongena with useful introgressions of S. aethiopicum gr. gilo obtained $[13,18,19]$. The aim of this work was to explore the possibility to use two accessions of S. aethiopicum gr. gilo and an initial highly fertile introgression line $\left(\mathrm{BC}_{1}\right)$ from the somatic hybrid between $S$. melongena and $S$. aethiopicum gr. gilo as rootstock for eggplant. The introgression line was resistant to Fusarium oxysporum f.sp. melongenae and is the founder of the series of improved eggplant lines resistant to Fusarium wilt carrying the resistant locus RfoSa1 [18]. The effects of these three genetic materials when used as rootstock, on vigor, yield, and fruit quality traits of eggplant 'Scarlatti' $F_{1}$ hybrid were evaluated. The results are compared with those obtained from ungrafted, self-grafted, and S. torvum rootstock grafted plants. Therefore, our aim was also to validate the assumption that using interspecific hybrid rootstocks may be a good approach to enhance eggplant performance because the presence of the eggplant genome together that one of the wild/allied species may improve the overall affinity between rootstock and scion exploiting the advantage of grafting.

\section{Materials and Methods}

\subsection{Plant Material}

The eggplant $F_{1}$ hybrid 'Scarlatti' (black cylindrical shape) (EnzaZaden, The Netherlands) was used as the scion cultivar as well as the rootstock and ungrafted control. Five rootstocks were evaluated, which included materials corresponding to the three species S. melongena $\left(\mathrm{F}_{1}\right.$ hybrid 'Scarlatti'), Solanum torvum, and Solanum aethiopicum gr. gilo (two accessions, named accession 1 and accession 2), and one interspecific hybrid of S. melongena $\times$ S. aethiopicum gr. gilo, which is a double haploid line obtained from another culture of the tetraploid backcrosses from the somatic hybrid eggplant $\mathrm{cv}$ 
Dourga(+) S. aethiopicum gr. gilo accession 2 with a tetraploid plant of the eggplant line DR2 [13,18]. The materials used as rootstocks originated from the germplasm collection of the Consiglio per la Ricerca in Agricoltura e 1'Analisi dell'Economia Agraria CREA-GB, Centro di Ricerca Genomica e Bioinformatica (Montanaso Lombardo, Italy).

\subsection{Seedlings Production and Grafting}

For the production of the grafted plant material, on 10 February 2014 and 9 February 2015, S. aethiopicum gr. gilo and S. torvum rootstock seeds were planted in 40-cell seedling trays (cell volume of $83 \mathrm{~cm}^{3}$ ), under a temperature regime of $25^{\circ} \mathrm{C} / 18^{\circ} \mathrm{C}$ (day/night) in a propagation greenhouse. After 20 days, seeds of the $F_{1}$ 'Scarlatti' eggplant were planted in 104-cell trays (cell volume of $33 \mathrm{~cm}^{3}$ ) under the same temperature regime and planting method as the rootstocks. Due to the faster germination and growth, the $S$. melongena $\times$ S. aethiopicum gr. gilo hybrid rootstock was sown simultaneously to the $F_{1}$ 'Scarlatti' hybrid. Trays were watered manually every day to maintain the substrate at water holding capacity. Seventy-five days after the sowing of S. torvum and S. aethiopicum gr. gilo (accessions 1 and 2), all seedlings had reached an adequate diameter for grafting. The eggplant cultivar Scarlatti was grafted onto 'Scarlatti' rootstocks (self-grafted), S. toroum, S. aethiopicum gr. gilo (accession 1 and accession 2 ), and S. melongena $\times$ S. aethiopicum gr. gilo rootstocks using the tube grafting method described by Lee [20] and modified by Miceli et al. [21]. Plants at the 3-4 leaf stage were used as rootstocks. The grafted plantlets were misted, incubated within a plastic tunnel in a greenhouse, and maintained at a temperature of $20{ }^{\circ} \mathrm{C}$ and a humidity rate of $95 \%$ for 7 days. After 7 days, the grafted plantlets were acclimatized to the natural conditions of the greenhouse by slowly dropping the humidity ( $\mathrm{RH} 70-80 \%$ ) for 3 days, until they were ready for transplant.

\subsection{Cultivation Conditions}

'Scarlatti' plants ungrafted, self-grafted, and grafted onto S. melongena, S. torvum, and accession 1 and 2 of S. aethiopicum gr. gilo rootstocks were transplanted on 5 May 2014 and 4 May 2015 on a Typic Rhodoxeralf soil in the experimental farm of the Department of Agricultural, Alimentary and Forest Sciences (SAAF) (longitude $13^{\circ} 19^{\prime} \mathrm{E}$, latitude $38^{\circ} 09^{\prime} \mathrm{N}$ ), of the University of Palermo, Italy. The field trials were conducted in a sandy clay loam soil ( $46.5 \%$ sand, $22.3 \%$ silt, 31.2 clay) at pH 7.2 in a completely randomized design with 4 replications of 10 plants ( 40 plants per treatment). In both years, the preceding crop was cauliflower. Plants were spaced $1.0 \mathrm{~m}$ between rows and $0.5 \mathrm{~m}$ apart within the row and drip irrigated. Fertilization was applied with drip irrigation throughout the growing cycle and consisted of $250 \mathrm{~kg}$ nitrogen $\mathrm{ha}^{-1}, 150 \mathrm{~kg}$ phosphorous pentoxide ha ${ }^{-1}$, and $250 \mathrm{~kg}$ potassium oxide ha ${ }^{-1}$ (Yara, Oslo, Norway). Standard horticultural practices for eggplant production in the Mediterranean environment were adopted [22].

Average daily temperature during the experimental period from May to August of 2014 and 2015 was obtained from the meteorological station of the experimental farm of the Department SAAF (Figure S1). In terms of temperatures, the weather during the experimental period in 2014 and 2015 was similar to the long term average. Nevertheless, the average monthly temperatures showed the highest negative deviation in June ( 1.8 and $2.2^{\circ} \mathrm{C}$ in 2014 and 2015, respectively).

\subsection{Grafting Success, Biometric Parameters, Yield, and Apparent Fruit Quality Evaluation}

Grafting success was recorded after two weeks from grafting and was calculated on 100 grafted seedlings for each rootstock used. Plant height and root collar diameter (via a digital caliper) at 50, 80, and 110 days after transplanting (DAT), number of leaves at 50 DAT, and aboveground biomass produced at the end of fruit harvest (including total yield and vegetative part produced (weight of the plant at the end of harvests plus vegetative part removed by pruning after plant branching)) were determined. First flower formation (expressed as DAT) were also recorded. 
Immediately after harvesting fruits were weighed. Total yield $\left(\mathrm{kg} \mathrm{plant}^{-1}\right)$, marketable yield $(\mathrm{kg}$ plant $\left.^{-1}\right)$, and number of marketable fruits per plant were collected. Average marketable fruit weight (g) was calculated.

Color ( $\mathrm{a}^{*}$ and $\mathrm{b}^{*}$ parameters -CIELab) was measured on four replications of five fruits per rootstock-scion combination. The records were taken on two opposite point of eggplant fruit skin (equatorial zone) by a colorimeter (Chroma-meter CR-400, Minolta Corporation, Ltd., Osaka, Japan). Hue angle $\left(\mathrm{H}^{\circ}\right)$ was calculated as follows: $\mathrm{H}^{\circ}=\arctan \left(\mathrm{b}^{*} / \mathrm{a}^{*}\right)$.

Fruit firmness was determined by measuring its resistance to the plunger of a digital penetrometer (Trsnc, Italy). Each fruit was subjected to a compression in two opposite point in the equatorial part using a $6 \mathrm{~mm}$ diameter stainless steel cylinder probe. The mean peak force was calculated in Newton (N).

Apparent fruit quality traits of 'Scarlatti' eggplant fruit were measured in four replications of ten representative commercially mature fruits from non-grafted and self-grafted plants, and from plants derived from 'Scarlatti' scions grafted onto S. torvum and accession 1 and 2 of S. aethiopicum gr. gilo hybrid rootstocks. Fruit length/width ratios were calculated. Several traits were measured in an arbitrary scale according to the European Eggplant Genetic Resources Network (EGGNET) descriptors [23]. These traits included fruit curvature $(1=$ none; $9=\mathrm{U}$-shaped), fruit cross section $(1=$ circular; 9 = very irregular), fruit calyx length $(1=$ very short $(>10 \%) ; 9=$ very long $(>75 \%))$, and fruit calyx prickles $(0=$ none; $9=$ very many $(>30))$. In addition to these EGGNET descriptors, seed index $(0=$ none; $5=$ very many $(>80)$ seeds visible in a longitudinal fruit section) was measured.

\subsection{Pulp Browning, Soluble Solid Content, and Chemicals}

The colorimeter was also used to determine the lightness of fruit pulp by measuring $L^{*}$ value $(0=$ black and $100=$ white). Fruits were sectioned in the equatorial part and the color of the pulp was measured immediately after cutting $\left(\mathrm{L}_{0}\right)$ and after $30 \mathrm{~min}\left(\mathrm{~L}_{30}\right)$ in two areas (central and lateral) of the section. The oxidation potential was estimated using Larrigaudiere et al. [24] method with little modifications as in part suggested by Concellòn et al. [25]. The oxidation potential was expressed as $\Delta \mathrm{L}_{30}=\left(\mathrm{L}_{30}-\mathrm{L}_{0}\right)$.

Sampling for the quality analysis of the fruits was carried out as described by Sabatino et al. [10] and Sabatino et al. [26]. Thus, 3-5 commercially mature fruits for each replication from the second and third harvest were used; only healthy fruits were chosen. Care was taken to ensure that each sample contained the same percentage weight of apical, middle, and distal parts of the fruits. Qualitative fruit characteristic analyses were conducted on fruits harvested from labeled fruits (the flowers were labeled at the fruit set stage) and all fruits were harvested after 35 days from labeling (fruit commercial maturity stage).

Sample of the fruit pulp were squeezed by hand with a garlic squeezer. The juice was filtered and soluble solids content (SSC) was measured using a digital refractometer (MTD-045nD, Three-In-One Enterprises Co. Ltd. Taiwan).

Fruit dry matter percentage was determined in samples dried at $105^{\circ} \mathrm{C}$ until constant weight as $100 \% \times($ dry weight/fresh weight).

Proteins, metals, total anthocyanins, chlorogenic acid, and glycoalkaloids were determined only in the second trial (2015). Protein concentration was determined from $\mathrm{N}$ content obtained from the Kjeldahl method. In particular, a sample rate was subjected to acid-catalyzed mineralization to turn the organic nitrogen into ammoniacal nitrogen. The ammoniacal nitrogen was then distilled in an alkaline $\mathrm{pH}$. The ammonia formed during this distillation was collected in a boric acid solution and determined through titrimetric dosage. The protein concentration was reported as $\mathrm{N} \times 6.25$. Phosphorus content were assessed using colorimetry [27]. $\mathrm{Ca}, \mathrm{Mg}$, and $\mathrm{K}$ were determined using atomic absorption spectroscopy following wet mineralization [28].

Polyphenols were extracted and analyzed according to Stommel and Whitaker [29] with minor modifications. The analyses were performed through a Waters E-Alliance HPLC system constituted 
by a 2695 separations module with quaternary pump, auto sampler, and a 2996 photodiode array detector; data were acquired and analyzed with Waters Empower software on a personal computer. A binary mobile phase gradient of methanol in $0.01 \%$ aqueous phosphoric acid was used according to this procedure: $0-15 \mathrm{~min}$, linear increase from 5 to $25 \%$ methanol; $15-28 \mathrm{~min}$, linear increase from 25 to $50 \%$ methanol; $28-30 \mathrm{~min}$, linear increase from 50 to $100 \%$ methanol; $30-32 \mathrm{~min}, 100 \%$ methanol; 32-36 min, linear decrease from 100 to 5\% methanol; $36-43 \mathrm{~min}, 5 \%$ methanol. The flow rate was $0.8 \mathrm{~mL} / \mathrm{min}$. Quantification of chlorogenic acid (CA), carried out after a RP-HPLC separation, was based on absorbance at $325 \mathrm{~nm}$ relative to the sesamol internal standard and an external standard of authentic CA (Sigma-Aldrich, St. Louis, MO). The results were expressed as $\mathrm{mg} \cdot 100 \mathrm{~g}^{-1} \mathrm{of} \mathrm{fw}$.

The extraction and the analysis of anthocyanins were carried out on $200 \mathrm{mg}$ of lyophilized and powdered peel as reported in Mennella et al. [30]. Briefly, the chromatographic separations were performed at a flow rate of $0.8 \mathrm{~mL} / \mathrm{min}$ and at 0.1 absorbance units full scale (AUFS). Purified delphinidin-3-rutinoside (D3R, Polyphenols Laboratories AS, Sandnes, Norway) was used as external standard in RP-HPLC analyses, with a different retention time (23.9 $\mathrm{min}$ ) compared to delphinidin-3-(p-coumaroylrutinoside)-5-glucoside (nasunin), that was eluted at a longer retention time (25.8 $\mathrm{min}$ for cis-nasunin and $26.1 \mathrm{~min}$ for trans-nasunin, respectively). As for nasunin quantification, a partially purified standard was used according to Lo Scalzo et al. [31]. The results were expressed as $\mathrm{mg} \cdot 100 \mathrm{~g}^{-1}$ of peel fw; the limit of detection was $2.00 \mathrm{mg} \cdot 100 \mathrm{~g}^{-1}$ of peel $\mathrm{dw}$.

Glycoalkaloids were extracted as described by Birner [32] with some modifications. Glycoalkaloid extraction was detected from $0.5 \mathrm{~g}$ lyophilized samples and powdered flesh tissue by $95 \%$ ethanol. The analyses were carried out by means of RP-HPLC according to Kuronen et al. [33] using partially purified solasonine and solamargine as the external standard. The data were expressed as $\mathrm{mg} \cdot 100 \mathrm{~g}^{-1}$ $\mathrm{fw}$; the limit of detection was $0.03 \mathrm{mg} \cdot 100 \mathrm{~g}^{-1}$ of $\mathrm{dw}$.

\subsection{Statistical Analysis}

Data were statistically analyzed by a two-way analysis of variance (ANOVA) (year $(\mathrm{Y}) \times$ rootstock (R)) using SPSS software package version 14.0 (StatSoft, Inc., Chicago, IL, USA). Proteins, metals, total anthocyanins, chlorogenic acid and glycoalkaloids, which were determined only in the second trial (2015), were analyzed via one-factor analysis of variance (ANOVA) using a fixed-effects model for the effect of rootstock treatment. For data expressed in percentage, the arcsin transformation before ANOVA analysis $\left[\varnothing=\arcsin (p / 100)^{1 / 2}\right]$ was applied. To separate treatment means within each measured parameter, Tukey HSD test was performed at $p=0.05$.

\section{Results}

The interaction between rootstock and year was always not significant; therefore, for the sake of simplicity it was omitted from the tables and graphs. Similarly, the factor year was statistically significant only for first flower formation and is reported only in the correspondent table.

\subsection{Grafting Success and Plant Biometric Parameters}

Rootstock significantly affected grafting success, number of leaves at 50 DAT and aboveground biomass (Table 1). 
Table 1. Year and rootstock effects on grafting success and plant biometric parameters of 'Scarlatti' $\mathrm{F}_{1}$ scion.

\begin{tabular}{ccccc}
\hline Treatments & $\begin{array}{c}\text { Grafting } \\
\text { Success (\%) }\end{array}$ & $\begin{array}{c}\text { No. Leaves 50 } \\
\text { DAT (No.) }\end{array}$ & $\begin{array}{c}\text { Aboveground } \\
\text { Biomass (kg) }\end{array}$ & $\begin{array}{c}\text { First Flower } \\
\text { Formation (DAT) }\end{array}$ \\
\hline $\begin{array}{c}\text { Rootstock } \\
\text { 'Scarlatti' ungrafted }\end{array}$ & - & $17.5 \mathrm{~b}$ & $4.5 \mathrm{ab}$ & $53.1 \mathrm{a}$ \\
S. torvum & $99.3 \mathrm{a}$ & $24.3 \mathrm{ab}$ & $5.1 \mathrm{a}$ & $49.0 \mathrm{~d}$ \\
'Scarlatti' self-grafted & $99.6 \mathrm{a}$ & $25.4 \mathrm{a}$ & $4.9 \mathrm{a}$ & $52.9 \mathrm{ab}$ \\
Hybrid S. melongena $\times$ & $99.0 \mathrm{a}$ & $21.1 \mathrm{ab}$ & $4.6 \mathrm{ab}$ & $49.3 \mathrm{~d}$ \\
S. aethiopicum & $93.6 \mathrm{~b}$ & $27.3 \mathrm{a}$ & $3.7 \mathrm{c}$ & $51.9 \mathrm{bc}$ \\
S. aethiopicum (accession 1) & $89.1 \mathrm{~b}$ & $17.6 \mathrm{~b}$ & $4.0 \mathrm{bc}$ & $51.5 \mathrm{c}$ \\
S. aethiopicum (accession 2) & & & & $52.0 \mathrm{a}$ \\
Year & $96.5 \mathrm{a}$ & $22.3 \mathrm{a}$ & $4.4 \mathrm{a}$ & $50.6 \mathrm{~b}$ \\
2014 & $95.8 \mathrm{a}$ & $22.1 \mathrm{a}$ & $4.5 \mathrm{a}$ & $* * *$ \\
2015 & $* * *$ & $* *$ & $* *$ & $* *$ \\
Significance & $\mathrm{NS}$ & $\mathrm{NS}$ & $\mathrm{NS}$ & \\
Rootstock & & &
\end{tabular}

DAT, days after transplanting. Values within a column and a year followed by the same letter are not significantly different at $p \leq 0.05$ (Tukey HSD Test). The significance is designated by asterisks as follows: *, statistically significant differences at $p$-value below $0.05 ;{ }^{* *}$, statistically significant differences at p-value below 0.01 ; ${ }^{* *}$, statistically significant differences at $p$-value below $0.001 ; \mathrm{NS}=$ not significant.

The tube grafting method proved highly efficient with success percentages that ranged from 89.1 to $99.6 \%$ among the materials used (Table 1). No significant differences were found in terms of success rate among 'Scarlatti', S. torvum, and S. melongena $\times$ S. aethiopicum gr. gilo hybrid rootstocks, which showed percentages of graft success ranging from $99 \%$ (S. melongena $\times$ S. aethiopicum gr. gilo hybrid) to $99.6 \%$ ('Scarlatti'). In contrast, S. aethiopicum gr. gilo (accessions 1 and 2) had a significantly lower percentage of success (93.6 and 89.1\%, respectively) with respect to the other rootstocks (Table 1). No visible disaffinity signals at the grafting zone were observed for any rootstock-scion combination.

The mean number of leaves at 50 DAT varied between 17.5 and 27.3 leaves per plant for the 'Scarlatti' ungrafted and S. aethiopicum gr. gilo (accession 1) rootstock, respectively (Table 1). 'Scarlatti' scions grafted onto S. melongena ('Scarlatti') and S. aethiopicum gr. gilo (accession 1) rootstocks had a higher number of leaves at 50 DAT than those ungrafted or grafted onto S. aethiopicum gr. gilo (accession 2). However, eggplant plants grafted onto S. torvum and S. melongena $\times$ S. aethiopicum gr. gilo hybrid did not significantly differ from those grafted onto the other rootstocks tested.

Aboveground biomass produced ranged from $5.1 \mathrm{~kg}$ for 'Scarlatti' grafted on S. torvum rootstock to $3.7 \mathrm{~kg}$ for those grafted on S. aethiopicum gr. gilo (accession 1) rootstock (Table 1). Plants grafted onto $S$. torvum rootstock did not significantly differ compared to those grafted onto S. melongena (self-grafted plants), whereas the lowest aboveground biomass values were collected from eggplant plants grafted onto S. aethiopicum gr. gilo (accessions 1 and 2) (3.7 and $4.0 \mathrm{~kg}$ ).

Regardless of the rootstock, the second trial (2015) gave the shortest time of first flower formation (50.6 DAT), whereas, irrespective of the year, plants grafted onto S. melongena $\times$ S. aethiopicum gr. gilo hybrid and S. torvum gave the shortest time of first flower formation (49.3 and 49.0 DAT, respectively). 'Scarlatti' ungrafted had the longest first flower formation (53.1 DAT) (Table 1).

Rootstock significantly influenced plant height at 50, 80, and 110 DAT (Figure 1).

Plants grafted onto S. aethiopicum gr. gilo (accession 1) had the highest plant height, whereas plants grafted onto S. aethiopicum gr. gilo (accession 2) had the lowest values (Figure S2).

At 80 DAT, no significant differences were found in plant height among 'Scarlatti', S. torvum, S. aethiopicum gr. gilo (accession 1), and S. melongena $\times$ S. aethiopicum gr. gilo hybrid rootstocks. S. aethiopicum gr. gilo (accession 2) had a significantly lower plant height value with respect to the other rootstocks (Figure 1). However, plant height at 50 and 110 DAT, in 'Scarlatti' F 1 grafted onto 
S. melongena $\times$ S. aethiopicum gr. gilo hybrid rootstocks did not significantly differ from those grafted onto S. aethiopicum gr. gilo (accession 2).

Rootstock significantly influenced root collar at 50, 80, and 110 DAT (Figure S3). Plants grafted onto S. aethiopicum gr. gilo (accession 2 ) and S. melongena $\times$ S. aethiopicum gr. gilo hybrid rootstocks had the lowest root collar values, whereas plants grafted on S. aethiopicum gr. gilo (accession 1) had the highest value (Figure S3).

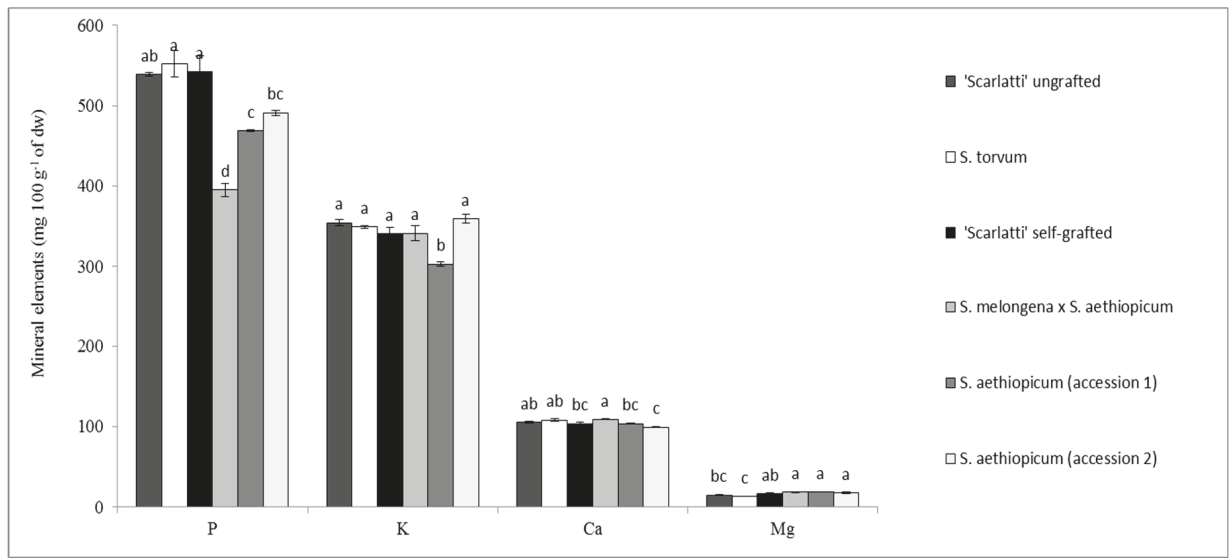

Figure 1. Mineral elements of 'Scarlatti' eggplant fruits produced from ungrafted, self-grafted, and grafted onto S. torvum, S. aethiopicum gr. gilo (accession 1), S. aethiopicum gr. gilo (accession 2), and S. melongena $\times$ S. aethiopicum gr. gilo rootstocks. Bars with different letters are significant by Tukey HSD Test $(p<0.05)$.

\subsection{Yield}

Rootstock significantly influenced total yield, marketable yield and number of marketable fruits (Table 2).

Table 2. Rootstock effects on yield traits of 'Scarlatti' $F_{1}$ scion.

\begin{tabular}{ccccc}
\hline Treatments & $\begin{array}{c}\text { Total Yield } \\
\text { Plant }^{-\mathbf{1}} \mathbf{( k g )}\end{array}$ & $\begin{array}{c}\text { Marketable Yield } \\
\text { Plant }^{-\mathbf{1}} \mathbf{( k g )}\end{array}$ & $\begin{array}{c}\text { No. Marketable } \\
\text { Fruits Plant }^{-\mathbf{1}} \text { (No.) }\end{array}$ & $\begin{array}{c}\text { Average Fruit } \\
\text { Weight } \mathbf{( g )}\end{array}$ \\
\hline $\begin{array}{c}\text { Rootstock } \\
\text { 'Scarlatti' ungrafted }\end{array}$ & $3.4 \mathrm{ab}$ & $3.3 \mathrm{ab}$ & $14.5 \mathrm{a}$ & $231.3 \mathrm{~ns}$ \\
S. torvum & $3.8 \mathrm{a}$ & $3.6 \mathrm{a}$ & $16.6 \mathrm{a}$ & $216.8 \mathrm{~ns}$ \\
'Scarlatti' self-grafted & $3.9 \mathrm{a}$ & $3.6 \mathrm{a}$ & $16.2 \mathrm{a}$ & $223.5 \mathrm{~ns}$ \\
$\begin{array}{c}\text { Hybrid S. melongena } \times \\
\text { S. aethiopicum }\end{array}$ & $3.4 \mathrm{ab}$ & $3.2 \mathrm{ab}$ & $15.1 \mathrm{a}$ & $213.9 \mathrm{~ns}$ \\
$\begin{array}{c}\text { S. aethiopicum (accession 1) } \\
\text { S. aethiopicum (accession 2) }\end{array}$ & $2.7 \mathrm{c}$ & $2.5 \mathrm{c}$ & $9.1 \mathrm{~b}$ & $330.1 \mathrm{~ns}$ \\
Significance & $3.1 \mathrm{bc}$ & $2.9 \mathrm{bc}$ & $14.1 \mathrm{a}$ & $207.5 \mathrm{~ns}$ \\
Rootstock & $* * *$ & $* *$ & $* * *$ & NS
\end{tabular}

Values within a column and a year followed by the same letter are not significantly different at $p \leq 0.05$ (Tukey HSD Test). The significance is designated by asterisks as follows: ${ }^{*}$, statistically significant differences at $p$-value below $0.05 ;{ }^{* *}$, statistically significant differences at $p$-value below $0.01 ;{ }^{* *}$, statistically significant differences at $p$-value below 0.001 ; NS = not significant.

Total yield ranged between $2.7 \mathrm{~kg}$ plant $^{-1}$ for 'Scarlatti' grafted on S. aethiopicum gr. gilo (accession 1) and $3.9 \mathrm{~kg} \mathrm{plant}^{-1}$ for those grafted onto $S$. melongena (self-grafted plants) (Table 2). No significant differences were found in the total yield among 'Scarlatti' and S. torvum rootstocks, which had total yield that ranged from $3.8 \mathrm{~kg}$ plant $^{-1}$ (S. torvum) to $3.9 \mathrm{~kg} \mathrm{plant}^{-1}$ ('Scarlatti' self-grafted). S. aethiopicum 
gr. gilo (accessions 1 and 2) had a significantly lower total yield (2.7 and $3.1 \mathrm{~kg} \mathrm{plant}^{-1}$, respectively) than the other rootstocks (Table 2). However, plants grafted onto S. melongena $\times$ S. aethiopicum gr. gilo rootstock and 'Scarlatti' ungrafted plants did not significantly differ in total yield compared to the plants grafted onto 'Scarlatti' and S. torvum rootstocks. Data collected on marketable yield supported the trend established for total yield (Table 2). Plants with S. aethiopicum gr. gilo (accession 1) as rootstock had a significantly lower fruit number in comparison to those grafted onto 'Scarlatti', S. torvum, and S. melongena $\times$ S. aethiopicum gr. gilo hybrid, and not different from those grafted onto S. aethiopicum gr. gilo (accession 2) (Table 2). In addition, no differences were found among plants grafted onto 'Scarlatti', S. torvum, S. melongena $\times$ S. aethiopicum gr. gilo hybrid, and S. aethiopicum gr. gilo (accession 2) for number of marketable fruits plant ${ }^{-1}$ which produced a significantly higher number of fruits than accession 1 of S. aethiopicum gr. gilo. No significant differences among treatments were found for the average fruit weight (Table 2).

\subsection{Apparent Fruit Quality}

Rootstock significantly influenced fruit length and fruit calyx length parameters (Table S1). Fruit from plants grafted on S. melongena $\times$ S. aethiopicum gr. gilo hybrid rootstock were significantly more elongated than those from plants grafted onto 'Scarlatti' rootstock or from ungrafted 'Scarlatti' plants (Table S1), which in turn had more elongated fruits than those from plants grafted onto S. aethiopicum gr. gilo (accession 2).

Fruit calyx length in 'Scarlatti' scion grafted onto S. aethiopicum gr. gilo $\times$ S. melongena hybrid rootstock was significantly higher than in plants grafted onto $S$. torvum; however, fruits from self-grafted and ungrafted 'Scarlatti' plants did not significantly differ neither from fruits from plants grafted onto S. melongena $\times$ S. aethiopicum gr. gilo hybrid nor from those from plants grafted onto $S$. torvum. No significant differences among rootstocks tested were found for fruit width (average of $4.7 \mathrm{~cm}$ ), fruit length-width ratio (average of 3.9), fruit curvature (average of 1.0), fruit cross-section (average of 7.1), fruit calyx prickles (average of 0.2), or seeds index (average of 1.1) (Table S1).

\subsection{Intrinsic and Extrinsic Fruit Quality}

Hue color parameter in fruits from plants grafted onto S.torvum and S. aethiopicum gr. gilo (accession 1) had the highest values (360.3 and 360.2, respectively) (Table 3).

Table 3. Rootstock effects on Hue ${ }^{\circ}$, fruit dry matter, firmness, and soluble solids content (SSC) in 'Scarlatti' $\mathrm{F}_{1}$ scion.

\begin{tabular}{ccccc}
\hline Treatments & $\mathbf{H}^{\circ}$ & Fruit Dry Matter (\%) & Firmness (N) & SSC $\left({ }^{\circ}\right.$ Brix) \\
\hline Rootstock & & & & \\
Scarlatti' ungrafted & $360.1 \mathrm{~b}$ & $7.3 \mathrm{~ns}$ & $60.0 \mathrm{~ns}$ & $4.5 \mathrm{~b}$ \\
S. torvum & $360.3 \mathrm{a}$ & $7.2 \mathrm{~ns}$ & $43.2 \mathrm{~ns}$ & $3.9 \mathrm{c}$ \\
Scarlatti' self-grafted & $360.1 \mathrm{~b}$ & $6.8 \mathrm{~ns}$ & $44.2 \mathrm{~ns}$ & $4.1 \mathrm{c}$ \\
Hybrid S. melongena & $360.0 \mathrm{~b}$ & $6.8 \mathrm{~ns}$ & $49.0 \mathrm{~ns}$ & $4.6 \mathrm{ab}$ \\
S. aethiopicum & $360.2 \mathrm{ab}$ & $6.9 \mathrm{~ns}$ & $50.6 \mathrm{~ns}$ & $4.6 \mathrm{ab}$ \\
S. aethiopicum (accession 1) & $360.1 \mathrm{~b}$ & $6.8 \mathrm{~ns}$ & $38.8 \mathrm{~ns}$ & $4.9 \mathrm{a}$ \\
S. aethiopicum (accession 2) & & & $\mathrm{NS}$ & $* * *$ \\
Significance & $* * *$ & $\mathrm{NS}$ & & \\
Rootstock & &
\end{tabular}

Values within a column and a year followed by the same letter are not significantly different at $p \leq 0.05$ (Tukey HSD Test). The significance is designated by asterisks as follows: *, statistically significant differences at $p$-value below 0.05 ; ${ }^{* *}$, statistically significant differences at $\mathrm{p}$-value below $0.01 ;{ }^{* * *}$, statistically significant differences at $p$-value below 0.001 ; NS $=$ not significant.

Treatments tested had no effects on fruit dry matter and firmness (Table 3).

Rootstock significantly influenced SSC (Table 3). The highest value of SSC (4.6, 4.9 and $4.6^{\circ} \mathrm{Brix}$, respectively) were found in plants grafted onto S. aethiopicum gr. gilo (accessions 1 and 2 ) and $S$. 
melongena $\times$ S. aethiopicum gr. gilo hybrid, whereas the lowest value (3.9 and $4.1^{\circ}$ Brix, respectively) were observed in plants grafted onto S. torvum and 'Scarlatti'(Table 3).

'Scarlatti' scions grafted onto S. aethiopicum gr. gilo (accession 1) and S. melongena $\times$ S. aethiopicum gr. gilo, had the highest values of $\mathrm{L}_{0}$ central area (Table 4), while fruits from plants grafted onto $S$. aethiopicum gr. gilo (accession 2 ) rootstocks had the lowest value.

Table 4. Rootstock effect on pulp lightness measured immediately after cutting $\left(\mathrm{L}_{0}\right)$ in the central and lateral area and the fruit browning $\left(\Delta \mathrm{L}_{30}\right)$ of the lateral area in 'Scarlatti' $\mathrm{F}_{1}$ scion.

\begin{tabular}{cccc}
\hline Treatments & $\mathbf{L}_{0}$ Central Area & $\mathbf{L}_{0}$ Lateral Area & $\Delta \mathbf{L}_{30}$ Lateral Area \\
\hline Rootstock & & & \\
'Scarlatti' ungrafted & $82.4 \mathrm{bc}$ & $80.6 \mathrm{~b}$ & $2.5 \mathrm{bc}$ \\
S. torvum & $82.9 \mathrm{~b}$ & $81.0 \mathrm{~b}$ & $2.3 \mathrm{c}$ \\
'Scarlatti' self-grafted & $82.5 \mathrm{~b}$ & $80.6 \mathrm{~b}$ & $2.5 \mathrm{bc}$ \\
Hybrid S. melongena $\times$ & $83.5 \mathrm{ab}$ & $81.5 \mathrm{ab}$ & $2.7 \mathrm{ab}$ \\
S. aethiopicum & $84.8 \mathrm{a}$ & $82.9 \mathrm{a}$ & $2.7 \mathrm{ab}$ \\
S. aethiopicum (accession 1) & $80.7 \mathrm{c}$ & $78.9 \mathrm{c}$ & $2.9 \mathrm{a}$ \\
S. aethiopicum (accession2) & $* * *$ & $* * *$ & $* * *$ \\
Significance & & &
\end{tabular}

Values within a column and a year followed by the same letter are not significantly different at $p \leq 0.05$ (Tukey HSD Test). The significance is designated by asterisks as follows: ${ }^{*}$, statistically significant differences at p-value below $0.05 ;{ }^{* *}$, statistically significant differences at $p$-value below $0.01 ; * *$, statistically significant differences at $p$-value below 0.001 ; NS = not significant.

Data collected for $\mathrm{L}_{0}$ lateral area supported the trend established for $\mathrm{L}_{0}$ central area (Table 4).

S. aethiopicum gr. gilo (accessions 1 and 2) and S. melongena $\times$ S. aethiopicum gr. gilo hybrid rootstocks induced the highest $\Delta \mathrm{L}_{30}$ lateral area values (Table 4). While, $S$. torvum rootstock induced the lowest one.

ANOVA for total anthocyanins was not statistically significant (Table 5).

Table 5. Rootstock effect on total antocyanins, glycoalkaloids, chlorogenic acid, and proteins in 'Scarlatti' $\mathrm{F}_{1}$ scion.

\begin{tabular}{|c|c|c|c|c|}
\hline Treatments & $\begin{array}{c}\text { Total } \\
\text { Anthocyanins } \\
\left(\mathrm{mg} \cdot 100 \mathrm{~g}^{-1} \text { of } \mathrm{fw}\right)\end{array}$ & $\begin{array}{c}\text { Glycoalkaloids } \\
\left(\mathrm{mg} \cdot 100 \mathrm{~g}^{-1} \text { of } \mathrm{fw}\right)\end{array}$ & $\begin{array}{l}\text { Chlorogenic Acid } \\
\left(\mathrm{mg} \cdot 100 \mathrm{~g}^{-1} \text { of } \mathrm{fw}\right)\end{array}$ & $\begin{array}{l}\text { Proteins }(g \cdot 100 \\
\left.g^{-1} \text { of } \mathrm{fw}\right)\end{array}$ \\
\hline \multicolumn{5}{|l|}{ Rootstock } \\
\hline 'Scarlatti' ungrafted & $60.6 \mathrm{~ns}$ & $8.4 \mathrm{a}$ & $21.7 \mathrm{ab}$ & $1.0 \mathrm{ab}$ \\
\hline S. torvum & $43.0 \mathrm{~ns}$ & $1.0 \mathrm{~b}$ & $40.3 \mathrm{a}$ & $1.0 \mathrm{ab}$ \\
\hline 'Scarlatti' self-grafted & $47.8 \mathrm{~ns}$ & $2.7 \mathrm{~b}$ & $34.1 \mathrm{a}$ & $1.0 \mathrm{ab}$ \\
\hline $\begin{array}{c}\text { Hybrid S. melongena } \times \\
\text { S. aethiopicum }\end{array}$ & $70.8 \mathrm{~ns}$ & $8.6 \mathrm{a}$ & $4.4 \mathrm{~b}$ & $0.9 \mathrm{bc}$ \\
\hline S. aethiopicum (accession 1) & $80.0 \mathrm{~ns}$ & $3.7 \mathrm{~b}$ & $40.0 \mathrm{a}$ & $1.1 \mathrm{ab}$ \\
\hline S. aethiopicum (accession 2) & $106.4 \mathrm{~ns}$ & $1.9 \mathrm{~b}$ & $17.9 \mathrm{ab}$ & $0.8 \mathrm{~d}$ \\
\hline \multicolumn{5}{|l|}{ Significance } \\
\hline Rootstock & NS & * & $* *$ & $* * *$ \\
\hline
\end{tabular}

Values within a column and a year followed by the same letter are not significantly different at $p \leq 0.05$ (Tukey HSD Test). The significance is designated by asterisks as follows: ${ }^{*}$, statistically significant differences at $p$-value below $0.05 ;{ }^{* *}$, statistically significant differences at $p$-value below $0.01 ; * *$, statistically significant differences at $p$-value below 0.001 ; NS = not significant; fw $=$ fresh weight.

The highest glycoalkaloids content was observed in fruits from ungrafted plants and in those from plants grafted onto S. melongena $\times$ S. aethiopicum gr. gilo rootstocks (Table 5).

Fruits from 'Scarlatti' grafted on S. torvum, S. aethiopicum gr. gilo (accession 1), and 'Scarlatti' self-grafted plants had the highest chlorogenic acid content, whereas, fruits from plants grafted onto $S$. melongena $\times$ S. aethiopicum gr. gilo hybrid rootstock showed the lowest value (Table 5). 
We found that protein content in fruits from plants grafted onto S. aethiopicum gr. gilo (accession 1) was slightly higher than those from 'Scarlatti' ungrafted, self-grafted, and S. toroum grafted plants. The lowest protein content was detected in fruits from plants grafted onto S. aethiopicum gr. gilo (accession 2) (Table 5).

Rootstock significantly affected mineral content (Figure 1).

Ungrafted, self-grafted, and S. torvum rootstock grafted plants had the highest fruit P content (538, 551 , and $541 \mathrm{mg} \cdot 100 \mathrm{~g}^{-1}$ of $\mathrm{dw}$, respectively). The lowest fruit P content value $\left(395.4 \mathrm{mg} \cdot 100 \mathrm{~g}^{-1} \mathrm{of}\right.$ $\mathrm{dw}$ ) was found in S.melongena $\times$ S. aethiopicum gr. gilo hybrid rootstock (Figure 1). Fruits harvested from plants grafted on S. aethiopicum gr. gilo (accession 1) rootstock had a significantly lower K content (302.9 mg.100 g $\mathrm{g}^{-1}$ of $\mathrm{dw}$ ) in comparison to those grafted onto 'Scarlatti', S. torvum, S. melongena $\times$ S. aethiopicum gr. gilo hybrid, S. aethiopicum gr. gilo (accession 2), and 'Scarlatti ungrafted (341.0, 349.0, $341.3,359.1$, and $354.4 \mathrm{mg} \cdot 100 \mathrm{~g}^{-1}$ of $\mathrm{dw}$, respectively) (Figure 1). Moreover, no significant differences were found among plants grafted onto 'Scarlatti', S. torvum, S. melongena $\times$ S. aethiopicum gr. gilo hybrid, S. aethiopicum gr. gilo (accession 2), and 'Scarlatti ungrafted for fruit K content. 'Scarlatti' grafted onto S. melongena $\times$ S. aethiopicum gr. gilo hybrid gave the highest fruit Ca content $\left(108.9 \mathrm{mg} \cdot 100 \mathrm{~g}^{-1} \mathrm{of} \mathrm{dw}\right)$, whereas fruits from plants grafted S. aethiopicum gr. gilo (accession 2) gave the lowest Ca fruit content (99.4 mg.100 g $\mathrm{g}^{-1}$ of dw) (Figure 1). 'Scarlatti' grafted onto S. aethiopicum gr. gilo (accessions 1 and 2) and S. melongena $\times$ S. aethiopicum gr. gilo hybrid had the highest Mg content $(19.3,18.1$, and $18.6 \mathrm{mg} 100$ $\mathrm{g}^{-1}$ of $\mathrm{dw}$, respectively) (Figure 1), whereas the lowest $\mathrm{Mg}$ contents were found in fruits from 'Scarlatti' grafted on S. torvum (13.8 $\mathrm{mg} \cdot 100 \mathrm{~g}^{-1}$ of $\left.\mathrm{dw}\right)$.

\section{Discussion}

Nowadays, both a high yield performance and fruit quality attributes (intrinsic and extrinsic) are very important due to the functional role of vegetables in the human diet [29].

Along with approaches such as genetic improvement and optimization of the cultivation conditions, herbaceous grafting technique represents a toolbox for securing or increasing yield stability and fruit quality with or without stress conditions [26,34-37]. In this paper, we investigated the effects of $S$. aethiopicum gr. gilo (accessions 1 and 2 ) versus the interspecific hybrid of S. melongena $\times$ S. aethiopicum gr. gilo on plant performance and fruit quality attributes of 'Scarlatti' eggplant $\mathrm{F}_{1}$ hybrid (black cylindrical shape). All the results are compared with those obtained from non-grafted, self-grafted, and S. torvum rootstock grafted plants.

Grafting success is an important concern when using new scion-rootstock combinations [37]. Generally, Solanaceous crops are grafted by cleft or tube grafting methods $[4,20,38]$. In our experiment using the tube grafting technique, grafting success rates of $89.1 \%$ for S. aethiopicum gr. gilo (accession 1), 93.6\% for S. aethiopicum gr. gilo (accession 2), and over $99 \%$ for grafting onto 'Scarlatti', S. torvum, and S. melongena $\times$ S. aethiopicum gr. gilo hybrid, were observed. Our findings are in accord with those obtained by Bletsos et al. [4] and Rahman et al. [39], who reported a high grafting success rate of eggplant cultivars grafted onto $S$. torvum. Although, Solanum aethiopicum gr. gilo is a close relative species of S. melongena [16], from our results it appears that graft incompatibility might exist especially when 'Scarlatti' is grafted onto S. aethiopicum gr. gilo accession 2. Thus, we may assume that the genotype is a crucial aspect for the identification of a suitable rootstock as significant differences may exist between different accessions of a species. Regarding the S. melongena $\times$ S. aethiopicum gr. gilo hybrid rootstock, our outcomes are in accord with those obtained by Gisbert et al. [9], who reported a high graft success rate when interspecific hybrids of eggplants were used as rootstocks. Our results are also consistent with those of Sabatino et al. [10], who reported a high graft success rate of eggplant 'Birgah' $F_{1}$ hybrid (violet globose shape) grafted onto $S$. melongena $\times$ S. aethiopicum rootstock, confirming the capacity of this interspecific hybrid to give good results with two different types of common eggplant. In fact, Birgah is one of the violet $\mathrm{F}_{1}$ hybrid belonging to a local Sicilian fruit typology that has been subjected to lower breeding improvement efforts when compared to elongated black-purple typelike 'Scarlatti', which is world-wide diffused especially in the most industrialized countries. Our experiment confirms 
that rootstock might play a major role on plant biometric parameters. Plant height, which may be considered an indicator of vigor was highest in plants with S. aethiopicum gr. gilo (accession 1), S. torvum, and interspecific hybrid S. melongena $\times$ S. aethiopicum gr. gilo rootstocks and lowest in those plants with S. aethiopicum gr. gilo (accession 2) rootstock grafts. Therefore, vigor of the rootstock is important in conferring scion vigor. In the absence of grafting incompatibility signals, grafted plants may also develop more rapidly, hence contributing to earliness. In our work, plants grafted onto S. torvum and S. melongena $\times$ S. aethiopicum gr. gilo hybrid rootstocks flowered earlier than those grafted on the other rootstocks tested. Our results are consistent with those obtained by Gisbert et al. [9] and Sabatino et al. [10], who reported that plant vigor is positively related to fruit earliness. Increased earliness has also been reported for other fruiting vegetables such as melon grafted onto Cucurbita rootstock [40,41]. In our experiment, grafting has proved a useful technique to enhance eggplant 'Scarlatti' $F_{1}$ hybrid yield traits. We also found that plants grafted onto S. melongena $\times$ S. aethiopicum gr. gilo hybrid rootstock had higher total and marketable yield plant ${ }^{-1}$ than plants grafted onto S. aethiopicum gr. gilo (accessions 1 and 2), confirming that this latter rootstock has little value for enhancing eggplant yield. Conversely, interspecific hybrid of $S$. melongena $\times S$. aethiopicum gr. gilo rootstock demonstrated great improvements in agronomic performance due to grafting. However, in our study grafting did not increase the number of marketable fruits. These findings are different from those of Gisbert et al. [9] and Sabatino et al. [10], who reported that eggplants grafted onto interspecific hybrids produced consistently more fruits per plant than ungrafted ones. However, despite in the present work grafting did not significantly improve the number of fruits per plant, the data recorded in our experiment supported the trend established in the experiments by Gisbert et al. [9] and Sabatino et al. [10]. On the other hand, these findings seem to be consistent with those obtained by Maršič et al. [42], who reported that, in the second trial, grafting did not increase the number of fruit per plant in eggplant 'Galine' $F_{1}$ (eggplant cylindrical shape). Therefore, it seems that the number of fruit per plant is a yield component influenced by the genetic background of the rootstock scion combination.

Apparent visual quality is an important criterion when consumers decide to purchase eggplant fruits. In our study, rootstocks affect fruit length and fruit calyx length. Our results are in accord with those obtained by Gisbert et al. [9], who hypothesized that fruit shape changes are probably due to changes in the concentration of growth regulators induced by the rootstock. Our findings on apparent visual quality are partially different from those of Sabatino et al. [10], who reported that rootstock significantly influences fruit width but has no significant effect on calyx length. Thus, it seems that, although fruit shape in eggplant is highly heritable and under genetic control $[43,44]$ and even though rootstocks may affect cultivar fruit shape parameters due to changes in the concentration of growth regulators [9], rootstock may differently affect specific fruit shape characters in relation to the scion genotype.

Our results demonstrated that rootstock may enhance $\mathrm{H}^{\circ}$ color parameter of skin eggplant fruit. Our outcomes are in contrast with those of Moncada et al. [45], who revealed that S. torvum rootstock decreased $\mathrm{H}^{\circ}$ parameter in 'Black Bell', 'Black Moon', and 'Longo' eggplants. Thus, it seems that fruit skin color parameters are differently affected by scion-rootstock combination. Moreover, in our study, fruits from plants grafted onto S. torvum and S. melongena $\times$ S. aethiopicum gr. gilo hybrid had the highest $\mathrm{H}^{\circ}$ color parameter value, which is an important commercial and qualitative prerequisite in eggplant fruit. Eggplant ranks among the top 10 vegetables in terms of antioxidant fruit activity. Accordingly to these data, a high fruit pulp browning potential could be expected $[46,47]$. Mishra et al. [46], King et al. [48], and Prohens et al. [49] revealed that eggplant cultivars differed in their extents of post-cut browning, which could be due to variations in the PPO activity or level of soluble phenolics. Our results on pulp browning are consistent with the findings of Sabatino et al. [10], who reported little or no effect of grafting by using $S$. torvum rootstock. However, we also found that fruits from plant grafted onto S. aethiopicum gr. gilo (accessions 1 and 2) revealed the highest value in terms of $\Delta \mathrm{L}_{30}$. 
Mennella et al. [19] revealed that chlorogenic acid is the major monomeric phenolic compound in eggplant fruits. Although few differences were found in fruit composition traits, higher fruit chlorogenic acid content was found in fruits harvested from plants with 'Scarlatti', S. torvum, S. aethiopicum gr. gilo (accessions 1 and 2) rootstocks, and ungrafted plants in comparison to fruits harvested from 'Scarlatti' scions grafted onto S. melongena $\times$ S. aethiopicum gr. gilo hybrid. This higher chlorogenic acid concentration may be an additional indication of stress in this rootstock-scion combination, as stress conditions induce accumulation of phenolics [50,51]. Our results are dissimilar from those of Sabatino et al. [10], who reported no differences in terms of fruit chlorogenic acid content among rootstocks tested, but are consistent with those of Sabatino et al. [26] who reported that grafting significantly increased phenolic concentration in fruits from grafted eggplant landraces only in three out of four genotypes. Our outcomes on phenolic content are also consistent with those of Maršič et al. [42] who demonstrated that grafting significantly increased phenolic concentration in fruits from a grafted eggplant landrace as opposed to commercial varieties. Moreover, Toppino et al. [52] discovered environment-specific QTLs associated to the amount of chlorogenic acid. Accordingly, it seems that fruit phenolic content in eggplant is a quality trait also affected by scion-rootstock interactions. Mennella et al. [19], Friedman and McDonald [53], and Friedman [54] observed that genetic, environment, and growing conditions may affect glycoalkaloids concentration in potato, tomato, and eggplant. In addition, Jones and Fenwick [55] and Krits et al. [56] assessed that the level of total glycoalkaloids in potato tubers should not exceed $200 \mathrm{mg} \cdot \mathrm{kg}^{-1}$ of fw (or $200 \mathrm{mg} \cdot 100 \mathrm{~g}^{-1} \mathrm{of} \mathrm{dw}$ ). Glycoalkaloids concentration ranged from 0.98 to $8.64 \mathrm{mg} \cdot 100 \mathrm{~g}^{-1}$ of fresh weight. Rootstock affected glycoalkaloids concentration in eggplant; however, it is important to remark that glycoalkaloids amount in fruits from grafted plant remained below the recommended threshold value. Our findings are in contrast with those of Sabatino et al. [10], who observed no significant differences in terms of glycoalkaloids concentration in 'Birgah' $F_{1}$ eggplant fruits from plants grafted onto several potential rootstocks including hybrids and allied species.

Generally, changes in overall fruit composition between grafted and ungrafted plants were reported in tomato [57] and pepper [58]. Our results are in accord with those of Sabatino et al. [10], who found some differences in fruit quality attributes among fruits from ungrafted or self-grafted plants.

\section{Conclusions}

After the ban of methyl bromide use for soil fumigation, the soilborne diseases arising from continuous cropping are major issues that negatively affect productivity in eggplant. In this scenario, grafting is an effective tool to control vegetable crop stresses. Nowadays, S. torvum and tomato hybrids are the main eggplant rootstocks commercially used. However, investigations on the influence of new rootstocks on biometric parameters, yield performance, and fruit quality characteristics of different eggplant groups can provide further advances in this specific grafting field. In the present study, the interspecific hybrid of S. melongena $\times$ S. aethiopicum gr. gilo exhibited high grafting compatibility and high yield performance. These findings, together with the absence of negative effects on apparent 'Scarlatti' $F_{1}$ hybrid fruit quality and composition, demonstrate that this interspecific hybrid may be a viable rootstock alternative to $S$. torvum.

Supplementary Materials: The following are available online at http://www.mdpi.com/2073-4395/9/5/223/s1, Figure S1: Monthly meteorological data from May to August of 2014 and 2015 from the meteorological station of the experimental farm of the Department of Agricultural, Alimentary and Forest Sciences, University of Palermo, Italy, Figure S2: Plant height evolution of 'Scarlatti' eggplant plant ungrafted, self-grafted and grafted onto S. torvum, S. aethiopicum gr. gilo (accession 1), S. aethiopicum gr. gilo (accession 2) and S. melongena $\times$ S aethiopicum gr. gilo rootstocks. Bars indicate the standard error of the mean. ANOVA analysis for plant height at 50,80 , and 110 DAT showed the following significance: ${ }^{* * *}$ (statistically significant differences at $p$-value below $0.001),{ }^{* * *}$ and * (statistically significant differences at $p$-value below 0.05), respectively, Figure S3: Root collar evolution of 'Scarlatti' eggplant plant ungrafted, self-grafted and grafted onto S. torvum, S. aethiopicum gr. gilo (accession 1), S. aethiopicum gr. gilo (accession 2) and S. melongena $\times$ S. aethiopicum gr. gilo rootstocks. Bars indicate the standard error of the mean. ANOVA analysis for root collar at 50, 80, and 110 DAT showed the 
following significance: ${ }^{* * *}$ (statistically significant differences at $p$-value below 0.001$),{ }^{* * *}$ and ${ }^{* * *}$, respectively. Table S1: Rootstock effects on apparent fruit quality in 'Scarlatti' F1 scion.

Author Contributions: L.S., G.I., G.L.R., and F.D., conceived and designed the research. L.S. also carried out field work, analyzed the data, and wrote the manuscript. E.P. and G.M. performed laboratory analytical determination. G.I. and G.L.R. helped draft the manuscript. All authors read and approved the manuscript.

Funding: This research received no external funding.

Acknowledgments: We thank Carlo Prinzivalli for his assistance in establishing the field trial.

Conflicts of Interest: The authors declare no conflict of interest.

\section{References}

1. FAOSTAT. Production. Available online: www.fao.org (accessed on 16 January 2019).

2. Kaushik, P.; Prohens, J.; Vilanova, S.; Gramazio, P.; Plazas, M. Phenotyping of eggplant wild relatives and interspecific hybrids with conventional and phenomics descriptors provides insight for their potential utilization in breeding. Front. Plant Sci. 2016, 7, 677. [CrossRef]

3. D'Anna, F.; Sabatino, L. Morphological and agronomical characterization of eggplant genetic resources from the Sicily area. J. Food Agri. Environ. 2013, 11, 401-404.

4. Bletsos, F.; Thanassoulopoulos, C.; Roupakias, D. Effect of grafting on growth, yield and Verticillium wilt of eggplant. HortScience 2003, 38, 183-186. [CrossRef]

5. Colla, G.; Rouphael, Y.; Jawad, R.; Kumar, P.; Rea, E.; Cardarelli, M. The effectiveness of grafting to improve $\mathrm{NaCl}$ and $\mathrm{CaCl}_{2}$ tolerance in cucumber. Sci. Hortic. 2013, 164, 380-391. [CrossRef]

6. Kumar, P.; Rouphael, Y.; Cardarelli, M.; Colla, G. Vegetable grafting as a tool to improve drought resistance and water use efficiency. Front. Plant Sci. 2017, 8, 1130. [CrossRef] [PubMed]

7. Kumar, P.; Lucini, L.; Rouphael, Y.; Cardarelli, M.; Kalunke, R.M.; Colla, G. Insight into the role of grafting and arbuscular mycorrhiza on cadmium stress tolerance in tomato. Front. Plant Sci. 2015, 6, 477. [CrossRef]

8. Ginoux, G.; Laterrot, H. Greffage de l'aubergine. Proceedings reflexions du portegreffe. PHM Revue Hortic. 1991, 321, 49-54.

9. Gisbert, C.; Prohens, J.; Raigón, M.D.; Stommel, J.R.; Nuez, F. Eggplant relatives as sources of variation for developing new rootstocks: Effects of grafting on eggplant yield and fruit apparent quality and composition. Sci. Hortic. 2011, 128, 14-22. [CrossRef]

10. Sabatino, L.; Iapichino, G.; D’Anna, F.; Palazzolo, E.; Mennella, G.; Rotino, G.L. Hybrids and allied species as potential rootstocks for eggplant: Effect of grafting on vigour, yield and overall fruit quality traits. Sci. Hortic. 2018, 228, 81-90. [CrossRef]

11. Kyriacou, M.C.; Rouphael, Y.; Colla, G.; Zrenner, R.; Schwarz, D. Vegetable grafting: The implications of a growing agronomic imperative for vegetable fruit quality and nutritive value. Front. Plant Sci. 2017, 8, 741. [CrossRef]

12. Cappelli, C.; Stravato, V.M.; Rotino, G.L.; Buonaurio, R. Sources of resistance among Solanum spp. to an Italian isolate of Fusarium oxysporum $\mathrm{f}$ sp. melongenae. In Proceedings of the 9th EUCARPIA Meeting Genetic and Breeding of Capsicum and Eggplant, Budapest, Hungary, 21-25 August 1995; pp. 221-224.

13. Rizza, F.; Mennella, G.; Collonnier, C.; Shiachakr, D.; Kashyap, V.; Rajam, M.V.; Prestera, M.; Rotino, G.L. Androgenic dihaploids from somatic hybrids between Solanum melongena and S. aethiopicum group gilo as a source of resistance to Fusarium oxysporum f. sp. melongenae. Plant Cell Rep. 2002, 20, 1022-1032.

14. Hébert, Y. Comparative resistance of nine species of the genes Solanum to bacterial wilt Psedomonas solanacearum and the nematode Meloidogyne incognita. Implications for the breeding of aubergine (S. melongena) in the humid tropical zone. Agronomie 1985, 5, 27-32. [CrossRef]

15. Prohens, J.; Plazas, M.; Raigón, M.D.; Seguí-Simarro, J.M.; Stommel, J.R.; Vilanova, S. Characterization of interspecific hybrids and backcross generations from crosses between two cultivated eggplants (Solanum melongena and S. aethiopicum Kumba group) and implications for eggplant breeding. Euphytica 2012, 186, 517-538. [CrossRef]

16. Sawadogo, B.; Bationo-Kando, P.; Sawadogo, N.; Kiebre, Z.; Kiebre, M.; Nanema, K.R.; Traore, R.E.; Sawadogo, M.; Zongo, J.D. Variation, correlation and heritability of interest characters for selection of African eggplant. Afr. Crop Sci. J. 2016, 24, 213-221. [CrossRef] 
17. Toppino, L.; Mennella, G.; Rizza, F.; D’alessandro, A.; Sihachakr, D.; Rotino, G.L. ISSR and isozyme characterization of androgenetic dihaploids reveals tetrasomic inheritance in tetraploid somatic hybrids between Solanum melongena and Solanum aethiopicum group gilo. J. Hered. 2008, 99, 304-315. [CrossRef] [PubMed]

18. Toppino, L.; Vale, G.; Rotino, G.L. Inheritance of fusarium wilt resistance introgressed from Solanum aethiopicum Gilo and Aculeatum groups into cultivated eggplant (S. melongena) and development of associated PCR-based markers. Mol. Breed. 2008, 22, 237-250. [CrossRef]

19. Mennella, G.; Rotino, G.L.; Fibiani, M.; D’Alessandro, A.; Francese, G.; Toppino, L.; Cavallanti, F.; Acciarri, N.; Lo Scalzo, R. Characterization of health-related compounds in eggplant (Solanum melongena L.) lines derived from introgression of allied species. J. Agric. Food Chem. 2010, 58, 7597-7603. [CrossRef]

20. Lee, J.M. Cultivation of grafted vegetables I: Current status, grafting methods and benefits. Hort. Sci. 1994, 29, 235-239. [CrossRef]

21. Miceli, A.; Sabatino, L.; Moncada, A.; Vetrano, F.; D'Anna, F. Nursery and field evaluation of eggplant grafted onto unrooted cuttings of Solanum torvum Sw. Sci. Hortic. 2014, 178, 203-210. [CrossRef]

22. Baixauli, C. Berenjena. In La horticultura espãnola; Nuez, F., Llácer, G., Eds.; Ediciones de Horticultura: Reus, Spain, 2001.

23. Prohens, J.; Blanca, J.M.; Nuez, F. Morphological and molecular variation in a collection of eggplant from a secondary center of diversity: Implications for conservation and breeding. J. Am. Soc. Hortic. Sci. 2005, 130, 54-63. [CrossRef]

24. Larrigaudiere, C.; Lentheric, I.; Vendrell, M. Relationship between enzymatic browning and internal disorders in controlled atmosphere stored pears. J. Sci. Food Agric. 1998, 78, 232-236. [CrossRef]

25. Concellòn, A.; Añón, M.; Chaves, A.R. Effect of low temperature storage on physical and physiological characteristics of eggplant fruit (Solanum melongena L.). LWT 2007, 40, 389-396. [CrossRef]

26. Sabatino, L.; Iapichino, G.; Maggio, A.; D’Anna, E.; Bruno, M.; D’Anna, F. Grafting affects yield and phenolic profile of Solanum melongena L. landraces. J. Integr. Agric. 2016, 15, 1017-1024. [CrossRef]

27. Fogg, D.N.; Wilkinson, N.T. The colorimetric determination of phosphorus. Analist 1958, 83, 406-414. [CrossRef]

28. Morand, P.; Gullo, J.L. Mineralisation des tissus vegetaux en vue du dosage de P, Ca, Mg, Na, K. Ann. Agron. 1970, 21, 229-236.

29. Stommel, J.R.; Whitaker, B.D. Phenolic acid content and composition of eggplant fruit in a germplasm core subset. J. Am. Soc. Hortic. Sci. 2003, 128, 704-710. [CrossRef]

30. Mennella, G.; Lo Scalzo, R.; Fibiani, M.; D'Alessandro, A.; Francese, G.; Toppino, L.; Acciarri, N.; De Almeida, A.E.; Rotino, G.L. Chemical and bioactive quality traits during fruit ripening in eggplant (S. melongena L.) and allied species. J. Agric. Food Chem. 2012, 60, 11821-11831. [CrossRef]

31. Lo Scalzo, R.; Fibiani, M.; Mennella, G.; Rotino, G.L.; Dal Sasso, M.; Culici, M.; Spallino, A.; Braga, P.C. Thermal treatments of eggplant (Solanum melongena L.) increases the antioxidant content and the inhibitory effect on human neutrophil burst. J. Agric. Food Chem. 2010, 58, 3371-3379. [CrossRef]

32. Birner, J. A method for the determination of total steroid bases. J. Pharm. Sci. 1969, 58, 258-259. [CrossRef]

33. Kuronen, P.; Väänänen, T.; Pehu, E. Reversed-phase liquid chromatographic separation and simultaneous profiling of steroidal glycoalkaloids and their aglycones. J. Chromatogr. A. 1999, 863, 25-35. [CrossRef]

34. Sabatino, L.; Palazzolo, E.; D’Anna, F. Grafting suitability of Sicilian eggplant ecotypes onto Solanum torvum: Fruit composition, production and phenology. J. Food Agric. Environ. 2013, 11, 1195-1200.

35. Davis, A.R.; Perkins-Veazie, P.; Hassell, R.; Levi, A.; King, S.R.; Zhang, X.P. Grafting effects on vegetable quality. HortScience 2008, 43, 1670-1672. [CrossRef]

36. Rouphael, Y.; Kyriacou, M.; Colla, G. Vegetable grafting: A toolbox for securing yield stability under multiple stress conditions. Front. Plant Sci. 2018, 8, 2255. [CrossRef]

37. Kawaguchi, M.; Taji, A.; Backhouse, D.; Oda, M. Anatomy and physiology of graft incompatibility in solanaceous plants. J. Hortic. Sci. Biotechnol. 2008, 83, 581-588. [CrossRef]

38. Miguel, A.; de la Torre, F.; Baixauli, C.; Maroto, J.V.; Jordá, M.C.; López, M.M.; García- Jiménez, J. Elinjerto de hortalizas; Ministerio de Agricultura, Pesca y Alimentación: Madrid, Spain, 2007.

39. Rahman, M.A.; Rashid, M.A.; Hossain, M.M.; Salam, M.A.; Masum, A.S.M.H. Grafting compatibility of cultivated eggplant varieties with wild Solanum species. Pak. J. Biol. Sci. 2002, 5, 755-757. 
40. Cohen, R.; Horev, C.; Burger, Y.; Shriber, S.; Hershenhorn, J.; Katanand, J.; Edelstein, M. Horticultural and pathological aspects of Fusarium wilt management using grafted melons. Hort. Sci. 2002, 37, 1069-1073. [CrossRef]

41. Fita, A.; Picó, B.; Roig, C.; Nuez, F. Performance of Cucumis melo spp. agrestis as a rootstock for melon. J. Hortic. Sci. Biotechnol. 2004, 82, 184-190.

42. Maršič, N.K.; Mikulič-Petkovšek, M.; Štampar, F. Grafting influences phenolic profile and carpometric traits of fruits of greenhouse-grown eggplant (Solanum melongena L.). J. Agric. Food Chem. 2014, 62, 10504-10514. [CrossRef] [PubMed]

43. Muñoz-Falcón, J.E.; Prohens, J.; Rodríguez-Burruezo, A.; Nuez, F. Potential of local varieties and their hybrids for the improvement of eggplant production in the open field and greenhouse cultivation. J. Food Agric. Environ. 2008, 6, 83-88.

44. Portis, E.; Barchi, L.; Toppino, L.; Lanteri, S.; Acciarri, N.; Felicioni, N.; Fusari, F.; Barbierato, V.; Cericola, F.; Valè, G.; et al. QTL mapping in eggplant reveals clusters of yield-related loci and orthology with the tomato genome. PLoS ONE 2014, 9, e89499. [CrossRef] [PubMed]

45. Moncada, A.; Miceli, A.; Vetrano, F.; Mineo, V.; Planeta, D.; D'Anna, F. Effect of grafting on yield and quality of eggplant (Solanum melongena L.). Sci. Hortic. 2013, 149, 108-114. [CrossRef]

46. Mishra, B.B.; Gautam, S.; Sharma, A. Free phenolics and polyphenol oxidase (PPO): The factors affecting post-cut browning in eggplant (Solanum melongena). Food Chem. 2013, 139, 105-114. [CrossRef] [PubMed]

47. Singh, A.P.; Luthria, D.; Wilson, T.; Vorsa, N.; Singh, V.; Banuelos, G.S.; Pasakdee, S. Polyphenols content and antioxidant capacity of eggplant pulp. Food Chem. 2009, 114, 955-961. [CrossRef]

48. King, S.R.; Davis, A.R.; Zhang, X.; Crosby, K. Genetics, breeding and selection of rootstocks for Solanaceae and Cucurbitaceae. Sci. Hortic. 2010, 127, 106-111. [CrossRef]

49. Prohens, J.; Rodriguez-Burruezo, A.; Raigon, M.D.; Nuez, F. Total phenolic concentration and browning susceptibility in a collection of different varietal types and hybrids of eggplant: Implications for breeding for higher nutritional quality and reduced browning. J. Am. Soc. Hortic. Sci. 2007, 132, 1-9. [CrossRef]

50. Dixon, R.A.; Paiva, N.L. Stress-induced phenylpropanoid metabolism. Plant Cell 1995, 7, 1085-1097. [CrossRef] [PubMed]

51. Moglia, A.; Lanteri, S.; Comino, C.; Acquadro, A.; de Vos, R.; Beekwilder, J. Stress induced biosynthesis of dicaffeoylquinic acids in globe artichoke. J. Agric. Food Chem. 2008, 56, 8641-8649. [CrossRef]

52. Toppino, L.; Barchi, L.; Lo Scalzo, R.; Palazzolo, E.; Francese, G.; Fibiani, M.; D’Alessandro, A.; Papa, V.; Laudicina, V.A.; Sabatino, L.; et al. Mapping quantitative trait loci affectingbiochemical and morphologicalfruitproperties in eggplant (Solanum melongena L.). Front. Plant Sci. 2016, 7, 256. [CrossRef]

53. Friedman, M.; McDonald, G.M. Potato glycoalkaloids: Chemistry, analyses, safety and plant physiology. Crit. Rev. Plant Sci. 1997, 16, 55-132. [CrossRef]

54. Friedman, M. Tomato glycoalkaloids: Role in the plant and in the diet. J. Agric. Food Chem. 2002, 50, 5751-5780. [CrossRef]

55. Jones, P.G.; Fenwick, G.R. The glycoalkaloid content of some edible solanaceous fruits and potato products. J. Sci. Food Agric. 2006, 32, 419-421. [CrossRef]

56. Krits, P.; Fogelman, E.; Ginzberg, I. Potato steroidal glycoalkaloid levels and the expression of key isoprenoid metabolic genes. Planta 2007, 227, 143-150. [CrossRef]

57. Khah, E.M.; Kakava, E.M.A.; Chachalis, D.; Goulas, C. Effect of grafting on growth and yield of tomato (Lycopersicon esculentum Mill.) in greenhouse and open field. J. Appl. Hortic. 2006, 8, 3-7.

58. Gisbert, C.; Sánchez-Torres, P.; Raigón, M.D.; Nuez, F. Phytophthora capsici resistance evaluation in pepper hybrids: Agronomic performance and fruit quality of pepper grafted plants. J. Food Agric. Environ. 2010, 8, 116-121.

(C) 2019 by the authors. Licensee MDPI, Basel, Switzerland. This article is an open access article distributed under the terms and conditions of the Creative Commons Attribution (CC BY) license (http://creativecommons.org/licenses/by/4.0/). 

Article

\title{
Combined Influence of Cutting Angle and Diameter Differences between Seedlings on the Grafting Success of Tomato Using the Splicing Technique
}

\author{
José-Luis Pardo-Alonso ${ }^{1}$, Ángel Carreño-Ortega ${ }^{1, *}$, Carolina-Clara Martínez-Gaitán ${ }^{2}$ \\ and Ángel-Jesús Callejón-Ferre ${ }^{1}$ \\ 1 Department of Engineering, University of Almería, Agrifood Campus of International Excellence (CeiA3), \\ La Cañada de San Urbano, Almería 04120, Spain; jolupa@ual.es (J.-L.P.-A.); acallejo@ual.es (A.-J.C.-F.) \\ 2 Tenova, Technological Center: Foundation for Auxiliary Technologies for Agriculture; Parque Tecnológico \\ de Almería, Avda. de la Innovación, 23, Almería 04131, Spain; cmartinez@fundaciontecnova.com \\ * Correspondence: acarre@ual.es; Tel.: +34-950-214-098
}

Received: 11 November 2018; Accepted: 19 December 2018; Published: 21 December 2018

\begin{abstract}
Herbaceous crop yield intensification creates favourable conditions for the development of pests that intensify the attack of soil pathogens traditionally controlled by disinfectant, which are mostly prohibited and unlisted because of their toxicity. The use of grafted plants solves this problem and assists in addressing abiotic stress conditions. Within Solanaceae, specifically tomato crops (Solanum lycopersicum), the use of the splicing technique (simple and easily automated) is of special interest. This experiment attempts to present the combined influence of cutting angle and different random diameters on grafting success with the objective of detecting an optimum working range that will be applicable to automated and robotic grafting systems. An increase in the grafting angle is associated with a higher survival of grafted plants despite variations in diameter. Moreover, a threshold cutting angle is observed from which the success rate no longer increases but decreases drastically. Therefore, for a given working range with a significant cutting angle, whether the seedlings of origin are similar in diameter is not important, and this factor is more influential outside the optimal cutting angle range.
\end{abstract}

Keywords: tomato grafting; splice grafting technique; graft angle; random diameter

\section{Introduction}

The objective of the experimental study was to determine the combined importance of random rootstock and scion diameters at different cutting angles on splice grafting success. The proposed working hypothesis suggests that both parameters have a statistically significant relationship with grafting success and an optimum working range can be defined to achieve successful grafts.

The experiment was developed as part of a larger study to optimize working conditions for the automation of grafting via the splicing technique. The study is autonomous and independent and presents sufficient and consistent results for the definition and specification of the splice grafting conditions that provide the most optimal results, whether performed manually or automated.

Grafting can be defined as a natural or deliberate fusion of plant parts by which vascular continuity is established [1], so that the resulting organisms function as a single plant [2].

The portion of the upper tissue or crown of a plant, which is also known as the stem or scion, adheres to another portion of the plant, specifically its root and lower part, which is commonly called rootstock, under stock or stock, and both parts come in contact and join with each other so that the resulting composite plant grows and develops as a single organism (graft). The callus corresponds to 
the mass of parenchyma cells that develop from the plant tissue of the scion and the rootstock around the wound and where the development of vascular connections of the resulting graft union occurs [3].

Reducing the impact of pathogens is a challenge in all agricultural production systems [4], and monocultures are even more vulnerable than more diversified agricultural production systems [5]. Thus, grafting has become a tool of enormous potential to quickly enhance the efficiency of modern vegetable cultivars to promote wider adaptability or resistance to different stress situations [6].

The sequence of structural and biological events that occur in the development of a compatible graft between plants has been described in many studies, and the following development pattern is observed in which three fundamental phases can be distinguished: fusing of the rootstock and scion; proliferation of the callus around the union; and vascular re-differentiation through the interface establishing continuity between rootstock and scion $[1,3,7,8]$ :

1. The meristematic tissues of the stem are placed in direct contact with the tissues of the rootstock. Once both components of the graft are in intimate contact, cambium cells from the rootstock and the scion produce parenchyma cells that fuse forming a callus tissue [9]. This first phase of cohesion that forms the callus is a reaction similar to wound healing, and it does not require recognition between rootstock and scion, occurring in both compatible and incompatible grafts.

2. If the graft is compatible, a differentiation of certain vessels and sieve tube elements of the phloem is observed in the callus, and they are not derived from the cambium and constitute the first transitional and continuous union between the rootstock and the scion.

3. In the last part of the grafting process, the cambium layer newly formed in the bridge of the callus begins its own meristematic tissue activity, thus forming new vascular tissue. Production of these new vascular elements that join xylem and phloem allows establishing a symplastic communication between rootstock and scion [1].

The success of the graft performed with a variety of compatible seedlings is determined by the three events previously described, assuming an important role of the plant hormones related to growth, such as auxin, in the grafting process [10]. Thus, the graft may originate from a combined mechanism of wound healing and conductive vessels formation [11]. Therefore, vascular connection is the last event in a successful healing process and represents the most important event because once such a vascular connection is established, water and solute transport begins from the stock to the scion, and the mechanical strength at the graft union increases [7,12]. One difficulty is to understand when the grafting process is completed [13], since a simple technique for continuous evaluation of graft development is not available [14]. Nonetheless, the assessment can be based on various techniques, including destructive and non-destructive techniques as follows:

(1) Visual estimation of the constituent seedlings and the appearance of graft growth [15]; (2) thermal camera imagery because the temperature of the leaves is 2 to $3{ }^{\circ} \mathrm{C}$ lower than that in a failed graft due to the transpiration of a successful graft [16]; (3) vertical cut performed on the graft surface and observation of the curvature of the vascular system formed at the union [17]; (4) measurement of the electrical resistance transferred from the scion to the rootstock through the surface area of its connection, which undergoes variations associated with histological changes during the union of the rootstock and the scion [14]; (5) assay performed to evaluate the tensile strength of the graft and analyse the strength of the graft union between rootstock and scion until breaking [18,19]; (6) displacement transducers used to perform a continuous and non-disruptive evaluation of the functional hydraulic connections within the plant [20]; and (7) NMR-based method (Nuclear magnetic resonance), that reveals water flux vectors inside individual vessels of intact plants [21].

The tomato is one of the world's most important herbaceous crops [22], and grafting of tomato plants is a widespread practice. Grafting methods among seedlings vary greatly and considerably depending upon the type of crops, farmer's experience and preferences, availability of facilities and machines, the number of grafts to perform and even the purpose and destination of the grafts, i.e., whether they are for the farmer's own uses or for sale and commercial distribution [23]. Grafting is 
a common practice among herbaceous crops, and its use for Solanaceae is highlighted as follows: cleft or split grafting [21,24], splice or tube grafting [25,26], plug-in grafting [27], double-stem grafting [28,29], or pin grafting [15,30], among others.

Splice grafting, also known as tube grafting, top grafting or slant cut grafting, is the most popular [31] and widely used technique for tomato as well as eggplant [32]. The rootstock is cut below the cotyledons, thus eliminating the need to continually eliminate the sprouting of the stock over the plant's life [33]. The scion is also slant cut on a complementary angle above the cotyledons. Both parts are then placed in contact and secured by means of a tube or elastic tube-shaped clip with side slit. This method has the disadvantage of being highly demanding in terms of post-grafting microclimatic conditions, which require meticulous timing and delicate handling after the cut until healing and the maintenance of optimal temperature and humidity conditions to stimulate rooting [34]. As an advantage, the splicing method allows grafting with smaller plants, which reduces the pre-graft cultivation time and takes up less space in cultivation chambers and nurseries [35].

Velasco [12] and Villasana [36] affirmed that successful grafting is contingent upon similar stem diameters and the alignment of the vascular cambium area. However, such claims are dependent on the effect that the seedling diameter variable has on grafting success and do not consider the interrelated influence of other parameters and constraints of the grafting process.

For studying the success or failure of splice grafting, Yamada [37] established three factors of importance for its execution: (a) area of the cut surface; (b) gripping force of the union clip; and (c) smoothness of the cut surface and sharpness of the blade. For the first factor, allusive to the coincidence rate between seedlings, from coincidences of $50 \%$ graft successes of over $85 \%$ were achieved, and up to $95 \%$ success rates were observed for alignments over $80 \%$; all this referred exclusively to a test angle of $30^{\circ}$, so these results were obtained regardless of the effect of the cutting angle on the success of the process.

Furthermore, although the number of vascular bundles does not affect the grafting success, differences in diameters between the rootstock and the scion [38], that mark the alignment between them do have an effect. Thus, when a graft is performed, it is important to increase the chances that the vascular bundles from the rootstock and the scion come in direct contact, maximizing the area of the cut surfaces that are joined by pressing them together [39].

For manual and automated grafting, the alignment of diameter of both seedlings must be identified, classified, and visually paired. This is an expensive and arduous task that applies a series of calibrations and visual comparison criteria based on morphological characteristics, which may be subjective and susceptible to human error [40,41]. The present study analyses the importance of these pre-grafting tasks based on grafting success and whether an optimal working zone can be established that guarantees adequate grafting success without having to pre-sort the seedlings.

\section{Materials and Methods}

\subsection{Definition of Operating Conditions}

The experimental study was carried out at the Tenova Technological Center: Foundation for Auxiliary Technologies for Agriculture (Centro Tecnológico Tecnova: Fundación para las Tecnologías Auxiliares de la Agricultura) in Almería between March and June 2017. Almería's surroundings correspond to a model of agricultural exploitation of high technical and economic performance of greenhouse herbaceous fruit crops, especially for the tomato crop (Figure 1). 


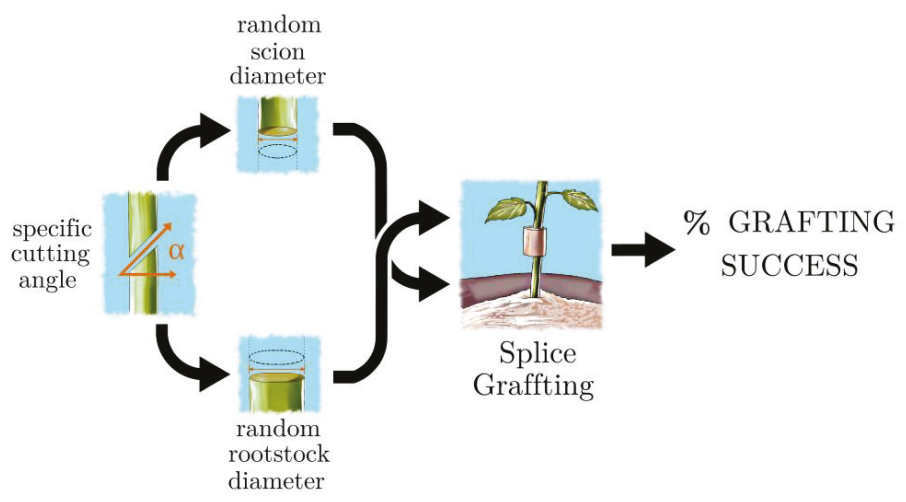

Figure 1. Working procedure of the experimental study to determine the combined importance of random rootstock and scion diameters at different cutting angles on splice grafting success.

For the study, rootstocks of the interspecific hybrid KNVF (L. esculentum $x$ L. hirsutum) were used since it is the most used stock for tomato grafting [42-44]. The commercial rootstock Maxifort was used because of its strong roots and vigour and good performance at lower temperatures and in high salinity conditions. It presents high resistance (HR): ToMV: 0-2/Fol: 0,1/For/PI/Va: $0 / \mathrm{Vd}: 0$; intermediate resistance (IR): $\mathrm{Ma} / \mathrm{Mi} / \mathrm{Mj}$ [45]. Likewise, the Ventero variety has been used as a grafting scion as an indeterminate tomato hybrid for truss harvesting, and it presents medium vigour, with good foliar coverage, very uniform fruits, slightly flattened of good red colour and deep shine, very good cracking and micro-cracking tolerance, and compact and well-formed clusters. It presents high genetic resistance (HR): ToMV: 0-2/Ff: B, D/Fol: 0,1/Va: 0/Vd: 0; and intermediate resistance (IR): TYLCV $/ \mathrm{Ma} / \mathrm{Mi} / \mathrm{Mj}$ [39]. Both varieties are commonly used for manual grafting using the "tomato on tomato" (ToT) splicing technique, which demonstrated their compatibility prior to the experiment.

The working environment during the study was maintained under stable and controlled environmental conditions throughout all grafting experiments, with temperatures oscillating between $20^{\circ}$ and $25^{\circ}$, relative humidity conditions occasionally forced between $75 \%$ and $90 \%$ and stable brightness conditions of natural in-direct light. Oda [39] indicated that grafting must be performed in the shade in an area protected from the wind and the sun to avoid wilting of grafted seedlings. Grafting was performed at the lowest period of plant transpiration during morning hours [46], between $8 \mathrm{~h}$ and $12 \mathrm{~h}$ to maintain transpiration similar among the experiments and at the time period when the transport of water from the roots to the leaves is slowest, which makes the graft less susceptible to water stress and therefore to water loss. Other parameters with possible influence, such as atmospheric $\mathrm{CO} 2$ and other air contaminants, were not been controlled.

In the nursery, the plants were cultivated and attended to from sowing until 25 to 35 days after, and the scions were sown 2 to 5 days before the rootstock seeds. This variability of days is determined by the growth rate since different plants require different germination periods [47], and such periods are directly related to climatic conditions of the month of growing.

For the experiment, the plants were considered mature and ready for grafting when they had 2 to 4 well-defined true compound leaves [32], preferably with little foliage, thus decreasing the transpiration demand and post-grafting stress. The peat root ball remained wet but not soggy at all times during the grafting process, thus ensuring proper root respiration. The substrate used was $80 \%$ black peat with $10 \%$ perlite and $10 \%$ mulch. The experiments were always conducted with seedlings whose stems were still green and tender (herbaceous and non-woody). 
For the splicing method, the seedling stems diameters should be at least $1.5 \mathrm{~mm}$ [48], and not too thick but with some natural and random variation. In the study, the diameters in the area close to the cut have varied from 1.5 to $2.5 \mathrm{~mm}$ for the scion and 2 to $3 \mathrm{~mm}$ for the rootstock.

The matching of the rootstock and scion samples was established randomly among plants that were healthy, had an acceptable anatomy and growth and presented diameters between the established reference limits. Seedlings with anomalous growth and diameters outside the established range were discarded. Diameters were measured using a digital calliper with a resolution of $1 \mathrm{dmm}(0.1 \mathrm{~mm})$ and repeatability of $1 \mathrm{dmm}$ in the areas close to where the cut was performed both for the rootstocks and for the scions. The cut in the rootstock was always performed below the cotyledons, whereas the cut in the scion was performed above the cotyledons.

The complete experiment consisted of 10 individual events of 150 grafts each distributed over 4 months. Each graft consisted of 10 series of 15 grafts per tested angle. Therefore, 10 representative angles of the possible cutting range were selected: $0^{\circ}, 10^{\circ}, 20^{\circ}, 30^{\circ}, 40^{\circ}, 50^{\circ}, 60^{\circ}, 70^{\circ}, 80^{\circ}$ and $85^{\circ}$. Once each of the experiments was performed, grafts were grouped for healing on a single grafting tray of $15 \times 10$ cells, placing each group of grafts of a given angle in each of the 10 rows of the tray. Each of the grafted plants was rotated within their row for every tested angle eliminating in this way the position factor and its possible effects (ventilation and luminosity among others).

\subsection{Device Description}

For the experiment, two seedling-cutting machines were implemented to ensure the accuracy of the cutting angle required for each test and the integrity of the dissected seedling. The machines were similar and complementary to each other, where one was designated for cutting the rootstock and the other for cutting the scion. Each of the machines had a double acting dual rod cylinder, model CXSM15-15 by SMC, which operated at 3.5 bars and used dry-pressed air to produce a clean bisection of the seedling via a stainless steel cutting blade (type BA-160-9 mm from NT Cutter) that can be attached as a tip and is interchangeable with an adjustable inclination angle, thus providing optimal sharpness (Figure 2). To ensure a clean cut, the machine has a fitting notch adapted to accommodate the seedling, ensuring the verticality of the stem ahead of the blade and another notch fitted for the blade at each cutting angle. The blade was replaced prior to each experiment (150 grafts per blade), and it was below the limit of 5000 grafts per blade established by Yamada [35], who determined that as the number of cuts per blade increases, the roughness of the cutting area becomes notable, thus reducing the grafting success. Before each use, the blade was cleaned and disinfected as Bumgarner suggests by soaking in alcohol [45], exposure to flame and air drying.

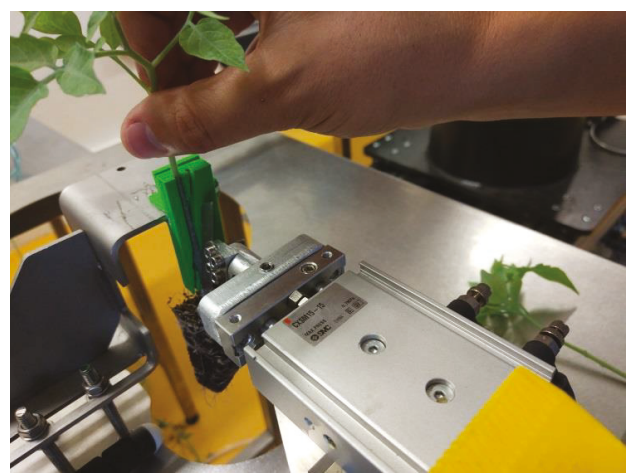

Figure 2. Cutting device. As can be seen, a fitting device is used to guarantee or ensure the verticality of seedling in the cutting process, beside a groove for insertion of the cutting blade. A specific fitting device for each cutting angle was developed. Once inserted, the seedling is disectioned in two by a sharp blow of the sharp blade. 
The union of the seedlings cut by the machines was executed manually using the traditional splice grafting technique described by Oda [49] and expanded on by DeMiguel [33]. For this, plastic grafting clips of different lengths were used according to the tested angles. Clips were cut from a continuous flexible transparent plastic roll and outfitted with lateral wings for opening and placement to allow for easy observation of the success or failure of the graft. The clip diameter was less than $3 \mathrm{~mm}$, and the shape was slightly oval, which guaranteed a better grip when the rootstock and scion diameters were unequal. Grafting clips that were too long inhibited the attached graft union, and clips that were too short exerted too much pressure and deformed the graft union [50].

Manual handling of the seedlings was always performed after thorough washing with antibacterial soap. Direct contact with the wounds was constantly avoided. Once grafted, the plants were placed on the tray and introduced into a healing chamber, similar to a small acclimatization tunnel as described by Oda [51]. This chamber was itself placed inside a larger growth chamber that allows for the appropriate basic environmental conditions as follows: $14 \mathrm{~h}$ photoperiod and a daily light integral (DLI) of $\approx 100 \mu \mathrm{mol} \cdot \mathrm{m}^{-2} \cdot \mathrm{s}^{-1} \mathrm{PAR},(\sim 3000 \mathrm{Lux})$ of indirect diffuse light during the callus development stage [52,53], temperature of $26^{\circ} \mathrm{C}$ and relative humidity of $95 \%$.

After the trays were transferred to the chamber, the plants were not manipulated or moved for 3 full days so that the natural healing process was not disturbed. From the fourth day of the graft, the first individual plant by plant visual inspection was conducted inside the chamber. This inspection was routinely repeated during the following days from the $4^{\circ} \mathrm{DAG}$ (day after the graft) until the $9^{\circ}$ DAG to assess changes and the healing process in each plant and therefore the success or failure of the graft. During this period and from the $6^{\circ} \mathrm{DAG}$, the environmental conditions of the chamber were gradually relaxed, acclimatising to external environment, and the inside chamber was opened to decrease the humidity and temperature, acording to outside. Between the $10^{\circ} \mathrm{DAG}$ and the $14^{\circ}$ DAG, the plants were eventually removed from the growth chamber and allowed to develop without being transplanted.

While the rootstock and scion establish a vascular connection during the first days [54], at least 14 days are needed for the graft union to heal completely and be considered functional. After 14 DAG of performing daily observations for each experiment, the experiment was ended. Grafts that did not survive the healing process within the stipulated period were considered failures.

The success or failure of the graft has been evaluated by daily visual estimations and observations that evaluated the development of the graft and analysed other external symptoms and evidence, such as physiological abnormalities or signs of wound healing and scarring. Symptoms of internal failure generally precede those of external failure [55]. If the graft is successful, evident progress is generally seen from the wilt stage to greater vigour in the aerial part of the graft, which is reflected in a palpable recovery and associated with a gradual disappearance of signs of dehydration, which implies that adequate vascular continuity has been generated among the elements of the xylem. In addition, this factor is accompanied with the occurrence of axillary buds in the aerial part, thus indicating that the graft is successful and the resulting plant is functional. These factors are used to determine whether the graft is successful. Regardless, the behaviour and subsequent evolution of the grafts continue to be evaluated until 14 DAG to corroborate and validate the evolution of the natural healing process of the graft (Figure 3). 


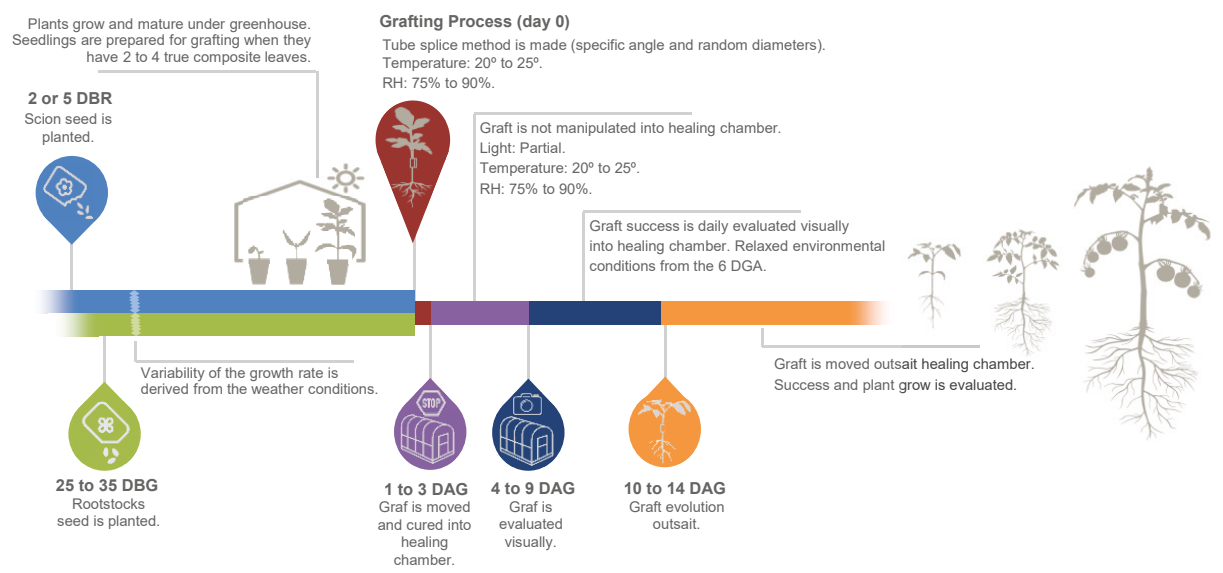

Figure 3. Timeline of the grafting process developed. DBR (days before rootstock has been planted). DBG (days before grafting process). DAG (days after grafting process).

\section{Results and Discussion}

The results of the 1500 individual experiences were collected and grouped polytomously in 10 sections of equal height to compare the cutting angle and differences in diameter of rootstock and scion and to evaluate the grafted plant survival for each case.

The data analysis process included two stages: the first phase consisted of conducting a descriptive analysis of the data distribution and their correlation through the application of One-way ANOVA for Randomized Complete Block Design (RCBD ANOVA), and the second phase consisted of a two-way analysis of variance in which only one sample per group was run, and the results were then assessed by a post-hoc comparison test, such as Student's $t$-test.

\subsection{Data Analysis: Descriptive Statistics}

An analysis of the experimental results showed that the effect of variations in diameter on the grafting success decreases as the grafting angle increases, and the differences are nearly negligible in the range between $50^{\circ}$ and $80^{\circ}$ and between $60^{\circ}$ and $80^{\circ}$, where percentage changes between the grafted seedling and the successful graft were maintained at an overall success rate of greater than $90 \%$ or even greater than $95 \%$, respectively. This finding confirms that for greater angles, the success probability depends less on the diameter of the seedlings. From $80^{\circ}$ onward, successful execution of the graft began to be materially more complicated due to two factors: physical limitations related to the technology used for the cutting and subsequent union of the seedlings; and the exponential increase in the sectioned surface that was directly related to the tangent of the cutting angle, which determined both the exposed surface and the rigidity and firmness of the structure of the dissected and subsequently joined seedlings.

Grouped data confirm that independent of section variation among the seedlings of origin, a working zone between $50^{\circ}$ and $80^{\circ}$ offers good results in terms of graft success (Figure 4). 


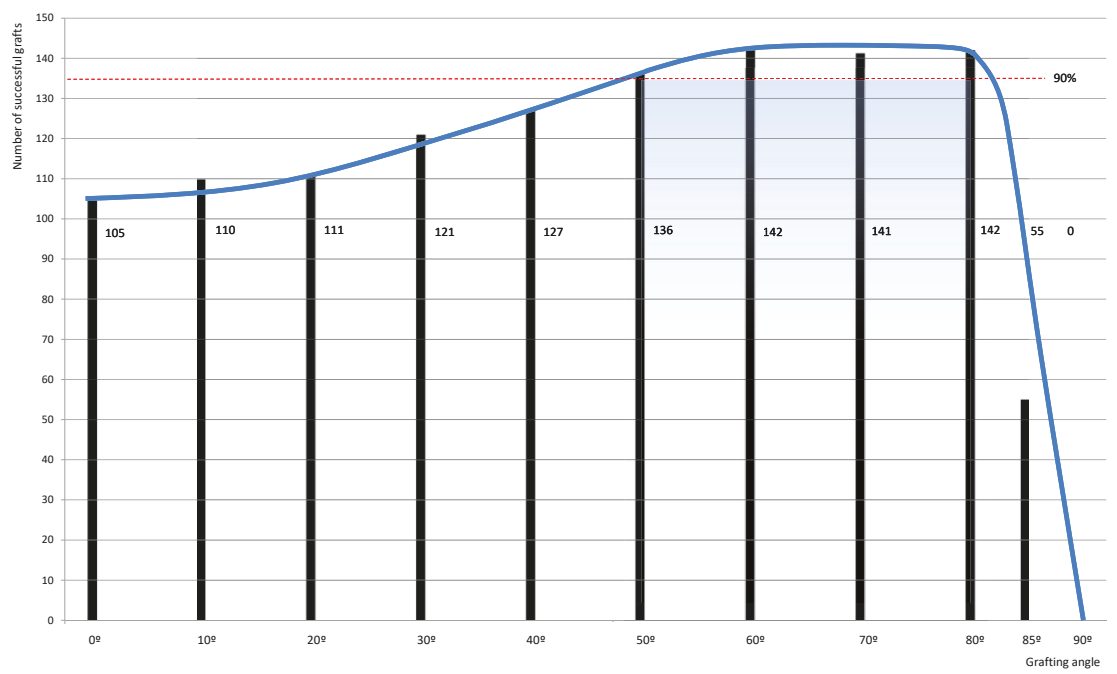

Figure 4. Distribution of successful grafts according to different cutting angles. It can be seen that the zone between $50^{\circ}$ and $80^{\circ}$ (blue zone), has a success rate higher than $90 \%$, so we can consider it an optimal work zone. This graph represents the absolute number of successes for each cutting angle, without considering the variable of difference between diameters.

Having studied the diametric differences with respect to grafting angles, it is apparent that at small cutting angles and with highly variable diameters, the failure probability is high, and success was not observed, while at larger cutting angles, success associated with high diametric differences was recorded. A slightly greater range between quartiles is observed at angles between $50^{\circ}$ and $70^{\circ}$, which indicates a greater tolerance to variable diameters during the grafting process (Figure 5).

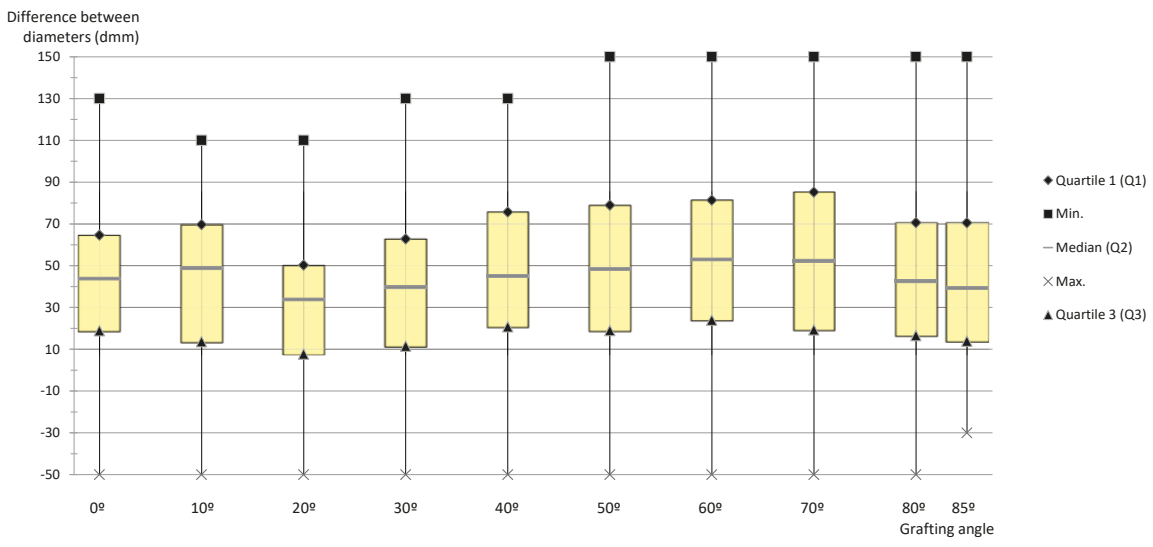

Figure 5. Distribution of successful grafts according to the differences between diameters of plants for each angle of union. This graph represents the density function of successes for each cutting angle $\left(1 \mathrm{dmm}\right.$ is a tenths of a millimeter, $\left.10^{-4} \mathrm{~m}\right)$. A slightly greater amplitude between quartiles is appreciable at angles between $50^{\circ}$ and $70^{\circ}$ degrees, which indicates a greater tolerance in this range to the disparity of diameters.

The combined representation of cutting angle and diameter differences between plants versus the success of the graft provide evidence of the combined effect that both factors have on the successful 
execution of the graft. This representation has been developed through the use of the software Surfer12 and the Local Polynomial gridding method for the interpolation of points of the spatial matrix, which only uses points within the defined neighbourhood and adjusts the matrix to a first-order polynomial to the power of two. Polynomial interpolation allows us to create a uniform surface and identify long-range trends in the data set (Figure 6).

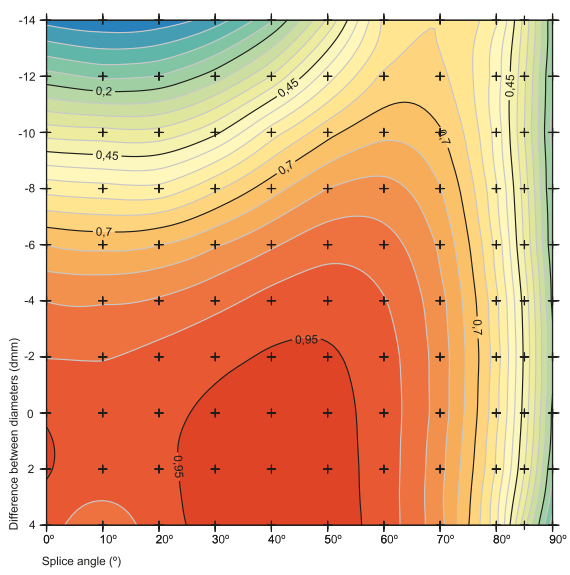

(a)

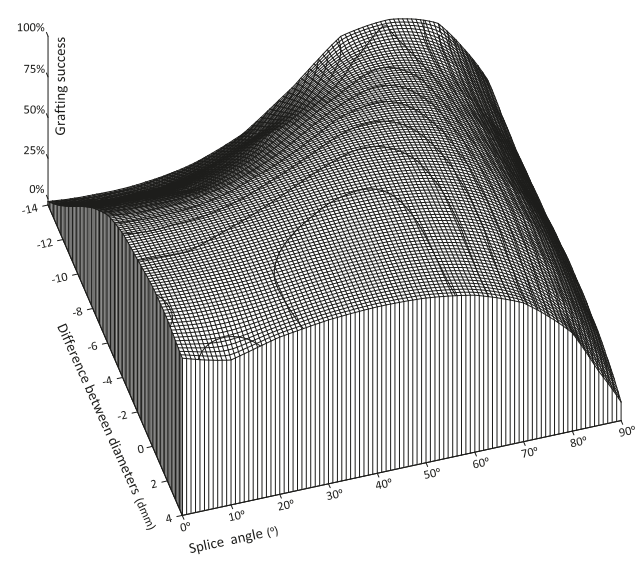

(b)

Figure 6. Graphical representation of the combined influence of cutting angle and diameter differences between seedlings on the grafting success of tomato using the splice grafting thecnique. These graphs represent the successes for each concrete difference of diameters, associated to each angle of union $\left(1 \mathrm{dmm}\right.$ is a tenths of a millimeter, $10^{-4} \mathrm{~m}$ ). Results represented by the Local Polynomial Gridding Method (Polynomial Order 1, Power 2). (a) Coloured contour diagram of successful grafts (\%), as a function of cutting angle $\left(^{\circ}\right)$ and difference between diameters of grafted $(\mathrm{dmm}) ;(\mathbf{b}) 3 \mathrm{D}$ wireframe of successful grafts (\%), as function of cutting angle $\left(^{\circ}\right)$ and difference between diameters of grafted (dmm).

At small differences in diameter, the success rate is high for cutting angles between $30^{\circ}$ and $60^{\circ}$, whereas when this difference between diameters increases, the maximum values move to values between $50^{\circ}$ and $70^{\circ}$, and the percentage of success gradually decreases.

One of the possible causes that justify grafting success within this range of working angles is the exponential increase of the contact surface, which increases in equal measure the possibility of matching between vascular bundles arranged in a circle around the stem [34]. Effective contact depends on the surface and arrangement of the bundles in the two plants that are grafted; therefore, at a larger cutting surface with an appropriate arrangement and matching of the seedlings, a greater area of contact is observed. Thus, this range of graft angles between $50^{\circ}$ and $70^{\circ}$ is associated with a decrease in failure and substantially less importance and influence of uniformity in stem diameter between both plants on grafting success.

By increasing the difference between the sections at the point of union and at greater graft angles, the area of contact surface increases exponentially, thus increasing the probability of vascular correlation. Moreover, for uncovered surfaces, the area remaining outside the contact area is exposed to pathogens, such as bacteria and fungi, which cause the graft to fail [56]. In addition, greater stress associated with scarring is evident based on the proliferation of a larger callus in response to the wound. As the cutting angle approaches $90^{\circ}$, the successful execution of the graft begins to become more mechanically complicated due to the technology used in the process and the firmness of the 
dissected seedling themselves. In addition, the uncovered or unmatched surface between the seedlings increases excessively.

Therefore, when significant differences in diameter occur between the rootstock and the scion, the probability of failure is higher at small cutting angles close to horizontal, while the probability of success is higher at similar diameters. This correlation reflects the farmer's own practice and experience and represents a frequently observed factor that is directly related to the success of the graft as observed in the first known publication referring to seedling grafting for herbaceous crops, which indicated that seedlings with similar diameters should be selected [57]. However, subsequent studies have corroborated the direct relationship between the cutting angle and the success of the graft [19], which supports the premise that seedlings should have similar diameters in the cutting zone. Zhao [58] stated that expanding the area of contact between the rootstock and scion is the key to graft survival.

\subsection{Data Analysis: ANOVA}

The experimental results for grafting success were tested via two-way ANOVA of the cutting angle and diameter difference, where each of these factors has been grouped into 10 blocks, with a single sample or repetition per group (ANOVA). The randomized complete block design (RCBD ANOVA) analysis technique used as the usual standard for agriculture was used, where similar experimental units were grouped into blocks. We consider $\alpha=0.05$ (95\% confidence level). The statistical package Real Statistics Resource Pack 5.8 in Microsoft Excel 2010 was used for the study. Analysis of variance was performed to answer the following general research question (RQ): Are statistically significant differences observed between the means of grafting success for different cutting angles and different diameters between seedlings? (Tables 1 and 2).

Table 1. Analysis of variance of two factors without replication. Factor 1: the difference between the rootstock and scion diameters, where the positive values represent a larger diameter of the rootstock and the negative ones a larger diameter of the scion. Factor 2: cutting angles of the seedlings.

\begin{tabular}{ccccc}
\hline \multicolumn{5}{c}{ Analysis of Variance of Two Factors without Replication } \\
\hline Summary & Count & Sum & Mean & Variance \\
\hline 15 to $13 \mathrm{dmm}$ & 10 & 3.3333 & 0.3333 & 0.1806 \\
13 to $11 \mathrm{dmm}$ & 10 & 3.7242 & 0.3724 & 0.1253 \\
11 to $9 \mathrm{dmm}$ & 10 & 5.8789 & 0.5879 & 0.1009 \\
9 to $7 \mathrm{dmm}$ & 10 & 7.1258 & 0.7126 & 0.0589 \\
7 to $5 \mathrm{dmm}$ & 10 & 8.4487 & 0.8449 & 0.0545 \\
5 to $3 \mathrm{dmm}$ & 10 & 9.0306 & 0.9031 & 0.0202 \\
3 to $1 \mathrm{dmm}$ & 10 & 9.1009 & 0.9101 & 0.0245 \\
1 to $(-1) \mathrm{dmm}$ & 10 & 9.2110 & 0.9211 & 0.0284 \\
$(-1)$ to $(-3) \mathrm{dmm}$ & 10 & 9.2333 & 0.9233 & 0.0239 \\
$(-3)$ to $(-5) \mathrm{dmm}$ & 10 & 8.6000 & 0.8600 & 0.1071 \\
\hline Summary & Count & Sum & Mean & Variance \\
\hline $0^{\circ}$ & 10 & 6.7621 & 0.6762 & 0.1398 \\
$10^{\circ}$ & 10 & 6.3766 & 0.6377 & 0.1391 \\
$20^{\circ}$ & 10 & 6.0410 & 0.6041 & 0.1725 \\
$30^{\circ}$ & 10 & 6.9445 & 0.6945 & 0.1644 \\
$40^{\circ}$ & 10 & 7.5000 & 0.7500 & 0.1405 \\
$50^{\circ}$ & 10 & 8.5650 & 0.8565 & 0.0645 \\
$60^{\circ}$ & 10 & 9.5815 & 0.9582 & 0.0031 \\
$70^{\circ}$ & 10 & 9.1847 & 0.9185 & 0.0117 \\
$80^{\circ}$ & 10 & 9.4521 & 0.9452 & 0.0022 \\
$85^{\circ}$ & 10 & 3.2792 & 0.3279 & 0.0326 \\
\hline
\end{tabular}


Table 2. Combined influence of the cutting angle and the difference betwen diameters in graft success. All statistical analyzes were done using a significance factor of $95 \%(p \leq 0.05)$. ANOVA summary tables ( $1 \mathrm{dmm}$ is a tenths of a millimeter, $10^{-4} \mathrm{~m}$ ). The result of the analysis ANOVA (two factors without replication) indicates that the statistical value of " $F$ " is much higher than the critical value for " $F$ " for both factors: angles and differences between diameters. Therefore, we can assure that the results of our tests are significant.

\begin{tabular}{ccccccc}
\hline \multicolumn{1}{c}{ ANOVA } \\
\hline $\begin{array}{c}\text { Sourface of } \\
\text { Variation }\end{array}$ & $\begin{array}{c}\text { Sum of } \\
\text { Squares }\end{array}$ & $\begin{array}{c}\text { Degrees of } \\
\text { Freedom }\end{array}$ & $\begin{array}{c}\text { Mean of the } \\
\text { Squares }\end{array}$ & F & $\begin{array}{c}\text { Probability } \\
\text { Value }\end{array}$ & $\begin{array}{c}\text { Critical } \\
\text { Value for F }\end{array}$ \\
\hline $\begin{array}{c}\text { Diameter difference } \\
\text { Cutting angle }\end{array}$ & 4.7160 & 9.0000 & 0.5240 & 13.6138 & 0.0000 & 1.9976 \\
Error & 3.4002 & 9.0000 & 0.3778 & 9.8154 & 0.0000 & 1.9976 \\
\hline Total & 3.1178 & 81.0000 & 0.0385 & & & \\
\hline
\end{tabular}

After running the ANOVA analysis, the null hypotheses $\mathrm{H} 0$ were rejected for both cases, and the alternative hypotheses Hi were accepted. Therefore, confirmable cases of significant differences between success means and cutting angles and seedling diametric differences were observed with a 95\% confidence. To compare the differences, post-hoc rank tests were conducted to determine which means differ from each other. Student's $t$-type comparison tests (RCBD ANOVA and $t$-test) were performed (Table 3).

Table 3. Comparison of means differences between angles using Student's $t$-test ( $t$-test). Use of contrasts to determine whether there is a significant difference $(p \leq 0.05)$.

\begin{tabular}{|c|c|c|c|c|c|c|c|c|c|c|}
\hline & $0^{\circ}$ & $10^{\circ}$ & $20^{\circ}$ & $30^{\circ}$ & $40^{\circ}$ & $50^{\circ}$ & $60^{\circ}$ & $70^{\circ}$ & $80^{\circ}$ & $85^{\circ}$ \\
\hline $0^{\circ}$ & & $\mathrm{N}$ & $\mathrm{N}$ & $\mathrm{N}$ & $\mathrm{N}$ & $\mathrm{Y}$ & $\mathrm{Y}$ & $\mathrm{Y}$ & $\mathrm{Y}$ & $\mathrm{Y}$ \\
\hline $10^{\circ}$ & & & $\mathrm{N}$ & $\mathrm{N}$ & $\mathrm{N}$ & $Y$ & Y & $Y$ & Y & Y \\
\hline $20^{\circ}$ & & & & $\mathrm{N}$ & $\mathrm{N}$ & $Y$ & $Y$ & $Y$ & $Y$ & $\mathrm{~N}$ \\
\hline $30^{\circ}$ & & & & & $\mathrm{N}$ & $\mathrm{N}$ & $\mathrm{N}$ & $\mathrm{N}$ & $\mathrm{N}$ & Y \\
\hline $40^{\circ}$ & & & & & & $\mathrm{N}$ & $\mathrm{N}$ & $\mathrm{N}$ & $\mathrm{N}$ & Y \\
\hline $50^{\circ}$ & & & & & & & $\mathrm{N}$ & $\mathrm{N}$ & $\mathrm{N}$ & $Y$ \\
\hline $60^{\circ}$ & & & & & & & & $\mathrm{N}$ & $\mathrm{N}$ & $Y$ \\
\hline $70^{\circ}$ & & & & & & & & & $\mathrm{N}$ & $Y$ \\
\hline $80^{\circ}$ & & & & & & & & & & Y \\
\hline $85^{\circ}$ & & & & & & & & & & \\
\hline
\end{tabular}

Significant differences in the mean grafting success values were not observed for similar angles, whereas clearly significant differences were observed when larger angles were compared, especially for angles equal to $20^{\circ}$ or less and angles equal to $50^{\circ}$ or greater. A cutting angle of $85^{\circ}$ produced significant differences in the mean grafting success compared with most angles, including angles close to each other and distant, since the response of grafting success to cutting angle was random and irregular (Table 4).

Variations in the diameters of grafting seedlings greater than $90 \mathrm{cmm}$ produced significant differences in the mean success with respect to the other variations in diameter, which may be due to a random and unpredictable response to the success of the graft from these diametric differences. The remaining variations in diameters below $90 \mathrm{cmm}$ did not produce significant differences between their success means. 
Table 4. Comparison of means differences between diameter of seedlings using Student's $t$-test ( $1 \mathrm{dmm}$ is a tenths of a millimeter, $10^{-4} \mathrm{~m}$ ). Use of contrasts to determine whether there is a significant difference $(p \leq 0.05)$.

\begin{tabular}{|c|c|c|c|c|c|c|c|c|c|c|}
\hline & 15 to $13 \mathrm{dmm}$ & 13 to $11 \mathrm{dmm}$ & 11 to $9 \mathrm{dmm}$ & 9 to $7 \mathrm{dmm}$ & 7 to $5 \mathrm{dmm}$ & 5 to $3 \mathrm{dmm}$ & 3 to $1 \mathrm{dmm}$ & $\begin{array}{c}\text { to }(-1) \\
\text { dmm }\end{array}$ & $\begin{array}{c}(-1) \text { to } \\
(-3) \mathrm{dmm}\end{array}$ & $\begin{array}{c}(-3) \text { to } \\
(-5) \mathrm{dmm}\end{array}$ \\
\hline 15 to $13 \mathrm{dmm}$ & & $\mathrm{N}$ & $Y$ & Y & $\mathrm{Y}$ & Y & Y & Y & Y & Y \\
\hline 13 to $11 \mathrm{dmm}$ & & & Y & Y & Y & Y & Y & Y & Y & Y \\
\hline 11 to $9 \mathrm{dmm}$ & & & & Y & Y & Y & Y & Y & Y & Y \\
\hline 9 to $7 \mathrm{dmm}$ & & & & & $\mathrm{N}$ & Y & Y & Y & Y & $\mathrm{N}$ \\
\hline 5 to $3 \mathrm{dmm}$ & & & & & & & $\mathrm{N}$ & $\mathrm{N}$ & $\mathrm{N}$ & $\mathrm{N}$ \\
\hline 3 to $1 \mathrm{dmm}$ & & & & & & & & $\mathrm{N}$ & $\mathrm{N}$ & $\mathrm{N}$ \\
\hline 1 to $(-1) \mathrm{dmm}$ & & & & & & & & & $\mathrm{N}$ & $\mathrm{N}$ \\
\hline $\begin{array}{c}(-1) \text { to }(-3) \\
\text { dmm }\end{array}$ & & & & & & & & & & $\mathrm{N}$ \\
\hline
\end{tabular}

\section{Conclusions}

A review of the scientific literature suggests that the success of the splice grafting process increases as the cutting angle increases as long as the union is based on similarities between the stems of the grafting seedlings. However, until now, the success rate based on the interaction between the cutting angle and diameter of the seedling has not been reported.

The present study has concluded that the success of a graft depends to a great extent on the cutting angle and diameter of the seedlings, with disparities or similarities between the seedling sections playing an important role in the success of smaller cutting angles, although the stem diameter shows decreasing importance as the cutting angle increases, with the minimum influence of diameter observed within a cutting angle range of $50^{\circ}$ and $70^{\circ}$.

Consequently, using the splicing technique with a cutting angle between $50^{\circ}$ and $70^{\circ}$ can lead to a substantial improvement of grafting conditions and techniques and can eliminate, to some extent, the random factor of differences between diameters as well as the pre-selection and matching requirements for sections between seedlings, thereby simplifying the demands for manual, automated and robotized grafting systems.

Author Contributions: J.-L.P.-A. conceived and designed the experiments, performed the experiments, collected, analyzed the data and interpreted the results, and developed the manuscript. A.C.-O. conceived and designed the experiments, analyzed the data, interpreted the results, and developed the manuscript. C.-C.M.-G. conceived and designed the experiments and performed the experiments. A.-J.C.-F. provided constructive suggestions on experiment analysis.

Acknowledgments: This study was supported by Tenova, Technological Center: Foundation for Auxiliary Technologies for Agriculture. The authors would like to acknowledge to all the employees involved for their contributions to experimental setting and data collection.

Conflicts of Interest: The authors declare no conflict of interest.

\section{References}

1. Pina, A.Y.; Errea, P. A review of new advances in mechanism of graft compatibility-incompatibility. Sci. Hortic. 2005, 106, 1-11. [CrossRef]

2. Mudge, K.; Janick, J.; Scoffield, S.; Goldschmidt, E.E. A history of grafting. Hortic. Rev. 2009, 35, 437-494. [CrossRef]

3. Hartmann, H.T.; Kester, D.E.; Davies, F.T.; Geneve, R.L. Principles of grafting and budding. In Plant Propagation. Principles and Practices, 8th ed.; Pearson: London, UK, 2010; Chapter 11; ISBN 978-0-13-501449-3.

4. Hartman, G.; Pawlowski, M.; Herman, T.; Eastburn, D. Organically Grown Soybean Production in the USA: Constraints and Management of Pathogens and Insect Pests. Agronomy 2016, 6, 16. [CrossRef]

5. Diacono, M.; Persiani, A.; Fiore, A.; Montemurro, F.; Canali, S. Agro-Ecology for Potential Adaptation of Horticultural Systems to Climate Change: Agronomic and Energetic Performance Evaluation. Agronomy 2017, 7, 35. [CrossRef]

6. Pradeep, K.; Youssef, R.; Mariateresa, C.; Giuseppe, C. Vegetable Grafting as a Tool to Improve Drought Resistance and Water Use Efficiency. Front. Plant Sci. 2017, 8, 1130. 
7. Moore, R. A model for graft compatibility-incompatibility in higher plants. Am. J. Bot. 1984, 71, 751-758. [CrossRef]

8. De Miguel, A.; Cebolla, V. Terralia 53, Pages 50-60. Octubre 2005. Unión del Injerto. Available online: https:/ / www.terralia.com/terralias/view_report?magazine_report_id=365 (accessed on 1 September 2018).

9. Acosta Muñoz, A. La Técnica del Injerto en Plantas Hortícolas. Horticom (Extra Viveros I), Extra 2005. pp. 62-65. Available online: http:// bit.do/eAgQc (accessed on 15 September 2018).

10. Saravana Kumar, R.M.; Gao, L.X.; Yuan, H.W.; Xu, D.B.; Liang, Z.; Tao, S.C.; Guo, W.B.; Yan, D.L.; Zheng, B.S.; Edqvist, J. Auxin enhances grafting success in Carya cathayensis (Chinese hickory). Planta 2018, 247, 761-772. [CrossRef]

11. Melnyk, C.W. Plant grafting: Insights into tissue regeneration. Regeneration 2017, 4, 3-14. [CrossRef]

12. De Velasco Alvarado, M.J. Tesis: Anatomía y Manejo Agronómico de Plantas Injertadas en Jitomate. Universidad Autónoma de Chapingo (Mexico), 2013. Available online: https:/ / chapingo.mx/horticultura/ pdf/tesis/TESISMCH2013050810128186.pdf (accessed on 15 September 2018).

13. Leonardi, C.; Romano, D. Recent issues on vegetable grafting. Acta Hortic. 2004, 631, 163-174. [CrossRef]

14. Yang, S.; Xiang, G.; Zhang, S.; Lou, C. Electrical resistance as a measure of graft union. J. Plant Physiol. 1993, 141, 98-104. [CrossRef]

15. Bletsos, F.A.; Olympios, C.M. Rootstocks and Grafting of Tomatoes, Peppers and Eggplants for Soil-borne Disease Resistance, Improved Yield and Quality. 2008. Available online: http://www.globalsciencebooks.info/Online/ GSBOnline/images/0812/EJPSB_2(SI1)/EJPSB_2(SI1)62-73o.pdf (accessed on 15 September 2018).

16. Torii, T.; Kasiwazaki, M.; Okamoto, T.; Kitani, O. Evaluation of graft-take using a thermal camera. Acta Hortic. 1992, 319, 631-634. [CrossRef]

17. Oda, M.; Maruyama, M.; Mori, G. Water Transfer at Graft Union of Tomato Plants Grafted onto Solanum Rootstocks. J. Jpn. Soc. Hortic. Sci. 2005, 74, 458-463. [CrossRef]

18. De Miguel, A.; Cebolla, V. Terralia 53, Pages 50-60. Octubre 2005. Unión del Injerto.

19. Bausher, M.G. Road, South Rock, Pierce, Fort Graft Angle and Its Relationship to Tomato Plant Survival. Hort Sci. 2013, 48, 34-36. Available online: http://hortsci.ashspublications.org/content/48/1/34.short (accessed on 15 September 2018).

20. Turquois, N.; Malone, M. Non-destructive assessment of developing hydraulic connections in the graft union of tomato. J. Exp. Bot. 1996, 47, 701-707. [CrossRef]

21. Xia, Y.; Sarafis, V.; Campbell, E.O.; Callaghan, P.T. Non invasive imaging of water flow in plants by NMR microscopy. Protoplasma 1993, 173, 170-176. [CrossRef]

22. Mutisya, S.; Saidi, M.; Opiyo, A.; Ngouajio, M.; Martin, T. Synergistic Effects of Agronet Covers and Companion Cropping on Reducing Whitefly Infestation and Improving Yield of Open Field-Grown Tomatoes. Agronomy 2016, 6, 42. [CrossRef]

23. Lee, J.-M.; Kubota, C.; Tsao, S.J.; Bie, Z.; Echevarria, P.H.; Morra, L.; Oda, M. Current status of vegetable grafting: Diffusion, grafting techniques, automation. Sci. Hortic. 2010, 127, 93-105. [CrossRef]

24. Tian, S.; Xu, D. Current status of grafting robot for vegetable. In Proceedings of the 2011 International Conference on Electronic \& Mechanical Engineering and Information Technology, Harbin, China, 12-14 August 2011; Volume 4, pp. 1954-1957. [CrossRef]

25. Ito, T. Present state of transplant production practices in Japanese horticultural industry. In Proceedings of the International Symposium on Transplant Production Systems, Transplantant Production Systems, Yokohama, Japan, 21-26 July 1992; Kurata, K., Kozai, T., Eds.; Kluwer Academic Publishers: Amsterdam, The Netherlands, 1992. Available online: http:/ / www.springer.com/us/book/9780792317975 (accessed on 15 September 2018).

26. Lee, J.-M.; Oda, M. Grafting of Herbaceous Vegetable and Ornamental Crops. Hortic. Rev. 2003, 28. [CrossRef]

27. Nishiura, Y.; Murase, H.; Honami, N.; Taira, T. Devlopment of Plug-in Grafting Robotic System Osaka Prefecture University. In Proceedings of the IEEE Lnternatlonal Conference on Robotics and Automatlon, Nagoya, Japan, 25-27 May 1995; pp. 2510-2517. Available online: http://ieeexplore.ieee.org/abstract/ document/525636/ (accessed on 15 September 2018).

28. Oda, M. Grafting of Vegetable Crops. Osaka Perfecture Univ. 2002, 54, 49-72. Available online: http:/ /repository. osakafu-u.ac.jp/dspace/bitstream/10466/1053/1/KJ00000052064.pdf (accessed on 15 September 2018).

29. Oda, M. Use of Grafted Seedlings for Vegetable Production in Japan. Acta Hortic. 2008, 770, 15-20. Available online: https:/ / www.actahort.org/books/770/770_1.htm (accessed on 15 September 2018). [CrossRef] 
30. Lee, J.-M.; Bang, H.J.; Ham, H.S. Grafting of Vegetables. Jpn. Soc. Agric. Mach. Food Eng. 1998, 67, 1098-1104. Available online: https://www.jstage.jst.go.jp/article/jjshs1925/67/6/67_6_1098/_pdf (accessed on 15 September 2018). [CrossRef]

31. Singh, H.; Kumar, P.; Chaudhari, S.; Edelstein, M. Tomato Grafting: A Global Perspective. HortScience 2017, 52, 1328-1336. [CrossRef]

32. Same as 49 Miles, C.; Flores, M.; Estrada, E. Hoja de Datos de la Extensión, FS052ES. INJERTO de Verduras Berenjenas y Tomates; Washington State University: Washington, DC, USA, 2013; pp. 1-4. Available online: http:/ / cru.cahe.wsu.edu/CEPublications/FS052ES/FS052ES.pdf (accessed on 15 September 2018).

33. Same as 52 De Miguel Gómez, A. Serie Documentos: El Injerto de Plantas de Tomate. Postcosecha 2011, Www.poscosecha.com-Postharvest, Www.postharvest.biz. Available online: www.poscosecha.com/es/ publicaciones/ (accessed on 15 September 2018).

34. Alvarez, C.; Herzog, D. La técnica del injerto (Presentation by Rijk Zwaan Ibérica). Rijk Zwaan Ibérica, 2011. Available online: https:/ / es.slideshare.net/directorarica/presentacin-injerto-semilleros (accessed on 15 September 2018).

35. Oda, M. Grafting of Vegetables to Improve Greenhouse Production; Food \& Fertilizer Technology Center: Kawana, Japan, 1998; pp. 1-11. Available online: http:/ / www.agnet.org/library.php?func=view\&id=20110803135029 (accessed on 15 September 2018).

36. Villasana Rojas, J.A. Tesis: Efecto del Injerto en la Producción de Tomate (Lycopersicon esculentum Mill.) Bajo Condiciones de Invernadero en Nuevo León; Universidad Autónoma de Nuevo León: San Nicolás de los Garza, Mexico, 2010; Available online: http:/ / eprints.uanl.mx/5613/1/1080194762\%20\%281\%29.PDF (accessed on 15 September 2018).

37. Yamada, H. Research for Development of the Grafting Robot for Solanaceae. Tech. Pap. Agric. Mach. Res. Assoc. 2003, 65, 142-149. Available online: https://www.jstage.jst.go.jp/article/jsam1937/65/5/65_5_ 142/_pdf/_char/ja (accessed on 15 September 2018).

38. Oda, M.; Tsuji, K.; Sasaki, H. Effect of Hypocotyl Morphology on Survival Rate and Growth of Cucumber Seedling Grafted on Cucurbita ssp. Japan Agricultural Research Quarterly. 1993. Available online: http: //www.jircas.affrc.go.jp/english/publication/jarq/26-4/26-4-259-263.pdf (accessed on 15 September 2018).

39. Same as 46 Oda, M. Vegetable seedling grafting in Japan. Acta Hortic. 2007, 759, 175-180.

40. Ashraf, M.A.; Kondo, N.; Shiigi, T. Use of Machine Vision to Sort Tomato Seedlings for Grafting Robot. Eng. Agric. Environ. Food 2011, 4, 119-125. [CrossRef]

41. Tian, S.; Ashraf, M.A.; Kondo, N.; Shiigi, T.; Momin, M.A. Optimization of Machine Vision for Tomato Grafting Robot. Sens. Lett. 2013, 11, 1190-1194. [CrossRef]

42. Division, P.B.; Crops, O. Use of Rootstocks in Solanaceous Fruit- Vegetable Production in Japan Plant Breed; JIRCIS: Tsukuba, Japan, 1980.

43. Camacho Ferre, F.; (Coordinador Obra). V. autores. Técnicas de Producción de Cultivos Protegidos. Tomo II. Caja Rural Intermediterránea, Instituto Cajamar. Ediciones Agrotécnicas, S.L.; II, 776. 2003. Available online: http://www.publicacionescajamar.es/pdf/series-tematicas/agricultura/tecnicas-deproduccion-en-cultivos.pdf (accessed on 15 September 2018).

44. Gaion, L.A.; Braz, L.T.; Carvalho, R.F. Grafting in Vegetable Crops: A Great Technique for Agriculture. Int. J. Veg. Sci. 2017, 1-18. [CrossRef]

45. Montsanto, De Ruiter Product guide. Rut. Prod. Guid. 2012. Available online: http:/ /www.deruiterseedstemp.com/ global/au/products/Documents/DeRuiterAUProductGuide.pdf (accessed on 15 September 2018).

46. Johnson, S.; Kreider, P.; Miles, C. Vegetable Grafting: Eggplants and Tomatoes. 2013. Available online: http:// extension.wsu.edu/publications/wp-content/uploads/sites/54/publications/fs052e.pdf (accessed on 15 September 2018). Washington State Univ.; WSU Mount Vernon Northwestern Washington, Fact Sheet, 1-6.

47. Rivard, C.L.; Louws, F.J. Grafting for Disease Resistance in Heirloom Tomatoes; AG-675; North Carolina Cooperative Extension Service: Raleigh, NC, USA, 2007; pp. 1-8.

48. Bumgarner, N.R.; Kleinhenz, M.D. Grafting Guide: A Pictorial Guide to the Cleft and Splice Graft Methods as Applied to Tomato and Pepper. Ohio State University. Research and Development Center, 2014. Available online: http:/ / web.extension.illinois.edu/smallfarm/downloads/50570.pdf (accessed on 15 September 2018).

49. Oda, M. New Grafting Methods for Fruit-Bearing Vegetables in Japan. Jpn. Agric. Res. Q. 1995, 194, 187-194.

50. Maurya, A.K. Role of Grafting in vegetable Production. Vegetable Grafting. GB Pant University of Agriculture and Technology, Pantnagar Uttarakhand, 2014. Available online: http://es.slideshare.net/ ashish7891/vegetable-grafting (accessed on 15 September 2018). 
51. Oda, M. Grafting of Vegetables to Improve Greenhouse Production, p. 1-11. Extension Bulletin—Food \& Fertilizer Technology Center, 1999. Available online: https://es.scribd.com/document/220401141/Veggie-Grafting (accessed on 15 September 2018).

52. Torres, A.P.; Lopez, G.R. Medición de Luz Diaria Integrada en Invernaderos. Purdue Agriculture. Available online: https:/ / www.extension.purdue.edu/extmedia/HO/HO-238-SW.pdf (accessed on 15 September 2018).

53. Kubota, C.; McClure, M.A.; Kokalis-Burelle, N.; Bausher, M.G.; Rosskopf, E.N. Vegetable grafting: History, use, and current technology status in North America. Hortscience 2008, 43, 1664-1669.

54. Velasco-alvarado, M.D.J.; Castro-brindis, R.; Avitia-garcía, E.; Castillo-gonzáles, A.M.; Sahagún, J. Proceso de unión del injerto de empalme en jitomate (Solanum lycopersicum L.). Revista Mexicana de Ciencias Agrícolas. 2017. Available online: http:/ / www.redalyc.org/html/2631/263152411004/ (accessed on 15 September 2018).

55. Andrews, P.K.; Marquez, C. Graft incompatibility. Hortic. Rev. 1993, 1, 183-232.

56. De Miguel, Alfredo II Jornadas Sobre Semillas y Semilleros Hortícolas. Libro Editado: ISBN: 84-87564-40-2 1997, 216. Available online: http://www.juntadeandalucia.es/export/drupaljda/1337170141II_Jornadas_sobre_Semillas_y_ Semilleros_Horticolas_BAJA.pdf (accessed on 15 September 2018).

57. Tateishi, K. Grafting Watermelon onto Pumpkin Suggested Potential Applications. Available online: https://pdfs. semanticscholar.org/2d91/f2d762af27589ecffd858c5eed25bd98ad93.pdf (accessed on 15 September 2018).

58. Zhao, X. Grading system of tomato grafting machine based on machine vision. In Proceedings of the 8th International Congress on Image and Signal Processing, Shenyang, China, 14-16 October 2015; pp. 604-609. Available online: http:/ /ieeexplore.ieee.org/document/7407950/ (accessed on 15 September 2018).

(C) 2018 by the authors. Licensee MDPI, Basel, Switzerland. This article is an open access article distributed under the terms and conditions of the Creative Commons Attribution (CC BY) license (http:/ / creativecommons.org/licenses/by/4.0/). 

MDPI

St. Alban-Anlage 66

4052 Basel

Switzerland

Tel. +41 616837734

Fax +41 613028918

www.mdpi.com

Agronomy Editorial Office

E-mail: agronomy@mdpi.com www.mdpi.com/journal/agronomy

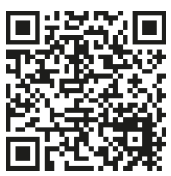



MDPI

St. Alban-Anlage 66

4052 Basel

Switzerland

Tel: +41 616837734

Fax: +41 613028918

www.mdpi.com 